Technical Report - 2012 - 061

\title{
Policies to encourage sustainable consumption
}

Full report 
Europe Direct is a service to help you find answers

to your questions about the European Union

New freephone number:

0080067891011

A great deal of additional information on the European Union is available on the Internet. It can be accessed through the Europa server (http://ec.europa.eu).

ISBN : 978-92-79-25952-4

doi : $10.2779 / 6032$

(c) European Communities, 2012

Reproduction is authorised provided the source is acknowledged. 
CLIENT:

CONTRACT NUMBER:

REPORT TITLE:

PROJECT NAME:

DATE:

AUTHORS:

KEY CONTACTS:

ACKNOWLEDGEMENTS:

\section{Disclaimer:}

The project team does not accept any liability for any direct or indirect damage resulting from the use of this report or its content. This report contains the results of research by the authors and is not to be perceived as the opinion of the European Commission.

\section{Please cite this publication as:}

BIO Intelligence Service (2012), Policies to encourage sustainable consumption, Final report prepared for. European Commission (DG ENV)

Photo credit: cover @ Per Ola Wiberg

(CBIO Intelligence Service 2012

\section{European Commission (DG ENV)}

A project under the Sustainable Management of Natural Resources framework contract ENV.G.4/FRA/2008/0112

Final report

Policies to encourage sustainable consumption

August 2012

Dr. Pierre Sonigo, BIO Intelligence Service Mr. Jonathan Bain, BIO Intelligence Service Ms. Mary Ann Kong, BIO Intelligence Service Ms. Doreen Fedrigo, IEEP

Ms. Sirini Withana, IEEP

Ms. Emma Watkins, IEEP

Dr. Gerd Scholl, IOEW

Dr. Frieder Rubik, IOEW

Mr. Robin Vanner, PSI

Dr. Simon Dresner, PSI

Dr. Pierre Sonigo or Jonathan Bain

pierre.sonigo@biois.com, jonathan.bain@biois.com

$+33(0) 153901180$

The project team would like to thank everyone who has made this study possible, including members of the European Commission, the participants who attended the study's workshop, and other stakeholders who have provided the team with invaluable information and support. We especially thank Dr Franck Nievens for facilitating the "Future Vision" workshop. We also warmly thank Shailendra Mudgal and Eric Labouze for continuous support to this work. 
Table of contents

ABSTRACT 7

SUMMARY REPORT

INTRODUCTION

CHAPTER 1: "FUTURE VISION" WORKSHOP ON SUSTAINABILITY 37

1.1 Structure of the workshop 37

1.2 Main findings of the workshop 37

CHAPTER 2: OVERVIEW OF TOOLS AND APPROACHES TOWARDS SUSTAINABLE CONSUMPTION

2.1 Inventory of existing tools 42

2.2 Classification of key behavioural approaches 61

CHAPTER 3: ASSESSMENT OF FIFTEEN REAL WORLD CASE STUDIES OF SUSTAINABLE $\begin{array}{ll}\text { CONSUMPTION } & 68\end{array}$

3.1 Identification of case studies 68

3.2 Selection of 15 case studies 68

3.3 Assessment of the selected case studies $\quad 72$

3.4 Summary of case study analysis $\quad 72$

CHAPTER 4: ANALYSIS OF POLICY TOOLBOXES IN NINE CONSUMPTION SECTORS 80

4.1 Summary of key consumption sectors 80

4.2 Selection of five sectors for further analysis 84

CHAPTER 5: ASSESSMENT OF FIVE KEY CONSUMPTION SECTORS 86

5.1 Terminology and aspects of analysis 86

5.2 General EU policy context 87

5.3 Cross-cutting actions 88

5.4 Housing: Energy and water using appliances 94

$\begin{array}{ll}5.5 \text { Food and drink } & 104\end{array}$

$\begin{array}{ll}5.6 \text { Clothing/textiles } & 116\end{array}$

$\begin{array}{ll}5.7 \text { Tourism } & 123\end{array}$

$\begin{array}{ll}5.8 \text { Citizen community action } & 131\end{array}$

5.9 Comparison of policy options 136

CHAPTER 6: POLICY RECOMMENDATIONS AND CONCLUSIONS 146

6.1 Recommended policy options for the five sectors 146 
6.2 The sustainable consumption challenge $\quad 158$

6.3 General messages for a policy response $\quad 158$

6.4 Questions for the future: needs, desire and constraints; production-side reinforcement?

\section{ANNEXES $\quad 166$}

7.1 Annex 1: List of identified case studies 166

7.2 Annex 2: Detailed assessments of selected case studies 168

7.5 Annex 3: Detailed assessment of toolboxes of key sectors 203

\section{List of tables}

Table 1: Summary of results of the assessment of real world case studies

Table 2: Summary of results of the analysis of nine consumption sectors

Table 3: Recommended policy options in the Food and Drink sector 20

Table 4: Recommended policy options in the Food and Drink sector 23

Table 5: Recommended policy options in the Clothing sector 26

Table 6: Recommended policy options in the Tourism sector 27

Table 7: Recommended policy options in citizen community action $\quad 28$

Table 9: Values and principles that should accompany a sustainable system 39

Table 10: Major social media websites 53

Table 11: Inventory of existing tools

Table 12 : Summary of Defra's behavioural segmentation model for the population in England 64

Table 13 : Illustrative model of behavioural policy tools and mechanisms 66

Table 14: Selected case studies for analysis $\quad 70$

Table 15 : Summary of lessons learned 73

Table 16: Sector summaries $\quad 81$

Table 17: Cost-effectiveness of policy instruments to healthy food consumption 108

Table 18 : Implementation costs of initiatives 137

Table 19 : Comparison table of specific actions $\quad 140$

Table 20: Recommended policy options in the Housing sector $\quad 147$

Table 21: Recommended policy options in the Food and Drink sector $\quad 150$ 
Table 22: Recommended policy options in the Clothing sector

Table 23: Recommended policy options in the Tourism sector

Table 24: Recommended policy options in citizen community action

\section{List of figures}

Figure 1: Diagrammatic representation of Defra's 4E's model 62

Figure 2: Unilever's five levers for change. 63

Figure 3: Decision balance in consumption .162

Figure 4: Consumer decision: internal ("free") vs external ("constrained") needs. 163

Figure 5: Trade-offs impacting the choice of product and policy tool 164 
This page is left intentionally blank 


\section{"In brief"}

A new study for the European Commission shows that, despite the consensus on methods to influence consumption through the "classic" instruments of policy (regulatory, economic and informational) and increasing discussion on the potential of the "behavioural" approach, some essential conditions are forgotten. These include the need for strong engagement of citizens on values, leading to an effective and long-term behavioural change. Similarly, it has rarely been considered to favour the action that could be most effective, that is to say, where consumption is the result of constraints rather than the satisfaction of needs or desires.

\section{Context}

In 2012, the European Commission will review its Action Plan for Sustainable Consumption and Production and Sustainable Industrial Policy (SCP / SIP Action Plan) published in 2008. Issues related to sustainable consumption and consumer behaviour are a major aspect of this review. That is why the Commission (DG Environment) launched, in 2011, the study "Policies to promote sustainable consumption".

Conducted by BIO Intelligence Service, IEEP, IOEW and PSI, the study identifies the main policy instruments currently in use, but also new approaches, and provides recommendations for changing consumer behaviour using the full range of instruments available.

\section{Study objectives: the challenge of sustainable consumption}

The current, complex environmental challenges (climate change, depletion of natural resources, etc.) are linked to major drivers such as increased wealth and consumption patterns. Addressing these challenges requires integration into the political process of citizen engagement in a debate on values and actions. Behavioural instruments and those based on incentives, which seek to encourage consumers to change their choices and behaviour, certainly provide useful additional measures; but behavioural approaches, even if they increase the probability of a pro-environmental outcome, are not sufficient in themselves to achieve sustainable consumption. They may however be used to target certain segments of populations and improve the design of policy measures.

\section{Structure of the study and results}

The study's goal was to outline policies to promote sustainable consumption in several sectors or areas of consumption. It was aimed primarily at consumer demand, in particular referencing behavioural instruments.

It consisted of five tasks:

1. Organisation of a "Future Visioning" workshop, bringing together experts and pioneers to outline the shape of a sustainable society. The workshop highlighted the importance of policy 
coherence, including infrastructure where required, production and distribution systems, and also the essential role of credibility ("Be the change you want") and local ownership.

2. Development of an inventory and evaluation of the main instruments available (regulatory, economic, informational and behavioural), with regard to consumer segmentation, and highlighting their variable efficacy in changing behaviours of different population segments.

3. Analysis of fifteen case studies with a focus on the following aspects: price signals, "smart" technologies and new media, infrastructure and support, public involvement, accessibility for all levels of society, transparency, credibility, and trust, clear definition of target groups.

4. Analysis of nine consumption sectors that appear most promising in terms of reducing environmental impact: residential infrastructure, energy- or water-using household appliances, food, clothing/textiles, urban mobility, air travel, tourism and citizen community actions.

5. Detailed analysis of six of these sectors: household energy- or water-using appliances, food, tourism, clothing / textiles, and citizen community actions, to draw conclusions and specific recommendations.

\section{Beyond the sectoral analysis: principles and common problems}

Beyond the sectoral analysis, the study raises common principles and questions for the future.

- The different categories of instruments should be combined into "bundles" to mutually strengthen their effects, emphasizing coherence and synergy (in both short and long term: for example awareness raising action develops acceptability of future regulatory measures).

- Above all, sustainable consumption involves the engagement of three main actors: professionals, public authorities and individuals.

- Cross-cutting policies should include the development of sectoral roadmaps involving the various stakeholders, but also taking into account the durability of products as extending their service life can provide environmental benefits.

- In a "bundle" of policy instruments, the regulatory tools can be very effective in counteracting unsustainable consumption behaviour.

- Regarding economic tools, the social costs of environmental policy must be taken into account, due to their possible regressive or perverse effects.

- Communication tools such as environmental labels, beyond their mere informative purpose, can lead to the development of tools to quantify the impacts and also allow the development of indicators, thereby encouraging the identification of improvement potentials, paving the way for regulatory measures and increasing their political acceptability.

- To implement an effective awareness campaign at the European level, several aspects must be considered: the content, the messenger, the choice of media 
and tone; targeting a specific audience with a specific message, as it is cheaper and more effective than extensive advertising campaigns.

- Do not consider the possibility of using the behavioural approach and "nudges" until the consumer decision-making process has been well understood.

- Existing examples of good practice at national and local levels can be shared through a coordination mechanism, such as a European platform for knowledge exchange.

\section{The rebound effect}

The "rebound effect" can neutralize, in some sectors, up to $80 \%$ of environmental benefits attained. The possible "rebound" effects should therefore be anticipated before the implementation of price signals. The study proposes four approaches to address this problem: use a bundle of instruments including fiscal, behavioural and technological instruments, aim to encourage "sustainable" lifestyles, raise awareness, and push professionals toward behavioural changes.

Questions for the future: needs, desires and constraints; strengthening the production side

- Sustainable consumption is seen by some as a reversal of progress towards greater quality of life. It would involve a sacrifice of our current, tangible needs and desires, in the name of a better but uncertain future. The work of "marketers" and advertisers rich in resources is a key factor in this perception: it influences and shapes consumers' understanding of their own needs and desires. The consumer's decision is classically described as a balance between these needs and desires, and product prices. In this view, the only way to influence the consumer's decision is to change either the needs and desires, or prices.

- The behavioural approach may lead policy makers into competition with commercial marketing. Most actions targeting consumers therefore require careful adaptation, which can vary according to country or even by region. This is an obstacle to centralized European action on consumer behaviour. Moreover, the social incentives for sustainable consumption often develop at the local level or by the action of communities of citizens.

- Identifying areas where consumption is the result of constraints, rather than needs or desires, allows a different approach. Thus, in the transport sector, the daily commute to get to work when it would be possible to work from home can be seen as a constraint. Reducing this type of consumption could be viewed as progress, and not a sacrifice. Incentives to work at home could therefore be well received. Similarly, in the clothing sector, changing dress codes at work, which are perceived as a modifiable rule, could be easier than for leisure and fashion, where freedom of consumer choice reigns. The analysis of hierarchical 
chains (employee/employer, tenant/landlord, legislator/citizen, etc.) could help identify similar situations where the consumer does not feel free in their decision. These situations of "forced consumption" should be the easiest targets to modify consumer behaviour.

- The "product" oriented approach is currently used to promote sustainable consumption through a "win/win" alliance between "consuming better" and "producing better". To enhance product policy, communication directed at the consumer (advertising) or infrastructures dedicated to consumption (shopping centres) could be subject of specific policies, such as, for example, requiring shopping centres to provide services or cultural activities that are more resource efficient. 
Contents

Context

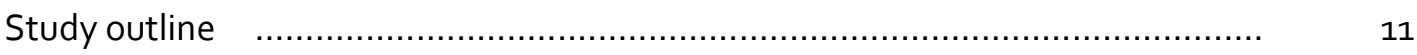

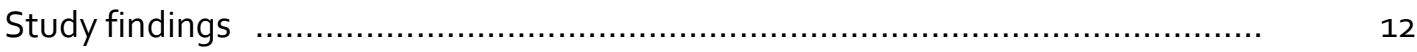

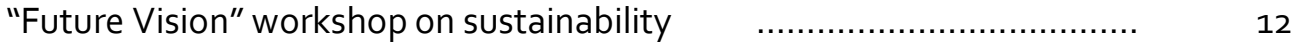

Overview of tools and approaches towards sustainable consumption 13

Assessment of fifteen real world case studies of sustainable consumption $\quad 14$

Analysis of policy toolboxes in nine consumption sectors $\quad \ldots \ldots \ldots \ldots . . . .16$

Assessment of five key consumption sectors $\quad$............................. 20

Beyond the sectoral analysis: common guiding principles and questions for the future

\section{Context}

In 2012, the European Commission will revise its 2008 Sustainable Consumption and Production Industrial Policy (SCP/SIP) Action Plan. The core of the Action Plan is a dynamic framework aiming to improve the environmental performance of products throughout their life-cycle, to stimulate the demand for better products and to help consumers make better choices.

Under the Action Plan, several EU policies have been established to reduce the environmental impacts of products. For example, EU legislation such as the Eco-design Directive, the EU Ecolabel and EMAS Regulations (all revised in 2009/2010), GPP and ECAP policies, and other EU initiatives, such as the Retail Forum and the European Food SCP Round Table.

Issues related to sustainable consumption and behaviour will be a major aspect under review for the 2012 revision of the Action Plan. This study Policies to Encourage Sustainable Consumption was launched by the European Commission - DG Environment, and carried out by BIO Intelligence Service, IEEP, IOEW and PSI. The aim of this study is to provide policy guidance on how to change consumption patterns using the range of policy instruments available, including those based on behavioural approaches.

\section{Study outline}

A "Future vision" workshop was held during the initial stages of the study, with key experts in the field of sustainable consumption. The objective of the workshop was to discuss and define concepts of sustainable consumption and envision a sustainable urban environment in 2050 (Chapter 1 of the report).

Policy tools were listed and categorised (section 2.1.3) based on the type of tool, the tool's target audience, the initiator/implementer of the tool and the stage of the consumption cycle at which 
the tool is usually used. The four main categories of tools include regulatory, economic, information, and behavioural. In addition, the behavioural approach was evaluated against a consumer segmentation model (section 2.2.3 of the report).

An assessment of real life use of tools to achieve more sustainable consumption was also carried out. In each case study, the main lessons, barriers, and key success factors were highlighted (Table 1 and section 3.4 of the report).

Nine consumption sectors which seem the most promising in terms of reduction of environmental impacts from the consumption point of view were analysed (including housing infrastructure, housing - energy using appliances, housing - water using appliances, food and drink, clothing/textiles, tourism, urban mobility, air travel and citizen community action). The examination of the sectors can provide preliminary guidelines for policy options (Table 2 and section 4.1 of the report).

Six of the nine consumption setors (housing appliances, food and drink, clothing/textiles, tourism and citizen community action) were selected (in Chapter 4 of the report) for further analysis, as they were considered as the most relevant for instant action. The selection was based on the feasibility of implementation at EU level, the potential to implement tools from a short to midterm perspective (by 2020), the significance of the environmental impacts, and the coherence with ongoing policy initiatives at the EU level. Recommendations on specific sector-relevant policy actions are examined in Assessment of five key consumption sectors on page 20 (and section 6.1 of the report).

In addition, beyond the sectoral approach, common guiding principles and questions for the future are considered. A particular attention has been attached to the rebound effect, notably under its economy-wide aspects, as it can lead to take-back in anticipated environmental savings of $10-80 \%$ for certain sectors (highlighted in section 3.4 and elaborated in section 5.3 .4 of the report). Questions on the future of sustainable consumption are posed in the report, and the answers to these appear to be fundamental in successfully paving the way towards truly sustainable consumption and society (sections 5.3 and 6.2 to 6.4 of the report).

\section{Study findings}

\section{1. "Future Vision" workshop on sustainability}

During the envisioning exercise at the workshop participants felt that the following objectives should be part of obtaining sustainable consumption: shared resources and space; localized employment; activity and knowledge sharing. Establishing infrastructure that supports sustainable behaviour (e.g. access to public transport or local foods), credibility ("be the change you want" from public authorities and governments) and local ownership (enable and empower) were also important visions of sustainable consumption. However, in many instances these contradict current trends of individualism (more single-person households), globalization (international food, appliance and clothing supply chains) and increased mobility (both personal vehicles and international travel).

The main challenges and barriers identified to developing sustainable consumption policies are: a number of consumption related measures require complementary production/supply side measures to be effective; in certain sectors policy is limited due to institutional and material 
infrastructure lock-in and economic concerns; and the lack of integration of the costs of resource scarcity and environmental impact into the prices of goods. Some of the above barriers can only be overcome by systemic changes such as: tax reform, institutional reform, and provision of infrastructure that enables and encourages sustainable behaviour.

\section{Overview of tools and approaches towards sustainable consumption}

The "classical" policy tools are:

- Behavioural tools: behavioural tools aim at influencing consumer behaviour using understanding drawn from a broad field of domains such as psychology, sociology and cultural studies. Some behavioural tools are known as "nudges" (inspired by the work of Thaler and Sunstein ${ }^{1}$ ). A typical example is the "red orb", from Southern California Edison, indicating an excessive energy consumption in the household. Behavioural tools have been used for a long time in areas such as health and safety. However, little is known about the concrete results and benefits of such measures.

- Communication/information provision tools: Environmental product labels provide information to consumers with the hopes of influencing their purchasing decisions. However, the quantity and quality of the information on product labels may be problematic. There is much to be learned from marketing experts on how to effectively communicate information aimed at influencing consumers' decisions. It is clearly easier to leverage marketing work through product policy actions than to develop centralised sustainable consumption marketing that would go against or control product marketing from the producers. The use of information and awareness-raising instruments has to go hand-in-hand with the provision of infrastructure and proper price incentives. Information tools like eco-labelling also lead to development of methods for quantifying impacts, allowing investigation of benchmarks, identifying areas for improvement potential, preparing the ground for mandatory measures and increasing their political acceptability.

- Economic tools: Economic instruments are seen as key in influencing people's choices, since the price of a good, quality and income is often the influencing factor for purchasing decisions (e.g. French "bonus/malus" system for environmentally friendly cars led to $30 \%$ rise in purchase of fuel-efficient vehicles in $2007,45 \%$ in 2008 and $56 \%$ in 2009). Currently, consumers do not face the full costs of their consumption patterns and the associated environmental costs. Economic tools are used to introduce price signals and could be used to integrate the costs of pollution into the price of products. Finally, it is important to consider the social costs of environmental policy, as

\footnotetext{
${ }^{1}$ Richard Thaler, Cass Sunstein, Nudge. Improving Decisions about Health, Wealth, and Happiness, New Haven, Yale University Press, 2008.
} 
they can have regressive effects ${ }^{2}$. However, the regressive effects of higher pricing could be mitigated through assistance to low-income households or progressively graduated prices based on taxes.

Regulatory tools: Regulatory instruments require intensive research, enforcement, and administrative burdens on governments compared to the other policy tools. Legislation directly aimed at the consumer can receive less public acceptance. Nonetheless, when implementing a mix of tools or "policy packages", there may be a significant time-lag for households to adjust and therefore use of regulatory tools within the "package" can be particularly effective in order to counteract unsustainable consumption behaviour (as concluded by the EUPOPP study ${ }^{3}$ ).

Existing attempts to categorise behavioural policy tools have grouped tools by how they seek to promote behavioural change. For example, Defra's "4Es" categorises the approaches to behavioural change into either engaging, encouraging, enabling or exemplifying consumers to change, while Unilever's 5 levers of behavioural change is integrated into their products and services marketing strategy and corresponds closely to the "Four A's" principles for sustainable consumption: affordability, availability, attractiveness and awareness.

\section{Assessment of fifteen real world case studies of sustainable consumption}

Table 1: Summary of results of the assessment of real world case studies

\begin{tabular}{|c|c|}
\hline Case study & Description \\
\hline \multicolumn{2}{|c|}{ Tool category: Economic (taxes and charges; subsidies/incentives; green payment/investment schemes) } \\
\hline $\begin{array}{l}\text { Bonus-Malus } \\
\text { (France - } \\
\text { mobility) }\end{array}$ & $\begin{array}{l}\text { Objective: To reduce } \mathrm{CO}_{2} \text { emissions from passenger vehicles in France (household and industry). } \\
\text { Innovative aspects: The combination of a credit and a tax, which is designed to ensure that the credits } \\
\text { paid out are offset by the tax revenue generated (i.e. revenue-neutral for the government) makes. }\end{array}$ \\
\hline $\begin{array}{l}\text { Canadian } \\
\text { EcoENERGY } \\
\text { Retrofit program } \\
\text { (energy efficient } \\
\text { housing retrofits) }\end{array}$ & $\begin{array}{l}\text { Objective: To provide financial assistance to encourage owners of existing low-rise properties to make } \\
\text { smart energy retrofit decisions that will result in significant energy savings. } \\
\text { Innovative aspects: Encourages homeowners to invest in multiple energy efficiency measures, which } \\
\text { may have not been otherwise considered. The programme requires both pre and post evaluations of the } \\
\text { home by a qualified energy expert, which brings credibility and builds on the principle of continuous } \\
\text { improvement. }\end{array}$ \\
\hline $\begin{array}{l}\text { Dutch Green Funds } \\
\text { cheme (investment } \\
\text { in green projects) }\end{array}$ & $\begin{array}{l}\text { Objective: Providing access to lower-than-standard-interest loans for green projects. Promoting green } \\
\text { and socially-responsible investment by individuals. } \\
\text { Innovative aspects: The Dutch environmental policy tool does not represent an innovative approach. } \\
\text { However, the GFS could be a promising instrument for other MS if governments and banks are willing to } \\
\text { work closely together. }\end{array}$ \\
\hline $\begin{array}{c}\text { London's } \\
\text { Congestion Charge }\end{array}$ & $\begin{array}{l}\text { Objective: To reduce congestion charging the use of vehicles at busy times. } \\
\text { Innovative aspects: Congestion charging represents the application of the established theory that } \\
\text { charging represents an efficient way of allocating scares road space. The Central London Congestion } \\
\text { Charging scheme represents the largest use of the tool and therefore is a novel application. }\end{array}$ \\
\hline
\end{tabular}

\footnotetext{
${ }^{2}$ The cost of environmental policy measures (i.e. prices increases for certain goods and services to reflect their 'cost' to the environment) are not always distributed in a balanced and equitable way. Several studies indicate that it is essentially modest households that are impacted by the cost of environmental measures and therefore environmental policy can have regressive effects; for example, a residential energy tax may impose greater financial burden on lowerincome households. The UK's Fuel Poverty Strategy is an initiative that addresses the distributional issues of environmental policy, targeting households whose energy consumption exceeds $10 \%$ of income.

3 Öko-Institut (and partners) (2011) Policies to Promote Sustainable Consumption Patterns (EUPOPP). See: www.eupopp.net/publications.htm
} 


\begin{tabular}{|c|c|}
\hline Case study & Description \\
\hline \multicolumn{2}{|c|}{ Tool category: Information provision and awareness raising (information campaign; labelling; education) } \\
\hline $\begin{array}{l}\text { Danish Brug Mere } \\
\text { Spild Mindre } \\
\text { (efficient resource } \\
\text { use) }\end{array}$ & $\begin{array}{l}\text { Objective: To improve the prevention of waste in Denmark. } \\
\text { Innovative aspects: Communications campaign combined the web supports (and social media) with } \\
\text { public events and competitions. }\end{array}$ \\
\hline $\begin{array}{l}\text { FairTrade Label for } \\
\text { cotton }\end{array}$ & $\begin{array}{l}\text { Objective: To strengthen the position of developing country producers in the market place through an } \\
\text { international consumer product label. } \\
\text { Innovative aspects: The FairTrade label's message addresses the need to tackle poverty and empower } \\
\text { producers in developing countries. This message may be more successful in gathering consumer } \\
\text { support than others. The connection between farmers and consumers that is emphasised touches upon } \\
\text { behavioural aspects that help to build consumer trust. The Fairtrade Certification Mark is also used as a } \\
\text { tool to build a social consumer movement pushing for change in global trading. }\end{array}$ \\
\hline $\begin{array}{l}\text { Food Dudes } \\
\text { programme (UK - } \\
\text { healthy eating in } \\
\text { children) }\end{array}$ & $\begin{array}{l}\text { Objective: School-based intervention designed for use in primary schools that encourages children to } \\
\text { eat fruit and vegetables both at school and at home and changes the 'culture' of a school to one that } \\
\text { strongly supports healthy eating. } \\
\text { Innovative aspects: A range of insights identified by behavioural psychology research was used in the } \\
\text { development of the programme: children are motivated by praise, recognition, and rewards, the } \\
\text { influence of positive role models and successful experimentation with the taste acquisition theory. }\end{array}$ \\
\hline $\begin{array}{l}\text { Love Food, Hate } \\
\text { Waste (UK - reduce } \\
\quad \text { food waste) }\end{array}$ & $\begin{array}{l}\text { Objective: To raise awareness among households of the need to reduce food waste, reduce the level of } \\
\text { food waste being sent to landfills and help residents save money. } \\
\text { Objective: The campaign actions were combined together to represent an effective and sophisticated } \\
\text { behavioural tool and presenting the action as a social norm or practice. Strategies included: } \\
\text { Identification of the problem and framing it in terms of potential savings; The focus on loving food (i.e. } \\
\text { not calling on people to change what they eat); The focus on enabling people via practical steps. The } \\
\text { local focus on local communities - thereby influencing via mavens. }\end{array}$ \\
\hline $\begin{array}{l}\text { Vienna City (de- } \\
\text { materialisation } \\
\text { activities) }\end{array}$ & $\begin{array}{l}\text { Objective: To reduce waste generation in Vienna, with prevention seen as the most desirable waste } \\
\text { management option as it eliminates the need for handling, transporting, recycling or disposal of waste. } \\
\text { Innovative aspects: The novelty of focusing on encouraging a shift to immaterial consumption is very } \\
\text { high, given consumption levels in Western societies. Two approaches to waste prevention have been } \\
\text { developed corresponding to high- and low-income sectors of society. In terms of trying to change } \\
\text { consumption patterns it appears that much of the activities are focused on information provision and } \\
\text { awareness-raising which are not high novelty in themselves. }\end{array}$ \\
\hline \multicolumn{2}{|c|}{$\begin{array}{l}\text { Tool category: Behavioural (comparative evaluations, pledges or commitments; community/public } \\
\text { participation; "nudge"-type) }\end{array}$} \\
\hline $\begin{array}{l}\text { Eco-challenge } \\
\text { (promote } \\
\text { sustainable } \\
\text { lifestyles) Starting } \\
\text { from US to } \\
\text { worldwide event } \\
\end{array}$ & $\begin{array}{l}\text { Objective: To reduce } \mathrm{CO}_{2} \text { emissions from everyday consumption. To change consumer behaviour } \\
\text { towards a more sustainable lifestyle and consumption, in the short and long-term. } \\
\text { Innovative aspects: A combination was used of different approaches of motivational psychology, } \\
\text { especially the close connection between the specific sustainability content, the "smart" design } \\
\text { technology and the opportunity of social comparison. Compared to other sustainability platforms and } \\
\mathrm{CO}_{2} \text { calculators, EcoChallenge has a mobile format and is accessible worldwide. }\end{array}$ \\
\hline $\begin{array}{l}\text { Middelgrunden } \\
\text { Wind Cooperative } \\
\text { (DK, locally-owned } \\
\text { wind farm creating } \\
\text { renewable energy) }\end{array}$ & $\begin{array}{l}\text { Objective: To produce electricity through the establishment and management of wind turbines on the } \\
\text { Middelgrunden shoal and enable the local community of Middelgrunden in Denmark to share expenses } \\
\text { and income from a wind turbine. } \\
\text { Innovative aspects: This project was the biggest of its kind, and based on sale of shares and dual } \\
\text { ownership, which included local ownership by a cooperative and a utility. } \\
\text { Rather than taking a purely informational approach, a much more active information and participation } \\
\text { strategy was used for the successful implementation. }\end{array}$ \\
\hline $\begin{array}{l}\text { Paris Velib } \\
\text { Programme (bike } \\
\text { share } \\
\text { programme) }\end{array}$ & $\begin{array}{l}\text { Objective: To offer a complementary and new means of transportation for both local citizens and } \\
\text { tourists and to promote soft transportation. } \\
\text { Innovative aspects: The initiative is unprecedented in terms of its scale and scope. It is a } \\
\text { comprehensive addition to the Parisian transportation network. Innovative also because the } \\
\text { programme has managed to create a cheap, convenient, and environmentally-friendly mode of } \\
\text { transportation. }\end{array}$ \\
\hline $\begin{array}{l}\text { Transition Towns } \\
\text { (network starting } \\
\text { from Ireland to } \\
\text { spreading } \\
\text { worldwide) }\end{array}$ & $\begin{array}{l}\text { Objective: To create community-led responses and resilience to the challenges and opportunities of } \\
\text { peak oil, climate change and economic stagnation. } \\
\text { Innovative aspects: This is a highly novel approach, from its community-led nature, to its collaborative } \\
\text { approach in creating a 'model' that communities can follow as appropriate for their situation, the } \\
\text { integration of permaculture and psychology principles to what can be considered an environmental } \\
\text { initiative, local community resilience, localisation and reform of the local economy. }\end{array}$ \\
\hline
\end{tabular}




\begin{tabular}{|l|l|}
\hline \multicolumn{1}{|c|}{ Case study } & \multicolumn{1}{c|}{ Description } \\
\hline $\begin{array}{l}\text { VISIT initiative } \\
\text { (sustainable } \\
\text { tourism) }\end{array}$ & $\begin{array}{l}\text { Objective: To promote and support the development of sustainable tourism at international, national } \\
\text { and regional levels. } \\
\text { Innovative aspects: VISIT is the first initiative in Europe that aims to gather tourism-related } \\
\text { organisations and make them exchange their practices as well as make their requirements uniform. This } \\
\text { alliance between the different eco-labels is based on mutual understanding and recognition and the } \\
\text { agreement to adopt a common standard. }\end{array}$ \\
\hline Tool category: Mixed (behavioural and information provision) \\
\hline $\begin{array}{l}\text { Picture Health } \\
\text { Warnings on } \\
\text { Cigarette Packets }\end{array}$ & $\begin{array}{l}\text { Objective: To raise awareness on the health risks related to smoking, encourage smokers to quit } \\
\text { smoking, repulse non-smokers (especially when they are young before they start smoking), and reduce } \\
\text { the consumption of cigarettes. Raising awareness prepares for future bans. } \\
\text { Innovative aspects: Using pictures/images rather than text is innovative, as previously only textual } \\
\text { health warnings had been used on cigarette packs. Furthermore, they reach illiterate people, who } \\
\text { otherwise may not be able to read the textual health warnings. }\end{array}$ \\
\hline
\end{tabular}

The case studies highlighted advantages and disadvantages of various tools and draw attention to the following aspects:

Price signal (e.g. French "bonus/malus" system for environmentally friendly cars): When designing tools that will affect prices, it is necessary to anticipate possible rebound effects and the magnitude of resulting take back in environmental savings.

Use of smart technologies and new media (e.g. the Eco-challenge initiative): this includes for example using smartphone applications and technologies and social networks.

Involving the public, encouraging local ownership and involvement (e.g. UK "Love Food, Hate Waste" initiative): Gaining support in advance of implementation.

Focus on infrastructure and support, financial and technical or informational (e.g. VISIT initiative and Paris "Velib" Programme): Accessibility from all levels of society, regardless of income level, level of education, etc (e.g. Vienna City "dematerialisation" initiative): Transparency, credibility and trust (e.g. FairTrade Label and Danish "Brug Mere Spild Mindre" campaign): Initiatives tend to be more credible when robust data is provided and when several different levels of stakeholders are involved.

- Clearly defining the targeted groups and design tailor made communication strategies and objectives to reach each one (e.g. UK Food Dudes programme).

Although there is a good cross-section of case studies, local and grassroots initiatives are not usually as well documented as initiatives implemented by government agencies (which often have formal impact analyses or activity reports).

\section{Analysis of policy toolboxes in nine consumption sectors}

Table 2: Summary of results of the analysis of nine consumption sectors

\begin{tabular}{|l|l|l|l|}
\hline \multicolumn{1}{|c|}{ Sector } & \multicolumn{1}{|c|}{ Overview of sector } & $\begin{array}{l}\text { Pros and cons of } \\
\text { further analysis }\end{array}$ & \multicolumn{1}{c|}{ Key elements of possible toolbox } \\
\hline Urban & - Significant environmental impact, in & $\underline{\text { PROS }}$ & $\bullet$ Guidelines for spatial planning (e.g. \\
\hline
\end{tabular}




\begin{tabular}{|c|c|c|c|}
\hline Sector & Overview of sector & $\begin{array}{l}\text { Pros and cons of } \\
\text { further analysis }\end{array}$ & Key elements of possible toolbox \\
\hline mobility & $\begin{array}{l}\text { particular with regard to GHG } \\
\text { emissions. } \\
\text { - Expected increases in transport and } \\
\text { associated energy needs to } 2030 \text {. } \\
\text { - EU focus has been on technological } \\
\text { improvements rather than modal shifts. } \\
\text { - Need to address policy incoherence, } \\
\text { social aspects, infrastructure lock-in. }\end{array}$ & $\begin{array}{l}\text { - Significant GHG } \\
\text { impact } \\
\text { - Rising } \\
\text { consumption } \\
\frac{\text { CONS }}{\text { - Infrastructure }} \\
\text { lock-in }\end{array}$ & $\begin{array}{l}\text { to promote public transport, modal } \\
\text { shift, non-motorised travel); } \\
\text { - Revise fiscal and taxation policies } \\
\text { (e.g. congestion and road use } \\
\text { charging, vehicle taxes, fuel taxes); } \\
\text { - Redirect infrastructure funding (e.g. } \\
\text { to prioritise non-motorised and } \\
\text { public transport infrastructure); } \\
\text { - Introduce demand-side } \\
\text { management policies (e.g. } \\
\text { restricted access schemes, deploy } \\
\text { ITS applications in support of eco- } \\
\text { driving, provide incentives to } \\
\text { encourage people to try new forms } \\
\text { of transport - e.g. free trial bus } \\
\text { passes). }\end{array}$ \\
\hline Air travel & $\begin{array}{l}\text { - Major contributor to EU GHG } \\
\text { emissions } \\
\text { - Significant growth expected. } \\
\text { - EU focus has been on market-based } \\
\text { tools (EU ETS, taxes) and innovation } \\
\text { (e.g. EU Clean Sky Joint Initiative) } \\
\text { rather than influencing consumer } \\
\text { behaviour. } \\
\text { - Need to address price elasticity of air } \\
\text { travel, GHG emissions, use of } \\
\text { alternative fuels, and new modes of } \\
\text { propulsion. } \\
\text { - Need to take into account } \\
\text { international dimension (opposition to } \\
\text { international measures that limit air } \\
\text { travel, competitive distortion, carbon } \\
\text { leakage) when designing initiatives in } \\
\text { the area. }\end{array}$ & $\begin{array}{l}\frac{\text { PROS }}{\text { - Significant GHG }} \\
\text { impact } \\
\text { - Rising } \\
\text { consumption } \\
\frac{\text { CONS }}{\text { - Price elasticity }} \\
\text { of air travel } \\
\text { - International } \\
\text { dimension }\end{array}$ & $\begin{array}{l}\text { - Launch well-designed } \\
\text { information/education campaigns to } \\
\text { raise awareness and influence } \\
\text { attitudes/and practices (e.g. by } \\
\text { proposing concrete practices such as } \\
\text { only flying once a year); } \\
\text { - Provide competitive alternatives to } \\
\text { air travel through investments and } \\
\text { incentives differentiating between } \\
\text { different types of travel/travellers; } \\
\text { - Harmonise calculation and } \\
\text { quality of carbon offsets; } \\
\text { - Extend use of airport taxes so they } \\
\text { can distinguish between long and } \\
\text { short haul flights; } \\
\text { - Encourage take-up of provisions in } \\
\text { energy taxation Directive on levying } \\
\text { fuel taxes on domestic and intra- } \\
\text { Europe flights on the basis of bilateral } \\
\text { agreements. }\end{array}$ \\
\hline $\begin{array}{l}\text { Housing: } \\
\text { Infrastructure }\end{array}$ & $\begin{array}{l}\text { - Significant environmental impact, } \\
\text { particularly through energy/materials/ } \\
\text { biodiversity/ water consumption, land } \\
\text { use (and soil sealing). } \\
\text { - Trend towards smaller households and } \\
\text { hence growing demand of living space } \\
\text { per person is expected to continue to } \\
2020 \text {. } \\
\text { - EU focus has been on promoting } \\
\text { sustainability on supply side rather than } \\
\text { changing consumer demands. } \\
\text { - Need to address social factors, } \\
\text { infrastructure lock-in, weak incentives } \\
\text { and lack of information on supply and } \\
\text { demand side. }\end{array}$ & $\begin{array}{l}\frac{\text { PROS }}{\text { - Significant }} \\
\text { environmental } \\
\text { impact } \\
\text { - Existing policy } \\
\text { framework for } \\
\text { energy } \\
\text { performance } \\
\frac{\text { CONS }}{\text { - Infrastructure }} \\
\text { lock-in } \\
\text { - Focus to date } \\
\text { on supply side }\end{array}$ & $\begin{array}{l}\text { - Develop reliable differentiator } \\
\text { mechanisms (e.g. certification, } \\
\text { labelling); } \\
\text { - Launch targeted information } \\
\text { campaigns; } \\
\text { - Provide economic tools (e.g. } \\
\text { subsidies, green loans, fiscal } \\
\text { measures) to incentivise installation } \\
\text { of sustainability features; } \\
\text { - Encourage retrofitting and } \\
\text { renovation schemes in existing } \\
\text { housing stock; } \\
\text { - Avoid split incentives with } \\
\text { mechanisms to ensure investors } \\
\text { recoup benefits of investments. }\end{array}$ \\
\hline
\end{tabular}




\begin{tabular}{|c|c|c|c|}
\hline Sector & Overview of sector & $\begin{array}{l}\text { Pros and cons of } \\
\text { further analysis }\end{array}$ & Key elements of possible toolbox \\
\hline $\begin{array}{l}\text { Housing: } \\
\text { Energy using } \\
\text { appliances }\end{array}$ & $\begin{array}{l}\text { - 'Midrange' environmental impact. } \\
\text { - Demand for small appliances growing } \\
\text { rapidly (e.g. personal computers, } \\
\text { mobile phones), offsetting efficiency } \\
\text { gains from large appliances and space } \\
\text { heating. } \\
\text { - EU regulatory tools focus on producers, } \\
\text { application of voluntary information } \\
\text { tools not widespread and have limited } \\
\text { effect. } \\
\text { - Need to address amount and type of } \\
\text { appliances consumed, change use } \\
\text { patterns, improve eco-design, restrict } \\
\text { sale of inefficient products, and } \\
\text { incentivise purchase of energy- } \\
\text { efficient devices. }\end{array}$ & $\begin{array}{l}\text { PROS } \\
\text { - Rising } \\
\text { consumption } \\
\text { - Existing policy } \\
\text { framework for } \\
\text { eco-design } \\
\text { CONS } \\
\text { - Environmental } \\
\text { impacts not as } \\
\text { significant as } \\
\text { other sectors; } \\
\text { focused on } \\
\text { energy }\end{array}$ & $\begin{array}{l}\text { - Introduce well-designed information } \\
\text { and labelling tools together with } \\
\text { financial incentives. Ensure } \\
\text { availability of substitutes or new } \\
\text { technologies to support change in } \\
\text { behaviour; } \\
\text { - Encourage retailers to provide } \\
\text { product trials or money back } \\
\text { guarantees; } \\
\text { - Establish 'buy back' and 'trade-in' } \\
\text { schemes complemented by financial } \\
\text { incentives; } \\
\text { - Develop consumer support } \\
\text { mechanisms; } \\
\text { - In promoting energy-efficient devices, } \\
\text { highlight costs associated with high } \\
\text { energy-using appliances, promote } \\
\text { product features with policy } \\
\text { relevance, avoid additional taxation } \\
\text { and offer 'free' benefits (e.g. VAT } \\
\text { free, free extended warrantee). }\end{array}$ \\
\hline $\begin{array}{l}\text { Housing: } \\
\text { Water using } \\
\text { appliances }\end{array}$ & $\begin{array}{l}\text { - Water scarcity is an increasing } \\
\text { problem. } \\
\text { - Trend towards smaller households } \\
\text { expected to increase water } \\
\text { consumption. } \\
\text { - EU focus on improving quality of water, } \\
\text { the need to address demand } \\
\text { increasingly recognised. } \\
\text { - Need to address consumer awareness } \\
\text { and behaviour, technical performance } \\
\text { of water supply systems, and politically } \\
\text { sensitive issue of managing water } \\
\text { demand. }\end{array}$ & $\begin{array}{l}\frac{\text { PROS }}{\text { - Addresses }} \\
\text { increasing issue } \\
\text { of water scarcity } \\
\text { - Existing policy } \\
\text { framework } \\
\text { CONS } \\
\text { - Addresses a } \\
\text { specific } \\
\text { sustainability } \\
\text { issue }\end{array}$ & $\begin{array}{l}\text { - Improve implementation of Water } \\
\text { Framework Directive provisions on } \\
\text { water tariffs and compulsory } \\
\text { metering; } \\
\text { - To minimise regressive impact of } \\
\text { water charging, couple full-cost } \\
\text { water pricing with assistance to low- } \\
\text { income households/progressively } \\
\text { graduate water prices based on } \\
\text { taxes; } \\
\text { - Promote demand management } \\
\text { measures through guidelines and } \\
\text { sharing best practices; } \\
\text { - Complement above with public } \\
\text { information campaigns and eco- } \\
\text { labelling schemes. }\end{array}$ \\
\hline $\begin{array}{l}\text { Food and } \\
\text { drink }\end{array}$ & $\begin{array}{l}\text { - Significant environmental impacts, } \\
\text { especially from consumption of meat } \\
\text { and dairy products. } \\
\text { - In the EU, changes in composition of } \\
\text { diets (e.g. replace beef with pork and } \\
\text { poultry, increasing imports) and the } \\
\text { way food is produced and sold (e.g. } \\
\text { favour pre-prepared, frozen meals and } \\
\text { convenience foods) expected to } \\
\text { continue to 2020. } \\
\text { - EU focus has been on } \\
\text { production/process side, interventions } \\
\text { on consumption side have been } \\
\text { restricted to soft measures like }\end{array}$ & 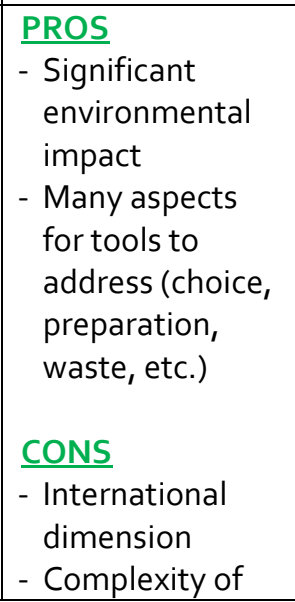 & $\begin{array}{l}\text { - Reorient market frameworks towards } \\
\text { sustainability practice by eliminating } \\
\text { perverse subsidies, promoting } \\
\text { standardised labelling and providing } \\
\text { integrated infrastructure solutions } \\
\text { that cater to local and regional needs; } \\
\text { - Engage retailers and major food } \\
\text { producers (e.g. through public- } \\
\text { private partnerships, setting } \\
\text { standards) to green upstream supply } \\
\text { chains and reduce downstream } \\
\text { impact of products (e.g. choice } \\
\text { editing, free trials and price } \\
\text { promotions); }\end{array}$ \\
\hline
\end{tabular}




\begin{tabular}{|c|c|c|c|}
\hline Sector & Overview of sector & $\begin{array}{l}\text { Pros and cons of } \\
\text { further analysis }\end{array}$ & Key elements of possible toolbox \\
\hline & $\begin{array}{l}\text { education and awareness raising. } \\
\text { - Reluctance of policy-makers to act in } \\
\text { area of consumer choice, structure of } \\
\text { food supply chain, infrastructure, } \\
\text { social, cultural and emotional factors, } \\
\text { cost and availability of sustainable } \\
\text { food and drink products. }\end{array}$ & $\begin{array}{l}\text { preferences } \\
\text { involved in food } \\
\text { decisions }\end{array}$ & $\begin{array}{l}\text { - Launch targeted awareness-raising } \\
\text { and information campaigns; } \\
\text { - Establish price mechanisms and } \\
\text { quality standards that support / } \\
\text { stimulate dietary change; } \\
\text { - Support local/community-led niche } \\
\text { practices or initiatives. }\end{array}$ \\
\hline $\begin{array}{l}\text { Clothing/ } \\
\text { Textiles }\end{array}$ & $\begin{array}{l}\text { - Significant environmental impact, } \\
\text { aggravated by rising consumption } \\
\text { levels. } \\
\text { - EU focus has been on the production } \\
\text { phase, however most textile products } \\
\text { are imported and thus the scope for EU } \\
\text { supply-side policy is limited. } \\
\text { - Need to address consumer } \\
\text { choice/behaviour. }\end{array}$ & $\begin{array}{l}\text { PROS } \\
\text { - Significant } \\
\text { environmental } \\
\text { impact } \\
\text { - Rising } \\
\text { consumption } \\
\frac{\text { CONS }}{- \text { International }} \\
\text { dimension }\end{array}$ & $\begin{array}{l}\text { - Establish standardised labelling and } \\
\text { certification schemes; } \\
\text { - Launch targeted information } \\
\text { campaigns covering whole lifecycle of } \\
\text { clothing; } \\
\text { - Partner with retail industry and } \\
\text { encourage engagement in greening } \\
\text { upstream supply-chains and } \\
\text { influencing consumer behaviour. }\end{array}$ \\
\hline Tourism & $\begin{array}{l}\text { - Significant environmental impacts } \\
\text { both inside and outside Europe. } \\
\text { - Trends in tourism are changing, in } \\
\text { particular experimental tourism which } \\
\text { includes eco-tourism, rural and } \\
\text { community tourism is expected to grow } \\
\text { quickly over next two decades. } \\
\text { - EU focus on voluntary and } \\
\text { informational initiatives, however } \\
\text { action is limited to domestic EU } \\
\text { tourism sector. } \\
\text { - Need to address social aspects, lack of } \\
\text { resources/information/skills, } \\
\text { infrastructure/destination 'lock-in', } \\
\text { economic interests including those of } \\
\text { less developed countries. } \\
\text { - Take into account 'carrying capacity' } \\
\text { of tourism areas in terms of visitors } \\
\text { and their impacts in designing } \\
\text { initiatives in the area. }\end{array}$ & $\begin{array}{l}\text { PROS } \\
\text { - Significant } \\
\text { environmental } \\
\text { impact } \\
\text { - Existing trends } \\
\text { toward eco- } \\
\text { tourism } \\
\text { CONS } \\
\text { - International } \\
\text { dimension } \\
\text { - Complexity of } \\
\text { social and } \\
\text { economic } \\
\text { aspects in } \\
\text { destination } \\
\text { locations }\end{array}$ & $\begin{array}{l}\text { - Introduce additional information } \\
\text { tools that engage consumers and } \\
\text { industry (e.g. information and } \\
\text { education programmes in } \\
\text { cooperation with local stakeholders } \\
\text { on appropriate behaviour, potential } \\
\text { harmful environmental impacts of } \\
\text { tourism, benefits of activities such as } \\
\text { eco-tourism); } \\
\text { - Use financial instruments such as } \\
\text { price signals (e.g. tax on aircraft } \\
\text { fuel/use of airports). }\end{array}$ \\
\hline $\begin{array}{l}\text { Citizen } \\
\text { community } \\
\text { action }\end{array}$ & $\begin{array}{l}\text { Recent studies and the workshop } \\
\text { organised for this study identify the need } \\
\text { to go beyond traditional approaches to } \\
\text { SCP to address societal values and } \\
\text { norms through public/community } \\
\text { engagement processes and systems that } \\
\text { make sustainable living easier. }\end{array}$ & $\begin{array}{l}\text { PROS } \\
\text {-Opportunity to } \\
\text { address societal } \\
\text { values and norms } \\
\text {-Bottom-up } \\
\text { citizen-led } \\
\text { movements } \\
\text {-Innovative } \\
\text { approach } \\
\text { CONS } \\
\text {-Requires political } \\
\text { support and } \\
\text { funding }\end{array}$ & $\begin{array}{l}\text { - Political and financial support for } \\
\text { bottom-up citizen-led movements; } \\
\text { - Provide incentives and stimulate } \\
\text { investments in wider systems and } \\
\text { infrastructures (e.g. invest in local } \\
\text { recycling facilities, provide loans and } \\
\text { grants for products such as } \\
\text { insulation); } \\
\text { - Increase knowledge and } \\
\text { understanding on how sustainable } \\
\text { consumption policies and practices } \\
\text { can evolve, building on research from } \\
\text { social and behavioural sciences; } \\
\text { - Increase awareness and share best } \\
\text { practices on on-going efforts (e.g. } \\
\text { Transition Towns). }\end{array}$ \\
\hline
\end{tabular}




\section{Assessment of five key consumption sectors}

Prioritised based on technical and administrative/political feasibility and the potential of the action to promote more sustainable consumption. The recommended sector actions are proposed as packages of options that should ideally be implemented as a "bundle", as evidence shows this is what is most effective in achieving long-term behavioural change.

\section{Housing (energy and water using appliances)}

Priority actions for this sector are:

- Promote green public procurement practices for catering in public offices and institutions ${ }^{4}$ : This action would demonstrate the public sector's commitment to sustainable food choices. This action would provide leadership, an awareness-raising tool, and could encourage a 'domino effect' on purchasing habits of private institutions and consumers.

- Awareness raising campaigns: Consumers know a lot about the importance of eating healthy but not necessarily about the importance of consuming food sustainably. Therefore, awareness-raising could focus on 'healthy and sustainable' diets as a 'win-win' for consumers and the environment. However, such recommended diet, both healthy and sustainable is still to define.

More detailed policy options recommended are presented in Table 3.

Table 3: Recommended policy options in the Housing sector

\begin{tabular}{|c|c|c|c|}
\hline Recommended action & $\begin{array}{l}\text { Specific } \\
\text { tool used }\end{array}$ & Lessons learned from case studies & Specific implementation guidance \\
\hline $\begin{array}{l}\text { Raising awareness about: } \\
\text { The existence of efficient } \\
\text { appliances } \\
\text { How to use efficient } \\
\text { appliances }\end{array}$ & $\begin{array}{l}\text { Awareness } \\
\text { raising }\end{array}$ & $\begin{array}{l}\text {-Canadian EcoENERGY Retrofit programme: } \\
\text { The visit of a qualified energy advisor allows homeowners personal } \\
\text { contact with a local energy expert. The guidance and } \\
\text { recommendations from the energy expert on how to efficiently use } \\
\text { the retro fit devices was a good way to ensure that the homeowner } \\
\text { completely understood the advice. } \\
\text {-Food dudes programme: define who the main target groups are for } \\
\text { specific products in order to develop tailored awareness campaigns } \\
\text { and programmes. } \\
\text {-Eco-challenge: Integrate smart technologies and social networking, } \\
\text { modernise advertising - into information campaigns. Integrating } \\
\text { competition and the aspect of a challenge to motivate consumers. }\end{array}$ & $\begin{array}{l}\text {-Awareness raising campaigns could be combined to strengthen the } \\
\text { messages being conveyed. } \\
\text {-Avoid sending mixed messages or including too much information. } \\
\text {-Collaborating with other partners such as local NGOs and } \\
\text { associations would help to build up consumer trust and credibility. } \\
\text {-Industry involvement is also essential to strengthen messages and } \\
\text { aid in dissemination. Current policies such as the Ecodesign Directive } \\
\text { have raised the interest and involvement of many key industry } \\
\text { members on energy using products; therefore they may be more } \\
\text { inclined to promote the best products covered under the Ecodesign } \\
\text { Directive. }\end{array}$ \\
\hline
\end{tabular}

${ }^{4}$ Institutions such as in schools, hospitals, prisons, at the European Commission offices, etc. 


\begin{tabular}{|c|c|c|c|}
\hline Recommended action & $\begin{array}{l}\text { Specific } \\
\text { tool used }\end{array}$ & Lessons learned from case studies & Specific implementation guidance \\
\hline & & $\begin{array}{l}\text {-Love food, Hate Waste campaign: Direct one to one engagement } \\
\text { was an effective method of communicating at a local level. }\end{array}$ & \\
\hline $\begin{array}{l}\text { Labelling of most efficient } \\
\text { appliances }\end{array}$ & \multirow[t]{2}{*}{$\begin{array}{l}\text { Information } \\
\text { provision }\end{array}$} & \multirow[t]{2}{*}{$\begin{array}{l}\text {-Fair trade label: Including labels as part of a wider communication } \\
\text { strategy can be very effective. } \\
\text {-Visit initiative: Unification of several similar labels was key in the } \\
\text { initial success of the initiative. }\end{array}$} & $\begin{array}{l}\text {-Build upon the existing EU energy label and the technical } \\
\text { information derived from the Ecodesign preparatory studies }{ }^{5} \text { For } \\
\text { example, the EU energy label could be applied to a wider range of } \\
\text { products and include special notation for products which are the most } \\
\text { efficient in its product category. This would clearly distinguish the } \\
\text { most efficient appliances from other similar products. This would also } \\
\text { give incentive to industry to develop and offer more energy efficient } \\
\text { appliances; Another possibility is to include running costs or savings } \\
\text { due to energy use on the energy label. Including this information in } \\
\text { monetary terms could further incite consumers, especially those who } \\
\text { are particularly concerned by energy prices. } \\
\text {-Voluntary agreements with retail for importing and selling energy } \\
\text { efficient appliances and educating sales staff about the topic of } \\
\text { energy efficiency. }\end{array}$ \\
\hline $\begin{array}{l}\text { Incorporation of estimate of } \\
\text { appliance energy } \\
\text { consumption in energy label } \\
\text { for rented accommodation to } \\
\text { reduce split incentives }\end{array}$ & & & $\begin{array}{l}\text { - Teaming up with local and national rental agencies and landlord } \\
\text { associations (e.g. European Council for Real estate Professions) would } \\
\text { facilitate knowledge needed and implementation of the initiative. } \\
\text { - In addition to including appliance energy consumption, running } \\
\text { costs (or savings) in monetary terms could also be included on the } \\
\text { label to further incite consumers. }\end{array}$ \\
\hline $\begin{array}{l}\text { Promote demand } \\
\text { management measures } \\
\text { through guidelines and } \\
\text { sharing of best practice }\end{array}$ & $\begin{array}{l}\text { Information } \\
\text { provision }\end{array}$ & & $\begin{array}{l}\text {-These two actions are also information-provision actions; however, } \\
\text { target specifically public authorities, Member States, and policy- } \\
\text { makers as opposed to consumers. }\end{array}$ \\
\hline Leadership through GPP & $\begin{array}{l}\text { Information } \\
\text { provision/le } \\
\text { ad by } \\
\text { example }\end{array}$ & $\begin{array}{l}\text { Vienna City Dematerialisation: The initiative tends to be more } \\
\text { credible when several different levels of stakeholders are involved. }\end{array}$ & $\begin{array}{l}\text {-Public authorities have a direct influence on consumption: their own } \\
\text { purchases represent } 16 \% \text { of EU GDP6. Therefore, important that the } \\
\text { Commission continues to set clear and ambitious criteria for the } \\
\text { purchase of products below or above a certain level of energy or } \\
\text { environmental performance. }\end{array}$ \\
\hline $\begin{array}{l}\text { Encourage retailers to } \\
\text { provide product trials or }\end{array}$ & $\begin{array}{l}\text { Financial } \\
\text { incentive }\end{array}$ & n.a. & $\begin{array}{l}\text {-Policy-makers will need to be able to ensure retailer participation. } \\
\text { The success of a targeted awareness campaign (see first }\end{array}$ \\
\hline
\end{tabular}

${ }^{5}$ http://ec.europa.eu/energy/efficiency/studies/ecodesign_en.htm

${ }^{6}$ TNO et BIO, 2011, Report for the JRC, Analysis of the future application of product policy instruments in the EU, Task 3: Proposed policy mixes for prioritized products, Not yet published

biossumer 


\begin{tabular}{|c|c|c|c|}
\hline Recommended action & $\begin{array}{c}\text { Specific } \\
\text { tool used }\end{array}$ & Lessons learned from case studies & Specific implementation guidance \\
\hline $\begin{array}{l}\text { Increase duration of } \\
\text { mandatory product } \\
\text { warranties }\end{array}$ & $\begin{array}{l}\text { Injunction } \\
\text { tools }\end{array}$ & $\begin{array}{l}\text { Vienna City Dematerialisation: Promote waste prevention and } \\
\text { dematerialisation by adopting approaches that target both high and } \\
\text { low income populations. }\end{array}$ & $\begin{array}{l}\text {-Would need to be carried out in consultation with major stakeholders } \\
\text { (manufacturers), } \\
\text {-This would be a good longer-term action to implement as it would } \\
\text { most likely involve a longer implementation process compared to } \\
\text { above actions. }\end{array}$ \\
\hline
\end{tabular}

\footnotetext{
${ }^{7}$ http://ec.europa.eu/enterprise/policies/sustainable-business/ecodesign/product-policy/financial-incentives/index_en.htm
} 


\section{Food and drink}

Priority actions for this sector are:

- Awareness raising campaigns: The choice of clothing is one of the most visually obvious ways for people to express their social status, values and individual and/or collective identity. Social concern and social justice have also always been an important for consumers in the clothing sector, therefore a successful awareness campaign would be one that could combine social concerns with the environmental aspects of clothing. One way for policy makers to take action in this sector is to work with major clothes retailers and designers, celebrities, and NGOs to help spread the messages about the importance of sustainable clothing, ways to reduce energy and water consumption during clothes cleaning, and promoting better disposal activities. The participation of celebrities, and targeted campaigns (i.e. at specific types of consumers, regions, lifestyles, etc.), could be effective in making sustainable clothing more fashionable.

- Working with the retail and manufacturing sector: Service-led business models could be promoted, highlighting the reputational and economic advantages. The models could include activities such as promote take-back/ return, reuse, and recycling of used/ discarded clothing. Building on the growing second-hand sector, businesses could offer services such as repair and other maintenance services (e.g. via service certification schemes), novel coatings, remanufacturing, or 'fashion upgrades' ${ }^{8}$.

More detailed policy options recommended are presented in Table 4.

Table 4: Recommended policy options in the Food and Drink sector

\begin{tabular}{|c|c|c|c|}
\hline Recommended action & $\begin{array}{c}\text { Specific tool } \\
\text { used }\end{array}$ & Lessons learned from case studies & Specific implementation guidance \\
\hline $\begin{array}{l}\text { Develop overarching strategy for } \\
\text { sustainable food in Europe }\end{array}$ & \multirow{3}{*}{ n.a } & \multirow{3}{*}{ n.a. } & \multirow{3}{*}{$\begin{array}{l}\text { - Further research initiatives to collect quantified data on impacts across food } \\
\text { products (similar to what is being done for energy-using appliances). } \\
\text { - Cross-cutting actions should be linked with the upcoming reforms of the } \\
\text { CAP and CFP to provide a complete and comprehensive vision of the food } \\
\text { sector. Many policies are related to food production, for example the Nitrates } \\
\text { or animal welfare directives. } \\
\text { - Build on/improve on initiatives such as the EU Retail Forum and the Food } \\
\text { SCP Roundtable. }\end{array}$} \\
\hline $\begin{array}{l}\text { Launch cross-sectoral research } \\
\text { initiatives }\end{array}$ & & & \\
\hline $\begin{array}{l}\text { Strengthen institutional structures } \\
\text { and administrative capacities }\end{array}$ & & & \\
\hline
\end{tabular}

${ }^{8}$ Fashion upgrading refers to the upgrade of discarded clothing by some form of remanufacturing: for instance replacing certain panels within a dress, which would allow a sufficient 'fashion upgrade' to give new value to otherwise outdated styles. A similar approach has been used in the Smart Car - with simple replacement of body panels to allow a cheap change of style. See: www.ifm.eng.cam.ac.uk/.../mass/uk_textiles.pdf (wrong link) 


\begin{tabular}{|c|c|c|c|}
\hline Recommended action & $\begin{array}{c}\text { Specific tool } \\
\text { used }\end{array}$ & Lessons learned from case studies & Specific implementation guidance \\
\hline $\begin{array}{l}\text { Continue and improve voluntary } \\
\text { agreements and public-private } \\
\text { partnerships }\end{array}$ & & & - Support promotion of eco-innovation through ETAP and CIP \\
\hline $\begin{array}{l}\text { Launch targeted awareness-raising } \\
\text { and information campaigns and } \\
\text { education programmes }\end{array}$ & $\begin{array}{l}\text { Information } \\
\text { provision / } \\
\text { Education }\end{array}$ & $\begin{array}{l}\text {-Food dudes programme and Eco-challenge: Important } \\
\text { to be able to identify key consumer segments and } \\
\text { markets for tailor made information campaigns and } \\
\text { adapt campaigns by using relevant communication } \\
\text { channels (i.e. social marketing websites for younger } \\
\text { consumers). } \\
\text {-Anti-tobacco picture campaigns: Possibilities of making } \\
\text { the food industry pay for sustainable food ad campaigns } \\
\text { (similar to tobacco companies). The use of graphic } \\
\text { images (e.g. rotting waste, sick animals, etc.) }\end{array}$ & $\begin{array}{l}\text {-Focus on changing long-term consumption patterns among targeted } \\
\text { consumer groups. } \\
\text {-Visible information campaigns come also from NGOs. }\end{array}$ \\
\hline $\begin{array}{l}\text { Develop EU-level sustainable food } \\
\text { labelling scheme and establish } \\
\text { credible certification mechanisms }\end{array}$ & $\begin{array}{l}\text { Information } \\
\text { provision }\end{array}$ & $\begin{array}{l}\text { Fair trade label: See explanations from above tables } \\
\text { VISIT initiative: This initiative was able to gather the } \\
\text { tourism labels of several organisms to create a } \\
\text { harmonised label. It was financially supported by an EU- } \\
\text { funded LIFE project in tourism eco-labelling. }\end{array}$ & $\begin{array}{l}\text { - EU rules on food labelling (Directive } 2000 / 13 / E C \text { ) ensure consumers receive } \\
\text { correct information to enable informed choices about the food they buy - } \\
\text { information requirements could be expanded to include information on the } \\
\text { environmental impacts of products. Funding to promote research into } \\
\text { sustainability impacts of food and drink, to allow more accurate information } \\
\text { on food labels, could come from EU funded LIFE projects (similar to the VISIT } \\
\text { initiative). } \\
\text { - A label alone is not sufficient; Labels could be synergized by tax measures, } \\
\text { such as asking low VAT for sustainable products or communication campaigns }\end{array}$ \\
\hline $\begin{array}{l}\text { Promote green public procurement } \\
\text { practices for catering in public } \\
\text { offices and institutions }\end{array}$ & $\begin{array}{l}\text { Information } \\
\text { provision / } \\
\text { lead by } \\
\text { example }\end{array}$ & n.a. & $\begin{array}{l}\text {-This action could build on the on-going efforts of DG ENV in relation to GPP, } \\
\text { for example, EU level guidelines could be prepared building on the GPP- } \\
\text { toolkit. }\end{array}$ \\
\hline $\begin{array}{l}\text { Support local/community-led } \\
\text { initiatives }\end{array}$ & $\begin{array}{l}\text { Behavioural/ } \\
\text { community }\end{array}$ & $\begin{array}{l}\text { Transition towns: Community led initiatives work } \\
\text { particularly well at the local level. }\end{array}$ & $\begin{array}{l}\text {-The EU could support local/community-led initiatives through funding, } \\
\text { endorsement, and raising awareness of them. Further, the EU can provide } \\
\text { information about best practice examples, financial support to pilot projects } \\
\text { and follow-up support to enable such pilot projects to sustain and make their } \\
\text { innovation durable and ready for broader market application. }\end{array}$ \\
\hline $\begin{array}{l}\text { Differentiate consumption taxes } \\
\text { based on the environmental } \\
\text { performance of products }\end{array}$ & $\begin{array}{l}\text { Financial } \\
\text { tools }\end{array}$ & $\begin{array}{l}\text { Bonus-Malus: - Importance of the price signal (acting } \\
\text { both on supply and demand). }\end{array}$ & $\begin{array}{l}\text {-This action could be implemented under the VAT Directive } 2006 / 112 / E C \text {, } \\
\text { which stipulates that a specific list of goods and services for which Member } \\
\text { States may apply a reduced rate of VAT of at least } 5 \% \text {. } \\
\text {-Need to assess potential and consequences of the rebound effect. }\end{array}$ \\
\hline
\end{tabular}




\section{Clothing}

Priority actions for this sector are:

- Awareness raising campaigns: The choice of clothing is one of the most visually obvious ways for people to express their social status, values and individual and/or collective identity. Social concern and social justice have also always been an important for consumers in the clothing sector, therefore a successful awareness campaign would be one that could combine social concerns with the environmental aspects of clothing. One way for policy makers to take action in this sector is to work with major clothes retailers and designers, celebrities, and NGOs to help spread the messages about the importance of sustainable clothing, ways to reduce energy and water consumption during clothes cleaning, and promoting better disposal activities. The participation of celebrities, and targeted campaigns (i.e. at specific types of consumers, regions, lifestyles, etc.), could be effective in making sustainable clothing more fashionable.

- Working with the retail and manufacturing sector: Service-led business models could be promoted, highlighting the reputational and economic advantages. The models could include activities such as promote take-back/ return, reuse, and recycling of used/ discarded clothing; renting, leasing, lending or sharing schemes of high-quality garments; innovative design strategies like co-creation of products with consumers ${ }^{9}$. Businesses could offer services such as repair and other maintenance services (e.g. via service certification schemes), novel coatings, remanufacturing, or 'fashion upgrades ${ }^{10}$.

\footnotetext{
${ }^{9}$ The use of a product could be extended through the new design strategies making the consumer the centre of the innovation processes. If the design of clothing is to be personalised, this would allow consumers to develop an emotional attachment with the garment or textile. Designers can co-create products with consumers to increase attachment to the product, for example, through the internet, with consumers making the final design decisions. See: Niinimäki, K., Hassi, L. (2011) Emerging design strategies in sustainable production and consumption of textiles and clothing. Journal of Cleaner Production 19: 1876-1883.

${ }^{10}$ Fashion upgrading refers to the upgrade of discarded clothing by some form of remanufacturing: for instance replacing certain panels within a dress, which would allow a sufficient 'fashion upgrade' to give new value to otherwise outdated styles. A similar approach has been used in the Smart Car - with simple replacement of body panels to allow a cheap change of style. See: www.ifm.eng.cam.ac.uk/uploads/Resources/Reports/UK_textiles.pdf
} 
More detailed policy options recommended are presented in Table 5.

Table 5: Recommended policy options in the Clothing sector

\begin{tabular}{|c|c|c|c|}
\hline Recommended action & $\begin{array}{l}\text { Specific } \\
\text { tool used }\end{array}$ & Lessons learned from case studies & Specific implementation guidance \\
\hline Information campaigns & \multirow{3}{*}{$\begin{array}{l}\text { Information } \\
\text { provision }\end{array}$} & \multirow{3}{*}{$\begin{array}{l}\text { Fair trade label: Combining social aspects along with } \\
\text { environmental protection was effective among consumers. } \\
\text { Food dudes programme and Eco-challenge: Important to } \\
\text { be able to identify key consumer segments and markets for } \\
\text { tailor made information campaigns and adapt campaigns } \\
\text { by using relevant communication channels } \\
\text { Visit initiative: Possibilities of combining several existing } \\
\text { labels to create harmonised standards and methodology. }\end{array}$} & \multirow{3}{*}{$\begin{array}{l}\text { These actions, which fall under information provision, can be addressed in } \\
\text { collaboration with the EU Retail Forum. A rise in consumer awareness can } \\
\text { be achieved through more and consistent labelling through channels such } \\
\text { as the European Ecolabel for clothing and footwear. A vision/roadmap for } \\
\text { a European fair and sustainable clothing market and leading by example } \\
\text { by including sustainable clothing and textiles in EU Green Public } \\
\text { Procurement Policy could also be employed to create collective } \\
\text { awareness. } \\
\text {-The EU Ecolabel, which covers textiles should consider including criteria } \\
\text { related to social justice. The EU Ecolabel competes with a large number of } \\
\text { other labels and research indicates that social justice is an important focus } \\
\text { for consumers in the textile sector. }\end{array}$} \\
\hline $\begin{array}{l}\text { Sustainable/ environmental } \\
\text { labelling }\end{array}$ & & & \\
\hline $\begin{array}{l}\text { Consider sustainable clothing } \\
\text { and textiles in } \\
\text { green/sustainable public } \\
\text { procurement }\end{array}$ & & & \\
\hline $\begin{array}{l}\text { Promoting a service-led } \\
\text { business model within the } \\
\text { retail and manufacturing } \\
\text { sector (i.e. promote take- } \\
\text { back/ return, reuse, and } \\
\text { recycling of used/ discarded } \\
\text { clothing, promote second } \\
\text { hand clothing, promote repair } \\
\text { and fashion upgrades, e.g. by } \\
\text { service certification schemes) }\end{array}$ & n.a. & n.a. & $\begin{array}{l}\text { Working with the EU Retail Forum to encourage retailers to transition } \\
\text { towards a service-led business model by highlighting the various } \\
\text { advantages for retailers: } \\
\text { - Reuse of worn clothing and texts to produce new clothing, rather than } \\
\text { using raw materials } \\
\text { - Creating competitive advantage by appealing to consumers' social } \\
\text { concerns (i.e. by providing a clothing take back scheme to re-distribute } \\
\text { useable second hand clothing to developing countries and those in need) }\end{array}$ \\
\hline
\end{tabular}

\section{Tourism}

Priority actions for this sector are:

- Awareness raising campaigns: Evidence shows that tourists are not widely aware of the environmental impacts of their tourism choices. There is potential for actors in existing EU initiatives (such as the EDEN initiative and the Natura 2000 sites) to collaborate on an awareness campaign to lower implementation costs.

- Education/training programmes on sustainable tourism for tourism professionals: As an equivalent to a "product policy", engaging the tourism industry to take more action is a priority in this sector. A possible first step is implementing sustainability training programmes for tourism professionals so they can differentiate their offers by sustainability features and pass on relevant messages and information to consumers about the issues. 
More detailed policy options recommended are presented in Table 6.

Table 6: Recommended policy options in the Tourism sector

\begin{tabular}{|c|c|c|c|}
\hline Recommended action & $\begin{array}{l}\text { Specific tool } \\
\text { used }\end{array}$ & Lessons learned from case studies & Specific implementation guidance \\
\hline $\begin{array}{l}\text { Targeted information } \\
\text { campaigns combining the } \\
\text { principles of well-being, eco- } \\
\text { friendly activities and cultural } \\
\text { heritage }\end{array}$ & $\begin{array}{l}\text { Information } \\
\text { provision }\end{array}$ & $\begin{array}{l}\text { Fairtrade label: The Fairtrade label succeeded } \\
\text { in combining respecting working conditions } \\
\text { and the environment at the same time, which } \\
\text { is very appealing to consumers. } \\
\text { Food dudes programme: Identify possible } \\
\text { target groups for specific strategies. Eco- } \\
\text { challenge: Modernise to the new channels of } \\
\text { communication. }\end{array}$ & $\begin{array}{l}\text {-The combination of both a targeted information campaign and website } \\
\text { could spark and generate widespread interest and demand. Information } \\
\text { campaigns could also include alternative ways of getting to tourist } \\
\text { destinations, by favouring railways, carpooling, etc. } \\
\text {-Campaigns can aim at improving individuals' well-being and cohesion of the } \\
\text { local community, while at the same time protecting the environment. } \\
\text {-Targeted information campaigns could also build upon the existing EDEN } \\
\text { initiative for greater visibility. }\end{array}$ \\
\hline $\begin{array}{l}\text { Support voluntary } \\
\text { agreements with tour } \\
\text { operators and travel agencies } \\
\text { to offer more sustainable } \\
\text { consumption possibilities in } \\
\text { tourism }\end{array}$ & Behavioural & n.a. & $\begin{array}{l}\text {-At the EU level, the existing VISIT initiative could be an ideal place to } \\
\text { continue and support existing actions. }\end{array}$ \\
\hline $\begin{array}{l}\text { Education/training } \\
\text { programmes on sustainable } \\
\text { tourism for tourism } \\
\text { professionals }\end{array}$ & $\begin{array}{l}\text { Information } \\
\text { provision/behav } \\
\text { ioural }\end{array}$ & n.a. & $\begin{array}{l}\text {-This could be funded through Leonardo Da Vinci training programme or } \\
\text { through voluntary industry initiatives on training programmes. }\end{array}$ \\
\hline $\begin{array}{l}\text { Tourist code of conduct or } \\
\text { pledge to engage in } \\
\text { environmentally responsible } \\
\text { behaviour }\end{array}$ & Behavioural & $\begin{array}{l}\text { Fair trade label: Online pledge was used as } \\
\text { part of the overall communication strategy. }\end{array}$ & $\begin{array}{l}\text {-The pledge could be provided online and could be linked to the information } \\
\text { campaign and/or the website dedicated to comparing the environmental } \\
\text { impacts of different tourist destinations and activities. } \\
\text {-Pledges would probably be most effective if implemented by national } \\
\text { tourism authorities, local tourism offices in collaboration with the EU. }\end{array}$ \\
\hline Visitor charging mechanisms & Financial & $\begin{array}{l}\text { London congestion charge: Public and political } \\
\text { acceptance is crucial (before and after the } \\
\text { scheme). Beware of the possible social costs: } \\
\text { pricing many on low and medium incomes out } \\
\text { of nature sites }\end{array}$ & $\begin{array}{l}\text {-Charges could be applied to specific Natura } 2000 \text { sites, which are part of the } \\
\text { EU wide network of nature protection areas. }\end{array}$ \\
\hline
\end{tabular}




\section{Citizen community action}

Citizen community action aims at a collaborative approach towards tackling the challenges related to sustainable consumption - by preparing community resilience and adaptability, increasing local value, changing cultural norms, promoting less material consumption and more wellbeing. It ties in with the roadmap process proposed in section 6.1.

Policy options recommended are presented in Table 7.

Table 7: Recommended policy options in citizen community action

\begin{tabular}{|c|c|c|c|}
\hline $\begin{array}{l}\text { Recommended } \\
\text { action }\end{array}$ & $\begin{array}{l}\text { Specific } \\
\text { tool used }\end{array}$ & Lessons learned from case studies & Specific implementation guidance \\
\hline $\begin{array}{l}\text { Political and } \\
\text { financial support } \\
\text { for bottom-up } \\
\text { citizen-led } \\
\text { movements }\end{array}$ & Behavioural & $\begin{array}{l}\text { Anti-tobacco campaigns: - Strong public support is important } \\
\text { and it creates social movements and helps to create "social } \\
\text { norms". Connecting social norms with health and well being } \\
\text { could be effective to gain public support. } \\
\text { London congestion charge, Transition towns, and } \\
\text { Middlegrunden Wind cooperative: Involving the public and } \\
\text { gaining their support in advance of implementation. In some } \\
\text { cases, taking a bottom up approach and delegating roles to } \\
\text { local communities (as opposed to top-down) is quite effective. }\end{array}$ & $\begin{array}{l}\text { Support could be provided for such citizen-led initiatives by increasing attention to } \\
\text { such activities under EU financial instruments such as LIFE+ and the Cohesion } \\
\text { Policy and community-level initiatives could be promoted as a theme under } \\
\text { LEADER+. }\end{array}$ \\
\hline $\begin{array}{l}\text { Increase knowledge } \\
\text { and understanding }\end{array}$ & $\begin{array}{l}\text { Information } \\
\text { provision }\end{array}$ & $\begin{array}{l}\text { Fair trade label: combining social aspects along with } \\
\text { environmental protection in campaigns } \\
\text { Transition towns: Raising awareness at the local and } \\
\text { community level which Transition towns does, is a good way } \\
\text { to communicate and share best practices - through word of } \\
\text { mouth from friends, family, and neighbours }\end{array}$ & $\begin{array}{l}\text { This action can build on the FP7 and FP8 research programmes. Such actions will } \\
\text { also complement various EU-level actions, for example action in relation to urban } \\
\text { mobility the recently launched Smart Cities \& Communities Initiative which will } \\
\text { help in the dissemination of knowledge among local authorities on innovative low } \\
\text { carbon technologies, as well as recent action by DG Information Society and Media } \\
\text { to build platforms for Collective Awareness and Action. }\end{array}$ \\
\hline $\begin{array}{l}\text { Increase awareness } \\
\text { and share best } \\
\text { practices }\end{array}$ & $\begin{array}{l}\text { Information } \\
\text { provision }\end{array}$ & & $\begin{array}{l}\text { The EU could provide information to community leaders on best practice examples } \\
\text { from around the EU, as well as provide financial support for pilot projects. }\end{array}$ \\
\hline $\begin{array}{l}\text { Financial incentives } \\
\text { to support } \\
\text { behaviour change }\end{array}$ & Financial & $\begin{array}{l}\text { Eco-energy retrofit programme: Set up a maximum budget as } \\
\text { seen in the Dutch green finds system }\end{array}$ & $\begin{array}{l}\text { This could be in the form of loans and grants that would support the development } \\
\text { of a 'system' that makes sustainable living easier. For example, this could include } \\
\text { providing incentives for the installation of sustainability features such as energy } \\
\text { and water retrofit devices in housing) or improving existing infrastructures e.g. } \\
\text { efficient and easy to use used clothing collection and take back schemes }\end{array}$ \\
\hline $\begin{array}{l}\text { Investments in } \\
\text { sustainable local } \\
\text { infrastructures }\end{array}$ & Financial & $\begin{array}{l}\text { Paris-Velib: Local city initiatives had existed for quite some } \\
\text { time to help promote bike use. Therefore, building on existing } \\
\text { infrastructures can be very effective. }\end{array}$ & $\begin{array}{l}\text { This could be implemented at the EU level (through prioritisation under different } \\
\text { EU funding instruments, in particular under Cohesion Policy) as well as at the } \\
\text { national level through relevant public funding investments. }\end{array}$ \\
\hline
\end{tabular}




\section{Beyond the sectoral analysis: common guiding principles and questions for the future}

\section{The sustainable consumption challenge}

Initially, environmental policy makers were challenged with the elimination of specific threats, often caused by methods of production, where it was clear an action or process was detrimental to the environment. With the emergence of more complex challenges, such as climate change and depletion of natural resources, policy objectives have moved towards "reductions" (in resource consumption and emissions), rather than "elimination" (of specific pollutants).

Because these sustainability challenges are linked to broad drivers such as increases in wealth and consumption trends, successfully addressing these challenges necessitates engagement of citizens in a conversation on values and action as part of the policy process. Incentive-based and behavioural tools, seeking to encourage consumers to change their choices and actions, are examples of additional policy measures that can be taken. However, behavioural and nudge approaches, that increase the probability of a pro-environmental outcome, are not alone sufficient to achieve sustainable consumption; they can be used to target certain segments of populations and to improve the design of policy measures. More challenging debates on aspects such as consumers' "wants" and "needs" can be foreseen.

Above all, as highlighted by Allwood and Cullen ${ }^{11}$, sustainable consumption involves the commitment and participation of three principal players - businesses, the government and individuals. Obtaining sustainable consumption is not just about policy, business initiatives, or citizen action - it is about the involvement of all three players and their alignment with each other.

\section{General messages for a policy response}

- The tool inventory and categories (i.e. regulatory, economic, informational, behavioural) represent a classical consensus on tools to influence consumer behaviour $^{12}$. From these classical tools, self-reinforcing "bundles" of policy actions, with instruments taken from each category, should be built. Bundles should be conceived not only as combinations but also as successions of actions. For example, awareness is most efficient when built upon local community initiatives. Awareness forms the basis for comprehension and use of labels. In turn, awareness and labels can prepare stakeholders for regulation.

- When implementing the mix of tools, there may be a significant time-lag for households to adjust. Within the package of policy tools, regulatory tools can be particularly effective ${ }^{13}$, in order to counteract unsustainable consumption behaviour.

\footnotetext{
11 Allwood, J. and Cullen, J. (2012) Sustainable Materials: With both eyes open. Available at: http://www.withbotheyesopen.com/read.php

${ }^{12}$ Kronenberg J. (2007) Ecological Economics and Industrial Ecology. A case study of the Integrated Product Policy of the European Union. London, New York, Routledge.

13 Öko-Institut (and partners) (2011) Policies to Promote Sustainable Consumption Patterns (EUPOPP). See: www.eupopp.net/publications.htm
} 
- Communication tools such as environmental product labels also lead to development of tools for quantifying impacts, allowing investigation of benchmarks, identifying areas for improvement potential, preparing the ground for mandatory measures and increasing political acceptability of these. However, there is good practice that should be considered: use of a limited number of indicators when communicating environmental information, use of an absolute value to ensure transparency (or a unique mark, colour, or logo), putting the results in context (compared to a familiar order of magnitude), and ensuring that the consumer is able to assess the product within a short timeframe.

- In terms of implementing an effective EU level awareness campaign (which has not always been the case), section 2.1.2 describes guidance for environmental communications. Several aspects should be considered:

Carefully consider the content, the messenger, the choice of media and tone. Do not use jargon.

Avoid patronising, guilt-laden or disapproving messages - be positive

Use the drama of the challenges and the excitement of the solutions to make the message inspiring and motivating

Communication must be supported by other measures in policy or infrastructure

Due to the abundance of diverse marketing messages in the usual channels, consider alternative channels

Targeting a specific audience with a specific message is cheaper and more effective than large advertising campaigns.

- For economic tools, the social costs of environmental policy need to be considered, as they can have regressive effects. Beyond income, a range of socio-demographic factors may impact on household consumption, but these factors can be very heterogeneous depending on the category of households. Knowledge of consumer habits and preferences is limited; however, examples of strategies to address the distributional issues of environmental policy exist.

- Consumer segmentation can help to adapt the policy approach. A drawback of such segmentation approaches in relation to this EU level project is that they tend to be specific to each society and culture and that they are not static, as values and attitudes can change with time.

- Consider opportunities to use behavioural and nudge approaches, once an understanding of consumer decision-making is achieved, in order to design 
aspects of a policy tool, such as the default option or display of information, to maximise the probability of a pro-environmental outcome.

- The participation of the public should be systematically considered in sustainable consumption policies, whether public participation in EU and national policy, or encouraging community groups to get involved at the local level. Actively engaging the public through bottom-up involvement in policy decisions is an effective way of encouraging consumers to change behaviour in sustainably and in the long term.

- Development of sectoral roadmaps (e.g. UK product roadmaps ${ }^{14}$ ): the establishment of a multi-stakeholder roadmap/envisioning exercise for each sector would help to understand better the values and behaviours across the EU for each sector of consumption.

- In the context of sustainable production and consumption, multiple initiatives (e.g. current and planned initiatives under the SCP Action Plan, the local and national initiatives highlighted in the case studies) are already implemented or in the process of development. Policy coherence is a delicate issue.

- Consideration of durability of products: A recent study ${ }^{15}$ commissioned by the UK's Defra assessed impacts of extending product lifetimes and measures to achieve this, showing that there is a high likelihood that lifetime extensions results in environmental benefits. However, few policy or government initiatives cover lifetime extension, and none has extended product lifetimes as their primary objective ${ }^{16}$.

- Examples of good practice actions at the local and MS level are available, which might be shared through a coordinated mechanism - such as a knowledge exchange platform (similar to the Business and Biodiversity Platform ${ }^{17}$ ) across the EU.

\section{Rebound effect}

There is evidence from many sources of direct rebound effects for certain sectors (in the range of $10-80 \%$, without taking into account economy-wire rebound effects that can be much higher). Isolating the rebound effects from other factors that cause increased consumption is a key issue that needs resolution in the definition and measurement techniques for estimating the magnitude of rebound effects. Four approaches may be used to address rebound effects:

- Recognise and account for rebound effect in policy design; include possible take back in projected environmental savings during evaluation, incorporating

\footnotetext{
${ }^{14}$ See: www.defra.gov.uk/environment/economy/products-consumers/

${ }^{15}$ Environmental Resources Management (2011) Longer Product Lifetimes

${ }^{16}$ Policy initiatives that do discuss product lifetime include EU Directives, such as the Ecodesign Directive and the Waste Framework Directive, referencing relevant aspects such as waste minimisation or extended producer responsibility. The UK's Defra's product roadmap work and WRAP's Love Food Hate Waste campaign discuss lifetime extension issues and aim to extend the lifetime of foodstuffs in the home

${ }^{17}$ www. business-biodiversity.eu/default.asp? Menue $=132 \&$ News $=46$
} 
assessment criteria, e.g. price, income, substitutability, technology type, resource intensity of the production sector, potential for perverse outcomes/burden shifting and time span of the intervention, in tools such as Regulatory Impact Assessment (RIA).

Use an integrated mixture of instruments encompassing fiscal, behavioural and technology; evidence shows that implementing a mixed instrument approach, incorporating technology, fiscal and behavioural aspects can help to mitigate direct rebound effects.

- Sustainable lifestyles and consumer behaviour change; while common approaches to tackle direct rebound effects include provision of information at consumption, measures to tackle indirect or economy-wide rebound effects are scarce. Such measures would need to be extensive and aim at a more profound change in the awareness and priorities of consumers.

- Awareness raising and education for leveraging behaviour change through business; inclusion of how to avoid inadvertently causing indirect rebound in awareness raising and capacity building tools aimed at businesses (examples show that there can be well intentioned but misguided advertising approaches).

\section{Questions for the future: needs, desires and constraints; reinforcing the production-side}

Sustainable consumption is perceived by some as a reversal of progress towards a higher quality of life: a frustrating sacrifice of our present, tangible needs and desires in the name of an uncertain promise for a better future. The long-running and well-resourced work of marketers and advertisers, which influences and in effect creates modern consumer understanding of "needs" and "desires" is a crucial factor. Consumer decision is classically represented as a balance between these complex needs and desires on one side and price on the other. In such a representation the obvious way to influence consumer decision is to change needs and desires, or prices.

Behavioural approaches may lead policy makers into a position where they are in competition with commercial marketing activities. Most consumer-focused interventions require careful consumer segmentation, which can vary across nations if not regions. This characteristic presents particular difficulties to centralised EU action on consumption behaviours. In addition, (social) incentives for sustainable consumption behaviours are often built on and strengthened by local exchanges and community action.

Alternatively, identifying the areas where consumption does not result from needs or desires, but rather from constraints, might help to build a different approach. For example, in the sector of transport, commuting to the office when working home is possible might be perceived as a constraint. Reduction of such consumption should be favourably received by consumers, as a progress not as a sacrifice. Thus, setting up guidelines and incentives favouring or regulating home work might be rewarding. Similarly, in the area of clothing, changes in dress-code at workplaces, which is perceived as a rule that can be modified, should be easier to implement than 
in leisure or fashion clothing where there is no existing rule but freedom of consumer choice. Analysis of the chains of hierarchies (employer to employee, owner to rental, regulation to citizen, etc.) that drive specific consumption actions might help to identify similar situations, where the consumer does not feel "free" in their consumption decision. This "constrained consumption" should be the easiest target for consumer behavioural change.

Finally, the product-oriented approach is currently used to influence the sustainability of consumption in a "win-win" alliance of "better" consumption through "cleaner" production. To reinforce product policy, communication for consumption (advertising) or infrastructure of consumption (shopping centres) could be targeted by policy actions; for example, requiring shopping centres to provide services or cultural activities that increase resource efficiency. 
This page is left intentionally blank 
This report serves as the draft final report deliverable and output of Tasks 1 to 6 for the project "Policies to Encourage Sustainable Consumption", launched by the European Commission - DG Environment, and carried out by BIO Intelligence Service, IEEP, IOEW and PSI. The research and analysis is based on an expert workshop and literature review.

The European Commission currently intends to revise its Sustainable Consumption and Production Industrial Policy (SCP/SIP) Action Plan, which was adopted on 4 December 2008. The core of the Action Plan is a dynamic framework aiming to improve the energy and environmental performance of products throughout their life-cycle, to stimulate the demand for better products and to help consumers make better choices. Issues related to sustainable consumption and behaviour, which received less consideration in the 2008 Action Plan, will be a major aspect under review. Closely linked to the SCP/SIP action plan is the Resource Efficiency flagship initiative of the Europe 2020 Strategy. To achieve greater resource-efficiency, Europe needs to make technological improvements, a significant transition in energy, industrial, agricultural and transport systems, and changes in behaviour as producers and consumers ${ }^{18}$.

Several EU policies have been established to reduce the environmental impacts of products. For example, EU legislation such as the Eco-design Directive, tools and policies such as the EU Ecolabel, EMAS, GPP, and ETAP, and other EU initiatives, such as the Retail Forum and the European Food SCP Round Table, aim at knowledge provision and exchange to achieve sustainable consumption and production. Despite the existence of these initiatives, major shifts in consumption behaviour are still needed to achieve the environmental, social, and economic objectives that have been set at EU level.

A number of EU policies to date have been based on the premise that providing consumers with information is sufficient to bring about change, but there are indications that the approach of "providing consumers with information" in order to make decisions is not sufficient to bring about changes in consumption behaviour; a Eurobarometer survey from the European Commission shows that $83 \%$ of consumers consider sustainability as important when buying products, but only $15 \%$ do it really. In addition to information provision, other measures such as legislation and regulation can compel people to act in certain ways, and financial incentives can encourage changes in consumption decisions, but these approaches can also have other drawbacks. Evidence suggests that another type can also be considered: "behavioural approaches" that try to influence consumer behaviour directly, based on an understanding of how people think and act in everyday situations, are particularly relevant in periods when there is caution about introducing too many legal instruments, and given the difficulties of establishing fiscal changes at EU level.

Therefore, the aim of this study is to provide policy guidance on how to change consumer patterns, using the range of policy instruments available, including those based on behavioural

${ }^{18}$ EC Communication, 2011, A resource-efficient Europe - Flagship initiative under the Europe 2020 Strategy ec.europa.eu/resource-efficient-europe/pdf/resource efficient europe en.pdf 
approaches. The policy options that are being proposed in this study for the selected sectors complement existing policy instruments or and provide recommendations for measures where gaps exist. Objectives include the categorisation of policy tools, the compilation of case studies to provide examples of relevant current policies and initiatives, and the assessment of selected consumption sectors for recommendation of policy actions.

The focus of this study is on measures that seek to influence consumer choice/demand towards more sustainable consumption patterns. However, a number of consumption related measures require complementary production/supply side measures to be effective, and where relevant these are also included in the report.

Chapter 1 provides a summary of the discussions and principal findings of the "Future vision" workshop held on 13 April 2011.

Chapter $\mathbf{2}$ provides an inventory of the different tools, which can be used to promote sustainable consumption and proposes a classification for the behavioural approaches identified.

Chapter 3 provides a detailed assessment of real world and instructive examples of initiatives towards changing behaviour, including the methodology used to identify and select the case studies, an assessment of the main success factors, target groups, consumption sectors, and tools used in each of the case studies, and an overall summary of the main lessons learned from the case studies analysis.

Chapter 4 provides an assessment of policy toolboxes in nine consumption sectors. These sectors were selected for their significant contribution to environmental pressures or their role in stimulating necessary behaviour changes for sustainable consumption.

Chapter 5 provides further assessment of five key sectors selected in Chapter 4, providing policy context, identification of policy options for each sector and comparison of policy options.

Chapter 6 sets out policy recommendations, guidelines and key lessons learned, as well as a discussion on shaping the future of sustainable consumption in the EU.

The Annex of this report includes supporting information on the case studies and consumption sectors analysed. 


\section{Chapter 1: "Future vision" workshop on}

\section{sustainability}

This chapter provides a summary of the discussions of the "Future vision" workshop held on 13 April 2011. The workshop was inspired by 35 experts in a wide variety of domains from academia, marketing, consumer associations, policy, industry, and research institutes.

Within the context of this study, the purpose of the workshop was to discuss, debate and cocreate an image/narrative on what consumption and production should look like in a sustainable future, and experience the process of envisioning. The Future Vision Workshop also had the aim of providing global and long-term visions of a sustainable city in 2050.

\subsection{Structure of the workshop}

The workshop was a one-day event, facilitated by Dr. Frank Nevens from VITO, Jim Baeten from Tri-Zone and organised by BIO Intelligence Service. A graphic artist from Visual Harvester, Martine Van Remoortele, was also present during the day's events to record the discussions and ideas of the workshop through graphical representations. The agenda of the workshop included:

presentation of participants' view on sustainable consumption through the use of objects and images brought in by participants;

discussion of the values that underlie a sustainable future;

discussion on the principles that are signposts of a desirable future;

brainstorming groups to design sustainable cities in the future;

solutions for obtaining a vision of a sustainable future.

The workshop was structured in order to enable small group discussions and creative activities that involved brainstorming and creating pictures of the meaning of being sustainable.

\subsection{Main findings of the workshop}

This section provides an overall summary of the main findings of the workshop. In particular, the focus is on the discussions on the meaning of sustainable consumption to the participants and how their visions of sustainable consumption can be achieved.

\subsubsection{What is sustainable consumption?}

In preparation for the workshop, participants were asked to present an object or drawing that represented how they see themselves living, working, and spending their free time in 2050. This 
exercise revealed the many aspects and domains that sustainable consumption touches upon. Some important points raised by the participants included:

- Consideration of the concept of time. Slowing down, working less to leave more time to participate in other activities such as community initiatives, family time, exercising, etc.

Sustainable transport (walking and biking).

Community and participation.

Health and exercise.

Preserving the environment.

Interconnectivity between resource use and sustainable living.

Ensuring that the current generation does not compromise future generations.

Less consumption.

- Economic growth -debate on smart growth versus de-growth.

Many participants considered that sustainable consumption means consuming less with less environmental impact and that it is not uniquely about consuming more green products and services or greening of products and services; that underlying sustainable consumption is the principle of using fewer resources with fewer environmental impacts ("absolute decoupling" of economic development from the use of natural resources).

For the workshop participants, sustainable consumption is not just about environmental concerns; sustainability should be considered through a holistic perspective. In this view, the social and economic aspects of sustainable consumption were also raised. For example, the participants considered that:

Community and participation in local activities are of great importance.

Preserving and promoting a sense of community as well as culture is a crucial step towards creating the attitude changes necessary for sustainable consumption.

Health is a significant factor underlying sustainable consumption.

Health, coupled with sustainable modes of transport - walking and biking - were also mentioned as activities that participants hoped would become a part of sustainable lifestyles in the future.

\subsubsection{Values and principles of a sustainable system}

To promote and efficiently implement policies towards sustainable consumption, it is necessary to base them on some basic and socially accepted values and principles. A brainstorming session was held with the workshop participants on these values and principles.

Values were defined as important and enduring beliefs or ideals shared by the members of a community. Values are what underpin a person's or an organisation's decisions and actions. 
Principles are the connections between values and encode how values can be expressed in decisions and actions. They can be written down and serve as the guidelines that govern actions and decisions based on the underlying values.

Table 8 summarises values and principles considered by participants to be important.

Table 8 : Values and principles that should accompany a sustainable system

\begin{tabular}{|l|l|}
\hline \multicolumn{1}{|c|}{ Values } & \multicolumn{1}{c|}{ Principles } \\
\hline Responsibility & Participation \\
Connectedness & Coherence \\
Tolerance & Sufficiency \\
Respect & Cyclic/durable/lean \\
Equity & Equal rights \\
Altruism & Symbiotic \\
Creativity & Precaution \\
Health & Synergy \\
Diversity & Zero/smart/de-growth \\
Generosity & Cooperation \\
Inspiration & Resilience \\
Peace & Connected learning \\
Trust & Environmental limits \\
Conviviality & Self-empowerment/enablement \\
Simplicity & Eco-centric \\
\hline
\end{tabular}

\subsubsection{Sustainable lifestyles \& cities}

One of the afternoon sessions of the workshop included the separation of participants into small brainstorming groups with the objective of designing sustainable cities from the perspective of a specific social/demographic group: singles, families, children and young people, non-EU citizens, and the elderly.

This activity led to a discussion on lifestyles and what lifestyle changes are necessary to promote sustainable consumption. According to one report's definition, "lifestyles are fundamental and distinctive modes of living and working that are accomplished by persons and groups through socially sanctioned and culturally intelligible patterns of action ${ }^{\prime \prime 19}$. Lifestyles are constantly changing - historically, regionally, globally, between generations - and differ between societies based on different cultural backgrounds. Interestingly, the exercise carried out by the workshop participants demonstrated several common ideas and values, despite the different social roles each group was playing. These aspects included:

Less motorised travel and personal vehicles, with a significant focus on biking and other sustainable modes of transport;

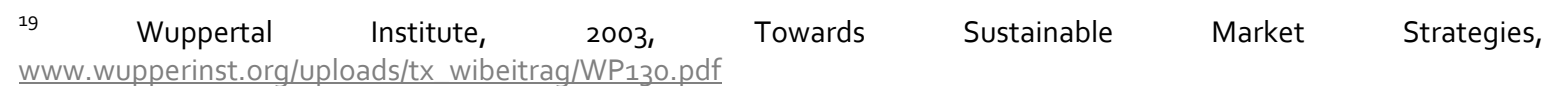


- Shared spaces (centralised meeting places for social services, recreation, health and wellbeing activities, gardens, markets, etc.);

- Shared housing facilities/communal environment (shared facilities, resources, appliances, etc.);

Emphasis on local economic activities and services, e.g. locally grown goods and markets;

Tele-working and shared office blocks to cut down commuting time;

Emphasis on learning and knowledge transfer of individuals in a community; and

Emphasis on green spaces in cities.

\subsubsection{Towards achieving the visions of sustainable consumption}

The last part of the workshop was dedicated to brainstorming the ways and the tools that policymakers can use to achieve the different objectives of sustainable consumption. These included: 


\begin{tabular}{|c|c|}
\hline Specific policy measures & General guidelines and principles \\
\hline $\begin{array}{l}\text { Monetary initiatives: } \\
\text { - Monetary initiatives should realistically } \\
\text { reflect the price of resources and be } \\
\text { based on scarcity. } \\
\text { - Enforcement of polluter pays initiatives } \\
\text { - Implementation of environmental tax } \\
\text { reform (including energy). } \\
\text { - Economic incentives such as eco-taxes } \\
\text { and subsidies should be used for } \\
\text { sustainable products and services and } \\
\text { unsustainable subsidies should be } \\
\text { removed. }\end{array}$ & $\begin{array}{l}\text { Be the change you want to see } \\
\text { - Sustainable procurement by the public } \\
\text { sector. } \\
\text { - Development of a clear, bold, } \\
\text { appealing mission statement for the } \\
\text { EU (no jargon and based on values). } \\
\text { - Institutional reform - promote more } \\
\text { policy coherence. }\end{array}$ \\
\hline $\begin{array}{l}\text { Adapted spatial planning/policy } \\
\text { - Re-invention of planning (urban and } \\
\text { rural). } \\
\text { - Urban planning - stop urban sprawl } \\
\text { and public transport for low-income } \\
\text { groups. } \\
\text { - Better land-use management. }\end{array}$ & $\begin{array}{l}\text { Genuinely integrate sustainability in } \\
\text { policy actions and monitoring of } \\
\text { sustainability } \\
\text { - Additional indicators: not just GDP. } \\
\text { - Sustainability criteria in every area of } \\
\text { policy. } \\
\text { - Integration of a wider range of ideas } \\
\text { from social sciences. } \\
\text { - Promote / define education on smart } \\
\text { consumption. } \\
\text { - "Citizen Education". }\end{array}$ \\
\hline $\begin{array}{l}\text { Establish infrastructures that support } \\
\text { sustainable behaviour } \\
\text { - Definition of infrastructure. } \\
\text { - Walk/cycle infrastructure. } \\
\text { - Infrastructure normalising sustainable } \\
\text { behaviour (public transport, recycling } \\
\text { systems, shorter commutes, food } \\
\text { delivery). }\end{array}$ & $\begin{array}{l}\text { Enable and empower } \\
\text { - Pilot things that currently seem } \\
\text { radical/impossible. } \\
\text { - EU should support local-level decision } \\
\text { making. }\end{array}$ \\
\hline
\end{tabular}




\section{Chapter 2: Overview of tools and approaches towards sustainable consumption}

The first section of this chapter provides an overview inventory based on a literature review of the different tools, which are used to promote sustainable consumption, including approaches to changing consumer behaviour based on behavioural economics and other areas of social sciences. This section provides brief descriptions of the tool in question and examples of how the tool is used in practice.

The second section of the chapter proposes a classification for the behavioural approaches identified. The literature reviewed covers a large array of sources including NGOs (e.g. WWF), academia, journals, reports, international organisations (e.g. OECD, UNEP), European institutions (e.g. EEA, European Commission, DG Sanco), and MS institutions (e.g. Sustainable Development Commission, UK). A full list of the sources used for the development of the inventory table of tools is included in the Annex of this document.

The inventory table of tools (Table 10) serves as a basis for the following chapters by providing a detailed overview and basic information concerning existing and potential policy tools used to influence consumer behaviour. Tools in the table include both public policy tools and tools that are used in the private sector by actors such as banks, independent organisations and retailers. The inventory serves as an important information base for identifying relevant case studies, and the 9 collections of policy tools and key sectors for promoting sustainable consumption. Therefore, examples of how the tool can be used or case studies of the tool in real world use are also included in the inventory table.

The inventory table of tools includes information on 4 tool categories (regulatory, economic, information, and behavioural) and the specific policy instruments that they cover. It should be noted that for regulatory, economic, and information tools, they can be either mandatory or voluntary. For example, mandatory tools would include the bans on the use of incandescent light bulbs (regulatory tool), environmental taxation (economic tool), and the EU energy label (information tool).

The following sections describe the information provided in Table 10 in further detail.

\subsubsection{Tool categories}

\section{Regulatory tools}

Regulatory tools aim at influencing consumer behaviour through laws, directives and regulations. Regulatory tools generally target local/national authorities, producers or retailers, rather than consumers e.g. ban on incandescent light bulbs, EU waste directive. Under the 
regulatory tools category, several sub-categories are included to describe the ways in which they influence consumption.

The sub-category "injunction tools" refers to "command" tools that obligate the targeted audience to comply. These tools are usually mandatory and require some degree of enforcement and monitoring measures. Examples include policies which completely remove or ban environmentally harmful products (e.g. incandescent light bulbs) and policies that may constrain the consumer to behave in a certain way - as in the case of waste separation (i.e. prohibition to throw certain dangerous products into the "normal" household waste stream).

'Lead-by-example' tools refer to tools or actions that governments use to demonstrate the appropriate behaviours, standards and methodologies, and help to establish new social norms. Many lead-by-example tools can also be considered information provision tools as they as inform the public of government activities. Actions that governments take to be a 'good role model' in sustainable consumption could encourage consumers to do the same, as well as increase trust of citizens in government Tools such as green public procurement and government investment in socially-responsible businesses and projects send the message to consumers that governments are also doing their part in consuming more sustainably. Furthermore, green public procurement can play a potentially key role in sustainable consumption, especially since public procurement represents $17 \%$ of EU GDP ${ }^{20}$. An increased amount of "green" purchases by public authorities would not only help to develop awareness among managers, workers, and public opinion but would also increase demand for greener products and help them penetrate the market, which in turn could also reduce the price of green products.

\section{Economic tools}

Economic tools are market-based instruments, mainly employed by governments to influence and monitor the economy by adjusting taxes and/or public spending (expenditure). Economic tools often influence the price of goods and services, and directly distort consumer preferences. However, it should be noted that private business often have the final say over the final price of goods and services depending on their tax prescriptions. Market-based instruments help internalise negative externalities and allows the market to play the critical role of changing purchasing patterns ${ }^{21}$. In general, economic tools, such as taxes and charges, will influence consumers only if the financial stimulus is strong enough to enter the decision-making process (i.e. taxes need to be set at a sufficiently high level to influence consumer-purchasing decisions). In other words, economic tools can be used to make environmentally friendlier products more competitive and affordable for consumers as well as make environmental harmful products more expensive to discourage their consumption.

\footnotetext{
${ }^{20}$ EC, DG Enterprise, Workshop on "Promoting Innovation Through Public Procurement:

Best Practice \& Networking" Brussels, 23-24 March 2010, Available online: ec.europa.eu/enterprise/policies/innovation/policy/lead-market-initiative/files/draft_agenda_pp_en.pdf

${ }^{21}$ OECD, 2008, Promoting Sustainable Consumption: Good Practices in OECD Countries
} 
Subsidies and other financial incentives are an example of economic tools given by governments as "carrots" to encourage consumers and households to make more sustainable product and service selections. These include for example, subsidies for energy-efficient products, or fiscal incentives in the form of tax reductions or tax exemptions. For example, the Swedish Government has decided that to exempt new fuel-efficient cars from vehicle tax for five years. This new law came into force starting 1 January $2010^{22}$.

Economic tools can also come in the form of trading/purchasing schemes (e.g. green credit cards operated by financial institutions) to encourage the purchase of green products by facilitating purchasing schemes (credit cards with low interest to purchase green products) or trading schemes (e.g. the EU emissions trading scheme which can encourage the uptake of environmentally friendly goods). Less traditional trading schemes also exist that are directly targeted at consumers. An example is seen in the "Swap-o-matic" programme, which was started in New York City. The programme attempts to promote the recycling of objects through the interface of a vending machine, which features used rather than new products. Each item in the Swap-O-Matic machine is donated by another user and does not cost the recipient any money, although it requires "credits". Credits are earned when the user donates to the system, and a credit is required to retrieve an item from the machine ${ }^{23}$. Local exchange trading schemes (LETS) and time banks are locally based skill-swapping schemes, which aim to rebuild local communities ${ }^{24}$. Members use a local currency for transactions and individuals match "wants" and "offers" by consulting a directory and then making direct arrangements. Time banks work similar to LETS, except that the unit of currency is time, in which time for enacting certain activities and services (e.g. helping senior citizens, watching pets, etc.) are "traded".

Economic tools can be combined, as in the case of the "Bonus-Malus" system, which provides grants or tax exemption ("bonus") to consumers who buy greener products and/or, at the contrary, apply additional fees ("malus") on purchases of less green alternative. France has implemented the Bonus-Malus systems to promote the purchase of greener cars and eliminating older and inefficient cars.

The social costs of environmental policies may act as a barrier to sustainable consumption, as described in Box 1 below, which also provides insight into good practice for design of fiscal tools.

Box 1: Social cost of environmental policy and design of fiscal tools

The main objectives of environmental policy have typically been to maximise economic and environmental efficiency, in order to maintain economic competition, while the social impacts of environmental policies are still often seen as competing with environmental objectives. However, social costs need to be considered to ensure that sustainable consumption is possible for all.

Oftentimes, prices increase for certain goods and services to reflect their 'cost' to the environment. Prices and costs principally depend on price elasticity of the goods concerned - in

\footnotetext{
${ }^{22}$ Swedish Ministry of Environment, www.sweden.gov.se/sb/d/1176o/a/122175

${ }^{23}$ www.swap-o-matic.com/

${ }^{24}$ Seyfang, Gill, 2009, The New Economics of Sustainable Consumption: Seeds of Change
} 
other worlds the \% that consumers are willing to decrease their consumption when prices increase a certain \%. This elasticity varies based on the good and the (income) category of households. The cost of environmental policy measures therefore depends on households ability to adjust their consumption and to sacrifice a certain amount of well-being associated with these efforts (trade-offs); hence, there are repercussions of these increased costs on households which is not always distributed in a balanced and equitable way. Several studies indicate that it is essentially modest households that are impacted by the cost of environmental measures and therefore environmental policy can have regressive effects. ${ }^{25,26}$

The UK's Fuel Poverty Strategy is an initiative that addresses the distributional issues of environmental policy ${ }^{27}$. This strategy targets all households whose energy consumption exceeds $10 \%$ of income to meet their heating needs, with particular attention to vulnerable populations (elderly, children, sick or disabled).

\section{Information provision and awareness raising}

Information provision and awareness raising tools are those that aim at providing information on a product or service (e.g. product qualities, certification, how to use the product, etc.) to consumers, with the hope that informing the consumer or raising awareness about certain product attributes will influence consumer behaviour. It is often assumed that when individuals make poor choices it is due to misinformation or lack of information. Because of its political acceptability, information provision is often used in policies to influence consumer behaviour. The limitations of information provision demonstrate that consumers rarely search out, read or properly digest all of the information available to them when making a decision. The type, complexity and amount of information provided, and the way in which it is presented, all have a significant impact on the likelihood of people reading and understanding. Therefore, it is important to strike a balance between providing enough information to inform discerning consumers, while also meeting regulatory requirements (on information that has to be provided) and ensuring that less concerned consumers are not overwhelmed by information. Examples of information provision tools include education programmes, labels, websites, printed materials, marketing and advertising campaigns, and capacity building and training of sales personnel.

Despite the challenges that information provision presents, it is an important tool to consider towards promoting sustainable consumption. Box 2 below describes how information provision can be used in an effective manner in order to positively influence sustainable consumer purchasing decisions.

\section{Box 2: Effective display of environmental information}

Providing product or service environmental performance information to consumers is critical, particularly at the point of sale, where purchasing decisions often take place. Once consumers are aware that products entail certain environmental impacts and that some have higher

\footnotetext{
${ }^{25}$ OECD, 2006, The distributional effects of environmental policy

${ }^{26}$ CEDD, 2011, Préservation de l'environnement, équité et accès aux services essentiels

${ }^{27}$ UK Department of Energy and Climate website: 
environmental performance compared to others, the implementation of more stringent tools such as taxes or products bans may become more politically acceptable.

A key aspect of information provision is how and what information is displayed to the consumer. Provision of information must be usable. Optimal communication tools differ based on the type of product addressed, the type of consumer targeted, and the context of the purchasing situation (e.g. in-store versus on-line shopping), etc.

The following aspects should be considered to ensure that environmental information is being effectively communicated to consumers:

- What to communicate: Information must be clear and simple for consumers to understand, while simultaneously sufficient to influence consumers to make an informed purchasing decision.

- How to communicate: This aspect is related to the design and physical appearance of the information. Studies indicate that the use of a scaling system to display environmental information and performance would enable consumers to rank and compare environmental performance between products ${ }^{28}$. This could then facilitate their understanding of environmental impacts, which would hopefully then influence their purchasing decision. Labels that present the performance of a product on a comparative scale such as stars, letters or numbers, or a colour coding system are vastly preferred and are more easily understood and motivating than those that present technical information only.

- Where to communicate: Where information is located is an essential aspect related to how the consumer will process information. It seems clear that information must be provided at the point of purchase, as this is often when consumers make their purchasing decision.

The French Ministry of the Environment is currently running the French national experimentation on the display of environmental information. The government has announced its aim to adopt a mandatory labelling scheme but final decision will be made after an experimental period of at least one year starting $1^{\text {st }}$ of July 2011. Therefore, the French Ministry for Sustainable Development (MEDDTL) ${ }^{29}$ is to carry out a national experimentation for the environmental display of products. Companies (retailers or producers) and trade associations of all sizes and from every sector (Food products, beverages, equipments, clothes, publishing, etc.) were invited to join the national experiment on a voluntary basis. It is expected that this preliminary largescale testing will provide valuable feedback on optimizing conditions for environmental labelling in France thanks to the variety of stakeholders and sectors covered by the experimentation. Some important findings have already been established by the national experimentation. These include the following observations :

- In general, a maximum of three different environmental indicators should be

\footnotetext{
${ }^{28}$ BIO Intelligence Service, 2011, Ongoing study for the European Commission on " Different options for products' environmental information communication »

${ }^{29}$ Ministry of Ecology, Sustainable Development, Transport and Housing - French: Ministère de l'Écologie, du Développement durable, des Transports et du Logement
} 
communicated (when communicating multi-criteria environmental information).

- Environmental impacts shall be communicated with the absolute value to ensure transparency and to consumer education (however, a synthesis of the criteria can be proposed by mean of a unique mark, colour, or logo.

- Results must be put in context, compared or comparable to a familiar order of magnitude such as reference product, an average of the market, an order of magnitude (kilometres, number of showers etc.)

- The consumer must be able to assess the product within a short timeframe

Finally, communication tools such as environmental product labels also lead to development of tools for quantifying the impact of products and services, important because it can allow investigation of benchmarks, not only for consumers, but also for retailers, manufacturers, and policy makers. This could further encourage manufacturers to offer more environmentally friendly products (e.g. due to competitive advantage gained). Quantified environmental impacts can also identify areas for improvement potential and comparison across product groups and market segments, preparing the ground for mandatory measures, and increasing political acceptability of this potential future policy approach.

\section{Behavioural tools}

The use of information provision as a policy tool (discussed in the previous paragraph) to change behaviour is greatly linked to neo-classical economics and the idea that individuals are purely rational decision-makers. The 'homo economicus' or 'economic man' is an entirely rational individual blessed with access to perfect information, motivated entirely by self-interest and a desire to maximise their own welfare, and possessing the cognitive abilities to accurately weigh the costs and benefits of any given course of action ${ }^{30}$. In reality, consumer decision-making is subject to a host of internal and external factors that bias decisions and over-turn preferences. Therefore, behavioural tools aim at influencing consumer behaviour (e.g. targeting consumers' feelings, influence of others, influence of social norms, etc.) based on a broad field of domains such as psychology, sociology and cultural studies. Behavioural tools have been used for a long time in areas such as health and safety.

A recent study ${ }^{31}$ identified seven underlying principles of human behaviour and psychology and its impact on consumption. These seven principals are:

1. Other people's behaviour matters: people do many things by observing others and copying; people are encouraged to continue to do things when they feel other people approve of their behaviour.

\footnotetext{
${ }^{30} \mathrm{PSI}$ et al., 2009, Designing policy to influence consumers: Consumer behaviour relating to the purchasing of environmentally preferable goods

${ }^{31}$ New Economics Foundation, 2007Behavioural Economics: Seven Principles for Policymakers
} 
2. Habits are important: people do many things without consciously thinking about them. These habits are hard to change - even though people might want to change their behaviour, it is not easy for them. In other words, old behaviours have to be unlearned.

3. People are motivated to 'do the right thing': there are cases where money is demotivating as it undermines people's intrinsic motivation, for example, you would quickly stop inviting friends to dinner if they insisted on paying you.

4. People's self-expectations influence how they behave: they want their actions to be in line with their values and their commitments.

5. People are loss-averse and hang on to what they consider 'theirs'.

6. People are bad at computation when making decisions: they put undue weight on recent events and too little on far-off ones; they cannot calculate probabilities well and worry too much about unlikely events; and they are strongly influenced by how the problem/information is presented to them. Therefore, immediate feedback and reaction is important.

7. People need to feel involved and effective to make a change: just giving people the incentives and information is not necessarily enough.

The behavioural tools listed in the inventory table have been included with some of the above principals of human behaviour and decision-making in mind. Principal 1 above corresponds with tools that make use of the role of "advocates" and endorsement (such as celebrities, philanthropists, civil society activists, etc., to convey and influence the behaviour of others). Furthermore, tools that allow for comparative evaluation of one's own behaviour with the performance/behaviour of others can motivate individuals to improve their own behaviour (e.g. allowing for a benchmark for one's own energy consumption compared to the performance of others). Peer rating builds upon the influence of how others rate products and services and the choices others make in one's social circle, such as family, neighbours, friends, community, workplace, etc. These tools correspond to the first principal listed above.

Public/community participation is also listed under behavioural tools and corresponds to principal 7 above. Inciting people to participate and be involved in the political decision making process as well as changing things locally can be empowering. There are many examples of locally based community participation initiatives that have proven to be successful (e.g. Transition towns and Eco-teams). By involving consumers who are at the root of both causes and solutions of sustainable consumption challenges, transparency and accountability are also more likely to be achieved.

Pledges and commitments correspond to principals 3 and 4 above. Commitments are an important aspect of human behaviour because generally speaking, when individuals agree to a small request, it often alters the way they perceive themselves. For example, when individuals sign a petition favouring the building of a new recycling facility, the act of signing subtly alters their attitudes on the topic. They come to view themselves as the type of person who supports initiatives for recycling and increases the likelihood that they will later act in a way that is 
consistent with new attitudes. ${ }^{32}$ In a recent field experiment, results showed that obtaining a signed commitment increased kerbside recycling in the community more than receiving a flyer, a telephone call or personal contact alone ${ }^{33}$. Studies also show that written commitments appear to be more effective than verbal commitments. Further, making commitments public, actively involving the person, and seeking commitments in groups can also be effective.

Nudge tools could be linked to principal 2 and 6 because consumers often do not take the time to fully think about or weigh their decisions and thus often act in the easiest manner - and stick to their habits. A nudge is a small change in the social context that makes behaviour very different without forcing anyone to do anything. Therefore, nudge tools are those that enable and make easy sustainable choices for consumers. Nudge-type tools impose no mandates and instead, with strategic combinations of framing, informing, and encouragement, nudge tools can inspire voluntary decisions to eat healthier and consume more wisely. The concept behind nudges is "libertarian paternalism" which implies that it is possible to maintain freedom of choice (libertarian) while also moving people in directions that make their own lives a bit better (paternalism). Examples of how nudge-type tools have been used in the real world include removing the trays for people who eat at the self-service restaurant on a university campus, which immediately reduced the portions the students took for themselves and reducing food wastage by an average of $50 \%{ }^{34}$. Another well-known example of a nudge is seen in initiatives to reduce the number of plastic bags by not providing customers with plastic bags at checkouts. This obliges customers to ask for or even pay for them encouraging people to favour alternative options, such as reusable bags.

\footnotetext{
${ }^{32}$ Fostering Sustainable Behaviour website $: \underline{w w w . c b s m . c o m / p a g e s / g u i d e / c o m m i t m e n t ~}$

${ }^{33}$ Fostering Sustainable Behaviour website : www.cbsm.com/pages/guide/commitment

34 Centre d'Analyse Strategique, "Green nudges": new incentives for ecological behaviour, www.strategie.gouv.fr/IMG/pdf/2011-03-09-NA-216-NudgesVertsGB-2.pdf
} 


\section{Box 3: Thaler's concept of nudges}

Richard Thaler is considered one of the founding fathers of the concept of nudge. He recently published a book, Nudge (2008) on the potential of using nudges in policy to change behaviour. Some of the major ideas of his book are resumed below:

- Public policy can exploit the general passiveness and inertia of individuals by providing default options that lead individuals to make smarter and more beneficial decisions. Thaler proposes for example to automatically open a savings plan for employees, rather than leaving them the choice. Studies show that when opening a savings plan is automatic, the salary savings rate from 20 to $90 \%$. Thaler also suggests that the framing (the way the decision is out into context or the language that is used is also a very effective nudge).

- Individuals need nudges especially when faced with particularly tough and uncommon decisions of which we do not know the impact. Business and marketers are very much aware of consumers' difficulty in making decisions in certain circumstances and have been able to develop marketing strategies to exploit the "indecision" of consumers.

- Choice architecture is also essential in terms of fully manipulating the nudge concept. Choice architecture refers to the organization and framing (which is not meant to be neutral) of the context in which we make decisions. Every detail and the creation of this decision making environment can guide individuals in a given direction. This concept covers several dimensions such as choosing a good default option that prevents consumers from having to constantly make decisions and then to confirm them. For example, in London, there are indications on the sidewalk for pedestrians at each street crossing to "look right" so avoid car accidents. The nudge concept simplifies complex options and implements measures that incentivise consumers to make the right decisions.

\subsubsection{Environmental communication strategies}

The European Environmental Communication Networks (EECN) is part of a European Commission initiative started in May 2002 to provide an overarching secretariat for all European networks that are active in the field of public information, communication and awareness raising about environmental issues. The EECN provides many resources, best practices and facilitates knowledge exchange on environmental communication ${ }^{35}$. Information is available by theme ${ }^{36}$, targeted group ${ }^{37}$ and communication means ${ }^{38}$. Descriptions and contact details of environmental

\footnotetext{
35 ec.europa.eu/environment/networks/bestpractice_en.htm

${ }^{36}$ Waste management, climate change and energy, environment and biodiversity, sustainable consumption and development.

${ }^{37}$ Kids and young people, general public, special target audiences.
} 
communication networks active in the field of environmental public information, communication and awareness-raising are also provided ${ }^{39}$. Some extracts from these guidelines are included below.

\section{General principles of environmental communication $4^{40}$}

- "Important factors of success include content, messenger, choice of media and tone. Experts are coming to realise that traditional messages from governments and green groups urging the public to adopt the environment into their day-to-day decisions need to be overhauled. Many of these messages are simply too patronising, guilt-laden or disapproving. Instead of turning people on to the environment, they risk switching them off. The lesson to be learned is that communication styles have to be positive and tailored to different circumstances and cultural contexts." (Klaus Töpfer, executive director UNEP, 2005)

- Communication must be supported by other measures in policy or infrastructure. Obviously encouraging recycling is useless if an efficient and accessible waste collection system is absent. Consistency between words and actions is key.

- Attitude change campaigns can shift public opinion; this is an easier target than behaviour change (which can take a generation to come into effect) and can provide the appetite for radical policy change.

- Do not underestimate the abundance of diverse marketing messages in the usual channels and the resulting dilution in our information overloaded world. Institutions might use alternative channels. For example Hungary used national airport exhibition and leaflets in travel agencies to communicate around trafficking of endangered species.

- Targeting a specific audience with a specific message is cheaper and more effective than large advertising campaigns.

- Think like a storyteller; use the drama of the challenges and the excitement of the solutions to make the message inspiring and motivating. Do not use jargon.

\footnotetext{
${ }^{8}$ Communication tools and materials, communication initiatives and projects, communication campaigns, communication guides.

${ }^{39}$ ec.europa.eu/environment/networks/networks_en.htm

$4^{0}$ UNEP (2005) Communicating sustainability. Available at: www.unep.fr/shared/publications/pdf/DTIx0679xPACommunicatingEN.pdf
} 
- Plan your communications:

Understand the situation before starting

Conduct audience research

Set clear and achievable objectives

Define message(s) and channel(s)

Plan how you will manage the campaign as it progresses

Measure and evaluate the communication

\section{New tools for communication campaigns: Social media ${ }^{41}$}

"If Facebook were a country, it would be the third most populated in the world ${ }^{42 "}$.

As is indicated by the above citation, social media is now the number one activity on the web today. Consequently, social media marketing now represents a fundamental segment of the overall communication strategy of most organisations. Social media can also directly serve environmental communication. It can be used with very limited cost and under various forms such as Internet forums, blogs, pictures, videos or networking. Several major international NGOs and organisations have already taken into account the importance of these new media for awareness-raising campaigns (e.g. EC's 2010 campaign on biodiversity, UNEP's flagship 'Billion Tree campaign'). Following are important guidelines to keep in mind when launching environmental campaigns using social media:

- Start by preparing a strategy: establishing a frame of action, precise objectives, different campaign outcome scenarios, and rules and guidelines for the team members.

- Ask for easy commitments: this includes for example signing an online petition. Asking for a donation or a personal commitment works less well than for actions that are less engaging. Social media campaigning is therefore more adapted to objectives that do not seek to trigger complex actions.

- Communication is crucial; therefore it is important that organisations are courteous in a press-relations context. Specifically in the case of environmental campaigns, supporters can often get emotional or aggressive, which can have a negative impact on the campaigns.

\footnotetext{
${ }^{41}$ http://ec.europa.eu/environment/networks/doc/newsflash/Newsflash 88.pdf

42 http://www.thetechherald.com/article.php/201029/5922/Facebook-population-equivalent-to-third-biggest-countryon-Earth
} 
- Pay close attention to the content posted online: using social media for environmental campaigns implies risks such as pirating of ideas and data, identity theft, copyright issues, and lawsuits for defamation.

- Makes full use of the functionalities offered by the various networks (e.g. the "like" feature and "comment" box on Facebook).

Table 9 lists the main social media websites. Facebook and Youtube are particularly valuable networks for reaching large numbers of users, and have been utilised by a range of organisations, from automobile corporations to NGOs, to communicate with individuals. Twitter provides a platform for individuals or organisations to make comments on personal or current affairs - to receive these, users opt to follow the individual or organisation. Linkedln is used mainly for professional networking purposes. Flickr and Myspace are predominantly used for the arts, and smaller social or interest groups.

Table 9: Major social media websites

\begin{tabular}{|l|l|c|c|l|}
\hline Network & \multicolumn{1}{|c|}{ Website } & $\begin{array}{c}\text { Year } \\
\text { created }\end{array}$ & $\begin{array}{c}\text { Number of } \\
\text { users (millions) }\end{array}$ & \multicolumn{1}{c|}{ Comments } \\
\hline Facebook & www.facebook.com & 2004 & 750 & Social networking \\
\hline Youtube & www.youtube.com & 2005 & 300 & Video sharing and video blogging \\
\hline Twitter & www.twitter.com & 2006 & 200 & $\begin{array}{l}\text { Social networking and microblogging } \\
\text { - enables its users to send/read text- } \\
\text { based posts of up to 140 characters }\end{array}$ \\
\hline Linkedln & www.linkedin.com & 2002 & 100 & Professional networking \\
\hline Flickr & www.flickr.com & 2004 & 81 & Image and video hosting \\
\hline Myspace & www.myspace.com & 2003 & 61 & Social networking \\
\hline
\end{tabular}

\section{Reaching out to targeted audiences: Young people ${ }^{43}$}

Awareness raising campaigns are often more effective when they are targeted towards specific audiences. One such example is of young people, who are key in getting environmental messages through to society at large. They can act as effective intermediaries, transmitting environmental messages to their families, and they represent the adults - citizens, consumers, workers - of tomorrow. Some general rules for effective environmental communication and education, relevant for teachers and communicators include:

- Help children to build a common definition and values around sustainability

- Underline the idea that action triggers change, "instead of a deterministic worldview"

- Try to generate a balance between passionate commitment and critical thinking among young people

${ }^{43}$ http://ec.europa.eu/environment/networks/doc/newsflash/newsflash79.pdf 
- Help students "to experience feelings of being action-competent for sustainable development" to enhance confidence to take action.

- Engage children and encourage them to participate in projects is a good way of involving them in their community and of raising their awareness on environmental issues

- Use multiple "child friendly principles", with activities reinforcing each other

- Involve local communities

\section{Best practice example: The Finnish National Teleworking Day ${ }^{44}$}

This initiative was the winner of the Green Spider Network 2011 Best Practice competition. The SYKE (Finnish Environment Agency) was strategic in selecting the date of the one-day campaign - it corresponded to the first day of European Mobility Week. This gave the campaign more symbolical impact and media coverage. The campaign was organised with a network of 22 organisations, representing a great diversity of private and public stakeholders. Microsoft was the main partner, providing technical skills and tools for the webpage, advertisement, attracted private companies, and organised a workshop. The principal strengths of the campaign include:

- Connect the campaign to a much larger event, already well known, to gain the attention of journalists and the public.

- The partnership between public and private actors to show that it is a topic that affects all employees and managers.

- The action of street marketing tips which were distributed for successful telecommuting day (have a computer with internet connection, settle into a comfortable, quiet rhythm to his day with work sequences interspersed with pauses nice ...).

- The message of the content and form of the action is important: it is not just to save miles and hours of drive, pleasure and well-being are at stake

- The use of several different distribution channels: a dedicated website, a Facebook page, a Twitter account, press inserts, and a street marketing campaign, which attracted widespread coverage in the traditional media and many discussions on social media.

${ }^{44}$ http://ec.europa.eu/environment/networks/doc/newsflash/Newsflash 90.pdf 


\subsubsection{Policy tools inventory and categorisation}

Before setting out the categorisation of policy tools, the following paragraphs introduce aspects of policy tools that are assessed and used to categorise the inventory. The information provided in Table 10 (the policy tool inventory) on these aspects should be taken as indicative, as they can vary widely depending on circumstances related to the objectives and how the tool is used within the initiative in question.

\section{Level of encouragement}

The column labelled level of encouragement (or enforceability/coerciveness of the tool) refers to the extent the tool category compels consumers to change their behaviour. For example, legal and regulatory tools may force consumers to comply towards certain behaviours to a greater degree compared to "softer" and less coercive tools such as labels or peer reviews. This is because often legal and regulatory tools carry sanctions such as fines, which "punish" consumers for not abiding by the policy measure. However, it should be noted that the coerciveness of certain regulatory tools also greatly depends on how they are implemented and the characteristics of sanctions. For the sake of consistency, in the inventory tool, all injunction tools are rated 4 (with 4 being most coercive as they usually include sanctions for non-compliance), fiscal tools and other economic tools are rated 3 , behavioural tools which seek to tap into social norms and identity are rated as 2, and lead-by-example tools and informational tools are rated 1.

\section{Who does the tool target?}

The column labelled 'who does the tool target?' refers to which actors a specific tool can be targeted. Depending on the overall objective of the tool, it can be targeted at different audiences. In the example of a tax, a tax can be targeted at consumers (e.g. a tax on household consumption of electricity), but also at private actors, such as retailers or manufacturers (e.g. specific tax on the use of a certain substance used in the production process). In other cases, tools are targeted for a more specific audience. For example, behavioural tools in sustainable consumption are often targeted at consumers as they affect the purchase phase of the consumption cycle. Tools that are not targeted directly at consumers, but directed instead at producers or retailers can nonetheless have an indirect impact on consumption through 'choice editing'. Choice editing refers to limiting the choice of non-sustainable products by banning certain substances and practices, setting product performance standards or removing these products from the market. For example, the EU's Ecodesign Directive for energy-related products sets minimum energy efficiency standards, which producers must comply to. This means that less efficient products are taken off the market, prohibiting consumers to purchase poorly performing products.

\section{Tool initiators and implementers}

Several different actors can be involved in the initiation and implementation of a tool. Oftentimes, this depends on the specific case in which the tool is being implemented. For example, in the case of national eco-labels, they are often initiated by national governments, such as the Blue Angel, and the local public authorities actually run the implementation and 
monitoring of the label (in terms of setting product criteria, monitoring and enforcement). Actors involved in the implementation and operation of tools to promote sustainable consumption include national governments, local public authorities, energy agencies, financial institutions, industries, retailers, consumers, independent organisations and consumer associations.

Tools that are used in initiatives to promote sustainable consumption can be public or private or both depending on the type of actor implementing the tool. Public tools are usually implemented by government and other public organisations, private tools implemented by businesses, manufacturers and other private organisations.

\section{Phase of the consumption cycle}

The inventory table also classifies specific tools into 4 broad categories based on which stage of the consumption cycle the tool is usually or can be used. These categories correspond to specific stages of consumption behaviour, whether it be during the stage of buying decision (information provision); during the actual purchase of the product (fiscal and other economic tools); during the use phase of the product or service (injunction tools such as limits and targets); or, at the end of life stage of the product in terms of disposal options (tools which provide adequate waste collection and treatment services). Classifying tools into these consumption phase categories could potentially assist policy makers by indicating which tools are available or appropriate based on which stage of the consumption cycle the policy is intended to be addressed by the policy. 
Table 10: Inventory of existing tools ${ }^{45}$

\begin{tabular}{|c|c|c|c|c|c|c|c|c|c|c|}
\hline \multicolumn{2}{|c|}{ Tools category } & Specific tools & $\begin{array}{l}\text { Encourage- } \\
\text { ment level } \\
(1 \text { to } 4)\end{array}$ & $\begin{array}{l}\text { Who does } \\
\text { the tool } \\
\text { target? }\end{array}$ & $\begin{array}{c}\text { Tool } \\
\text { initiators }\end{array}$ & $\begin{array}{c}\text { Tool } \\
\text { implementors }\end{array}$ & $\begin{array}{c}\text { Phase of the } \\
\text { consumption } \\
\text { cycle }\end{array}$ & Additional information & Case studies & $\begin{array}{l}\text { Further info. on } \\
\text { case studies }\end{array}$ \\
\hline \multirow{7}{*}{$\begin{array}{l}\text { Regulatory } \\
\text { tools }\end{array}$} & \multirow{4}{*}{ 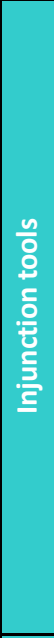 } & Bans & 4 & Manufacturers & Government & Government & Purchase & $\begin{array}{l}\text { Bans are ususally targeted at manufacturers, for ex. } \\
\text { on the use of certain chemicals in products, which } \\
\text { would have an indirect imact on consumption. }\end{array}$ & $\begin{array}{c}\text { Bans on the use of } \\
\text { incandescant lightbulbs } \\
\text { (EU) }\end{array}$ & $\begin{array}{l}\frac{\text { ec.europa.eu/energy/efficie }}{\text { ncy/ecodesign/doc/committ }} \\
\frac{\text { ee/2008 12 08 technical b }}{\text { eefing household lamps.pd }} \\
\frac{f}{\mathrm{riefin}}\end{array}$ \\
\hline & & Targets/limits & 4 & $\begin{array}{l}\text { Consumers, } \\
\text { authorities, } \\
\text { and } \\
\text { businesses }\end{array}$ & Government & Government & Use & $\begin{array}{l}\text { Targets are usually set with a defined indicator of a } \\
\text { measurable quantifiable limit, e.g. a reduction of } \\
\text { domestic material consumption by X\% compared to a } \\
\text { reference year. }\end{array}$ & $\begin{array}{l}\text { Limits on household use } \\
\text { of water (AUS) }\end{array}$ & $\begin{array}{l}\frac{\text { www.nwc.gov.au/www/html }}{2524-\text {-national-review-of- }} \\
\text { water-restrictions-in- } \\
\text { australia.asp?intSitelD=1 } \\
\end{array}$ \\
\hline & & $\begin{array}{l}\text { Standards (for } \\
\text { products and } \\
\text { services) }\end{array}$ & 4 & Manufacturers & Government & Government & - & $\begin{array}{l}\text { Similar to targets, product standards force } \\
\text { manufactuers to produce products that comply to a } \\
\text { mininum performance or energy efficiency standard, } \\
\text { else they are removed from the market. }\end{array}$ & $\begin{array}{l}\text { Energy efficiency } \\
\text { standards for energy- } \\
\text { using products (EU) }\end{array}$ & $\begin{array}{l}\text { ec.europa.eu/energy/efficie } \\
\begin{array}{l}\text { ncy/ecodesign/eco design e } \\
\text { n.htm }\end{array}\end{array}$ \\
\hline & & Polluter-pays & 4 & Manufacturers & Government & $\begin{array}{c}\text { Manufactuers, } \\
\text { govt. }\end{array}$ & End-of-life & $\begin{array}{l}\text { This tool can also be referred to as "extended } \\
\text { producer responsibility" (EPR). It stipulates that } \\
\text { producers be held accountable for their products end } \\
\text { of life impact or recycling. This is to help encourage } \\
\text { the use of less materials and design products to last } \\
\text { longer in order to cut costs. }\end{array}$ & $\begin{array}{l}\text { WEEE collection schemes } \\
\text { (EU) } \\
\text { Take-back schemes }\end{array}$ & $\begin{array}{l}\text { ec.europa.eu/environment/ } \\
\text { waste/weee/index en.htm }\end{array}$ \\
\hline & \multirow{3}{*}{ 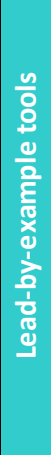 } & \multirow{2}{*}{$\begin{array}{l}\text { Green public } \\
\text { Procurement } \\
\text { (GPP) } \\
\end{array}$} & \multirow[b]{2}{*}{1} & \multirow[b]{2}{*}{$\begin{array}{c}\text { Public } \\
\text { authorities }\end{array}$} & \multirow[b]{2}{*}{ Government } & \multirow[b]{2}{*}{ Government } & \multirow[b]{2}{*}{ Purchase } & \multirow{2}{*}{$\begin{array}{l}\text { GPP is when public authorities integrate } \\
\text { environmental criteria into all stages of their } \\
\text { procurement process, thus encouraging the spread of } \\
\text { environmental technologies and the development of } \\
\text { environmentally sound products. Green public } \\
\text { procurement sends messages to consumers that govts. } \\
\text { are also doing their part in preserving the } \\
\text { environment and influence their own actions as well. }\end{array}$} & $\begin{array}{l}\text { EU Green public } \\
\text { procurement programme }\end{array}$ & $\begin{array}{l}\text { www.euractiv.com/en/susta } \\
\text { inability/public- } \\
\text { procurement-buying-- } \\
\text { green/article-117505 }\end{array}$ \\
\hline & & & & & & & & & $\begin{array}{l}\text { Canada's Office of } \\
\text { Greening Government } \\
\text { Operations }\end{array}$ & $\begin{array}{l}\text { www.tpsgc- } \\
\text { pwwsc.gc.ca/ecologisation- } \\
\text { greening/index-eng.html }\end{array}$ \\
\hline & & $\begin{array}{l}\text { Socially- } \\
\text { responsible } \\
\text { investment }\end{array}$ & 1 & $\begin{array}{l}\text { Socially } \\
\text { responsible } \\
\text { organisations }\end{array}$ & Government & $\begin{array}{l}\text { Government, } \\
\text { private and } \\
\text { public orgs. }\end{array}$ & - & $\begin{array}{l}\text { Similar to public procument, government investment } \\
\text { (or government grants/funds) in certain socially } \\
\text { accepted causes could increase consumer confidence } \\
\text { and trust in govt. }\end{array}$ & $\begin{array}{l}\text { Govt. funded projects } \\
\text { such as Defra's EAF } \\
\text { (Environmental Action } \\
\text { Fund) scheme }\end{array}$ & $\begin{array}{l}\text { http://archive.defra.gov.uk/c } / \mathrm{a} \\
\text { orporate/funding/eaf.htm }\end{array}$ \\
\hline
\end{tabular}

${ }^{45}$ Data for Who does the tool target, Tool initiators and Tool implementers is indicative, mentioning the most commonly found actors or targets. However, exceptions to these actors or targets are possible - for example: regarding GPP, the Government can set mandatory rules for local authorities; bans can be aimed at retailers. 


\begin{tabular}{|c|c|c|c|c|c|c|c|c|c|}
\hline Tools category & Specific tools & $\begin{array}{l}\text { Encourage- } \\
\text { ment level } \\
(1 \text { to } 4)\end{array}$ & $\begin{array}{l}\text { Who does } \\
\text { the tool } \\
\text { target? }\end{array}$ & $\begin{array}{c}\text { Tool } \\
\text { initiators }\end{array}$ & $\begin{array}{c}\text { Tool } \\
\text { implementors }\end{array}$ & $\begin{array}{c}\text { Phase of the } \\
\text { consumption } \\
\text { cycle }\end{array}$ & Additional information & Case studies & $\begin{array}{l}\text { Further info. on } \\
\text { case studies }\end{array}$ \\
\hline \multirow{11}{*}{ Economic tools } & \multirow{4}{*}{$\begin{array}{l}\text { Subsidies/incent } \\
\text { ives }\end{array}$} & \multirow[b]{2}{*}{3} & \multirow[b]{2}{*}{$\begin{array}{l}\text { Consumers, } \\
\text { manufacturers }\end{array}$} & \multirow[b]{2}{*}{\begin{tabular}{|c|}
$\begin{array}{c}\text { Government, } \\
\text { local } \\
\text { authorites, } \\
\text { private actors }\end{array}$ \\
\end{tabular}} & \multirow[b]{2}{*}{ Government } & \multirow[b]{2}{*}{ Purchase, use } & \multirow{2}{*}{$\begin{array}{l}\text { By raising prices on less sustainable products, taxes } \\
\text { can be effective in influencing consumer behaviour } \\
\text { towards sustainability. These tools help internalise } \\
\text { negative externalities and let the market play the } \\
\text { critical role of changing purchasing patterns. }\end{array}$} & $\begin{array}{l}\text { London congestion } \\
\text { charge }\end{array}$ & www.tfl.gov.uk/roadusers/c \\
\hline & & & & & & & & \begin{tabular}{|l|} 
Reducing household \\
water consumption \\
through a combination \\
of various taxes (DK) \\
\end{tabular} & $\begin{array}{l}\text { www.oecd.org/dataoecd/1/ } \\
\text { 59/40317373.pdf }\end{array}$ \\
\hline & & & & $\begin{array}{c}\text { Government, } \\
\text { local }\end{array}$ & & & $\begin{array}{l}\text { Subsidies and incentives are given by governments as } \\
\text { "carrots" to encourage consumers and households to } \\
\text { make more sustainable product and service } \\
\text { selections. These include monetary grants, donations } \\
\text { of goods and fiscal incentives in the form of tax }\end{array}$ & \begin{tabular}{|l|} 
Canada's ecoEnergy \\
Retrofit scheme (up to C\$ \\
5000 to improve energy \\
efficiency of homes)
\end{tabular} & 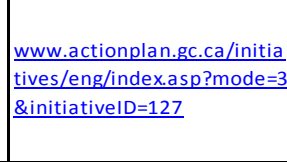 \\
\hline & & 3 & manufacturers & private actors & Government & Purchase & reductions. & Eco-cheque (FR, BE) & www.ecocheques.be \\
\hline & Loans & 3 & Consumers & \begin{tabular}{|c|}
$\begin{array}{c}\text { Government, } \\
\text { local } \\
\text { authorites, } \\
\text { private actors }\end{array}$ \\
\end{tabular} & $\begin{array}{l}\text { Government, } \\
\text { credit unions }\end{array}$ & Purchase & $\begin{array}{l}\text { Consumer loans such as green car loans encourage } \\
\text { the purchase of cars that demonstrate high fuel } \\
\text { efficiency. Most green car loans are being offered by } \\
\text { credit unions. }\end{array}$ & $\begin{array}{l}\text { Mecu's goGreen }{ }^{\circledast} \text { Auto } \\
\text { Loan (Aus) } \\
\text { Green Home Equity Loans }\end{array}$ & $\begin{array}{l}\text { www.mecu.com.au/Borrowi } \\
\text { ng/Loans/Car- } \\
\text { Loans/goGreen-car- } \\
\text { loan.html } \\
\end{array}$ \\
\hline & Bonus-malus & 3 & Consumers & Government & $\begin{array}{c}\text { Government, } \\
\text { manufacturers }\end{array}$ & Purchase & $\begin{array}{l}\text { Bonus-malus scheme: A financial reward (bonus) for } \\
\text { purchasers of environmentally friendly products (e.g. } \\
\text { cars) and a financial penalty (malus) for those buying } \\
\text { products emitting high levels of } \mathrm{CO} 2 \text {. }\end{array}$ & \begin{tabular}{|l|} 
Bonus-malus car scheme \\
(FR)
\end{tabular} & $\begin{array}{l}\frac{\text { www.notre- }}{\text { planete.info/actualites/actu }} \\
1456 \text { bonus malus achat } \\
\text { voitures France.php } \\
\end{array}$ \\
\hline & & & & & & & $\begin{array}{l}\text { Trading schemes can include more traditional trading } \\
\text { system such as the the EU emissions trading scheme }\end{array}$ & $\begin{array}{l}\text { EU emissions trading } \\
\text { scheme }\end{array}$ & \begin{tabular}{|l|} 
www.euractiv.com/en/clima \\
te-change/eu-emissions- \\
trading-scheme/article-
\end{tabular} \\
\hline & & & Government, & $\begin{array}{c}\text { Government, } \\
\text { manufacturer }\end{array}$ & $\begin{array}{c}\text { Government, } \\
\text { manufacturers, }\end{array}$ & & $\begin{array}{l}\text { which can encourage the uptake of environmentally } \\
\text { friendly goods or more alternative trading methods } \\
\text { such as the Swap-o-matic programme or local }\end{array}$ & \begin{tabular}{|l|} 
Personal carbon trading \\
\end{tabular} & 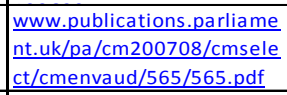 \\
\hline & Trading schemes & 3 & $\begin{array}{c}\text { private actors, } \\
\text { consumers }\end{array}$ & $\begin{array}{c}\text { s, local } \\
\text { communities }\end{array}$ & $\begin{array}{c}\text { local } \\
\text { communities } \\
\end{array}$ & Purchase & exchange trading systems. & $\begin{array}{l}\text { Local exchange trading } \\
\text { system }\end{array}$ & $\begin{array}{l}\text { www.cedworks.com/files/pd } \\
\text { f/free/P203FSS06.pdf }\end{array}$ \\
\hline & $\begin{array}{l}\text { Purchasing } \\
\text { schemes }\end{array}$ & 3 & Consumers & $\begin{array}{l}\text { Retailers, } \\
\text { local } \\
\text { governments }\end{array}$ & $\begin{array}{c}\text { Retailers, } \\
\text { financial } \\
\text { institutions }\end{array}$ & Purchase & $\begin{array}{l}\text { Purchasing schemes include tools such as savings } \\
\text { cards designed to provide a financial incentive for } \\
\text { consumers to purchase environmentally-friendly } \\
\text { products. Discount coupons or direct discounts at the } \\
\text { cash register can help consumers can become readily } \\
\text { acquainted with new or eco-friendly products. }\end{array}$ & $\begin{array}{l}\text { NU-spaarpas } \\
\text { (Rotterdam): points } \\
\text { forsustainable } \\
\text { purchases in exchange } \\
\text { for an admission ticket } \\
\text { to a movie, admission } \\
\text { ticket to an event, etc. } \\
\end{array}$ & $\begin{array}{l}\text { www.nuspaarpas.nl/www_e } \\
\text { n }\end{array}$ \\
\hline & $\begin{array}{l}\text { Green payment } \\
\text { schemes }\end{array}$ & 3 & Consumers & $\begin{array}{c}\text { Financial } \\
\text { institutions }\end{array}$ & $\begin{array}{c}\text { Retailers, } \\
\text { financial } \\
\text { institutions }\end{array}$ & Purchase & $\begin{array}{l}\text { Green credit cards are usually offered by large credit } \\
\text { card companies or banks and offer to make NGO, } \\
\text { projects such as the planting of new trees, or projects } \\
\text { that are related to sustainable energy. The instrument } \\
\text { does not actually change the purchase itself, but } \\
\text { method of payment that changes, ensuring that the } \\
\text { purchase become more environmentally responsible. }\end{array}$ & $\begin{array}{l}\text { Barclay's climate credit } \\
\text { cards }\end{array}$ & $\begin{array}{l}\text { www.barclaycard.co.uk/pers } \\
\text { onal-home/cards/breathe }\end{array}$ \\
\hline
\end{tabular}




\begin{tabular}{|c|c|c|c|c|c|c|c|c|c|}
\hline Tools category & Specific tools & $\begin{array}{c}\text { Encourage- } \\
\text { ment level } \\
(1 \text { to } 4)\end{array} \mid$ & $\begin{array}{l}\text { Who does } \\
\text { the tool } \\
\text { target? }\end{array}$ & $\begin{array}{c}\text { Tool } \\
\text { initiators }\end{array}$ & \begin{tabular}{c|} 
Tool \\
implementors
\end{tabular} & $\left|\begin{array}{c}\text { Phase of the } \\
\text { consumption } \\
\text { cycle }\end{array}\right|$ & Additional information & Case studies & $\begin{array}{l}\text { Further info. on } \\
\text { case studies }\end{array}$ \\
\hline \multirow{10}{*}{$\begin{array}{c}\text { Information } \\
\text { provision \& } \\
\text { awareness raising }\end{array}$} & & & & & & & \multirow{2}{*}{$\begin{array}{l}\text { Implementation of educational programmes or } \\
\text { developing curricula on sustainable development, } \\
\text { which generally include material for promoting } \\
\text { sustainable consumption. }\end{array}$} & Food dudes programme & $\begin{array}{l}\text { www.fooddudes.co.uk/en/ev } \\
\text { idence/ }\end{array}$ \\
\hline & $\begin{array}{l}\text { Education } \\
\text { programmes }\end{array}$ & 1 & $\begin{array}{l}\text { Children and } \\
\text { consumers }\end{array}$ & $\begin{array}{l}\text { Government } \\
\text { and } \\
\text { assocations }\end{array}$ & Local authorities & All phases & & \begin{tabular}{|l|} 
Foundation for \\
Environmental Education \\
(FEE)
\end{tabular} & $\begin{array}{l}\text { www.fee- } \\
\text { international.org/en } \\
\end{array}$ \\
\hline & \multirow[b]{2}{*}{$\begin{array}{l}\text { Publicity \& } \\
\text { marketing }\end{array}$} & \multirow[b]{2}{*}{1} & \multirow[b]{2}{*}{ Consumers } & \multirow{2}{*}{$\begin{array}{l}\text { Governments, } \\
\text { private } \\
\text { actors, } \\
\text { associations }\end{array}$} & \multirow{2}{*}{$\begin{array}{c}\text { Retailers, } \\
\text { manufacturers, } \\
\text { gov. }\end{array}$} & \multirow[b]{2}{*}{ Purchase } & \multirow{2}{*}{$\begin{array}{l}\text { Marketing tools can come in large variety (TV, posters, } \\
\text { etc) and can be done inside outside of stores, online, } \\
\text { etc. In addition to private commercial media to } \\
\text { influence consumer behaviour, public service media } \\
\text { can also be used to offer alternative perspectives on } \\
\text { consumption (e.g. health effects of smoking, etc.) }\end{array}$} & $\begin{array}{l}\text { FR/UNEP: the on-line } \\
\text { Creative Gallery on } \\
\text { Sustainable } \\
\text { Communications }\end{array}$ & $\begin{array}{l}\text { http://www.uneptie.org/scp } \\
\text { Lcommunications/ads.htm }\end{array}$ \\
\hline & & & & & & & & Marketing within stores & \begin{tabular}{|l|} 
www.mdpi.com/2071- \\
$1050 / 1 / 4 / 815 /$ pdf \\
\end{tabular} \\
\hline & \multirow{2}{*}{$\begin{array}{l}\text { (ICT) } \\
\text { Information and } \\
\text { communication } \\
\text { technology }\end{array}$} & \multirow[b]{2}{*}{1} & \multirow[b]{2}{*}{ Consumers } & \multirow{2}{*}{$\begin{array}{l}\text { Governments, } \\
\quad \text { private } \\
\text { actors, } \\
\text { associations }\end{array}$} & \multirow[b]{2}{*}{$\begin{array}{c}\text { Retailers, } \\
\text { manufacturers, } \\
\text { gov. }\end{array}$} & \multirow[b]{2}{*}{ Purchasing } & \multirow{2}{*}{$\begin{array}{l}\text { Specific ICT tools that consumers can use to obtain } \\
\text { information on environmentally-friendly products. }\end{array}$} & $\begin{array}{l}\text { UK's Red/Green } \\
\text { calculator }\end{array}$ & $\begin{array}{l}\text { www.mtprog.com/cms/retai } \\
\text { ler/ }\end{array}$ \\
\hline & & & & & & & & \begin{tabular}{|l|} 
TopTen website on \\
energy-efficient products
\end{tabular} & www.topten.info \\
\hline & $\begin{array}{l}\text { Employee } \\
\text { training/retailer } \\
\text { communication } \\
\text { methods }\end{array}$ & 1 & Consumers & Retailers & $\begin{array}{c}\text { Retailers, } \\
\text { manufacturers, } \\
\text { independent orgs. }\end{array}$ & - & $\begin{array}{l}\text { Retailers have great potential to promote sustainable } \\
\text { consumption to their customers because of the } \\
\text { privileged position that this industry holds as } \\
\text { intermediary between producers and customers. } \\
\text { Methods includes for example training of salesperson } \\
\text { with product information and marketing techniques to } \\
\text { influence consumer purchases. }\end{array}$ & \begin{tabular}{|l|} 
Retailer communication \\
to promote sustainable \\
consumption
\end{tabular} & $\begin{array}{l}\text { www2.medioambiente.gov. } \\
\text { ar/ciplycs/documentos/arch } \\
\text { ivos/Archivo 126.pdf }\end{array}$ \\
\hline & $\begin{array}{l}\text { Corporate } \\
\text { reporting }\end{array}$ & 1 & $\begin{array}{l}\text { Private and } \\
\text { public } \\
\text { organisations }\end{array}$ & \begin{tabular}{|l} 
Government, \\
Private actors
\end{tabular} & $\begin{array}{c}\text { Business, } \\
\text { governments, } \\
\text { independent orgs. }\end{array}$ & - & $\begin{array}{l}\text { Corporate sustainability reporting is used by } \\
\text { companies to inform consumers of their social and } \\
\text { environmental values and practices beyond the } \\
\text { sustainability characteristics of individual products. }\end{array}$ & $\begin{array}{l}\text { Global reporting } \\
\text { initiative }\end{array}$ & $\begin{array}{l}\text { www.globalreporting.org/Ho } \\
\text { me }\end{array}$ \\
\hline & $\begin{array}{l}\text { Labels with } \\
\text { product } \\
\text { information }\end{array}$ & 1 & Consumers & $\begin{array}{l}\text { Governments, } \\
\quad \text { private } \\
\text { actors, } \\
\text { associations }\end{array}$ & $\begin{array}{l}\text { Govt., Retailers, } \\
\text { manufacturers, } \\
\text { independent orgs. }\end{array}$ & Purchase & $\begin{array}{l}\text { An environmental label provides the consumer with } \\
\text { product environmental information or information } \\
\text { about its impact on the environment. A label may be } \\
\text { affixed to the packaging itself, on accompanying } \\
\text { documentation, on general tickets, etc. }\end{array}$ & $\begin{array}{l}\text { Casino's carbon } \\
\text { labelling initiative }\end{array}$ & $\begin{array}{l}\text { www.foodproductiondaily.c } \\
\text { om/Supply-Chain/French- } \\
\text { retailer-in-green-labelling- } \\
\text { initiative }\end{array}$ \\
\hline & $\begin{array}{l}\text { Labels with } \\
\text { certifications or } \\
\text { quality marks }\end{array}$ & 1 & Consumers & $\begin{array}{l}\text { Governments, } \\
\quad \text { private } \\
\text { actors, } \\
\text { associations }\end{array}$ & \begin{tabular}{|c|} 
Govt., Retailers, \\
manufacturers, \\
independent orgs.
\end{tabular} & Purchase & $\begin{array}{l}\text { These labels do not usually contain product } \\
\text { information but assurance and guarantee that an } \\
\text { independent outside party has determined that a } \\
\text { product meets all environmental criteria. }\end{array}$ & European Eco-label & $\begin{array}{l}\text { ec.europa.eu/environment// } \\
\text { ecolabel }\end{array}$ \\
\hline
\end{tabular}




\begin{tabular}{|c|c|c|c|c|c|c|c|c|c|}
\hline Tools category & Specific tools & $\begin{array}{c}\text { Encourage- } \\
\text { ment level } \\
(1 \text { to } 4)\end{array}$ & $\begin{array}{l}\text { Who does } \\
\text { the tool } \\
\text { target? }\end{array}$ & $\begin{array}{c}\text { Tool } \\
\text { initiators }\end{array}$ & Tool & $\begin{array}{c}\text { Phase of the } \\
\text { consumption } \\
\text { cycle }\end{array}$ & Additional information & Case studies & $\begin{array}{l}\text { Further info. on } \\
\text { case studies }\end{array}$ \\
\hline \multirow{9}{*}{ Behavioural tools } & Peer rating & 2 & Consumers & $\begin{array}{c}\text { Private } \\
\text { businesses }\end{array}$ & $\begin{array}{l}\text { Consumers, } \\
\text { retailers, } \\
\text { manufacturers }\end{array}$ & Purchase & $\begin{array}{l}\text { Consumers are often very influenced by their peers } \\
\text { and other people's experiences, therefore peer rating } \\
\text { would provide a way to influence consumers who may } \\
\text { be indecisive about the purchase of a particular } \\
\text { product or service. }\end{array}$ & Good guide & www.goodguide.com \\
\hline & $\begin{array}{l}\text { Comparative } \\
\text { evaluations }\end{array}$ & 2 & Consumers & \begin{tabular}{|} 
Public \\
authorities, \\
$\quad$ local \\
associations, \\
private actors
\end{tabular} & $\begin{array}{c}\text { Communities, } \\
\text { local } \\
\begin{array}{c}\text { associations and } \\
\text { authorities }\end{array}\end{array}$ & Purchase, Use & $\begin{array}{l}\text { Tools that allow for comparative evaluation of one's } \\
\text { own behaviour with the performance/behaviour of } \\
\text { others can motivate individuals to improve their own } \\
\text { behaviour (e.g. allowing for a benchmark for one's } \\
\text { own energy consumption compared to the } \\
\text { performance of others). }\end{array}$ & $\begin{array}{l}\text { Household energy } \\
\text { benchmarking } \\
\text { programmes }\end{array}$ & $\begin{array}{l}\text { www.strategie.gouv.fr/IMG/ } \\
\text { ddf/2011-03-09-NA-216- } \\
\text { NudgesVertsGB-2.pdf }\end{array}$ \\
\hline & Endorsement & 2 & Consumers & $\begin{array}{l}\text { Governments, } \\
\text { private } \\
\text { actors, } \\
\text { associations }\end{array}$ & \begin{tabular}{|c|} 
Celebrities, govt. \\
independent orgs.
\end{tabular} & Purchase & $\begin{array}{l}\text { Endors ements underline with the idea that consumers } \\
\text { are easily influenced by other consumers and } \\
\text { cel ebrities. They can come in the form of a product } \\
\text { label or publicity endorsed by a celebrity or by other } \\
\text { consumers. }\end{array}$ & $\begin{array}{l}\text { Brad Pitt endorsing of } \\
\text { green organic skin care }\end{array}$ & $\begin{array}{l}\text { www.greenorganics.com.au/ } \\
\text { organic-natural-skin-care- } \\
\text { products/green-celebrity-of- } \\
\text { the-month-brad-pitt/ }\end{array}$ \\
\hline & \multirow[b]{2}{*}{$\begin{array}{l}\text { Pledges or } \\
\text { commitments }\end{array}$} & \multirow[b]{2}{*}{2} & \multirow[b]{2}{*}{ Consumers } & \multirow{2}{*}{$\begin{array}{c}\text { Public } \\
\text { authorities, } \\
\text { local } \\
\text { associations, } \\
\text { private actors }\end{array}$} & \multirow{2}{*}{$\begin{array}{l}\text { Government. } \\
\text { - Consumer } \\
\text { organisations. } \\
\text { - Distribution. }\end{array}$} & \multirow{2}{*}{ Purchase, use } & \multirow{2}{*}{$\begin{array}{l}\text { Consumer pledges can deepen the consumer's } \\
\text { commitment to the behaviour, and increases the } \\
\text { chances that they will carry it out as well as } \\
\text { committing to more significant behavioural changes. }\end{array}$} & $\begin{array}{l}\text { "Eco challenge" } \\
\text { programme }\end{array}$ & eco-challenge.eu \\
\hline & & & & & & & & \begin{tabular}{|l|}
$\begin{array}{l}\text { Voulntary carbon } \\
\text { rationing }\end{array}$ \\
\end{tabular} & www.carbonrationing.org.uk \\
\hline & \multirow[b]{2}{*}{$\begin{array}{l}\text { Public/communi } \\
\text { ty participation }\end{array}$} & \multirow[b]{2}{*}{2} & \multirow[b]{2}{*}{ Consumers } & \multirow[b]{2}{*}{$\begin{array}{l}\text { Governments } \\
\text { and } \\
\text { associations }\end{array}$} & \multirow[b]{2}{*}{$\begin{array}{c}\text { Local } \\
\text { governments and } \\
\text { associations }\end{array}$} & \multirow[b]{2}{*}{ All phases } & \multirow{2}{*}{$\begin{array}{l}\text { Public/community participation incites people to } \\
\text { participate and be involved in the political decision } \\
\text { making process as well as changing things locally can } \\
\text { be empowering. By involving consumers who are at } \\
\text { the root of both causes and solutions of sustainable } \\
\text { consumption challenges, transparency and } \\
\text { accountability are also more likely to be achieved. }\end{array}$} & Eco-teams & ecoteams.org.uk \\
\hline & & & & & & & & Transition towns & www.transitionnetwork.org \\
\hline & \multirow[b]{2}{*}{$\begin{array}{l}\text { Nudge-type } \\
\text { tools }\end{array}$} & \multirow[b]{2}{*}{2} & \multirow[b]{2}{*}{ Consumers } & \multirow{2}{*}{$\begin{array}{l}\text { Governments, } \\
\text { private } \\
\text { actors, } \\
\text { associations }\end{array}$} & \multirow{2}{*}{$\begin{array}{c}\text { Governments, } \\
\text { private actors, } \\
\text { associations }\end{array}$} & & \multirow{2}{*}{$\begin{array}{l}\text { Nudge-type tools impose no mandates and instead, } \\
\text { with strategic combinations of framing, informing, } \\
\text { and encouragement, nudge tools can inspire } \\
\text { voluntary decisions to eat healthier and consume } \\
\text { more wisely. }\end{array}$} & $\begin{array}{l}\text { Electronic format as the } \\
\text { default means of sending } \\
\text { correspondence and } \\
\text { billing }\end{array}$ & $\begin{array}{l}\frac{\text { www.strategie.gouv.fr/IMG/ }}{\text { pdf/2011-03-09-NA-216- }} \\
\text { NudgesVertsGB-2.pdf } \\
\end{array}$ \\
\hline & & & & & & & & $\begin{array}{l}\text { Plastic bags campaign - } \\
\text { Ireland }\end{array}$ & $\begin{array}{l}\text { plasticbags.planetark.org/a } \\
\text { bout/othercountries.cfm }\end{array}$ \\
\hline
\end{tabular}


In Table 10, tools are listed individually. In reality, these tools are often used in succession or in combination with other tools as part of an overall policy to influence consumption (e.g. introduction of a tax on cigarettes with the use of a label to discourage smokers on cigarette packs). Furthermore, the impacts or success of the tool also depends on the way it is implemented and the approach used. Oftentimes, the way in which a tool is implemented can demonstrate innovation by considering the use of a tool (or combination thereof) on a specific targeted consumer group. Examples of behavioural approaches using traditional policy tools are provided in the following section.

\subsection{Classification of key behavioural approaches}

This section provides further information of the different behavioural approaches that can be used with the tools listed in the inventory table (see Table 10). A short overview is given on existing categorisations of behavioural approaches. With this in mind, a simple integrated categorisation of policy tools is proposed as well as a categorisation of behavioural tools and mechanisms.

\subsubsection{Existing policy tool and consumer categorisations}

Existing attempts to categorise behavioural policy tools have grouped tools by how they seek to promote behavioural change. For example, Defra's 4E's model was developed as part of Defra's 2008 Framework for Pro-Environmental Behaviours. It categorises the approaches to behavioural change into either engaging, encouraging enabling or exemplifying consumers to change (see Figure 1). The $4 \mathrm{E}^{\prime} \mathrm{s}$ model assumes that the use of these 4 groupings of tools will evolve as attitudes and behaviours change. 
Figure 1: Diagrammatic representation of Defra's 4E's model

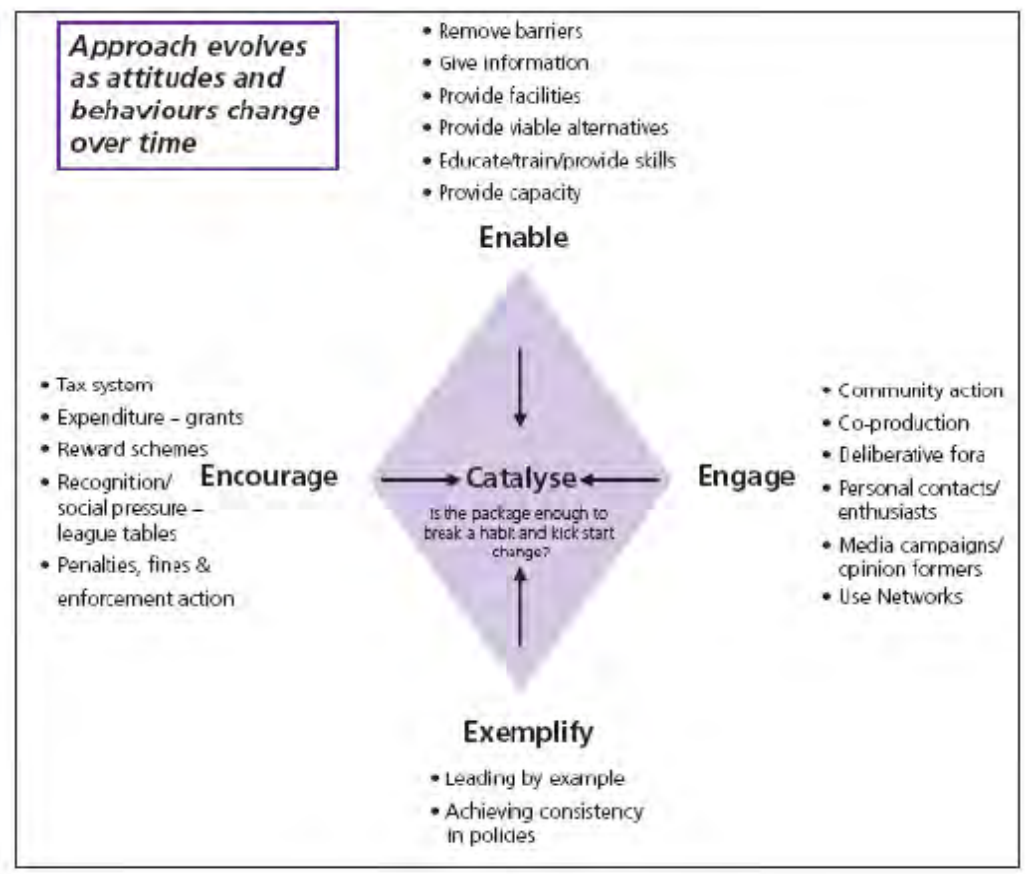

Other behavioural models include those from the private sector. For example, Unilever's 5 levers of behavioural change is integrated into their products and services marketing strategy. Their levers for change aims at helping people to change their behaviour - from encouraging consumers to use less hot water when showering or washing their hands before meals and after going to the toilet. ${ }^{46}$ Unilever's levers of change include (see Figure 2):

- Make it understood: by raising awareness and encourages acceptance.

- Make it easy: to establish convenience and confidence.

- Make it desirable: this Lever is about 'self and society' because humans are social animals. Humans tend to emulate the lifestyles and habits of people we respect like parents or sometimes a celebrity - and follow norms in society.

- Make it rewarding: by demonstrating the proof and payoff.

- Make it a habit: by reinforcing and reminding.

\footnotetext{
${ }^{46}$ Unilever, Inspiring Sustainable Living: Expert insights into consumer behaviour and Unilever's five levers for change, www.unilever.com/.../slp_5-Levers-for-Change tcm13-276807.pdf
} 
Figure 2: Unilever's five levers for change ${ }^{47}$

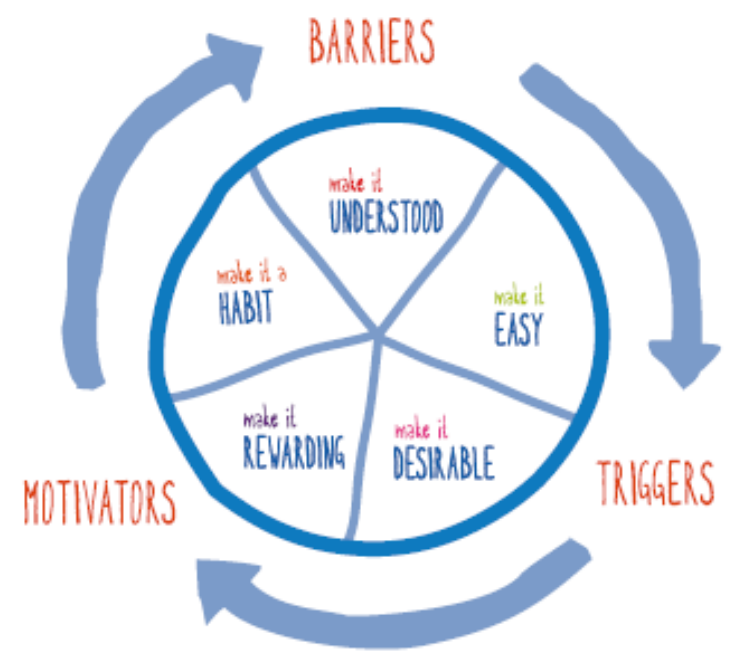

Unilever's five levers for change corresponds closely to the "Four A's principles" for sustainable consumption. These include:

- Affordability: "sustainable consumption must not be a luxury". Sustainable consumption must be affordable for everybody, not only for reasons of social justice, but also because it has to be practiced by everybody to be efficient and succeed in promoting supply of green goods. See Box 1 for further information on integrating social costs in environmental policy.

- Availability (and facilitation): "consumers must have the right to consume sustainably". Green products and services must be not only affordable, but they have to be available for purchasing. It means that the offer must be able to respond to demand. "

- Attractiveness: "sustainable consumption must be a pleasure". Sustainable consumption is sometimes perceived as a sad, unpleasant way of life. Sustainable consumption must be pleasant and comfortable to attract consumers.

- Awareness: "awareness is the final touch to guide consumers towards sustainable consumption". Awareness is often presented as the key element to persuade consumers to consume sustainably.

A further part of developing behavioural change policy has been the acceptance that not all people hold the same environmental attitudes, or will respond in the same way to a particular policy tool. In response a number of segmentation models have been developed which aim to be used in conjunction with categorisation models to predict both who and how different people will respond to different policy tools. An example would be the segmentation model as developed for Defra in

\footnotetext{
47 Unilever, Inspiring Sustainable Living: Expert insights into consumer behaviour and Unilever's five levers for change, www.unilever.com/.../slp_5-Levers-for-Change_tcm13-276807.pdf
} 
England in 2008, which segments the population in England into seven roughly equal segments based on their environmental attitudes and their willingness to adopt behavioural change actions. These segments range from the committed 'deep greens' at one extreme to the 'honestly disengaged' at the other extreme (see Table 11).

Table 11 : Summary of Defra's behavioural segmentation model for the population in England

\begin{tabular}{|l|l|c|c|}
\hline \multicolumn{1}{|c|}{$\begin{array}{c}\text { Population } \\
\text { segment }\end{array}$} & \multicolumn{1}{|c|}{ Description } & $\begin{array}{c}\text { Willingness to } \\
\text { act }\end{array}$ & $\begin{array}{c}\text { Ability to } \\
\text { act }\end{array}$ \\
\hline Positive greens & $\begin{array}{l}\text { Committed to look and act on their behaviour in all areas of their } \\
\text { lives }\end{array}$ & High & High \\
\hline $\begin{array}{l}\text { Concerned } \\
\text { consumers }\end{array}$ & $\begin{array}{l}\text { Tend to be identity motivated and seek that their consumption } \\
\text { choices reflect this }\end{array}$ & High & High \\
\hline Waste watchers & $\begin{array}{l}\text { Tend to be highly motivated by the avoidance of waste and the } \\
\text { saving of money }\end{array}$ & Medium & High \\
\hline $\begin{array}{l}\text { Sideline } \\
\text { supporters }\end{array}$ & $\begin{array}{l}\text { Tend to readily adopt the values of others but would not naturally } \\
\text { lead }\end{array}$ & High & Low \\
\hline $\begin{array}{l}\text { Cautious } \\
\text { participants }\end{array}$ & $\begin{array}{l}\text { Can be engaged on values but would unlikely identify themselves } \\
\text { as 'green' }\end{array}$ & Medium & Low \\
\hline Stalled starters & $\begin{array}{l}\text { tend to have other more pressing challenges to resolve before } \\
\text { considering wider environmental issues }\end{array}$ & Low & Medium \\
\hline $\begin{array}{l}\text { Honestly } \\
\text { disengaged }\end{array}$ & Tend not to hold environmental values or seek to adopt them & Low \\
\hline
\end{tabular}

A major drawback of such segmentation approaches in relation to this project is that they tend to be specific to each society and culture and that they are not static, as values and attitudes can change with time. Therefore, not only would the proportions within each segment very likely differ for different Member States, but also the segments would very likely have been constructed differently if developed for different populations. Therefore, an ideal classification of behavioural approaches would be one which integrates these two types of models in a way which is transferable to all cultures and societies. It would also ideally be simple for a diverse range of professionals to understand and use.

\subsubsection{Tools categorisation}

A 4-level categorisation is proposed, taking into account what works for different types of people, irrespective of where they live:

Level one: Injunction tools (e.g. all bans and limits).

Level two: Encouragement tools including tools which encourage changes in behaviour including lead by example tools and economic and non-economic "nudge" type tools (such as framing of information and human ergonomics).

Level three: Social value engagement tools including all non-economic incentive tools which seek to establish and justify a social value and then challenge any gap between this value and people's behaviour.

Level four: Value neutral tools represent more of a reference category as it assumes that (some) people do not need value engagement and are able to act to change their individual behaviour in response to no more than being aware of the situation. 
Levels one and two do not require that people necessarily share the values behind the policy for the tools to be effective. They are therefore more suitable to people who respond best when value judgements are made on their behalf by governance systems. Such people also often require that everyone acts on an equal basis for them to feel that the policy is fair. Tools classified under levels three and four are more suited to people who are willing to consider their individual values, identities and responsibilities, and have the potential to act irrespective of the actions of others.

A key further limitation of level one and two tools is the lack of influence over the way that any saved money is re-spent. This is because these policies do not set out to influence consumers' overall environmental attitudes. Therefore, the applying only level one and two polices has limited effectiveness in terms of reducing overall consumption.

\subsubsection{Categorisation of behavioural tools and mechanisms}

The categorisation as introduced above can be used to categorise:

- the tools which are applicable to each level;

- the behavioural mechanisms that make these tools effective; and,

- the characteristics of the people who would likely respond.

The first two of these are illustrated in Table 12 below with the mechanisms being illustrated by how the policy tool is communicated. 
Table 12 : Illustrative model of behavioural policy tools and mechanisms

\begin{tabular}{|c|c|c|c|c|c|c|c|}
\hline Tool category & $\begin{array}{l}\text { Population segments relevant } \\
\text { (based on Defra model) }\end{array}$ & \multicolumn{5}{|c|}{ Relevant policy tools } & $\begin{array}{c}\text { Communication } \\
\text { approaches }\end{array}$ \\
\hline Level 1 & $\begin{array}{l}\text { Sideline supporters } \\
\text { Stalled starters } \\
\text { Honestly disengaged }\end{array}$ & Bans & Limits & $\begin{array}{l}\text { Product } \\
\text { standards }\end{array}$ & - & - & Notices \\
\hline \multirow{2}{*}{ Level 2} & Waste watchers & Taxes & $\begin{array}{l}\text { Subsidies / } \\
\text { incentives }\end{array}$ & Loans & Polluter-pays & \multirow{3}{*}{$\begin{array}{c}\text { Provision of } \\
\text { infrastructu } \\
\text { re and } \\
\text { public } \\
\text { services }\end{array}$} & \multirow{3}{*}{$\begin{array}{l}\text { Framing of } \\
\text { information }\end{array}$} \\
\hline & $\begin{array}{l}\text { Cautious participants } \\
\text { Honestly disengaged }\end{array}$ & Bonus-malus & $\begin{array}{l}\text { Trading } \\
\text { schemes }\end{array}$ & $\begin{array}{l}\text { Purchasing } \\
\text { schemes }\end{array}$ & $\begin{array}{c}\text { Green } \\
\text { payment } \\
\text { schemes }\end{array}$ & & \\
\hline \multirow{3}{*}{ Level 3} & \multirow{3}{*}{$\begin{array}{l}\text { Positive greens } \\
\text { Concerned consumers } \\
\text { Sideline supporters } \\
\text { Cautious participants }\end{array}$} & $\begin{array}{c}\text { Education } \\
\text { programmes }\end{array}$ & $\begin{array}{l}\text { Capacity } \\
\text { building and } \\
\text { training }\end{array}$ & $\begin{array}{l}\text { Publicity and } \\
\text { marketing }\end{array}$ & $\begin{array}{c}\text { Green public } \\
\text { Procurement } \\
\text { (GPP) }\end{array}$ & & \\
\hline & & Peer rating & Endorsement & $\begin{array}{c}\text { Pledges or } \\
\text { commitments }\end{array}$ & $\begin{array}{l}\text { Community- } \\
\text { based } \\
\text { initiatives }\end{array}$ & $\begin{array}{l}\text { Socially- } \\
\text { responsible } \\
\text { investment }\end{array}$ & $\begin{array}{c}\text { Endorsement by } \\
\text { others }\end{array}$ \\
\hline & & \multirow{2}{*}{$\begin{array}{l}\text { (ICT) } \\
\text { Information and } \\
\text { communication } \\
\text { technology } \\
\text { consumer tools }\end{array}$} & \multirow{2}{*}{$\begin{array}{l}\text { Labels with } \\
\text { certifications } \\
\text { or quality } \\
\text { marks }\end{array}$} & \multirow{2}{*}{$\begin{array}{l}\text { Labels with } \\
\text { product } \\
\text { information }\end{array}$} & \multirow{2}{*}{$\begin{array}{l}\text { Corporate } \\
\text { reporting }\end{array}$} & \multirow[t]{2}{*}{-} & $\begin{array}{l}\text { Social influence } \\
\text { and identity } \\
\text { branding }\end{array}$ \\
\hline Level 4 & Positive greens & & & & & & Information \\
\hline
\end{tabular}


Table 12 illustrates that some tools work on more than one level. There is also some cross-over in how product information is provided. Both level 2 and 1 consumers seek environmentally relevant product information. However, level 2 consumers are more susceptible to be influenced by others and the value based identity this provide $4^{4}$. These consumers are more susceptible to how the value information is framed, whereas the level 1 type consumers are more likely to carefully consider any information provided and come to their own decision irrespective of others.

\subsubsection{The evolution in the use of policy tools and environmental challenges}

The uses of these policy tools have evolved in conjunction with the sustainability challenges that society faces, and the fact that people need to make their own value judgements and engage in more complex challenges. Historically, environmental policy was mostly injunction based. The value judgements were clear and the need for all to act was apparent. With more complex environmental challenges emerging, such as climate change and depletion of natural resources, the objective has moved more towards "reductions" (in resource consumption and emissions), rather than "elimination" (of specific pollutants). Because complex environmental and sustainability challenges are linked to broad drivers such as increases in wealth and consumption trends, successfully addressing these challenges necessitates engagement of citizens in a conversation on values and action as part of the policy process. Incentive-based and behavioural tools, seeking to encourage consumers to change their choices and actions, are examples of additional policy measures that can be taken.

This range of policy tools are still required to respond to the range of environmental challenges and to address different types of people. To illustrate, policy attempts to stop people from littering are often applied as a legal injunction in all EU Member States (i.e. a level 1 tool). This is often backed up by encouragement tools seen under level 2 (by providing plenty of small waste bins and therefore nudging people to avoid littering). However, where this cannot be effective (where for example some people do not hold this social norm and no authority is monitoring), governments might try to promote this social norm by using social value engagement tools (i.e. level 3 tools). Whilst this might successfully be adopted as a social norm by most within a society, some people will continue to litter when others are not present to object. Hidden within the group who hold the value not to litter, will be people who never needed such tools to see that it is undesirable and irresponsible to litter (i.e. level 1).

\footnotetext{
${ }^{48}$ Acting ecologically may generate a positive return of image, personally and socially
} 


\section{Chapter 3: Assessment of fifteen real world case studies of sustainable consumption}

This chapter provides a detailed assessment of real world and instructive examples of initiatives towards changing behaviour in areas such as healthy eating and food, mobility, housing, clothing, and tourism.

The first section provides the methodology used to identify and select the case studies. The second section provides an assessment of the main success factors, target groups, consumption sectors, and tools used in each of the case studies. The last section provides an overall summary of the main lessons learned from the case studies analysis.

The process of identifying the tools used to promote sustainable consumption identified several case study examples of the tools being put into action. Furthermore, during the Future Vision workshop several examples of case studies were mentioned in discussions and through the experience of the some of the participants.

Finally, a case study search was also carried out to fill any gaps by ensuring that important consumption sectors and tools were covered by the identified case studies. The sources used to identify case studies included reports, OECD papers, policy briefings, and internet databases. Several aspects were considered during the case study identification process, such as how innovative and non-traditional the case study is, at what level and scale the case study is implemented and the type of tools being used. Case studies were mainly identified in the EU, however several case studies were also found outside the EU.

Over 40 potential case studies aimed at promoting sustainable consumption were identified. A full list of the case studies is provided in the Annex on page 166

\subsection{Selection of 15 case studies}

Out of the $40+$ case studies identified, 15 were selected for further analysis. Several criteria for the selection of the case studies were considered:

coverage of a wide variety of geographical, economic and demographic conditions ;

coverage of a wide array of different issues, as well as sectors where sustainable consumption is a pressing matter;

coverage of initiatives and policies representing different levels of integration (initiatives implemented by national, regional or local authorities);

diversity of approaches, measures, types of programmes, tools and actions used to change behaviour; 
- level of innovation of the initiative that led to behaviour change;

- length of time for which the initiative has been in place (i.e. initiatives that have been in place for a couple years may offer deeper insights into level of success compared to an initiative that has not been in place for very long); and the amount of information available on the case study.

A preliminary proposal of the 15 case studies was discussed with the $E C$ along with other experts in the domain of sustainable consumption. A finalised list of the 15 selected case studies is shown in Table 13. The table lists the types of tools used within the initiative as well as the consumption sector and the phase of the consumption cycle that the initiative targets. 
Table 13 : Selected case studies for analysis

\begin{tabular}{|c|c|c|c|c|c|}
\hline Case study & Tool category & Specific tool(s) & Consumption sector & Topic, target addressed & $\begin{array}{c}\text { Phase of the } \\
\text { consumption } \\
\text { cycle } \\
\end{array}$ \\
\hline Bonus-Malus & Economic & Taxes and charges & Passenger vehicles & Many & Purchase \\
\hline $\begin{array}{l}\text { Canadian EcoENERGY } \\
\text { Retrofit program }\end{array}$ & Economic & Subsidies/incentives & Housing & $\begin{array}{l}\text { Buildings and homes, } \\
\text { households }\end{array}$ & Purchase \\
\hline $\begin{array}{l}\text { Danish Brug Mere } \\
\text { Spild Mindre (Use } \\
\text { more, waste less) }\end{array}$ & $\begin{array}{l}\text { Information } \\
\text { provision \& } \\
\text { awareness raising }\end{array}$ & Information campaign & Products & Many & Use \\
\hline $\begin{array}{l}\text { Dutch Green Funds } \\
\text { Scheme }\end{array}$ & Economic & $\begin{array}{l}\text { Green payment } \\
\text { /investment scheme }\end{array}$ & Products & $\begin{array}{l}\text { Green and socially } \\
\text { responsible investment by } \\
\text { individuals }\end{array}$ & Purchase \\
\hline Eco-challenge & Behavioural & $\begin{array}{l}\text { Comparative evaluations, } \\
\text { pledges or commitments }\end{array}$ & $\begin{array}{l}\text { Mobility, Food, } \\
\text { Housing }\end{array}$ & $\begin{array}{l}\text { Sustainable lifestyles using a } \\
\text { "competition" approach }\end{array}$ & All \\
\hline $\begin{array}{l}\text { FairTrade Label for } \\
\text { Cotton }\end{array}$ & $\begin{array}{l}\text { Information } \\
\text { provision \& } \\
\text { awareness raising }\end{array}$ & Labelling / education & Products & Clothing/textiles & Purchase \\
\hline $\begin{array}{l}\text { Food Dudes } \\
\text { programme }\end{array}$ & $\begin{array}{l}\text { Information } \\
\text { provision \& } \\
\text { awareness raising }\end{array}$ & Education & Food & $\begin{array}{l}\text { Healthy eating for children } \\
\text { between ages of } 2 \text { and } 7 \text { in } \\
\text { homes, schools and nursery } \\
\text { schools }\end{array}$ & Use \\
\hline $\begin{array}{l}\text { London's Congestion } \\
\text { Charge }\end{array}$ & Economic & Taxes and charges & Mobility & $\begin{array}{l}\text { Transport and mobility, } \\
\text { urban congestion }\end{array}$ & Use \\
\hline $\begin{array}{l}\text { Love Food, Hate } \\
\text { Waste }\end{array}$ & $\begin{array}{l}\text { Information } \\
\text { provision \& } \\
\text { awareness raising }\end{array}$ & Information campaign & Food & Food waste, households & Use/Disposal \\
\hline
\end{tabular}


Chapter 3: Assessment of 15 real world case studies

\begin{tabular}{|c|c|c|c|c|c|}
\hline Case study & Tool category & Specific tool(s) & Consumption sector & Topic, target addressed & $\begin{array}{c}\text { Phase of the } \\
\text { consumption } \\
\text { cycle }\end{array}$ \\
\hline $\begin{array}{l}\text { Middelgrunden Wind } \\
\text { Cooperative }\end{array}$ & Behavioural & Public participation & Housing, energy & Renewable energy & Use \\
\hline Paris Velib Programme & Behavioural & Nudge-type & Mobility & $\begin{array}{l}\text { Public transportation, } \\
\text { biking, Infrastructure }\end{array}$ & Use \\
\hline $\begin{array}{l}\text { Picture Health } \\
\text { Warnings on Cigarette } \\
\text { Packets }\end{array}$ & $\begin{array}{l}\text { Behavioural and } \\
\text { Information } \\
\text { provision }\end{array}$ & $\begin{array}{l}\text { Picture health warnings on } \\
\text { cigarette packages - labels }\end{array}$ & Health & Smoking habits & Purchase \\
\hline Transition Towns & Behavioural & $\begin{array}{l}\text { Community/public } \\
\text { participation }\end{array}$ & $\begin{array}{l}\text { Mobility, Food, } \\
\text { Housing }\end{array}$ & Sustainable urban living & All \\
\hline Vienna City & $\begin{array}{l}\text { Information } \\
\text { provision \& } \\
\text { awareness raising }\end{array}$ & Information / education & Products & $\begin{array}{l}\text { Recreation - } \\
\text { 'dematerialisation', re-use of } \\
\text { products through repair }\end{array}$ & Use, disposal \\
\hline VISIT initiative & Behavioural & $\begin{array}{l}\text { Community/public } \\
\text { participation }\end{array}$ & Tourism & $\begin{array}{l}\text { Alternative vacations, } \\
\text { younger generation }\end{array}$ & - \\
\hline
\end{tabular}




\subsection{Assessment of the selected case studies}

For most of the case studies, information was readily available through existing publications or directly through the initiative's website. In some cases, interviews were carried out with those responsible or involved in the implementation of the case study. The following information has been collected for each of the case studies:

title

date and duration of the intervention

location/scope

organiser/initiator (who initiated the tool and how is the tool managed? Is it an independent initiative or was it linked to other national, regional, or European initiatives?)

sector(s)

objectives (including measureable, quantified objectives if relevant) and target audience

type of tool(s) used

how the programme works

costs: where data available, costs on implementation and operation of the initiative

level of novelty (e.g. does it introduce a new approach towards promoting sustainable consumption?)

impacts/savings/ behavioural change (what types of savings has the initiative been able to achieve? Measurable behaviour change? Were objectives met?).

key factors of success (how did the initiative achieve its objectives? Were specific conditions necessary for its successful implementation?)

weaknesses that prevented the initiative from being more successful and actions/measures that may have helped (key factors of failure)

- questions and gaps in knowledge

contacts

data sources/references

\subsection{Summary of case study analysis}

Table 14 below summarises the main innovative aspects and lessons learned from each of the case studies analysed. The detailed information on the case studies is provided in the Annex. 
Table 14 : Summary of lessons learned

\begin{tabular}{|c|c|c|c|c|}
\hline Case study & Objective & Innovative aspects & Impacts & Lessons learned \\
\hline $\begin{array}{l}\text { Bonus-Malus } \\
\text { (France - } \\
\text { mobility) }\end{array}$ & $\begin{array}{l}\text { To reduce } \mathrm{CO}_{2} \\
\text { emissions from } \\
\text { passenger vehicles in } \\
\text { France (household } \\
\text { and industry). }\end{array}$ & $\begin{array}{l}\text { The combination of a credit and a tax, } \\
\text { which is designed to ensure that the } \\
\text { credits paid out are offset by the tax } \\
\text { revenue generated (i.e. revenue- } \\
\text { neutral for the government) makes. }\end{array}$ & 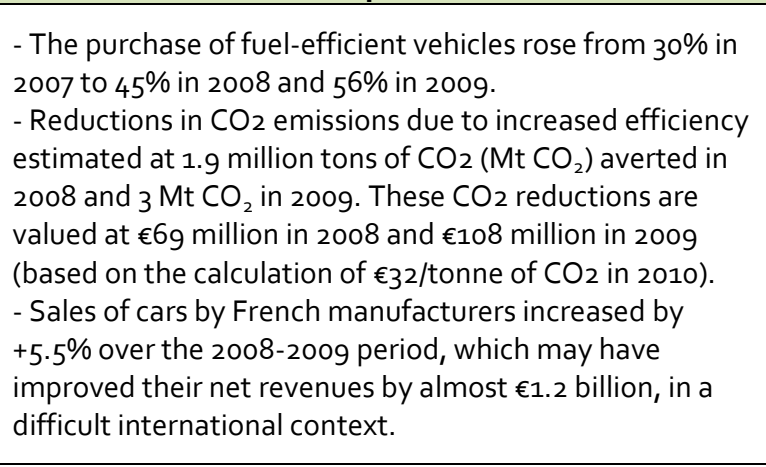 & $\begin{array}{l}\text { - Importance of the price signal: the scheme delivers a } \\
\text { price signal that acts on both on demand (directs choice } \\
\text { of consumers to more energy-efficient vehicles) and the } \\
\text { supply (encourages manufacturers to produce vehicles } \\
\text { that meet demand and to innovate in this direction). } \\
\text { - Importance of considering impacts and consequences } \\
\text { of rebound effects: the programme resulted in an } \\
\text { increase of car sales, which also means an increase in } \\
\text { environmental damages due to the increased production } \\
\text { of cars. Furthermore, due to the price incentive given by } \\
\text { the bonus/malus, many cars were replaced when they } \\
\text { could have been used for a longer period. }\end{array}$ \\
\hline $\begin{array}{l}\text { Canadian } \\
\text { EcoENERGY } \\
\text { Retrofit } \\
\text { program } \\
\text { (energy } \\
\text { efficient } \\
\text { housing } \\
\text { retrofits) }\end{array}$ & $\begin{array}{l}\text { To provide financial } \\
\text { assistance to } \\
\text { encourage owners of } \\
\text { existing low-rise } \\
\text { properties to make } \\
\text { smart energy retrofit } \\
\text { decisions that will } \\
\text { result in significant } \\
\text { energy savings. }\end{array}$ & $\begin{array}{l}\text { Encourages homeowners to invest in } \\
\text { multiple energy efficiency measures, } \\
\text { which may have not been otherwise } \\
\text { considered. The programme requires } \\
\text { both pre and post evaluations of the } \\
\text { home by a qualified energy expert, } \\
\text { which brings credibility and builds on } \\
\text { the principle of continuous } \\
\text { improvement. }\end{array}$ & $\begin{array}{l}\text { - To date, approximately } 1 \text { in } 20 \text { homeowners in Canada } \\
\text { have participated in the scheme. } \\
\text { - Participants have reduced their energy consumption by } \\
\text { over } 20 \% \text { and reduced greenhouse gas emissions by } \\
\text { approximately } 3 \text { tonnes per house. } \\
\text { - By implementing the energy retrofit recommendations, } \\
\text { a typical homeowner could save } \$ 700 \text { a year on a } \$ 2000 \\
\text { annual heating bill. Since the programme's inception, } \\
\text { there has been a reduction of approximately } 0.32 \\
\text { megatonnes (Mt) of GHG emissions } \\
\text { - It is expected that the incentives will promote smart } \\
\text { energy use in over } 340 \text { ooo homes and yield an average } 23 \\
\% \text { reduction in energy use. }\end{array}$ & $\begin{array}{l}\text { - It is important to make the programme available and } \\
\text { accessible to all, regardless of income level. } \\
\text { - The incentive offered must be high enough and } \\
\text { appealing in order to entice consumers. } \\
\text { - The monitoring and evaluation process of the initiative } \\
\text { adds credibility and allows for the measurement of real } \\
\text { impacts. } \\
\text { - Personalised recommendations and information } \\
\text { provided to homeowners on the rated impact and } \\
\text { savings allows the homeowner autonomy to decide for } \\
\text { themselves the measures to implement and gives them } \\
\text { a certain feeling of responsibility. } \\
\text { - Beware of becoming a "victim of your own success": } \\
\text { set up a maximum budget as seen in the Dutch GFS. }\end{array}$ \\
\hline $\begin{array}{l}\text { Danish Brug } \\
\text { Mere Spild } \\
\text { Mindre } \\
\text { (efficient } \\
\text { resource use) }\end{array}$ & $\begin{array}{l}\text { To improve the } \\
\text { prevention of waste } \\
\text { in Denmark. }\end{array}$ & $\begin{array}{l}\text { Communications campaign combined } \\
\text { the web supports (and social media) } \\
\text { with public events and competitions. }\end{array}$ & $\begin{array}{l}\text { - A survey showed that } 11 \% \text { of those surveyed } \\
\text { remembered the campaign - considering the relatively } \\
\text { small budget and 'low interest' topic, this was considered } \\
\text { satisfactory - and that: } \\
\text { - the share of Danes that associated waste prevention } \\
\text { with 'a good conscience' }(+9 \%) \text { and the 'right thing to } \\
\text { do' }(+7 \%) \text { increased } \\
\text { - it resulted in more Danes }(+3 \%) \text { saying they will } \\
\text { reduce their 'use and throw away' behaviour } \\
\text { - an increase of awareness of food waste was observed } \\
(+12 \%)\end{array}$ & $\begin{array}{l}\text { - Successful campaigning often uses a mix of internet } \\
\text { (social) media and events to raise awareness. } \\
\text { - Information that is based on solid evidence brings } \\
\text { credibility and trust from consumers. } \\
\text { It is important to provide clear and easy guidelines. }\end{array}$ \\
\hline
\end{tabular}




\begin{tabular}{|c|c|c|c|c|}
\hline Case study & Objective & Innovative aspects & Impacts & Lessons learned \\
\hline & & & $\begin{array}{l}\text { - The campaign website has had over 32,000 visits. To } \\
\text { date over } 2000 \text { people on Facebook have shared their "I } \\
\text { like" for the campaign. } \\
\text { - There is agreement that it is still too soon to observe any } \\
\text { actual changes in waste quantities due to the campaign. }\end{array}$ & \\
\hline $\begin{array}{l}\text { Dutch Green } \\
\text { Funds } \\
\text { Scheme } \\
\text { (investment in } \\
\text { green } \\
\text { projects) }\end{array}$ & $\begin{array}{l}\text { Providing access to } \\
\text { lower-than-standard- } \\
\text { interest loans for } \\
\text { green projects. } \\
\text { Promoting green and } \\
\text { socially-responsible } \\
\text { investment by } \\
\text { individuals. }\end{array}$ & $\begin{array}{l}\text { The Dutch environmental policy tool } \\
\text { does not represent an innovative } \\
\text { approach. However, the GFS could be } \\
\text { a promising instrument for other MS if } \\
\text { governments and banks are willing to } \\
\text { work closely together. }\end{array}$ & $\begin{array}{l}\text { - In the period } 2003-2009 \text {, on average the green projects } \\
\text { funded through the scheme resulted in a decrease in } \mathrm{CO}_{2} \\
\text { emissions of o.5 MT per year. NOx emissions are reduced } \\
\text { by } 0.25 \mathrm{MT} \text { per year. The green projects have also resulted } \\
\text { in } 1,250 \text { square kilometres of woods and nature } \\
\text { conservation area }{ }^{49} \text {. } \\
\text { - In total, the scheme causes no financial losses to the } \\
\text { government, but rather generates additional income. } \\
\text { - The scheme succeeded in reinterpreting the meaning of } \\
\text { environmental protection - from environment as a threat, } \\
\text { to environment as an (economic) opportunity. With all the } \\
\text { top Dutch banks having a green bank or green funds in } \\
\text { their product portfolio now, there is a new willingness to } \\
\text { actively look for and fund green projects. }\end{array}$ & $\begin{array}{l}\text { - Important that there is trust and good collaboration } \\
\text { between the different partners involved in implementing } \\
\text { the initiative. } \\
\text { - The use of financial tools that have government } \\
\text { support reassures consumers. } \\
\text { - The scheme has been successful from an economic } \\
\text { perspective because it is strongly connected to the } \\
\text { mechanisms of traditional lending and investment, with } \\
\text { funds allocated on a market-driven basis, and with } \\
\text { minimal governmental costs. } \\
\text { - Important to assess whether the financial incentive is } \\
\text { high enough, and the feasibility of lower tax rates. }\end{array}$ \\
\hline $\begin{array}{l}\text { Eco- } \\
\text { challenge } \\
\text { (promote } \\
\text { sustainable } \\
\text { lifestyles) } \\
\text { Starting from } \\
\text { US to } \\
\text { worldwide } \\
\text { event }\end{array}$ & $\begin{array}{l}\text { To reduce } \mathrm{CO}_{2} \\
\text { emissions from } \\
\text { everyday } \\
\text { consumption. To } \\
\text { change consumer } \\
\text { behaviour towards a } \\
\text { more sustainable } \\
\text { lifestyle and } \\
\text { consumption, in the } \\
\text { short and long-term. }\end{array}$ & $\begin{array}{l}\text { A combination was used of different } \\
\text { approaches of motivational } \\
\text { psychology, especially the close } \\
\text { connection between the specific } \\
\text { sustainability content, the "smart" } \\
\text { design technology and the opportunity } \\
\text { of social comparison. Compared to } \\
\text { other sustainability platforms and } \mathrm{CO}_{2} \\
\text { calculators, EcoChallenge has a mobile } \\
\text { format and is accessible worldwide. }\end{array}$ & $\begin{array}{l}\text { - The project is being monitored very thoroughly and has } \\
\text { generated a large amount of data; nevertheless, with the } \\
\text { current measuring instruments and sampling, no } \\
\text { statement can be given on whether consumption patterns } \\
\text { have truly changed in the short term and - in case they } \\
\text { have changed - will remain more sustainable (gap } \\
\text { between knowledge and action). 80oo EcoChallenge apps } \\
\text { were downloaded between Mid February } 2011 \text { and the } \\
\text { end of April } 2011.1900 \text { "challenges" were completed. }\end{array}$ & $\begin{array}{l}\text { - Successful projects can be implemented with little } \\
\text { investment (optimising costs through smart } \\
\text { technologies). } \\
\text { - Public funding, lack of advertisements, and the open- } \\
\text { source nature of the application have made this initiative } \\
\text { very trustworthy in the eyes of many consumers. } \\
\text { - Rewards are quickly felt by the consumer when a } \\
\text { "challenge" is achieved. This creates a positive } \\
\text { behavioural change towards a more sustainable } \\
\text { consumption activity. }\end{array}$ \\
\hline $\begin{array}{l}\text { FairTrade } \\
\text { Label for } \\
\text { cotton }\end{array}$ & $\begin{array}{l}\text { To strengthen the } \\
\text { position of } \\
\text { developing country } \\
\text { producers in the } \\
\text { market place through } \\
\text { an international }\end{array}$ & $\begin{array}{l}\text { The FairTrade label's message } \\
\text { addresses the need to tackle poverty } \\
\text { and empower producers in developing } \\
\text { countries. This message may be more } \\
\text { successful in gathering consumer } \\
\text { support than others. The connection }\end{array}$ & $\begin{array}{l}\text { - In } 2008 \text {, global Fairtrade cotton sales reached } € 176 \\
\text { million, amounting to over } 27 \text { million items, almost double } \\
\text { the sales in the previous year. } \\
\text { - Fairtrade certification of cotton is currently helping over } \\
95,000 \text { people - farmers, workers, their families and } \\
\text { communities - through receipt of a fair price for their }\end{array}$ & $\begin{array}{l}\text { - Marketing strategies that cover several behavioural } \\
\text { aspects have made campaigning quite successful. } \\
\text { - Wide media coverage and support and harmonisation } \\
\text { of a number of other international fair-trade labels have } \\
\text { helped the initiative gain wide visibility. } \\
\text { - The label is used in combination with several other }\end{array}$ \\
\hline
\end{tabular}

\footnotetext{
${ }^{49}$ Scholtens, Bert, 2011, The sustainability of green funds, Natural Resources Forum 35, pp. 223-232
} 


\begin{tabular}{|c|c|c|c|c|}
\hline Case study & Objective & Innovative aspects & Impacts & Lessons learned \\
\hline & $\begin{array}{l}\text { consumer product } \\
\text { label. }\end{array}$ & $\begin{array}{l}\text { between farmers and consumers that } \\
\text { is emphasised touches upon } \\
\text { behavioural aspects that help to build } \\
\text { consumer trust. The Fairtrade } \\
\text { Certification Mark is also used as a tool } \\
\text { to build a social consumer movement } \\
\text { pushing for change in global trading. }\end{array}$ & $\begin{array}{l}\text { cotton and a Fairtrade premium. } \\
\text { - According to a } 2008 \text { GlobeScan study of } 14,500 \\
\text { consumers in } 15 \text { countries, half of consumers are now } \\
\text { familiar with the FMC and } 91 \% \text { trust the Mark. A further } \\
64 \% \text { of all consumers believe that Fairtrade has strict } \\
\text { standards, a quality that closely correlates to consumer } \\
\text { trust. }\end{array}$ & $\begin{array}{l}\text { tools such as awareness-raising campaigns and } \\
\text { commitments made by consumers. }\end{array}$ \\
\hline $\begin{array}{l}\text { Food Dudes } \\
\text { programme } \\
\text { (UK - healthy } \\
\text { eating in } \\
\text { children) }\end{array}$ & $\begin{array}{l}\text { School-based } \\
\text { intervention } \\
\text { designed for use in } \\
\text { primary schools that } \\
\text { encourages children } \\
\text { to eat fruit and } \\
\text { vegetables both at } \\
\text { school and at home } \\
\text { and changes the } \\
\text { 'culture' of a school } \\
\text { to one that strongly } \\
\text { supports healthy } \\
\text { eating. }\end{array}$ & $\begin{array}{l}\text { A range of insights identified by } \\
\text { behavioural psychology research was } \\
\text { used in the development of the } \\
\text { programme: children are motivated by } \\
\text { praise, recognition, and rewards, the } \\
\text { influence of positive role models and } \\
\text { successful experimentation with the } \\
\text { taste acquisition theory. }\end{array}$ & $\begin{array}{l}\text { - To date, } 1103 \text { schools and } 162 \text { ooo children have } \\
\text { participated. } \\
\text { - An evaluation in five schools shows that the programme } \\
\text { resulted in increases in fruit and vegetable consumption; } \\
\text { children increased their daily consumption of fruit by } 54 \% \\
\text { and vegetables by } 48 \% \text {. Children's unhealthy snack food } \\
\text { consumption was reduced by } 20 \% \text {. Those children who } \\
\text { are, at the start, the poorest eaters of fruit and } \\
\text { vegetables, show the greatest increases in consumption. } \\
\text { - Based on the success of the programme, Food Dudes is } \\
\text { being rolled out in Europe and beyond. }\end{array}$ & $\begin{array}{l}\text { - The programme clearly defines the target groups and } \\
\text { has specific strategies and objectives to reach each one. } \\
\text { - The pilot programme was based on solid academic } \\
\text { research on behavioural and psychological factors, } \\
\text { which gave the programme greater chances of success. } \\
\text { - The project had very good knowledge and evidence on } \\
\text { the behavioural aspects surrounding children's food. }\end{array}$ \\
\hline $\begin{array}{l}\text { London's } \\
\text { Congestion } \\
\text { Charge }\end{array}$ & $\begin{array}{l}\text { To reduce congestion } \\
\text { charging the use of } \\
\text { vehicles at busy } \\
\text { times. }\end{array}$ & $\begin{array}{l}\text { Congestion charging represents the } \\
\text { application of the established theory } \\
\text { that charging represents an efficient } \\
\text { way of allocating scares road space. } \\
\text { The Central London Congestion } \\
\text { Charging scheme represents the } \\
\text { largest use of the tool and therefore is } \\
\text { a novel application. }\end{array}$ & $\begin{array}{l}\text { - The actual increase in speed within the charge zone (an } \\
\text { indicator of reduced congestion) was found to be } 31 \% \text { in } \\
2003 \text { compared to the predicted } 8-12 \% \text {. } \\
\text { - The ex-ante modelling predicted a } 12-17 \% \text { reduction in } \\
\text { vehicles entering charging zone between 7am to } 6: 30 p m \\
\text { but observed levels were in fact a reduction of } 21 \% \text {. } \\
\text { - Surveys of the attitude of Londoners to the scheme } \\
\text { before and after show a shift of opinion towards favouring } \\
\text { the scheme and its effects. } \\
\text { - Benefits of the scheme estimated to have led to savings } \\
\text { of } 19 \% \text { in traffic related CO } 2 \text { emissions, and } 20 \% \text { in fuel } \\
\text { consumed by road transport within the charging zone. } \\
\text { - Data shows a fall in accidents that is proportionally } \\
\text { greater than elsewhere in London. }\end{array}$ & $\begin{array}{l}\text { - Public support for the scheme in advance of } \\
\text { implementation is key. Public support was largely } \\
\text { motivated by the local and immediate benefits offered } \\
\text { by the scheme. } \\
\text { - The scale of the scheme also made its application } \\
\text { possible without confusion. Most drivers are aware of } \\
\text { the scheme. }\end{array}$ \\
\hline $\begin{array}{l}\text { Love Food, } \\
\text { Hate Waste } \\
\text { (UK - reduce } \\
\text { food waste) }\end{array}$ & $\begin{array}{l}\text { To raise awareness } \\
\text { among households of } \\
\text { the need to reduce } \\
\text { food waste, reduce }\end{array}$ & $\begin{array}{l}\text { The campaign actions were combined } \\
\text { together to represent an effective and } \\
\text { sophisticated behavioural tool and } \\
\text { presenting the action as a social norm }\end{array}$ & $\begin{array}{l}\text { - Research estimates suggest that } 1.8 \text { million more UK } \\
\text { households are now taking steps to cut back on the } \\
\text { amount of food they throw away due to WRAP's national } \\
\text { Love Food Hate Waste campaign. }\end{array}$ & $\begin{array}{l}\text { - Direct one to one engagement to help people waste } \\
\text { less food is a positive and effective method of } \\
\text { communicating at a local level. } \\
\text { - Working with local groups who wish to save money and }\end{array}$ \\
\hline
\end{tabular}




\begin{tabular}{|c|c|c|c|c|}
\hline Case study & Objective & Innovative aspects & Impacts & Lessons learned \\
\hline & $\begin{array}{l}\text { the level of food } \\
\text { waste being sent to } \\
\text { landfills and help } \\
\text { residents save } \\
\text { money. }\end{array}$ & $\begin{array}{l}\text { or practice. Strategies included: } \\
\text { - Identification of the problem and } \\
\text { framing it in terms of potential } \\
\text { savings. } \\
\text { - The focus on loving food (i.e. not } \\
\text { calling on people to change what } \\
\text { they eat). } \\
\text { - The focus on enabling people via } \\
\text { practical steps. } \\
\text { - The local focus on local } \\
\text { communities - thereby } \\
\text { influencing via mavens. }\end{array}$ & $\begin{array}{l}\text { - This relates to an overall saving of } £ 296 \text { million a year, } \\
\text { preventing } 137 \text { ooo tonnes of food being thrown away } \\
\text { which would have emitted } 600 \text { ooo tonnes of greenhouse } \\
\text { gases. } \\
\text { - In terms of awareness and attitudes, the pre- and post- } \\
\text { campaign surveys established increases in awareness, } \\
\text { recognition and stated actions. } \\
\text { - The proportion of Committed Food Waste Reducers } \\
\text { increased by } 10 \% \text { from } 13 \% \text { to } 23 \% \text { in } 5 \text { months. This } \\
\text { therefore matched the campaign's objectives (i.e. as } 10 \% \\
\text { increase which diverted an estimated } 2310 \text { tonnes of food } \\
\text { waste from landfill in 2008/og). }\end{array}$ & $\begin{array}{l}\text { waste less food is more cost effective and is preferred. } \\
\text { - Door to door engagement appears to be inefficient for } \\
\text { certain campaigns. }\end{array}$ \\
\hline $\begin{array}{l}\text { Middelgrund } \\
\text { en Wind } \\
\text { Cooperative } \\
\text { (DK, locally- } \\
\text { owned wind } \\
\text { farm creating } \\
\text { renewable } \\
\text { energy) }\end{array}$ & $\begin{array}{l}\text { To produce } \\
\text { electricity through } \\
\text { the establishment } \\
\text { and management of } \\
\text { wind turbines on the } \\
\text { Middelgrunden shoal } \\
\text { and enable the local } \\
\text { community of } \\
\text { Middelgrunden in } \\
\text { Denmark to share } \\
\text { expenses and income } \\
\text { from a wind turbine. }\end{array}$ & $\begin{array}{l}\text { This project was the biggest of its kind, } \\
\text { and based on sale of shares and dual } \\
\text { ownership, which included local } \\
\text { ownership by a cooperative and a } \\
\text { utility. } \\
\text { Rather than taking a purely } \\
\text { informational approach, a much more } \\
\text { active information and participation } \\
\text { strategy was used for the successful } \\
\text { implementation. }\end{array}$ & $\begin{array}{l}\text { - The annual production of the wind farm is estimated to } \\
\text { be } 99,000 \text { MWh. The guarantied production is } 89,000 \\
\text { MWh per year. The farm efficiency is estimated to be } \\
93.3 \% \text {. } \\
\text { - The farm delivers about } 4 \% \text { of the power for } \\
\text { Copenhagen, producing electricity for more than } 40,000 \\
\text { households in Copenhagen. } \\
\text { - An environmental impact assessment (EIA) was carried } \\
\text { out and has estimated since the start of the wind farm, } \\
258 \text { tonnes of sulphur dioxide, } 231 \text { tonnes of nitrogen } \\
\text { oxides; } 76000 \text { tonnes of carbon dioxide and } 4900 \text { tons of } \\
\text { dust are prevented. }\end{array}$ & $\begin{array}{l}\text { - The integral use of cooperatives is important to obtain } \\
\text { local acceptance. } \\
\text { - The locally-based commitment, along with } \\
\text { cooperation between the cooperative, the local utilities } \\
\text { and the municipality of Copenhagen constituted a } \\
\text { significant precondition for the development of the } \\
\text { project. } \\
\text { - Discussions with different interest groups were carried } \\
\text { out before the planning process to secure local } \\
\text { acceptance at an early stage of the project. } \\
\text { - The concept of local ownership has been crucial to the } \\
\text { success of the project. Local ownership creates local } \\
\text { dialogue and acceptance, and raises public awareness. } \\
\text { - It is essential to disseminate the appropriate } \\
\text { information at the right time. } \\
\text { - The programme is clearly visible from the capital of } \\
\text { Denmark by travellers and local citizens, which has } \\
\text { generated widespread public acceptance and public } \\
\text { awareness of renewable energy. }\end{array}$ \\
\hline $\begin{array}{l}\text { Paris Velib } \\
\text { Programme } \\
\text { (bike share } \\
\text { programme) }\end{array}$ & $\begin{array}{l}\text { To offer a } \\
\text { complementary and } \\
\text { new means of } \\
\text { transportation for } \\
\text { both local citizens } \\
\text { and tourists and to } \\
\text { promote soft } \\
\text { transportation. }\end{array}$ & $\begin{array}{l}\text { The initiative is unprecedented in } \\
\text { terms of its scale and scope. It is a } \\
\text { comprehensive addition to the Parisian } \\
\text { transportation network. } \\
\text { Innovative also because the } \\
\text { programme has managed to create a } \\
\text { cheap, convenient, and } \\
\text { environmentally-friendly mode of }\end{array}$ & $\begin{array}{l}\text { - JCDecaux reported } 27.5 \text { million Vélib trips in the first } \\
\text { year and an average of } 75000 \text { trips/day. } \\
\text { - Since Vélib's introduction, Paris has seen a } 70 \% \text { increase } \\
\text { in bicycle use and a } 5 \% \text { reduction in car use and } \\
\text { congestion. } \\
\text { - According to a recent survey, } 61 \% \text { of users regularly use } \\
\text { Vélib for commuting to work or school and } 20 \% \text { stated } \\
\text { that they use cars less. }\end{array}$ & $\begin{array}{l}\text { - The density and the importance of the coverage of the } \\
\text { bike stations has been an important element. } \\
\text { - Local city initiatives had existed for quite some time to } \\
\text { help promote bike use. Therefore, existing } \\
\text { infrastructures made it relatively convenient for a bike } \\
\text { sharing programme. }\end{array}$ \\
\hline
\end{tabular}




\begin{tabular}{|c|c|c|c|c|}
\hline Case study & Objective & Innovative aspects & Impacts & Lessons learned \\
\hline & & transportation. & $\begin{array}{l}\text { - The Vélib programme has inspired many other similar } \\
\text { initiatives in other French cities as well as abroad. }\end{array}$ & \\
\hline $\begin{array}{l}\text { Picture } \\
\text { Health } \\
\text { Warnings on } \\
\text { Cigarette } \\
\text { Packets }\end{array}$ & $\begin{array}{l}\text { To raise awareness } \\
\text { on the health risks } \\
\text { related to smoking, } \\
\text { encourage smokers } \\
\text { to quit smoking, } \\
\text { repulse non-smokers } \\
\text { (especially when they } \\
\text { are young before } \\
\text { they start smoking), } \\
\text { and } \\
\text { reduce the } \\
\text { consumption of } \\
\text { cigarettes. }\end{array}$ & $\begin{array}{l}\text { Using pictures/images rather than text } \\
\text { is innovative, as previously only textual } \\
\text { health warnings had been used on } \\
\text { cigarette packs. Furthermore, they } \\
\text { reach illiterate people, who otherwise } \\
\text { may not be able to read the textual } \\
\text { health warnings. }\end{array}$ & $\begin{array}{l}\text { - After the picture health warnings had been introduced, } \\
\text { more adults and young people agreed that the message } \\
\text { made smoking seem less attractive and more adults } \\
\text { agreed that the messages 'put me off smoking'. } \\
\text { - The range and depth of knowledge about the health risks } \\
\text { of smoking did not change after the pictures were } \\
\text { introduced. However, awareness of some conditions } \\
\text { depicted by the picture warnings, such as gum and mouth } \\
\text { disease or oral cancer, increased significantly. These } \\
\text { health warning pictures are arguably the most graphic and } \\
\text { were the messages that smokers reported had made } \\
\text { them think the most about their smoking behaviour. }\end{array}$ & $\begin{array}{l}\text { - Strong public support is important: creates social } \\
\text { movements and helps to create "social norms". } \\
\text { - Health warnings can be effective raising awareness of } \\
\text { the potential health effects of certain products. } \\
\text { - Countries such as Canada and Australia have shown } \\
\text { that picture health warnings (use of graphic images) are } \\
\text { more effective than text-based warnings alone. } \\
\text { - Explore the possibilities of making the industry pay for } \\
\text { ad campaigns (similar to tobacco companies). }\end{array}$ \\
\hline $\begin{array}{l}\text { Transition } \\
\text { Towns } \\
\text { (network } \\
\text { starting from } \\
\text { Ireland to } \\
\text { spreading } \\
\text { worldwide) }\end{array}$ & $\begin{array}{l}\text { To create } \\
\text { community-led } \\
\text { responses and } \\
\text { resilience to the } \\
\text { challenges and } \\
\text { opportunities of peak } \\
\text { oil, climate change } \\
\text { and economic } \\
\text { stagnation. }\end{array}$ & $\begin{array}{l}\text { This is a highly novel approach, from } \\
\text { its community-led nature, to its } \\
\text { collaborative approach in creating a } \\
\text { 'model' that communities can follow as } \\
\text { appropriate for their situation, the } \\
\text { integration of permaculture and } \\
\text { psychology principles to what can be } \\
\text { considered an environmental initiative, } \\
\text { local community resilience, localisation } \\
\text { and reform of the local economy. }\end{array}$ & $\begin{array}{l}\text { As the founding group and therefore longest existing, } \\
\text { Transition Town Totnes (TTT) identified the following } \\
\text { results to April 2011: } \\
\text { - } \quad \text { raised the funding for } 74 \text { solar panels on Totnes Civic } \\
\text { Hall which will generate around } 13, \text { oookWh (a third of } \\
\text { its demand), leading to the Council saving over } £ 5 \\
500(€ 6250) ; \\
\text { - } \quad \text { planted } 186 \text { hybrid nut trees throughout the town; } \\
\text { the Garden Share scheme means that now } 30 \\
\text { gardeners in } 13 \text { gardens are able to grow food, } \\
\text { providing food to over } 50 \text { families; } \\
\text { over } 70 \text { businesses now accept the Totnes Pound; } \\
\text { there are now } 59 \text { 'Transition Together' groups in and } \\
\text { around the town, who will each reduce their carbon } \\
\text { emissions by } 1.2 \text { tonnes, each saving } £ 601 \text { ( } € 685 \text { ) per } \\
\text { year (over } 50 \% \text { of those households are low-income); } \\
57.2 \% \text { of local people feel the group's work is either } \\
\text { 'highly relevant' or 'relevant' to their lives. }\end{array}$ & $\begin{array}{l}\text { - The programme has built and relied upon community } \\
\text { strength and solidarity. It has promoted the principle of } \\
\text { a more resilient community focus on 'localism' and } \\
\text { 'localisation'. } \\
\text { - This sort of initiative works well at local levels but it is } \\
\text { not sure how feasible it would be to scale up this type of } \\
\text { programme (i.e. at EU level) }\end{array}$ \\
\hline $\begin{array}{l}\text { Vienna City } \\
\text { (de- } \\
\text { materialisatio } \\
\text { n activities) }\end{array}$ & $\begin{array}{l}\text { To reduce waste } \\
\text { generation in Vienna, } \\
\text { with prevention seen } \\
\text { as the most desirable }\end{array}$ & $\begin{array}{l}\text { The novelty of focusing on } \\
\text { encouraging a shift to immaterial } \\
\text { consumption is very high, given } \\
\text { consumption levels in Western }\end{array}$ & $\begin{array}{l}\text { - According to Vienna's most recent } 2007 \text { Environmental } \\
\text { Report, } 1 \mathrm{~m} \text { tonnes of waste are collected every year, with } \\
\text { around } 40 \% \text { of this being collected separately for } \\
\text { recycling. Furthermore, by reducing the quantity of waste }\end{array}$ & $\begin{array}{l}\text { - The group of many experts from different sectors is } \\
\text { likely to be listened to more than a city department, and } \\
\text { yet it has buy-in from many crucial departments and } \\
\text { individuals. }\end{array}$ \\
\hline
\end{tabular}




\begin{tabular}{|c|c|c|c|c|}
\hline Case study & Objective & Innovative aspects & Impacts & Lessons learned \\
\hline & $\begin{array}{l}\text { waste management } \\
\text { option as it } \\
\text { eliminates the need } \\
\text { for handling, } \\
\text { transporting, } \\
\text { recycling or disposal } \\
\text { of waste. }\end{array}$ & $\begin{array}{l}\text { societies. Two approaches to waste } \\
\text { prevention have been developed } \\
\text { corresponding to high- and low- } \\
\text { income sectors of society. In terms of } \\
\text { trying to change consumption patterns } \\
\text { it appears that much of the activities } \\
\text { are focused on information provision } \\
\text { and awareness-raising which are not } \\
\text { high novelty in themselves. }\end{array}$ & $\begin{array}{l}\text { and switching to more cost-effective categories, around } \\
180 \text { tonnes of waste was reduced from } 2005 \text { to } 2006 \text {, } \\
\text { saving around } € 30000 \text { in additional costs. } \\
\text { - In 2004, demand for the Repair and Service Centres } \\
\text { (RUSZ) increased substantially and exceeded previously } \\
\text { set targets largely as a result of extensive media coverage. } \\
\text { - The Vienna authorities calculate that about } 11,000 \\
\text { tonnes of waste is saved by the RUSZ centres, while the } \\
\text { flea market saves around } 1000 \text { tonnes of waste annually. }\end{array}$ & $\begin{array}{l}\text { - The competition format is a good instrument to } \\
\text { generate new ideas, but needs strong local buy-in and } \\
\text { must be followed up by adequate funding for } \\
\text { demonstration and continuing projects - one year } \\
\text { projects are just not long enough. }\end{array}$ \\
\hline $\begin{array}{l}\text { VISIT } \\
\text { initiative } \\
\text { (sustainable } \\
\text { tourism) }\end{array}$ & $\begin{array}{l}\text { To promote and } \\
\text { support the } \\
\text { development of } \\
\text { sustainable tourism } \\
\text { at international, } \\
\text { national and regional } \\
\text { levels. }\end{array}$ & $\begin{array}{l}\text { VISIT is the first initiative in Europe } \\
\text { that aims to gather tourism-related } \\
\text { organisations and make them } \\
\text { exchange their practices as well as } \\
\text { make their requirements uniform. This } \\
\text { alliance between the different eco- } \\
\text { labels is based on mutual } \\
\text { understanding and recognition and the } \\
\text { agreement to adopt a common } \\
\text { standard. }\end{array}$ & $\begin{array}{l}\text { - More than } 1100 \text { tourism businesses are now labelled with } \\
\text { the VISIT initiative including hotels, camping sites and } \\
\text { eco-friendly accommodations. } \\
\text { - Efforts also contributed to raising consumer awareness } \\
\text { and demand for these products, and reducing duplication } \\
\text { of efforts and resources in the field of sustainable tourism. }\end{array}$ & $\begin{array}{l}\text { - Harmonised criteria for labels facilitate } \\
\text { implementation. } \\
\text {-Important to have continued EU funding and support to } \\
\text { maintain momentum. }\end{array}$ \\
\hline
\end{tabular}


The case studies draw attention to the need to incorporate the following aspects into policy tools:

- The right price signal: When designing tools that will affect prices, it is important to assess possible rebound effects by understanding the magnitude of the take back in anticipated environmental savings. Further, beware of becoming a "victim of your own success" (as seen in the EcoEnergy Retrofit programme), which can be avoided by setting up a maximum budget as seen in the Dutch GFS or being prepared to follow up success with possible non-financial incentive or alternative.

- Use of smart technologies and new media (including social networks and media): this includes for example using Smartphone applications and technologies and social networks such as YouTube, facebook, etc.

- Involving the public and gaining their support in advance of implementation (local ownership and involvement): Locally-based commitment and ownership "responsibilises" consumers and households which ensures motivation and a more long-term commitment to behaviour change. Local ownership creates local dialogue and acceptance, and raises public awareness.

- Having the right infrastructure and support (financial and technical/informational): this is essential for the long-term success of a project as well as for large-scale projects as seen in the Paris Velib case study, in existing traffic initiatives helped in its success.

- Accessibility from all levels of society (regardless of income level, level of education, etc: It is important that sustainable consumption initiatives are accessible to consumers from all income and education levels (see Box 1). The picture warnings on cigarette packages are able to be interpreted from all social classes regardless of education level.

- Transparency, credibility and trust: Initiatives tend to be more credible when several different levels of stakeholders are involved.

- Clearly defining the targeted groups and design tailor made communication strategies and objectives to reach each one

Many parallels can be drawn between these findings and the objectives discussed at the Future Visioning workshop, such as infrastructure ("establishing infrastructure that supports sustainable behaviour"), credibility ("be the change you want to be") and local ownership ("enable and empower").

Although there is a good cross-section of case studies, a limitation of research conducted is that it was based on literature review. Local and grassroots initiatives are not usually as well documented as initiatives implemented by government agencies, which often have formal impact analyses or activity reports. 


\section{Chapter 4: Analysis of policy toolboxes in nine}

\section{consumption sectors}

In this chapter, assessments of nine key sectors of consumption are carried out. These sectors were selected for their significant contribution to environmental pressures or their role in stimulating necessary behaviour changes for sustainable consumption. This selection builds on the main lessons learned from the case studies analysed in the previous chapter and from the different types of tools listed in previous chapters. The policy toolbox assessments for each sector are included in the Annex of this report (page 166).

Given the focus of this study, the proposed policy toolboxes focus primarily on measures that seek to influence consumer choice/demand towards more sustainable consumption patterns. However, a number of consumption related measures require complementary production/supply side measures to be effective, which are also mentioned in the report where relevant. The toolboxes include measures that can be taken forward at EU, national and local levels.

The nine toolboxes were assessed according to the following key sectors: tourism, air travel, housing (which was further divided into the three sub-areas of infrastructure, energy using appliances, and water using appliances) clothing/textiles, mobility, food, and citizen community action.

\subsection{Summary of key consumption sectors}

The consumption areas of housing, food and drink, and mobility were included in the selection as they have been identified by a number of studies as being responsible for a large part of the pressures caused by consumption in the $\mathrm{EU}^{50,51}$. For instance, an analysis of nine EU Member States ${ }^{52}$ found that these three broad consumption areas contributed approximately $68 \%$ of GHG emissions, $73 \%$ of acidifying emissions, $69 \%$ of tropospheric ozone precursor emissions and $64 \%$ of the direct and indirect material input caused by overall consumption in 2005 in these countries ${ }^{53}$. It is

\footnotetext{
${ }^{50} \mathrm{JRC/IPTS}$, (2006), Environmental Impact of Products (EIPRO) - Analysis of the life cycle environmental impacts related to the final consumption of the EU-25, Main report, EUR 22284 EN. Institute for Prospective Technological Studies, Sevilla. http://ec. europa. eu/environment/ipp/pdf/eipro report.pdf [Accessed 31/05/2011]

${ }^{51}$ ETC/SCP, (2009), Environmental Pressures from European Consumption and Production A study in integrated environmental and economic Analysis, ETC/SCP working paper 1/2009, http://scp.eionet.europa.eu/publications/working\%20paper\%20namea200g/wp/working\%20paper\%20namea2009 [Accessed 31/05/2011]

$5^{2}$ ETC/SCP, (2009), Environmental Pressures from European Consumption and Production A study in integrated environmental and economic Analysis, ETC/SCP working paper 1/2009, http://scp.eionet.europa.eu/publications/working\%20paper\%20namea2009/wp/working\%20paper\%2onamea2009

[Accessed 31/05/2011]

${ }^{53}$ Austria, Czech Republic, Denmark, Germany, France, Italy, the Netherlands, Portugal and Sweden
} 
worth noting that in all the sectors, there are a number of examples of good practice at the domestic level, which could be shared through a coordinated mechanism across EU Member States. Moreover, the rebound effect also needs to be taken into account when designing policy mechanisms in several of these sectors. These aspects are elaborated further in section 5.3.4.

A summary of the sectors and pros and cons for further analysis are provided in Table 15.

Table 15: Sector summaries

\begin{tabular}{|c|c|c|c|}
\hline Sector & Overview of sector & $\begin{array}{l}\text { Pros and cons of } \\
\text { further analysis }\end{array}$ & Key elements of possible toolbox \\
\hline $\begin{array}{l}\text { Urban } \\
\text { mobility }\end{array}$ & $\begin{array}{l}\text { - Significant environmental impact, in } \\
\text { particular with regard to GHG } \\
\text { emissions. } \\
\text { - Expected increases in transport and } \\
\text { associated energy needs to } 2030 \text {. } \\
\text { - EU focus has been on technological } \\
\text { improvements rather than modal shifts. } \\
\text { - Need to address policy incoherence, } \\
\text { social aspects, infrastructure lock-in. }\end{array}$ & $\begin{array}{l}\frac{\text { PROS }}{\text { - Significant GHG }} \\
\text { impact } \\
\text { - Rising } \\
\text { consumption } \\
\frac{\text { CONS }}{- \text { Infrastructure }} \\
\text { lock-in }\end{array}$ & $\begin{array}{l}\text { - Guidelines for spatial planning (e.g. } \\
\text { to promote public transport, modal } \\
\text { shift, non-motorised travel); } \\
\text { - Revise fiscal and taxation policies } \\
\text { (e.g. congestion and road use } \\
\text { charging, vehicle taxes, fuel taxes); } \\
\text { - Redirect infrastructure funding (e.g. } \\
\text { to prioritise non-motorised and } \\
\text { public transport infrastructure); } \\
\text { - Introduce demand-side } \\
\text { management policies (e.g. } \\
\text { restricted access schemes, deploy } \\
\text { ITS applications in support of eco- } \\
\text { driving, provide incentives to } \\
\text { encourage people to try new forms } \\
\text { of transport - e.g. free trial bus } \\
\text { passes). }\end{array}$ \\
\hline Air travel & $\begin{array}{l}\text { - Major contributor to EU GHG } \\
\text { emissions } \\
\text { - Significant growth expected. } \\
\text { - EU focus has been on market-based } \\
\text { tools (EU ETS, taxes) and innovation } \\
\text { (e.g. EU Clean Sky Joint Initiative) } \\
\text { rather than influencing consumer } \\
\text { behaviour. } \\
\text { - Need to address price elasticity of air } \\
\text { travel, GHG emissions, use of } \\
\text { alternative fuels, and new modes of } \\
\text { propulsion. } \\
\text { - Need to take into account } \\
\text { international dimension (opposition to } \\
\text { international measures that limit air } \\
\text { travel, competitive distortion, carbon } \\
\text { leakage) when designing initiatives in } \\
\text { the area. }\end{array}$ & $\begin{array}{l}\text { PROS } \\
\text { - Significant GHG } \\
\text { impact } \\
\text { - Rising } \\
\text { consumption } \\
\frac{\text { CONS }}{- \text { Price elasticity }} \\
\text { of air travel } \\
\text { - International } \\
\text { dimension }\end{array}$ & $\begin{array}{l}\text { - Launch well-designed } \\
\text { information/education campaigns to } \\
\text { raise awareness and influence } \\
\text { attitudes/and practices (e.g. by } \\
\text { proposing concrete practices such as } \\
\text { only flying once a year); } \\
\text { - Provide competitive alternatives to } \\
\text { air travel through investments and } \\
\text { incentives differentiating between } \\
\text { different types of travel/travellers; } \\
\text { - Harmonise calculation and } \\
\text { quality of carbon offsets; } \\
\text { - Extend use of airport taxes so they } \\
\text { can distinguish between long and } \\
\text { short haul flights; } \\
\text { - Encourage take-up of provisions in } \\
\text { energy taxation Directive on levying } \\
\text { fuel taxes on domestic and intra- } \\
\text { Europe flights on the basis of bilateral } \\
\text { agreements. }\end{array}$ \\
\hline $\begin{array}{l}\text { Housing: } \\
\text { Infrastructure }\end{array}$ & $\begin{array}{l}\text { - Significant environmental impact, } \\
\text { particularly through energy/materials/ } \\
\text { biodiversity/ water consumption, land } \\
\text { use (and soil sealing). } \\
\text { - Trend towards smaller households and }\end{array}$ & $\begin{array}{l}\text { PROS } \\
\text { - Significant } \\
\text { environmental } \\
\text { impact } \\
\text { - Existing policy }\end{array}$ & $\begin{array}{l}\text { - Develop reliable differentiator } \\
\text { mechanisms (e.g. certification, } \\
\text { labelling); } \\
\text { - Launch targeted information } \\
\text { campaigns; }\end{array}$ \\
\hline
\end{tabular}




\begin{tabular}{|c|c|c|c|}
\hline Sector & Overview of sector & $\begin{array}{l}\text { Pros and cons of } \\
\text { further analysis }\end{array}$ & Key elements of possible toolbox \\
\hline & $\begin{array}{l}\text { hence growing demand of living space } \\
\text { per person is expected to continue to } \\
2020 . \\
\text { - EU focus has been on promoting } \\
\text { sustainability on supply side rather than } \\
\text { changing consumer demands. } \\
\text { - Need to address social factors, } \\
\text { infrastructure lock-in, weak incentives } \\
\text { and lack of information on supply and } \\
\text { demand side. }\end{array}$ & $\begin{array}{l}\text { framework for } \\
\text { energy } \\
\text { performance } \\
\frac{\text { CONS }}{- \text { Infrastructure }} \\
\text { lock-in } \\
\text { - Focus to date } \\
\text { on supply side }\end{array}$ & $\begin{array}{l}\text { - Provide economic tools (e.g. } \\
\text { subsidies, green loans, fiscal } \\
\text { measures) to incentivise installation } \\
\text { of sustainability features; } \\
\text { - Encourage retrofitting and } \\
\text { renovation schemes in existing } \\
\text { housing stock; } \\
\text { - Avoid split incentives with } \\
\text { mechanisms to ensure investors } \\
\text { recoup benefits of investments. }\end{array}$ \\
\hline $\begin{array}{l}\text { Housing: } \\
\text { Energy using } \\
\text { appliances** }\end{array}$ & $\begin{array}{l}\text { - 'Midrange' environmental impact. } \\
\text { - Demand for small appliances growing } \\
\text { rapidly (e.g. personal computers, } \\
\text { mobile phones), offsetting efficiency } \\
\text { gains from large appliances and space } \\
\text { heating. } \\
\text { - EU regulatory tools focus on producers, } \\
\text { application of voluntary information } \\
\text { tools not widespread and have limited } \\
\text { effect. } \\
\text { - Need to address amount and type of } \\
\text { appliances consumed, change use } \\
\text { patterns, improve eco-design, restrict } \\
\text { sale of inefficient products, and } \\
\text { incentivise purchase of energy- } \\
\text { efficient devices. }\end{array}$ & $\begin{array}{l}\frac{\text { PROS }}{\text { - Rising }} \\
\text { consumption } \\
\text { - Existing policy } \\
\text { framework for } \\
\text { eco-design } \\
\text { CONS } \\
\text { - Environmental } \\
\text { impacts not as } \\
\text { significant as } \\
\text { other sectors; } \\
\text { focused on } \\
\text { energy }\end{array}$ & $\begin{array}{l}\text { - Introduce well-designed information } \\
\text { and labelling tools together with } \\
\text { financial incentives. Ensure } \\
\text { availability of substitutes or new } \\
\text { technologies to support change in } \\
\text { behaviour; } \\
\text { - Encourage retailers to provide } \\
\text { product trials or money back } \\
\text { guarantees; } \\
\text { - Establish 'buy back' and 'trade-in' } \\
\text { schemes complemented by financial } \\
\text { incentives; } \\
\text { - Develop consumer support } \\
\text { mechanisms; } \\
\text { - In promoting energy-efficient devices, } \\
\text { highlight costs associated with high } \\
\text { energy-using appliances, promote } \\
\text { product features with policy } \\
\text { relevance, avoid additional taxation } \\
\text { and offer 'free' benefits (e.g. VAT } \\
\text { free, free extended warrantee). }\end{array}$ \\
\hline $\begin{array}{l}\text { Housing: } \\
\text { Water using } \\
\text { appliances** }\end{array}$ & $\begin{array}{l}\text { - Water scarcity is an increasing } \\
\text { problem. } \\
\text { - Trend towards smaller households } \\
\text { expected to increase water } \\
\text { consumption. } \\
\text { - EU focus on improving quality of water, } \\
\text { the need to address demand } \\
\text { increasingly recognised. } \\
\text { - Need to address consumer awareness } \\
\text { and behaviour, technical performance } \\
\text { of water supply systems, and politically } \\
\text { sensitive issue of managing water } \\
\text { demand. }\end{array}$ & $\begin{array}{l}\frac{\text { PROS }}{\text { - Addresses }} \\
\text { increasing issue } \\
\text { of water scarcity } \\
\text { - Existing policy } \\
\text { framework } \\
\frac{\text { CONS }}{\text { - Addresses a }} \\
\text { specific } \\
\text { sustainability } \\
\text { issue }\end{array}$ & $\begin{array}{l}\text { - Improve implementation of Water } \\
\text { Framework Directive provisions on } \\
\text { water tariffs and compulsory } \\
\text { metering; } \\
\text { - To minimise regressive impact of } \\
\text { water charging, couple full-cost } \\
\text { water pricing with assistance to low- } \\
\text { income households/progressively } \\
\text { graduate water prices based on } \\
\text { taxes; } \\
\text { - Promote demand management } \\
\text { measures through guidelines and } \\
\text { sharing best practices; } \\
\text { - Complement above with public } \\
\text { information campaigns and eco- } \\
\text { labelling schemes. }\end{array}$ \\
\hline $\begin{array}{l}\text { Food and } \\
\text { drink* }\end{array}$ & $\begin{array}{l}\text { - Significant environmental impacts, } \\
\text { especially from consumption of meat } \\
\text { and dairy products. } \\
\text { - In the EU, changes in composition of }\end{array}$ & $\begin{array}{l}\text { PROS } \\
\text { - Significant } \\
\text { environmental } \\
\text { impact }\end{array}$ & $\begin{array}{l}\text { - Reorient market frameworks towards } \\
\text { sustainability practice by eliminating } \\
\text { perverse subsidies, promoting } \\
\text { standardised labelling and providing }\end{array}$ \\
\hline
\end{tabular}




\begin{tabular}{|c|c|c|c|}
\hline Sector & Overview of sector & $\begin{array}{l}\text { Pros and cons of } \\
\text { further analysis }\end{array}$ & Key elements of possible toolbox \\
\hline & $\begin{array}{l}\text { diets (e.g. replace beef with pork and } \\
\text { poultry, increasing imports) and the } \\
\text { way food is produced and sold (e.g. } \\
\text { favour pre-prepared, frozen meals and } \\
\text { convenience foods) expected to } \\
\text { continue to } 2020 \text {. } \\
\text { - EU focus has been on } \\
\text { production/process side, interventions } \\
\text { on consumption side have been } \\
\text { restricted to soft measures like } \\
\text { education and awareness raising. } \\
\text { - Reluctance of policy-makers to act in } \\
\text { area of consumer choice, structure of } \\
\text { food supply chain, infrastructure, } \\
\text { social, cultural and emotional factors, } \\
\text { cost and availability of sustainable } \\
\text { food and drink products. }\end{array}$ & $\begin{array}{l}\text { - Many aspects } \\
\text { for tools to } \\
\text { address (choice, } \\
\text { preparation, } \\
\text { waste, etc.) } \\
\text { CONS } \\
\text { - International } \\
\text { dimension } \\
\text { - Complexity of } \\
\text { preferences } \\
\text { involved in food } \\
\text { decisions }\end{array}$ & $\begin{array}{l}\text { integrated infrastructure solutions } \\
\text { that cater to local and regional needs; } \\
\text { - Engage retailers and major food } \\
\text { producers (e.g. through public- } \\
\text { private partnerships, setting } \\
\text { standards) to green upstream supply } \\
\text { chains and reduce downstream } \\
\text { impact of products (e.g. choice } \\
\text { editing, free trials and price } \\
\text { promotions); } \\
\text { - Launch targeted awareness-raising } \\
\text { and information campaigns; } \\
\text { - Establish price mechanisms and } \\
\text { quality standards that support / } \\
\text { stimulate dietary change; } \\
\text { - Support local/community-led niche } \\
\text { practices or initiatives. }\end{array}$ \\
\hline $\begin{array}{l}\text { Clothing/ } \\
\text { Textiles* }\end{array}$ & $\begin{array}{l}\text { - Significant environmental impact, } \\
\text { aggravated by rising consumption } \\
\text { levels. } \\
\text { - EU focus has been on the production } \\
\text { phase, however most textile products } \\
\text { are imported and thus the scope for EU } \\
\text { supply-side policy is limited. } \\
\text { - Need to address consumer } \\
\text { choice/behaviour. }\end{array}$ & $\begin{array}{l}\frac{\text { PROS }}{- \text { Significant }} \\
\text { environmental } \\
\text { impact } \\
\text { - Rising } \\
\text { consumption } \\
\text { CONS } \\
\text { - International } \\
\text { dimension }\end{array}$ & $\begin{array}{l}\text { - Establish standardised labelling and } \\
\text { certification schemes; } \\
\text { - Launch targeted information } \\
\text { campaigns covering whole lifecycle of } \\
\text { clothing; } \\
\text { - Partner with retail industry and } \\
\text { encourage engagement in greening } \\
\text { upstream supply-chains and } \\
\text { influencing consumer behaviour. }\end{array}$ \\
\hline Tourism* & $\begin{array}{l}\text { Significant environmental impacts } \\
\text { both inside and outside Europe. } \\
\text { - Trends in tourism are changing, in } \\
\text { particular experimental tourism which } \\
\text { includes eco-tourism, rural and } \\
\text { community tourism is expected to grow } \\
\text { quickly over next two decades. } \\
\text { - EU focus on voluntary and } \\
\text { informational initiatives, however } \\
\text { action is limited to domestic EU } \\
\text { tourism sector. } \\
\text { - Need to address social aspects, lack of } \\
\text { resources/information/skills, } \\
\text { infrastructure/destination 'lock-in', } \\
\text { economic interests including those of } \\
\text { less developed countries. } \\
\text { - Take into account 'carrying capacity' } \\
\text { of tourism areas in terms of visitors } \\
\text { and their impacts in designing } \\
\text { initiatives in the area. }\end{array}$ & $\begin{array}{l}\text { PROS } \\
\text { - Significant } \\
\text { environmental } \\
\text { impact } \\
\text { - Existing trends } \\
\text { toward eco- } \\
\text { tourism } \\
\\
\text { CONS } \\
\text { - International } \\
\text { dimension } \\
\text { - Complexity of } \\
\text { social and } \\
\text { economic } \\
\text { aspects in } \\
\text { destination } \\
\text { locations }\end{array}$ & $\begin{array}{l}\text { - Introduce additional information } \\
\text { tools that engage consumers and } \\
\text { industry (e.g. information and } \\
\text { education programmes in } \\
\text { cooperation with local stakeholders } \\
\text { on appropriate behaviour, potential } \\
\text { harmful environmental impacts of } \\
\text { tourism, benefits of activities such as } \\
\text { eco-tourism); } \\
\text { - Use financial instruments such as } \\
\text { price signals (e.g. tax on aircraft } \\
\text { fuel/use of airports). }\end{array}$ \\
\hline
\end{tabular}




\begin{tabular}{|c|c|c|c|}
\hline Sector & Overview of sector & $\begin{array}{l}\text { Pros and cons of } \\
\text { further analysis }\end{array}$ & Key elements of possible toolbox \\
\hline $\begin{array}{l}\text { Citizen } \\
\text { community } \\
\text { action* }\end{array}$ & $\begin{array}{l}\text { Recent studies and the workshop } \\
\text { organised for this study identify the need } \\
\text { to go beyond traditional approaches to } \\
\text { SCP to address societal values and } \\
\text { norms through public/community } \\
\text { engagement processes and systems that } \\
\text { make sustainable living easier. }\end{array}$ & $\begin{array}{l}\text { PROS } \\
\text {-Opportunity to } \\
\text { address societal } \\
\text { values and norms } \\
\text {-Bottom-up } \\
\text { citizen-led } \\
\text { movements } \\
\text {-Innovative } \\
\text { approach } \\
\text { CONS } \\
\text {-Requires political } \\
\text { support and } \\
\text { funding }\end{array}$ & $\begin{array}{l}\text { - Political and financial support for } \\
\text { bottom-up citizen-led movements; } \\
\text { - Provide incentives and stimulate } \\
\text { investments in wider systems and } \\
\text { infrastructures (e.g. invest in local } \\
\text { recycling facilities, provide loans and } \\
\text { grants for products such as } \\
\text { insulation); } \\
\text { - Increase knowledge and } \\
\text { understanding on how sustainable } \\
\text { consumption policies and practices } \\
\text { can evolve, building on research from } \\
\text { social and behavioural sciences; } \\
\text { - Increase awareness and share best } \\
\text { practices on on-going efforts (e.g. } \\
\text { Transition Towns). }\end{array}$ \\
\hline
\end{tabular}

\subsection{Selection of five sectors for further analysis}

Based on the assessment of the nine tool collections and literature review carried out in the previous sections, five key sectors are selected, for which possible policy options have been developed to reorient consumer behaviour towards more sustainable consumption and purchasing patterns. The five sectors selected for further analysis are:

Housing appliances (energy and water using appliances)

Food and Drink

Clothing/textiles

Tourism

Citizen community action

The above sectors have been selected based on the following justifications:

The feasibility of implementation at EU level (i.e. proposed action falls within the area of EU competence) and the potential to implement tools in the sector from a short to midterm perspective (with a vision of 2020).

The significance of the environmental impacts of the sector.

Coherence of the sector with what is already being done at EU level - currently many EU policies target the supply/production side of the above sectors. The demand/consumption side is less well addressed and there is a need to fill this gap. The measures in these sectors will be in line with the objectives of the SCP Action Plan and would also complement or feed into the implementation of several on-going processes such as the forthcoming resource efficiency roadmap.

The citizen community action sector has been selected to ensure that a social/behavioural 
perspective on policy is included. Many sectors can be addressed through bottom-up, community-led action, and this innovative approach to policy should be further analysed.

The two sub-sectors under housing: energy using appliances and water using appliances have been combined into one sector, housing appliances. Both of these sectors were deemed important to address and strongly linked in terms of possible policy options and frameworks. 


\section{Chapter 5: Assessment of five key consumption sectors}

This chapter provides further assessment of the five key sectors selected in the previous chapter, including discussion of the policy context and cross-cutting issues, identification of policy options for each sector and comparison of policy options.

\subsection{Terminology and aspects of analysis}

A policy option refers to the general policy framework that includes the sector objective (for most of the sectors the objective would be to promote sustainable consumption), and specific policy actions or tools to fulfil the objectives, and guidance on how these actions could most efficiently be implemented. Each policy option can have several sector objectives. Objectives are either qualitative or quantitative. Several specific actions are proposed to fulfil these objectives.

Sector objectives are based on the priority areas and actions of specific sectors that were identified in Chapter 5 . For each of the sectors the following information has been sought:

What are the sector objectives?

What specific actions/tools are proposed to fulfil objectives?

How would the specific actions under the policy option interact?

- At what level should the specific actions be implemented? Is the policy option realistic and feasible to implement at EU level? If not, what action could be taken at the EU level to facilitate take up at the relevant level?

Who do specific actions target (in most cases consumers)?

Which actor(s) would be involved in the implementation of the specific action (e.g. EC, MS, local authority, retailer, etc)

Potential costs of specific actions (should data be available, quantification where possible)

The political acceptability of certain policy measures

How specific actions should be implemented: e.g. using community and group approaches, behavioural approach, and specific marketing/advertising guidelines? Using a mixture of soft and hard measures can be discussed here? Regulatory approaches?

Possible advantages and disadvantages of the specific actions

What are the possible impacts of specific actions? (E.g. potential impacts on the economy, on industry, local community, etc.) 
Are there any possible indicators or measurable indicators that can be used to monitor and evaluate the impacts of the specific action?

Are there any best practice examples of the specific action that can be used as evidence of its successful implementation?

Consider whether the policy mix is coherent with existing EU policies

Will the specific action be coherent with the SCP Action Plan? Other EU policies?

What Directorate-Generals (DG) and other EU institutions would be involved?

\subsection{General EU policy context}

Setting the policy context helps to shape the different objectives and tools necessary to bring about more sustainable consumption in specific key sectors.

Several EU policies have been established to reduce the environmental impacts of products. For example, EU initiated tools such as the EU Eco-label and the energy performance label help to inform consumers about the environmental impact of products. Other EU initiatives such as the Retail Forum and the European Food SCP Round Table are both multi-stakeholder platforms set up in order to exchange best practices on sustainability in the European retail and food sectors. Both groups aim at knowledge exchange to identify opportunities and barriers that may further or hinder the achievement of sustainable consumption and production. Other policies such as EMAS, GPP, and ETAP aim to assist SMEs and public authorities to partake in more sustainable purchasing and management practices, as well as to invest in eco-friendly technologies. Finally, legislation such as the Eco-design Directive also helps in reducing the energy consumption and other key environmental impacts from products through binding product requirements.

The above initiatives are all part of the Sustainable Consumption and Production and Sustainable Industrial Policy (SCP/SIP) Action Plan, adopted on 4 December 2008. Measures under the SCP/SIP Action Plan aim to improve the environmental performance of products and increase the demand for more sustainable goods and production technologies. Closely linked to the SCP/SIP action plan is the Resource Efficiency flagship initiative of the Europe 2020 Strategy. The strategy aims to use resources more efficiently to help achieve many of the EU's objectives regarding job growth, climate change, strengthening EU economic sectors, food insecurity in developing countries, and security of Europe's supply of raw materials. To achieve a resource-efficient Europe, the Europe needs to make technological improvements, a significant transition in energy, industrial, agricultural and transport systems, and changes in behaviour as producers and consumers ${ }^{54}$.

Despite the existence of these initiatives, major shifts in consumption behaviour are still needed to achieve the environmental, social, and economic objectives that have been set at EU level. Up until now, policies within the SCP/SIP Action Plan have mainly been focused on the supply/production side. However, the SCP Action Plan is to be revised in 2012, therefore, the policy options that are

\footnotetext{
${ }^{54}$ EC Communication, 2011, A resource-efficient Europe - Flagship initiative under the Europe 2020 Strategy ec.europa.eu/resource-efficient-europe/pdf/resource efficient europe en.pdf
} 
being proposed in this study for the selected sectors aim at complement these policy instruments and provide measures where gaps exist.

\section{Cross-cutting actions}

\subsubsection{Sectoral roadmaps and envisioning}

An important cross-cutting action would be the establishment of a multi-stakeholder roadmap/envisioning exercise for each sector as a first step for policy-makers. This would help to understand better the values and behaviours across the EU for each sector of consumption, to provide input toward the design of specific policy actions and, importantly, allow formulation of a compelling and integrated set of visions of sustainable living. These visions, intertwined into a reinvigorated European cultural identity, could then be communicated by senior politicians and other influential people as mission statements.

The central proposal is for a political rather than policy type message. Examples include starting the NHS in the UK, the HIV public health response and response to energy crises; what they all have in common is a call for action combined with an offered vision of how society could be better if the shared identity changes. Examples of an element of this approach include the methods used in the project's Future Visioning Workshop, and initiatives by the UK's Defra, which initiated sectoral roadmaps ${ }^{55}$ as means to reduce environmental impacts.

\section{Food and drink}

In the food and drink sector, a sectoral roadmap could highlight the importance of food and agriculture in European culture and healthy communities. Sustainable local production could play an essential part of the roadmap. Therefore, a 'vision' of a future sustainable food system in the EU would link local food products with the cultural identity and heritage of Europe. Action could be taken at the EU, Member State, local or regional level, and would ideally be linked with the CAP.

\section{Housing appliances}

This might involve simpler to use more robust, efficient and durable appliances, which are marketed as a reflection of the attitudes of the buyer. There is some scope among European consumers for a more realistic and measured assessment purchase, which is also driven by style identity ${ }^{56}$. Ergonomically, an appliance which is ready to use, easy to understand without an instruction manual as there are only a few easy to interpret buttons responds better to how people live their busy lives. Action could be taken at the EU and Member State level, and would ideally be linked with the energy performance of buildings labelling.

\footnotetext{
${ }^{55}$ Defra page on sustainable products and consumers: www.defra.gov.uk/environment/economy/products-consumers/

${ }^{56} \mathrm{PSI}$ et al., 2009, Designing policy to influence consumers: Consumer behaviour relating to the purchasing of environmentally preferable goods
} 


\section{Clothing and textiles}

Whilst more sustainable forms of clothing could be promoted as an expression of fashion and identity, it is likely that fashion would move on and reject this within a short time: clothes are central to how people express their changing identities. In addition, the low price of clothing may make consumption patterns difficult to change. A more fundamental set of norms are called for which survive fashion trends, which could involve building on aspects of social equality, as has been raised via Fairtrade labelling.

\section{Tourism}

A vision of sustainable EU based tourism could be emphasise the cultural experience on offer within the EU and offer a re-vitalised image of a more sustainable local community culture within the EU. EU tourism tends away from commoditisation, as what is on offer is more differentiated than beach based tourism. As the analysis in o shows, it is challenging to change behaviours around tourism outside the EU. The best approach would be to try to envisage how sustainable tourism could become fashionable, and something that people talk about when discussing their holidays and travel experiences.

\section{Citizen community action}

Building on the food and drink vision, offer a compelling vision of there being an active local community able to respond to local challenges (but not only environmental challenges), providing benefits through the ability to take local decisions and implement sustainability solutions at a local level. Rationale for including these visions include:

They invite a greater overall level of environmental consciousness and therefore avoid some of the indirect rebound impacts possible with less environmental overt policies.

They would provide an overall coherent message for the public, which may be more acceptable, and within which the more detailed policy actions would fit; in doing so, they may make a portfolio of far-reaching environmental policy easier to implement, rather than building up resistance.

They may provide wider social benefits such as health and local production.

\subsubsection{Funding}

Some of the sector analyses in Chapter 4 propose that funding be provided to support initiatives. Funding mechanisms such as Life ${ }^{57}$ may be considered for such funding initiatives. However, one consideration is the practical policy limits such as those set out in competition policy that regulates

\footnotetext{
${ }^{57}$ See: ec.europa.eu/environment/life/funding/lifeplus/background/index.htm
} 
State aid (Article 107 of the Treaty on the Functioning of the European Union) ${ }^{58}$ and Council Regulation (EC) No 1260/99 on Structural Funds ${ }^{59}$.

\subsubsection{Sharing of local and MS level best practice}

It is worth noting that in all the nine sectors considered in Chapter 4 , there are examples of good practice at the MS and regional level. However, this information is not always easy to access, and the detail of the information not consistent - particularly for novel approaches. A coordinated mechanism across MS could help to encourage provision of data on results of initiatives and policy actions, improve the consistency and quality of the data, and facilitate sharing of ideas. Hence, this mechanism would encompass a searchable database and, further, could include a communications team to disseminate updates on best practice.

\subsubsection{The rebound effect}

The rebound effect is defined as increases in consumption due to environmental efficiency interventions that can occur through a price reduction (i.e. an efficient product being cheaper and hence more is consumed) or other behavioural responses. ${ }^{60}$ This encompasses both price induced and mental /psychological rebound effects. The mental rebound effect is where a feel good perception of being "green" encourages increased consumption for certain products where "green" or lower impact options are readily available.

Three types of price induced rebound effect were recognised:

- Direct Rebound Effect - where increased efficiency and associated cost reduction for a product/service results in its increased consumption because it is cheaper.

- Indirect Rebound Effect - where savings from efficiency cost reductions enable more income to be spent on other products and services.

- Economy wide Rebound Effect - where more efficiency drives economic productivity overall resulting in more economic growth and consumption at a macroeconomic level.

There is evidence from many sources of direct rebound effects for certain sectors (in the range 10$80 \%$ ). Understanding the magnitude of the take back in anticipated environmental savings from the rebound effect is important when developing interventions; where rebound effects are significant, efficiency policies need to be more ambitious, and other measures will be required, in particular sustainable consumption focused interventions.

\footnotetext{
${ }^{58}$ See: ec.europa.eu/competition/state_aid/overview/index_en.html

${ }^{59}$ See: europa.eu/legislation_summaries/regional_policy/provisions_and_instruments/160014_en.htm

${ }^{60} \mathrm{EC}$ (2011) Addressing the rebound effect. Available at: rebound.eu-smr.eu
} 
However, as the factors that influence the rebound effect are varied, generalising the available direct rebound effect estimates is not appropriate. One of the reasons there is debate on the rebound effect is because it is hard to measure and varies depending on the intervention, the type of products/services/resources investigated, as well as other related factors, e.g. price elasticity. Isolating the rebound effects from other factors that cause increased consumption is a key issue that needs resolution in the definition and measurement techniques for estimating the magnitude of rebound effects. Traditional economic models for measuring environmental policy savings do not cater for the rebound effect, but measurement approaches can include income/price elasticity studies (for direct rebound effects), econometric modelling, general equilibrium modelling and expenditure surveys; this lack of inclusion has contributed to scepticism on the significance of the effect. The study proposes four approaches to address rebound effects:

Recognise and account for rebound effect in policy design; the first step for policy is to recognise and account for rebound effect take back in projected environmental savings during evaluation, incorporating assessment criteria, e.g. price, income, substitutability, technology type, resource intensity of the production sector, potential for perverse outcomes/burden shifting and time span of the intervention, in tools such as Regulatory Impact Assessment (RIA). A toolbox (ideally web based) to support awareness raising /engagement of policy makers on rebound effect facts and how to include them in policy design and evaluation is proposed. The UK DECC, which already accounts for direct rebound effects where they occur, using the Valuation of energy use and GHG emissions for appraisal \& evaluation Guidance \& Tool, provides an example to build on. Further, a trial involving a selection of MS to assess rebound effects in policy is recommended.

Use of an integrated mixture of instruments encompassing fiscal, behavioural and technology; where the rebound effect is significant, evidence shows implementing a consistent mixed instrument approach, incorporating technology, fiscal and behavioural aspects, is suited to addressing direct rebound effects. Measures that can dampen rebound effects in the short term include raising the price or rationing supply, i.e. cap and trade schemes for industry or smart meters for consumers. It is however cautioned that taxes are distortive; where fiscal measures are uniformly applied across sectors they can be too indirect to be effective, and lead to unnecessary costs (for example with a uniformly applied energy tax as sectors have different price elasticity). A sectoral approach targeting the differing influencing factors and consumer/market responses driving the direct rebound effects and economy wide respectively are required; however, these will come at a higher administrative cost and require a minimum knowledge of the sectors considered.

Sustainable lifestyles \& behaviour change in consumers; while common approaches to tackle direct rebound effects include provision of information on the consumption, measures to tackle indirect or economy-wide rebound effects are scarce. Such measures, promoting consistently sustainable lifestyles and accustoming consumers to assessing their activities with regard to their environmental impact, would need to be extensive and aim at a more profound change in the awareness and the priorities of consumers. Much rebound effect evidence cites the role of wider initiatives to reduce growth and consumption and overcoming the conflict that traditional economic models have where GDP growth is the main success factor; recent recognition of this in France and the UK with the consideration of introducing social and environmental well being indicators and making GDP a measure of market activity only are relevant developments. 
Awareness raising and education for leveraging behaviour change in business; through inclusion of how to avoid inadvertently causing indirect rebound in awareness raising and capacity building tools. For example, the UK Green Claims Guide for business ${ }^{61}$ provide guidance for business on how to make good environmental claims; several examples are identified that show well intentioned, but misguided advertising using air miles to motivate other pro- environmental choices, e.g. replacing inefficient lighting with low energy light bulbs.

Within the context of the rebound effect, it is also important to consider the "windfall effect", also referred to as the "deadweight effect". The windfall effect is a situation when an economic agent behaves in a certain way, and would have continued to behave in the same way even if the benefit had not been granted. The European Commission defines as a windfall effect "that would have occurred even if the public expenditure program did not exist". In the context of public policy, the windfall is a form of loss of public money since the costs associated with the implementation of policies could have been saved while achieving the target. Mastering the windfall effect is therefore an important issue in the design of public policies that seek primarily to allocate resources in order to obtain optimum additional effects.

\subsubsection{Product durability}

A recent study ${ }^{62}$ commissioned by the UK's Defra assessed impacts of extending product lifetimes and measures to achieve this, covering nine products: washing machines; mobile phones; toasters; laptops; printers; carpets; commercial flooring; toasters; and t-shirts.

The review of existing policy measures shows that, in general, few policy or government initiatives have within their remit lifetime extension, and none has extended product lifetimes as their primary objective. Some EU Directives, such as the Ecodesign Directive and the Waste Framework Directive, include reference to relevant aspects such as waste minimisation or extended producer responsibility, and the UK's Defra's product roadmap work and WRAP's Love Food Hate Waste campaign discuss lifetime extension issues and aim to extend the lifetime of foodstuffs in the home.

The report identifies thirteen potential measures to extend product lifetimes:

1. Manufacturers voluntarily improve product design to increase product durability.

2. Manufacturers voluntarily introduce Product Service System (PSS) or leasing business models.

3. Manufacturers or retailers voluntarily offer enhanced aftercare and maintenance services by selling products that include an aftercare service in the product price (e.g., the retail price includes refurbishment or maintenance as standard).

4. Manufacturers or retailers voluntarily offer a deposit scheme on products, in order to collect them after use, refurbish them, and bring them to a second market.

\footnotetext{
61 Defra (2011) Green Claims Guidance. Available at: www.defra.gov.uk/publications/files/pb13453-green-claimsguidance.pdf

${ }^{62}$ Environmental Resources Management (2011) Longer Product Lifetimes
} 
5. Government develops and funds a consumer awareness campaign on product longevity, aiming to change consumer choice at point of sale and/ or consumer behaviour during product use.

6. Government provides grants for industry players to work in partnership to find ways to increase product lifetime (e.g., developing consistent product declaration on product lifetime, designing products with increased optimal life, carrying out product reuse, remanufacture, repair or maintenance.).

7. Government introduces Enhanced Capital Allowances (ECAs) or tax breaks for products that meet product standards as defined in the 'green procurement' standards (see measure 11).

8. Government provides VAT incentives for durable goods (e.g. reduced rates of VAT for products which are designed/ guaranteed to last for an optimum product lifetime).

9. Government introduces industry standards for product longevity which industry can voluntarily sign up to.

10. Government introduces compulsory industry standards for product longevity.

11. Government introduces a mandatory green public procurement specification on product longevity.

12. Manufacturers or importers are subject to individual producer responsibility requirements that legally require companies to take back their own products at end of life.

13. Manufacturers of product voluntarily extend warranties on products.

Some of the main conclusions of the study are:

Product LCA modelling showed that there is a high likelihood that lifetime extensions results in environmental benefits, even if there is increased environmental impact from refurbishment or upgrading processes.

- Consumers seek to achieve good value and are generally interested in assessing how long a product might last, but only rarely interested in longer-lasting products. The classification of attitudes to products described them as "up-to-date" (use until replaced by new product), "investment" (use until investment is repaid) and "workhorse" (use until end of life).

Extending product lifetimes requires consumers to use products until the end of their lives, therefore product design measures require complementary measures aimed at changing consumer behaviour.

- The appropriateness and effectiveness of a measure is related to a range of product features; implementation of any measure will face specific challenges but an overriding challenge is the lack of consumer demand for longer life products.

The Extended Warranties measure appears to show significant opportunity for shifting the market without the need to rely on consumer demand for longer lasting products; government support, VAT incentives, Green Public Procurement and subsidies will help to bring about a less significant change to the market; and deposits/product buy back, leasing business models and mandatory durability standards may have some success in 
bringing about change if applied to appropriate products.

There should be focus on extending the life of any products which are discarded prematurely and which are in working order, for example through product retention and reuse, and where consumer demand exists for longer life products; and to counterbalance the reduced economic activity in manufacturing of new products, there should be focus on measures stimulating economic activity, for example in repair and refurbishment, and optimising product lifetime.

- Further work should be carried out to understand what influences or motivates individuals' attitudes to different products, what can be done to encourage customers to consider their products as "investment" or "workhorse" products, and the effect of the different measures across the different products and attitudes ${ }^{63}$.

The following sections propose several sector objectives as well as specific actions to fulfil the objectives. At the end of each section a summary table is provided.

\subsection{Housing: Energy and water using appliances}

\subsubsection{Policy context}

A number of policies and instruments exist at EU and MS level which seek to contribute to the EU objective of reducing domestic energy and water consumption. For energy, a significant driver is the target of reduction in consumption of $20 \%$ by 2020 , whereas for water, EU focus has historically been on improving water quality, although the need to address demand is increasingly recognised.

For domestic energy use, EU regulatory tools focus on the building scale and appliances, much of it aimed at producers, and regarding water use, the Water Framework Directive requires MS to ensure that the price charged to water consumers - such as for the abstraction and distribution of fresh water and the collection and treatment of waste water - reflects the true cost (with potential for some derogations). River Basin Management Plans have been developed in some MS, due to localised scarcity, and can include water efficiency standards in buildings or water using appliances.

At the building scale, the Energy Performance of Buildings Directive (EPBD) requires Member States to apply minimum requirements on the energy performance of new and existing buildings when undergoing major renovations. The Commission is actively considering the option of issuing a water performance of buildings directive, similar to the EPBD. Certification schemes such as BREEAM and LEED are international standards that rate the sustainability of housing and other

\footnotetext{
${ }^{6}$ Influencing or motivating individuals' attitudes to the more extended use of a products (in clothing) could be, for instance, done through the new design strategies making the consumer the centre of the innovation processes. If the design of clothing is to be personalised, this would allow consumers to develop an emotional attachment with the garment or textile. Designers can co-create products with consumers to increase attachment to the product, for example, through the internet, with consumers making the final design decisions. See: Niinimäki, K., Hassi, L. (2011) Emerging design strategies in sustainable production and consumption of textiles and clothing. Journal of Cleaner Production 19: 1876-1883.
} 
buildings. This certification helps to ensure a minimum standard and provides a form of labelling. Although these are not discussed further in this section on appliances, they will help to raise awareness and enable consumers to compare the performance of housing infrastructure, and hence to encourage the consideration of energy and water efficiency during housing construction and investments.

At the appliance scale, the Eco-design Directive sets efficiency classes for many energy using appliances that are displayed through the EU energy label, a mandatory information tool. The Ecodesign Directive was extended in 2009 from Energy-using Products to Energy-related Products (such as windows), which can influence energy use. It has to date been used mostly to set energyefficiency performance criteria, but its scope also covers water consumption where relevant, and also the impacts of resources embodied in the appliances. In addition the voluntary EU eco-label sets appliance standards (e.g. the standards for dishwashers and washing machines include water consumption), amongst other aspects, and is currently used at EU and the national level.

In terms of addressing the impacts of materials embodied within appliances, the Restriction of the use of Hazardous Substances in electrical and electronic equipment and the Waste Electrical and Electronic Equipment Directive are targeted at producers, including responsibility for proper waste management at the end of life processing of wastes.

Various MS has introduced additional instruments to tackle the habitual behaviours associated with unnecessary energy and water use. In particular, fiscal tools such as eco-taxes on energy and charging for water consumption are used, and can have significant environmental improvements ${ }^{64}$. There is a huge variety in the types of metered tariff for public water supply and many countries also tax water use; taxes may be based on consumption, the size of the house or number of occupants. Another instrument providing incentives to reduce energy consumption is the installation of smart metering devices in private homes which display real time information of energy consumption, allowing household members to adjust consumption accordingly; this tool helps to raise awareness and initiate behavioural changes and is being introduced in some $\mathrm{MS}^{65}$. For water use, mandatory restrictions such as hosepipe bans are commonly applied as a temporary measure in response to severe and unexpected water shortages; it has been argued that such a policy places less of a burden on poorer households than a pricing policy ${ }^{66}$. A small number of MS also have schemes to support the purchase of rainwater harvesting, waste water reuse, or water-efficient equipment for households and businesses.

The EU also funds awareness-raising programmes, such as the Eco-schools which educated on issues such as energy and water consumption and their impacts. Awareness-raising and behaviour change tools appear to be widely used in many countries.

\footnotetext{
${ }^{64}$ Tukker, A.; Diaz Lopez, F.; Mudgal, S., (2011), Analysis of the future application of product policy instruments in the EU, First Interim Report (WP1 - WP2); Delft

65 OECD, (2011), Greening Household Behaviour: The Role of Public Policy, OECD Publishing, dx.doi.org/10.1787/9789264096875-en

66 OECD, (2011), Greening Household Behaviour: The Role of Public Policy, OECD Publishing, dx.doi.org/10.1787/9789264096875-en
} 


\subsubsection{Policy options}

Manufacturers have an important role in providing efficient and effective appliances (effective appliances might include functions such as advising consumers that they are not loaded to full capacity, hence not using the appliance to full efficiency), providing appliances that are durable, recyclable and that are manufactured from sustainable resources and, further, providing appliances that are easy to repair. Consumers should ensure that appliances are used efficiently, both through reducing the amount of energy and water consumed while the appliances are performing their functions, and ensuring that the appliances are used to their full potential (in other words that the use of the resources embodied within the appliances is maximised).

Hence the main objectives of policies to enable sustainable consumption of energy and water using appliances are:

- Increase the market dissemination of energy and water efficient appliances (including those with functions to prevent inefficient use by consumers and standby mode for relevant electronic appliances)

- Reduce consumption of energy and water during use phase (particularly inefficient consumption such as needlessly running taps)

- Maximise the use of resources embodied within appliances (e.g. reuse, recycle)

Considerations and actions proposed to achieve the three objectives are discussed in the following sections. While actions to address energy consumption would be relevant across the EU, due to the often localised nature of water scarcity, the appropriate mix of actions to address water consumption may vary between MS or regions.

\section{Objective 1: Increase the market dissemination of energy and water efficient appliances}

Existing EU and MS tools to increase market dissemination include labelling and fiscal measures. However, potential barriers to increased dissemination remain, including high capital costs and split incentives. The following actions are therefore proposed:

Lower VAT rates, or VAT free, for most efficient appliances, since consumers are averse to loss, additional taxation will be more off-putting than an incentive. Also, as many consumers are attracted to things that are 'free', appliances that offer something for free will be more attractive.

Bonuses, or grants, for efficient appliances, to overcome the potential affordability issue. Further development of subsidies, green loans and fiscal measures is required to allow innovation and stimulate demand. In addition, to avoid split incentives, mechanisms need to be in place to ensure that investors recoup the benefits of their investments.

Labelling of most efficient appliances to allow consumers to distinguish performance levels and to provide a framework on which fiscal measures can be established. However, labels do not relate purely to rational and cognitive thought processes; other important elements of labels are recognition and trust (in the verification process and intentions). 
Raising awareness about efficient appliances to highlight increased costs associated with high energy and water consumption ${ }^{67}$ and develop consumer support mechanisms (e.g. efficiency and lifetime cost comparison websites) to reduce complexity, enable product comparison and promote product features with policy relevance. Current application across the EU-27 of informative tools/ information provision policy instruments is not widespread and could be better.

Encourage retailers to provide product trials or money back guarantees so that consumers can become accustomed to new technologies and substitutes.

Leadership through public procurement to stimulate the market for efficient appliances and raise awareness, for example extending on the EU GPP-toolkit ${ }^{68}$.

\section{Objective 2: Reduce consumption of energy and water during use phase}

In terms of reducing consumption of energy and water during function of appliances, existing tools focus on awareness raising, including metering, and, in some cases, increasing the price of energy and water as a monetary disincentive to unnecessary use; an underlying challenge is that appliances provide important and valued information and convenience in people's lives which exceeds the financial cost of the energy or water consumed during use of the product. There are also other potential means of encouraging changes in use by addressing the issue of split incentives and ensuring that those consuming the energy and water pay for it. The following actions are therefore proposed:

Awareness-raising to change use patterns of appliances, through public information campaigns and work with utilities to design monitoring and billing mechanisms that promote awareness, as many households are unaware of their consumption levels even when they are charged for it (OECD, 2011).

Metering and smart metering, to raise awareness, ensure that the consumers using the energy and water understand their use patterns (and pay for the use when metering is combined with fiscal measures) and encourage people to reduce energy and water consumption.

Incorporation of estimate of appliance energy consumption in energy label for rented accommodation to reduce split incentives, building on the EPBD labelling.

Modulated price of resource through energy taxes, with unit prices increasing with the level of consumption or progressively graduate water prices based on taxes. This action could also help to avoid split incentives.

Promote demand management measures through guidelines and sharing best practices.

Ensure availability of substitutes or new technologies to support change in behaviour; e.g. the provision of water-saving devices (e.g. special taps or tap attachments, dual flush toilets, waterefficient washing machines and dishwashers) can help consumers to reduce water use and raise

\footnotetext{
${ }^{67}$ Due to loss aversion, highlighting the will be more motivating to consumers than focusing on the savings.

${ }^{68}$ http://ec.europa.eu/environment/gpp/gpp criteria en.htm
} 
awareness. The biggest impacts have been observed where substitutes were available, or where a new technology has supported change ${ }^{69}$.

\section{Objective 3: Maximise the use of resources embodied within appliances}

In order to maximise the use of the resources embodied in the appliances, tools need to be developed that extend the durability and life of the products through changing behaviour to encourage reuse, swapping, repair and good practice at end of life (to enable recycling). Measures to achieve this have been investigated in a recent Defra study ${ }^{70}$, and concluded that the most effective measure to lengthen product lifetime is extended warranties (as is not dependent on consumer demand). Product 'buy back', service provision and mandatory durability standards may have some success in bringing about change if applied to appropriate products; however, consumer awareness is critical for success of many measures. The following actions are therefore proposed:

Increase sharing, reuse of appliances, and encourage rental of appliances through service provision, through encouragement of 'buy back' and 'trade-in' schemes which allow consumers to trade in old for new, awareness-raising and minimum standards for appliances under consumer rights regulation.

Increase durability of appliances to address short application period, mandating minimum warranties and declaration of durability, and working with producers to increase lifetime, modularity and ease of repair of appliances.

Improve end of life outcomes (i.e. reuse or recycling), through provision of infrastructure, raising awareness and taking leadership in public sector action.

Awareness raising to encourage consumers to engage in cultural, social and educational activities, to promote alternative activities to those requiring energy and water consumption and reduce the purchase of inessential appliances.

When considering combinations of actions, the following could be combined to increase their potential:

Introduce well-designed information and labelling tools ${ }^{71}$ together with financial incentives. In promoting efficient appliances, highlight high costs associated with inefficient appliances and develop consumer support mechanisms (e.g. efficiency and lifetime cost comparison websites), promote product features with policy relevance, and offer 'free' benefits (e.g. VAT free, free extended warrantee) rather than punitive fiscal measures ${ }^{72}$.

\footnotetext{
${ }^{69}$ Tukker, A.; Diaz Lopez, F.; Mudgal, S., (2011), Analysis of the future application of product policy instruments in the EU, First Interim Report $\left(\mathrm{WP}_{1}-\mathrm{WP}_{2}\right)$; Delft

70 ERM Longer L (2011) Lifetimes Seduct
archive.defra.gov.uk/environment/business/scp/evidence/theme2/productsog1o.htm

${ }^{71}$ UNECE indicates that the residential sector could generate huge energy savings when maximized efficiency standards in household appliances are enforced together with more widespread behaviour changes in practices and habits (UNECE, 2009).

${ }^{72}$ In many countries the provision of information alone failed to encourage more than a minority of people to buy energyefficient dishwashers, refrigerators and washing machines, even when labels highlighted savings on operating costs
} 
Ensure availability of substitutes or new technologies to support change in behaviour; encourage retailers to provide product trials or money back guarantees.

Meter the use of energy and water; to minimise regressive impact of water charging ${ }^{73}$, couple full-cost water pricing with assistance to low-income households, and progressively graduate energy and water prices based on taxes or modulate based on $\mathrm{use}^{74}$. The price Work with utilities to design monitoring and billing mechanisms that promote awareness.

Promote demand management measures through guidelines and sharing best practices; complement with public information campaigns.

Enhance 'buy back' and 'trade-in' schemes for product replacement where substitutes with significant improvements in efficiency are available, through the use of financial incentives, or to maximise reuse or recycling for products with short consumer use periods (due to rapid technological advancement such as personal computers).

$(O E C D, 2008)$. Well-designed information-based measures may lead to notably reduced energy consumption in the shortterm, whereas fiscal tools such as taxes and charges have a more significant impact in the long-term (OECD, 2011).

${ }^{73}$ As a percentage of income, low-income households spend more than twice as much on their water bill as high-income households; assistance to low-income households in the form of a low or zero fixed fee, or via transfer payments.

${ }^{74}$ Charging households for the amount of water they use is effective in promoting water conservation. Denmark, Hungary and the Netherlands have also successfully combined public information campaigns with increases in household water prices to decrease water wastage $(\mathrm{OECD}, 2008)$. 


\subsubsection{Summary of policy options for Housing: Energy and water using appliances sector}

\begin{tabular}{|c|c|c|c|c|c|c|}
\hline $\begin{array}{c}\text { Sector } \\
\text { objective }\end{array}$ & Specific actions & $\begin{array}{l}\text { Level of } \\
\text { impleme } \\
\text { ntation }\end{array}$ & $\begin{array}{l}\text { Policy-makers and other } \\
\text { stakeholders to consider }\end{array}$ & Implications for EU policy & $\begin{array}{l}\text { Implementation costs for } \\
\text { EU/MS and Political } \\
\text { acceptability/ feasibility }\end{array}$ & Examples of relevant initiatives \\
\hline \multirow{3}{*}{$\begin{array}{l}\text { Increase the } \\
\text { market } \\
\text { dissemination } \\
\text { of energy and } \\
\text { water efficient } \\
\text { appliances }\end{array}$} & $\begin{array}{l}\text { Lower VAT rates, or VAT } \\
\text { free, for most efficient } \\
\text { appliances }\end{array}$ & MS & $\begin{array}{l}\text { Policy-makers: } \\
\text { DG ENTR, DG ENER, DG } \\
\text { TAXUD ,MS } \\
\text { Other stakeholders: } \\
\text { Retailers }\end{array}$ & $\begin{array}{l}\text {-Can be linked to EU } \\
\text { energy label grades and/or } \\
\text { EU Ecolabel } \\
\text {-Few appliances have water } \\
\text { standards set }\end{array}$ & $\begin{array}{l}\text {-Low implementation costs } \\
\text {-Low political acceptability due } \\
\text { to potential competition } \\
\text { distortion, and additional costs } \\
\text { for industry. }\end{array}$ & $\begin{array}{l}\text { Lower VAT for energy-efficient eco-labelled } \\
\text { goods in UK }{ }^{75}\end{array}$ \\
\hline & $\begin{array}{l}\text { Bonuses, or grants, for } \\
\text { efficient appliances }\end{array}$ & MS & $\begin{array}{l}\text { Policy-makers: } \\
\text { DG ENTR, DG ENER, MS } \\
\text { Other stakeholders: } \\
\text { Retailers }\end{array}$ & $\begin{array}{l}\text {-Can be linked to EU } \\
\text { energy label grades and/or } \\
\text { EU Ecolabel } \\
\text {-Few appliances have water } \\
\text { standards set }\end{array}$ & $\begin{array}{l}\text {-High implementation costs } \\
\text { because of the funds needed to } \\
\text { supply the incentives. } \\
\text {-Could be cost-effective in the } \\
\text { long run if well-designed } \\
\text {-Technically difficult to } \\
\text { implement for water using } \\
\text { products as would need to set } \\
\text { criteria to identify the products } \\
\text { to be included in the scheme. }\end{array}$ & $\begin{array}{l}\text {-Crédit d'impôt fiscal bonus }(\mathrm{FR})^{76} \\
\text {-Schemes to support the purchase of } \\
\text { rainwater harvesting and waste water reuse } \\
\text { equipment in } \mathrm{FR}, \mathrm{CY} \text { and } \mathrm{NL}_{i} \\
\text {-Bonus-Malus for passenger vehicles in } \mathrm{FR})_{i} \\
\text {-Development of schemes to enable } \\
\text { businesses to claim allowances for } \\
\text { investments in water-efficient technologies } \\
\text { and equipment (UK); } \\
\text {-Natural Resources Canada's ecoENERGY } \\
\text { Retrofit program (INT) }\end{array}$ \\
\hline & $\begin{array}{l}\text { Labelling of most } \\
\text { efficient appliances }\end{array}$ & EU & $\begin{array}{l}\text { Policy-makers: } \\
\text { DG ENTR, DG ENER } \\
\text { Other stakeholders: } \\
\text { Retailers, MS }\end{array}$ & $\begin{array}{l}\text {-Extension/development of } \\
\text { Ecodesign Directive and } \\
\text { other top-runner schemes } \\
\text {-Focus on development of } \\
\text { water performance } \\
\text { standards } \\
\text { - Potential disadvantage is } \\
\text { dilution of the message due } \\
\text { to high number of schemes }\end{array}$ & $\begin{array}{l}\text { - Low implementation cost if } \\
\text { implemented through existing } \\
\text { labelling policies }\end{array}$ & $\begin{array}{l}\text {-EU energy label; ISO TYPE-I Ecolabelling } \\
\text { Schemes (e.g. EU-Ecolabel, Blue Angel, Nordic } \\
\text { Swan); } \\
\text {-Voluntary product labelling (e.g. TCO, Energy } \\
\text { star) (EU); } \\
\text {-Waterwise Marque (UK) - awarded to } \\
\text { products that reduce water wastage or raise } \\
\text { awareness on water efficiency }\end{array}$ \\
\hline
\end{tabular}

${ }^{75}$ www.hmrc.gov.uk/vat/forms-rates/rates/goods-services.htm

${ }^{76}$ ecocitoyens.ademe.fr/financer-mon-projet/renovation/credit-dimpot-developpement-durable 
Chapter 5: Assessment of 5 sectors

\begin{tabular}{|c|c|c|c|c|c|c|}
\hline $\begin{array}{c}\text { Sector } \\
\text { objective }\end{array}$ & Specific actions & $\begin{array}{l}\text { Level of } \\
\text { impleme } \\
\text { ntation }\end{array}$ & $\begin{array}{l}\text { Policy-makers and other } \\
\text { stakeholders to consider }\end{array}$ & Implications for EU policy & $\begin{array}{l}\text { Implementation costs for } \\
\text { EU/MS and Political } \\
\text { acceptability/ feasibility }\end{array}$ & Examples of relevant initiatives \\
\hline & $\begin{array}{l}\text { Raising awareness about } \\
\text { efficient appliances, life } \\
\text { cycle cost implications } \\
\text { and providing consumer } \\
\text { support mechanisms }\end{array}$ & $\begin{array}{l}\mathrm{EU}, \mathrm{MS} \\
\text { and local }\end{array}$ & $\begin{array}{l}\text { Policy-makers: } \\
\text { DG ENV, DG ENTR, DG } \\
\text { ENER, MS } \\
\text { Other stakeholders: } \\
\text { Retailers, NGOs }\end{array}$ & $\begin{array}{l}\text { - Ecodesign Directive to } \\
\text { require general information } \\
\text { on the energy cost of } \\
\text { appliances on EU energy } \\
\text { label }\end{array}$ & $\begin{array}{l}\text {-Medium to high implementation } \\
\text { costs depending on scope of the } \\
\text { campaign, however easier to } \\
\text { implement politically at EU level } \\
\text { than for other tools }\end{array}$ & EcoTopTen (DE) \\
\hline & $\begin{array}{l}\text { Encourage retailers to } \\
\text { provide product trials or } \\
\text { money back guarantees }\end{array}$ & $\begin{array}{l}\text { EU and } \\
\text { MS }\end{array}$ & $\begin{array}{l}\text { Policy-makers: } \\
\text { DG ENV, MS } \\
\text { Other stakeholders: } \\
\text { Manufacturers, Retailers }\end{array}$ & $\begin{array}{l}\text { - Would require a voluntary } \\
\text { agreement / incentive for } \\
\text { retailers such as a } \\
\text { certification scheme for } \\
\text { retailer good practice }\end{array}$ & $\begin{array}{l}\text {-Medium to high implementation } \\
\text { costs depending on the incentive } \\
\text { used to gain retailer } \\
\text { participation. } \\
\text {-Low to medium political } \\
\text { acceptability due to potential } \\
\text { distortions of the market }\end{array}$ & \\
\hline & Leadership through GPP & $\begin{array}{l}\text { EU and } \\
\text { MS }\end{array}$ & $\begin{array}{l}\text { Policy-makers: } \\
\text { EC,MS } \\
\text { Other stakeholders: } \\
\text { Public authorities, } \\
\text { manufacturers }\end{array}$ & $\begin{array}{l}\text { - Directing procurement to } \\
\text { sustainable goods. } \\
\text { - Setting criteria /guidelines } \\
\text { for purchasing } \\
\text { departments. }\end{array}$ & $\begin{array}{l}\text {-Medium implementation cost } \\
\text { due to initial increased capital } \\
\text { expenditure } \\
\text {-High technical and political } \\
\text { feasibility for implementation }\end{array}$ & UK Government Buying Standards \\
\hline \multirow{4}{*}{$\begin{array}{l}\text { Reduce } \\
\text { consumption } \\
\text { of energy and } \\
\text { water during } \\
\text { use phase }\end{array}$} & $\begin{array}{l}\text { Awareness-raising to } \\
\text { change use patterns of } \\
\text { appliances }\end{array}$ & $\begin{array}{l}\mathrm{EU}, \mathrm{MS} \\
\text { and local }\end{array}$ & $\begin{array}{l}\text { Policy-makers: } \\
\text { DG ENV, DG ENTR, DG } \\
\text { ENER, MS } \\
\text { Other stakeholders: } \\
\text { Local authorities, NGOs }\end{array}$ & $\begin{array}{l}\text { - education } \\
\text { - giving a monetary } \\
\text { information on the cost of } \\
\text { use or efficiency benefits of } \\
\text { energy related appliances }\end{array}$ & $\begin{array}{l}\text {-Medium to high implementation } \\
\text { costs depending on scope of the } \\
\text { campaign, however easier to } \\
\text { implement politically at EU level } \\
\text { than for other tools }\end{array}$ & $\begin{array}{l}\text { Public information campaigns - "Initiative } \\
\text { EnergieEffizienz" of DENA (DE), EcoTopTen } \\
\text { (DE), "Energy Bus" (2003-2005) (PL) }\end{array}$ \\
\hline & $\begin{array}{l}\text { Metering and smart } \\
\text { metering }\end{array}$ & MS & $\begin{array}{l}\text { Policy-makers: } \\
\text { DG ENER, DG ENV, MS } \\
\text { Other stakeholders: } \\
\text { Local authorities, Energy } \\
\text { suppliers }\end{array}$ & $\begin{array}{l}\text {-Is foreseen under the WFD } \\
\text { implementation process. } \\
\text {-Major savings are only } \\
\text { achieved when more } \\
\text { efficient appliances are } \\
\text { available on the market }\end{array}$ & $\begin{array}{l}\text {-High implementation cost: } \\
\text { depending on who purchases / } \\
\text { installs metering equipment } \\
\text {-Low to medium feasibility of } \\
\text { implementation because of the } \\
\text { political barriers (e.g.subsidiarity) }\end{array}$ & Smart metering (various MS) \\
\hline & $\begin{array}{l}\text { Incorporation of estimate } \\
\text { of appliance energy } \\
\text { consumption in energy } \\
\text { label for rented } \\
\text { accommodation to } \\
\text { reduce split incentives }\end{array}$ & $\begin{array}{l}\text { EU and } \\
\text { MS }\end{array}$ & $\begin{array}{l}\text { Policy-makers: } \\
\text { DG ENV, DG ENER, MS } \\
\text { Other stakeholders: } \\
\text { Landlords, Tenants }\end{array}$ & $\begin{array}{l}\text { Require information from } \\
\text { owners on the energy cost } \\
\text { of appliances in rented } \\
\text { accommodation, extending } \\
\text { the EPBD label }\end{array}$ & Medium cost: administration & \\
\hline & Modulated price of & MS & Policy-makers: & -Improving & - Low implementation costs & -Eco-taxation: Residential electricity charges \\
\hline
\end{tabular}




\begin{tabular}{|c|c|c|c|c|c|c|}
\hline $\begin{array}{l}\text { Sector } \\
\text { objective }\end{array}$ & Specific actions & $\begin{array}{c}\text { Level of } \\
\text { impleme } \\
\text { ntation }\end{array}$ & $\begin{array}{l}\text { Policy-makers and other } \\
\text { stakeholders to consider }\end{array}$ & Implications for EU policy & $\begin{array}{l}\text { Implementation costs for } \\
\text { EU/MS and Political } \\
\text { acceptability/ feasibility }\end{array}$ & Examples of relevant initiatives \\
\hline & $\begin{array}{l}\text { resource through energy } \\
\text { taxes }\end{array}$ & & $\begin{array}{l}\text { DG ENV, DG ENER, DG } \\
\text { TAXUD, MS } \\
\text { Other stakeholders: } \\
\text { Energy suppliers }\end{array}$ & $\begin{array}{l}\text { implementation of Water } \\
\text { Framework Directive } \\
\text { provisions on water pricing } \\
\text {-Provision of } \\
\text { guidance/regulation to MS } \\
\text { for application of tax }\end{array}$ & $\begin{array}{l}\text {-Low to medium political } \\
\text { acceptance due to possibility of } \\
\text { affecting the market. }\end{array}$ & $\begin{array}{l}\text { (e.g. } \mathrm{DK}, \mathrm{Fl}, \mathrm{DE}, \mathrm{NL}, \mathrm{SE}) \text {; } \\
\text {-EU energy label has been reinforced with an } \\
\text { energy tax in some MS. This inter-relation and } \\
\text { in particular the tax designed with a clear-cut } \\
\text { environmental objective can lead to significant } \\
\text { environmental improvements (OECD 2008). }\end{array}$ \\
\hline & $\begin{array}{l}\text { Promote demand } \\
\text { management measures } \\
\text { through guidelines and } \\
\text { sharing best practice }\end{array}$ & $\begin{array}{l}\mathrm{EU}, \mathrm{MS} \\
\text { and local }\end{array}$ & $\begin{array}{l}\text { Policy-makers: } \\
\text { DG ENV, DG ENER, DG } \\
\text { ENTR, MS } \\
\text { Other stakeholders: } \\
\text { Local authorities, } \\
\text { Businesses, NGOs }\end{array}$ & $\begin{array}{l}\text {-Develop central guidance } \\
\text { website } \\
\text {-Smart metering required } \\
\text { to maximise benefits } \\
\text { - NGOs and businesses as } \\
\text { sources of best practice }\end{array}$ & $\begin{array}{l}\text { - Low implementation costs } \\
\text { - Medium administration burden } \\
\text { to organise platform to exchange } \\
\text { best practices among diverse } \\
\text { stakeholders }\end{array}$ & \\
\hline & $\begin{array}{l}\text { Ensure availability of } \\
\text { substitutes or new } \\
\text { technologies to support } \\
\text { change in behaviour }\end{array}$ & $\begin{array}{l}\text { EU and } \\
\text { MS }\end{array}$ & $\begin{array}{l}\text { Policy-makers: } \\
\text { DG ENV, DG ENTR } \\
\text { Other stakeholders: } \\
\text { Manufacturers, Retailers }\end{array}$ & $\begin{array}{l}\text { Ecodesign Directive to } \\
\text { require consideration of } \\
\text { technologies/product } \\
\text { features to encourage } \\
\text { behaviours that reduce } \\
\text { energy and water use } \\
\end{array}$ & $\begin{array}{l}\text {-Low implementation cost for } \\
\text { governments but could mean } \\
\text { higher costs for industry, which } \\
\text { could affect political acceptance }\end{array}$ & $\begin{array}{l}\text {-Hippo the Water Saver (UK); } \\
\text {-Free water/energy efficiency kits - including } \\
\text { devices to fit to showerhead and toilet cistern } \\
\text { (UK) }\end{array}$ \\
\hline \multirow{4}{*}{$\begin{array}{l}\text { Maximise the } \\
\text { use of } \\
\text { resources } \\
\text { embodied } \\
\text { within } \\
\text { appliances }\end{array}$} & $\begin{array}{l}\text { Increase sharing, reuse of } \\
\text { appliances, and } \\
\text { encourage rental of } \\
\text { appliances through } \\
\text { service provision }\end{array}$ & Local & $\begin{array}{l}\text { Policy-makers: } \\
\text { DG ENV, DG ENTR,MS, } \\
\text { local authorities, } \\
\text { Other stakeholders: } \\
\text { Retailers, Businesses, } \\
\text { NGOs }\end{array}$ & $\begin{array}{l}\text {-Awareness raising } \\
\text {-Provision of infrastructure }\end{array}$ & - Low implementation cost & $\begin{array}{l}\text { Vienna City "dematerialisation" information, } \\
\text { education and action campaign. }\end{array}$ \\
\hline & $\begin{array}{l}\text { Increase duration of } \\
\text { mandatory product } \\
\text { warranties }\end{array}$ & EU & $\begin{array}{l}\text { Policy-makers: } \\
\text { DG ENV, DG ENTR } \\
\text { Other stakeholders: } \\
\text { Manufacturers }\end{array}$ & $\begin{array}{l}\text {-Extending mandatory } \\
\text { guarantee period } \\
\text {-Mandatory declaration on } \\
\text { the durability of products } \\
\text {-Encourage modular design } \\
\text { to facilitate repair and } \\
\text { reuse }\end{array}$ & $\begin{array}{l}\text {-Low implementation cost for } \\
\text { governments but could mean } \\
\text { higher costs for industry, which } \\
\text { could affect political acceptance }\end{array}$ & \\
\hline & $\begin{array}{l}\text { Improve end of life } \\
\text { outcomes (i.e. reuse or } \\
\text { recycling) through } \\
\text { provision or improving } \\
\text { current infrastructure }\end{array}$ & $\begin{array}{l}\mathrm{EU}, \mathrm{MS} \\
\text { and local }\end{array}$ & $\begin{array}{l}\text { Policy-makers: } \\
\text { DG ENV, MS } \\
\text { Other stakeholders: } \\
\text { Local authorities, NGOs }\end{array}$ & -Awareness raising & $\begin{array}{l}\text {-Medium to high implementation } \\
\text { cost: capital cost of setting up } \\
\text { waste management options }\end{array}$ & $\begin{array}{l}\text { Danish Brug Mere Spild Mindre - "Use more, } \\
\text { waste less" campaign }\end{array}$ \\
\hline & Awareness raising to & EU and & Policy-makers: & See Citizen community & -Medium to high implementation & Vienna City "dematerialisation" information, \\
\hline
\end{tabular}




\begin{tabular}{|c|c|c|c|c|c|c|}
\hline $\begin{array}{c}\text { Sector } \\
\text { objective }\end{array}$ & Specific actions & $\begin{array}{l}\text { Level of } \\
\text { impleme } \\
\text { ntation }\end{array}$ & $\begin{array}{l}\text { Policy-makers and other } \\
\text { stakeholders to consider }\end{array}$ & Implications for EU policy & $\begin{array}{l}\text { Implementation costs for } \\
\text { EU/MS and Political } \\
\text { acceptability/ feasibility }\end{array}$ & Examples of relevant initiatives \\
\hline & $\begin{array}{l}\text { encourage consumers to } \\
\text { engage in cultural, social } \\
\text { and educational activities }\end{array}$ & MS & $\begin{array}{l}\text { DG ENV, MS } \\
\text { Other stakeholders: } \\
\text { Local authorities, NGOs }\end{array}$ & action sector & $\begin{array}{l}\text { costs depending on scope of the } \\
\text { campaign, however easier to } \\
\text { implement politically at EU level } \\
\text { than for other tools. }\end{array}$ & education and action campaign. \\
\hline
\end{tabular}




\subsection{Food and drink}

\subsubsection{Policy context}

Studies have estimated that the food and drink sector is responsible for some $15-30 \%$ of key pressures caused by consumption in the EU, placing it among the top three sectors (together with housing and transport) in terms of it environmental impacts ${ }^{77,78}$. The consumption of meat and dairy products is responsible for the bulk of key impacts associated with the sector ${ }^{79}$. Other impacts relate to inter alia food waste, water use and the overexploitation of fish stocks. Given the globalisation of the food supply chain, it is also worth noting that a large part of the environmental impacts of the EU's food and drink sector occur outside the boundaries of EU MS, for example in relation to land use change in third countries.

Changes in both consumption and production are important to ensure more sustainable food consumption patterns. To date, EU regulatory policy in the food and drink sector has largely focused on the production/process side of the chain, including in particular legislative requirements under the Common Agriculture Policy (CAP), the Common Fisheries Policy (CFP), and provisions relating to food processing under the Industrial Emissions Directive (previously the IPPC Directive). Food and drink production is also linked to other policies such as the Nitrates Directive, issues concerning animal welfare, organic foods and labels, as well in health related issues.

To date, interventions on the consumption side have been restricted to soft measures like education and awareness- raising activities, labelling schemes, as well as various voluntary and locallevel/community- based initiatives. Although helpful, to date these initiatives have not been undertaken on a sufficient scale to trigger the substantial shift in consumption behaviour that is required to stimulate dietary change towards more sustainable patterns. One source of nutrition that constitutes a significant portion of the average European diet and has high environmental impacts is animal-based proteins. European diets are high in livestock products at about 2.5 times the global average. Intake of protein exceeds dietary needs in all EU countries and the intake of animal sourced protein alone is sufficient for total protein needs in most countries. An important part of the impact is due to imports into the EU of animal feed grown in locations where land use

\footnotetext{
77 JRC/IPTS, (2006), Environmental Impact of Products (EIPRO) - Analysis of the life cycle environmental impacts related to the final consumption of the EU-25, Main report, EUR 22284 EN. Institute for Prospective Technological Studies, Sevilla. http://ec.europa.eu/environment/ipp/pdf/eipro_report.pdf [Accessed 31/05/2011]

${ }^{78} \mathrm{ETC} / \mathrm{SCP}$, (2009), Environmental Pressures from European Consumption and Production A study in integrated environmental and economic Analysis, ETC/SCP working paper 1/2009, http://scp.eionet.europa.eu/publications/working\%2opaper\%2onamea2009/wp/working\%2opaper\%20namea2009 [Accessed 31/05/2011]

${ }^{79} \mathrm{EEA}$, (2010), State and outlook for the environment thematic assessment - Consumption and the environment, State of the environment report No 1/2010, http://www.eea.europa.eu/soer/europe/consumption-and-environment [Accessed 31/05/2011]
} 
change is occurring (land use change to allow increased production of feed crops) ${ }^{80}$. Further effort relating to the consumption side is needed, to strengthen, revise or complement initiatives already underway.

These consumption-related measures will complement on-going and future efforts relating to the production side of the chain such as the upcoming reforms of the CAP and CFP and could help take forward the resource efficiency agenda. The extent to which change in food consumption behaviour will lead to reduced impacts on the environment will depend on a number of other factors such as the direct negative environmental effects from travelling to shops, storing and preparing food, and packaging/food waste generated, which although smaller than the indirect negative effects of food and drink consumption, are on the increase ${ }^{81}$. Thus, achieving more sustainable food consumption needs an integrated approach to different policies, such as transport (low transport costs for food), energy (low energy costs for energy-intensive producers in unsuitable regions), agriculture (further support beneficial farming practices) etc., thus cooperation across different sectors and at different levels will be key.

\subsubsection{Policy options}

The following objectives have been identified in the food and drink sector:

Encourage more sustainable and healthy patterns of food and drink consumption, including reduced consumption of livestock products, increased consumption of fruit and vegetables and/or vegetarian food, reduced consumption of bottled drinks;

Reduce direct GHG emissions from food and drink consumption (i.e. from travelling to shops, storing and preparing food etc.);

Reduce food and packaging waste.

There is a need to provide a solid evidence base to support and inform the specific actions set out below. Thus, another cross-cutting action proposed is the initiation of cross-sectoral research initiatives, for example to develop criteria to distinguish more clearly between sustainable and less sustainable food and drink products, tools to calculate the food footprint of individual consumers, retailers, restaurants etc., and methodologies for calculating food waste quantities. It will be important to ensure some degree of buy-in to the results of these initiatives from key actors such as the retail sector, thus one could consider setting up R\&D partnerships which bring together researchers and the retail sector. The results of such research would provide the baseline for several specific actions set out below and will contribute to the achievement of the objectives outlined above.

\section{Objective 1: Encourage more sustainable and healthy patterns of food and drink consumption}

\footnotetext{
${ }^{80}$ Westhoek, H., Rood, T., van der Berg, M., Janse, J., Nijdam., D., Reudink., Stehfest, E. (2011). The Protein Puzzle. Netherland Environmental Assessment Agency.

${ }^{81}$ EEA, (2005), Household consumption and the environment, EEA Report No 11/2005, http://www.eea.europa.eu/publications/eea_report_2005_11 [Accessed 01/06/2011]
} 
Retailers are key intermediaries in reaching consumers and influencing supply chains. The role of retailers is recognised in the SCP/SIP Action Plan and a number of initiatives are already underway. An action proposed is to continue, expand and improve the quality and effectiveness of on-going voluntary agreements, public-private partnerships and the EU Retail Forum. New ways of encouraging further participation could be investigated, for example by comparative surveys such as the MSC League Table on UK supermarkets' buying policies and the sustainability of their fish stocks. There are already several examples of best practice underway at the national and regional level which can be built on ${ }^{82}$.

Another action relates to the pricing of more sustainable food and drink products. This could be addressed through a system of differentiated consumption taxes based on the environmental performance of products, e.g. reduced VAT rates for eco-labelled food products, etc. Under VAT Directive 2006/112/EC a specific list of goods and services for which Member States may apply a reduced rate of VAT of at least $5 \%$ is set out and the EU could for example consider introducing a new reduced or zero-level tax for sustainable food products. Several studies have looked into the impacts of introducing a low VAT or zero VAT on environmentally friendly products ${ }^{83},{ }^{84}$. Compliance costs would be particularly large for the food sector due to its multitude of products. Further, there is also the risk of the rebound effect in that the market share of reduced VAT products will increase, however at a rate that could be unsustainable, shifting and increasing overall consumption.

Although a number of EU, national and local level food labelling schemes are already in place (e.g. on product origins and the environmental and energy intensity embodied within), this multiplicity has led to issues of incoherence, reliability, and information overload / confusion. There is a need to develop an EU-level sustainable food labelling scheme and establish credible certification mechanisms in order to enable consumers to more easily distinguish between sustainable and nonsustainable products. It is important that this labelling scheme is holistic in its approach, i.e. going beyond carbon or issues of organic food to assess impacts on different environmental media. EU rules on food labelling (Directive 2000/13/EC) ensure consumers receive correct information to enable informed choices about the food they buy. These information requirements could be expanded to include for example information on the environmental footprint of specific products. In its Communication on agricultural product quality policy (COM (2009)234), the Commission indicated that it "intends to ensure coherence of future EU agricultural product quality schemes and initiatives by proactively assessing the value added and advisability of any new schemes in collaboration with all services concerned".

\footnotetext{
${ }^{82}$ See for example study by Copenhagen Resource Institute et al (2011), Sustainable Consumption and Production in the Nordic Retail Sector, http://www.mst.dk/English/SustainableConsumptionandProductionintheNordicRetailSector/; and REAP (Retailer's Environmental Action Programme) Database for specific examples of commitments by members of the Retail Forum: http://ec.europa.eu/environment/industry/retail/reap/

${ }^{83}$ EC, 2007, Study on reduced VAT applied to goods and services in the Member States of the EU, ec.europa.eu/taxation_customs/resources/documents/taxation/vat/how_vat_works/rates/study_reduced_vat.pdf

${ }^{84}$ EC, 2008 Reduced VAT for Environmentally-friendly products, ec.europa.eu/taxation customs/resources/documents/taxation/gen_info/economic analysis/economic studies/study on reduced vat for environmental friendly products en.pdf
} 
Another recommended action is the launch of targeted awareness-raising and information campaigns and education programmes about the lifecycle environmental impacts of different food and drink products. Although a number of information, education, and training initiatives are already underway at EU, national and local level, to date, their effect in terms of influencing longterm consumption patterns among target groups has been relatively limited. There are several good practice examples to draw on, e.g. the efforts of British celebrity chefs such as Jamie Oliver to promote healthy food consumption in schools and the 'Fishfight' campaign by Hugh FearnleyWhittingstall. Where relevant, messages on food sustainability should be aligned with messages on positive health implications of such changes in diet. In order to do so, it will be important to define and communicate what an optimal diet(s) would be by linking health and environmental sustainability. In terms of education programmes, modules on sustainable consumption could be included in school curricula and partnerships between crèches, schools and universities could be established or strengthened.

Active promotion of green public procurement practices for catering in public offices and institutions can act as a potential trigger for wider changes in production patterns and further behaviour change among the general public. Promotion of GPP could involve introduction of a benchmarking system, an incentive scheme to reward effective GPP, making the GPP criteria for Food and Catering services mandatory, or setting an EU wide target. This action could build on the on-going efforts of DG ENV in relation to GPP, for example EU level guidelines could be prepared building on the GPP-toolkit ${ }^{85}$. A lack of high level political commitment may limit the take-up of action in this area.

There are numerous small-scale developments and initiatives taking place at the community/local level that promote more sustainable food consumption patterns. These include for example, the slow food movement, home-delivery services of organic/locally-sourced and in-season fruit and vegetables, food clubs, the campaign for meat-free days. These niche initiatives are gaining ground, however currently they only cover a small part of the market and there is a need for much broad consumer acceptance of these approaches. Supporting such local/community-led initiatives and consumer interest organisations operating at a national or regional level through funding, endorsement, and raising awareness of them would contribute to strengthening best practises for exemplifications. The EU can provide information about best practice examples, financial support to pilot projects and follow-up support to enable such pilot projects to sustain and make their innovation durable and ready for broader market application. For example, support for the wider introduction of incentive and rebate schemes such as the Sustainable Incentive Card ('NUSpaarpas' $)^{86}$.

${ }^{85}$ http://ec.europa.eu/environment/gpp/gpp criteria en.htm

86 PlusPunten - Demonstration project PlusPunten Rotterdam LIFEoo ENV/NL/000809, http://ec.europa.eu/environment/life/project/Projects/index.cfm?fuseaction=search.dspPage\&n_proj_id=1915 \&docType=pdf 
Estimating the costs of the above actions is difficult and will depend on a variety of conditions not least local/national circumstances. As cited in CE Delft, Fraunhofer ISI, LEI (2011) ${ }^{87}$, a 2010 OECD report provides some estimates of the cost-effectiveness of some of the above mentioned actions, namely mass-media campaigns, food product labelling, school-based interventions and consumption taxes in dollar per gram of increased fruit and vegetable consumption ${ }^{88}$. These estimates could serve as a proxy for the costs of similar measures applied to stimulate sustainable consumption. The cost of delivering the package of interventions was found to vary between 12 and 24 USD PPP per capita per year in the different countries surveyed ${ }^{88}$.

Table 16: Cost-effectiveness of policy instruments to healthy food consumption ${ }^{88}$

\begin{tabular}{|l|l|l|}
\hline Policy measure & $\begin{array}{l}\text { Increase in fruit and } \\
\text { vegetable consumption per } \\
\text { person (in grams) }\end{array}$ & $\begin{array}{l}\text { Cost per person exposed to } \\
\text { policy measure (in US\$ PPP) }\end{array}$ \\
\hline Mass-media campaigns & 18 & $0.5-2$ \\
\hline Food product labelling & 10 & $0.33-1.1$ \\
\hline School-based interventions & 38 & $1-2$ \\
\hline Consumption taxes & $4-11$ & $0.03-0.13$ \\
\hline
\end{tabular}

\section{Objective 2: Reduce direct GHG emissions from food and drink consumption}

Direct GHG emissions from food and drink consumption are related to energy consumed in activities such as personal travel for shopping, refrigeration and freezing of food products, cooking / preparation of food and dishwashing. Water consumption and waste generation are other important factors ${ }^{89}$.

In order to address this objective, action is needed to help increase awareness among consumers of the impacts of their behaviour. This can be achieved through targeted information and awareness raising campaigns and education programmes about the direct environmental impacts of food and drink consumption. The impact of past/current activities needs to be evaluated and future initiatives designed to address gaps in consumer awareness and understanding. Future campaigns could for example seek to influence the mode of personal transport used to travel to the supermarket (e.g. promoting biking to the local grocery store), encourage consumers to buy smaller amounts of perishable food products which require less refrigeration/freezing, promote efficient food preparation methods, raise awareness about the costs associated with high energy and water consumption, encourage the use of energy and water-efficient kitchen appliances such as stoves

\footnotetext{
${ }^{87}$ CE Delft, Fraunhofer ISI, LEI (2011), Second Interim Report (Draft): Quantification of measures and analysis of policy, Delft, June 2011 (unpublished)

${ }^{88}$ OECD 2010, Obesity and the Economics of Prevention: Fit not Fat (http://www.oecd.org/document/31/0,3746,en 26493392945999775 1 11 1 1,00.html). Further, a quantification of the effectiveness of food and other consumption policies with regard to GHG emission reductions is currently studied under the contract "Behavioural climate change mitigation options and their appropriate inclusion in quantitative longer term policy scenarios" for DG Climate Action, done by CE Delft, Fraunhofer-ISI and LEI.
}

89 EEA, (2005), Household consumption and the environment, EEA Report No 11/2005, http://www.eea.europa.eu/publications/eea report 2005 11 [Accessed 01/06/2011] 
and dishwashers etc. In terms of education programmes, home economics classes could for example be used to encourage more energy/water-efficient food preparation and storage practices. Such information and awareness-raising actions should be coordinated with actions in other sectors such as the transport sector so that changes are made in the underlying infrastructure which would make such changes in behaviour easier, e.g. integrated public transport system, accessible cycle routes etc.

Other relevant actions in this area will complement those set out above in section 5.4, which seek to increase the up-take of energy and water efficient appliances and reduce energy and water consumption during the use-phase. Thus, relevant actions could include inter alia well-designed labelling requirements on all relevant appliances products to allow consumers to distinguish performance levels, financial incentives such as lower VAT rates, bonuses/ or grants to encourage purchase of new and larger refrigerators and freezers, energy-efficient ovens and microwaves and water-efficient dishwashers, work with utility companies to design monitoring and billing mechanisms that promote awareness, introduce metering and smart metering to help people better understand and reduce their use patterns, support innovation for the development of substitutes or new technologies to support change in behaviour, provide leadership through public procurement to stimulate the market for efficient appliances etc.

\section{Objective 3: Reduce food/packaging waste}

Food waste is a complex issue that involves parties along the whole food chain. Given the focus of this study, the actions set out below focus primarily on those that affect the consumption side of the chain. However, a number of actions are needed in parallel to address waste on the production side of the chain, for example innovations to prevent or reduce waste and encourage use of food residues in the agricultural and fisheries sectors.

A recommended action to reduce food waste is the introduction of targeted awareness-raising and information campaigns and education programmes. There are several examples of successful initiatives that have been introduced in various Member States which can be drawn on, e.g. the WRAP's 'Love Food Hate Waste' campaign in the UK and the 'Taste the waste' campaign in the Netherlands. Education campaigns would also be useful in this regard, e.g. the provision of general information in schools. As noted in a 2010 study on food waste, the cost of such initiatives for the European Commission is estimated at between $€ 90,000$ and $€ 180,000$ based on the website and network costs of the Green Spider Network. The cost for Member State campaigns is estimated at $€ 0.04$ per inhabitant, based on the WRAP Love Food Hate Waste campaign, approximately $€ 20$ million for EU27. ${ }^{90}$

Another action to reduce food / packaging waste is the establishment of voluntary agreements with food retailers, food producers and the restaurant/catering sector that seek to limit food waste. Such agreements could for example include a commitment by retailers to abandon quantity based marketing strategies such as buy-one-get-one-free offers on perishable products, address food waste in the retail part of the product chain through establishing or supporting initiatives such

\footnotetext{
${ }^{90}$ Bio Intelligence Service, Umweltbundesamt, AEA, (2010), Preparatory study on food waste across EU-27, Contract No: 07.0307/2009/540024/SER/G4, Final Report, October 2010,
} ec.europa.eu/environment/eussd/pdf/bio_foodwaste_report.pdf 
as food banks. ${ }^{91}$ Suppliers could be encouraged to develop healthy convenience foods with less packaging through the setting of relevant standards. Best practices on how to reduce or avoid food losses could be shared and new initiatives supported.

The amount of avoidable food waste could be reduced by action to reduce confusion relating to date labelling. A 2010 study on food waste recommends the harmonisation of date labels with the Food Information Regulation and disseminating information to the public through information and awareness-raising campaigns ${ }^{92}$. Such information campaigns can help to improve clarification and understanding of current food date labels such as 'best before', 'sell by' and 'display until', and encouraging them to use their own judgement (visual, olfactory and taste) to reduce the amount of food waste generated. According to this 2010 study on food waste, the cost of this action for the EU and for Member States is considered negligible. Based on data from the UK Food Standards Agency, the costs for industry based on familiarisation costs with the new regulation is estimated at $€ 232,000$ per EU-15 Member State and at $€ 47,000$ per EU-12 Member State ${ }^{93}$.

Supporting best practises for exemplification could also contribute towards this objective. For example, pilots to explore possibilities for sustainable catering in public institutions e.g. to reduce food waste within governmental offices and for local/community-led initiatives and consumer interest organisations operating at a national or regional level through funding, endorsement, and raising awareness of them.

\footnotetext{
${ }^{91}$ Copenhagen Resource Institute et al (2011), Potential policies to promote SCP via the food retail sector in Nordic
} Countries, http://www.mst.dk/NR/rdonlyres/23068349-ED79-4BA3-AF50-8D1CD58BFFD2/o/Potentialpolicies.pdf

\footnotetext{
92 Bio Intelligence Service, Umweltbundesamt, AEA, (2010), Preparatory study on food waste across EU-27, Contract No: 07.0307/2009/540024/SER/G4, Final Report, October 2010, http://ec.europa.eu/environment/eussd/pdf/bio_foodwaste_report.pdf

${ }^{93}$ Bio Intelligence Service, Umweltbundesamt, AEA, (2010), Preparatory study on food waste across EU-27, Contract No: 07.0307/2009/540024/SER/G4, Final Report, October 2010, 


\subsubsection{Summary of policy options for Food and Drink Sector}

\begin{tabular}{|c|c|c|c|c|c|c|}
\hline Sector objective & Specific actions & $\begin{array}{l}\text { Implement- } \\
\text { ation Scale }\end{array}$ & $\begin{array}{l}\text { Policy-makers and other } \\
\text { stakeholders to consider }\end{array}$ & Implications for EU policy & $\begin{array}{l}\text { Implementation costs for } \\
\text { EU/MS and Political } \\
\text { acceptability/ feasibility }\end{array}$ & Best practices \\
\hline Cross-cutting & $\begin{array}{l}\text { Develop overarching } \\
\text { strategy for } \\
\text { sustainable food in } \\
\text { Europe }\end{array}$ & EU, MS & $\begin{array}{l}\text { Policy-makers: } \\
\text { DG AGRI, DG MARE, DG ENV, } \\
\text { DG ENTR, DG Research, DG } \\
\text { MOVE } \\
\text { Other stakeholders: } \\
\text { MS, Farmers, food retailers, } \\
\text { producers of intermediate or } \\
\text { finished food products, } \\
\text { restaurants, cafeterias etc. }\end{array}$ & $\begin{array}{l}\text { Build on on-going efforts, e.g. by DG } \\
\text { AGRI, DG MARE, DG ENV, DG ENTR } \\
\text {, DG Research } \\
\text { Feed into the resource efficiency } \\
\text { agenda and link to the innovation } \\
\text { initiative of Europe } 2020 \text { Strategy }\end{array}$ & $\begin{array}{l}\text { - Low implementation cost } \\
\text { - Low to medium feasibility } \\
\text { of implementation due to } \\
\text { the many political actors } \\
\text { involved and the diversity } \\
\text { of "food cultures" across } \\
\text { the EU. }\end{array}$ & \\
\hline Cross-cutting & $\begin{array}{l}\text { Launch research } \\
\text { initiatives }\end{array}$ & EU, MS & $\begin{array}{l}\text { Policy-makers } \\
\text { EC, MS } \\
\text { Other stakeholders: } \\
\text { Research institutes, food } \\
\text { producers, retailers etc. }\end{array}$ & $\begin{array}{l}\text { Take forward in FP7 and FP8 work } \\
\text { programmes } \\
\text { Link to eco-innovation agenda } \\
\text { Link to health/nutrition aspects }\end{array}$ & $\begin{array}{l}\text {-Low to high } \\
\text { implementation cost - } \\
\text { variable depending on } \\
\text { nature of research } \\
\text { initiatives and whether } \\
\text { funding is provided by EU }\end{array}$ & \\
\hline Cross-cutting & $\begin{array}{l}\text { Strengthen } \\
\text { institutional } \\
\text { structures and } \\
\text { administrative } \\
\text { capacities }\end{array}$ & $\begin{array}{l}\text { EU, MS, } \\
\text { regional/ } \\
\text { local level }\end{array}$ & $\begin{array}{l}\text { Policy-makers } \\
\text { EU, MS, regional/local level } \\
\text { public authorities } \\
\text { Other stakeholders: } \\
\text { NGOs, other relevant } \\
\text { organisations }\end{array}$ & & $\begin{array}{l}\text {-Medium to high } \\
\text { implementation costs } \\
\text {-Low political acceptance } \\
\text { and feasibility in terms of } \\
\text { changing existing structures }\end{array}$ & \\
\hline $\begin{array}{l}\text { Encourage more } \\
\text { sustainable and healthy } \\
\text { patterns of food and drink } \\
\text { consumption }\end{array}$ & $\begin{array}{l}\text { Continue, expand and } \\
\text { improve voluntary } \\
\text { agreements, public- } \\
\text { private partnerships }\end{array}$ & EU, MS & $\begin{array}{l}\text { Policy-makers: } \\
\text { EC, MS, food retailers, } \\
\text { restaurants, cafeterias } \\
\text { Other stakeholders: } \\
\text { Producers of intermediate or } \\
\text { finished food and drink } \\
\text { products, consumers, financial } \\
\text { institutions }\end{array}$ & $\begin{array}{l}\text { Build on/improve on initiatives such } \\
\text { as the EU Retail Forum and the Food } \\
\text { SCP Roundtable. } \\
\text { Support promotion of eco- } \\
\text { innovation through ETAP and CIP }\end{array}$ & $\begin{array}{l}\text {-Low to medium } \\
\text { implementation cost } \\
\text { depending on whether } \\
\text { funding is involved. }\end{array}$ & $\begin{array}{l}\text { See: Copenhagen } \\
\text { Resource Institute et al } \\
\text { (2011), Sustainable } \\
\text { Consumption and } \\
\text { Production in the Nordic } \\
\text { Retail Sector; } \\
\text { http://www.mst.dk/English/ } \\
\text { SustainableConsumptionan } \\
\text { dProductionintheNordicRet } \\
\end{array}$ \\
\hline
\end{tabular}




\begin{tabular}{|c|c|c|c|c|c|c|}
\hline Sector objective & Specific actions & $\begin{array}{l}\text { Implement- } \\
\text { ation Scale }\end{array}$ & $\begin{array}{l}\text { Policy-makers and other } \\
\text { stakeholders to consider }\end{array}$ & Implications for EU policy & $\begin{array}{l}\text { Implementation costs for } \\
\text { EU/MS and Political } \\
\text { acceptability/ feasibility }\end{array}$ & Best practices \\
\hline & & & & & & ailSector/REAP Database \\
\hline & $\begin{array}{l}\text { Introduce } \\
\text { differentiated } \\
\text { consumption taxes } \\
\text { based on the } \\
\text { environmental } \\
\text { performance of } \\
\text { products }\end{array}$ & MS & $\begin{array}{l}\text { Policy-makers: } \\
\text { MS, DG TAXUD } \\
\text { Other stakeholders: } \\
\begin{array}{l}\text { Consumers, retailers, food } \\
\text { producers }\end{array}\end{array}$ & $\begin{array}{l}\text {-VAT Directive } 2006 / 112 / E C \\
\text {-Requires stringently defined } \\
\text { labelling system }\end{array}$ & $\begin{array}{l}\text { - Low implementation costs } \\
\text {-Low to medium political } \\
\text { acceptance and feasibility } \\
\text { due to possibility of } \\
\text { affecting the market. }\end{array}$ & \\
\hline & $\begin{array}{l}\text { Develop an EU-level } \\
\text { sustainable food } \\
\text { labelling scheme and } \\
\text { establish credible } \\
\text { certification } \\
\text { mechanisms }\end{array}$ & EU & $\begin{array}{l}\text { Policy-makers: } \\
\text { MS, retailers, food producers, } \\
\text { DG SANCO, DG AGRI, DG } \\
\text { ENV, independent } \\
\text { organisations (verifiers) } \\
\text { Other stakeholders: } \\
\text { Consumers }\end{array}$ & $\begin{array}{l}\text { The Commission intends to ensure } \\
\text { coherence of future EU agricultural } \\
\text { product quality } \\
\text { schemes and initiatives by } \\
\text { proactively assessing the value } \\
\text { added and advisability of any new } \\
\text { schemes in collaboration with all } \\
\text { services concerned (COM(2009) 234) }\end{array}$ & $\begin{array}{l}\text {-Medium implementation } \\
\text { costs: the impact } \\
\text { assessment accompanying } \\
\text { the } 2008 \text { revision to the EU } \\
\text { eco label scheme }{ }^{94} \text { provided } \\
\text { an estimate of } € 25,000 \text { per } \\
\text { product group for the } \\
\text { development of eco-label } \\
\text { criteria, although noting } \\
\text { that costs vary significantly } \\
\text { depending on the scale, } \\
\text { complexity and scope of the } \\
\text { product group. }\end{array}$ & \\
\hline & $\begin{array}{l}\text { Launch targeted } \\
\text { information and } \\
\text { awareness-raising } \\
\text { campaigns and } \\
\text { education } \\
\text { programmes. }\end{array}$ & $\begin{array}{l}\text { EU, MS, } \\
\text { local }\end{array}$ & $\begin{array}{l}\text { Policy-makers: } \\
\text { EU, MS, local authorities, } \\
\text { NGOs, educational institutions } \\
\text { Other stakeholders: } \\
\text { Consumers, pupils }\end{array}$ & $\begin{array}{l}\text {-Build on existing initiatives } \\
\text {-Provide support under LIFE+ } \\
\text {-Information and Communication } \\
\text { component to consider (using social } \\
\text { networks and media campaigns) }\end{array}$ & $\begin{array}{l}\text {-High implementation costs } \\
\text { (cost of implementing Food } \\
\text { Dudes education } \\
\text { programme in } 150 \text { schools } \\
\text { in Ireland over the } 2005- \\
2008 \text { required } € 484000 \text { per } \\
\text { year) }\end{array}$ & $\begin{array}{l}\text { 'Love food hate waste' } \\
\text { campaign (UK); Food } \\
\text { Dudes Healthy Eating } \\
\text { Programme (several } \\
\text { countries); Efforts of } \\
\text { British celebrity chefs } \\
\text { such as Jamie Oliver to } \\
\text { promote healthy food } \\
\text { consumption in schools } \\
\text { and the 'Fishfight' }\end{array}$ \\
\hline
\end{tabular}

94 EC (2008), COMMISSION STAFF WORKING DOCUMENT Accompanying document to the Revision of Regulation (EC) No $1980 / 2000$ of the European Parliament and of the Council of 17 July 2000 on a revised Community eco-label award scheme IMPACT ASSESSMENT, http://ec.europa.eu/environment/ecolabel/about ecolabel/revisions/ecolabel ia.pdf 


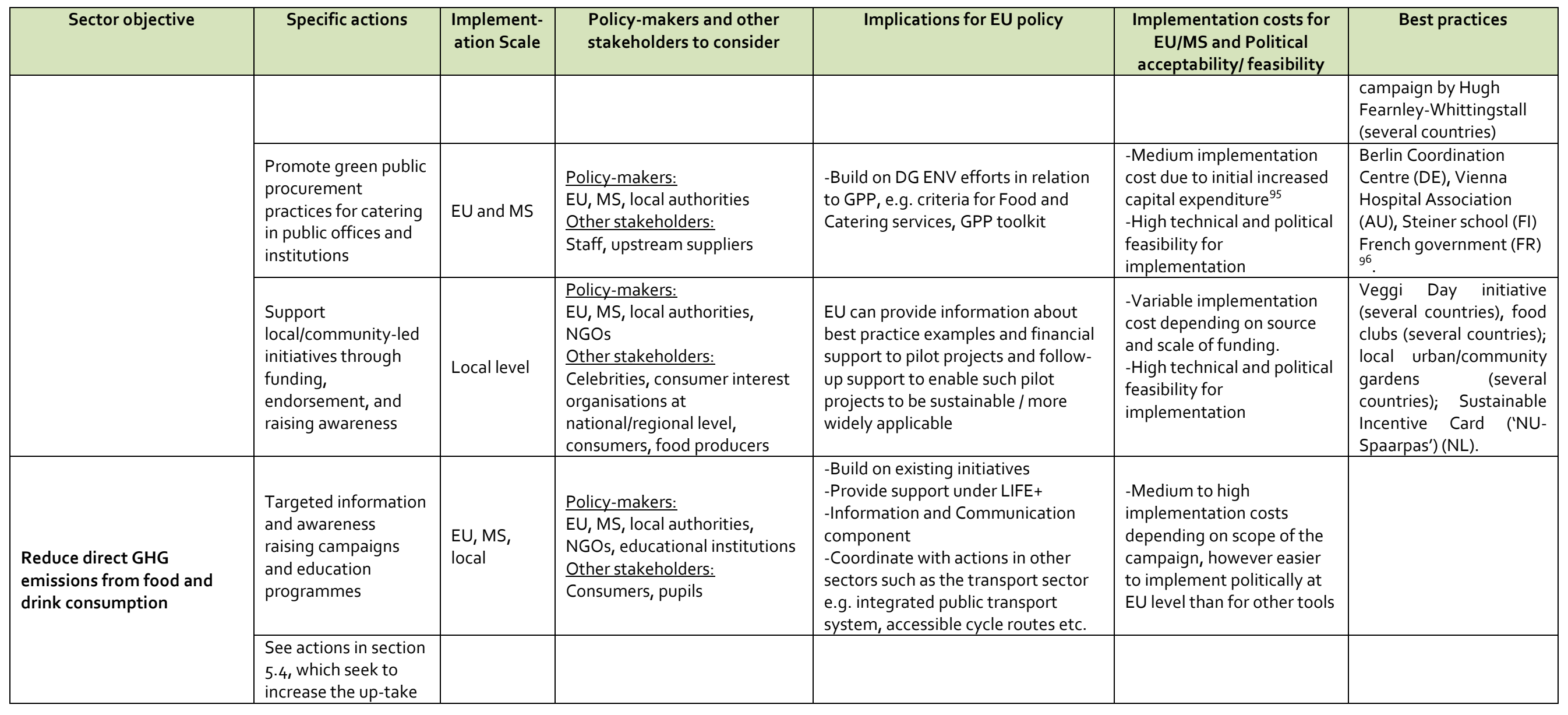

${ }^{95}$ The Swedish city of Malmo adopted a goal to serve $100 \%$ organic food in all of its public catering services by 2020 . $€ 36$ million was spent on school restaurants over four years. At the end of $2009,43 \%$ of the food served in all school restaurants in Malmö was organic

${ }^{96}$ Ochoa, A., Defranceschi, P., (2011) Strategy Paper on the Sustainability Potential of Public Procurement for Food and Housing, EUPOPP Work package 2.2, Deliverable 3.2.1, "Public purchasers as mediators of change for sustainable consumption", March 2011, ICLEI - Local Governments for Sustainability, European Secretariat http://www.eupopp.net/docs/eupopp deliverable 3.2.1 final.pdf 


\begin{tabular}{|c|c|c|c|c|c|c|}
\hline Sector objective & Specific actions & $\begin{array}{l}\text { Implement- } \\
\text { ation Scale }\end{array}$ & $\begin{array}{l}\text { Policy-makers and other } \\
\text { stakeholders to consider }\end{array}$ & Implications for EU policy & $\begin{array}{l}\text { Implementation costs for } \\
\text { EU/MS and Political } \\
\text { acceptability/ feasibility }\end{array}$ & Best practices \\
\hline & $\begin{array}{l}\text { of energy and water } \\
\text { efficient appliances } \\
\text { and reduce energy } \\
\text { and water } \\
\text { consumption during } \\
\text { the use-phase }\end{array}$ & & & & & \\
\hline \multirow{3}{*}{$\begin{array}{l}\text { Reduce food waste/reduce } \\
\text { packaging waste }\end{array}$} & $\begin{array}{l}\text { Targeted awareness- } \\
\text { raising and } \\
\text { information } \\
\text { campaigns and } \\
\text { education } \\
\text { programmes }\end{array}$ & $\begin{array}{l}\text { EU, MS, } \\
\text { local }\end{array}$ & $\begin{array}{l}\text { Policy-makers: } \\
\text { EU, MS, local authorities, } \\
\text { NGOs, educational institutions } \\
\text { Other stakeholders: } \\
\text { Consumers, pupils }\end{array}$ & $\begin{array}{l}\text {-Build on existing initiatives } \\
\text {-Provide support under LIFE+ } \\
\text {-Information and Communication } \\
\text { component } \\
\text {-Support implementation and future } \\
\text { developments in EU waste } \\
\text { legislation }\end{array}$ & $\begin{array}{l}\text {-Medium to high } \\
\text { implementation costs } \\
\text { depending on scope of the } \\
\text { campaign, however easier } \\
\text { to implement politically at } \\
\text { EU level than for other } \\
\text { tools }^{97} \text {. }\end{array}$ & $\begin{array}{l}\text { WRAP's 'Love Food Hate } \\
\text { Waste' campaign (UK); } \\
\text { 'Taste the waste' } \\
\text { campaign (NL); Brug } \\
\text { Mere Spild Mindre (Use } \\
\text { More Waste Less) } \\
\text { campaign (DK); }\end{array}$ \\
\hline & $\begin{array}{l}\text { Establish voluntary } \\
\text { agreements with } \\
\text { food retailers, food } \\
\text { producers and the } \\
\text { restaurant/catering } \\
\text { sector }\end{array}$ & EU, MS & $\begin{array}{l}\text { Policy-makers: } \\
\text { EC, MS, food retailers, } \\
\text { restaurants, cafeterias } \\
\text { Other stakeholders: } \\
\text { Producers of intermediate or } \\
\text { finished food and drink } \\
\text { products, consumers, financial }\end{array}$ & $\begin{array}{l}\text {-Build on/improve initiatives such as } \\
\text { EU Retail Forum or the Food SCP } \\
\text { Roundtable } \\
\text {-Support promotion of eco- } \\
\text { innovation efforts under ETAP and } \\
\text { CIP } \\
\text {-Support implementation and future } \\
\text { developments in EU waste } \\
\text { legislation }\end{array}$ & $\begin{array}{l}\text {-Low implementation cost } \\
\text {-Feasible to implement if } \\
\text { built on existing structures } \\
\text { and initiatives }\end{array}$ & \\
\hline & $\begin{array}{l}\text { Harmonise date } \\
\text { labels with the Food } \\
\text { Information } \\
\text { Regulation }\end{array}$ & $\begin{array}{l}\text { EU, MS, } \\
\text { local }\end{array}$ & & $\begin{array}{l}\text { Regulation on the provision of food } \\
\text { information to consumers } \\
\text { (COM(2008)40) [political agreement } \\
\text { reached, awaiting adoption of final } \\
\text { legislative text] which repeals } \\
\text { Directive } 2000 / 13 / E C \text { on the } \\
\text { labelling, presentation and } \\
\text { advertising of foodstuffs; Council }\end{array}$ & $\begin{array}{l}\text {-Low implementation cost: } \\
\text { based on data from the UK } \\
\text { Food Standards Agency, } \\
\text { the cost for industry based } \\
\text { on familiarisation costs with } \\
\text { the new regulation is } \\
\text { estimated at } € 232,000 \text { per } \\
\text { EU-15 Member State and at }\end{array}$ & \\
\hline
\end{tabular}

${ }^{97}$ Cost for the EU estimated at between $€ 90,000$ and $€ 180,000$ based on the website and network costs of the Green Spider Network, the cost for Member State campaigns is estimated at $€ 0.04$ per inhabitant, based on the WRAP Love Food Hate Waste campaign ${ }^{97}$ 


\begin{tabular}{|c|c|c|c|c|c|c|}
\hline Sector objective & Specific actions & $\begin{array}{l}\text { Implement- } \\
\text { ation Scale }\end{array}$ & $\begin{array}{l}\text { Policy-makers and other } \\
\text { stakeholders to consider }\end{array}$ & Implications for EU policy & $\begin{array}{l}\text { Implementation costs for } \\
\text { EU/MS and Political } \\
\text { acceptability/ feasibility }\end{array}$ & Best practices \\
\hline & & & & $\begin{array}{l}\text { Directive } 90 / 496 / E E C \text { on nutrition } \\
\text { labelling for foodstuffs in one } \\
\text { instrument }\end{array}$ & $\begin{array}{l}€ 47,000 \text { per EU-12 Member } \\
\text { State }^{98} \text {. }\end{array}$ & \\
\hline & $\begin{array}{l}\text { Disseminate } \\
\text { information on date } \\
\text { labels through } \\
\text { information and } \\
\text { awareness-raising } \\
\text { campaigns }\end{array}$ & $\begin{array}{l}\text { EU, MS, } \\
\text { local }\end{array}$ & $\begin{array}{l}\text { Policy-makers: } \\
\text { EU, MS, local authorities, } \\
\text { NGOs, educational institutions } \\
\text { Other stakeholders: } \\
\text { Consumers }\end{array}$ & $\begin{array}{l}\text { Provide support under LIFE+ } \\
\text { Information and Communication } \\
\text { component }\end{array}$ & $\begin{array}{l}\text {-Medium to high } \\
\text { implementation costs } \\
\text { depending on scope of the } \\
\text { campaign, however easier } \\
\text { to implement politically at } \\
\text { EU level than for other } \\
\text { tools. }\end{array}$ & \\
\hline & $\begin{array}{l}\text { Support best } \\
\text { practises for } \\
\text { exemplification }\end{array}$ & EU, MS & $\begin{array}{l}\text { Policy-makers: } \\
\text { EU, MS, local authorities, } \\
\text { NGOs } \\
\text { Other stakeholders: } \\
\text { Celebrities, consumer interest } \\
\text { organisations at } \\
\text { national/regional level, } \\
\text { consumers, food producers }\end{array}$ & $\begin{array}{l}\text { Support implementation and future } \\
\text { developments in EU waste } \\
\text { legislation }\end{array}$ & - Low implementation cost & \\
\hline
\end{tabular}

${ }^{98}$ Bio Intelligence Service, Umweltbundesamt, AEA, (2010), Preparatory study on food waste across EU-27, Contract No: 07.0307/2009/540024/SER/G4, Final Report, October 2010, http://ec.europa.eu/environment/eussd/pdf/bio foodwaste report.pdf 


\subsection{Clothing/textiles}

\subsubsection{Policy context}

The European Commission's 2006 EIPRO study found that clothing is the fourth highest impact area (following food and drink, transport and housing), with an estimated share of $\mathbf{2 - 1 0 \%}$ in total environmental impact. According to the yet unpublished IMPRO Textiles report, clothing and textiles have a significant environmental impact across their lifecycle, with the production, processing and the use phase contributing most to environmental impacts. ${ }^{99}$

Clothes are becoming cheaper, have a shorter lifespan ("fast fashion") and are purchased in ever growing quantities. However, social barriers to the consumption of sustainable clothing persist: The choice of clothing is one of the most visually obvious ways for people to express their social status, values and individual and/or collective identity. Unless quality and longevity form part of this identity, it is likely that fashion consumers will seek to pay the lowest price to achieve their intended identity statement. Because of the symbolic significance of clothes there is an important political constraint: Policy-makers are reluctant to create policies that intervene in people's lifestyle choices because there is low social acceptance for such interventions.

With the REACH legislation (restricting the use of harmful chemicals during production and processing, affecting producers inside and outside the EU) ${ }^{100}$, the EMAS voluntary instrument (recognising organisations that improve their environmental performance on a continuous basis) ${ }^{101}$ and the Water Framework Directive (governing the quality of industry wastewater) EU legislation has so far primarily focused on the production phase. The EU eco-design Directive will have a significant impact on the efficiency of appliances and therefore influence energy consumption during the use phase of clothing.

As most textile products are imported, the scope for EU and MS regulatory supply-side-policy is relatively limited. However, the following measures should be integrated in EU policy in order to increase the supply of sustainable clothing:

For the promotion of sustainable cotton farming ${ }^{102}$ guidance and support for local producers should be provided. In the case of developing country producers such as China, India, Pakistan or Brazil (Top 1, 2, 4, 5 cotton producers in 2011) ${ }^{103}$ this could form a part of

\footnotetext{
${ }^{99}$ For more on the sector's impact see the work on clothing and textiles in Task 4.

${ }^{100}$ See http://reach-support.com/REACHtextilebrochur\%28SSS\%29.pdf.

${ }^{101}$ See http://ec.europa.eu/environment/emas/index_en.htm

102 Though having grown steadily during the last years, organic cotton, for example, represents just $1 \%$ of global cotton production (http://organicexchange.org/sites/default/files/

TE 2010 Farm and Fiber Press Release 011211 Final.pdf, accessed 01/08/11).

${ }^{103}$ http://www.cotton.org/econ/cropinfo/cropdata/rankings.cfm.
} 
development cooperation. The "Cotton made in Africa" initiative is an interesting example. It provides training in sustainable farming methods to African farmers in order to increase productivity and income. It also fosters social development by financing community projects to improve education and health services. In order to finance these activities, retailers pay a small licensing fee. ${ }^{104}$

Greece (which ranks $10^{\text {th }}$ ) and Spain (which ranks $27^{\text {th }}$ in the top cotton producers list $2011)^{105}$ should also be encouraged to gradually substitute conventional by sustainable cotton farming. According to the Fairtrade Foundation they receive $€ 202 \mathrm{~m}$ (Greece) and $€ 73 \mathrm{~m}$ (Spain) in production subsidies as a part of the EU Common Agricultural Policy (CAP) annually. ${ }^{106}$ Since the 2008 reform of the Common Market Organisation for cotton, these subsidies are significantly decoupled from production ( $35 \%$ still coupled). Following this reform, the EU cotton area went roughly back to the mid-eighties level, thus compensating the production distorting effect of the previous EU support scheme. In addition, Greece and Spain use rural development funds to support more environmentally-friendly or higher quality production. Moreover, textile companies and retailers should be encouraged, e.g. in the Retail Forum, to adopt ethical sourcing in order to further pull more sustainable cotton supplies.

For the use of harmful chemicals to be reduced, awareness-raising, education and training in the supply chain is vital, e.g. through addressing this issue among European textile companies and retailers in the Retail Forum, and through development cooperation. The trainings and courses of the "Society of Dyers and Colourists", for example, are a good case illustrating the dissemination of (environmental) best practice in the dyeing process. Courses are offered in the UK, India, Hong Kong, China, Pakistan and Bangladesh. ${ }^{107}$

The EU should promote responsible and ethical garment manufacturing, i.e. better social and labour conditions for workers in countries of production, amongst textile companies and retailers (e.g. in the Retail Forum). On a MS level we identified the "Responsible and Accountable Garment Sector" initiative (RAGS), funded by the UK Department for International Development, as a good practice example. ${ }^{108}$ The fund supports projects in Asia and Sub-Saharan Africa that aim at improving working conditions in the garment production industries as well as rendering responsible and ethical production the norm in clothes manufacturing.

The aforementioned measures target the production and processing phase. However, in order to address the purchase, use and disposal phase, more consumer-oriented instruments are needed to effectively complement supply-side action. The European Eco-label for clothing and footwear is a good starting point, targeting consumers during the purchase decision. However, the multitude of

\footnotetext{
${ }^{104}$ See Defra (2011) Sustainable Clothing Roadmap Progress Report 2011, p. 14.

${ }^{105}$ http://www.cotton.org/econ/cropinfo/cropdata/rankings.cfm.

${ }^{106} \mathrm{http}: / /$ www.publications.parliament.uk/pa/cm201011/cmselect/cmenvfru/writev/671/capo7.htm.

${ }^{107}$ See Defra (2011) Sustainable Clothing Roadmap Progress Report 2011, p. 14.

${ }^{108}$ See Defra (2011) Sustainable Clothing Roadmap Progress Report 2011, p. 16.
} 
existing labels and the differing labelling criteria may confuse consumers and reduce the information value of labelling. Moreover, eco-labelling alone is not sufficient to induce behavioural change and, hence, further EU action in the field is needed.

\subsubsection{Policy options}

\section{Objective 1: Promote sustainable production and processing}

The objective of more sustainable production and processing methods encompasses three subobjectives: a) promote sustainable cotton farming, b) reduce use of hazardous chemicals and c) improve social and labour conditions in textile production. In order to fulfil these objectives, policies that directly target consumers such as campaigning, labelling and point-of-sale measures are vital. However, they should be supplemented with supply-side measures as outlined above in the policy context.

For the promotion of sustainable cotton farming, a rise in consumer awareness is essential. This can be achieved through more and consistent labelling, e.g. the European Ecolabel. Better labelling and a rise in public awareness could offset potential short-term costs associated with the shift to sustainable/organic cotton farming.

The use of hazardous chemicals during the production and processing phase poses several severe risks to the environment and human health - not only in countries where textiles are produced, but also to European consumers ${ }^{109}$. Toxic residues can, for example, trigger allergies, resulting in costs for the health sector. The EU should raise consumer awareness, e.g. through campaigning and further dissemination of the European Ecolabel for Clothing and Footwear. The strict requirements used by the German "Blue Angel" could serve as a best-practice example for more rigorous criteria: textiles and shoes must be totally safe for human health as well as produced in an environmentally and ethically sound manner. The Oeko-Tex 1ooplus standard, for example, requires that a product is completely safe in terms of human ecology and has been manufactured exclusively in environmentally friendly manufacturing processes. ${ }^{110}$

The EU should raise awareness for social and labour conditions amongst consumers, e.g. through the promotion of fair trade cotton and the inclusion of social standards in the European Ecolabel. A good example of labelling is the FairTrade Certification Mark for Cotton.

\section{Objective 2: Reduce energy and water consumption of clothes cleaning}

In order to achieve this objective, behavioural change towards washing clothes less often and at reduced temperatures whilst optimising the load of appliances as well as line drying clothes is needed. This can be achieved by campaigning actions of NGOs, businesses and the EU. Successful examples include the private sector "Wash Right" and public-private "Wash at $30^{\circ}$ " campaign. Better information of detergent manufacturers on optimum washing techniques and clothing labels

\footnotetext{
${ }^{109}$ See for example:
}

www.greenpeace.org/international/Global/international/publications/toxics/Water\%202011/dirty-laundry-report.pdf.

${ }^{110}$ Oeko website: $w$ ww.oeko-tex1000.com/uk/main/index.asp?IDMain=17\&IDSub=107\&sid= 


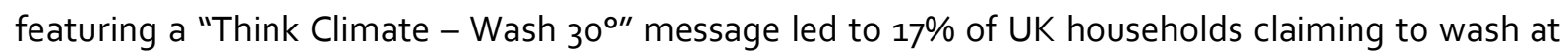
$30^{\circ} \mathrm{C}$ in 2007 compared to only $2 \%$ of households in $2002 .{ }^{111}$ The EU should encourage further dissemination of these POS measures and care label instructions, e.g. in the Retail Forum. Second, the EU should extend research funding in "smart textile functions" in order to reduce the need for washing, allow faster drying and less ironing and to increase durability. This could become part of the European Research Framework Programmes.

Finally, the promotion of efficient appliances for washing and drying should become a supportive action for a more sustainable use of clothes (see section on energy and water using appliances).

\section{Objective 3: Reduce textile waste}

In order to achieve this objective, we suggest three concrete actions: First, the EU, MS and NGOs should promote second hand clothing. This could be achieved by pan-European campaigning. Business models like the UK charity TRAID's practice of collecting clothing, sorting it by hand, reconstructing or redesigning torn or stained items and then selling it in charity shops in the UK could serve as a best-practice example. Second, repair services and fashion upgrades should be promoted, e.g. by service certification schemes. Again, consumer awareness could be raised by campaigning and the development of a European Ecolabel for textile repair and alteration services. Third, the EU should promote take-back/return and recycling of discarded clothing through campaigning and the definition of standards for fair and responsible collection and recycling of clothes. Good practice examples are the German FairWertung label stipulating specific requirements for fair and responsible collection and sorting as well as the take-back-scheme of Oxfam and M\&S. ${ }^{112}$

\section{Objective 4: Promote the substitution of conventional by sustainable clothing}

The EU should raise consumer awareness by accelerating the dissemination of its European Ecolabel for clothing and footwear. The well-known German "Blue Angel" label has recently established strict criteria for textiles and shoes and could serve as a good example for the establishment of ecological and social criteria in the sector. The Global Organic Textile Standard (GOTS) is probably the best-known label for sustainable clothing worldwide. GOTS-certified products must contain a minimum of $70 \%$ organic fibres and fulfil high level environmental criteria along the entire supply chain as well as comply with social criteria. ${ }^{113}$

Following the motto "Be the change you want to see", the EU and its MS should take the lead as promoters of sustainable clothing and develop a 2025 vision/roadmap for a European fair and sustainable clothing market. Testimonials and various marketing techniques could be employed not only to create collective awareness but to actually pull European citizens towards more sustainable lifestyles and fashion choices. Evidence shows that collaborating with celebrities to promote lifestyle changes and fashion is particularly effective in influencing consumers.

\footnotetext{
${ }^{111}$ See also Task 4 Clothing/Textiles.

${ }^{112}$ See task 4 Clothing/Textiles.

${ }^{113}$ http://www.global-standard.org/the-standard.html.
} 
To lead by example also means taking concrete actions. Consequently, the EU should make sustainable clothing and textiles an objective of the EU Green Public Procurement Policy, e.g. be defining EU GPP criteria for clothing. ${ }^{114}$

${ }^{114}$ Defra (UK) has launched a Sustainable Public Procurement study at its National Health Service and the result of this trial could be used to further advance EU policymaking regarding the sector objective. 


\subsubsection{Summary of policy options for Clothing/Textiles sector}

\begin{tabular}{|c|c|c|c|c|c|c|}
\hline Sector objective & Specific actions & $\begin{array}{l}\text { Implement- } \\
\text { ation Scale }\end{array}$ & $\begin{array}{l}\text { Policy-makers and other } \\
\text { stakeholders to consider }\end{array}$ & Implications for EU policy & $\begin{array}{l}\text { Implementation costs for } \\
\text { EU/MS and Political } \\
\text { acceptability/ feasibility }\end{array}$ & Best practices \\
\hline $\begin{array}{l}\text { Promote sustainable } \\
\text { production and } \\
\text { processing } \\
\text { a) promote } \\
\text { sustainable cotton } \\
\text { farming } \\
\text { b) reduce use of } \\
\text { hazardous chemicals } \\
\text { c) improve social and } \\
\text { labour conditions in } \\
\text { textile production }\end{array}$ & $\begin{array}{l}\text {-Raise awareness through } \\
\text { campaigning, labelling and point- } \\
\text { of-sale measures }\end{array}$ & EU & $\begin{array}{l}\text { Policy-makers: } \\
\text { DG ENV, DG ENTR, DG ENER, } \\
\text { DG AGRI, MS } \\
\text { Other stakeholders: } \\
\text { Retailers, consumers }\end{array}$ & $\begin{array}{l}\text {-Include social standards and } \\
\text { standards for sustainable cotton } \\
\text { farming in the European Ecolabel for } \\
\text { Clothing and Footwear } \\
\text {-Further dissemination of the } \\
\text { European Ecolabel for Clothing and } \\
\text { Footwear }\end{array}$ & $\begin{array}{l}\text {-Medium to high } \\
\text { implementation costs } \\
\text { depending on scope of the } \\
\text { awareness campaign (esp. } \\
\text { If celebrities are used) } \\
\text { - Labelling and point of sale } \\
\text { measures more difficult to } \\
\text { implement at EU level due } \\
\text { to potential differences in } \\
\text { clothing cultures and } \\
\text { markets across MS }\end{array}$ & $\begin{array}{l}\text { German "Blue } \\
\text { Angel" for textiles } \\
\text { and shoes, } \\
\text { Oeko-Tex 1ooplus, } \\
\text { FairTrade } \\
\text { Certification Mark } \\
\text { for Cotton }\end{array}$ \\
\hline \multirow{3}{*}{$\begin{array}{l}\text { Reduce energy and } \\
\text { water consumption } \\
\text { of clothes cleaning }\end{array}$} & $\begin{array}{l}\text { Promote optimum washing } \\
\text { techniques } \\
\text { (washing less often, at reduced } \\
\text { temperatures, optimising the load } \\
\text { of appliances, line drying ) through } \\
\text { awareness campaigns and } \\
\text { provision of infrastructure (e.g. } \\
\text { supplying practical line drying } \\
\text { solutions) }\end{array}$ & EU, MS & $\begin{array}{l}\text { Policy-makers: } \\
\text { DG ENV, DG SANCO, DG } \\
\text { ENER, MS } \\
\text { Other stakeholders: } \\
\text { NGOs, Business }\end{array}$ & $\begin{array}{l}\text { - Awareness-raising in through } \\
\text { initiatives such as the EU Retail } \\
\text { Forum or EU Ecolabel for clothing } \\
\text { and footwear }\end{array}$ & $\begin{array}{l}\text {-Medium to high } \\
\text { implementation costs } \\
\text { depending on scope of the } \\
\text { awareness campaign }\end{array}$ & $\begin{array}{l}\text { "Wash Right" } \\
\text { campaign by } \\
\text { A.I.S.E. } \\
\text { (www.washright.c } \\
\text { om) }\end{array}$ \\
\hline & $\begin{array}{l}\text { Promote research and product } \\
\text { innovation ('smart' functions for } \\
\text { easy care and longer product } \\
\text { durability) }\end{array}$ & EU/MS & $\begin{array}{l}\text { Policy-makers: } \\
\text { DG RES, MS } \\
\text { Other stakeholders: } \\
\text { Research institutions, Business }\end{array}$ & $\begin{array}{l}\text { Promote sustainability and smart } \\
\text { functions in textile research as part } \\
\text { of European Research Framework } \\
\text { Programmes } \\
\text { Make sustainability objectives a } \\
\text { prerequisite for funding of textile } \\
\text { research projects }\end{array}$ & $\begin{array}{l}\text {-Low to high } \\
\text { implementation cost - } \\
\text { variable depending on } \\
\text { nature of research } \\
\text { initiatives and whether } \\
\text { funding is provided by EU }\end{array}$ & - \\
\hline & $\begin{array}{l}\text { Promote efficient appliances for } \\
\text { washing and drying (see "Housing: } \\
\text { Energy and water using appliances) }\end{array}$ & - & - & - & - & - \\
\hline
\end{tabular}




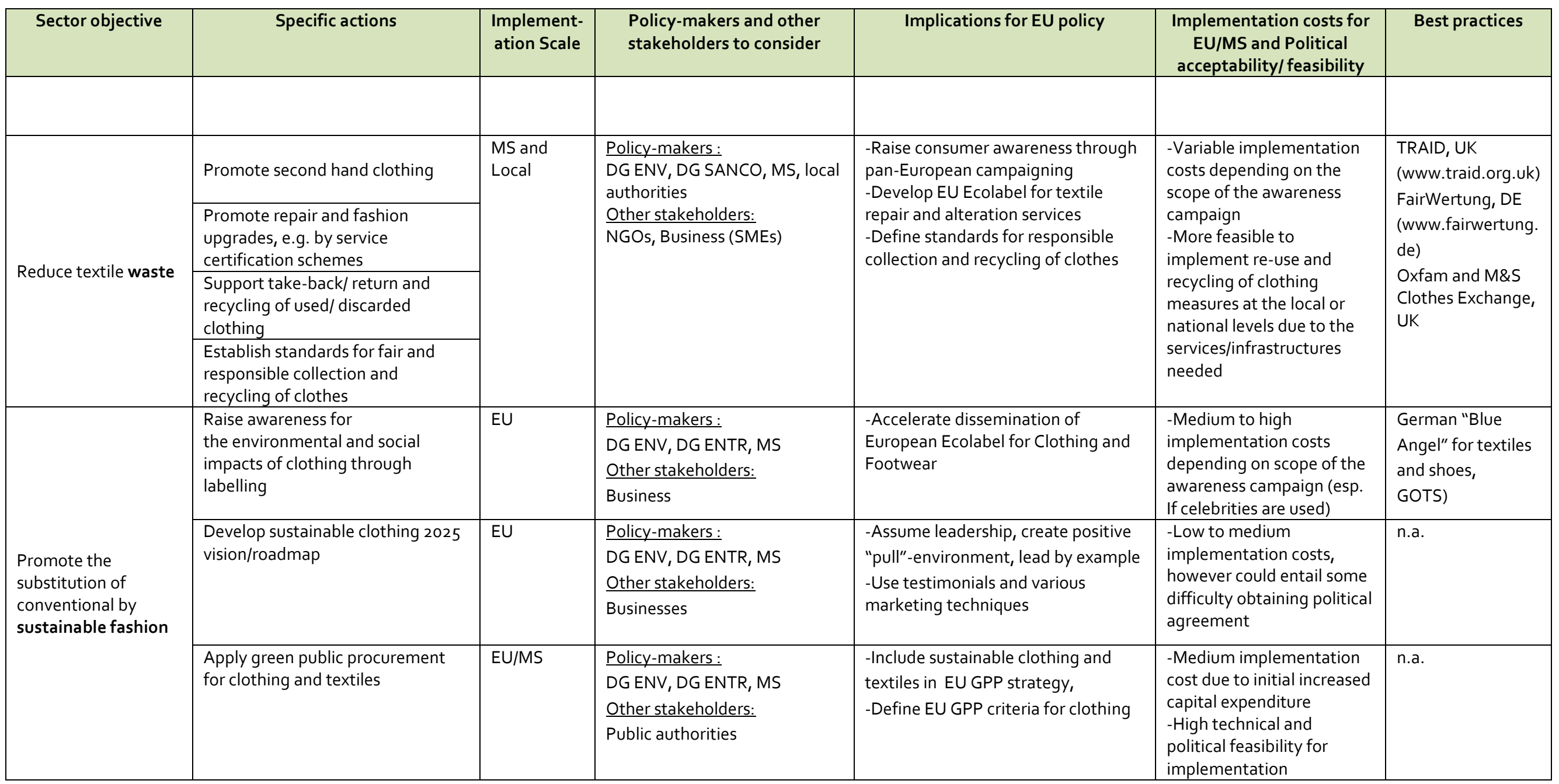




\subsection{Tourism}

\subsubsection{Policy context}

The EU has been involved in numerous initiatives for a number of years to promote more sustainable tourism, while at the same time strengthening EU competitiveness and growth. A summary of recent EU actions towards sustainable tourism include:

Commission Communication (2006) on A renewed EU Tourism Policy: Towards a stronger partnership for European Tourism. Relevant areas that the policy focuses on includes:

Promoting tourism sustainability through a European Agenda 21 for tourism and specific supporting actions for sustainability.

Improving the understanding of European tourism through better statistical knowledge

Supporting the promotion of European destinations using the European destination of Excellence awards (EDEN)

The European Commission created the Tourism Sustainability Group (TSG) in 2005 to provide input to the process for the sustainability of European tourism. The TSG formulated its proposals and recommendations in the form of a report in February 2007. Based on this report and previous Communications on its tourism policy, the European Commission adopted its Agenda for a sustainable and competitive European tourism.

Many of the tools used today to promote sustainable tourism include information tools, awareness-raising campaigns, eco-taxes and other economic tools. One of the most important barriers to the development of sustainable tourism includes the lack of awareness and information of tourists and the tourism industry of the harmful environmental impacts of tourism and tourismrelated activities. This challenge is reflected in one of major gaps in current policies to promote sustainable tourism, which is that the demand/consumption side of tourism is not widely addressed in existing tourism policy. Finally, economic and regulatory policy tools available to EU and MS are limited to what can be achieved within the domestic EU tourism sector and what can be achieved at the point of departure.

\subsubsection{Policy options}

Three sector objectives were identified for the tourism sector:

Promote alternative forms of tourism

Encourage more sustainable/environmentally-responsible tourist behaviour while on visits

Link tourism with other important consumption sections 


\section{Sector objective 1: promote alternative forms of tourism}

Existing EU programmes can be used to go hand in hand with the objective of promoting alternative forms of tourism ${ }^{115}$. To promote alternative forms of tourism, three specific actions were identified and are discussed below:

Targeted information campaigns combining the principles of well-being, eco-friendly activities and cultural heritage: Trends indicate that tourists are becoming more interested in such activities; therefore, the EU could take advantage of this trend by making these tourism options even more visible to tourist ${ }^{116}$ through outlets which have a strong influence on travel choice ${ }^{117}$. A recent Eurobarometer study also indicates that Europeans generally prefer non-institutional sources of information about vacation possibilities: word-of-mouth information, social networks, and personal experience when choosing a destination. ${ }^{118}$ The information campaign would need to be exciting, easy to understand, and attractive, while communicating an overall positive message with opportunities, rather than restriction ${ }^{119}$.

Targeted information campaigns could also build upon the existing EDEN initiative by making it more visible through additional information campaigns and ensuring that annual themes ${ }^{120}$ (which) help to promote sustainable consumption.

Dedicated website that allows consumers to calculate and compare the environmental impacts of their choice of tourist destination: This could be similar to the European topten website (www.topten.eu), which guides consumers to the most energy efficient appliances and cars in Europe, allowing consumers to compare the environmental impacts of their choices - choice of transportation, distance travelled to point of destination, type of lodgement, and activities carried out. Tools that allow for comparative evaluation of one's own choices can motivate individuals to improve their behaviour. Lessons from the Top Ten website indicate that maintaining independence is crucial (credibility as a trusted highefficiency benchmark with independence from industry) and that sustaining funding is a

\footnotetext{
${ }^{115}$ Alternative forms of tourism can have less environmental impacts than more traditional tourist activities, including cultural heritage and nature-based tourism, which emphasizes activities such as environmentally friendly sporting activities (such as canoeing, hiking, and biking), local gastronomy (sustainable food), education programmes on nature sites, local arts and crafts tours; these can benefit environmental protection and personal well being.

116 EEA, (2010), The European Environment, State and Outlook: Consumption and the Environment, www.eea.europa.eu/soer/europe/consumption-and-environment

${ }^{117}$ For example, TV, cinemas, businesses, local authorities, commercial guidebooks and websites. TSG, 2007, Action for More Sustainable European Tourism: Report of the Tourism Sustainability Group, ec.europa.eu/enterprise/newsroom/cf/ getdocument.cfm?doc id=237

118 Eurobarometer, 2009, Survey on the attitudes of Europeans towards tourism, ec.europa.eu/public opinion/flash/fl 258 en.pdf

119 TSG, 2007, Action for More Sustainable European Tourism: Report of the Tourism Sustainability Group, ec.europa.eu/enterprise/newsroom/cf/ getdocument.cfm?doc id $=237$

${ }^{120}$ These are selected by the EC, in close cooperation with national tourism bodies. Past themes have included "best emerging rural destinations" (2007), "tourism and local intangible heritage" (2008), "tourism and protected areas" (2009), "aquatic tourism" (2010, and "regeneration of physical sites" (2011).
} 
challenge. ${ }^{121}$ Other possible challenges of this specific action include developing a reliable and harmonised methodology to select and compare the different tourist destinations and activities.

\section{Support voluntary agreements with tour operators and travel agencies to offer more} sustainable consumption possibilities in tourism: Voluntary agreements with industry could be a good way to get the tourism industry involved without having to go through the high administrative costs and burden associated with mandatory standards and restrictions. At the EU level, the existing VISIT initiative could be an ideal place to continue and support existing actions. In recent years, the VISIT initiative has lost momentum due to a shortage of funding and a lack of marketing and communication with the general public. Availability of funding is limited, but could be accessed through other EU programmes ${ }^{122}$.

The above actions do not have to be implemented in isolation. On the contrary, they are likely to be most effective used together. Targeted information campaign and website could spark and generate widespread interest and demand, while voluntary agreements could be expanded between the EU, MS and tourism industry in order to assist industry in meeting this demand for more sustainable tourism.

\section{Sector objective 2: Encourage more sustainable/environmentally-responsible tourist behaviour while on visits}

For real progress to be made towards more sustainable tourism, tourists must themselves reflect sustainability concerns in their travel behaviour and not just in their choice, which is addressed in the above specific action. Specific actions to promote more sustainable tourist behaviour include:

Creation of an EU wide tourist code of conduct or pledge to engage in environmentally responsible behaviour, while on holidays: A commitment made by the tourist in the form of a tourist code of conduct or pledge can deepen the consumer's commitment to the behaviour, and increases the chances that they will carry it out as well as committing to more significant behavioural changes. Pledges should be positively worded and well explained, and developed in conjunction with local businesses which are selected for their sustainable aspects and other interests ${ }^{123}$.

The potential advantages of pledges are that they are usually more flexible than legislation and can be amended more quickly to reflect changes. Further, the

\footnotetext{
${ }^{121}$ Funding sources: public government funding, environmental non-profit organizations, utilities, private foundations, and pro bono work (this resource has been significant). EEDAL, 2009, Topten.info: Market Pull for High Efficiency Products, www.topten.eu/uploads/File/Topten.info EEDAL\%2009.pdf
}

\footnotetext{
${ }^{122}$ European Regional Development and Social Funds, EU LIFE programme, Leonardo da Vinci programme for training initiatives, the European Fisheries fund and the 7th EC Framework Programme for Research. Tourism Insights website, May 2008, Peter Lane "The European Union Approach to Sustainable Tourism"

www.insights.org.uk/articleitem.aspx?title=The\%20European\%20Union\%20Approach\%20to\%20Sustainable\%20Tourism

${ }^{123}$ TSG, 2007, Action for More Sustainable European Tourism: Report of the Tourism Sustainability Group, ec.europa.eu/enterprise/newsroom/cf/_getdocument.cfm?doc_id=237
} 
demands on government resources and businesses are likely to be lower ${ }^{124}$. Pledges can be implemented by national tourism authorities, local tourism offices or at the EU level. Examples of existing pledges in sustainable tourism include The Friends of World Heritage "Responsible Travel Pledge"125 and the Cape Town "Responsible Tourism" pledge $\mathrm{e}^{126}$.

Education and training programmes on sustainable tourism: Tourism professionals (e.g. tourist agencies, local tour operators, office of tourism representatives, etc.) have a privileged position between tourists and their choices of lodging, food, activities, tips on responsible behaviour, etc.

In terms of what the EC can do to promote such training initiatives, possible funding can be provided through the Leonardo da Vinci training programme, which funds practical projects in the field of vocational education and training. Initiatives range from those giving individuals work-related training abroad to large-scale cooperation efforts. The tourism industry would also be another source of funding by providing this sort of training programme to their employees. It could be seen as a competitive advantage for tourism industry to have trained professionals on sustainable tourism which is seeing growing interest among consumers. The International Ecotourism Society (TIES) also offers a professional certificate in Sustainable Tourism Management, which is awarded jointly by TIES and the George Washington University (GWU).

Visitor charging mechanisms to promote sustainable consumption: Different charging mechanisms can be used as a mechanism to influence tourists' behaviour, both through providing discounts, waivers, and imposing charges. In many visited nature areas of Europe, tourists often benefit from the enjoyment of free amenities and a seemingly high level of willingness to pay. By implementing compulsory charges or taxes to be paid by tourists, the funds can be used towards conservation and maintenance activities. This charge would send a message to tourists that conservation is an important activity that everyone, including the tourists themselves should contribute to. It is also important to reassure tourists that the funds collected will be used for specific conservation or management purposes. ${ }^{127}$ Nevertheless, the use of fees to "punish" can be counter-productive. An example of this is when small fines were introduced for parents who arrived late to collect their children from a nursery school. Instead of parents arriving more on time, the result was that the parents arrived late more often than before the fines were introduced: by making a payment the parents no longer felt guilty about arriving late, and treated the situation as if they were

\footnotetext{
${ }^{124}$ OECD, 2010, Consumer Policy Toolkit, www.oecd.org/document/1/0,3746, en 2649 34267 44074466 1 1 1 1 1,00.html

${ }^{125}$ www.globalproblems-globalsolutions.org/site/PageNavigator/FWH survey travelPledge

${ }^{126}$ www.capetown.travel/responsibletourism

127 TSG, 2007, Action for More Sustainable European Tourism: Report of the Tourism Sustainability Group, ec.europa.eu/enterprise/newsroom/cf/_getdocument.cfm?doc_id=237
} 


\section{paying for a service ${ }^{128}$.}

Charges could be applied to specific Natura 2000 sites, which are part of the EU wide network of nature protection areas. To further promote sustainable consumption, a waiver of visitor fees could be applied to those who are partaking in sustainable activities. For example, in Ireland at the sites of the Cliffs of Moher (part of the Natura 2000 network), a fee is applied for the use of facilities on site, however this fee is waived for visitors arriving on foot or by bicycle ${ }^{129}$.

One of the disadvantages of the above specific actions is the potential difficulties in identifying ways to measure the impacts of the above options. Tourism overlaps with many other sectors (e.g. mobility, food and drink, housing, etc.) and in order to measure the impacts of proposed actions, it would be necessary to determine how to most effectively identify changes in consumption patterns due to specific actions implemented in the tourism sector.

\section{Sector objective 3 : Link tourism with other important consumption sections}

In addition to being an important aspect of environmental policies, tourism is also a significant economic sector in the Community, which comes with an array of issues: local development, employment, SME companies, etc. Rendering tourism more sustainable thus requires enhanced understanding and visibility of tourism as a wide and multi-sectoral phenomenon. This would need strong cooperation with other organisations, public administrations, destinations, stakeholders, academic world, etc. Changing the behavioural patterns of tourists is crucial; however it is also just as important to ensure that institutions are in place to implement and monitor tourism policies as well as to oversee the harmonisation and cross cutting issues with other consumption sectors (e.g. transport, consumer protection, environmental protection, food and drink, housing). Therefore, a possible action that could achieve this objective would be to create a competent authority at EU level on tourism.

Currently, DG ENTR carries out most actions specifically related to tourism in the EU, however many of the actions focus on improving the growth and visibility of EU tourism around the world. A dedicated competent authority on tourism at EU level would also be able to focus more on consumption matters and be in charge of implementing the specific actions that have already been discussed above. Other actions that a dedicated EU tourism competent body could carryout and oversee include: (1) implementing and operating the Tourism Satellite Account (TSA), which the EU is currently in the process of putting into place ${ }^{130}$ and (2)Network and liaison with national tourism agencies of MS.

The creation of an EU level competent body on tourism would mean high administrative costs; however it would ensure increased harmonisation, better regulation, and efficiency in terms of the

\footnotetext{
${ }^{128}$ New Economics Foundation, 2008, http://neweconomics.org/sites/neweconomics.org/files/Behavioural_Economics_1.pdf

${ }^{129}$ Official Cliffs of Moher website, www. cliffsofmoher.ie/Facilities/Environment.aspx? rowid=6692

${ }^{130}$ The TSA is a statistical accountant framework in the field of tourism and measures the goods and services according to international standards of concepts, classifications and definitions which allow valid comparisons from country to country in a consistent manner.
} 
impacts of specific policy actions in tourism and policies in other sectors that have a direct or indirect impact on the tourism sector. Countries such as India ${ }^{131}$, Kenya ${ }^{132}$, and Israel ${ }^{133}$ all have dedicated ministries that work on tourism.

\footnotetext{
${ }^{131}$ tourism.gov.in

${ }^{132}$ www.tourism.go.ke

${ }^{133}$ www.goisrael.com
} 


\subsubsection{Summary of policy options for Tourism sector}

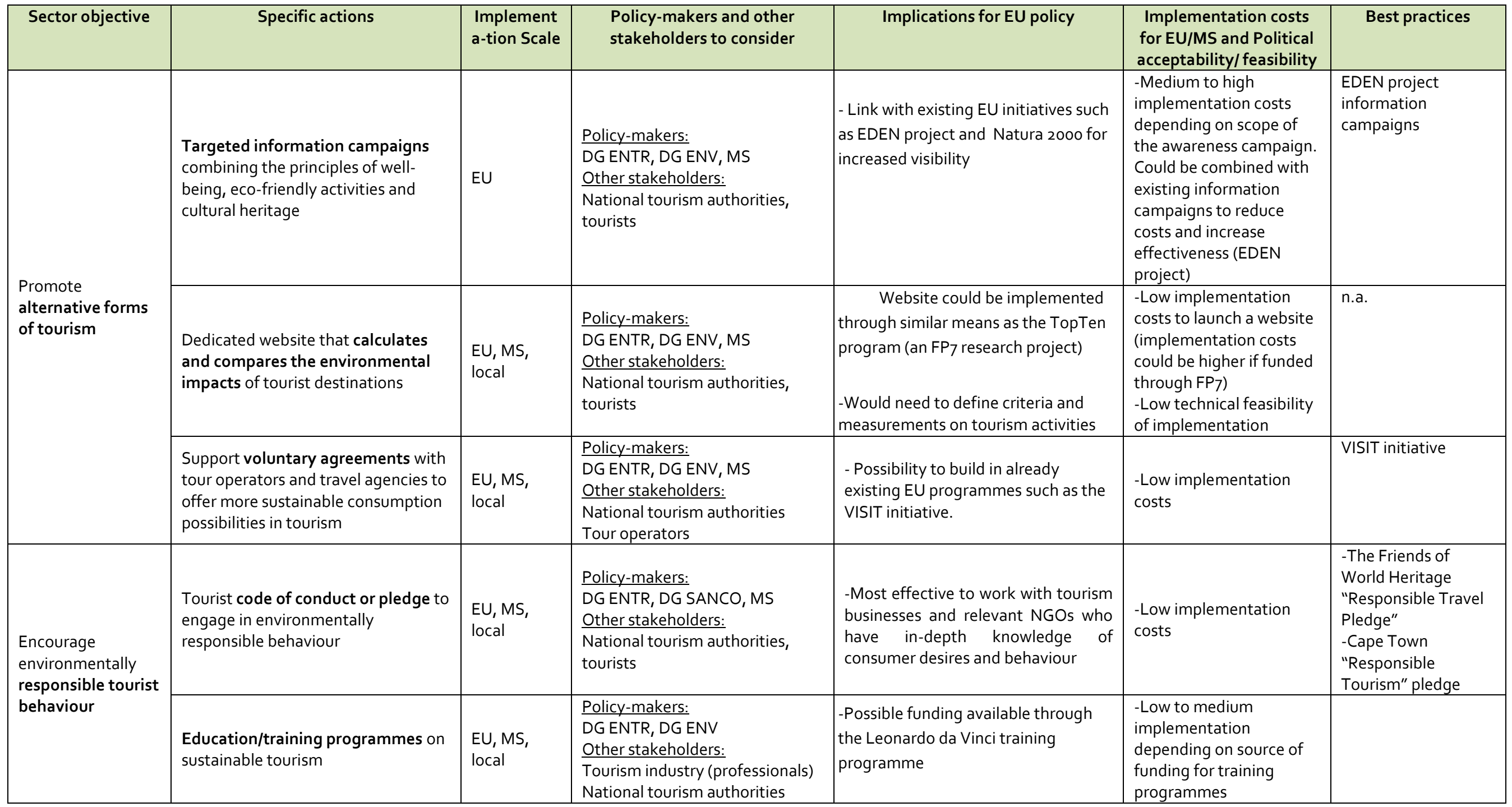


Chapter 5: Assessment of 5 sectors

\begin{tabular}{|c|c|c|c|c|c|c|}
\hline Sector objective & Specific actions & $\begin{array}{l}\text { Implement } \\
\text { a-tion Scale }\end{array}$ & $\begin{array}{l}\text { Policy-makers and other } \\
\text { stakeholders to consider }\end{array}$ & Implications for EU policy & $\begin{array}{l}\text { Implementation costs } \\
\text { for EU/MS and Political } \\
\text { acceptability/ feasibility }\end{array}$ & Best practices \\
\hline & & & & & $\begin{array}{l}\text {-Would only be feasible if } \\
\text { tourism industry willing } \\
\text { to participate in such } \\
\text { action }\end{array}$ & \\
\hline & Visitor charging mechanisms & $\begin{array}{l}\text { EU, MS, } \\
\text { local }\end{array}$ & $\begin{array}{l}\text { Policy-makers: } \\
\text { DG ENV, MS } \\
\text { Other stakeholders: } \\
\text { National tourism authorities, } \\
\text { tourists }\end{array}$ & $\begin{array}{l}\text { - Use of Natura } 2000 \text { network to } \\
\text { identify possible sites for charging }\end{array}$ & $\begin{array}{l}\text {-Low implementation } \\
\text { costs } \\
\text {-Some difficulty in } \\
\text { feasibility of } \\
\text { implementation - would } \\
\text { need to define the } \\
\text { amount to be charged } \\
\text { specific to the site and } \\
\text { MS }\end{array}$ & Cliffs of Moher (IE) \\
\hline $\begin{array}{l}\text { Link tourism with } \\
\text { other } \\
\text { consumption } \\
\text { sectors }\end{array}$ & $\begin{array}{l}\text { Creation of competent authority on } \\
\text { tourism }\end{array}$ & EU & $\begin{array}{l}\text { Policy-makers: } \\
\text { DG ENTR, DG ENV, MS } \\
\text { Other stakeholders: } \\
\text { National tourism authorities }\end{array}$ & $\begin{array}{l}\text {-Creation of a new competent body at } \\
\text { EU level would require significant } \\
\text { cooperation amongst existing } \\
\text { institutions }\end{array}$ & $\begin{array}{l}\text {-High administrative } \\
\text { costs and politically } \\
\text { difficult to implement }\end{array}$ & \\
\hline
\end{tabular}




\subsubsection{Policy context}

To date, EU and national activity on sustainable consumption has tended to focus on information provision as a means of raising awareness and a first step to achieving behavioural change. However, a number of studies have shown that information provision alone or as a major element of activities is not always enough to bring about behavioural change. The predominate finding emerging from the social science literature is that larger-scale behavioural changes require the active participation of citizens where communities have ownership and responsibility over how to respond to the challenges they face ${ }^{134}$. Clear, positive, inspiring visions of what sustainable lives can be are called for as a part of a broader public engagement process, which addresses cultural aspects, attitudes, practices, values, and norms. There is growing recognition that material consumption does not equate directly with quality of life and new indicators of well-being that go beyond GDP to encompass wider social, environmental, and community aspects are needed. There is also a need to provide a 'system' that makes sustainable living easier and enables consumers to escape the 'lock-in' of current consumption patterns, e.g. by providing better transport and recycling infrastructure, ensure the availability and affordability of sustainable products, fiscal measures to incentivise the installation of sustainability features in houses etc. There is a need to develop a collaborative relationship between different actors, including government, business and the general public to develop congruent visions, strategies, actions and evaluation processes necessary to effect the changes to achieve sustainable consumption and production.

These issues reflect some of aspects highlighted by participants at the 'Future Vision Workshop' organised in the context of this study on 13 April 2011.

\subsubsection{Policy options}

The following objectives in relation to action on citizen community action have been identified:

Address societal values and norms through public/community engagement processes; and

Develop a 'system' that makes sustainable living easier

The following actions are proposed to fulfil these objectives. The proposed actions will complement each other. The citizen-led initiatives will help stimulate lasting behavioural change among

\footnotetext{
${ }^{134}$ See for example: Hargreaves, T., Haxeltine, A., Longhurst, N., and Seyfang, G., (2011), Sustainability transitions from the bottom-up: Civil society, the multi-level perspective and practice theory, CSERGE Working Paper 2011-01, University of East Anglia, UK; Nye, M. and Hargreaves, T., (2010), Exploring the Social Dynamics of Proenvironmental Behaviour Change: A Comparative Study of Intervention Processes at Home and Work; Journal of Industrial Ecology, Volume 14, Number 1, 2010, Pages 137 - 149; Nye, M. and Burgess, J., (2008), Promoting Durable Change in Household Waste and Energy Use Behaviour, http://www.uea.ac.uk/env/cserge/pub/ext/evaluating_ecoteams.pdf
} 
individuals and in communities. This take-up of this change will be supported by changes in wider systems and infrastructures through the introduction of financial mechanisms, investments in infrastructure etc. that will help to make it easier for individuals to improve their behaviour environmentally, e.g. as eco-products are stocked in supermarkets, local recycling facilities are upgraded to accept a wider range of materials, loans and grants are provided for products such as insulation or micro-generation. Research into new policies and practices relating to bottom-up, community-led action will lead to the introduction of more effective, innovative and mutually supportive policies in the future.

\section{Objective 1: Address societal values and norms through public/community engagement}

Although top-down structures and processes will continue to play an important role in effecting the large-scale change that is needed to address the many environmental and societal challenges being faced, the scale of the change required demands increased effort in bottom-up structures and processes. There are numerous small-scale developments and initiatives underway at the community and local level which seek to promote more sustainable behaviour for example Transition Towns, Eco-teams, food clubs, the campaign for meat-free days etc. These actions help to increase participation among individuals and provide a sense of ownership and responsibility among citizens/communities. Although these initiatives are gaining ground, they currently only cover a small part of the market and there is a need for much broad consumer acceptance of the approaches they promote.

There is a need for political and financial support for bottom-up citizen-led movements in order to inspire deeper behavioural change, stimulate local community feeling and activity, reinvigorate local economies and develop more effective activities achieving sustainable consumption and lifestyles. In terms of EU-level action, support could be provided for such citizen-led initiatives by increasing attention to such activities under EU financial instruments such as LIFE+ and the Cohesion Policy and community-level initiatives could be promoted as a theme under LEADER+.

Another action is to increase awareness and share best practices of citizen/community-led initiatives through information and awareness raising campaigns and endorsement where relevant. The EU could provide information about best practice examples for exemplification, financial support to pilot projects and follow-up support to enable such projects to be sustainable and their innovation ready for broader market application, e.g. support for the wider introduction of incentive and rebate schemes such as the Sustainable Incentive Card ('NU-Spaarpas') ${ }^{135}$.

Increasing local support for activities such as community supported agriculture, use of local materials in construction, local currencies, local energy generation and other means of engaging with local businesses to increase their presence in the local community etc. will revitalise the local economy, leading to increased growth, creation of jobs etc. Such citizen-led initiatives will interact with the numerous 'push' and 'pull' mechanisms that have been introduced at the EU, national and local level (e.g. eco-design, eco-labelling, green public procurement etc.) that seek to encourage the development of more sustainable products, their purchase, use and disposal.

135 PlusPunten - Demonstration project PlusPunten Rotterdam LIFEoo ENV/NL/0oo8og, http://ec.europa.eu/environment/life/project/Projects/index.cfm?fuseaction=search.dspPage\&n_proj_id=1915\&docType= pdf 


\section{Objective 2: Develop a 'system' that makes sustainable living easier}

Ensuring changes in underlying structures/systems to support the shift in behaviour advocated under the above objective is critical. In order to develop a 'system' that makes sustainable living easier, financial incentives to support behaviour change (e.g. loans and grants to incentivise installation of sustainability features in housing) should be provided. In order to develop a 'system' that makes sustainable living easier. Investments in sustainable local infrastructures (e.g. local recycling facilities, public transport networks etc.) are also needed. The provision of these financial incentives and investments in infrastructure could be made at the EU level (through prioritisation under different EU funding instruments, in particular under Cohesion Policy) as well as at the national level through relevant public funding investments and the introduction of relevant fiscal instruments to support a transition to more sustainable living.

Investments in knowledge and understanding in the area of sustainable consumption policies and practices, building on research from social and behavioural sciences should also be promoted for example under the FP7 and FP8 research programmes. Such actions will complement various EUlevel actions, for example action in relation to urban mobility the recently launched Smart Cities \& Communities Initiative which will help in the dissemination of knowledge among local authorities on innovative low carbon technologies, as well as recent action by DG Information Society and Media to build platforms for Collective Awareness and Action ${ }^{136}$.

${ }^{136}$ http://ec.europa.eu/information_society/activities/collectiveawareness/index_en.htm 


\subsubsection{Summary of policy options for citizen community action sector}

\begin{tabular}{|c|c|c|c|c|c|c|}
\hline Sector objective & Specific actions & $\begin{array}{l}\text { Implement- } \\
\text { ation Scale }\end{array}$ & $\begin{array}{l}\text { Policy-makers and other } \\
\text { stakeholders to consider }\end{array}$ & Implications for EU policy & $\begin{array}{l}\text { Implementation } \\
\text { costs for EU/MS } \\
\text { and Political } \\
\text { acceptabilityl } \\
\text { feasibility } \\
\end{array}$ & Best practices \\
\hline \multirow[t]{2}{*}{$\begin{array}{l}\text { Address societal } \\
\text { values and norms } \\
\text { through } \\
\text { public/community } \\
\text { engagement }\end{array}$} & $\begin{array}{l}\text { Political and financial support } \\
\text { for bottom-up citizen-led } \\
\text { movements }\end{array}$ & Local & $\begin{array}{l}\text { Policy-makers: } \\
\text { EC, MS, local/community actors } \\
\text { Other stakeholders: } \\
\text { Individuals, other community/local } \\
\text { organisations }\end{array}$ & $\begin{array}{l}\text {-Interact with the numerous mechanisms at the } \\
\text { EU, national and local level (e.g. eco-design, eco- } \\
\text { labelling, green public procurement etc.) } \\
\text {-Target support under EU financial instruments: } \\
\text { LIFE+, Cohesion Policy, promote community-level } \\
\text { initiatives as a theme under LEADER+ } \\
\text {-Support DG Information Society and Media } \\
\text { initiative to build platforms for Collective } \\
\text { Awareness and Action }{ }^{137}\end{array}$ & $\begin{array}{l}\text {-Medium to high } \\
\text { implementation } \\
\text { costs depending on } \\
\text { funds needed }\end{array}$ & \\
\hline & $\begin{array}{l}\text { Information and awareness } \\
\text { raising campaigns and } \\
\text { endorsement of } \\
\text { citizen/community-led } \\
\text { initiatives }\end{array}$ & Local & $\begin{array}{l}\text { Policy-makers: } \\
\text { EC, MS, local authorities, } \\
\text { local/community actors } \\
\text { Other stakeholders: } \\
\text { Individuals, community/local } \\
\text { organisations }\end{array}$ & $\begin{array}{l}\text {-DG Information Society and Media initiative on } \\
\text { platforms for Collective Awareness and Action } \\
\text {-Prioritisation under different EU funding } \\
\text { instruments }\end{array}$ & $\begin{array}{l}\text {-Medium to high } \\
\text { implementation } \\
\text { costs depending on } \\
\text { scope of the } \\
\text { awareness } \\
\text { campaign. }\end{array}$ & $\begin{array}{l}\text { Transition } \\
\text { towns; Eco } \\
\text { teams; } \\
\text { Collaborative } \\
\text { consumption } \\
138\end{array}$ \\
\hline \multirow[t]{2}{*}{$\begin{array}{l}\text { Develop a 'system' } \\
\text { that makes } \\
\text { sustainable living } \\
\text { easier }\end{array}$} & $\begin{array}{l}\text { Provide financial incentives to } \\
\text { support behaviour change }\end{array}$ & Local & $\begin{array}{l}\text { Policy-makers: } \\
\text { EC, MS } \\
\text { Other stakeholders: } \\
\text { Individuals, local/community } \\
\text { actors }\end{array}$ & $\begin{array}{l}\text {-Build-on existing initiatives for example in the } \\
\text { buildings sector, implementation / further } \\
\text { development of EU waste policy } \\
\text {-Prioritisation under different EU funding } \\
\text { instruments, in particular under Cohesion Policy }\end{array}$ & $\begin{array}{l}\text {-Medium to high } \\
\text { implementation } \\
\text { costs depending on } \\
\text { funds needed }\end{array}$ & \\
\hline & $\begin{array}{l}\text { Investments in sustainable } \\
\text { local infrastructures }\end{array}$ & Local & $\begin{array}{l}\text { Policy-makers: } \\
\text { EC, MS, local authorities }\end{array}$ & $\begin{array}{l}\text {-Build-on existing initiatives } \\
\text {-Encourage further implementation of EU waste } \\
\text { policy, further take-up of actions in relation to }\end{array}$ & $\begin{array}{l}\text {-High } \\
\text { implementation } \\
\text { costs }\end{array}$ & \\
\hline
\end{tabular}

${ }^{137}$ INFSO website on collective awareness platforms: ec.europa.eu/information_society/activities/collectiveawareness/index_en.htm

${ }^{138}$ Collaborative consumption movements relating to the increase in peer-to-peer marketplaces and other initiatives for swapping, sharing, bartering, trading and renting products, services, experiences etc. www.collaborativeconsumption.com/ 
Chapter 5: Assessment of 5 sectors

\begin{tabular}{|c|c|c|c|c|c|c|}
\hline Sector objective & Specific actions & $\begin{array}{l}\text { Implement- } \\
\text { ation Scale }\end{array}$ & $\begin{array}{l}\text { Policy-makers and other } \\
\text { stakeholders to consider }\end{array}$ & Implications for EU policy & $\begin{array}{l}\text { Implementation } \\
\text { costs for EU/MS } \\
\text { and Political } \\
\text { acceptability/ } \\
\text { feasibility }\end{array}$ & Best practices \\
\hline & & & $\begin{array}{l}\text { Other stakeholders: } \\
\text { Local/community actors }\end{array}$ & $\begin{array}{l}\text { urban mobility } \\
\text {-Prioritisation under different EU funding } \\
\text { instruments, in particular under Cohesion Policy }\end{array}$ & $\begin{array}{l}\text {-Possible difficulties } \\
\text { in political } \\
\text { acceptance due to } \\
\text { funds needed for } \\
\text { infrastructure } \\
\text {-Due to } \\
\text { infrastructure } \\
\text { "lock-in", could be } \\
\text { difficult to } \\
\text { implement in } \\
\text { certain cases }\end{array}$ & \\
\hline & $\begin{array}{l}\text { Investment in knowledge and } \\
\text { understanding in the area of } \\
\text { sustainable consumption } \\
\text { policies and practices }\end{array}$ & EU, MS & $\begin{array}{l}\text { Policy-makers } \\
\text { EC, MS } \\
\text { Other stakeholders: } \\
\text { Research institutes, food } \\
\text { producers, retailers etc. }\end{array}$ & $\begin{array}{l}\text { Research priorities under FP7 and FP8 } \\
\text { Smart Cities \& Communities Initiative } \\
\text { DG Information Society and Media initiative on } \\
\text { platforms for Collective Awareness and Action }\end{array}$ & $\begin{array}{l}\text {-Variable } \\
\text { implementation } \\
\text { costs depending on } \\
\text { need for funds }\end{array}$ & \\
\hline
\end{tabular}




\subsection{Comparison of policy options}

This section discusses the cost effectiveness of policy tools and the feasibility of implementing policy options by the $\mathrm{EU}$, which are important aspects to consider when comparing policy tools and determining where EU action may be most effective. A summary table comparing all of the policy options is included at the end of this section.

\subsubsection{Cost-effectiveness of policy tools}

A review of additional literature has revealed some information on the cost effectiveness of certain tools. Economic instruments, such as environmentally-related taxes, are often believed to be the most cost-effective manner to meet environmental objectives ${ }^{139}$. This is because taxes have a direct effect on prices, which could for example drive up the price of a product that is less environmentally friendly, and thus provide an incentive for other businesses to develop more environmentally friendly products. Nonetheless, the political acceptability of economic instruments may be lower compared to information campaigns which are less politically sensitive to implement than taxes. For example, economic instruments can distort competition in certain industries, which could gather discontent in important economic sectors.

Direct regulation - such as minimum performance standards (e.g. energy using products that have to meet certain energy efficiency) and outright bans (for example the ban on incandescent light bulbs) - are widely-used policies. These measures can be quite effective because it limits the consumer's choice of choosing the more environmentally harmful option. Nonetheless, it is important to consider that once regulation is implemented, their environmental effectiveness and/or economic efficiency may be limited due to the rigidness of the regulation. Further, any potential modifications or change in regulations could involve a long political process. Regulation may also be less socially acceptable than other instruments due to the fact that consumer choice is constrained.

Information campaigns are in general more costly to implement than for tools such as implementing an environmental tax or product standard. Awareness campaigns are usually short-term, media oriented actions that focus on a specific issue. Despite, their high initial implementation costs, awareness campaign can be quite effective under certain conditions. Research shows that rather than governments alone launching an information campaign, joint initiatives can be particularly effective. This is because the partners can often more effectively communicate with target audiences, drawing on specific experiences, resources, and knowledge. ${ }^{140}$ For example, collaboration with NGOS could render information campaigns more effective as NGOs usually have in-depth knowledge of local and/or specific communities.

\footnotetext{
${ }^{139}$ OECD, 2011, Greening Household Behaviour: The Role of Public Policy, www.oecd.org/document/23/0,3746, en 264934331 47025303 1 1 1 1,00.htm/

${ }^{140}$ OECD, 2011, Consumer Policy Toolkit
} 

In terms of the potential costs of implementation of the specific actions, this is very difficult to generalise, as they depend on their respective policy design. Table 18 provides an overview of data collected from the case studies, which gives some indication on the cost of implementing certain types of initiatives. The costs of implementation of specific tools in the case studies below vary greatly depending on aspects such as the scale of the initiative, design, length of implementation, etc.; therefore it is very difficult to develop concrete cost estimations based on the case studies. However, based on discussions with policymakers and the case studies, some generalities can be made about the implementation costs of tools. In general, information and awareness raising campaigns are one of the most costly tools to implement compared to regulation or taxes. This is because media supports would be needed, as well as graphic designers, and the cost of dissemination activities. Economic tools that require initial government funding (e.g. grants and subsidies), could also require more implementation costs see case study example of the Canadian EcoENERGY Retrofit program (pg. 166). However, they could also result in benefits to offset initial costs - see case study example of the French Bonus-Malus scheme and Middelgrunden Wind Cooperative (pg. 166).

Table 17 : Implementation costs of initiatives

\begin{tabular}{|c|c|c|c|}
\hline Case study & Specific tool used & Implementation and operating costs & $\begin{array}{c}\text { Length of } \\
\text { implementation }\end{array}$ \\
\hline French Bonus-Malus & Taxes and charges & $\begin{array}{l}€ 214 \text { million in } 2008 \text { and } € 525 \text { million in } 2009 \text { and } \\
2010\end{array}$ & Since 2007 \\
\hline $\begin{array}{l}\text { Canadian } \\
\text { EcoENERGY Retrofit } \\
\text { program }\end{array}$ & $\begin{array}{l}\text { Subsidies/ } \\
\text { incentives }\end{array}$ & \$91 million total & $\begin{array}{l}\text { April 1, } 2007 \text { to } \\
\text { March 31, } 2011\end{array}$ \\
\hline $\begin{array}{l}\text { Danish Brug Mere } \\
\text { Spild Mindre (Use } \\
\text { more, waste less) }\end{array}$ & $\begin{array}{l}\text { Information } \\
\text { campaign }\end{array}$ & $\begin{array}{l}\text { The total campaign cost was } 226,000 \text { EUR (DKK } \\
1,685,000 \text { ) including the pre and post campaign } \\
\text { surveys. The evaluation after the campaign, } \\
\text { which included recommendations for a follow-up } \\
\text { to the campaign cost about EUR 13,400 (DKK } \\
100,000)\end{array}$ & $\begin{array}{l}\text { June - December } \\
2010\end{array}$ \\
\hline $\begin{array}{l}\text { Dutch Green Funds } \\
\text { Scheme }\end{array}$ & $\begin{array}{l}\text { Green payment } \\
\text { /investment } \\
\text { scheme }\end{array}$ & $\begin{array}{l}\text { Data has not been identified on the specific } \\
\text { implementation costs of the scheme, however } \\
\text { there is some information on other costs and } \\
\text { revenues of the scheme. The programme } \\
\text { originally expected to involve no more than } € 400 \\
\text { million in funds, but has grown precisely because } \\
\text { of the significant public demand for additional } \\
\text { funds. }\end{array}$ & Since 1995 , ongoing \\
\hline Eco-challenge & $\begin{array}{l}\text { Comparative } \\
\text { evaluations, } \\
\text { pledges or } \\
\text { commitments }\end{array}$ & $\begin{array}{l}€ 23010 \text { (The project was developed with } \\
\text { relatively little investment) }\end{array}$ & $\begin{array}{l}5 \text { months from } \\
\text { October } 2010 .\end{array}$ \\
\hline $\begin{array}{l}\text { FairTrade Label for } \\
\text { Cotton }\end{array}$ & $\begin{array}{l}\text { Labelling / } \\
\text { education }\end{array}$ & Approximately $€ 2000$ up to $€ 15000$ per year & - \\
\hline $\begin{array}{l}\text { Food Dudes } \\
\text { programme }\end{array}$ & Education & $€ 484$ ooo per year & 2005 - ongoing \\
\hline $\begin{array}{l}\text { London's Congestion } \\
\text { Charge }\end{array}$ & Taxes and charges & $\begin{array}{l}\text { £162 million in implementation costs. Running } \\
\text { costs were estimated to be } £ 130 \text { million per a } \\
\text { year. }\end{array}$ & 2003-ongoing \\
\hline $\begin{array}{l}\text { Love Food, Hate } \\
\text { Waste }\end{array}$ & $\begin{array}{l}\text { Information } \\
\text { campaign }\end{array}$ & $£ 90$ ooo per year ${ }^{141}$ & - \\
\hline
\end{tabular}

${ }^{141}$ As noted in a 2010 study on food waste and based on the WRAP Love Food Hate Waste campaign, the cost for Member State campaigns is estimated at €0.04 per inhabitant or approximately € 20 million for EU 27. 
Chapter 5: Assessment of 5 sectors

\begin{tabular}{|c|c|c|c|}
\hline Case study & Specific tool used & Implementation and operating costs & $\begin{array}{c}\text { Length of } \\
\text { implementation }\end{array}$ \\
\hline $\begin{array}{l}\text { Middelgrunden Wind } \\
\text { Cooperative }\end{array}$ & Public participation & $\begin{array}{l}\text { Investment/implementation costs: } € 48 \text { million } \\
\text { Euro }\end{array}$ & 2000-ongoing \\
\hline $\begin{array}{l}\text { Paris Velib } \\
\text { Programme }\end{array}$ & $\begin{array}{l}\text { Behavioural } \\
\text { (Nudge-type) }\end{array}$ & Start-up costs of about $€ 100$ million & $\begin{array}{l}\text { 2007-2017 (contract } \\
\text { ending) }\end{array}$ \\
\hline $\begin{array}{l}\text { Picture Health } \\
\text { Warnings on } \\
\text { Cigarette Packets }\end{array}$ & $\begin{array}{l}\text { Picture health } \\
\text { warnings on } \\
\text { cigarette packages } \\
\text { - labels }\end{array}$ & $\begin{array}{l}\text { According to a recent Impact Assessment report, } \\
\text { the initial administrative burden of introducing } \\
\text { mandatory pictorial warnings on all cigarette } \\
\text { packs would amount to between } € \mathbf{3 2 . 5} \text { million } \\
\text { and } € 125.4 \text { million in the EU-27 for the whole } \\
\text { cigarette manufacturing industry (DG Sanco, } \\
\text { 2010). }\end{array}$ & 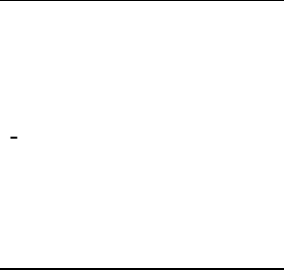 \\
\hline Transition Towns & $\begin{array}{l}\text { Community/ public } \\
\text { participation }\end{array}$ & $\begin{array}{l}\text { No data available on specific costs. Costs depend } \\
\text { on the type and scale of the project being } \\
\text { implemented. }\end{array}$ & 2005-ongoing \\
\hline Vienna City & $\begin{array}{l}\text { Information / } \\
\text { education }\end{array}$ & $€ 3$ Million in 2007 & Late 1990s - ongoing \\
\hline VISIT initiative & $\begin{array}{l}\text { Community/ public } \\
\text { participation }\end{array}$ & No data available on costs. & 2004 \\
\hline
\end{tabular}

\subsubsection{Feasibility of implementing policy options}

The specific options for the five sectors are presented below in Table 18. Information on feasibility of implementing the various policy options are described in the summary tables of policy options for each sector in Chapter 5 , sections 5.4.3, 5.5.3, 5.6.3, 5.7.3, 5.8.3 The following information is included for each of the specific actions:

Benefits: lists the expected benefits of proposed action

Technical feasibility: describes the extent that the action is feasible to implement on a technical level (i.e. is the technology available? Does the required infrastructure exist? Is the technical knowledge available?)

- Administrative / political feasibility: describes the extent that the action is feasible to implement on an administrative level (i.e. does a competent body to oversee the measure already exist? How politically acceptable would the specific action be?)

Level of encouragement in bringing about behaviour change (see section 2.1.1 for further explanation): The encouragement level have been harmonised with the categorisation provided in the inventory table list of tools, Table 10. Ratings for the policy actions are based on this categorisation, from most coercive to less coercive:

Injunction tools (4 rating)

Economic tools (3 rating)

Behavioural tools (2 rating)

Lead-by-example tools and informational tools (1 rating) 
Chapter 5: Assessment of 5 sectors

Consistency with other national and EU legislation 
Table 18 : Comparison table of specific actions

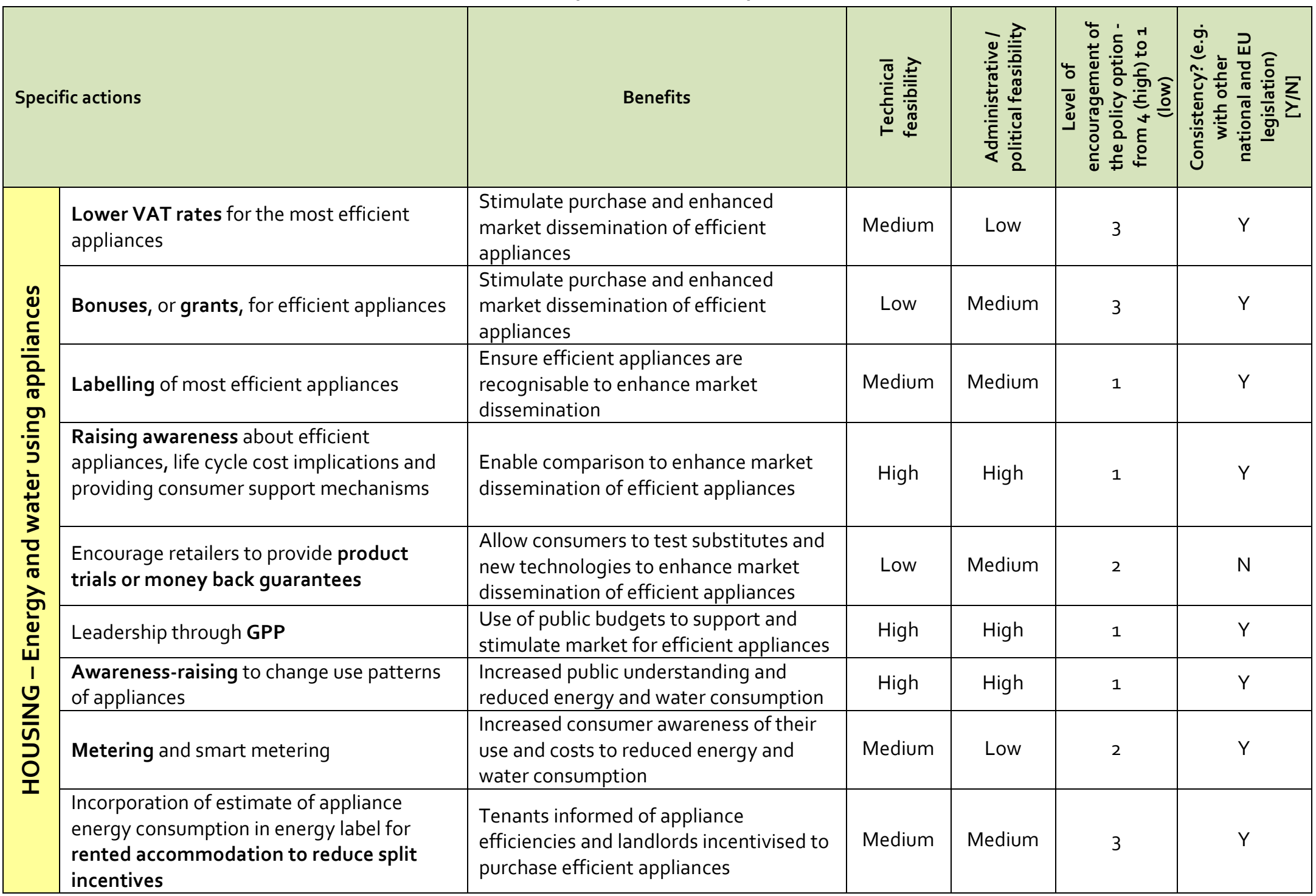


Chapter 5: Assessment of 5 sectors

\begin{tabular}{|c|c|c|c|c|c|}
\hline Specific actions & Benefits & 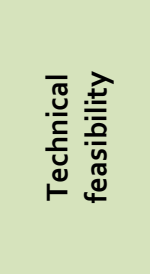 & 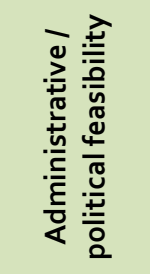 & 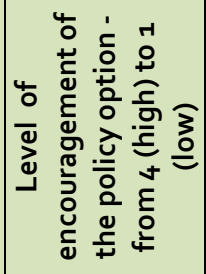 & 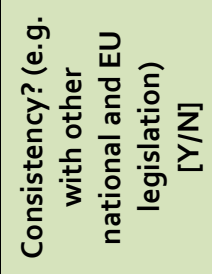 \\
\hline $\begin{array}{l}\text { Set prices to reflect the real cost of the } \\
\text { resource through energy taxes }\end{array}$ & $\begin{array}{l}\text { Price increased according to use to } \\
\text { reduce energy and water consumption. } \\
\text { This will also raise awareness among } \\
\text { consumers by setting a price on the use } \\
\text { of environment-related resources. }\end{array}$ & Medium & Medium & 3 & Y \\
\hline $\begin{array}{l}\text { Promote demand management measures } \\
\text { through guidelines and sharing best } \\
\text { practice }\end{array}$ & $\begin{array}{l}\text { Increased social awareness of use and } \\
\text { mainstream demand management to } \\
\text { reduce energy and water consumption }\end{array}$ & High & High & 1 & Y \\
\hline $\begin{array}{l}\text { Ensure availability of substitutes or new } \\
\text { technologies to support change in } \\
\text { behaviour }\end{array}$ & $\begin{array}{l}\text { Consumers enable to reduce their } \\
\text { energy and water consumption }\end{array}$ & Low & Low & 2 & $\mathrm{~N}$ \\
\hline $\begin{array}{l}\text { Increase sharing, reuse of appliances, and } \\
\text { encourage rental of appliances through } \\
\text { service provision }\end{array}$ & $\begin{array}{l}\text { Stabilised stock levels and reduced } \\
\text { consumption of new resources, } \\
\text { stimulate innovation toward durability } \\
\text { and modularity, reduced consumption of } \\
\text { resources }\end{array}$ & Medium & Low & 2 & $\mathrm{~N}$ \\
\hline $\begin{array}{l}\text { Increase duration of mandatory product } \\
\text { warranties }\end{array}$ & $\begin{array}{l}\text { Longer appliance lifetimes, greater } \\
\text { number of appliances available for reuse, } \\
\text { reduced consumption of new appliances, } \\
\text { reduced consumption of resources }\end{array}$ & Low & Low & 4 & $\mathrm{~N}$ \\
\hline $\begin{array}{l}\text { Improve end of life outcomes (i.e. reuse or } \\
\text { recycling) }\end{array}$ & $\begin{array}{l}\text { Reduced waste to landfill and reduced } \\
\text { resource consumption }\end{array}$ & Medium & Medium & 2 & $\mathrm{Y}$ \\
\hline $\begin{array}{l}\text { Awareness raising to encourage consumers } \\
\text { to engage in cultural, social and educational }\end{array}$ & $\begin{array}{l}\text { Reduced consumption of appliances, } \\
\text { energy and water }\end{array}$ & High & High & 1 & $\mathrm{~N}$ \\
\hline
\end{tabular}


Chapter 5: Assessment of 5 sectors

\begin{tabular}{|c|c|c|c|c|c|c|}
\hline \multicolumn{2}{|c|}{ Specific actions } & \multirow[t]{2}{*}{ Benefits } & \multirow{2}{*}{ 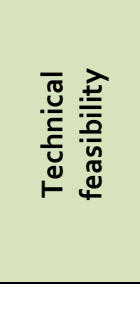 } & \multirow{2}{*}{ 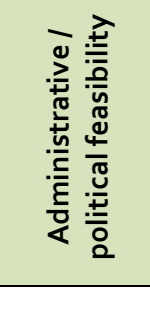 } & \multirow{2}{*}{ 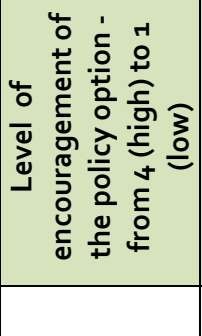 } & \multirow{2}{*}{ 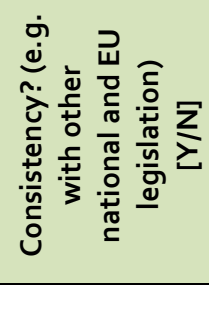 } \\
\hline & activities & & & & & \\
\hline \multirow{10}{*}{$\begin{array}{l}\frac{y}{Z} \\
\bar{\alpha} \\
0 \\
\infty \\
0 \\
0 \\
\text { ○ }\end{array}$} & $\begin{array}{l}\text { Overarching strategy for sustainable food in } \\
\text { Europe }\end{array}$ & $\begin{array}{l}\text { Provide a complete and comprehensive } \\
\text { vision for the whole food sector }\end{array}$ & Medium & Low & 2 & Y \\
\hline & Cross-sectoral research initiatives & $\begin{array}{l}\text { Provide a solid evidence base to support } \\
\text { and inform the specific actions }\end{array}$ & High & High & 3 & Y \\
\hline & $\begin{array}{l}\text { Strengthen institutional structures and } \\
\text { administrative capacities }\end{array}$ & $\begin{array}{l}\text { Support design of more effective policies } \\
\text { and provide a supportive structure for } \\
\text { their implementation }\end{array}$ & Medium & Low & 3 & $\mathrm{Y}$ \\
\hline & $\begin{array}{l}\text { Continue and improve voluntary } \\
\text { agreements, public-private partnerships }\end{array}$ & $\begin{array}{l}\text { Target retailers which are key } \\
\text { intermediaries in reaching consumers } \\
\text { and influencing supply chains }\end{array}$ & Medium & Medium & 3 & Y \\
\hline & $\begin{array}{l}\text { Differentiate consumption taxes based on } \\
\text { the environmental performance of products }\end{array}$ & $\begin{array}{l}\text { If reduced tax rates are passed onto } \\
\text { consumers in the form of reduced prices } \\
\text { this could help to address the price } \\
\text { barrier of sustainable products }\end{array}$ & Medium & Low & 3 & $\mathrm{Y}$ \\
\hline & $\begin{array}{l}\text { EU-level sustainable food labelling scheme } \\
\text { and credible certification mechanisms }\end{array}$ & $\begin{array}{l}\text { Enable consumers to more easily } \\
\text { distinguish between sustainable and } \\
\text { non-sustainable products }\end{array}$ & Medium & Medium & 2 & $\mathrm{Y}$ \\
\hline & $\begin{array}{l}\text { Targeted awareness-raising and } \\
\text { information campaigns and education } \\
\text { programmes }\end{array}$ & $\begin{array}{l}\text { Increase understanding and awareness } \\
\text { of the lifecycle environmental impacts of } \\
\text { different food and drink products }\end{array}$ & High & High & 2 & Y \\
\hline & $\begin{array}{l}\text { Promote green public procurement } \\
\text { practices for catering in public offices and } \\
\text { institutions }\end{array}$ & $\begin{array}{l}\text { Can act as a potential trigger for wider } \\
\text { changes in production patterns and } \\
\text { further behaviour change among the } \\
\text { general public }\end{array}$ & High & High & 1 & Y \\
\hline & Support local/community-led initiatives & $\begin{array}{l}\text { Encourage broader consumer } \\
\text { acceptance of niche practices/activities }\end{array}$ & High & Medium & 3 & $\mathrm{Y}$ \\
\hline & Harmonise date labels with the Food & Help to reduce confusion relating to date & Medium & Medium & 3 & $\mathrm{Y}$ \\
\hline
\end{tabular}


Chapter 5: Assessment of 5 sectors

\begin{tabular}{|c|c|c|c|c|c|c|}
\hline \multicolumn{2}{|c|}{ Specific actions } & Benefits & 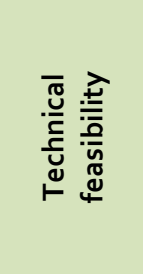 & 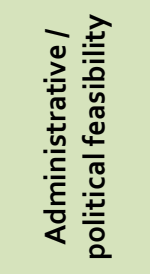 & 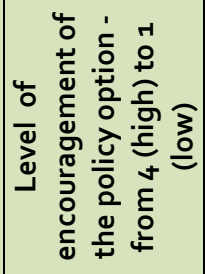 & 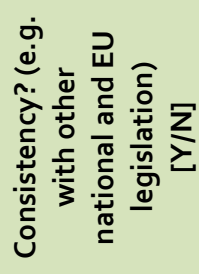 \\
\hline & Information Regulation & labelling & & & & \\
\hline \multirow{10}{*}{ 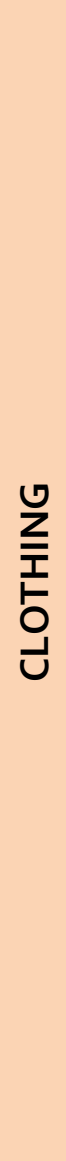 } & Information campaigns & Raise consumer awareness & High & High & 2 & $\mathrm{Y}$ \\
\hline & Sustainable/ environmental labelling & $\begin{array}{l}\text { Raises consumer awareness, informs } \\
\text { consumers }\end{array}$ & Low & Medium & 2 & $\mathrm{Y}$ \\
\hline & Promote sustainable cleaning of clothes & $\begin{array}{l}\text { Reduced energy and water use, } \\
\text { economic benefit for consumers }\end{array}$ & High & Medium & 2 & Y \\
\hline & Promote research and product innovation & $\begin{array}{l}\text { Increases product durability, decreases } \\
\text { use phase impacts (water and energy } \\
\text { use) }\end{array}$ & Medium & Medium & 2 & Y \\
\hline & Promote second hand clothing & $\begin{array}{l}\text { Reduces textile waste sent to landfill, } \\
\text { reduces production impacts through } \\
\text { reduced consumption }\end{array}$ & Low & Medium & 2 & Y \\
\hline & $\begin{array}{l}\text { Promote repair and fashion upgrades, e.g. } \\
\text { by service certification schemes }\end{array}$ & $\begin{array}{l}\text { Reduces textile waste sent to landfill, } \\
\text { reduces production impacts through } \\
\text { reduced consumption }\end{array}$ & Low & Medium & 2 & Y \\
\hline & $\begin{array}{l}\text { Establish standards for fair and responsible } \\
\text { collection and recycling of clothes }\end{array}$ & $\begin{array}{l}\text { Improves waste management practices } \\
\text { and reduces textile waste sent to landfill }\end{array}$ & Medium & Low & 2 & Y \\
\hline & $\begin{array}{l}\text { Promote take-back/ return, reuse, and } \\
\text { recycling of used/ discarded clothing }\end{array}$ & $\begin{array}{l}\text { Allows recycling, reduces textile waste } \\
\text { sent to landfill }\end{array}$ & Medium & Medium & 2 & \\
\hline & $\begin{array}{l}\text { Develop sustainable clothing } 2025 \\
\text { vision/roadmap }\end{array}$ & Creates positive "pull"-dynamics & High & Medium & 2 & Y \\
\hline & Consider sustainable clothing and textiles in & Leading by example, definition of GPP & High & High & 2 & $\mathrm{Y}$ \\
\hline
\end{tabular}


Chapter 5: Assessment of 5 sectors

\begin{tabular}{|c|c|c|c|c|c|c|}
\hline \multicolumn{2}{|c|}{ Specific actions } & \multirow{2}{*}{ Benefits } & \multirow{2}{*}{ 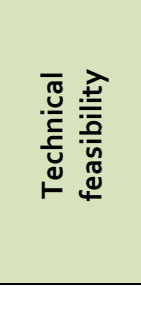 } & \multirow{2}{*}{ 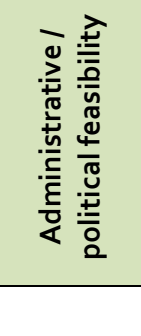 } & \multirow{2}{*}{ 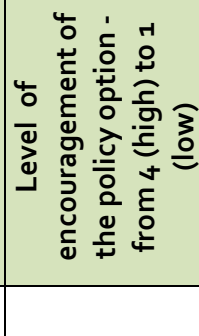 } & \multirow{2}{*}{ 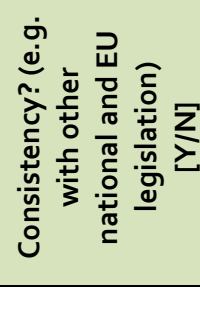 } \\
\hline & green/sustainable public procurement & & & & & \\
\hline \multirow{7}{*}{$\begin{array}{l}\frac{\sum}{n} \\
\frac{n}{2} \\
\frac{0}{n}\end{array}$} & $\begin{array}{l}\text { Targeted information campaigns } \\
\text { combining the principles of well-being, eco- } \\
\text { friendly activities and cultural heritage }\end{array}$ & $\begin{array}{l}\text { Helps to further promote current trends } \\
\text { in tourist activities that have less } \\
\text { environmental impact/ }\end{array}$ & High & High & 2 & $\mathrm{Y}$ \\
\hline & $\begin{array}{l}\text { Dedicated website that calculates and } \\
\text { compares the environmental impacts of } \\
\text { tourist destinations }\end{array}$ & $\begin{array}{l}\text { Allows consumers to compare the } \\
\text { environmental impacts of their choices }\end{array}$ & Low & Medium & 2 & Y \\
\hline & $\begin{array}{l}\text { Support voluntary agreements with tour } \\
\text { operators and travel agencies to offer more } \\
\text { sustainable consumption possibilities in } \\
\text { tourism }\end{array}$ & $\begin{array}{l}\text { A way to get industry involved without } \\
\text { using more forceful measures }\end{array}$ & Medium & Medium & 2 & $\mathrm{Y}$ \\
\hline & $\begin{array}{l}\text { Tourist code of conduct or pledge to } \\
\text { engage in environmentally responsible } \\
\text { behaviour }\end{array}$ & $\begin{array}{l}\text { Can help to deepen the consumer's } \\
\text { commitment to partaking in more } \\
\text { sustainable behaviour }\end{array}$ & Medium & High & 2 & Y \\
\hline & $\begin{array}{l}\text { Education/training programmes on } \\
\text { sustainable tourism }\end{array}$ & $\begin{array}{l}\text { Trained professionals could pass on } \\
\text { important environmental information to } \\
\text { tourists to help influence their behaviour }\end{array}$ & Low & Medium & 1 & $\mathrm{Y}$ \\
\hline & Visitor charging mechanisms & $\begin{array}{l}\text { A monetary charge would raise } \\
\text { awareness. Funds collected could go } \\
\text { towards conservation activities. }\end{array}$ & Medium & Low & 2 & Y \\
\hline & $\begin{array}{l}\text { Creation of competent authority on } \\
\text { tourism }\end{array}$ & $\begin{array}{l}\text { Ensure increased harmonisation, better } \\
\text { regulation, and efficiency in tourism and } \\
\text { other sectors }\end{array}$ & Low & Low & n.a. & - \\
\hline
\end{tabular}


Chapter 5: Assessment of 5 sectors

\begin{tabular}{|c|c|c|c|c|c|c|}
\hline \multicolumn{2}{|c|}{ Specific actions } & Benefits & 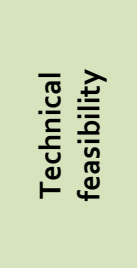 & 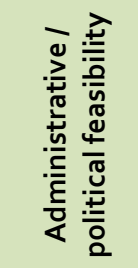 & 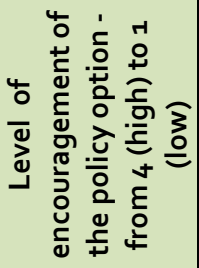 & 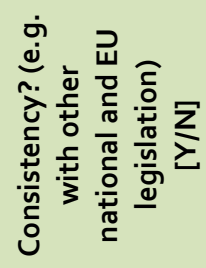 \\
\hline \multirow{5}{*}{ 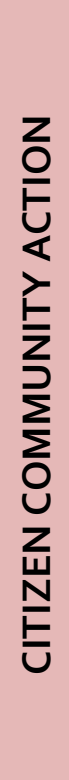 } & $\begin{array}{l}\text { Political and financial support for bottom- } \\
\text { up citizen-led movements }\end{array}$ & $\begin{array}{l}\text { Inspire deeper behavioural change, } \\
\text { stimulate local community feeling and } \\
\text { activity, reinvigorate local economies } \\
\text { and develop more effective activities } \\
\text { achieving sustainable consumption and } \\
\text { lifestyles }\end{array}$ & Medium & Medium & 4 & $\mathrm{Y}$ \\
\hline & $\begin{array}{l}\text { Increase awareness and share best } \\
\text { practices }\end{array}$ & $\begin{array}{l}\text { Encourage broader consumer } \\
\text { acceptance of niche } \\
\text { approaches/practices }\end{array}$ & High & High & 3 & $\mathrm{Y}$ \\
\hline & $\begin{array}{l}\text { Financial incentives to support behaviour } \\
\text { change }\end{array}$ & $\begin{array}{l}\text { Support shift towards more sustainable } \\
\text { behaviour }\end{array}$ & Medium & Low & 4 & $\mathrm{Y}$ \\
\hline & $\begin{array}{l}\text { Investments in sustainable local } \\
\text { infrastructures }\end{array}$ & $\begin{array}{l}\text { Support shift towards more sustainable } \\
\text { behaviour }\end{array}$ & Medium & Low & 4 & $\mathrm{Y}$ \\
\hline & Increase knowledge and understanding & $\begin{array}{l}\text { Improve effectiveness of sustainable } \\
\text { consumption policies and practices }\end{array}$ & High & High & 2 & Y \\
\hline
\end{tabular}




\section{Policy recommendations and}

\section{conclusions}

This final chapter discusses the main findings of the study and provides a short discussion on the future of sustainable consumption.

\subsection{Recommended policy options for the five sectors}

The establishment of a multi-stakeholder roadmap/envisioning exercise for each sector is recommended ${ }^{\mathbf{1 4 2}}$. As a follow-up to these sector roadmaps, pilot projects and public consultation are classically associated with the decision-making process, to gather further relevant information ${ }^{143}$.

Based on the analyses in the preceding chapters, the specific actions that hold the most potential in terms of technical and administrative/political feasibility for implementation and potential to change consumption patterns are discussed in sections 6.1.1 to 6.1.5. Priority actions that could be implemented in the short term are drawn out. However, the actions should be designed and progressively implemented as a package of options to be effective in achieving long-term behavioural change.

For example, in most cases, awareness-raising activities are listed first. This is because they take a shorter time to implement, compared to a fiscal tool or regulation, and because people need to first be aware of an issue to increase the effectiveness of any tool (i.e. to understand the problem and the necessity of action). Policy tools such as financial and injunction tools can then be implemented, further encouraging consumers to change their consumption behaviour. A recent OECD report supports this approach, indicating that information campaigns which raise people's environmental awareness may also increase the political acceptability of policies, facilitating their implementation. ${ }^{144}$ The report goes on to conclude that the impact of pricing measures and other tools that may affect the prices of goods and services can be more significant in the long term, whereas well-designed information-based measures can make a more of a difference in the short term.

\footnotetext{
${ }^{142}$ A roadmap exercise would consist in a consultation and reflection process involving key policy makers and stakeholders. Defining the objectives, important terms and definitions, as well as the challenges of implementing actions towards more sustainable consumption in the respective sector would be key aspects of a roadmap process. Sector "roadmaps" could also consider the durability of products by extending product lifetimes as one of the key objectives of the sector.

${ }^{143} \mathrm{~A}$ public consultation process could take several forms. For example, through an online survey - the Commission conducts several public consultations to gather diverse opinions from different stakeholders before proposing specific policy proposals. Some examples of public consultations carried out at the EU level can be found here: ec.europa.eu/yourvoice/consultations/index_en.htm

144 OECD, 2011, Greening Household Behaviour: The Role of Public Policy, www.oecd.org/document/23/0,3746,en_2649_34331_47025303_1_1_1_1,00.html
} 


\subsubsection{Housing}

Priority actions for this sector are:

- Labelling of most efficient appliances: the EU energy label is already widely recognised in Europe, therefore actions should build upon this tool and extend its impact and scope. Currently, only white goods (dishwashers, refrigerators, washing machines) and TVs are covered. Extension of the scope to provide labelling for widely used household energy-using products, such as consumer electronics and communication devices (e.g. depending on the impact of the use phase compared to production and disposal in their life cycle and the energy saving potential during use, these might include radios, microwaves, coffee machines, vacuum cleaners, mobile phones, computers, digital music players, etc.), would make energy efficient products more visible on the market.

- Awareness raising campaigns: Consumers are more aware about the importance of saving energy than saving water, one reason being that water is often incorrectly assumed to be a natural resource of unlimited supply. Awareness-raising should target the existence of water using appliances, and how to use water more efficiently in preparation for measures such as labelling or environmental taxes on water use.

More detailed policy options recommended are presented in Table 19.

Table 19: Recommended policy options in the Housing sector

\begin{tabular}{|c|c|c|c|}
\hline Recommended action & $\begin{array}{l}\text { Specific } \\
\text { tool used }\end{array}$ & Lessons learned from case studies & Specific implementation guidance \\
\hline $\begin{array}{l}\text { Raising awareness about: } \\
\text { The existence of efficient } \\
\text { appliances } \\
\text { How to use efficient } \\
\text { appliances }\end{array}$ & $\begin{array}{l}\text { Awareness } \\
\text { raising }\end{array}$ & $\begin{array}{l}\text {-Canadian EcoENERGY Retrofit programme: } \\
\text { The visit of a qualified energy advisor allows homeowners personal } \\
\text { contact with a local energy expert. The guidance and } \\
\text { recommendations from the energy expert on how to efficiently use } \\
\text { the retro fit devices was a good way to ensure that the homeowner } \\
\text { completely understood the advice. } \\
\text {-Food dudes programme: define who the main target groups are for } \\
\text { specific products in order to develop tailored awareness campaigns } \\
\text { and programmes. } \\
\text {-Eco-challenge: Integrate smart technologies and social networking, } \\
\text { modernise advertising - into information campaigns. Integrating }\end{array}$ & $\begin{array}{l}\text {-Awareness raising campaigns could be combined to strengthen the } \\
\text { messages being conveyed. } \\
\text {-Avoid sending mixed messages or including too much information. } \\
\text {-Collaborating with other partners such as local NGOs and } \\
\text { associations would help to build up consumer trust and credibility. } \\
\text {-Industry involvement is also essential to strengthen messages and } \\
\text { aid in dissemination. Current policies such as the Ecodesign Directive } \\
\text { have raised the interest and involvement of many key industry } \\
\text { members on energy using products; therefore they may be more } \\
\text { inclined to promote the best products covered under the Ecodesign } \\
\text { Directive. }\end{array}$ \\
\hline
\end{tabular}




\begin{tabular}{|c|c|c|c|}
\hline Recommended action & $\begin{array}{l}\text { Specific } \\
\text { tool used }\end{array}$ & Lessons learned from case studies & Specific implementation guidance \\
\hline & & $\begin{array}{l}\text { competition and the aspect of a challenge to motivate consumers. } \\
\text {-Love food, Hate Waste campaign: Direct one to one engagement } \\
\text { was an effective method of communicating at a local level. }\end{array}$ & \\
\hline $\begin{array}{l}\text { Labelling of most efficient } \\
\text { appliances }\end{array}$ & \multirow[t]{2}{*}{$\begin{array}{l}\text { Information } \\
\text { provision }\end{array}$} & \multirow[t]{2}{*}{$\begin{array}{l}\text {-Fair trade label: Including labels as part of a wider communication } \\
\text { strategy can be very effective. } \\
\text {-Visit initiative: Unification of several similar labels was key in the } \\
\text { initial success of the initiative. }\end{array}$} & $\begin{array}{l}\text {-Build upon the existing EU energy label and the technical } \\
\text { information derived from the Ecodesign preparatory studies }{ }^{145} \text { For } \\
\text { example, the EU energy label could be applied to a wider range of } \\
\text { products and include special notation for products which are the most } \\
\text { efficient in its product category. This would clearly distinguish the } \\
\text { most efficient appliances from other similar products. This would also } \\
\text { give incentive to industry to develop and offer more energy efficient } \\
\text { appliances; Another possibility is to include running costs or savings } \\
\text { due to energy use on the energy label. Including this information in } \\
\text { monetary terms could further incite consumers, especially those who } \\
\text { are particularly concerned by energy prices. } \\
\text {-Voluntary agreements with retail for importing and selling energy } \\
\text { efficient appliances and educating sales staff about the topic of } \\
\text { energy efficiency. }\end{array}$ \\
\hline $\begin{array}{l}\text { Incorporation of estimate of } \\
\text { appliance energy } \\
\text { consumption in energy label } \\
\text { for rented accommodation to } \\
\text { reduce split incentives }\end{array}$ & & & $\begin{array}{l}\text { - Teaming up with local and national rental agencies and landlord } \\
\text { associations (e.g. European Council for Real estate Professions) would } \\
\text { facilitate knowledge needed and implementation of the initiative. } \\
\text { - In addition to including appliance energy consumption, running } \\
\text { costs (or savings) in monetary terms could also be included on the } \\
\text { label to further incite consumers. }\end{array}$ \\
\hline $\begin{array}{l}\text { Promote demand } \\
\text { management measures } \\
\text { through guidelines and } \\
\text { sharing of best practice }\end{array}$ & $\begin{array}{l}\text { Information } \\
\text { provision }\end{array}$ & \multirow[t]{2}{*}{$\begin{array}{l}\text { Vienna City Dematerialisation: The initiative tends to be more } \\
\text { credible when several different levels of stakeholders are involved. }\end{array}$} & $\begin{array}{l}\text {-These two actions are also information-provision actions; however, } \\
\text { target specifically public authorities, Member States, and policy- } \\
\text { makers as opposed to consumers. } \\
\text {-Public authorities have a direct influence on consumption: their own }\end{array}$ \\
\hline Leadership through GPP & $\begin{array}{l}\text { Information } \\
\text { provision/le }\end{array}$ & & $\begin{array}{l}\text { purchases represent } 16 \% \text { of EU GDP146. Therefore, important that } \\
\text { the Commission continues to set clear and ambitious criteria for the }\end{array}$ \\
\hline
\end{tabular}

${ }^{145} \mathrm{http}: / /$ ec.europa.eu/energy/efficiency/studies/ecodesign_en.htm

${ }^{146}$ TNO et BIO, 2011, Report for the JRC, Analysis of the future application of product policy instruments in the EU, Task 3 : Proposed policy mixes for prioritized products, Not yet published 


\begin{tabular}{|c|c|c|c|}
\hline Recommended action & $\begin{array}{l}\text { Specific } \\
\text { tool used }\end{array}$ & Lessons learned from case studies & Specific implementation guidance \\
\hline & $\begin{array}{l}\text { ad by } \\
\text { example }\end{array}$ & & $\begin{array}{l}\text { purchase of products below or above a certain level of energy or } \\
\text { environmental performance. }\end{array}$ \\
\hline $\begin{array}{l}\text { Encourage retailers to } \\
\text { provide product trials or } \\
\text { money back guarantees }\end{array}$ & $\begin{array}{l}\text { Financial } \\
\text { incentive }\end{array}$ & n.a. & $\begin{array}{l}\text {-Policy-makers will need to be able to ensure retailer participation. } \\
\text { The success of a targeted awareness campaign (see first } \\
\text { recommendation above) could encourage retailers to be more willing } \\
\text { to participate in this initiative, as it would build on the momentum } \\
\text { raised by a campaign. Other ways to obtain retailer participation } \\
\text { include providing incentives such as rewarding the best performers } \\
\text { with free advertising of the initiative. The existing Retail Forum could } \\
\text { be a possible way to reach retailers. This initiative could also help to } \\
\text { encourage retailers towards more of a service-led business model. } \\
\text {-Financial incentives: harmonise existing } \\
\text {-Enable and encourage voluntary agreements with retail for } \\
\text { importing and selling energy efficient appliances and educating sales } \\
\text { staff about the topic of energy efficiency. } \\
\text {-Many MS provide incentives to purchase eco-friendly products } \\
\text { however based on different performance levels and criteria, therefore } \\
\text { harmonized incentives at EU level would help eco-friendly products to } \\
\text { reach that critical volume of sales for which their manufacturing } \\
\text { makes good business sense }{ }^{147} \text {. }\end{array}$ \\
\hline $\begin{array}{l}\text { Set prices to reflect costs of } \\
\text { resource use (energy and } \\
\text { water use) through taxes }\end{array}$ & $\begin{array}{l}\text { Fiscal/econ } \\
\text { omic tools }\end{array}$ & $\begin{array}{l}\text { Bonus-Malus: - Importance of the price signal (acting both on supply } \\
\text { nd demand). }\end{array}$ & $\begin{array}{l}\text {-Important to carefully analyse the amount of environmental tax to } \\
\text { implement taking into account specific MS conditions, as well as not } \\
\text { to disfavour lower income households. } \\
\text {-Need to assess potential and consequences of the rebound effect. }\end{array}$ \\
\hline $\begin{array}{l}\text { Increase duration of } \\
\text { mandatory product } \\
\text { warranties }\end{array}$ & $\begin{array}{l}\text { Injunction } \\
\text { tools }\end{array}$ & $\begin{array}{l}\text { Vienna City Dematerialisation: Promote waste prevention and } \\
\text { dematerialisation by adopting approaches that target both high and } \\
\text { low income populations. }\end{array}$ & $\begin{array}{l}\text {-Would need to be carried out in consultation with major stakeholders } \\
\text { (manufacturers), } \\
\text {-This would be a good longer-term action to implement as it would } \\
\text { most likely involve a longer implementation process compared to } \\
\text { above actions. }\end{array}$ \\
\hline
\end{tabular}

${ }^{147}$ http://ec.europa.eu/enterprise/policies/sustainable-business/ecodesign/product-policy/financial-incentives/index_en.htm 


\subsubsection{Food and Drink}

Priority actions for this sector are:

- Promote green public procurement practices for catering in public offices and institutions ${ }^{148}$ : This action would demonstrate the public sector's commitment to sustainable food choices. This action would provide leadership, an awareness-raising tool, and could encourage a 'domino effect' on purchasing habits of private institutions and consumers.

- Awareness raising campaigns: Consumers know a lot about the importance of eating healthy but not necessarily about the importance of consuming food sustainably. Therefore, awareness-raising could focus on 'healthy and sustainable' diets as a 'win-win' for consumers and the environment. However, such recommended diet, both healthy and sustainable is still to define.

More detailed policy options recommended are presented in Table 20.

Table 20: Recommended policy options in the Food and Drink sector

\begin{tabular}{|c|c|c|c|}
\hline Recommended action & $\begin{array}{l}\text { Specific tool } \\
\text { used }\end{array}$ & Lessons learned from case studies & Specific implementation guidance \\
\hline $\begin{array}{l}\text { Develop overarching strategy for } \\
\text { sustainable food in Europe }\end{array}$ & & & $\begin{array}{l}\text { - Further research initiatives to collect quantified data on impacts across food } \\
\text { products (similar to what is being done for energy-using appliances). }\end{array}$ \\
\hline $\begin{array}{l}\text { Launch cross-sectoral research } \\
\text { initiatives }\end{array}$ & n.a & n.a. & $\begin{array}{l}\text { - Cross-cutting actions should be linked with the upcoming reforms of the } \\
\text { CAP and CFP to provide a complete and comprehensive vision of the food } \\
\text { sector. Many policies are related to food production, for example the Nitrates } \\
\text { or animal welfare directives. }\end{array}$ \\
\hline $\begin{array}{l}\text { Strengthen institutional structures } \\
\text { and administrative capacities }\end{array}$ & & & $\begin{array}{l}\text { - Build on/improve on initiatives such as the EU Retail Forum and the Food } \\
\text { SCP Roundtable. } \\
\text { - Support promotion of eco-innovation through ETAP and CIP }\end{array}$ \\
\hline
\end{tabular}

${ }^{148}$ Institutions such as in schools, hospitals, prisons, at the European Commission offices, etc. 
Chapter 6: Recommendations and Conclusions

\begin{tabular}{|c|c|c|c|}
\hline Recommended action & $\begin{array}{c}\text { Specific tool } \\
\text { used }\end{array}$ & Lessons learned from case studies & Specific implementation guidance \\
\hline \multicolumn{4}{|l|}{$\begin{array}{l}\text { Continue and improve voluntary } \\
\text { agreements and public-private } \\
\text { partnerships }\end{array}$} \\
\hline $\begin{array}{l}\text { Launch targeted awareness-raising } \\
\text { and information campaigns and } \\
\text { education programmes }\end{array}$ & $\begin{array}{l}\text { Information } \\
\text { provision / } \\
\text { Education }\end{array}$ & $\begin{array}{l}\text {-Food dudes programme and Eco-challenge: Important } \\
\text { to be able to identify key consumer segments and } \\
\text { markets for tailor made information campaigns and } \\
\text { adapt campaigns by using relevant communication } \\
\text { channels (i.e. social marketing websites for younger } \\
\text { consumers). } \\
\text {-Anti-tobacco picture campaigns: Possibilities of making } \\
\text { the food industry pay for sustainable food ad campaigns } \\
\text { (similar to tobacco companies). The use of graphic } \\
\text { images (e.g. rotting waste, sick animals, etc.) }\end{array}$ & $\begin{array}{l}\text {-Focus on changing long-term consumption patterns among targeted } \\
\text { consumer groups. } \\
\text {-Visible information campaigns come also from NGOs. }\end{array}$ \\
\hline $\begin{array}{l}\text { Develop EU-level sustainable food } \\
\text { labelling scheme and establish } \\
\text { credible certification mechanisms }\end{array}$ & $\begin{array}{l}\text { Information } \\
\text { provision }\end{array}$ & $\begin{array}{l}\text { Fair trade label: See explanations from above tables } \\
\text { VISIT initiative: This initiative was able to gather the } \\
\text { tourism labels of several organisms to create a } \\
\text { harmonised label. It was financially supported by an EU- } \\
\text { funded LIFE project in tourism eco-labelling. }\end{array}$ & $\begin{array}{l}\text { - EU rules on food labelling (Directive } 2000 / 13 / E C \text { ) ensure consumers receive } \\
\text { correct information to enable informed choices about the food they buy- } \\
\text { information requirements could be expanded to include information on the } \\
\text { environmental impacts of products. Funding to promote research into } \\
\text { sustainability impacts of food and drink, to allow more accurate information } \\
\text { on food labels, could come from EU funded LIFE projects (similar to the VISIT } \\
\text { initiative). } \\
\text { - A label alone is not sufficient; Labels could be synergized by tax measures, } \\
\text { such as asking low VAT for sustainable products or communication campaigns }\end{array}$ \\
\hline $\begin{array}{l}\text { Promote green public procurement } \\
\text { practices for catering in public } \\
\text { offices and institutions }\end{array}$ & $\begin{array}{l}\text { Information } \\
\text { provision / } \\
\text { lead by } \\
\text { example }\end{array}$ & n.a. & $\begin{array}{l}\text {-This action could build on the on-going efforts of DG ENV in relation to GPP, } \\
\text { for example, EU level guidelines could be prepared building on the GPP- } \\
\text { toolkit. }\end{array}$ \\
\hline $\begin{array}{l}\text { Support local/community-led } \\
\text { initiatives }\end{array}$ & $\begin{array}{l}\text { Behavioural/ } \\
\text { community }\end{array}$ & $\begin{array}{l}\text { Transition towns: Community led initiatives work } \\
\text { particularly well at the local level. }\end{array}$ & $\begin{array}{l}\text {-The EU could support local/community-led initiatives through funding, } \\
\text { endorsement, and raising awareness of them. Further, the EU can provide } \\
\text { information about best practice examples, financial support to pilot projects } \\
\text { and follow-up support to enable such pilot projects to sustain and make their } \\
\text { innovation durable and ready for broader market application. }\end{array}$ \\
\hline $\begin{array}{l}\text { Differentiate consumption taxes } \\
\text { based on the environmental } \\
\text { performance of products }\end{array}$ & $\begin{array}{l}\text { Financial } \\
\text { tools }\end{array}$ & $\begin{array}{l}\text { Bonus-Malus: - Importance of the price signal (acting } \\
\text { both on supply and demand). }\end{array}$ & $\begin{array}{l}\text {-This action could be implemented under the VAT Directive } 2006 / 112 / E C, \\
\text { which stipulates that a specific list of goods and services for which Member } \\
\text { States may apply a reduced rate of VAT of at least } 5 \% \text {. }\end{array}$ \\
\hline
\end{tabular}

bi'Ol Intillence 


\begin{tabular}{|c|c|c|c|}
\hline Recommended action & $\begin{array}{c}\text { Specific tool } \\
\text { used }\end{array}$ & Lessons learned from case studies & Specific implementation guidance \\
\hline & & & -Need to assess potential and consequences of the rebound effect. \\
\hline
\end{tabular}

\subsubsection{Clothing}

Priority actions for this sector are:

- Awareness raising campaigns: The choice of clothing is one of the most visually obvious ways for people to express their social status, values and individual and/or collective identity. Social concern and social justice have also always been an important for consumers in the clothing sector, therefore a successful awareness campaign would be one that could combine social concerns with the environmental aspects of clothing. One way for policy makers to take action in this sector is to work with major clothes retailers and designers, celebrities, and NGOs to help spread the messages about the importance of sustainable clothing, ways to reduce energy and water consumption during clothes cleaning, and promoting better disposal activities. The participation of celebrities, and targeted campaigns (i.e. at specific types of consumers, regions, lifestyles, etc.), could be effective in making sustainable clothing more fashionable.

- Working with the retail and manufacturing sector: Service-led business models could be promoted, highlighting the reputational and economic advantages. The models could include activities such as promote take-back/ return, reuse, and recycling of used/ discarded clothing. Building on the growing second-hand sector, businesses could offer services such as repair and other maintenance services (e.g. via service certification schemes), novel coatings, remanufacturing, or 'fashion upgrades' ${ }^{149}$.

More detailed policy options recommended are presented in Table 21.

\footnotetext{
${ }^{149}$ Fashion upgrading refers to the upgrade of discarded clothing by some form of remanufacturing: for instance replacing certain panels within a dress, which would allow a sufficient 'fashion upgrade' to give new value to otherwise outdated styles. A similar approach has been used in the Smart Car - with simple replacement of body panels to allow a cheap change of style. See: www.ifm.eng.cam.ac.uk/.../mass/uk_textiles.pdf (wrong link)
} 
Table 21: Recommended policy options in the Clothing sector

\begin{tabular}{|c|c|c|c|}
\hline Recommended action & $\begin{array}{l}\text { Specific tool } \\
\text { used }\end{array}$ & Lessons learned from case studies & Specific implementation guidance \\
\hline Information campaigns & \multirow{3}{*}{$\begin{array}{l}\text { Information } \\
\text { provision }\end{array}$} & \multirow{3}{*}{$\begin{array}{l}\text { Fair trade label: Combining social aspects along with } \\
\text { environmental protection was effective among consumers. } \\
\text { Food dudes programme and Eco-challenge: Important to be } \\
\text { able to identify key consumer segments and markets for tailor } \\
\text { made information campaigns and adapt campaigns by using } \\
\text { relevant communication channels } \\
\text { Visit initiative: Possibilities of combining several existing labels } \\
\text { to create harmonised standards and methodology. }\end{array}$} & \multirow{3}{*}{$\begin{array}{l}\text { These actions, which fall under information provision, can be } \\
\text { addressed in collaboration with the EU Retail Forum. A rise in } \\
\text { consumer awareness can be achieved through more and } \\
\text { consistent labelling through channels such as the European } \\
\text { Ecolabel for clothing and footwear. A vision/roadmap for a } \\
\text { European fair and sustainable clothing market and leading by } \\
\text { example by including sustainable clothing and textiles in EU } \\
\text { Green Public Procurement Policy could also be employed to } \\
\text { create collective awareness. } \\
\text {-The EU Ecolabel, which covers textiles should consider including } \\
\text { criteria related to social justice. The EU Ecolabel competes with a } \\
\text { large number of other labels and research indicates that social } \\
\text { justice is an important focus for consumers in the textile sector. }\end{array}$} \\
\hline $\begin{array}{l}\text { Sustainable/ environmental } \\
\text { labelling }\end{array}$ & & & \\
\hline $\begin{array}{l}\text { Consider sustainable clothing } \\
\text { and textiles in } \\
\text { green/sustainable public } \\
\text { procurement }\end{array}$ & & & \\
\hline $\begin{array}{l}\text { Promoting a service-led } \\
\text { business model within the } \\
\text { retail and manufacturing } \\
\text { sector (i.e. promote take- } \\
\text { back/ return, reuse, and } \\
\text { recycling of used/ discarded } \\
\text { clothing, promote second } \\
\text { hand clothing, promote repair } \\
\text { and fashion upgrades, e.g. by } \\
\text { service certification schemes) }\end{array}$ & n.a. & n.a. & $\begin{array}{l}\text { Working with the EU Retail Forum to encourage retailers to } \\
\text { transition towards a service-led business model by highlighting } \\
\text { the various advantages for retailers: } \\
\text { - Reuse of worn clothing and texts to produce new clothing, } \\
\text { rather than using raw materials } \\
\text { - Creating competitive advantage by appealing to consumers' } \\
\text { social concerns (i.e. by providing a clothing take back scheme to } \\
\text { re-distribute useable second hand clothing to developing } \\
\text { countries and those in need) }\end{array}$ \\
\hline
\end{tabular}




\subsubsection{Tourism}

Priority actions for this sector are:

- Awareness raising campaigns: Evidence shows that tourists are not widely aware of the environmental impacts of their tourism choices. There is potential for actors in existing EU initiatives (such as the EDEN initiative and the Natura 2000 sites) to collaborate on an awareness campaign to lower implementation costs.

- Education/training programmes on sustainable tourism for tourism professionals: As an equivalent to a "product policy", engaging the tourism industry to take more action is a priority in this sector. A possible first step is implementing sustainability training programmes for tourism professionals so they can differentiate their offers by sustainability features and pass on relevant messages and information to consumers about the issues.

More detailed policy options recommended are presented in Table 22.

Table 22: Recommended policy options in the Tourism sector

\begin{tabular}{|l|l|l|l|}
\hline \multicolumn{1}{|c|}{ Recommended action } & $\begin{array}{c}\text { Specific tool } \\
\text { Used }\end{array}$ & \multicolumn{1}{c|}{ Lessons learned from case studies } & \multicolumn{1}{c|}{ Specific implementation guidance } \\
\hline $\begin{array}{l}\text { Targeted information } \\
\text { campaigns combining the } \\
\text { principles of well-being, eco- } \\
\text { friendly activities and cultural } \\
\text { heritage }\end{array}$ & $\begin{array}{l}\text { Information } \\
\text { provision }\end{array}$ & $\begin{array}{l}\text { Fairtrade label: The Fairtrade label succeeded } \\
\text { in combining respecting working conditions } \\
\text { and the environment at the same time, which } \\
\text { is very appealing to consumers. } \\
\text { Food dudes programme: Identify possible } \\
\text { target groups for specific strategies. Eco- } \\
\text { challenge: Modernise to the new channels of } \\
\text { communication. }\end{array}$ & $\begin{array}{l}\text {-The combination of both a targeted information campaign and website } \\
\text { could spark and generate widespread interest and demand. Information } \\
\text { campaigns could also include alternative ways of getting to tourist } \\
\text { destinations, by favouring railways, carpooling, etc. } \\
\text {-Campaigns can aim at improving individuals' well-being and cohesion of the } \\
\text { local community, while at the same time protecting the environment. } \\
\text {-Targeted information campaigns could also build upon the existing EDEN } \\
\text { initiative for greater visibility. }\end{array}$ \\
\hline
\end{tabular}




\begin{tabular}{|c|c|c|c|}
\hline Recommended action & $\begin{array}{l}\text { Specific tool } \\
\text { used }\end{array}$ & Lessons learned from case studies & Specific implementation guidance \\
\hline $\begin{array}{l}\text { Support voluntary } \\
\text { agreements with tour } \\
\text { operators and travel agencies } \\
\text { to offer more sustainable } \\
\text { consumption possibilities in } \\
\text { tourism }\end{array}$ & Behavioural & n.a. & $\begin{array}{l}\text {-At the EU level, the existing VISIT initiative could be an ideal place to } \\
\text { continue and support existing actions. }\end{array}$ \\
\hline $\begin{array}{l}\text { Education/training } \\
\text { programmes on sustainable } \\
\text { tourism for tourism } \\
\text { professionals }\end{array}$ & $\begin{array}{l}\text { Information } \\
\text { provision/behav } \\
\text { ioural }\end{array}$ & n.a. & $\begin{array}{l}\text {-This could be funded through Leonardo Da Vinci training programme or } \\
\text { through voluntary industry initiatives on training programmes. }\end{array}$ \\
\hline $\begin{array}{l}\text { Tourist code of conduct or } \\
\text { pledge to engage in } \\
\text { environmentally responsible } \\
\text { behaviour }\end{array}$ & Behavioural & $\begin{array}{l}\text { Fair trade label: Online pledge was used as } \\
\text { part of the overall communication strategy. }\end{array}$ & $\begin{array}{l}\text {-The pledge could be provided online and could be linked to the information } \\
\text { campaign and/or the website dedicated to comparing the environmental } \\
\text { impacts of different tourist destinations and activities. } \\
\text {-Pledges would probably be most effective if implemented by national } \\
\text { tourism authorities, local tourism offices in collaboration with the EU. }\end{array}$ \\
\hline Visitor charging mechanisms & Financial & $\begin{array}{l}\text { London congestion charge: Public and political } \\
\text { acceptance is crucial (before and after the } \\
\text { scheme). Beware of the possible social costs: } \\
\text { pricing many on low and medium incomes out } \\
\text { of nature sites }\end{array}$ & $\begin{array}{l}\text {-Charges could be applied to specific Natura } 2000 \text { sites, which are part of the } \\
\text { EU wide network of nature protection areas. }\end{array}$ \\
\hline
\end{tabular}




\subsubsection{Citizen community action}

Citizen community action aims at a collaborative approach towards tackling the challenges related to sustainable consumption - by preparing community resilience and adaptability, increasing local value, changing cultural norms, promoting less material consumption and more wellbeing. It ties in with the roadmap process proposed in section 6.1.

Policy options recommended are presented in Table 23.

Table 23: Recommended policy options in citizen community action

\begin{tabular}{|c|c|c|c|}
\hline $\begin{array}{l}\text { Recommended } \\
\text { action }\end{array}$ & $\begin{array}{l}\text { Specific } \\
\text { tool used }\end{array}$ & Lessons learned from case studies & Specific implementation guidance \\
\hline $\begin{array}{l}\text { Political and } \\
\text { financial support } \\
\text { for bottom-up } \\
\text { citizen-led } \\
\text { movements }\end{array}$ & Behavioural & $\begin{array}{l}\text { Anti-tobacco campaigns: - Strong public support is important } \\
\text { and it creates social movements and helps to create "social } \\
\text { norms". Connecting social norms with health and well being } \\
\text { could be effective to gain public support. } \\
\text { London congestion charge, Transition towns, and } \\
\text { Middlegrunden Wind cooperative: Involving the public and } \\
\text { gaining their support in advance of implementation. In some } \\
\text { cases, taking a bottom up approach and delegating roles to } \\
\text { local communities (as opposed to top-down) is quite effective. }\end{array}$ & $\begin{array}{l}\text { Support could be provided for such citizen-led initiatives by increasing attention to } \\
\text { such activities under EU financial instruments such as LIFE+ and the Cohesion } \\
\text { Policy and community-level initiatives could be promoted as a theme under } \\
\text { LEADER+. }\end{array}$ \\
\hline $\begin{array}{l}\text { Increase knowledge } \\
\text { and understanding }\end{array}$ & $\begin{array}{l}\text { Information } \\
\text { provision }\end{array}$ & \multirow[t]{2}{*}{$\begin{array}{l}\text { Fair trade label: combining social aspects along with } \\
\text { environmental protection in campaigns } \\
\text { Transition towns: Raising awareness at the local and } \\
\text { community level which Transition towns does, is a good way } \\
\text { to communicate and share best practices - through word of } \\
\text { mouth from friends, family, and neighbours }\end{array}$} & $\begin{array}{l}\text { This action can build on the FP7 and FP8 research programmes. Such actions will } \\
\text { also complement various EU-level actions, for example action in relation to urban } \\
\text { mobility the recently launched Smart Cities \& Communities Initiative which will } \\
\text { help in the dissemination of knowledge among local authorities on innovative low } \\
\text { carbon technologies, as well as recent action by DG Information Society and Media } \\
\text { to build platforms for Collective Awareness and Action. }\end{array}$ \\
\hline $\begin{array}{l}\text { Increase awareness } \\
\text { and share best } \\
\text { practices }\end{array}$ & $\begin{array}{l}\text { Information } \\
\text { provision }\end{array}$ & & $\begin{array}{l}\text { The EU could provide information to community leaders on best practice examples } \\
\text { from around the EU, as well as provide financial support for pilot projects. }\end{array}$ \\
\hline $\begin{array}{l}\text { Financial incentives } \\
\text { to support } \\
\text { behaviour change }\end{array}$ & Financial & $\begin{array}{l}\text { Eco-energy retrofit programme: Set up a maximum budget as } \\
\text { seen in the Dutch green finds system }\end{array}$ & $\begin{array}{l}\text { This could be in the form of loans and grants that would support the development } \\
\text { of a 'system' that makes sustainable living easier. For example, this could include } \\
\text { providing incentives for the installation of sustainability features such as energy } \\
\text { and water retrofit devices in housing) or improving existing infrastructures e.g. }\end{array}$ \\
\hline
\end{tabular}




\begin{tabular}{|l|l|l|l|}
\hline \multicolumn{1}{|c|}{$\begin{array}{c}\text { Recommended } \\
\text { action }\end{array}$} & $\begin{array}{c}\text { Specific } \\
\text { tool used }\end{array}$ & \multicolumn{1}{|c|}{ Lessons learned from case studies } & \multicolumn{1}{c|}{ Specific implementation guidance } \\
\hline & & & efficient and easy to use used clothing collection and take back schemes \\
\hline $\begin{array}{l}\text { Investments in } \\
\text { sustainable local } \\
\text { infrastructures }\end{array}$ & Financial & $\begin{array}{l}\text { Paris-Velib: Local city initiatives had existed for quite some } \\
\text { time to help promote bike use. Therefore, building on existing } \\
\text { infrastructures can be very effective. }\end{array}$ & $\begin{array}{l}\text { This could be implemented at the EU level (through prioritisation under different } \\
\text { EU funding instruments, in particular under Cohesion Policy) as well as at the } \\
\text { national level through relevant public funding investments. }\end{array}$ \\
\hline
\end{tabular}




\subsection{The sustainable consumption challenge}

Policy tools have evolved in conjunction with sustainability challenges that society has faced. Initially, environmental policy makers were challenged with the elimination of specific threats, often caused by methods of production, where it was clear an action or process was detrimental to the environment (such as the banning of use of certain pesticides or regulation on industrial emissions). With the emergence of more complex environmental and sustainability challenges that involve global public goods and whose future risks are less immediate, such as climate change and depletion of natural resources, policy objectives have moved more towards "reductions" (in resource consumption and emissions), rather than "elimination" (of specific pollutants).

As these complex challenges are linked to broad drivers associated with consumers, such as increases in wealth and consumption trends, it has necessitated engagement of citizens in a conversation on values and action as part of the policy process. It has also heralded the introduction of incentive-based and behavioural tools, seeking to encourage consumers to change their behaviour. However, behavioural and nudge approaches, that increase the probability of a pro-environmental outcome, are not alone sufficient to achieve sustainable consumption; they can be used to target certain segments of populations and to improve the design of policy measures. More challenging debates on aspects such as consumers' "wants" and "needs" can be foreseen.

Above all, sustainable consumption involves the commitment and participation of three principal players - businesses, the government and individuals ${ }^{150}$. Obtaining sustainable consumption is not just about policy, business initiatives, or citizen action - it is about the involvement of all three players and their dynamic alignment with each other.

The findings of this study closely follow the findings of other similar studies (e.g. EUPOPP ${ }^{151}$ ). The tool inventory and categories (i.e. regulatory, economic, informational and behavioural) represent a "classical" consensus on tools to influence consumer behaviour ${ }^{152}$. Tools from each category should be used together to reinforce each other in "bundles". Bundles should be conceived not only as combinations but also as successions of actions. For example, awareness is most efficient when built upon local community initiatives. Awareness forms a basis for understanding and effective use of labels. In turn, awareness and labels can help to prepare stakeholders for regulation.

\footnotetext{
150 Allwood, J. and Cullen, J. (2012) Sustainable Materials: With both eyes open. Available at: http://www.withbotheyesopen.com/read.php

${ }^{151}$ Öko-Institut (and partners) (2011) Policies to Promote Sustainable Consumption Patterns (EUPOPP). See: www.eupopp.net/publications.htm

${ }^{152}$ Kronenberg J. (2007). Ecological Economics and Industrial Ecology. A case study of the Integrated Product Policy of the European Union. London, New York, Routledge.
} 
- When implementing the mix of tools, there may be a significant time-lag for households to adjust. Within the package of policy tools, regulatory tools can be particularly effective ${ }^{153}$, in order to counteract unsustainable consumption behaviour.

- Communication tools such as environmental product labels also lead to development of tools for quantifying impacts, allowing investigation of benchmarks, identifying areas for improvement potential, preparing the ground for mandatory measures and increasing political acceptability of these. However, there is good practice that should be considered: use of a limited number of indicators when communicating environmental information, use of an absolute value to ensure transparency (or a unique mark, colour, or logo), putting the results in context (compared to a familiar order of magnitude), and ensuring that the consumer is able to assess the product within a short timeframe.

- In terms of implementing an effective EU level awareness campaign (which has not always been the case), section 2.1.2 describes guidance for environmental communications. Several aspects should be considered:

$\square$ Carefully consider the content, the messenger, the choice of media and tone. Do not use jargon.

$\square$ Avoid patronising, guilt-laden or disapproving messages - be positive

$\square$ Use the drama of the challenges and the excitement of the solutions to make the message inspiring and motivating

$\square$ Communication must be supported by other measures in policy or infrastructure

$\square$ Due to the abundance of diverse marketing messages in the usual channels, consider alternative channels

$\square$ Targeting a specific audience with a specific message is cheaper and more effective than large advertising campaigns.

- For economic tools, the social costs of environmental policy need to be considered, as they can have regressive effects. Beyond income, a range of socio-demographic factors may impact on household consumption, but these factors can be very heterogeneous depending on the category of households. Knowledge of consumer habits and preferences is limited; however, examples of strategies to address the distributional issues of environmental policy exist.

153 Öko-Institut (and partners) (2011) Policies to Promote Sustainable Consumption Patterns (EUPOPP). See: www.eupopp.net/publications.htm 
- Consumer segmentation can help to adapt the policy approach. A drawback of such segmentation approaches in relation to this EU level project is that they tend to be specific to each society and culture and that they are not static, as values and attitudes can change with time.

- Consider opportunities to use behavioural and nudge approaches, once an understanding of consumer decision-making is achieved, in order to design aspects of a policy tool, such as the default option or display of information, to maximise the probability of a pro-environmental outcome.

- The participation of the public should be systematically considered in sustainable consumption policies, whether public participation in EU and national policy, or encouraging community groups to get involved at the local level. Actively engaging the public through bottom-up involvement in policy decisions is an effective way of encouraging consumers to change behaviour in sustainably and in the long term.

Development of sectoral roadmaps (e.g. UK product roadmaps ${ }^{154}$ ): the establishment of a multi-stakeholder roadmap/envisioning exercise for each sector would help to understand better the values and behaviours across the EU for each sector of consumption.

- In the context of sustainable production and consumption, multiple initiatives (e.g. current and planned initiatives under the SCP Action Plan, the local and national initiatives highlighted in the case studies) are already implemented or in the process of development. Policy coherence is a delicate issue.

- Consideration of durability of products: A recent study ${ }^{155}$ commissioned by the UK's Defra assessed impacts of extending product lifetimes and measures to achieve this, showing that there is a high likelihood that lifetime extensions results in environmental benefits. However, few policy or government initiatives cover lifetime extension, and none has extended product lifetimes as their primary objective ${ }^{156}$.

- Examples of good practice actions at the local and MS level are available, which might be shared through a coordinated mechanism - such as a knowledge exchange platform (similar to the Business and Biodiversity Platform ${ }^{157}$ ) across the EU.

\footnotetext{
${ }^{154}$ See: www.defra.gov.uk/environment/economy/products-consumers/

${ }^{155}$ Environmental Resources Management (2011) Longer Product Lifetimes

${ }^{156}$ Policy initiatives that do discuss product lifetime include EU Directives, such as the Ecodesign Directive and the Waste Framework Directive, referencing relevant aspects such as waste minimisation or extended producer responsibility. The UK's Defra's product roadmap work and WRAP's Love Food Hate Waste campaign discuss lifetime extension issues and aim to extend the lifetime of foodstuffs in the home

${ }^{157}$ www.business-biodiversity.eu/default.asp? Menue $=132 \&$ News $=46$
} 


\subsection{Questions for the future: needs, desire and constraints; production-side reinforcement?}

Consumer decision is classically represented as a balance between complex needs and desire on one side and price on the other, as described in Figure 3. In such a representation the obvious way to influence consumer decision is to change needs and desires, or prices.

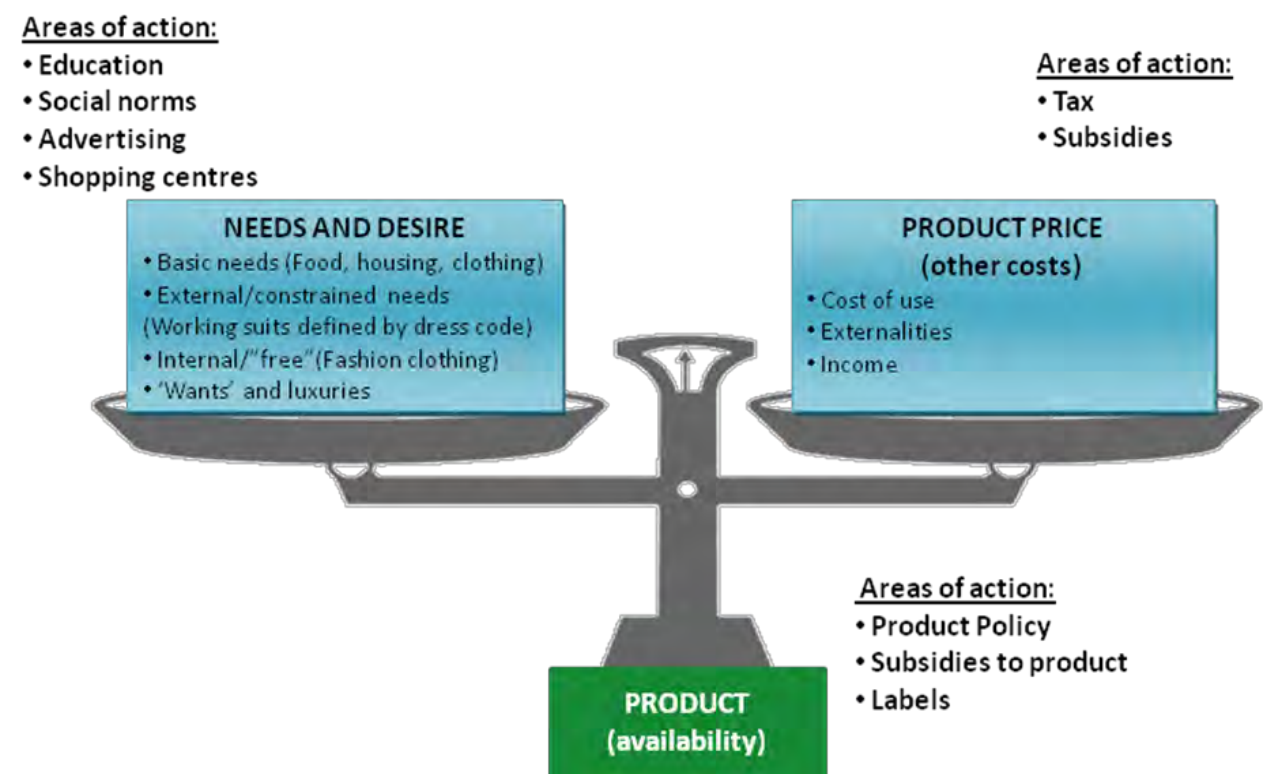

Figure 3: Decision balance in consumption

Behind consumption and consumer decisions is the long-running and well-resourced work of marketers and advertisers. Further, marketing creates said "needs" and "desires". Can policy control this? Is this the role of policy makers to develop a different communication in the same field? Behavioural approaches may lead policy-makers into a position where they are in competition with commercial marketing activities, as both parties vie to change consumption patterns. This is especially difficult from a central EU level as most consumptions approaches require careful consumer segmentation. In addition, incentives for sustainable consumption behaviours are often built on local exchanges and communities, setting limits for central EU action in this area.

Sustainable consumption is often perceived as a reverse route from previous lifestyle progress: a frustrating sacrifice of our present needs and desires, in the name of a better future. It would be thus interesting to locate the areas where consumption does not result from needs or desires, but rather from constraints (see Figure 4). It might help building a different behavioural approach to modify consumption. For example in the sector of transport: commuting from home to office when home work is possible might be perceived as a constraint. Reduction of such consumption should be favourably received by consumers, as a progress not as a sacrifice. Thus, setting up guidelines and incentives favouring or regulating home work might be rewarding. Similarly, in the area of clothing, more sustainable clothing may justify modifications of dress codes or nature 
of working suits. Changes in this area of clothing should be easier to implement than in leisure or fashion clothing where political intervention is not possible.

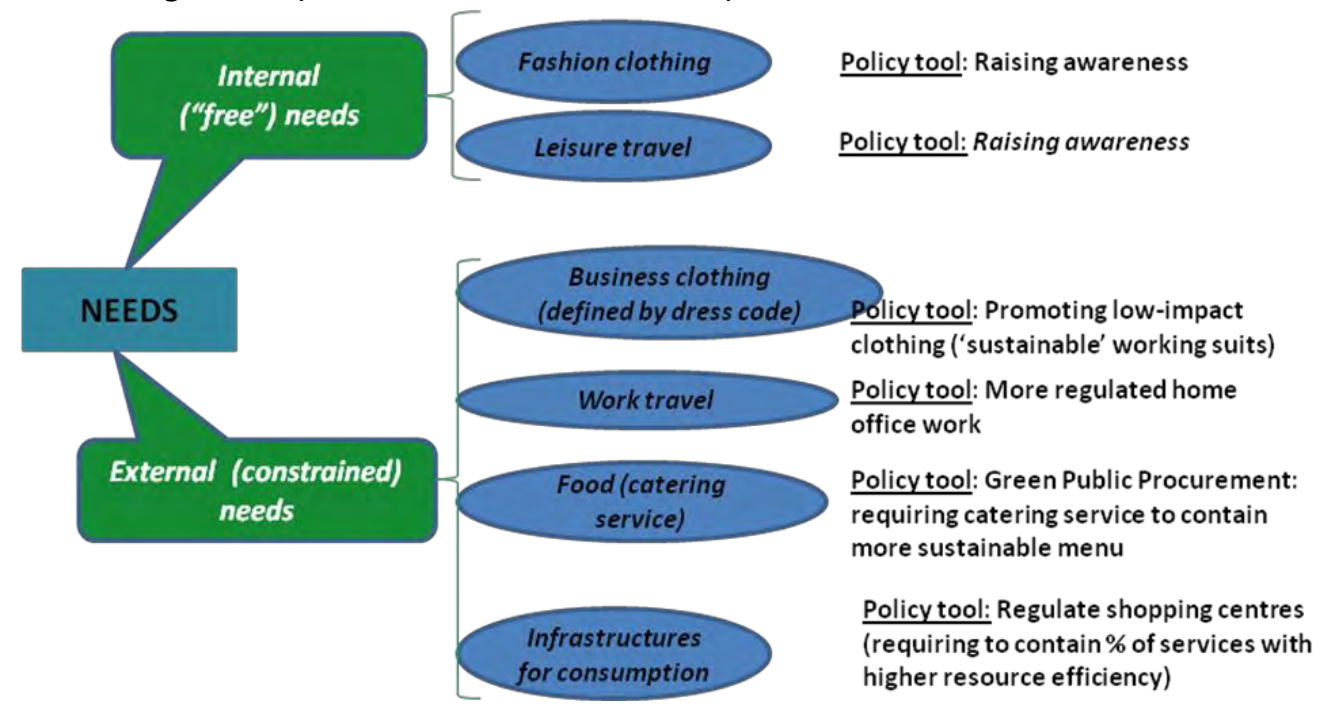

Figure 4: Consumer decision: internal ("free") vs external ("constrained") needs

Analyses of the chains of hierarchies (employer to employee, owner to rental, regulation to citizen, etc.) that drive specific consumption actions might help to identify similar situations, where the consumer does not feel "free" of their consumption decision. This "constrained consumption" should be the easiest target for consumer behavioural change.

To orient marketing power towards sustainable consumption, it is indeed more effective to maintain focus of sustainability policy on products. The "product approach" has been the traditional approach for policy makers to address consumption behaviour in a "win-win" alliance of consumption and production (see Figure 5). It is effective in driving towards more sustainable consumption, although altering consumption choices is not directly addressed. To reinforce product policy, it might be interesting to address other elements of consumption such as communication (regulation of advertising) or infrastructure of consumption (shopping centres). One might speculate about possible policy tools to require shopping centres to provide services or cultural activities with higher resource efficiency. 


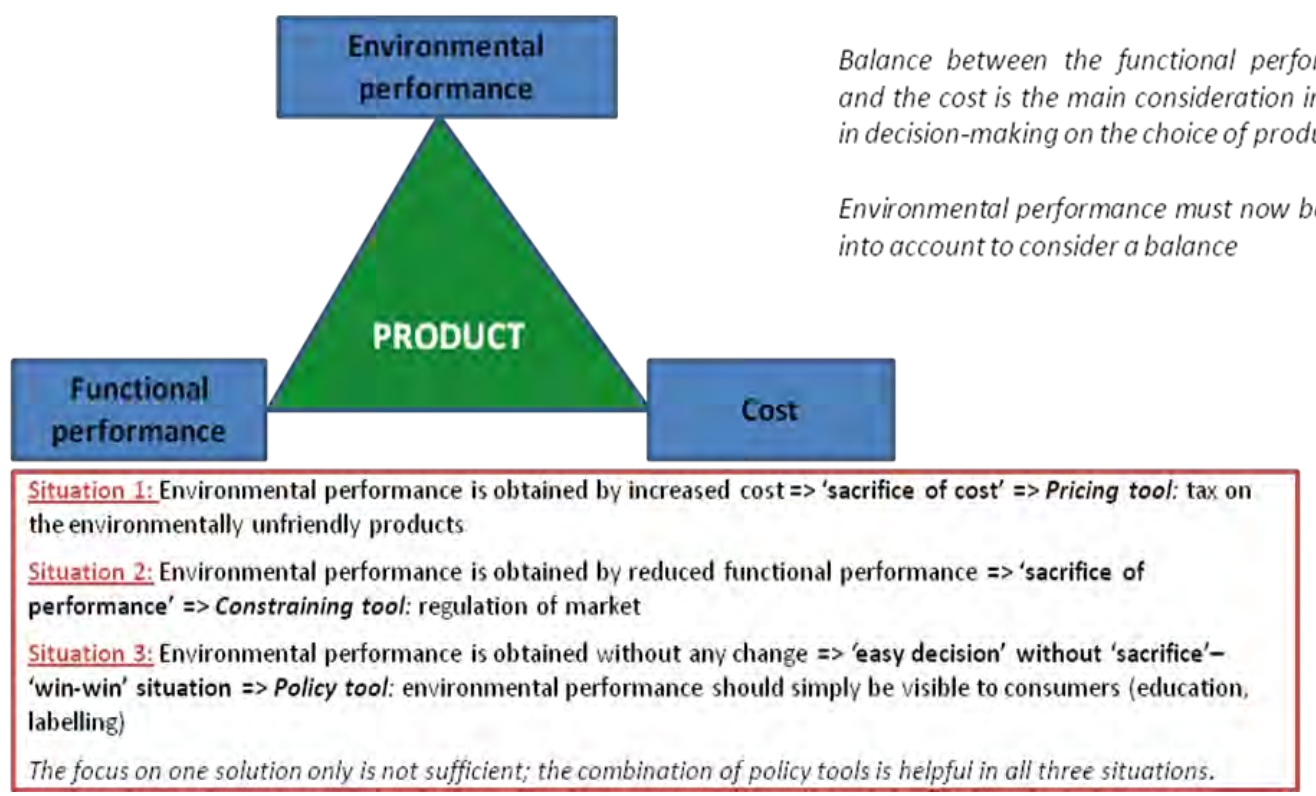

Figure 5: Trade-offs impacting the choice of product and policy tool 
This page is left intentionally blank 


\section{Annexes}

Annex 1: List of identified case studies

Annex 2: Detailed analysis of case studies

Annex 3: Detailed analysis of policy toolboxes

\subsection{Annex 1: List of identified case studies}

\begin{tabular}{|c|c|c|c|c|}
\hline \multicolumn{2}{|r|}{ Case study } & \multirow{2}{*}{$\begin{array}{l}\text { Tool category } \\
\text { Behavioural }\end{array}$} & \multirow{2}{*}{$\begin{array}{c}\text { Specific tool(s) } \\
\begin{array}{l}\text { Comparative evaluations, } \\
\text { pledges or commitments }\end{array}\end{array}$} & \multirow{2}{*}{$\begin{array}{l}\text { Consumption } \\
\text { sector }\end{array}$} \\
\hline 1 & Eco-challenge & & & \\
\hline 2 & $\begin{array}{l}\text { Food Dudes } \\
\text { programme }\end{array}$ & $\begin{array}{l}\text { Information provision \& } \\
\text { awareness raising }\end{array}$ & Education & Food \\
\hline 3 & $\begin{array}{l}\text { London's } \\
\text { Congestion Charge }\end{array}$ & Economic & Taxes and charges & Mobility \\
\hline 4 & $\begin{array}{l}\text { Love Food, Hate } \\
\text { Waste }\end{array}$ & $\begin{array}{l}\text { Information provision \& } \\
\text { awareness raising }\end{array}$ & Information campaign & Food \\
\hline 5 & $\begin{array}{l}\text { Canada's } \\
\text { ecoENERGY } \\
\text { Retrofit program } \\
\end{array}$ & Economic & Subsidies/incentives & Housing \\
\hline 6 & $\begin{array}{l}\text { Dutch Green Funds } \\
\text { Scheme }\end{array}$ & Economic & $\begin{array}{l}\text { Green payment } \\
\text { /investment scheme }\end{array}$ & Products \\
\hline 7 & Transition Towns & Behavioural & $\begin{array}{l}\text { Community/public } \\
\text { participation }\end{array}$ & $\begin{array}{l}\text { Mobility, Food, } \\
\text { Housing }\end{array}$ \\
\hline 8 & $\begin{array}{l}\text { Paris Velib } \\
\text { Programme }\end{array}$ & Behavioural & Nudge-type & Mobility \\
\hline 9 & $\begin{array}{l}\text { Middelgrunden } \\
\text { Wind Cooperative }\end{array}$ & Behavioural/Economic & $\begin{array}{l}\text { Public } \\
\text { participation/investment } \\
\text { scheme }\end{array}$ & Housing, energy \\
\hline 10 & $\begin{array}{l}\text { Picture Health } \\
\text { Warnings on } \\
\text { Cigarette Packets }\end{array}$ & $\begin{array}{l}\text { Behavioural and } \\
\text { Information provision }\end{array}$ & $\begin{array}{l}\text { Picture Health Warnings on } \\
\text { cigarette packages - labels }\end{array}$ & Health \\
\hline 11 & Bonus-Malus & Economic & Taxes and charges & Mobility \\
\hline 12 & $\begin{array}{l}\text { Danish Brug Mere } \\
\text { Spild Mindre }\end{array}$ & $\begin{array}{l}\text { Information provision \& } \\
\text { awareness raising }\end{array}$ & Information campaign & Products \\
\hline 13 & FairTrade & $\begin{array}{l}\text { Information provision \& } \\
\text { awareness raising }\end{array}$ & Labelling / education & Products \\
\hline 14 & VISIT initiative & Behavioural & $\begin{array}{l}\text { Community/public } \\
\text { participation }\end{array}$ & Tourism \\
\hline
\end{tabular}




\begin{tabular}{|c|c|c|c|c|}
\hline \multicolumn{2}{|r|}{ Case study } & \multirow{2}{*}{\begin{tabular}{l}
\multicolumn{1}{c}{ Tool category } \\
Information provision \& \\
awareness raising
\end{tabular}} & \multirow{2}{*}{$\frac{\text { Specific tool(s) }}{\text { Information / education }}$} & \multirow{2}{*}{$\begin{array}{c}\begin{array}{c}\text { Consumption } \\
\text { sector }\end{array} \\
\text { Products }\end{array}$} \\
\hline 15 & Vienna City & & & \\
\hline 16 & Eco-teams & Behavioural & $\begin{array}{l}\text { Community/public } \\
\text { participation \& } \\
\text { comparative evaluations }\end{array}$ & Food, Housing \\
\hline 17 & $\begin{array}{l}\text { Sieben Linden } \\
\text { Ecovillage }\end{array}$ & Behavioural & $\begin{array}{l}\text { Community/public } \\
\text { participation and } \\
\text { commitments }\end{array}$ & $\begin{array}{l}\text { Mobility, Food, } \\
\text { Housing }\end{array}$ \\
\hline 18 & $\begin{array}{l}\text { Nu Spaarpas green } \\
\text { points loyalty } \\
\text { system }\end{array}$ & Economic/Behavioural & $\begin{array}{l}\text { Purchasing system and } \\
\text { commitments }\end{array}$ & Green products \\
\hline 19 & $\begin{array}{l}\text { Green } \\
\text { Microgym/Calories } \\
\text { to Kilowatts (C2K) } \\
\text { program }\end{array}$ & Behavioural & $\begin{array}{l}\text { Community/public } \\
\text { participation }\end{array}$ & Health/energy \\
\hline 20 & $\begin{array}{l}\text { Barclaycard Breathe } \\
\text { Credit Card }\end{array}$ & Economic & Green payment scheme & Green products \\
\hline 21 & $\begin{array}{l}\text { The FEE Education } \\
\text { programme }\end{array}$ & $\begin{array}{l}\text { Information provision \& } \\
\text { awareness raising }\end{array}$ & Education & All \\
\hline 22 & $\begin{array}{l}\text { Marketing and } \\
\text { communicating } \\
\text { sustainable } \\
\text { consumption within } \\
\text { UK retailers }\end{array}$ & $\begin{array}{l}\text { Information provision \& } \\
\text { awareness raising }\end{array}$ & Marketing campaigns & Green products \\
\hline 23 & $\begin{array}{l}\text { Nordic Swan eco- } \\
\text { label }\end{array}$ & $\begin{array}{l}\text { Information provision \& } \\
\text { awareness raising }\end{array}$ & Labels & $\begin{array}{l}\text { Food, green } \\
\text { products }\end{array}$ \\
\hline 24 & The 'Red' label & $\begin{array}{l}\text { Information provision \& } \\
\text { awareness raising }\end{array}$ & Endorsement labels & Health \\
\hline 25 & $\begin{array}{l}\text { Mecu's goGreen }^{\circledR} \\
\text { Auto Loan }\end{array}$ & Economic & Loans & Mobility \\
\hline 26 & Bike to Work Week & Behavioural & $\begin{array}{l}\text { Community/public } \\
\text { participation }\end{array}$ & Mobility \\
\hline 27 & Durham Water & $\begin{array}{l}\text { Information provision \& } \\
\text { awareness raising/ } \\
\text { Behavioural }\end{array}$ & $\begin{array}{l}\text { Information campaign, } \\
\text { commitment, community } \\
\text { involvement }\end{array}$ & Housing \\
\hline 28 & $\begin{array}{l}\text { Evaluating the } \\
\text { impact of Picture } \\
\text { Health Warnings on } \\
\text { Cigarette Packets }\end{array}$ & $\begin{array}{l}\text { Information provision \& } \\
\text { awareness raising }\end{array}$ & $\begin{array}{l}\text { Picture Health Warnings on } \\
\text { cigarette packages - labels }\end{array}$ & Health \\
\hline 29 & $\begin{array}{l}\text { Carbon labelling } \\
\text { (e.g. Tesco) }\end{array}$ & $\begin{array}{l}\text { Information provision \& } \\
\text { awareness raising }\end{array}$ & Product label & $\begin{array}{l}\text { Green products, } \\
\text { Food }\end{array}$ \\
\hline 30 & Green VAT & Economic & Taxes & $\begin{array}{l}\text { Green products } \\
\text { and services }\end{array}$ \\
\hline 31 & Aids campaign(s) & $\begin{array}{l}\text { Information provision \& } \\
\text { awareness raising }\end{array}$ & $\begin{array}{l}\text { Informational targeted at } \\
\text { social norms \& practices }\end{array}$ & Health \\
\hline 33 & Meat-free Mondays & Information provision \& & Information / education / & Food, Health \\
\hline
\end{tabular}




\begin{tabular}{|c|c|c|c|c|}
\hline \multicolumn{2}{|r|}{ Case study } & Tool category & Specific tool(s) & $\begin{array}{l}\text { Consumption } \\
\text { sector }\end{array}$ \\
\hline & & $\begin{array}{l}\text { awareness } \\
\text { raising/Behavioural }\end{array}$ & $\begin{array}{l}\text { community participation } \\
\text { and commitments }\end{array}$ & \\
\hline 34 & $\begin{array}{l}\text { France's } 35 \text {-hour } \\
\text { week }\end{array}$ & Regulatory & Limits on work hours & - \\
\hline 35 & $\begin{array}{l}\text { Banning of outdoor } \\
\text { advertising in cities }\end{array}$ & $\begin{array}{l}\text { Information provision \& } \\
\text { awareness raising }\end{array}$ & Bans & - \\
\hline 36 & Wwoofing & Behavioural & Community participation & Tourism \\
\hline 37 & Craggs Movement & Behavioural & $\begin{array}{l}\text { Community } \\
\text { participation/commitments }\end{array}$ & \\
\hline 38 & $\begin{array}{l}\text { Cut in Spanish } \\
\text { motorway speed } \\
\text { limits slashes fuel } \\
\text { use }\end{array}$ & Regulatory & Limits & Mobility \\
\hline 39 & Eco-cheque & Economic & Purchasing scheme & $\begin{array}{l}\text { Green products } \\
\text { and services }\end{array}$ \\
\hline 40 & Swap-o-matic & Economic & Trading scheme & $\begin{array}{l}\text { Clothing, other } \\
\text { products }\end{array}$ \\
\hline 41 & $\begin{array}{l}\text { Local exchange } \\
\text { trading } \\
\text { schemes/Time } \\
\text { banks }\end{array}$ & Economic & Trading scheme & All \\
\hline
\end{tabular}

\subsection{Annex 2: Detailed assessments of selected case studies}

\begin{tabular}{|l|l|l|}
\hline \multicolumn{2}{|c|}{ Bonus/malus system for Environmentally Friendly Cars } \\
\hline \multirow{2}{*}{} & Location: & France \\
\cline { 2 - 3 } & Duration: & $\begin{array}{l}\text { Entry into force in December } 2007 \text { for the 'Bonus' and January } 2008 \text { for the 'Malus'. } \\
\text { Programme ongoing. }\end{array}$ \\
\cline { 2 - 3 } & Tool category: & Economic tools (combination of credits and taxes) \\
\cline { 2 - 4 } & $\begin{array}{l}\text { Consumption } \\
\text { sector: }\end{array}$ & Mobility/Passenger vehicles \\
\cline { 2 - 4 } & Objectives: & $\begin{array}{l}\text { The objective of the scheme is to reduce } \mathrm{CO}_{2} \text { emissions from passenger vehicles in } \\
\text { France. } \\
\text { The scheme applies to all persons that reside in France, with the exception of state } \\
\text { administrations. Households and industry also fall under the target audience of the } \\
\text { scheme. }\end{array}$ \\
\hline
\end{tabular}




\begin{tabular}{|c|c|}
\hline $\begin{array}{l}\text { Initiator(s) / } \\
\text { organiser(s): }\end{array}$ & $\begin{array}{l}\text { The Bonus/malus was initiated by the French government. It is monitored by ADEME } \\
\text { (French Environment and Energy Management Agency) and implemented DGEC } \\
\text { (Directorate General of Energy and Climate). The ASP (Services and Payments } \\
\text { Agency) is responsible for managing subsidies and funds towards purchasing new } \\
\text { and energy-efficient vehicles. }\end{array}$ \\
\hline $\begin{array}{l}\text { How does the } \\
\text { programme work? : }\end{array}$ & $\begin{array}{l}\text { The principle behind the Bonus/malus programme is to group new vehicles on the } \\
\text { market by category of } \mathrm{CO}_{2} \text { emissions, corresponding roughly to the European } \\
\text { Union's energy label. The French government offers a bonus (credit) for the purchase } \\
\text { of low-emission vehicles: the amount of the credit increases as the vehicle's level of } \\
\text { emissions decreases. Similarly, the government assesses a malus (tax), gradually } \\
\text { incremented as } \mathrm{CO}_{2} \text { emissions increase, on the purchase of high-emission vehicles. } \\
\text { Between these two categories there is a third group of neutral vehicles, those that } \\
\text { entail neither a credit nor a tax. The aim is to calculate the system to ensure that the } \\
\text { credits paid out are offset by the taxes collected: the programme should be revenue- } \\
\text { neutral for the government. Under the original legislation, the initial rate was to be } \\
\text { incremented by } 5 \mathrm{~g} \mathrm{CO}_{2} \text { at the start of both } 2010 \text { and } 2012 \text { (i.e., every two years), in } \\
\text { tandem with advances in technology. }\end{array}$ \\
\hline $\begin{array}{l}\text { Costs } \\
\text { (Implementation } \\
\text { and operation) }\end{array}$ & $\begin{array}{l}\text { The Bonus/malus system was originally designed to be financially self-sufficient. } \\
\text { However, because of an unexpected increase in sales of small cars, the final cost of } \\
\text { the operation turned to be relatively high. According to autoactu.com (2011) the } \\
\text { Bonus/Malus cost } € 214 \text { million in } 2008 \text { and } € 525 \text { million in } 2009 \text { and } 2010 \text {. }\end{array}$ \\
\hline $\begin{array}{l}\text { What is the level of } \\
\text { novelty? : }\end{array}$ & $\begin{array}{l}\text { France's Bonus/malus programme for automobiles was probably one of the first of its } \\
\text { kind. The innovative nature of the scheme derives from the combination of a } \\
\text { credit and a tax and the fact that the programme should be calibrated to ensure } \\
\text { that the tax revenue generated offsets the credits paid out. In other words, the } \\
\text { programme should be revenue-neutral for the government. ADEME continues to } \\
\text { monitor the progress of the scheme and is currently considering the possibility of } \\
\text { extending it to other product families. }\end{array}$ \\
\hline $\begin{array}{l}\text { Impacts/savings/ } \\
\text { behavioural } \\
\text { change: }\end{array}$ & $\begin{array}{l}\text { Despite some rebound effect, lower overall fuel consumption has led to an } \\
\text { environmental gain in terms of } \mathrm{CO}_{2} \text { estimated at } 1.9 \text { million tons of } \mathrm{CO}_{2}\left(\mathrm{Mt}^{\mathrm{C}} \mathrm{CO}_{2}\right) \\
\text { averted in } 2008 \text { and } 3 \mathrm{Mt} \mathrm{CO}_{2} \text { in } 2009 \text {. It is valued at } € 69 \text { million in } 2008 \text { and } € 108 \\
\text { million in } 2009 \text {. } \\
\text { Consistent with its objective, the Bonus/malus scheme has contributed to the } \\
\text { purchase of vehicles with low fuel consumption and low } \mathrm{CO}_{2} \text { emissions: their market } \\
\text { share has risen sharply among the new registrations from } 30 \% \text { in } 2007 \text { to } 45 \% \text { in } 2008 \\
\text { and } 56 \% \text { in } 2009 \text {. Over the same period (2008-2009), sales of cars by French } \\
\text { manufacturers increased by }+5.5 \% \text { over the same period, which may have improved } \\
\text { their net revenues by almost } € 1.2 \text { billion, in a difficult international context. } \\
\text { This measure has therefore had positive economic and environmental effects for a } \\
\text { modest cost to the taxpayer, costing } € 168 \text { million of public money in the first half of } \\
\text { 2008. This deficit should be reduced with future modifications to the malus rates. }\end{array}$ \\
\hline
\end{tabular}




\section{Bonus/malus system for Environmentally Friendly Cars}

\begin{tabular}{|c|c|c|}
\hline \multirow{4}{*}{ 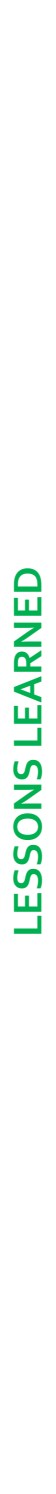 } & $\begin{array}{l}\text { Key factors for } \\
\text { success: }\end{array}$ & $\begin{array}{l}\text { Strengths: The Bonus/malus system delivers a price signal that acts on both the } \\
\text { supply and demand: firstly, it directs the choice of consumers towards more energy- } \\
\text { efficient vehicles, and secondly it encourages manufacturers to produce vehicles that } \\
\text { meet this demand and to innovate in this direction. } \\
\text { Weaknesses/difficulties: There were some difficulties encountered during } \\
\text { implementation, related to adapting the scheme to ensure an overall balance } \\
\text { between bonus and malus paid and collected. Further, there are some instances of } \\
\text { the so-called "rebound" effect: vehicles that emit less and are more efficient are less } \\
\text { expensive to operate per km travelled; therefore users have a tendency to go more } \\
\text { miles. The rebound effect then causes more traffic whose marginal costs (especially } \\
\text { congestion, insecurity, pollution and the greenhouse effect) are only partially } \\
\text { "internalised" in existing taxes. }\end{array}$ \\
\hline & $\begin{array}{l}\text { Questions and gaps } \\
\text { in knowledge }\end{array}$ & $\begin{array}{l}\text {-How should policy makers take into account possible rebound effects? For example, } \\
\text { there is some indication that due to the increased fuel efficiency of certain vehicles, } \\
\text { consumers are also increasing their average car mileage. } \\
\text {-How do policy makers take into account that an increase in sales - even if of fuel- } \\
\text { efficient cars - also implies an increase in environmental damages due to the } \\
\text { production of cars, which are very resource and energy-intensive products to } \\
\text { manufacture? } \\
\text {-To what extent has the price incentive provided by the Bonus/malus effected the } \\
\text { replacement of cars that could have been used for a longer period (thereby } \\
\text { generating more waste)? }\end{array}$ \\
\hline & Contacts & $\begin{array}{l}\text { Gaël Callonnec, ADEME } \\
\text { Email: gael.callonnec@ademe.fr }\end{array}$ \\
\hline & $\begin{array}{l}\text { Data sources / } \\
\text { references }\end{array}$ & $\begin{array}{l}\text {-Autoactu.com, 2011, www.caradisiac.com/Le-bonus-malus-ecologique-proche-de-l- } \\
\text { equilibre-financier-une-mauvaise-nouvelle-pour-les-emissions-de-CO2-68732.htm } \\
\text {-Callonnec, Gaël, Evaluation of the economic and ecological effects of the French } \\
\text { 'bonus malus', Paper presented at ECEEE Conference 2009, } \\
\text { www.eceee.org/conference_proceedings/eceee/2009/Panel_2/2.../Paper/ } \\
\text {-Blanc, Nicolas, 2010, The complementary use of qualitative and quantitative } \\
\text { methods in the assessment of public policies: France's environmental bonus/malus } \\
\text { programme, www.iepec.org/paris2010/BlancPresentation.pdf } \\
\text {-SEEIDD, 2010. Une évaluation du bonus malus automobile écologique, } \\
\text { www.developpement-durable.gouv.fr/IMG/pdf/LPS53.pdf }\end{array}$ \\
\hline
\end{tabular}

\begin{tabular}{|l|l|l|}
\hline \multicolumn{2}{|c|}{ Brug Mere Spild Mindre (Use More Waste Less) } \\
\hline \multirow{3}{*}{$z$} & Location: & Denmark \\
\cline { 2 - 3 } & Duration: & June - December 2010 \\
\cline { 2 - 3 } & Tool category: & Information provision and awareness raising \\
\cline { 2 - 3 } & $\begin{array}{l}\text { Consumption } \\
\text { sector: }\end{array}$ & Household (all waste categories with focus on food waste) \\
\cline { 2 - 3 } & Objectives: & $\begin{array}{l}\text { Each Dane generates about half a tonne of visible waste, but this does not take into } \\
\text { account the hidden resources. It is estimated that over 70 tonnes of resources are } \\
\text { consumed per capita each year. } \\
\text { The "Brug Mere Spild Mindre (Use More Waste Less)" campaign was launched to } \\
\text { improve the prevention of waste in Denmark. }\end{array}$ \\
\hline
\end{tabular}




\begin{tabular}{|c|c|}
\hline $\begin{array}{l}\text { Initiator(s) / } \\
\text { organiser(s): }\end{array}$ & $\begin{array}{l}\text { The Government's Waste Strategy for } 2009-2012 \text { stipulated that a national campaign } \\
\text { for waste prevention directed at households should be launched in } 2010 \text {. According } \\
\text { to the strategy, experience from other countries show that such campaigns can be } \\
\text { effective. The Danish Environmental Protection Agency (EPA) or Miljøstyrelsen took } \\
\text { the initiative to launch the campaign. The communication agency Operate and the } \\
\text { environmental consultancy Copenhagen Resource Institute managed the campaign } \\
\text { and took care of the practical elements. The campaign involved around } 70 \text { network } \\
\text { partners. These included local municipalities, waste management firms and NGOs. }\end{array}$ \\
\hline $\begin{array}{l}\text { How does the } \\
\text { programme work? : }\end{array}$ & $\begin{array}{l}\text { The campaign was launched in June } 2010 \text { with a national event called "Store } \\
\text { Byttedag (Great Exchange/Swap Day)". In Copenhagen, a central area was dedicated } \\
\text { to citizens to bring things they no longer used, to sell or swap with others. } \\
\text { Prior to the campaign, a background study was performed to collect data on current } \\
\text { resource consumption and waste generation. The report provided data on the hidden } \\
\text { flows of resources related to food, clothing, household goods and transport. The data } \\
\text { was based on the established methodology MIPS (Material Input per Service). Data } \\
\text { on water consumption and GHG emissions was also provided. } \\
\text { The main element of the campaign was the website: www.brugmerespildmindre.dk } \\
\text { Here easy tips and good advice are provided clearly for consumers to prevent waste. } \\
\text { The six main recommendations were: } \\
\text { 1. buy quality goods; } \\
\text { 2. use again and again; } \\
\text { 3. pass things on; } \\
\text { 4. buy something that never turns to waste (e.g. environmentally friendly } \\
\text { 5. avperiences); } \\
\text { 6. waste as little as possible. }\end{array}$ \\
\hline
\end{tabular}

Users can also post their own tips for preventing waste or reducing consumption. The website tries to be interactive and kept updated with news (e.g. a special on how to celebrate a "green Christmas"), polls, competitions (e.g. "best left-over recipe"), list of organisations that support the campaign, and links to Facebook and other organisations that also work to prevent waste. Furthermore, the website clearly presents the facts and information developed in the background study.

A special focus was given to food waste, where the five recommendations were:

1. Buy only food that is needed

2. Store food correctly

3. Prepare/cook only the food that will be eaten

4. Keep leftovers and use them later

5. Be aware of the use by date

This part of the campaign was supported by the consumer movement "Stop Spild af Mad (Stop Wasting Food)".

Costs
(Implementation and operation)

The total campaign cost was EUR 226,000 (DKK 1,685,000) including the pre and post campaign surveys. The evaluation after the campaign, which included recommendations for a follow-up to the campaign cost about EUR 13,400 (DKK 100,000)

What is the level of novelty? :

The use of internet media to promote waste prevention among consumers is not new. Similar campaigns have been launched in the UK and Ireland, e.g. www.lovefoodhatewaste.com and www.stopfoodwaste.ie, but these have focused on food and have not tried to combine the web campaign with events and competitions like the Danish campaign. 


\begin{tabular}{|c|c|c|}
\hline & \multicolumn{2}{|r|}{ Brug Mere Spild Mindre (Use More Waste Less) } \\
\hline & $\begin{array}{l}\text { Impacts/savings/ } \\
\text { behavioural } \\
\text { change: }\end{array}$ & 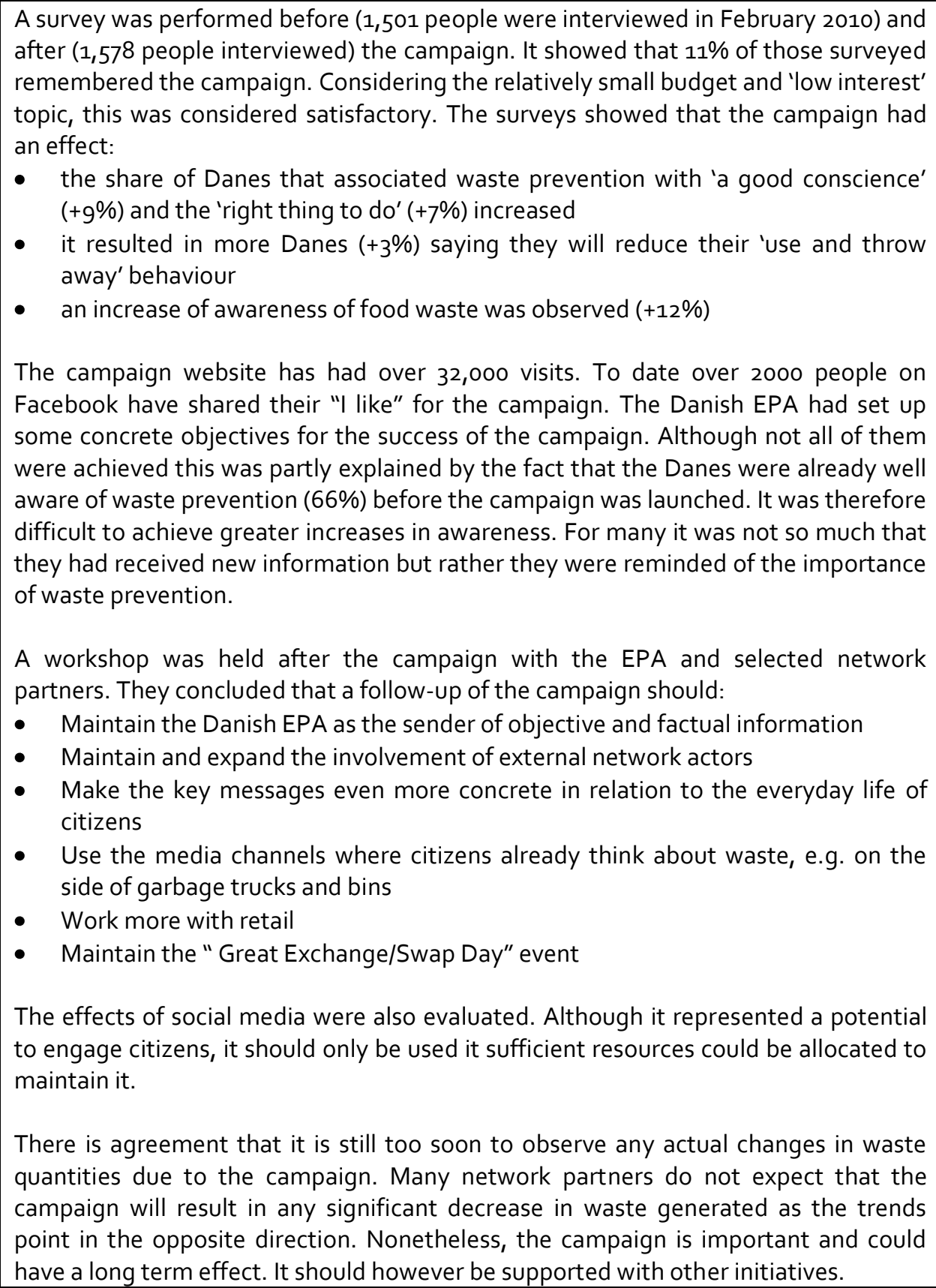 \\
\hline$\frac{0}{\underset{\alpha}{\alpha}}$ & $\begin{array}{l}\text { Key factors for } \\
\text { success: }\end{array}$ & $\begin{array}{l}\text { - Use of a mix of internet (social) media and events to raise awareness. } \\
\text { - Based on a study with factual evidence on hidden resource consumption. } \\
\text { - Involved over } 70 \text { network partners such as local municipalities, waste } \\
\text { management firms and NGOs. }\end{array}$ \\
\hline$\sum_{0}^{u}$ & $\begin{array}{l}\text { Questions and gaps } \\
\text { in knowledge }\end{array}$ & $\begin{array}{l}\text { Gaps in knowledge include the difficulty in measuring the actual impact on waste } \\
\text { reduction of the campaign. Although clear and easy guidelines are provided, it is not } \\
\text { known if consumers actually adopt these (although they say they do or intend to do). }\end{array}$ \\
\hline ษึ & Contacts & $\begin{array}{l}\text { Lone Lykke Nielsen, Miljøstyrelsen } \\
\text { Tel. }+4572544182 \\
\text { Email: In@@mst.dk }\end{array}$ \\
\hline
\end{tabular}




\section{Brug Mere Spild Mindre (Use More Waste Less)}

\begin{tabular}{|c|c|}
\hline $\begin{array}{l}\text { Data sources/ } \\
\text { references }\end{array}$ & $\begin{array}{l}\text { - Campaign website: www.brugmerespildmindre.dk } \\
\text { - Epinion (2011) Effektevaluering af kampagnen 'Brug mere - spild mindre'. Report } \\
\text { for the Danish EPA: } \\
\text { www.mst.dk/Virksomhed_og_myndighed/Affald/Nyheder+affald/Danskerne_sparer } \\
\text { _paa affaldet.htm } \\
\text { - Copenhagen Resource Institute's background report: } \\
\text { www.brugmerespildmindre.dk/sites/brugmerespildmindre.dk/files/CRI } \\
\text { documentation WP Campaign - final.pdf } \\
\text { - Danish Environmental Protection Agency (EPA): } \\
\text { www.mst.dk/Borger/Kampagner/Brug_mere_spild_mindre/ } \\
\text { - Government's Waste Strategy for 2009-2012_Part 2 (Affaldsstrategi '10): } \\
\text { www.mst.dk/NR/rdonlyres/5944D6BF-C455-4A94-A7D1- } \\
\text { go62EDo173Ao/o/Affaldsstrategi10.pdf } \\
\text { - Stop Wasting Food movement: www.stopspildafmad.dk }\end{array}$ \\
\hline
\end{tabular}

\begin{tabular}{|c|c|c|}
\hline & \multicolumn{2}{|r|}{ Canada's ecoENERGY Retrofit Homes programme } \\
\hline \multirow{6}{*}{ 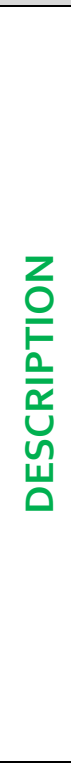 } & Location: & Canada \\
\hline & Duration: & $\begin{array}{l}\text { The programme was launched on April 1, } 2007 \text { as a four-year program and will end on } \\
\text { March 31, } 2011 .\end{array}$ \\
\hline & Tool category: & Economic - Incentives/Grants \\
\hline & $\begin{array}{l}\text { Consumption } \\
\text { sector: }\end{array}$ & Housing (Utilities) \\
\hline & Objectives: & $\begin{array}{l}\text { The ecoENERGY Retrofit Homes programme provides financial assistance to } \\
\text { encourage owners of existing low-rise properties to make smart energy retrofit } \\
\text { decisions that will result in significant energy savings, more comfortable living spaces } \\
\text { and a cleaner environment. Homeowners in most provinces and territories of Canada } \\
\text { are able to participate in the programme. }\end{array}$ \\
\hline & $\begin{array}{l}\text { Initiator(s) / } \\
\text { organiser(s): }\end{array}$ & $\begin{array}{l}\text { Natural Resources Canada's (NRCan's) Office of Energy Efficiency (OEE) administers } \\
\text { the programme and provides the grants, but local service organisations across the } \\
\text { country deliver the program to homeowners. }\end{array}$ \\
\hline
\end{tabular}




\section{Canada's ecoENERGY Retrofit Homes programme}

\section{How does the programme work? :}

\section{Costs}

(Implementation and operation)
To qualify for the ecoENERGY programme, all participants require a pre-retrofit evaluation before starting renovations, a post-retrofit evaluation and a signed grant application form within established deadlines. The certified energy advisor performs an energy evaluation on homes from the basement to the attic, including a blower door test to measure air tightness and to help locate air leakage sites. After the evaluation, a homeowner's report is provided with a list of recommended measures and an EnerGuide rating label. Recommended measures can include actions such as installing an Energy Star qualified air-source heat pump for both heating and cooling and replacing existing space and domestic water heating equipment with an integrated mechanical system compliant with Canadian standards. The energy advisor prepares a detailed personalised checklist of recommended upgrades for the property owner, including the EnerGuide pre-retrofit energy rating of the house. The checklist shows the recommended, most effective upgrades. The property owner chooses which upgrades to have done. After the retrofit work is complete, the advisor performs a post-retrofit energy evaluation and assigns a new energy-rating label. After the required improvements have been made, the property owner is entitled to a grant. The average federal grant for a single property is approximately $\$ 1,300$. The maximum grant available for one home is $\$ 5000$ or $\$ 5000$ per dwelling unit in a multi-unit residential building (MURB).

The Canadian government experienced unprecedented demand under the ecoENERGY Retrofit - Homes program, and allocated a further $\$ 80$ million to support additional retrofits by Canadian homeowners.

The program was expanded in 2009 to support as many as 200000 additional homeowners in making energy efficiency retrofits to their homes. In 2009, the government had paid out $\$ 91$ million to homeowners for more than 85,000 home retrofits.

\section{What is the level of} novelty? :

The goal of the programme is not to issue rebates for single renovation measures, but rather to act as an incentive to encourage homeowners to invest in multiple measures that they may not have otherwise considered. The strategy of requiring both a pre- and post-evaluation ensures that the Government of Canada offers a credible, results-based programme with demonstrated improvements in energy consumption. This strategy not only allows the homeowner to decide for himself what measures to take but encourages homeowners to implement multiple measures. An EnerGuide rating showing the energy efficiency of the home in comparison to other homes in Canada is also provided, which could motivate homeowners to make further energy-efficient improvements.

\section{Impacts/savings/}

behavioural

change:
As a result of home renovations, participants have reduced their energy consumption by over $20 \%$ and reduced greenhouse gas emissions by approximately 3 tonnes per house. By implementing the energy retrofit recommendations, a typical homeowner could save $\$ 700$ a year on a $\$ 2000$ annual heating bill. Since the programme's inception, a reduction of approximately 0.32 megatonnes (Mt) of GHG emissions can be attributed to the ecoENERGY Retrofit - Homes program. To date, approximately 1 in 20 homeowners in Canada have participated in this ecoENERGY programme. It is expected that the ecoENERGY Retrofit - Homes incentives will promote smart energy use in more than 340 ooo homes and will yield an average 23 percent reduction in energy use. 


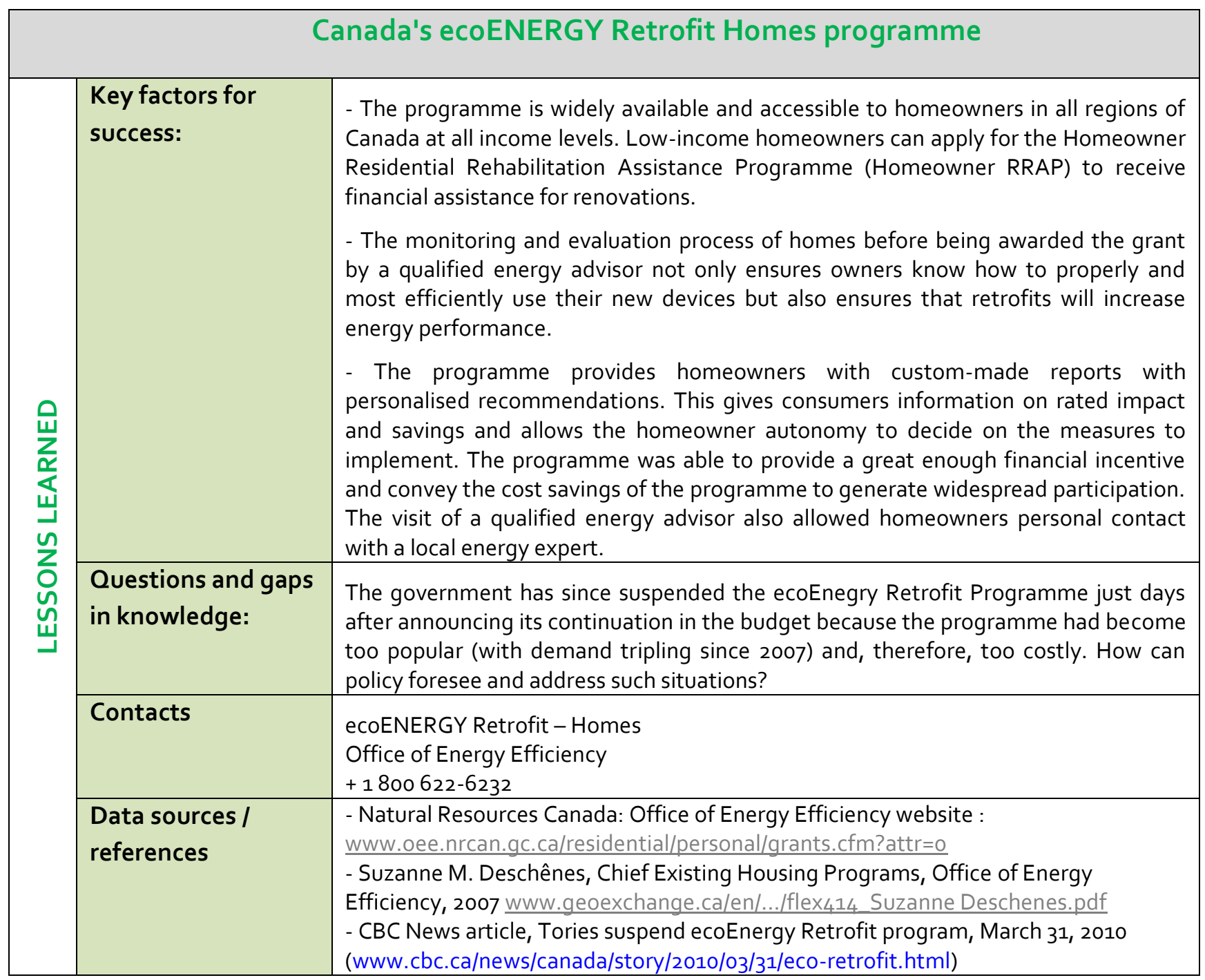

\begin{tabular}{|l|l|l|}
\hline \multicolumn{2}{|c|}{ Dutch Green Funds Scheme (GFS) } \\
\hline \multirow{3}{*}{} & Location: & Netherlands \\
\cline { 2 - 3 } & Duration: & Implemented in 1995, revised in 2010 and ongoing \\
\cline { 2 - 3 } & Tool category: & Economic tools (tax incentives) \\
\cline { 2 - 3 } & $\begin{array}{l}\text { Consumption } \\
\text { sector: }\end{array}$ & Financial products (green investment/saving) \\
\cline { 2 - 3 } & Objectives: & $\begin{array}{l}\text { Providing access to lower-than-standard-interest loans for green projects. Promoting } \\
\text { green and socially-responsible investment by individuals. }\end{array}$ \\
\cline { 2 - 3 } & $\begin{array}{l}\text { Initiator(s) / } \\
\text { organiser(s): }\end{array}$ & $\begin{array}{l}\text { The scheme was initiated by the Dutch government. Three Ministries are engaged in } \\
\text { the system: the Ministry of Housing, Spatial Planning \& the Environment, the } \\
\text { Ministry of Finance and the Ministry of Agriculture, Nature \& Food Quality. }\end{array}$ \\
\hline
\end{tabular}




\section{Dutch Green Funds Scheme (GFS)}

\section{How does the programme work? :}

\section{Costs \\ (Implementation and operation)}

The GFS encourages consumers to invest in green funds or save with green banks at an interest rate, which is lower than the average market rate. They are compensated by the provision of a tax advantage: green investments are fully exempted from the $1.2 \%$ capital gains tax (up to an amount of $€ 55,145$ per person in 2010). In addition, individuals benefit from a $1.3 \%$ income tax reduction on their green investments. Compared to standard savings, in 2010 investments in green funds were taxed $2.5 \%$ less ${ }^{158}$. The green banks can then offer cheaper loans to environmental projects and thereby improve their financial conditions. To qualify as a green bank or fund, at least $70 \%$ of the money received must be invested in green projects, which in turn need to meet certain ecological criteria set by the government.

Data has not been identified on the specific implementation costs of the scheme, however there is some information on other costs and revenues of the scheme. The programme originally expected to involve no more than $€ 400$ million in funds, but has grown precisely because of the significant public demand for additional funds.

Between 1995 and 2010 approximately 250,000 individuals invested $€ 7.3$ billion in green funds/savings, thereby financing 6,000 projects which might not have been viable without the scheme. In 2006, the GFS had a market share in all individual savings and investments of $1.8 \%$. With regard to the reference year 2001, a KPMG/CE study found that every euro the Dutch government invested via the Green Funds Scheme provided $€_{4} 0$ Euros from the private sector for investments in green projects, with the entire economic benefits of these projects amounting to $€_{51}$ million between 1995 and 2001.

What is the level of novelty? :
The Dutch environmental policy tool does not represent an innovative approach. However, the GFS could be a promising instrument for other MS.

\footnotetext{
${ }^{158}$ The income tax reduction will be cut gradually starting in 2011 and be fully abolished in 2014. However, investors will continue to benefit from the capital gains tax exemption.
} 


\section{Dutch Green Funds Scheme (GFS)}

\begin{tabular}{|c|c|c|}
\hline & $\begin{array}{l}\text { Impacts/savings/ } \\
\text { behavioural } \\
\text { change: }\end{array}$ & $\begin{array}{l}\text { Most projects funded under the GFS focus on organic agriculture, energy-efficient } \\
\text { greenhouses, renewable energy and nature conservation. In the period } 2003-2009 \text {, } \\
\text { on average the green projects funded through the scheme resulted in a decrease in } \\
\mathrm{CO} 2 \text { emissions of } 0.5 \mathrm{MT} \text { per year. NOx emissions are reduced by o.25 MT per year. } \\
\text { The green projects have also resulted in } 1,250 \text { square kilometres of woods and nature } \\
\text { conservation area.159 } \\
\text { The scheme also provides an incentive for innovation by adjusting the underlying } \\
\text { ecological criteria for the green certificates in a way that only best-in-class, i.e. } 5-10 \% \\
\text { of the market, may qualify for the green funds. The scheme has been successful from } \\
\text { an economic perspective because it is strongly connected to the mechanisms of } \\
\text { traditional lending and investment, with funds allocated on a market-driven basis, } \\
\text { and with minimal governmental costs. } \\
\text { Critics of the scheme point out the diminished tax revenues. However, the net fiscal } \\
\text { effect - resulting from the loss of income tax plus the corporate taxes obtained from } \\
\text { GFS-funded projects plus the VAT on goods and services generated through these } \\
\text { projects - turns out to be positive. Hence, in total, the scheme causes no financial } \\
\text { losses to the government, but rather generates additional income. The GFS } \\
\text { encourages more sustainable investment behaviour and contributed to a rise in } \\
\text { ecological awareness of the participating stakeholders. The scheme succeeded in } \\
\text { reinterpreting the meaning of environmental protection - from environment as a } \\
\text { threat, to environment as an (economic) opportunity. With all the top Dutch banks } \\
\text { having a green bank or green funds in their product portfolio now, there is a new } \\
\text { willingness to actively look for and fund green projects. }\end{array}$ \\
\hline \multirow[t]{3}{*}{ 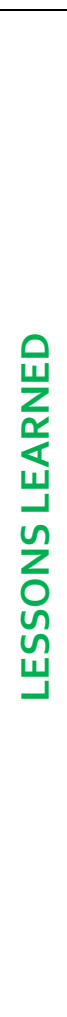 } & $\begin{array}{l}\text { Key factors for } \\
\text { success: }\end{array}$ & $\begin{array}{l}\text { Key factors for success: } \\
\text { - } \quad \text { trust and partnership between the banks and the government and a } \\
\text { - willingness to work together; } \\
\text { - } \quad \text { investors' interest in green financial products; } \\
\text { - } \quad \text { a tax regime that is adaptable to the credit structure; } \\
\text { principal support of the Ministry of Finance and a clarification on the } \\
\text { - } \quad \text { availability of green projects and experience with socially-responsible } \\
\text { - investments by at least some banks. } \\
\text { Weaknesses/difficulties: } \\
\text { - } \quad \text { for some investors, the financial incentive might not be high enough, and for } \\
\text { some project owners, the lower tax rate still may not be feasible (Thornley et } \\
\text { al., 2011); and } \\
\text { - the revision of the ecological criteria for green certificates (determining } \\
\text { which projects can qualify for green funding) was not conducted on a regular } \\
\text { basis. }\end{array}$ \\
\hline & $\begin{array}{l}\text { Questions and gaps } \\
\text { in knowledge }\end{array}$ & $\begin{array}{l}\text { - What kind of conditions would be necessary for other MS to implement a } \\
\text { similar initiative and for it to be successful? }\end{array}$ \\
\hline & Contacts & $\begin{array}{l}\text { NL Agency } \\
\text { P.O. Box } 93144 \\
2509 \text { AC The Hague, The Netherlands } \\
\text { Tel: +31 } 886025000\end{array}$ \\
\hline
\end{tabular}

${ }^{159}$ Scholtens, Bert, 2011, The sustainability of green funds, Natural Resources Forum 35, pp. 223-232 


\section{Dutch Green Funds Scheme (GFS)}

\begin{tabular}{|c|c|}
\hline $\begin{array}{l}\text { Data sources / } \\
\text { references }\end{array}$ & $\begin{array}{l}\text {-Rubik, Frieder et al, 2009: Innovative Approaches in European Sustainable } \\
\text { Consumption Policies. Schriftenreihe des IÖW 192/og, Berlin. } \\
\text { (www.ioew.de/uploads/tx ukioewdb/IOEW- } \\
\text { SR_192_Sustainable_Consumption_Policies.pdf, accessed 09.05.2011) } \\
\text {-Thornley, Ben; Wood, David; Grace, Katie; Sullivant, Sarah (2011): Impact Investing: } \\
\text { A Framework for Policy Design and Analysis, n.p., } \\
\text { (www.pacificcommunityventures.org/insight/impactinvesting/report/07- } \\
\text { Green_Funds_Scheme.pdf, accessed 10.05.2011) } \\
\text {-Ministerie van Volkshuisvesting, Ruimtelijke Ordening en Milieubeheer (2010): } \\
\text { Groen Beleggen: Jaarbericht 2010 met jaarcijfers 2009, Utrecht. (Ministry of Housing, } \\
\text { Spatial Planning, and the Environment (2010): The Green Funds Scheme: Annual } \\
\text { report 2010, Utrecht). (www.agentschapnl.nl/content/jaarbericht-groen-beleggen- } \\
\text { 2008-met-jaarcijfers-2007, accessed 10.05.2011) }\end{array}$ \\
\hline
\end{tabular}

\begin{tabular}{|c|c|c|}
\hline & \multicolumn{2}{|r|}{ EcoChallenge - Sustainability Application } \\
\hline \multirow{6}{*}{ 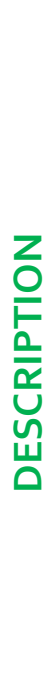 } & Location: & Germany \\
\hline & Duration: & $\begin{array}{l}\text { Entry into force in October } 2010 \text { with duration of } 5 \text { months. The operating time of the } \\
\text { project has been extended until October } 2011 \text {. }\end{array}$ \\
\hline & Tool category: & Behavioural tools - pledges or commitments, comparative evaluations \\
\hline & $\begin{array}{l}\text { Consumption } \\
\text { sector: }\end{array}$ & Basically all non- and semi-durable consumer goods \\
\hline & Objectives: & $\begin{array}{l}\text { The main objective of the EcoChallenge application is to reduce } \mathrm{CO}_{2} \text { emissions from } \\
\text { everyday consumption. It therefore strives to change consumer behaviour towards a } \\
\text { more sustainable lifestyle, including sustainable consumption patterns, in the short } \\
\text { and long-term. } \\
\text { Focussing on the mass market, the tool can easily used by consumers worldwide. }\end{array}$ \\
\hline & $\begin{array}{l}\text { Initiator(s) / } \\
\text { organiser(s): }\end{array}$ & $\begin{array}{l}\text { EcoChallenge is part of the research project EcoViz of the Interaction Design Labs at } \\
\text { University of Applied Sciences Potsdam und Raureif GmbH. }\end{array}$ \\
\hline
\end{tabular}




\section{EcoChallenge - Sustainability Application}

\begin{tabular}{|c|c|}
\hline $\begin{array}{l}\text { How does the } \\
\text { programme work? : }\end{array}$ & $\begin{array}{l}\text { Consumer citizens are supported to take first steps towards more sustainable } \\
\text { consumption patterns via an iPhone application (app) called EcoChallenge. This app } \\
\text { offers sustainability information in a fun and easily accessible way. It consists of } 4 \\
\text { main elements: } \\
\text { 1. Every week, information on new sustainability issues are provided to the users } \\
\text { of the EcoChallenge app. So far, } 8 \text { issues have been released concerning e.g. local } \\
\text { food, plastics/ packaging. The exceptional feature is that the complex content is } \\
\text { visualised in a very appealing way: graphs that are easy to understand and } \\
\text { recommendations for a more sustainable action. } \\
\text { 2. The app integrates a vcn calculator, which allows the user to check the } \mathrm{CO}_{2} \\
\text { emissions caused by her individual lifestyle. The calculator automatically compares } \\
\text { the result with the average } \mathrm{CO}_{2} \text { consumption of a German citizen. } \\
\text { 3. On a weekly basis, every user receives so-called "challenges". These are two } \\
\text { tasks supposed to deepen the knowledge in the respective field and motivate the } \\
\text { user to apply the acquired knowledge. } \\
\text { 4. Users are encouraged to share and compare their success in completing } \\
\text { "challenges" with friends on Facebook. This motivational component is used as an } \\
\text { incentive to truly complete the proposed tasks. }\end{array}$ \\
\hline $\begin{array}{l}\text { Costs } \\
\text { (Implementation } \\
\text { and operation) }\end{array}$ & $\begin{array}{l}\text { The project was developed with relatively little investment: } € 23010 \text { and reached a } \\
\text { large audience very quickly. It ran for one year only and was funded by the ministry of } \\
\text { science and culture of the German federal state of Brandenburg. }\end{array}$ \\
\hline & $\begin{array}{l}\text { The EcoChallenge app combines different approaches of motivational psychology, } \\
\text { especially the close connection between the specific sustainability content, the } \\
\text { "smart" design and the opportunity of social comparison. Compared to other } \\
\text { sustainability platforms and } \mathrm{CO}_{2} \text { calculators, EcoChallenge has a mobile format. It } \\
\text { can be accessed worldwide. } \\
\text { The app's prototype was realised within an unusually short period of time (month 1: } \\
\text { prototype on paper, month 2: website, month 3: start of the actual iPhone app). } \\
\text { The concept of the app is rather innovative. So-called "Design-Patterns" for draft } \\
\text { documents and the editorial procedure were developed. These "Design-Patterns" } \\
\text { allow for the generation of new content in a very short period of time. }\end{array}$ \\
\hline $\begin{array}{l}\text { Impacts/savings/ } \\
\text { behavioural } \\
\text { change: }\end{array}$ & $\begin{array}{l}\text { The project is being monitored very thoroughly. This evaluation has generated a } \\
\text { huge amount of data. Nevertheless, with the current measuring instruments and } \\
\text { sampling, no statement can be given on whether consumption patterns have truly } \\
\text { changed in the short term and - in case they have changed - will remain more } \\
\text { sustainable (gap between knowledge and action) } \\
\text { The monitoring has revealed that } 8000 \text { EcoChallenge apps were downloaded } \\
\text { between Mid February } 2011 \text { and the end of April 2011. } 1900 \text { "challenges" were } \\
\text { completed. }\end{array}$ \\
\hline
\end{tabular}




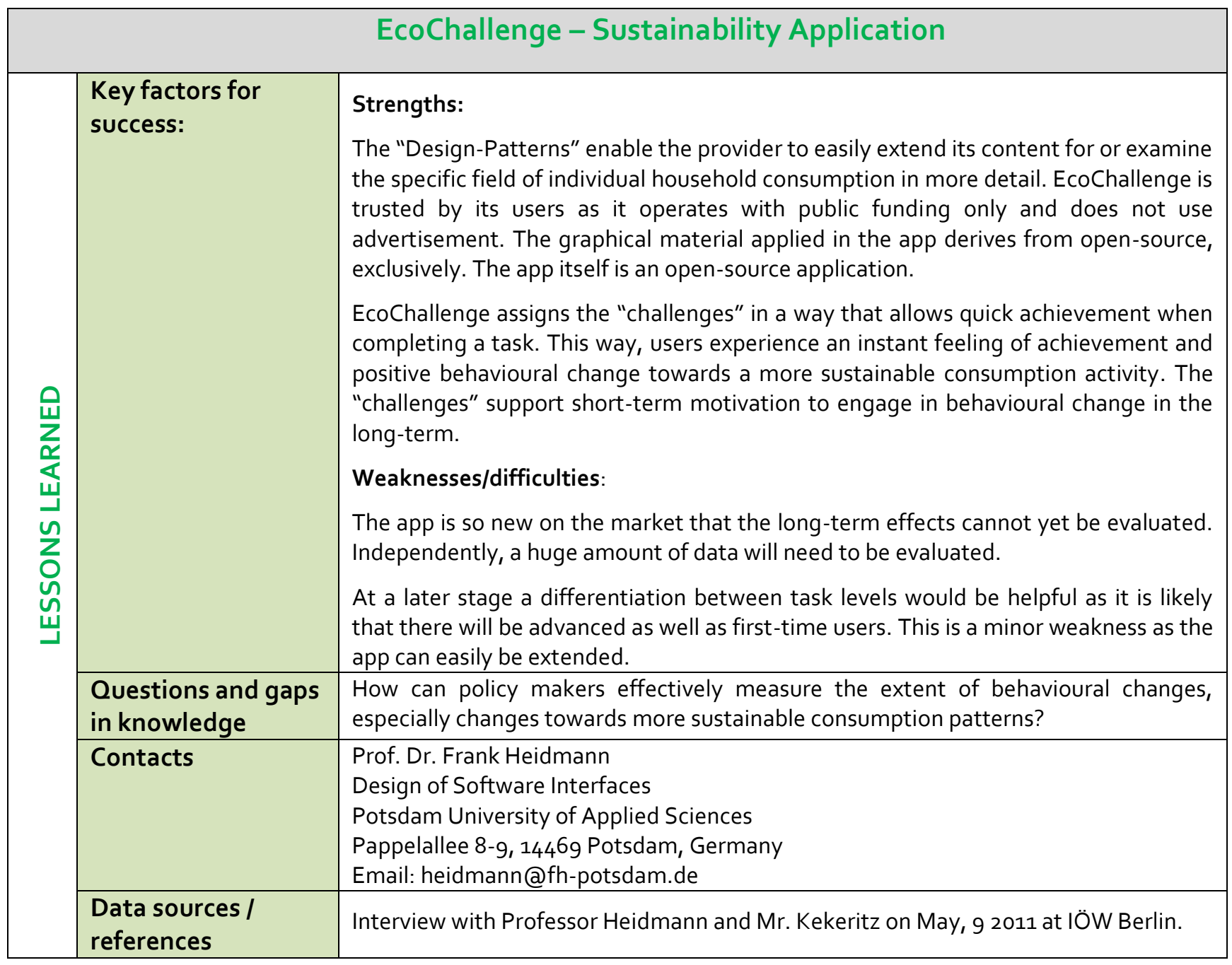

\begin{tabular}{|c|c|c|}
\hline \multicolumn{3}{|c|}{ FairTrade Certification Mark for Cotton } \\
\hline \multirow{5}{*}{ 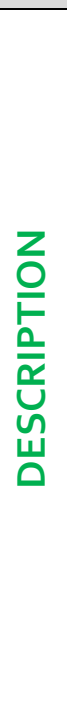 } & Location: & International (present in over 50 countries) \\
\hline & Duration: & $\begin{array}{l}\text { The International Fairtrade Certification Mark was established in 2002. Currently still } \\
\text { active. }\end{array}$ \\
\hline & Tool category: & Information provision/awareness raising/behavioural \\
\hline & $\begin{array}{l}\text { Consumption } \\
\text { sector: }\end{array}$ & Textiles/Cotton \\
\hline & Objectives: & $\begin{array}{l}\text { The objective of the International Fairtrade Certification mark (FCM) is to strengthen } \\
\text { the position of developing country producers in the market place through an } \\
\text { international consumer product label. Fairtrade certification of cotton is intended to } \\
\text { redress the current cotton market injustices and focus on improving the position of } \\
\text { cotton smallholders. Fairtrade certification of cotton aims to improve the situation of } \\
\text { the cotton farmers at the very bottom of supply chains, recognising that they are at } \\
\text { the sharp end of exploitation and injustice in international trade in the same way as } \\
\text { many other producers of agricultural commodities. }\end{array}$ \\
\hline
\end{tabular}




\section{FairTrade Certification Mark for Cotton}

\begin{tabular}{|c|c|}
\hline $\begin{array}{l}\text { Initiator(s) / } \\
\text { organiser(s): }\end{array}$ & $\begin{array}{l}\text { The International FCM is owned and protected by FLO International (Fairtrade } \\
\text { Labelling Organisations International), on behalf of its } 24 \text { member and associate } \\
\text { member Fairtrade producer networks and labelling initiatives. The certification body } \\
\text { is FLO-CERT, which is part of the FLO and serves as the international body } \\
\text { responsible for setting and monitoring the Fairtrade standards for cotton. The } \\
\text { system involves independent auditing of producers to ensure the agreed standards } \\
\text { are met. }\end{array}$ \\
\hline $\begin{array}{l}\text { How does the } \\
\text { programme work? : }\end{array}$ & $\begin{array}{l}\text { The International Fairtrade Certification mark signifies that the product in question } \\
\text { has gone through a product certification system meeting agreed environmental, } \\
\text { labour and developmental standards. Fairtrade cotton is cotton, which has met the } \\
\text { international Fairtrade standard for production of seed cotton and is therefore } \\
\text { eligible to carry the FMC. The Mark is an independent product certification label, } \\
\text { which guarantees that cotton farmers are receiving a fair and stable Fairtrade price } \\
\text { and Fairtrade premium; receiving pre-financing where requested; and benefiting } \\
\text { from longer-term, more direct trading relationships. The Fairtrade minimum price is } \\
\text { set at the farm gate level and is based on actual costs of sustainable production. If the } \\
\text { local market price is higher than this minimum price, then the market price applies. } \\
\text { An additional payment of a Fairtrade premium is set aside for farmers' organisations } \\
\text { to spend on social and environmental projects or to strengthen their businesses. } \\
\text { Fairtrade-certified cotton products are sourced from smallholder cooperatives in } \\
\text { India, Mali, Senegal, Cameroon, and Peru that are independently certified by the } \\
\text { international body FLO. All the traders in the supply chain have been registered with } \\
\text { the Fairtrade system and work to the organisation's trading standards. }\end{array}$ \\
\hline $\begin{array}{l}\text { Costs } \\
\text { (Implementation } \\
\text { and operation) }\end{array}$ & $\begin{array}{l}\text { Certification of producers and operators varies greatly depending of the size and the } \\
\text { type of the organisation. It generally goes from } € 2000 \text { up to } € 15000 \text { per year (FLO } \\
\text { CERT 2010) (Zschocke 2011). }\end{array}$ \\
\hline $\begin{array}{l}\text { What is the level of } \\
\text { novelty? : }\end{array}$ & $\begin{array}{l}\text { The FCM's message is different from other ethical labels in that its main objective is } \\
\text { not to 'protect the environment' or 'enable companies to trace their cotton'. } \\
\text { Fairtrade is the only certification scheme whose purpose is to tackle poverty and } \\
\text { empower producers in developing countries. Furthermore, one of the goals of the } \\
\text { programme is to connect disadvantaged producers and consumers - consumers of } \\
\text { Fairtrade-marked cotton can read about how their purchases are improving the lives } \\
\text { of local farmers across the world. This connection that is emphasised between } \\
\text { farmers and consumers, and the development of a rigorous and transparent system } \\
\text { of standards touches upon behavioural aspects that help to build consumer trust. } \\
\text { The Fairtrade Certification Mark is used as a tool to build a social consumer } \\
\text { movement pushing for change in global trading. }\end{array}$ \\
\hline $\begin{array}{l}\text { Impacts/savings/ } \\
\text { behavioural } \\
\text { change: }\end{array}$ & $\begin{array}{l}\text { - In } 2008 \text {, global Fairtrade cotton sales reached } € 176 \text { million, amounting to over } 27 \\
\text { million items, almost double the sales in the previous year. } \\
\text { - Fairtrade certification of cotton is currently helping over } 95,000 \text { people - farmers, } \\
\text { workers and their families - to improve their lives, as well as the wider community, } \\
\text { through receipt of a fair price for their cotton and a Fairtrade premium. } \\
\text { - According to a } 2008 \text { GlobeScan study of } 14,500 \text { consumers in } 15 \text { countries, half of } \\
\text { consumers are now familiar with the FMC and } 91 \% \text { trust the Mark. A further } 64 \% \text { of } \\
\text { all consumers believe that Fairtrade has strict standards, a quality that closely } \\
\text { correlates to consumer trust. }\end{array}$ \\
\hline
\end{tabular}




\section{FairTrade Certification Mark for Cotton}

\begin{tabular}{|c|c|c|}
\hline \multirow{4}{*}{ 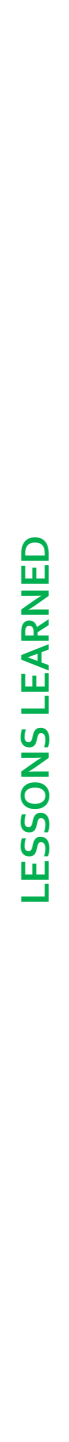 } & $\begin{array}{l}\text { Key factors for } \\
\text { success: }\end{array}$ & $\begin{array}{l}\text { - The FMC's marketing strategy covers several behavioural aspects that have made } \\
\text { its campaigns quite successful: they provide personal stories of the farmers } \\
\text { behind Fairtrade cotton - connecting the consumer to where their product is } \\
\text { coming from. Furthermore, the FMC has received wide media coverage as well as } \\
\text { gaining the support and harmonisation of a number of other international fair- } \\
\text { trade labels. } \\
\text { - The FMC is widely recognised by consumers and is generally trusted by consumers } \\
\text { due to its standards and certification criteria. } \\
\text { - The FMC for fair-trade cotton is not just a label used in isolation. It is also used in } \\
\text { combination with several other tools such as awareness raising campaigns (e.g. In } \\
\text { the UK, "The Great Cotton Stitch-Up campaign" was launched on the } 5^{\text {th }} \\
\text { anniversary of Fairtrade cotton in November 2010) and commitments made by } \\
\text { consumers by signing letters to MEPs (Members of the European Parliament). }\end{array}$ \\
\hline & $\begin{array}{l}\text { Questions and gaps } \\
\text { in knowledge }\end{array}$ & $\begin{array}{l}\text { - Are consumers purchasing Fairtrade products because the label has become a } \\
\text { "brand" or are consumers purchasing products with the FMC because they support } \\
\text { the cause? } \\
\text { - To what extent does the program really benefit the most disadvantaged } \\
\text { producers? }\end{array}$ \\
\hline & Contacts & $\begin{array}{l}\text { info@fairtrade.net } \\
\text { Telephone: }+49228949230\end{array}$ \\
\hline & $\begin{array}{l}\text { Data sources / } \\
\text { references }\end{array}$ & $\begin{array}{l}\text { - Fairtrade website, } \\
\text { www.fairtrade.org.uk/includes/documents/cm_docs/2008/c/cotton_qanda.pdf } \\
\text { - Fairtrade UK, Fact sheet on Cotton, 2009, } \\
\text { (www.fairtrade.org.uk/includes/documents/cm_docs/2010/f/fairtrade_cotton_facts } \\
\text { heetx vw latest.pdf) } \\
\text { - Fairtrade Cotton Certification Mark Manual for Traders Version January, } 2008 \\
\text { (revelfabrics.com/wp-content/themes/denim/images/fmc-manual-traders- } \\
\text { cotton.pdf) } \\
\text { - FLO CERT, 2010, http://www.flo-cert.net/flo-cert/main.php?id=29 } \\
\text { - Zschocke, A., 2011, http://www.flo- } \\
\text { cert.net/_admin/userfiles/file/TC\%20Appendix3TCFeeList\%20ED\%2080\%20en.pdf }\end{array}$ \\
\hline
\end{tabular}

\begin{tabular}{|c|c|c|}
\hline & \multicolumn{2}{|r|}{ Food Dudes Programme } \\
\hline \multirow{4}{*}{ 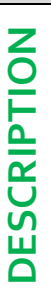 } & Location: & Ireland (original pilot project) - now implemented in England, Sicily and California \\
\hline & Duration: & Implemented in 2005 . Currently still active. \\
\hline & Tool category: & Information campaign \& awareness raising/Education/Behavioural \\
\hline & $\begin{array}{l}\text { Consumption } \\
\text { sector: }\end{array}$ & Food (Health) \\
\hline
\end{tabular}




\begin{tabular}{|c|c|}
\hline Objectives: & $\begin{array}{l}\text { The Food Dudes Healthy Eating Programme is a school-based intervention designed } \\
\text { for use in primary schools (among children } 4-11 \text { years old) that: } \\
\text { - encourages children to eat fruit and vegetables both at school and at home; } \\
\text { - helps children develop a liking for fruit and vegetables; } \\
\text { - encourages children to become proud to think of themselves as healthy eaters; } \\
\text { and } \\
\text { - changes the 'culture' of a school to one that strongly supports healthy eating. }\end{array}$ \\
\hline $\begin{array}{l}\text { Initiator(s) / } \\
\text { organiser(s): }\end{array}$ & $\begin{array}{l}\text { The Food Dudes Healthy Eating Programme, originated in } 1992 \text { by the Food and } \\
\text { Activity Research Unit at Bangor University in Wales. The first pilot program was } \\
\text { implemented in } 2005 \text { by the Irish Government, with support from the European } \\
\text { Union and Industry, in } 150 \text { primary schools across Ireland. }\end{array}$ \\
\hline $\begin{array}{l}\text { How does the } \\
\text { programme work? : }\end{array}$ & $\begin{array}{l}\text { The scheme uses four healthy eating cartoon characters - the Food Dudes - to } \\
\text { encourage children to develop a liking for fruit and vegetables, encourage them to } \\
\text { eat them at home and be proud that they are healthy eaters. In the first 16-day phase } \\
\text { of the project, children are read a letter and/or watch a specially designed DVD } \\
\text { episode starring the "Food Dudes", who provide influential role-models to imitate. } \\
\text { Children are then given a portion of a fruit and a vegetable, and those who eat both } \\
\text { are given a small reward (e.g. juggling balls, pedometers). They are given a small } \\
\text { reward - such as juggling balls, a pencil or a pedometer - to encourage them to } \\
\text { repeatedly taste the produce. Teachers also act as role models by trying the same } \\
\text { foods as the pupils and each child is given an information pack to take home to } \\
\text { encourage them to eat more fruit and vegetables with their family. In the second } \\
\text { phase, children are encouraged to continue eating fruit and vegetables and } \\
\text { classroom charts record what each pupil has eaten and they can earn further rewards } \\
\text { and Food Dudes certificates. After taking part in the programme, schools are } \\
\text { monitored for a further year to see if consumption of fruit and vegetables declines. }\end{array}$ \\
\hline $\begin{array}{l}\text { Costs } \\
\text { (Implementation } \\
\text { and operation) }\end{array}$ & $\begin{array}{l}\text { The initial Food Dudes Programme was supported by Fyffes (Europe oriented } \\
\text { importer and distributor of fresh produce). The positive results (see Research) } \\
\text { obtained in the pilot study enabled Bord Bia (the Irish Food Board) to receive funding } \\
\text { under the EU programme for the Promotion of Fruit and Vegetables on the Internal } \\
\text { Market to extend the programme to a larger number of schools commencing in } 2005 \text {. } \\
\text { Funding was approved for implementing the Food Dudes Programme in } 150 \text { schools } \\
\text { over a three-year period } 2005-2008 \text {. The funding of } € 484 \text { ooo per year was } \\
\text { provided as follows: } 41 \% \text { EU Commission, } 25 \% \text { from the fresh produce industry, } 17 \% \\
\text { Department of Agriculture, Fisheries \& Food, and from } 17 \% \text { Bord Bia (Irish Food } \\
\text { Board). }\end{array}$ \\
\hline $\begin{array}{l}\text { What is the level of } \\
\text { novelty? : }\end{array}$ & $\begin{array}{l}\text { A range of insights identified by behavioural psychology research were used in the } \\
\text { development of the Food Dudes Program. These include: } \\
\text {-children are motivated by praise, recognition, and rewards. This was borne out by } \\
\text { the evidence that when rewards were omitted from the Food Dudes intervention its } \\
\text { effectiveness was almost completely eliminated. } \\
\text {-positive role models were also identified as having a powerful influence over } \\
\text { children's learning and value systems. } \\
\text {-Taste Acquisition Theory: The programme works by encouraging children to taste } \\
\text { fruit and vegetables repeatedly, so that they are able to discover the intrinsically } \\
\text { rewarding properties of these foods and to develop a liking for them. In the process, } \\
\text { children come to view themselves as 'fruit and vegetable eaters'. This theory, } \\
\text { supported by a wide-ranging body of evidence, suggests that repeatedly tasting } \\
\text { particular foods leads to an acquired taste for them. }\end{array}$ \\
\hline
\end{tabular}




\section{Food Dudes Programme}

\begin{tabular}{|c|c|c|}
\hline & $\begin{array}{l}\text { Impacts/savings/ } \\
\text { behavioural } \\
\text { change: }\end{array}$ & $\begin{array}{l}\text { Based on the success of the programme, Food Dudes is being rolled out in Europe } \\
\text { and beyond. In Ireland the programme is being introduced into all primary schools. } \\
\text { To date, } 1103 \text { schools and } 162000 \text { children have participated. } \\
\text { An evaluation conducted in five schools that received the programme shows that the } \\
\text { programme resulted in substantial increases in children's fruit and vegetable } \\
\text { consumption both at school and at home; children increased their daily consumption } \\
\text { of fruit by } 54 \% \text { and vegetables by } 48 \% \text {. Children's unhealthy snack food consumption } \\
\text { was significantly reduced by } 20 \% \text {. Those children who are, at the start, the poorest } \\
\text { eaters of fruit and vegetables, show the greatest increases in consumption. }\end{array}$ \\
\hline \multirow{4}{*}{ 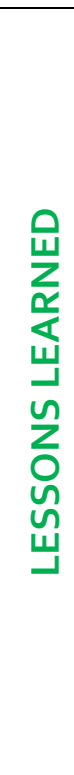 } & $\begin{array}{l}\text { Key factors for } \\
\text { success: }\end{array}$ & $\begin{array}{l}\text { - The Food Dudes Programme is two-tiered, working not just to influence children's } \\
\text { healthy food choices, but also to equip teachers, parents and caregivers with the } \\
\text { necessary resources for supporting this change. } \\
\text { - The pilot programme was based on solid academic research on behavioural and } \\
\text { psychological factors, which gave the programme greater chances of success. }\end{array}$ \\
\hline & $\begin{array}{l}\text { Questions and gaps } \\
\text { in knowledge }\end{array}$ & $\begin{array}{l}\text { - Would a similar programme work for adolescents? } \\
\text { - How can some of the behavioural/psychological aspects of the Food Dudes } \\
\text { Programme be applied to other population segments/age groups? (adults, elderly, } \\
\text { teenagers, etc) }\end{array}$ \\
\hline & Contacts & $\begin{array}{l}\text { Pauline Kelly - UK Food Dudes Co-ordinator: } \\
\text { Tel }+44 \text { (o) } 1248388534 \\
\text { p.kelly@ bangor.ac.uk }\end{array}$ \\
\hline & $\begin{array}{l}\text { Data sources / } \\
\text { references }\end{array}$ & $\begin{array}{l}\text { - Lowe, Fergus and Horne, Pauline. Food Dudes: Increasing children's fruit and } \\
\text { vegetable consumption. Cases in Public Health Communication \& Marketing. 2009; } \\
\text { 3:161-185. www.gwumc.edu/.../casesjournal/.../showcase/cases_3_10.pdf } \\
\text { - Food Dudes website, wwww.fooddudes.co.uk }\end{array}$ \\
\hline
\end{tabular}

Love Food Hate Waste campaign: Herefordshire and Worcestershire case study

\begin{tabular}{|l|l|l|}
\hline \multirow{2}{*}{} & Location: & Herefordshire and Worcestershire, England, UK \\
\cline { 2 - 3 } & Duration: & $\begin{array}{l}\text { WRAP campaign from 2007, Herefordshire and Worcestershire case study 2008 - } \\
2009\end{array}$ \\
\cline { 2 - 3 } & Tool category: & $\begin{array}{r}\text { Information provision \& awareness raising } \\
\text { Awareness raising (Pledges or commitments \& Community-based } \\
\text { initiatives). }\end{array}$ \\
\cline { 2 - 3 }
\end{tabular}




\begin{tabular}{|c|c|}
\hline $\begin{array}{l}\text { Initiator(s) / } \\
\text { organiser(s): }\end{array}$ & $\begin{array}{l}\text { The campaign was in part funded by WRAP, led by Herefordshire Council and } \\
\text { Worcestershire County Council, working in partnership with the six waste collection } \\
\text { authorities. Local and countywide activities were planned, some of which were run by } \\
\text { individual authorities and others jointly. }\end{array}$ \\
\hline $\begin{array}{l}\text { How does the } \\
\text { programme work? : }\end{array}$ & $\begin{array}{l}\text { The national campaign promotes practical advice and tips to help people make the } \\
\text { most of the food they are buying, and waste less of it. } \\
\text { The campaign in Herefordshire and Worcestershire involved a mix of advertising, } \\
\text { community engagement, and PR. In detail this included: the use of } 11 \text { billboards for } 4 \\
\text { weeks; bus advertising; door to door engagement trial ( } 21,700 \text { households visited and } \\
7,000 \text { canvassed); editorials - articles in district magazines and staff newsletters; } \\
\text { campaign launch with accompanying press opportunity; } 20,000 \text { leaflets printed for } \\
\text { road shows and events; posters in community locations; press adverts - } 7 \times 1 / 2 \text { page } \\
\text { press adverts X2; PR local links - press articles; pull up banners for road shows and } \\
\text { events; radio advertising using the national Love Food Hate Waste radio ads; and } \\
\text { over } 30 \text { road shows. }\end{array}$ \\
\hline $\begin{array}{l}\text { Costs } \\
\text { (Implementation } \\
\text { and operation) }\end{array}$ & $\begin{array}{l}\text { The cost of implementing the campaign was } 29 p \text { per household at a total cost of } f 90 \\
\text { ooo. The cost of the campaign was equivalent to } \pm 38.46 / \text { tonne in } 2008 / 09 \text { and is likely } \\
\text { to reduce to } £ 16.02 / \text { tonne over } 3 \text { years }(2008 / 09-2010 / 11) \text {; this is less than the } \\
\text { cost/tonne of disposing of food waste to landfill. The campaign saved more money } \\
\text { than it cost: when the savings from reduced landfill are included over three years } \\
(2008 / 09-2010 / 11) \text {, the campaign created savings of } £ 220 \text { ooo. This represents a } \\
\text { return on investment (ROI) over the three years of nearly } 1.5 \text {. }\end{array}$ \\
\hline $\begin{array}{l}\text { What is the level of } \\
\text { novelty? : }\end{array}$ & $\begin{array}{l}\text { None of the campaign actions could be said to be innovative on their own. However, } \\
\text { combined together the campaign represents an effective and sophisticated } \\
\text { behavioural tool in the following ways: } \\
\text { - The national level identification of the problem and framing it in terms of } \\
\text { potential savings. } \\
\text { - The focus on loving food (i.e. not calling on people to change what they eat). } \\
\text { - The focus on enabling people via practical steps. } \\
\text { - The local focus on local communities - thereby influencing via mavens. } \\
\text { - The multi-pronged approach at both national and local level so as to provide the } \\
\text { message from multiple routes; thereby presenting the action as a social norm or } \\
\text { practice. }\end{array}$ \\
\hline
\end{tabular}




\begin{tabular}{|c|c|c|}
\hline & \multicolumn{2}{|c|}{ Love Food Hate Waste campaign: Herefordshire and Worcestershire case study } \\
\hline & $\begin{array}{l}\text { Impacts/savings/ } \\
\text { behavioural } \\
\text { change: }\end{array}$ & $\begin{array}{l}\text { Research estimates suggest that } 1.8 \text { million more UK households are now taking } \\
\text { steps to cut back on the amount of food they throw away due to WRAP's national } \\
\text { Love Food Hate Waste campaign. This related to an overall saving of } f 296 \text { million a } \\
\text { year, preventing } 137 \text { ooo tonnes of food being thrown away which would have } \\
\text { emitted } 600 \text { ooo tonnes of greenhouse gases. } \\
\text { In terms of awareness and attitudes, the pre- and post-campaign surveys in } \\
\text { Herefordshire and Worcestershire established the following: } \\
\text { - Campaign awareness increased from } 23 \% \text { to } 40 \% \text {. } \\
\text { - The recall of the LFHW message from council publications increased from } 24 \% \\
\text { (from the national campaign) to } 42 \% \text {. For billboards \& other outdoor advertising } \\
\text { this increase was from } 8 \% \text { to } 15 \% \text {. } \\
\text { Over } 70 \% \text { of those who were aware of the campaign felt that it was informative; } \\
\text { over } 50 \% \text { felt it provided useful tips and practical advice; } 45 \% \text { felt that the } \\
\text { campaign made them more reluctant to throw food away. } \\
\text { Residents frequently identified supermarket road shows held by council staff as } \\
\text { being positive and informative. } \\
\text { - The campaign's objectives were achieved: The proportion of Committed Food } \\
\text { Waste Reducers increased by } 10 \% \text { from } 13 \% \text { to } 23 \% \text { in } 5 \text { months. This therefore } \\
\text { matched the campaign's objectives (i.e. as } 10 \% \text { increase which diverted an estimated } \\
2310 \text { tonnes of food waste from landfill in } 2008 / 09 \text { ) } \\
\text { - In terms of action and behaviour, a door to door engagement element of the } \\
\text { campaign had been included to test whether this communication method could be a } \\
\text { useful technique for waste prevention. Of those who stated they had been visited } \\
\text { only } 6 \% \text { felt they threw away less food waste and a further } 2 \% \text { said they threw away } \\
\text { much less. Therefore, despite the campaign's overall success, door to door } \\
\text { engagement appears to be an inefficient method of directly engaging with members } \\
\text { of the public regarding food waste. }\end{array}$ \\
\hline \multirow{4}{*}{ 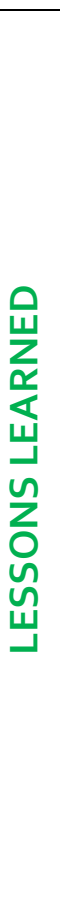 } & $\begin{array}{l}\text { Key factors for } \\
\text { success: }\end{array}$ & $\begin{array}{l}\text { Strengths: } \\
\text { - Direct one to one engagement to help people waste less food is a positive and } \\
\text { effective method of communicating at a local level. } \\
\text { - Working with local groups who wish to save money and waste less food is more } \\
\text { cost effective and is preferred. } \\
\text { Weaknesses: } \\
\text { - Door to door engagement appears to be inefficient. } \\
\text { - In terms of effectiveness, Defra's } 4 \text { E's model would suggest that those } \\
\text { promoting the action should exemplify the action (i.e. show leadership and do it } \\
\text { themselves) via their own food canteens. }\end{array}$ \\
\hline & $\begin{array}{l}\text { Questions and gaps } \\
\text { in knowledge }\end{array}$ & - \\
\hline & Contacts & $\begin{array}{l}\text { Laura Blackwell, Recycling Officer, Herefordshire Council, Email: } \\
\text { lblackwell@ @erefordshire.gov.uk, Tel: } 01432260 \text { 520, Web: } \\
\text { www.herefordshire.gov.uk }\end{array}$ \\
\hline & $\begin{array}{l}\text { Data sources/ } \\
\text { references }\end{array}$ & $\begin{array}{l}\text {-Wrap website, } \\
\text { www.wrap.org.uk/media_centre/press_releases/consumers_save_300.html } \\
\text {-WRAP, 2009, Local Authority waste prevention case study: Herefordshire and } \\
\text { Worcestershire Councils, www.wrap.org.uk/document.rm?id=10530 }\end{array}$ \\
\hline
\end{tabular}




\begin{tabular}{|c|c|c|}
\hline \multicolumn{3}{|r|}{ London Congestion Charge } \\
\hline \multirow{9}{*}{ 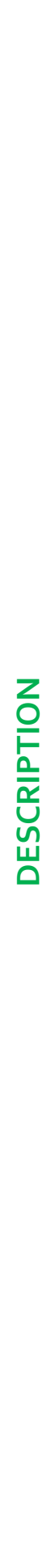 } & Location: & London, UK \\
\hline & Duration: & Ongoing: $f 5$ per day from 2003, $£ 8$ from 2005 \\
\hline & Tool category: & Economic tool (tax) \\
\hline & $\begin{array}{l}\text { Consumption } \\
\text { sector: }\end{array}$ & Mobility \\
\hline & Objectives: & $\begin{array}{l}\text { - Congestion charging schemes aim to reduce congestion charging the use of } \\
\text { vehicles at busy times. } \\
\text { - In his manifesto for election to the post of London Mayor in 2000, Ken } \\
\text { Livingstone pledged to reduce traffic congestion by } 15 \% \text { by } 2010 \text {, using a } \\
\text { congestion charge scheme to discourage unnecessary car journeys in a small } \\
\text { zone of central London... with all monies devoted to improving transport' } \\
\text { - The ex-ante analysis included the impact on traffic levels, congestion levels and } \\
\text { revenues, the costs of running the scheme, the benefits in terms of reduced } \\
\text { pollution and faster journey times, the effect on public transport and the degree } \\
\text { to which traffic would be diverted along alternative routes. }\end{array}$ \\
\hline & $\begin{array}{l}\text { Initiator(s) / } \\
\text { organiser(s): }\end{array}$ & $\begin{array}{l}\text { It was an independent initiative initiated by the Mayor of London in agreement with } \\
\text { the London Assembly. Its implementation was achieved via private contracting. It } \\
\text { also involved some of the revenues being used to improve public transport via the } \\
\text { publically owned Transport for London. }\end{array}$ \\
\hline & $\begin{array}{l}\text { How does the } \\
\text { programme work? : }\end{array}$ & $\begin{array}{l}\text { The London Congestion Charge was initiated by the Mayor of London but introduced } \\
\text { with the cooperation of the relevant London boroughs; it came into effect in } \\
\text { February } 2003 \text {. The Charging zone covers an area bounded by the London inner ring } \\
\text { road, and drivers of non-exempt vehicles must pay a charge of } 15 \text { per day } \\
\text { (approximately } € 7.5 \text { ) to enter and travel within this zone. A network of Automatic } \\
\text { Number Plate Recognition (ANPR) cameras that monitor all vehicles entering and } \\
\text { circulating within the zone enforces the scheme. The number plates of vehicles are } \\
\text { read and stored in a database. At the end of each } 24 \text {-hour period, the vehicle } \\
\text { registration data held in this database is cross-checked against vehicle registration } \\
\text { data collected from those drivers known to have paid to enter the charging zone. } \\
\text { Drivers who do not pay the charge are issued a Penalty Charge Notice. The } \\
\text { congestion charging zone is } 21 \text { square kilometres in size; representing } 1.3 \% \text { of the } \\
\text { total } 1579 \text { sq km of Greater London. }\end{array}$ \\
\hline & $\begin{array}{l}\text { Costs } \\
\text { (Implementation } \\
\text { and operation) }\end{array}$ & $\begin{array}{l}\text { Costs of around } £ 162 \text { million were incurred in implementing the congestion charging } \\
\text { leading up to its implementation in } 2003 \text {. The } 2003 \text { actual running costs were } \\
\text { estimated to be } £ 130 \text { million per a year. The } 2003 \text { valued benefits (time etc) } \\
\text { estimated to be } £ 180 \text { million. 'Government' revenues equal } £ 190 \text { million - charge } \\
\text { payments of } £ 120 \text { million and penalty payments of } £ 70 \text { million at } 2005 \text { prices. }\end{array}$ \\
\hline & $\begin{array}{l}\text { What is the level of } \\
\text { novelty? : }\end{array}$ & $\begin{array}{l}\text { Congestion charging represents the application of established theory among } \\
\text { economists who have been promoting the idea for some time that charging } \\
\text { represents an efficient way of allocating scares road space. The Central London } \\
\text { Congestion Charging scheme however represents the largest use of the tool and } \\
\text { therefore is a novel application. }\end{array}$ \\
\hline
\end{tabular}




\section{London Congestion Charge}

\begin{tabular}{|c|c|c|}
\hline & $\begin{array}{l}\text { Impacts/savings/ } \\
\text { behavioural } \\
\text { change: }\end{array}$ & $\begin{array}{l}\text { Comparing the ex-ante and ex-post quantifiable estimates, the scheme could be said } \\
\text { to have exceeded its objectives. The actual increase in speed within the charge zone } \\
\text { (an indicator of reduced congestion) was found to be } 31 \% \text { in } 2003 \text { rather than the } 8 \text { - } \\
12 \% \text { predicted in advance. The ex-ante modelling predicted a } 12-17 \% \text { reduction in } \\
\text { vehicles entering charging zone between 7am to } 6: 30 p m \text { but observed levels were in } \\
\text { fact a reduction of } 21 \% \text {. Other measures of success include: } \\
-\quad \text { Public and Political Acceptance: There were widespread concerns about the } \\
\text { scheme prior to introduction. Surveys of the attitude of Londoners to the } \\
\text { scheme before and after show a shift of opinion towards favouring the scheme } \\
\text { and its effects. London residents perceived fewer negative effects from the } \\
\text { scheme than they expected ex ante. } \\
\text { GHG reduction: No detailed ex ante predictions were made for the scheme. } \\
\text { However, the ex post benefits of the scheme estimated to have led to savings of } \\
19 \% \text { in traffic related CO2 emissions, and } 20 \% \text { in fuel consumed by road transport } \\
\text { within the charging zone. } \\
\text { Noise reduction: Predictions of changes in noise levels were made ex-ante and } \\
\text { ex-post for the scheme and found that changes in the charging zone and around } \\
\text { would be insignificant. } \\
\text { Accidents: Ex ante, it was predicted that the scheme would result in } 150 \text { - } 250 \\
\text { fewer accidents each year. This has not been analyzed properly but ex-post data } \\
\text { shows a fall in accidents that is proportionally greater than elsewhere in London. }\end{array}$ \\
\hline \multirow[t]{3}{*}{ 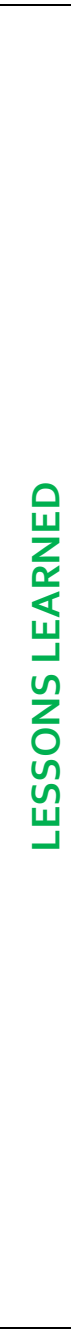 } & $\begin{array}{l}\text { Key factors for } \\
\text { success: }\end{array}$ & $\begin{array}{l}\text { Factors of successes: } \\
\text { - A key element of success was the relative public support for the scheme in } \\
\text { advance which increased still further once the scheme was found to have } \\
\text { exceeded its expectations. Although wider environmental objectives were } \\
\text { identified, the relative public support was largely motivated by the local and } \\
\text { immediate benefits offered by the scheme. } \\
\text { - The scale of the scheme also made its application possible without confusion. } \\
\text { Most British drivers driving into central London are aware of the scheme. } \\
\text { Weaknesses: } \\
\text { - The scheme could not be said to be motivated by achieving sustainable levels of } \\
\text { consumption or equitable access, but rather an efficient allocation which has the } \\
\text { effect of pricing many on low and medium incomes out of central London during } \\
\text { busy times. Whilst this was seen as appropriate within central London where it } \\
\text { was clearly not possible for all to use private cars, the scheme's regressive nature } \\
\text { has ultimately limited its extension into further residential areas. } \\
\text { Such schemes often make alternative arrangements for registered private hire } \\
\text { vehicles (i.e. mini-cabs) and licensed Hackney Carriages, who pay an annual } \\
\text { charge as if they are resident on the charge zone. Although not proven, such } \\
\text { exemptions risk incentivising an increase in the number of private hires vehicles } \\
\text { to avoid paying a daily charge. }\end{array}$ \\
\hline & $\begin{array}{l}\text { Questions and } \\
\text { gaps? }\end{array}$ & $\begin{array}{l}\text {-What conditions other than local community and public support would be necessary } \\
\text { for such a scheme to work in other heavily congested cities e.g. what type of urban } \\
\text { road network is needed, what size cities would a congestion charge work best for, } \\
\text { etc? }\end{array}$ \\
\hline & Contacts & $\begin{array}{l}\text { London Congestion Charging } \\
\text { P O Box } 4782 \\
\text { Worthing } \\
\text { BN11 gPS } \\
\text { Tel: }+442076499122 \\
\text { www.tfl.gov.uk/roadusers/congestioncharging/6711.aspx }\end{array}$ \\
\hline
\end{tabular}




\section{London Congestion Charge}

\begin{tabular}{|c|c|}
\hline $\begin{array}{l}\text { Data sources/ } \\
\text { references }\end{array}$ & 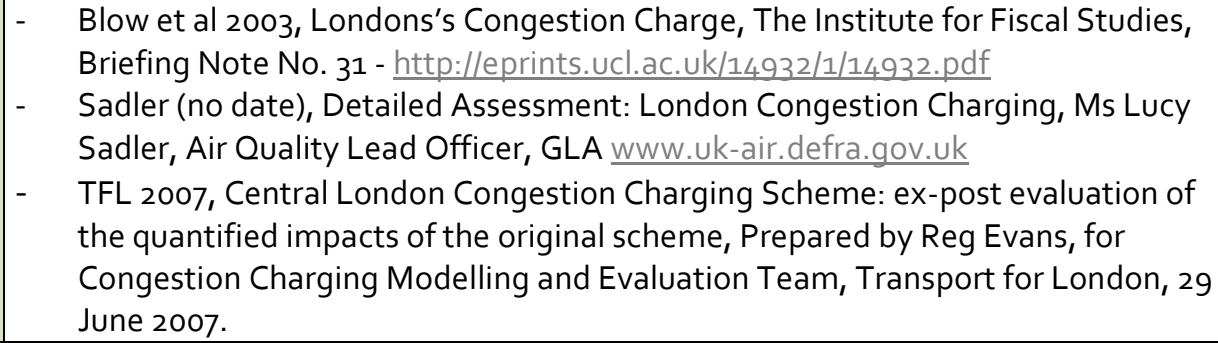 \\
\hline
\end{tabular}

\section{Middelgrunden Wind Turbine Cooperative}

\begin{tabular}{|c|c|c|}
\hline & Location: & Middelgrunden, Denmark \\
\hline & Duration: & $\begin{array}{l}\text { Cooperative founded in } 1997 \text { and wind turbine project implemented in } 2000 . \\
\text { Currently still active. }\end{array}$ \\
\hline & Tool category: & Behavioural - public participation and investment scheme \\
\hline & $\begin{array}{l}\text { Consumption } \\
\text { sector: }\end{array}$ & Housing (utilities and infrastructure) \\
\hline & Objectives: & $\begin{array}{l}\text { The Middelgrunden Wind Turbine Cooperative was founded in May } 1997 \text { with the aim } \\
\text { to produce electricity through the establishment and management of wind turbines } \\
\text { on the Middelgrunden shoal. It aimed to enable the local community of } \\
\text { Middelgrunden in Denmark to share expenses and income from a wind turbine. }\end{array}$ \\
\hline 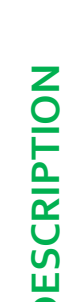 & $\begin{array}{l}\text { Initiator(s) / } \\
\text { organiser(s): }\end{array}$ & $\begin{array}{l}\text { In 1996, the Copenhagen Environment and Energy Office (CEEO) took the initiative } \\
\text { to organise the project, after the location of Middelgrunden had been pointed out as } \\
\text { a potential site in the Danish Action Plan for Offshore Wind. Together with CEEO, a } \\
\text { group of local people formed the Middelgrunden Wind Turbine Cooperative and } \\
\text { cooperation with Copenhagen Energy was established. As the Municipality of } \\
\text { Copenhagen owns Copenhagen Energy, a close link to politicians was thereby also } \\
\text { established. }\end{array}$ \\
\hline & $\begin{array}{l}\text { How does the } \\
\text { programme work? : }\end{array}$ & $\begin{array}{l}\text { When it was built in } 2000 \text {, the Middelgrunden wind farm was the world's largest } \\
\text { offshore farm, with } 20 \text { turbines and a capacity of } 40 \mathrm{MW} \text {. The wind farm is } 50 \% \\
\text { owned by the Middelgrunden Wind Turbine Cooperative (comprised of } 10,000 \\
\text { investors who are mainly local electricity consumers - and some from companies, } \\
\text { organisations, unions and foundations), and } 50 \% \text { by the Copenhagen utility } \\
\text { company. The two owners run as separate businesses. The cooperative owns and } \\
\text { manages the } 10 \text { southern turbines and the } 10 \text { northern turbines are owned by the } \\
\text { utility. Nonetheless, the two owners collaborate on all aspects related to the } \\
\text { operations of the site. The cooperative's part consists of } 40,500 \text { shares. }\end{array}$ \\
\hline & $\begin{array}{l}\text { Costs } \\
\text { (Implementation } \\
\text { and operation) }\end{array}$ & $\begin{array}{l}\text { The total investment budget of the Middelgrunden Offshore Wind Farm was } € 48 \\
\text { million Euro }(€ 2 \text { million above the original planned budget. Financing the } \\
\text { Cooperatives is carried out through the sale of shares - the cooperative's ten } 2 \mathrm{MW} \\
\text { turbines were sold in } 40,500 \text { shares, offered at } 570 \text { euro, each representing an annual } \\
\text { production of } 1,000 \mathrm{kWh} \text {. }\end{array}$ \\
\hline
\end{tabular}




\section{Middelgrunden Wind Turbine Cooperative}

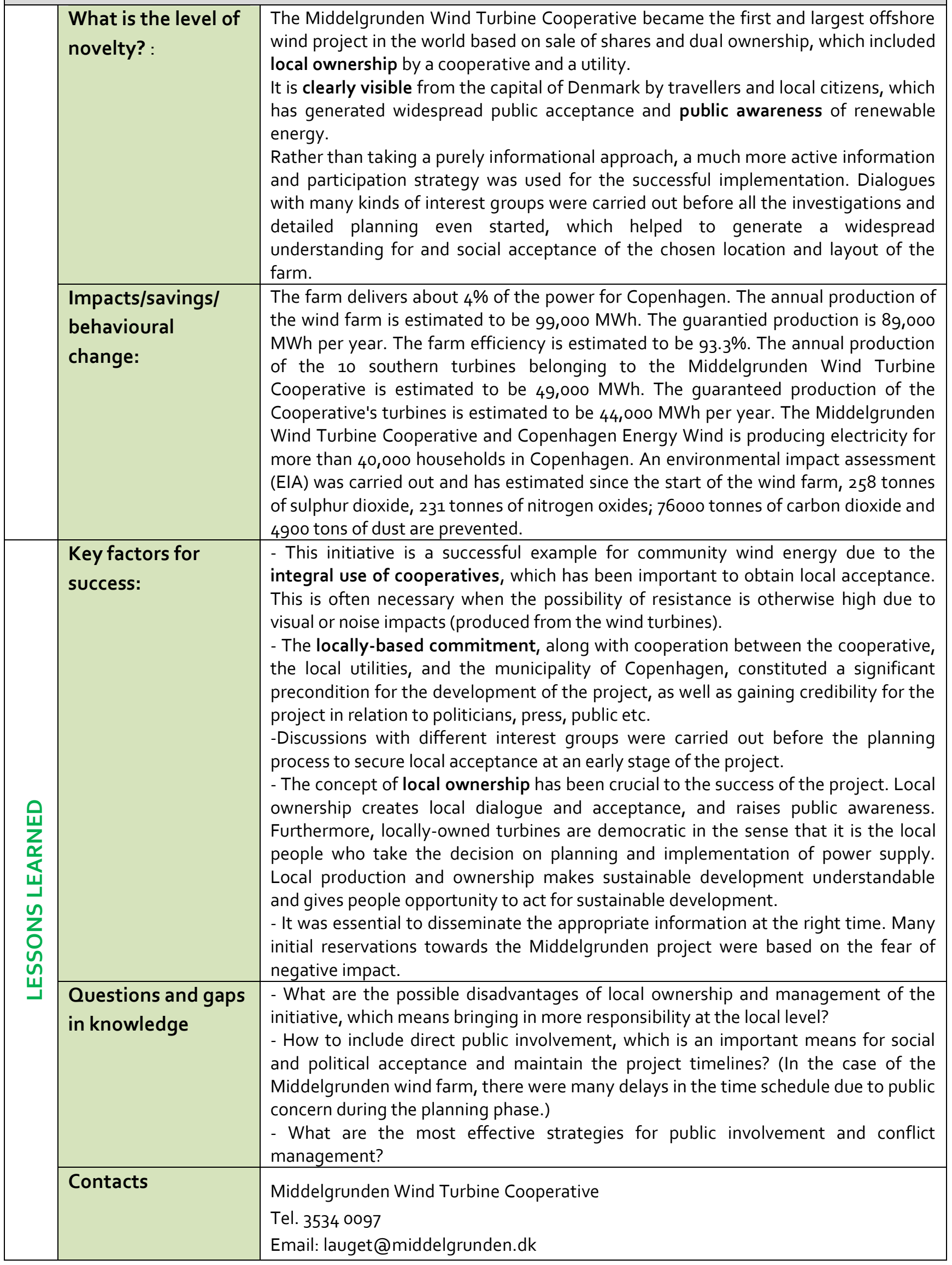




\section{Middelgrunden Wind Turbine Cooperative}

\begin{tabular}{|l|l|}
\hline $\begin{array}{l}\text { Data sources/ } \\
\text { references }\end{array}$ & $\begin{array}{l}\text { - Middelgrunden Wind cooperative website: } \\
\text { www.middelgrunden.dk/middelgrunden/?q=en }\end{array}$ \\
& $\begin{array}{l}\text { - Copenhagen Environment and Energy Office, 2005, The Middelgrunden Offshore } \\
\text { Wind Farm, } \\
\text { www.middelgrunden.dk/middelgrunden/sites/default/files/public/file/mg- } \\
\text { pjece_72dpi_rgb.pdf } \\
\text { - Sorensen, Hans et al., 2002, Middlegrunden 40 MW Offshore Wind farm Denmark, } \\
\text { Lessons Learned, } \\
\text { www.oceanrenewable.com/.../middlegrundendenwindlessonsspok02.pdf }\end{array}$ \\
\hline
\end{tabular}

\begin{tabular}{|c|c|c|}
\hline \multicolumn{3}{|c|}{ Paris Vélib Programme } \\
\hline \multirow{7}{*}{ 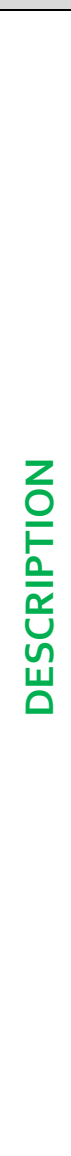 } & Location: & Paris, France \\
\hline & Duration: & Started in 2007 (JCDecaux contract ends in 2017) \\
\hline & Tool category: & Behavioural \\
\hline & $\begin{array}{l}\text { Consumption } \\
\text { sector: }\end{array}$ & Mobility, public transportation \\
\hline & Objectives: & $\begin{array}{l}\text { The Vélib programme aims to offer a complementary and new means of } \\
\text { transportation for both local citizens and tourists. This tool is also a good way to } \\
\text { promote soft transportation. }\end{array}$ \\
\hline & $\begin{array}{l}\text { Initiator(s) / } \\
\text { organiser(s): }\end{array}$ & $\begin{array}{l}\text { The idea of starting a large public bicycle system in Paris was inspired by the success } \\
\text { of the Vélo'v bike system in Lyon. The mayor of Paris, Bertrand Delanoë, championed } \\
\text { the idea. Though launched only in June } 2007 \text {, Vélib is already the largest bicycle } \\
\text { sharing system in the world. It is superior to all other systems in terms of the number } \\
\text { of bicycles and stations, the size of the service area, the number of registered users, } \\
\text { and the volume of daily uses. Vélib is operated by the French advertising company } \\
\text { JCDecaux under a 10-year contract with the City of Paris. In exchange for operating } \\
\text { the system, JCDecaux is allowed to exploit } 1600 \text { billboards across the city. }\end{array}$ \\
\hline & $\begin{array}{l}\text { How does the } \\
\text { programme work? : }\end{array}$ & $\begin{array}{l}\text { Bikes can be rented from any of the } 1451 \text { stations across the city. Users are required } \\
\text { to purchase a pass to use Vélib. An annual pass costs } € 39 \text {. Day and week passes are } \\
\text { also available at a cost of } € 1 \text { and } € 5 \text { respectively. The first half hour of every loan is } \\
\text { always free; the second half hour costs } € 1 \text {; the third half hour an additional } € 2 ; \text { and } \\
\text { each half hour afterwards costs an additional } € 4 \text {. This pricing was designed to } \\
\text { discourage people long term-use of the bikes. The system operates } 24 \text { hours a day, } 7 \\
\text { days a week. }\end{array}$ \\
\hline
\end{tabular}




\section{Costs}

(Implementation and operation)

What is the level of novelty? :

Impacts/savings/ behavioural change:

\section{Key factors for} success:

\section{Questions and gaps} in knowledge
The Velib system is financed by the JCDecaux advertising corporation, in return for the city of Paris signing over the income from a substantial portion of the on-street advertising hoardings. JCDecaux paid start-up costs of about $€ \mathbf{1 0 0}$ million and employs the equivalent of about 285 people full-time to operate the system and repair the bikes for 10 years. The city of Paris receives all revenue from the programme (estimated at $€ 30$ million annually) as well as a fee of about $€ 3$ million a year. In return JCDecaux receives exclusive control over 1628 city-owned billboards and the city receives about half of that advertising space at no charge for publicinterest advertising. Due to an unexpectedly high rate of vandalism compared to the Lyon system, the Paris City Council has agreed to pay $€ 350$ per bicycle needing replacement, which is expected to cost up to $€ 2$ million per year.

Vélib in Paris is unprecedented in terms of its scale and scope. It is the first time a selfservice bicycle hire has been so widely implemented in a major city such as Paris. Unlike any other bike-share programme currently in existence, Vélib covers the entire city of Paris, making it a comprehensive addition to the Parisian transportation network. The Vélib programme has managed to create a cheap, convenient, and environmentally friendly mode of transportation. Thanks to the widespread network of stations, all in strategic locations, customers can easily locate a Vélib station. The pricing system for Vélib was also designed so that both single ride and membership were designed to be affordable by everyone (and overall cheaper than taking a bus, metro, or taxi). Another innovation is the use of "smart technologies" such as smart phones or RFID chips. They make it even easier for customers to locate where the free bikes and empty parking slots are. The behaviour change of this initiative has spread outside of the city itself and inspired other cities in France and abroad such as Nantes, Dijon, Brussels and more.

From its very beginning, the Vélib program has been a real success. JCDecaux reported 27.5 million Vélib trips in the first year and an average of 75000 trips/day. Since Vélib's introduction, Paris has seen a $70 \%$ increase in bicycle use and a $5 \%$ reduction in car use and congestion. According to a recent survey, $61 \%$ of users regularly use Vélib for commuting to work or school and $20 \%$ stated that they use cars less. The Vélib programme has inspired many other similar initiatives in other French cities as well as abroad.

One of the key factors of success of the Vélib programme is the density and the importance of the coverage of the bikes stations (with 20600 bicycles and over 1400 bike-stations). Another element is the city of Paris itself, which has been working on promoting bikes use for a long time and is relatively convenient for cycling.

Some issues that can still be improved within the Paris Velib programme include addressing the issue of vandalism. Between the system's launch and early 2009, the entire initial fleet of 20,600 bicycles has been replaced as a result of theft and vandalism. The severity of theft and vandalism appears to be unique to Paris. Lyon, which uses the same JCDecaux technology as Paris, loses bicycles at less than half the rate that Paris does. Another aspect that needs further improvements includes maintaining the smooth use and operation of the service. Bicycle redistribution between stations is often insufficient to meet demand. Four hundred staff is probably not large enough to manage a 20600 bicycle system. Another small issue is the excavation and the trenching of city infrastructure, required for installation.

- How to address the issue of vandalism, which is one of the major issues with the Vélib programme? Due to unexpected thefts and vandalism, operating and capital costs are higher than any other bike-share programme. 


\begin{tabular}{|c|c|}
\hline \multicolumn{2}{|r|}{ Paris Vélib Programme } \\
\hline Contacts & $\begin{array}{l}\text { Mme Annick LEPETIT Adjoint(e) au Maire de Paris, Adjointe chargée des } \\
\text { déplacements, des transports et de l'espace public : } \\
27 \text { rue Lemercier } \\
75017 \text { Paris } \\
\text { Tél/fax: } 01.46 .27 .78 .32 \\
\text { annick-lepetit@wanadoo.fr }\end{array}$ \\
\hline $\begin{array}{l}\text { Data sources / } \\
\text { references }\end{array}$ & $\begin{array}{l}\text {-Anderson, John Ward, 2007-03-24, "Paris Embraces Plan to Become City of Bikes". } \\
\text { The Washington Post: www.washingtonpost.com/wp- } \\
\text { dyn/content/article/2007/03/23/AR2007032301753.html. Retrieved 2011-10-06. } \\
\text { www.Velib.paris.fr } \\
\text {-NYC Government, 2008, Bike-Share Opportunities in NYC, } \\
\text { www.nyc.gov/html/dcp/pdf/transportation/bike_share_part3.pdf } \\
\text {-Government of Canada website, www.tc.gc.ca/eng/programs/environment-urban- } \\
\text { guidelines-practitioners-bikesharingguide2009-6-1665.htm\#6.1 (Accessed } \\
\text { 10/05/2011) } \\
\text {-P. Van Den Noort, 2009, Velo mundial: } 33 \text { questions \& answers to learn everything } \\
\text { there is to know about Vélib', The Public Bicycle in Paris, } \\
\text { c0133251.cdn.cloudfiles.rackspacecloud.com/Case\%20Study\%20- } \\
\% 20 \text { Bike\%20Sharing\%20Velib\%20SF.pdf }\end{array}$ \\
\hline
\end{tabular}

\begin{tabular}{|c|c|c|}
\hline \multicolumn{3}{|c|}{ Picture Health Warnings on Cigarette Packets } \\
\hline \multirow{6}{*}{ 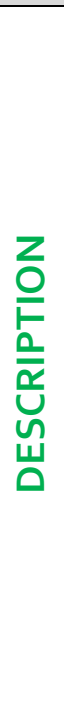 } & Location: & Worldwide \\
\hline & Duration: & First initiative in Canada in 2000-2001 \\
\hline & Tool category: & Behavioural and information provision \\
\hline & $\begin{array}{l}\text { Consumption } \\
\text { sector: }\end{array}$ & Health \\
\hline & Objectives: & $\begin{array}{l}\text { The objective of including picture health warnings on cigarette packets is to: } \\
\text { - raise awareness on the health risks related to smoking; } \\
\text { - incite smokers to quit smoking; } \\
\text { - repulse non-smokers, especially when they are young, before they start smoking; } \\
\text { and } \\
\text { - reduce the consumption of cigarettes. }\end{array}$ \\
\hline & $\begin{array}{l}\text { Initiator(s) / } \\
\text { organiser(s): }\end{array}$ & $\begin{array}{l}\text { Governments are leading the implementation of such initiatives. More than } 25 \\
\text { countries are now displaying health warning pictures on cigarette packets. }\end{array}$ \\
\hline
\end{tabular}




\section{Picture Health Warnings on Cigarette Packets}

\begin{tabular}{|c|c|}
\hline $\begin{array}{l}\text { How does the } \\
\text { programme work? : }\end{array}$ & $\begin{array}{l}\text { Graphic picture health warnings printed on one side of cigarette packets were } \\
\text { introduced in many countries since } 2001 \text {. Today, they are often placed on both sides. } \\
\text { The images cover different proportions of the pack, depending on the location. For } \\
\text { example, the amount of coverage ranges from } 45 \% \text { of the total surface of the pack in } \\
\text { Turkey, to } 60 \% \text { in Australia. } \\
\text { In the EU, The Tobacco Product Directive (2001/37/EC) governs health warnings on } \\
\text { tobacco products. The Directive allows Member States to require additional warnings } \\
\text { in the form of colour photographs and other illustrations. Belgium was the first EU } \\
\text { Member State to introduce pictorial warnings on cigarette packs in November } 2006 \text {, } \\
\text { followed by Romania in July } 2008 \text { and the UK in October } 2008 \text {. }\end{array}$ \\
\hline $\begin{array}{l}\text { Costs } \\
\text { (Implementation } \\
\text { and operation) }\end{array}$ & $\begin{array}{l}\text { Most studies point to the cost-effectiveness of using picture warnings on cigarette } \\
\text { packages. Further, most costs for including health warnings on the packages of } \\
\text { tobacco products are borne by the industry. According to a recent Impact } \\
\text { Assessment report, the initial administrative burden of introducing mandatory } \\
\text { pictorial warnings on all cigarette packs would amount to between } € 32.5 \text { million and } \\
€ 125.4 \text { million in the EU-27 for the whole cigarette manufacturing industry (DG } \\
\text { Sanco, 2010). }\end{array}$ \\
\hline $\begin{array}{l}\text { What is the level of } \\
\text { novelty? : }\end{array}$ & $\begin{array}{l}\text { The first initiative was experimented in Canada in 2001. Before that, warnings were } \\
\text { only textual. However, pictures increased the salience and vividness of health } \\
\text { communications, and are consistently rated by smokers to be more effective and } \\
\text { engaging than text-only warnings. Picture warnings are associated with greater } \\
\text { health knowledge, perceptions of risk, motivation to quit, and cessation behaviour. } \\
\text { Health warnings on cigarette packages are among the most prominent sources of } \\
\text { health information. It has been reported by most of smokers that they interpreted } \\
\text { more information about the risks of smoking from packages than any other source } \\
\text { except television. Health warnings are an extremely cost-effective public health } \\
\text { intervention and have tremendous reach. Pack-a-day smokers are potentially } \\
\text { exposed to the warnings over 7,0oo times per year. Non-smokers, including children } \\
\text { and youth, also report high exposure and awareness of health warnings on packages. } \\
\text { Furthermore, the use of picture health warning reaches illiterate people, who } \\
\text { otherwise may not be able to read the textual health warnings. }\end{array}$ \\
\hline $\begin{array}{l}\text { Impacts/savings/ } \\
\text { behavioural } \\
\text { change: }\end{array}$ & $\begin{array}{l}\text { Health warnings have been proven to be an effective way of communicating the } \\
\text { health risks associated with smoking. Countries such as Canada and Australia have } \\
\text { shown that picture health warnings are more effective than text-based warnings } \\
\text { alone. The range and depth of knowledge about the health risks of smoking did not } \\
\text { change after the pictures were introduced. However, awareness of some conditions } \\
\text { depicted by the picture warnings, such as gum and mouth disease or oral cancer, } \\
\text { increased significantly. These health warning pictures are arguably the most graphic } \\
\text { and were the messages that smokers reported had made them think the most about } \\
\text { their smoking behaviour. After the picture health warnings had been introduced, } \\
\text { more adults and young people agreed that the message made smoking seem less } \\
\text { attractive and more adults agreed that the messages 'put me off smoking'. }\end{array}$ \\
\hline
\end{tabular}




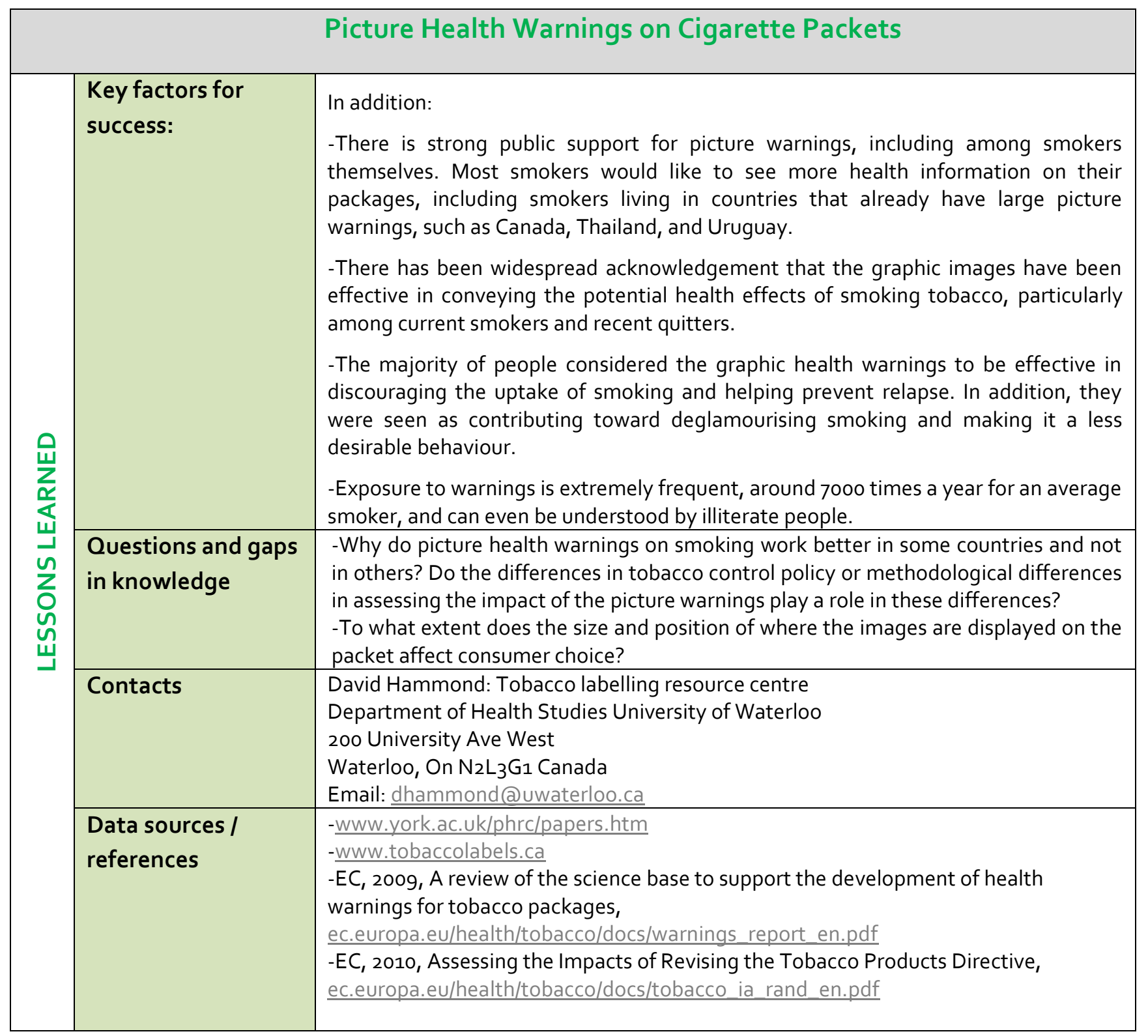

\begin{tabular}{|c|c|c|}
\hline \multicolumn{3}{|r|}{ Transition Towns } \\
\hline \multirow{3}{*}{ 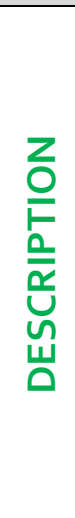 } & Location: & $\begin{array}{l}\text { Originated in Totnes, Devon in the UK, it has spread within the EU to local } \\
\text { communities in Austria, Belgium, Denmark, Finland, France, Germany, Greece, } \\
\text { Hungary, Italy, Latvia, The Netherlands, Poland, Portugal, Spain, and Sweden, as well } \\
\text { as Norway, with varying levels of development. Beyond the EU, groups are also } \\
\text { located in Australia, Bangladesh, Japan, North America, New Zealand, South Africa, } \\
\text { South America, and Thailand. }\end{array}$ \\
\hline & Duration: & $\begin{array}{l}\text { In existence since } 2005 \text { in Totnes, UK, these local community groups do not have a } \\
\text { set duration as they represent a change in community engagement and decision- } \\
\text { making. }\end{array}$ \\
\hline & Tool category: & Public/community participation (community-led) \\
\hline
\end{tabular}




\section{Transition Towns}

\begin{tabular}{|c|c|}
\hline $\begin{array}{l}\text { Consumption } \\
\text { sector: }\end{array}$ & All, as the general aim is to address peak oil and climate change \\
\hline Objectives: & $\begin{array}{l}\text { The objective of the scheme is to create community-led responses to the challenges } \\
\text { and opportunities of peak oil, climate change and economic stagnation. They begin } \\
\text { by forming an initiating group and then adopt the 'Transition Model' to engage a } \\
\text { significant proportion of the people in their community to help find the answers to } \\
\text { the question: "how can we make our community stronger and happier as we deal } \\
\text { with the impacts of peak oil and economic contraction while at the same time } \\
\text { urgently reducing } \mathrm{CO}_{2} \text { emissions?". Community resilience is also a key 'foundation } \\
\text { concept'. }\end{array}$ \\
\hline $\begin{array}{l}\text { Initiator(s) / } \\
\text { organiser(s): }\end{array}$ & Transition Towns are initiated by individuals in the local community. \\
\hline $\begin{array}{l}\text { How does the } \\
\text { programme work?: }\end{array}$ & $\begin{array}{l}\text { The community generally goes through three self-organised phases. First, the small } \\
\text { initiating group starts a programme of awareness-raising and connecting with } \\
\text { existing groups (social, environmental, etc). They articulate the rationale for } \\
\text { adopting/adapting a transition approach and show the creative responses that the } \\
\text { community might embark upon. } \\
\text { Second, as the group becomes larger, it self-organises in groups in all the key areas } \\
\text { such as food, transport, energy, housing, education, textiles, etc., and creates } \\
\text { practical projects in response to the question of how to create a stronger, happier } \\
\text { community that can deal with the impacts of peak oil and economic stagnation while } \\
\text { reducing its } \mathrm{CO}_{2} \text { emissions. This includes activities such as community-supported } \\
\text { agriculture, car clubs, local currencies, neighbourhood carbon reduction clubs, urban } \\
\text { orchards, and re-skilling classes. Most Transition Initiatives are in this phase. } \\
\text { Third, they begin to look at Energy Descent planning and the need to rebuild the local } \\
\text { economic fabric by starting up local energy companies, social enterprises, and } \\
\text { complementary currency systems. There are a number of initiatives in this phase. }\end{array}$ \\
\hline $\begin{array}{l}\text { Costs } \\
\text { (Implementation } \\
\text { and operation) }\end{array}$ & No data available on costs. \\
\hline $\begin{array}{l}\text { What is the level of } \\
\text { novelty?: }\end{array}$ & $\begin{array}{l}\text { This is a highly novel approach, from its community-led nature, to its collaborative } \\
\text { approach in creating a 'model' that communities can follow as appropriate for their } \\
\text { situation, the integration of permaculture and psychology principles to what can be } \\
\text { considered an environmental initiative, local community resilience, localisation and } \\
\text { reform of the local economy. }\end{array}$ \\
\hline
\end{tabular}




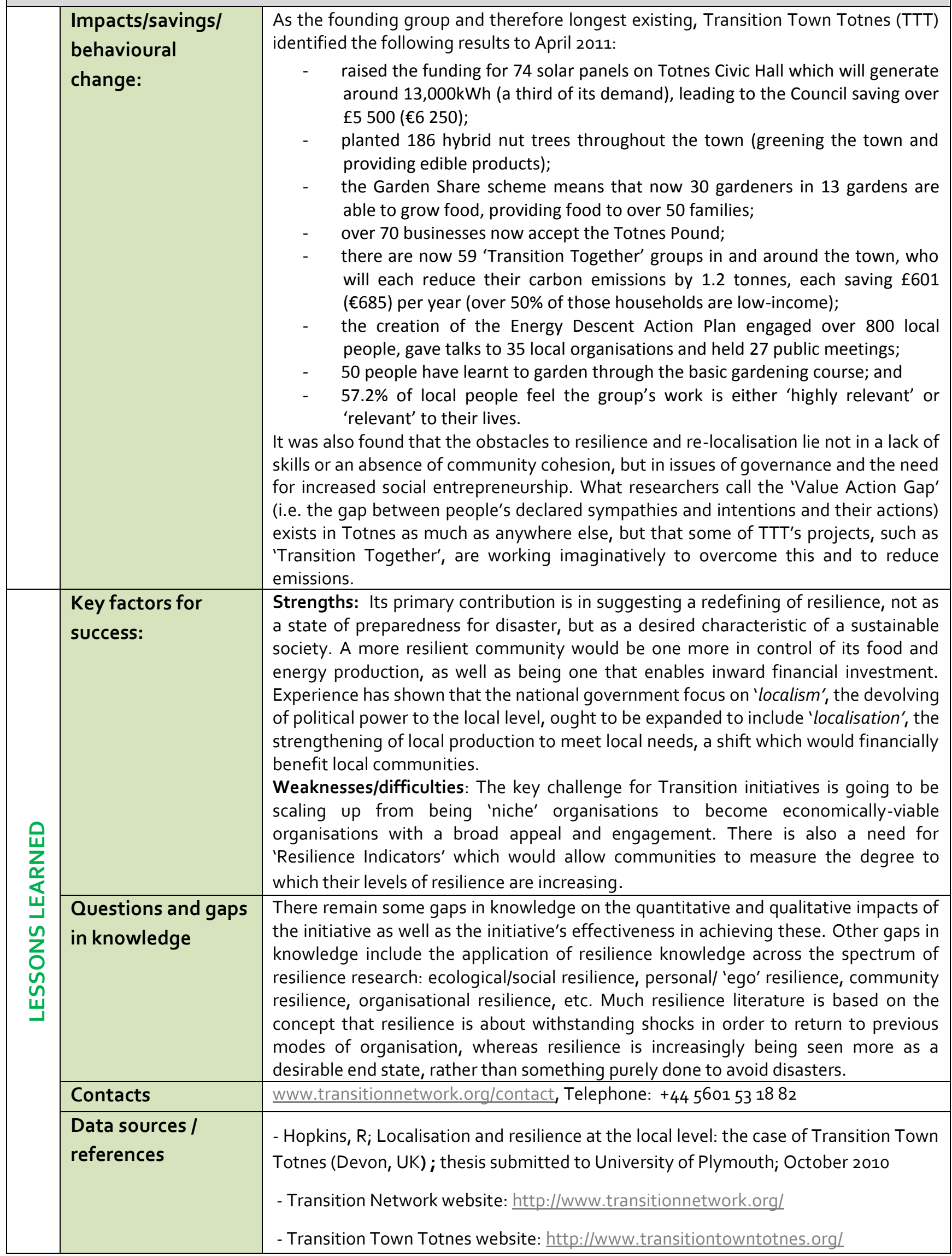




\begin{tabular}{|c|c|c|}
\hline & \multicolumn{2}{|r|}{ Vienna dematerialisation / waste prevention activities } \\
\hline \multirow{7}{*}{ 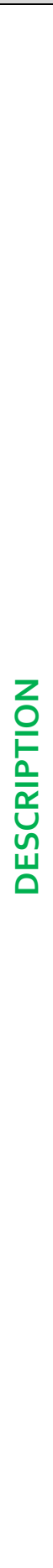 } & Location: & Vienna, Austria \\
\hline & Duration: & Activities undertaken since late 1990 ; programme ongoing. \\
\hline & Tool category: & Information-provision, financial incentives, \\
\hline & $\begin{array}{l}\text { Consumption } \\
\text { sector: }\end{array}$ & Purchasing decisions, end-of-life management, products designing \\
\hline & Objectives: & $\begin{array}{l}\text { The main goal is to slow down waste generation in Vienna, with prevention seen as } \\
\text { the most desirable waste management option as it eliminates the need for handling, } \\
\text { transporting, recycling or disposal of waste. The ideal target is to try to stabilise } \\
\text { waste at year } 2000 \text { levels, but more realistically, to keep waste growth at } 1.3 \% \text { per } \\
\text { annum instead of } 1.8 \% \text {. }\end{array}$ \\
\hline & $\begin{array}{l}\text { Initiator(s) } \\
\text { organiser(s): }\end{array}$ & $\begin{array}{l}\text { The City of Vienna is supported by the Austrian Society for Environment and } \\
\text { Technology (OGUT). OGUT is a non-party association building a platform between } \\
\text { economic, political and ecological interests. The Society acts as a platform to initiate } \\
\text { networking and communication between its members promoting development and } \\
\text { innovation in the environmental field. In } 2002 \text { a Strategic Waste Prevention Group } \\
\text { was founded in Vienna on a platform of coordination supported by OGUT. The aim of } \\
\text { the Strategic Waste Prevention Group is to involve all the city departments relevant } \\
\text { to waste prevention (i.e. waste management, environmental affairs, public relations, } \\
\text { planning, and climate change prevention). }\end{array}$ \\
\hline & $\begin{array}{l}\text { How does the } \\
\text { programme work?: }\end{array}$ & $\begin{array}{l}\text { Since the late } 1990 s, \text { Vienna has been developing waste prevention activities after a } \\
\text { Strategic Environmental Assessment carried out between } 1999 \text { to } 2001 \\
\text { recommended measures to reduce waste generation. The } 2002 \text { Austrian Waste } \\
\text { Management Act stipulates three areas of activity for sustainable waste prevention: } \\
\text { the application of appropriate production and distribution processes, the eco-design } \\
\text { of products and the behaviour of consumers. In } 2003 \text {, the Strategic Waste Prevention } \\
\text { Group had } € 5 \text { million to fund projects. Demonstration projects set up in } 2004 / 5 \\
\text { included encouraging the use of re-usable cups and glass pitchers, educational } \\
\text { schemes, the promotion of re-usable packaging for transporting goods; vouchers for } \\
\text { re-usable nappies and the promotion of repair services (for example for mobile } \\
\text { phones). } \\
\text { In particular, the Vienna Repair Network and Repair and Service Centre (RUSZ) are } \\
\text { successful and innovative instruments for the city. A novelty for customers was the } \\
\text { introduction of the 'repair bonus card' - allowing those who had already ordered } \\
\text { three repair jobs to receive } € 5 \text { discount on the fourth repair. } 5,200 \text { cards were } \\
\text { distributed valid for } 2005 \text {. Information about the repair, re-use and rental markets in } \\
\text { Vienna is provided in brochures and over the internet. In 1999, an internet exchange } \\
\text { platform for second-hand goods was set up by the city's Environmental Protection } \\
\text { Department in collaboration with the Waste Department. The exchange system is } \\
\text { divided into four streams: second-hand goods; compost; toys; and information. The } \\
\text { information stream provides online versions of practical guides for repair, rentals and } \\
\text { waste disposal. }\end{array}$ \\
\hline
\end{tabular}




\begin{tabular}{|c|c|c|}
\hline & \multicolumn{2}{|r|}{ Vienna dematerialisation / waste prevention activities } \\
\hline & $\begin{array}{l}\text { Costs } \\
\text { (Implementation } \\
\text { and operation) }\end{array}$ & $\begin{array}{l}\text { From } 1998 \text { to } 2007 \text { RUSZ was commissioned by the Viennese labour administration } \\
\text { (AMS) to reintegrate elderly long-term unemployed and disabled. In these ten years } \\
\text { RUSZ was funded with } € 35 \text { ooo per transitory work place per year on the average } \\
\text { (which amounted to about } € 3 \text { Million in 2007). RUSZ became a private, not for profit } \\
\text { enterprise in } 2008 \text { and has since successfully covered its costs }{ }^{160} \text {. }\end{array}$ \\
\hline & $\begin{array}{l}\text { What is the level of } \\
\text { novelty?: }\end{array}$ & $\begin{array}{l}\text { The novelty of focusing on encouraging a shift to immaterial consumption is very } \\
\text { high, given consumption levels in Western societies. Two approaches to waste } \\
\text { prevention have been developed corresponding to high-and low-income sectors of } \\
\text { society. For the lower earners, encouraging resource optimal consumption is the } \\
\text { priority. Information dissemination is the main instrument for this desired shift in } \\
\text { consumer attitudes to take place. For the higher earners the challenge is to divert } \\
\text { spending on products to spending on services instead. Rather than consuming } \\
\text { material objects in their leisure and luxury time, citizens are instead encouraged to } \\
\text { engage in cultural, social and educational activities. In terms of trying to change } \\
\text { consumption patterns it appears that many of the activities are focused on } \\
\text { information provision and awareness-raising so not high novelty in themselves. }\end{array}$ \\
\hline & $\begin{array}{l}\text { Impacts/savings/ } \\
\text { behavioural } \\
\text { change: }\end{array}$ & $\begin{array}{l}\text { A recent study claims that although the quantity of waste increases in total, residual } \\
\text { waste (2005: 509,922 t and 2006: } 508,918 \mathrm{t} \text { ) remained almost constant. On the } \\
\text { contrary the amount of separately collected recyclables and organic waste during the } \\
\text { same period increased by } 2.8 \% \text { ( } 2006: 325,130 \text { tons). The total mass of collected } \\
\text { waste ( } 1 \text { million tons) corresponds to an annual waste generation of } 624 \mathrm{~kg} \text { per } \\
\text { inhabitant, of which } 323 \mathrm{~kg} \text { are residual and bulky waste as well as } 200 \mathrm{~kg} \text { of } \\
\text { recyclables and hazardous waste. }\end{array}$ \\
\hline & & $\begin{array}{l}\text { In } 2004 \text {, demand for the Repair and Service Centres (RUSZ) increased substantially } \\
\text { and exceeded previously set targets largely as a result of extensive media coverage. } \\
\text { The Vienna authorities calculate that about } 11,000 \text { tonnes of waste is saved by the } \\
\text { RUSZ centres, while the flea market saves around } 1000 \text { tonnes of waste annually. }\end{array}$ \\
\hline & & $\begin{array}{l}\text { From Vienna's most recent }(2006 / 7) \text { Environmental Report, } 1 \mathrm{~m} \text { tonnes of waste are } \\
\text { collected every year, with around } 40 \% \text { of this being collected separately for recycling. } \\
\text { Furthermore, by reducing the quantity of waste and switching to more cost-effective } \\
\text { categories, around } 180 \text { tonnes of waste was reduced from } 2005 \text { to } 2006 \text {, saving } \\
\text { around } € 30 \text { ooo in additional costs. }\end{array}$ \\
\hline & $\begin{array}{l}\text { Key factors for } \\
\text { success: }\end{array}$ & $\begin{array}{l}\text { Strengths: The grouping of many experts on waste prevention from different sectors } \\
\text { is likely to be listened to more than a city department, and yet it has buy-in from } \\
\text { many crucial departments and individuals. }\end{array}$ \\
\hline 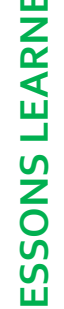 & & $\begin{array}{l}\text { The competition format is a good instrument to generate new ideas, but needs } \\
\text { strong local buy-in and must be followed up by adequate funding for demonstration } \\
\text { and continuing projects - one year projects are just not long enough. } \\
\text { Weaknesses/difficulties: Recycling and waste prevention are mixed together as } \\
\text { ideas in people's minds. It is hard to understand that prevention is a further step than } \\
\text { recycling It is important to be clear about what the city is trying to achieve in the } \\
\text { long-term. }\end{array}$ \\
\hline$\frac{山}{4}$ & $\begin{array}{l}\text { Questions and gaps } \\
\text { in knowledge }\end{array}$ & $\begin{array}{l}\text {-What is the effectiveness of activities and its relationships with other possible } \\
\text { mechanisms (household waste charges)? Have changes in consumption patterns } \\
\text { occurred and have these impacts been shifted elsewhere (e.g. personal transport to } \\
\text { attend cultural events)? }\end{array}$ \\
\hline
\end{tabular}

${ }^{160}$ A private, not for profit organisation refers to an organisation that is incorporated under State law and whose purpose is not to make a profit, but rather to further a charitable, civic, religious, scientific, or other lawful purpose (Source on RUSV here : www. unhabitat.org/bestpractices/2010/mainview.asp?BPID=2291) 


\begin{tabular}{|c|c|}
\hline \multicolumn{2}{|r|}{ Vienna dematerialisation / waste prevention activities } \\
\hline Contacts & $\begin{array}{l}\text { Dipl.Ing. Reinhard Siebenhandl } \\
\text { Einsiedlergasse } 2 \\
1050 \text { Wien } \\
\text { Tel.: + } 43158817 / 48051 \\
\text { Fax: + } 43158817 / 99 / 480038 \\
\text { e-mail: reinhard.siebenhandl@wien.gv.at }\end{array}$ \\
\hline $\begin{array}{l}\text { Data sources I } \\
\text { references }\end{array}$ & $\begin{array}{l}\text {-ACR+ webpage on 'promoting repair and reuse' in its changing consumption } \\
\text { behaviour section: } \\
\text { http://resourcities.acrplus.org/dematerialisation/practices/Repair.htm } \\
\text {-StadtWien 'Vienna Environmental Report 2006-2007': } \\
\text { http://www.wien.gv.at/english/environment/protection/reports/pdf/complete- } \\
\text { o6.pdf } \\
\text { - Green Alliance case study on Vienna as part of an international survey of Zero } \\
\text { Waste Initiatives: http://www.green- } \\
\text { alliance.org.uk/uploadedFiles/Our Work/Vienna.pdf } \\
\text { - European Commission website on waste prevention best practices (Vienna fact } \\
\text { sheet): } \\
\text { http://ec.europa.eu/environment/waste/prevention/pdf/Vienna_Factsheet.pdf } \\
\text { - StadtWien waste management service brochure 'Waste Management in Vienna'; } \\
\text { http://www.wien.gv.at/umwelt/ma48/service/publikationen/pdf/abfallwirtschaft- } \\
\text { - UN.pdf } \\
\text { www. } \\
\text { wwitat database: }\end{array}$ \\
\hline
\end{tabular}

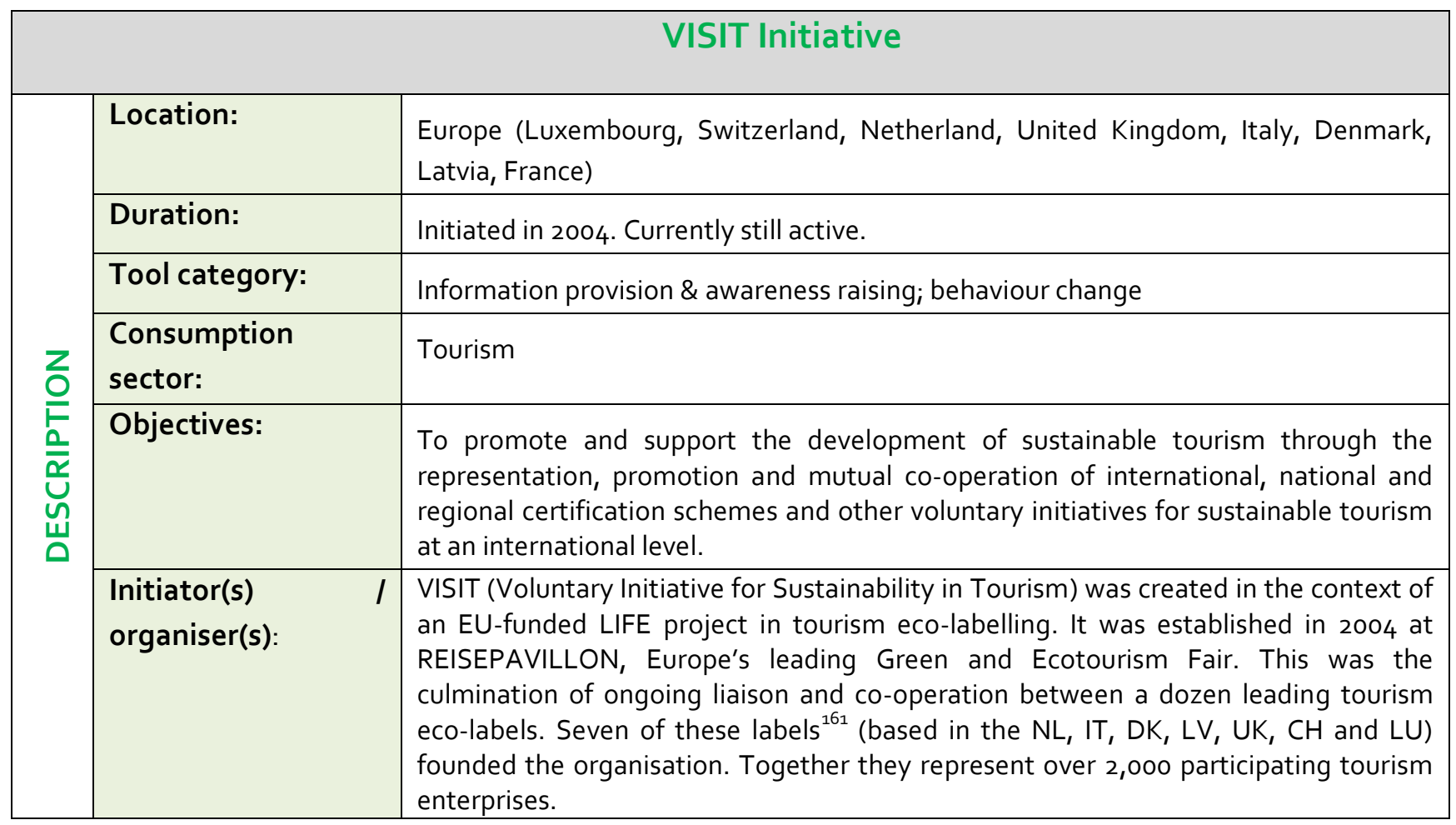

\footnotetext{
${ }^{161}$ Green key (FR \& DK), Legambiante Turismo (IT), Green Tourism Business (UK), OE Plus (CH), Zalãs Brïvdienas (LV), Milieu Barometer (NL) and Emweltzenterlu (LU).
} 


\section{VISIT Initiative}

\begin{tabular}{|c|c|}
\hline $\begin{array}{l}\text { How does the } \\
\text { programme work? : }\end{array}$ & $\begin{array}{l}\text { VISIT unites stakeholders of the tourism industry in order to create better co- } \\
\text { operations and exchanges in sustainable tourism. After having met the } 21 \text { key criteria } \\
\text { created by VISIT, any ecolabel has the right to join the association as a member. Any } \\
\text { other kind of organisation interested in sustainable tourism is also welcome to be } \\
\text { part of the network as an associate. The aim of VISIT is to move the market towards } \\
\text { sustainability. } \\
\text { This implies : } \\
\text { - promotion of and support to sustainable tourism development; } \\
\text { - promotion of its full members and their certified products; } \\
\text { - promotion of certification for sustainability in tourism in compliance with the } \\
\text { VISIT standards; } \\
\text { protection and further development of the VISIT standards for tourism } \\
\text { certification schemes; } \\
\text { support of the mutual recognition, co-operation and exchange of } \\
\text { information, experience and expertise among the members, as well as other } \\
\text { expressed members' interests; } \\
\text { support for activities between members and stakeholders; and } \\
\text { - development and protection of the VISIT name and concept. }\end{array}$ \\
\hline $\begin{array}{l}\text { Costs } \\
\text { (Implementation } \\
\text { and operation) }\end{array}$ & No data available on costs. \\
\hline $\begin{array}{l}\text { What is the level of } \\
\text { novelty? : }\end{array}$ & $\begin{array}{l}\text { Several tourism ecolabels were launched in Europe in the last decades. Practices and } \\
\text { requirements were set differently in each of them. VISIT is the first initiative in } \\
\text { Europe that aims to gather tourism-related organisations and make them exchange } \\
\text { their practices as well as make their requirements uniform. This alliance between the } \\
\text { different eco-labels is based on mutual understanding and recognition and the } \\
\text { agreement to adopt a common standard. The } 21 \text { key criteria }{ }^{162} \text {, developed by VISIT, } \\
\text { are the definition of the baseline set by VISIT. It includes various topics such as } \\
\text { energy and water use, waste generation, transportation, politic, social and cultural } \\
\text { performance and economic performance. }\end{array}$ \\
\hline $\begin{array}{l}\text { Impacts/savings/ } \\
\text { behavioural } \\
\text { change: }\end{array}$ & 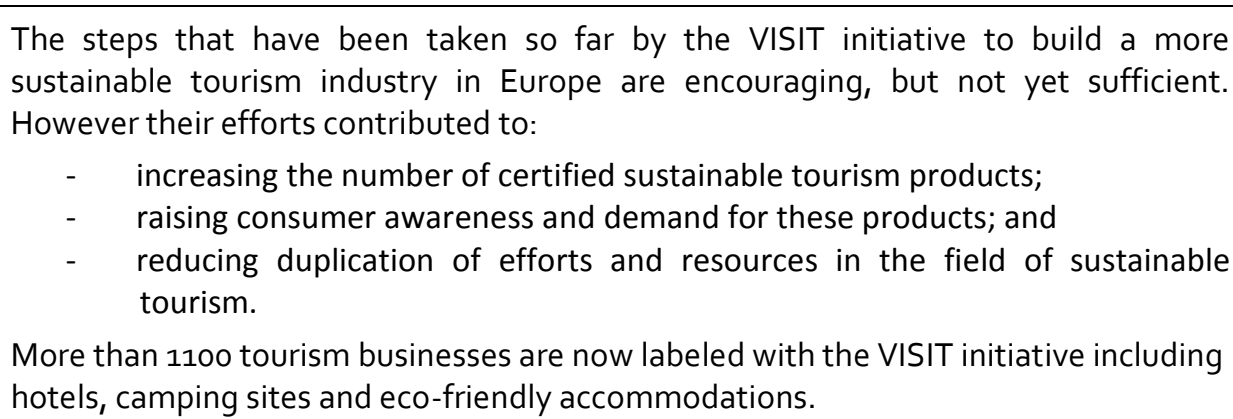 \\
\hline
\end{tabular}

${ }^{162}$ http://www.visit21.net/VISIT key criteria.html 


\section{VISIT Initiative}

\begin{tabular}{|c|c|}
\hline $\begin{array}{l}\text { Key factors for } \\
\text { success: }\end{array}$ & $\begin{array}{l}\text { The main key factors of success of the VISIT initiative are: } \\
\begin{array}{c}\text { - } \\
\text { - }\end{array} \text { ability to facilitate constructive exchanges between members and associates; } \\
\text { - } \quad \text { ability to gather the major actors of the sustainable tourism industry; and } \\
\text { ability to harmonise the diversity of ecolabels through the development of a } \\
\text { set of common criteria. } \\
\text { In order to achieve these goals, VISIT is constantly working on: } \\
\text { - } \quad \text { improving the VISIT Standard ( } 21 \text { criteria); } \\
\text { - } \quad \text { communicating and improve the VISIT message and vision; } \\
\text { - } \quad \text { comparing the VISIT Label to other labels; } \\
\text { - } \quad \text { helping member associations to communicate and collaborate. } \\
\text { VISIT is clearly facing a large range of difficulties. First of all the sustainable tourism is } \\
\text { not a very large market. The demand is relatively low compared to regular tourism. } \\
\text { The popularity of the organisation itself is quite low. There is a clear lack of marketing } \\
\text { and communication with the general public. As an example, their website has not } \\
\text { been updated since around } 2005 \text {. There is also a lack of a formal accreditation } \\
\text { procedure to check compliance with the } 21 \text { key criteria. On-going negotiations are } \\
\text { trying to address this issue and would make the initiative much stronger. }\end{array}$ \\
\hline $\begin{array}{l}\text { Questions and gaps } \\
\text { in knowledge }\end{array}$ & $\begin{array}{l}\text { Can the VISIT initiative be improved through experience of other major ecolabels } \\
\text { such as Nordic Swan or the EU Flower? }\end{array}$ \\
\hline Contacts & $\begin{array}{l}\text { - Chairman / President: Luigi Rambelli Legambiente TurismoPiazza XX, } \\
\text { Settembre 7, } \\
\text { 40121 Bologna, Italia } \\
\text { info@legambienteturismo.it }\end{array}$ \\
\hline $\begin{array}{l}\text { Data sources } \quad \text { } \\
\text { references }\end{array}$ & $\begin{array}{l}\text { VISIT official website: } \\
\text { http://www.visit21.net/ } \\
\text { Ecotrans website: } \\
\text { http://www.ecotrans.org/visit/brochure/fr/140.htm } \\
\text { Websites of affiliated ecolabels: } \\
\text { http://www.laclefverte.org/recherche-clef-verte.php } \\
\text { http://www.oe-plus.ch/ } \\
\text { http://www.greenkey.nl/ } \\
\text { http://www.green-business.co.uk/ } \\
\text { http://www.legambienteturismo.it/ } \\
\text { http://www.eco.celotajs.Iv/ } \\
\text { Tourism eco-labelling in Europe - moving the market towards sustainability: } \\
\text { http://www.ecotrans.org/visit/docs/pdf/visit_en.pdf }\end{array}$ \\
\hline
\end{tabular}




\title{
7.5 Annex 3: Detailed assessment of toolboxes of key sectors
}

\section{Urban mobility}

\author{
Sectoral analysis
}

General

trends in the

sector

Significant

environmental

impact, in

particular with

regard to $G H G$

emissions

Expect

increases in

demand for

transport and

associated

energy needs

to 2030
Transport is acknowledged as one of the three consumption activities with the greatest environmental impacts. The European Environment Agency's (EEA) 2010 State of the Environment Report identifies transport as a continuing problematic sector for GHG emissions. Transport-related GHGs increased by $24 \%$ in the EU-27 between 1990 and 2008, excluding aviation and marine transport. The rail freight and inland waterway market share declined, while the number of cars in the EU-27 increased by $22 \%$ ( 52 million cars) between 1995 and 2006 (EEA 2010).

The 2006 study on the Environmental Impacts of Products (EIPRO) identified transport as contributing to $15 \%$ of global warming potential and acidification and to $15-35 \%$ of the total environmental impacts of private consumption (IPTS/ESTO, 2006). The greatest impact (4/5) was found to originate from cars despite recent improvements in vehicle emissions. This was echoed in a 2010 UNEP Resource Panel report identifying the products and materials with the greatest environmental impacts which maintained that one of the two general activities with the greatest impact was the use of fossil fuels for transportation (UNEP, 2010). The study also provided a rare reflection on the types of capital investment with significant environmental impacts, transport infrastructure featured prominently in this regard. A follow-up study to EIPRO ('IMPRO-cars') identified improvement options for passenger cars from a product perspective. In addition to focusing on design and technology changes that could reduce impacts (such as light-weighting of vehicles, lowerresistant tyres, etc.), it also considered impact reductions via behaviour-focused measures such as reduced speed limits on motorways and eco-driving behaviour (JRC/IPTS, 2008).

Very few studies exist that set out future trends on EU mobility and its impacts. A 2004 Commission study provided forecasts to 2030 (EC, 2004), albeit from a more positive economic perspective than is currently being experienced. EU-25 passenger transport was anticipated to grow by $1.5 \%$ per year, and freight transport by about $2.5 \%$ per year. The rail share of both passenger and freight transport was forecasted to fall considerably, with road and air travel increasing. Transport energy demand growth was forecasted to decelerate in the long run due to technological progress (particularly due to limiting $\mathrm{CO}_{2}$ emissions from cars) and the projected decoupling of transport activity from economic growth. The report, however, does not appear to address the rebound effect usually seen through increasing consumption (e.g. distances travelled) due to reduced costs (e.g. from increased fuel efficiency) of which passenger car transport is the standard example given.

The transport sector is forecast to have increasing energy needs to 2030 despite the projected decoupling of transport activity from economic growth in the long run. At the time, this sector was identified as suffering from a lack of alternatives to change the fuel mix towards less carbon intensive fuels (although this is slowly changing). Transport was forecasted to remain an important element of energy needs, accounting for approximately one-third of final energy demand to 2030. It was also seen as the fastest growing demand sector amongst the EU-10 (at the time), rising from $19.2 \%$ in final energy demand in 2000 to $25.4 \%$ in 2030 (EC, 2004). To date, EU transport-related policies addressing climate change have focused primarily on 


\section{Urban mobility}

\begin{tabular}{l|l}
\hline $\begin{array}{l}\text { technical and } \\
\text { political } \\
\text { challenges }\end{array}$ & $\begin{array}{l}\text { technological improvements in terms of improved efficiency in fuel consumption and in } \\
\text { GHG reduction in fuels. However, most Member States are finding it difficult to achieve the } \\
\text { faced }\end{array}$ \\
$\begin{array}{l}\text { levels of reduction of air pollutants required under EU air quality legislation, mostly due to } \\
\text { difficulties in managing traffic levels, particularly in urban areas. It is therefore unlikely that a } \\
\text { continuing focus on technological solutions can achieve reductions in both GHG levels and } \\
\text { other air pollutants. }\end{array}$
\end{tabular}

Technical

improvements

alone are not

sufficient and

can generate

delicate trade-

offs

Company cars

are under-

taxed

The car has a

certain social

status

Personal

comfort and

convenience is

prioritised
A UNEP Resource Panel study identified an important consideration for the future impact of reduction strategies in relation to transport (something that few transport strategies have done yet, including the EU's). According to the study: "Developing impact reduction strategies has its complications. There are certain interlinkages between problems that may further aggravate them in future. For example, many proposed sustainable technologies for energy supply and mobility rely for a large part on the use of metals. Examples are batteries in electric cars, and components of solar cells and fuel cells. Metal refining usually is energy intensive. The production of such novel 'clean-tech' infrastructure may hence be energy-intensive, and create scarcity of certain materials, issues not yet investigated sufficiently. There is hence a need for analysis to evaluate trends, develop scenarios and identify sometimes complicated trade-offs between one type of environmental impacts and another" (UNEP, 2010).

Addressing policy incoherence is another important political challenge. For example, in relation to company car taxation a recent study for the Commission (EC, 2010) notes that company cars represent approximately $50 \%$ of car sales and the tax breaks for such cars and fuel represents a subsidy of $€ 54$ bn while increasing $\mathrm{CO}_{2}$ emissions from cars by $4-8 \%$. Company cars are under-taxed compared to income or other types of tax and results in many Member States losing potential revenue and welfare losses from increased GHG emissions and poorer air quality for more people than those that benefit from this corporate 'perk'. In some countries, company cars represent $50 \%$ of the total car market and a greater number of larger cars are leased than if employees were buying their own vehicles. In some extreme cases, business travel in company cars represents $20-30 \%$ of total travel by the employees, showing how such policies encourage car use far beyond what might have originally been anticipated.

Social aspects have an important role to play in influencing how people behave in relation to personal transport. In much of Western industrialised society, the car is often seen as a measure of success, as a status symbol to communicate our status in society. Company cars are also sometimes offered as a benefit to employees in replacement of higher salaries which would often mean higher income tax levels. Therefore, personal transport vehicles are often presented as an extension of the individual, rather than as one of a variety of means of transport available. Taking one's car is very habit-forming, with drivers often automatically opting to drive, even for short distances which are manageable on public transport, or by bike or foot. The personal vehicle also still carries with it an image of freedom and speed, despite increasing urban traffic levels making other forms of public or non-motorised traffic faster. Personal comfort, convenience and a sense of personal space and privacy seem also to be prioritised above the overall time taken to make the average journey.

These social factors coupled with the position given to the passenger vehicle in spatial design which has led to a certain degree of infrastructure lock-in means that any efforts to encourage modal shift from private to public transport need to take into consideration alternative transport options and the availability, convenience, comfort and price of public transport options. A number of cities have recently encouraged a modal shift to cycling by providing public bicycle networks. Initiatives encouraging cycling and walking have also long existed, sometimes with a particular focus on school children to help reduce the amount of traffic created by parents driving their children to and from school. However, to achieve the necessary model shifts called for, it will be necessary to either introduce far reaching restrictive policies such as congestion charging, or promote fundamental shifts in how people perceive public transport. 


\section{Urban mobility}

\section{Sectoral analysis of tools}

\section{Selection of available tools}

\begin{tabular}{|c|c|c|c|c|c|c|}
\hline Tool name and location & $\begin{array}{l}\text { D } \\
\text { D } \\
\stackrel{0}{C} \\
\frac{C}{0} \\
\stackrel{+}{0} \\
\stackrel{0}{2}\end{array}$ & $\begin{array}{l}\underline{T} \\
\underline{\hat{D}}\end{array}$ & 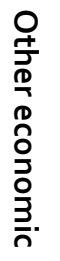 & $\begin{array}{l}\overline{5} \\
\overline{0} \\
\frac{0}{3} \\
3 \\
0 \\
\frac{2}{5} \\
\frac{0}{3}\end{array}$ & 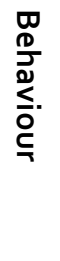 & 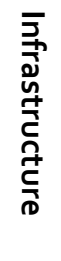 \\
\hline $\begin{array}{l}\text { Directive } 2009 / 33 / E C \text { on the promotion of clean and energy- } \\
\text { efficient vehicles }\end{array}$ & $\mathrm{X}$ & & & & & \\
\hline $\begin{array}{l}\text { City circulation charging (Milan, IT; Valletta, MT; Stockholm, } \\
\text { SE; London, UK) }\end{array}$ & & $\mathrm{x}$ & & & & \\
\hline $\begin{array}{l}\text { National eco-driving campaign (AT, BE, CZ, EL, FI, FR, NL, PL, } \\
\text { SE, UK) }\end{array}$ & & & & $x$ & $\mathrm{X}$ & \\
\hline $\begin{array}{l}\text { CO2 emissions vehicle bonus-malus schemes and } \\
\text { differentiated taxation (AT, CY, DE, DK, EI, EL, FI, FR, HU, IT, } \\
\mathrm{LT}, \mathrm{LU}, \mathrm{MT}, \mathrm{NL}, \mathrm{PL}, \mathrm{PT}, \mathrm{RO}, \mathrm{SI}, \mathrm{UK} \text { ) }\end{array}$ & & $x$ & & & & \\
\hline Scrappage schemes (DE, DK, EL, El, ES, FR, IT, UK) & & & $x$ & & & \\
\hline Vehicle labelling (required by Directive 1999/94/EC) & & & & $x$ & & \\
\hline $\begin{array}{l}\text { Parking-related activities - fees, caps on spaces, street design, } \\
\text { etc. (BE, DE, DK, ES, FR, NL, SE, UK) }\end{array}$ & $x$ & $x$ & $x$ & & & $x$ \\
\hline Modal shift activities (various cities) & & & $X$ & $x$ & $x$ & $X$ \\
\hline
\end{tabular}

Overview of Given that in the past most transport policy related to climate change / air pollution has available focused on technological improvements, notably to improve efficiency in vehicles; activity tools $\quad$ has historically focused on encouraging the purchase of more fuel efficient vehicles than in effecting modal shifts. For example, the EU Directive 2009/33/EC on the promotion of clean and energy-efficient vehicles requires that energy and environmental impacts linked to EU policy the operation of road transport vehicles are taken into account in purchase decisions, thus focus has been on promoting the use of low emission vehicles in public transport. The 'bonus-malus', differentiated charging schemes (for registration fees, circulation taxes, etc.), and scrappage technological improvements older, less efficient vehicles with newer ones (with scrappage schemes also being used to stimulate growth in the car industry). Further, the Clean Transport Systems started in 2010, is an important inititative launched by the Commission aimed at facilitating the long term substitution of fossil fuels in transport.

Modal shift activities, such as better alternative transport infrastructure design and provision (such as rail, public transport and bicycles), incentive schemes, congestion and road use charging, are all relatively recent activities. These activities aim to reduce actual private

Increasing number of passenger transport distances and road usage (numbers of passenger vehicles). As many of these activities are more recent, their impact is less evident on overall vehicle ownership or activities to encourage modal shift at vehicle trips. At the EU level, the Thematic Strategy on the Urban Environment was presented in 2006 and in 2009 the Commission presented the Action Plan on Urban Mobility and Directive $2009 / 33 / E C$ on the promotion of clean and energy-efficient vehicles which set out a number of non-legislative measures to increase knowledge, 


\section{Urban mobility}

\begin{tabular}{|c|c|}
\hline $\begin{array}{l}\text { The potential } \\
\text { of eco-driving } \\
\text { practices }\end{array}$ & 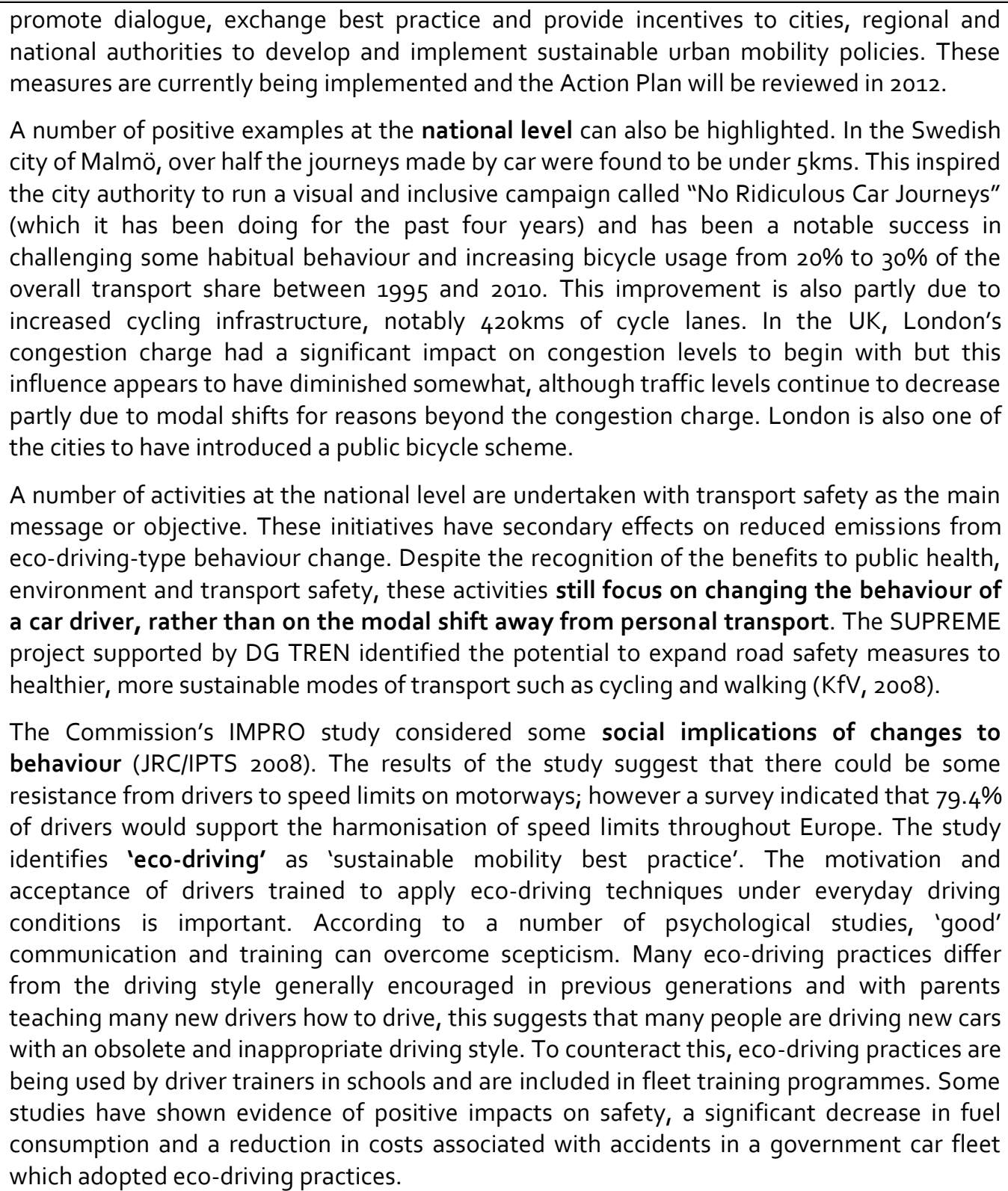 \\
\hline
\end{tabular}

Elements of an effective sectoral toolbox
Personal transport provides a prime example of the rebound effect where efficiency gains have been undermined by increases in both vehicle ownership and in the distances travelled. Therefore, any focus on efficiency gains will not ensure sustainable consumption unless steps are taken to get the prices of passenger vehicles right in order to encourage modal shift and change the status of car ownership.

Two long-term EU policy 'roadmaps' produced in 2011 are of direct relevance to transport and have taken different approaches to future transport policy needs. The 'low carbon economy roadmap' identifies transport as one of the contributing areas to deliver the goal of achieving GHG reductions of $80-95 \%$ by 2050 . It suggests that technological innovation on vehicle efficiency through new engines, materials and design; cleaner energy use through new fuels and propulsion systems; and better use of networks can help effect the shorter-term transition to a more efficient and sustainable EU transport system. The roadmap maintains that emissions from road, rail and inland waterways could be brought below 1990 levels by 2030 if fuel efficiency activities are combined with "measures such as 


\section{Urban mobility}

\begin{tabular}{l|l} 
Get the prices & $\begin{array}{l}\text { pricing schemes to tackle congestion and air pollution, infrastructure charging, intelligent city } \\
\text { planning, and improving public transport, whilst securing affordable mobility". Linking to } \\
\text { technological innovation, it suggests that improved efficiency and better demand-side } \\
\text { management, through } \mathrm{CO}_{2} \text { standards and smart taxation systems, could help drive the } \\
\text { development and spread of hybrid engine technologies in all transport modes. The } \\
\text { 'transport roadmap 2050' focuses on road charging as a way of generating revenue and } \\
\text { influencing travel behaviour. Guidelines on internalising charges of all vehicles for all the } \\
\text { main externalities are to be developed, with the long-term goal being to apply user charges } \\
\text { to all vehicles and on the whole network to reflect at least the maintenance costs of } \\
\text { infrastructure, congestion, air and noise pollution. Modal shift in transport forms a key } \\
\text { element of future transport policy options. Behavioural elements feature prominently in the } \\
\text { transport roadmap relating to modal shift, improved vehicle purchasing behaviour, carbon } \\
\text { footprints for different modes of transport, eco-driving and speed limits. }\end{array}$
\end{tabular}

These roadmaps indicate some of the different elements ranging from technological innovation to demand-side management that are needed for a sectoral toolbox that can affect modal shift. An important element of future policy activities relating to (urban) mobility will be building an appropriate societal context through infrastructure investment and spatial design that favours non-motorised and public transport and introducing financial mechanisms that are coherent with sustainable transport aims. Another important and related element will be repositioning the personal vehicle so that it is not the default choice of mode of transport. A mix of several different policies are required including:

Reposition the personal vehicle

- Guidelines for spatial planning (e.g. to promote public transport, encourage modal shift, promote non-motorised travel for urban personal transport and for freight transport reducing the number of lorries on the road and effecting the shift from road to rail);

- Revise fiscal and taxation policies (e.g. congestion and road use charging, vehicle taxes, fuel taxes) as a means to incentivise more environmental friendly travel);

- Redirect infrastructure funding (e.g. to prioritise non-motorised and public transport infrastructure);

- Introduce demand-side management policies (e.g. restricted access schemes, deploy ITS applications in support of eco-driving, provide incentives to encourage people to try new forms of transport - e.g. free trial bus passes).

- Where motorised personal transport is still a necessity, encourage coordinated action to promote eco-driving, explore technology improvement options for passenger vehicles etc.

There are a number of insights provided by behavioural sciences which can inform how policies might promote these kinds of model shifts:

- People are often reluctant to sell their old cars even if a new vehicle would be more cost-effective in the long-term. Such emotional attachments can be strong, leading some people to own a car even when the full costs of owning a car actually outweigh the benefits. Policy efforts to challenge this will need to make these cost comparisons explicit.

- The use of cars for short journeys is strongly habit forming. The more often people make such journeys, the more likely they are to become habitual, which means we often make them without really thinking about it. Free trial bus passes provide good incentives to encourage people to try a new form of transport and have proven effective.

- Cars say a great deal about the people that drive them. Some people have an outdated perception of electric vehicles; others see hybrid cars as making a statement about themselves. This is why some of the most successful alternative vehicles are not available in a conventional (non-hybrid) version. 


\begin{tabular}{|c|c|}
\hline \multicolumn{2}{|c|}{ Urban mobility } \\
\hline $\begin{array}{l}\text { Designing } \\
\text { policies to } \\
\text { encourage } \\
\text { modal shifts }\end{array}$ & $\begin{array}{l}\text { - People dislike losses more than they like gains. Highlighting the costs associated } \\
\text { with fuel inefficient cars will have more of an impact on consumer behaviour than } \\
\text { efforts that highlight the benefits of a fuel-efficient car. } \\
\text { - People are attracted to things that are 'free': A car that is tax-free or free from } \\
\text { some other up-front or long-term cost will be more attractive than an extremely } \\
\text { small rate of tax or cost. Thus, removing the tax on vehicles with the lowest levels } \\
\text { of } \mathrm{CO}_{2} \text { emissions will be more motivating to consumers than very low tax rates. } \\
\text { - People often seek what is 'normal' and follow others. If travelling by public transport } \\
\text { is perceived as a social norm, many people will follow this. Also, consumers often } \\
\text { assume that the standard vehicle mode (for example, the model they get if they do } \\
\text { not add any optional extra features) is preferable. Encouraging manufacturers of } \\
\text { fuel-efficient vehicles to make the most efficient vehicle the standard model will } \\
\text { improve take-up rates. } \\
\text { - A recent OECD survey showed that the relative price of different transport modes } \\
\text { has an influence on the mode chosen, with } 35 \% \text { of respondents saying they would } \\
\text { drive their cars less if public transport was cheaper. Accessibility of public transport } \\
\text { infrastructure, rapidity, convenience and comfort are other factors, which need to } \\
\text { be considered. }\end{array}$ \\
\hline \multicolumn{2}{|l|}{ References } \\
\hline & 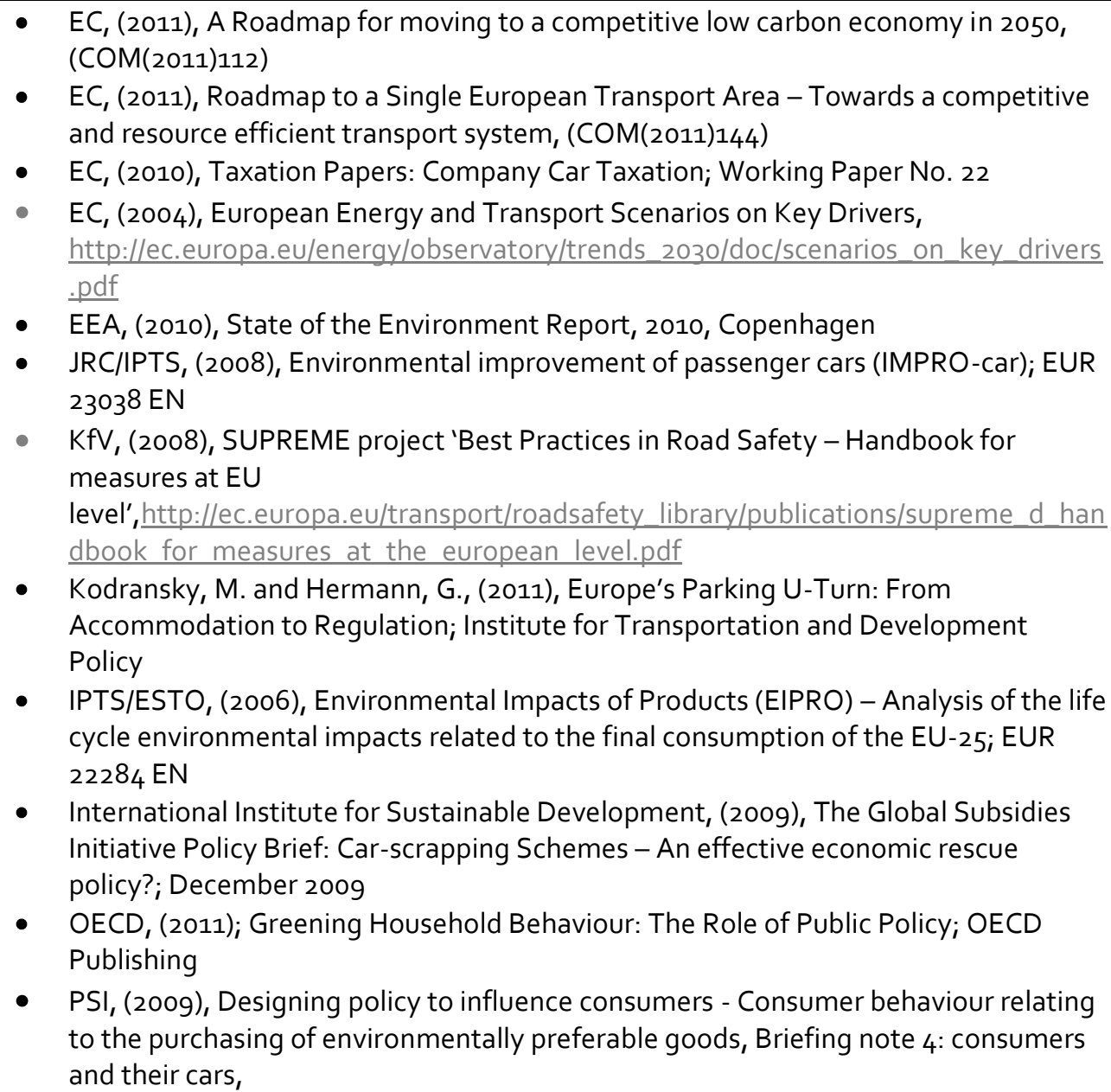 \\
\hline
\end{tabular}




\section{Urban mobility}

\begin{tabular}{|l|l|}
\hline http://ec.europa.eu/environment/enveco/pdf/RealWorld_Briefing4Cars.pdf \\
UNEP, (2010), Assessing the Environmental Impacts of Consumption and \\
Production: Priority Products and Materials, A Report of the Working Group on the \\
Environmental Impacts of Products and Materials to the International Panel for \\
Sustainable Resource Management. Hertwich, E., van der Voet, E., Suh, S., Tukker, \\
A, Huijbregts M., Kazmierczyk, P., Lenzen, M., McNeely, J., Moriguchi, Y.
\end{tabular}

\section{Air travel}

\section{Sectoral analysis}

\section{General} trends in the sector

\section{Major}

contributor to

GHG

emissions

with

significant

growth

expected

Air travel

becoming

more

accessible to

all social

classes and

has a number

of social and

economic

benefits

Social,

technical and

political

challenges

faced
According to the Intergovernmental Panel on Climate Change (IPCC), air travel is responsible for around 3.5\% of anthropogenic climate change (Penner et al., 2000). IPCC specialists also forecast that $\mathrm{CO}_{2}$ emissions due to air travel will increase by $5-15 \%$ by 2050 (Penner et al., 2000). Aside from $\mathrm{CO}_{2}$ emissions, air travel also releases other GHGs such as NOx, water vapour and sulphate particles. Emissions of $\mathrm{NOx}$ form ozone $\left(\mathrm{O}_{3}\right)$ in the upper troposphere have a global warming effect. Water vapour contributes to the formation of contrails, often visible from the ground, which is also linked to an increase in the formation of cirrus clouds. Both contrails and cirrus clouds warm the Earth's surface, amplifying the global warming effect of aviation (Airport watch, 2011).

Today, air travel represents $14 \%$ of the final energy consumption of transport in the EU (EC, 2011). Although this is relatively low compared to road transport (which represents $81 \%$ of the total energy consumption of transportation), air travel is the second largest contributor to GHG emissions in the EU after passenger transport (passenger cars) and has been growing at a higher rate than any other means of transport (EC, 2008). Between 1980 and 2000, air travel tripled in the EU and is expected to double again by 2020 (Eufocus, 2011). This growth has occurred due to the decreasing cost of air transportation, the proliferation of low cost companies, and the growth in incomes which allows for more frequent, faster, further and luxurious travelling.

Air travel also has many social and economic aspects which need to be taken into consideration. In Europe, the aviation industry (which includes airlines, airports, air traffic controllers, ground crews, and aircraft maintenance personnel) directly employs 700,000 people, with 3.2 million jobs-or $3 \%$ of the EU workforce-indirectly associated with the industry (Eufocus, 2011). Thus, making up an important part of the economy in a number of countries. Air travel also has many social benefits, in particular increasing prosperity combined with cheaper air fares have brought international travel within the reach of more people, while consumer choice has been increased by the transport of goods from around the world. Furthermore, air travel has allowed a greater range of experiences in people's lives, while recreational activities such as tourism offer opportunities for people to rebalance their lives through less conspicuous consumption, for example allowing them to spend more time on leisure activities.

There are several challenges in moving towards more sustainable air transportation. A recent meta-analysis of air travel price elasticity studies found that long distance travel is now less price elastic than short distance travel (Brons et al., 2002). The same study indicates that air travellers have become less price sensitive over the last two decades. This reflects societal values such as the value of freedom and the perceived right to travel. Limiting travel would also counteract wider societal trends of affordable travel, increasing individual mobility and global connectedness, recently referred to as "hypermobility". Global travel has a highly symbolic meaning and is a fundamental part of many individuals' positioning in society 


\section{Air travel}

\begin{tabular}{|c|c|}
\hline $\begin{array}{l}\text { Consumers } \\
\text { are less } \\
\text { sensitive to } \\
\text { the price of air }\end{array}$ & $\begin{array}{l}\text { (Becken, 2007). These findings show that market-based tools such as taxes and incentives, } \\
\text { which target a reduction in demand, could be less efficient than expected. Due to the } \\
\text { high-income elasticity of the demand for air travel, even a high kerosene tax might not } \\
\text { dampen demand substantially. However, little research has been undertaken to investigate } \\
\text { whether passengers are aware of their air travel impacts and whether they are willing to } \\
\text { mitigate those impacts. }\end{array}$ \\
\hline $\begin{array}{l}\text { Tools in the } \\
\text { aviation } \\
\text { sector need to } \\
\text { consider } \\
\text { business and } \\
\text { leisure } \\
\text { travellers }\end{array}$ & 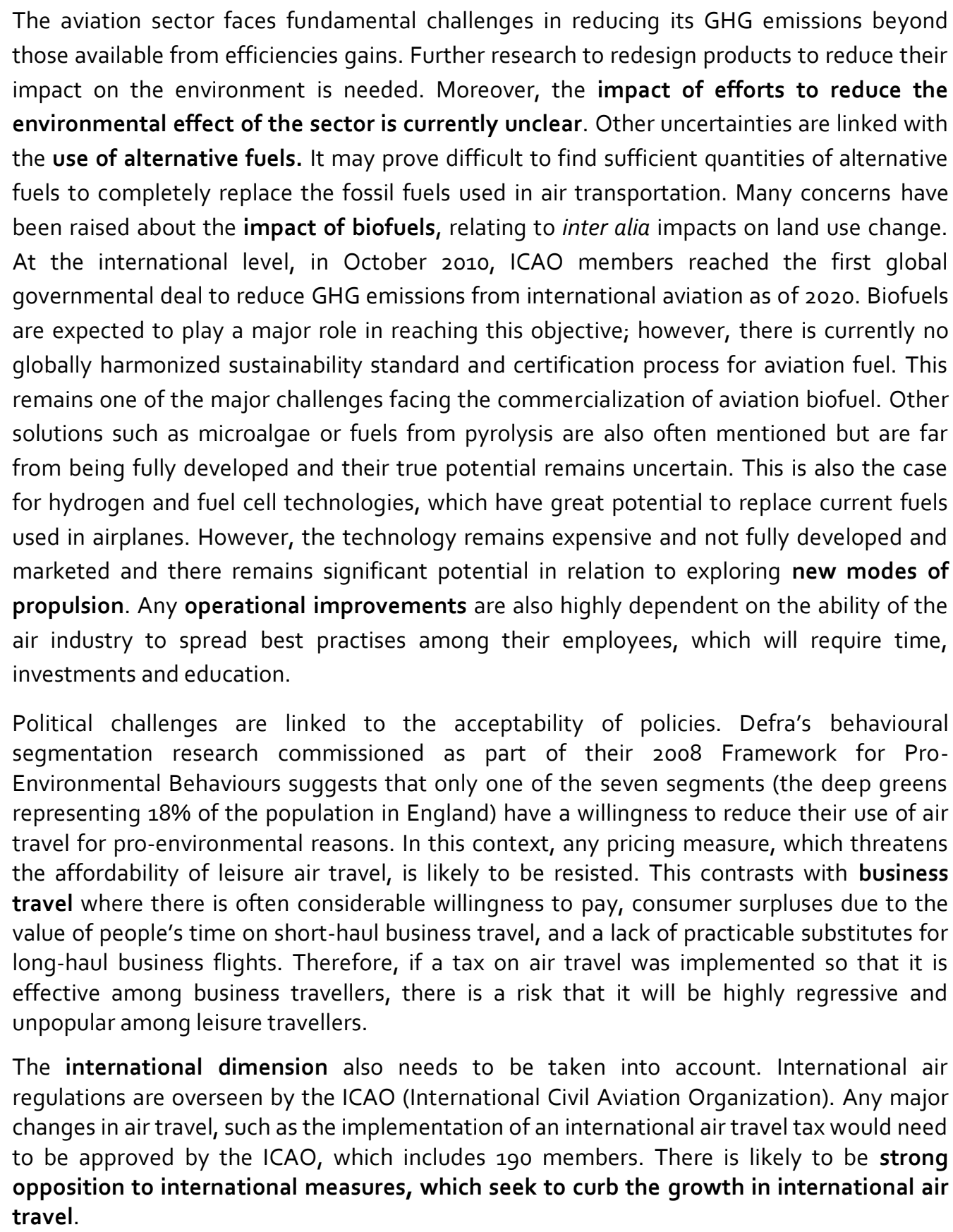 \\
\hline
\end{tabular}




\begin{tabular}{|c|c|c|c|c|c|}
\hline \multicolumn{6}{|l|}{ Selection of available tools } \\
\hline Tool name and location & 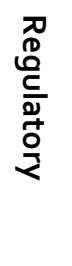 & $\begin{array}{l}\underline{T} \\
\stackrel{n}{\varrho}\end{array}$ & 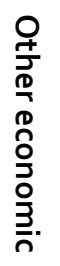 & 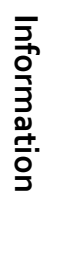 & 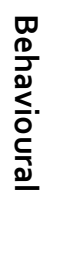 \\
\hline Voluntary carbon off-setting programmes (implemented by airlines) & & & $\mathrm{X}$ & & $x$ \\
\hline Domestic aviation fuel tax (SE) & $x$ & $x$ & & & \\
\hline EU Emissions trading scheme (2012) & $x$ & & $x$ & & \\
\hline $\begin{array}{l}\text { Chirac Air travel Tax - international tax on airline tickets to help fund } \\
\text { the global fight against HIVIAIDS, tuberculosis and malaria (FR) }\end{array}$ & & $x$ & & & \\
\hline Personal carbon trading (not currently implemented for air travel) & & & $x$ & & $X$ \\
\hline $\begin{array}{l}\text { Airport taxes (as a proxy for fuel taxes which can be adjusted to avoid } \\
\text { market distortions) }\end{array}$ & & $x$ & & & \\
\hline
\end{tabular}

Overview of available tools

EU focus has been on market-based tools and innovation rather than influencing consumer behaviour

Use of certain economic tools in the aviation sector is limited due to its international governance
At the EU level, several tools and initiatives are planned or are already in place to promote more sustainable aviation. In July 2008, the EU agreed to bring the aviation sector into the EU Emissions Trading Scheme (ETS) system from 2012. By putting a price on carbon, the EU ETS acts as a permanent incentive to industry to reduce emissions and as a catalyst for innovation. As of $1 / 1 / 2012$, all flights to and from EU airports will be covered by the ETS. Total caps on airlines' $\mathrm{CO}_{2}$ emissions will be set at 3\% below 2004-06 emissions levels in 2012, and at 5\% below 2004-06 emissions levels between 2013 and 2020. Iceland, Norway, and Liechtenstein included aviation in their ETS as of 2010.

The greening of transport including the development of a new generation of greener, quieter, and more efficient aircraft is a priority under the EU's Clean Sky Joint Initiative. The EU's flagship Clean Sky Joint Technology Initiative (JTI) is designed to reduce fuel consumption and $\mathrm{CO}_{2}$ emissions by $50 \%$ per passenger kilometre, lower $\mathrm{NOx}$ emissions by $80 \%$ (during landings and take-offs according to ICAO standards), and decrease unburned hydrocarbons and CO emissions by $50 \%$, all by 2020 .

In terms of aviation taxes, Directive 2003/96/EC on energy taxation allows EU Member States the option to levy a kerosene tax on domestic flights and on intra-Europe flights on the basis of bilateral agreements. However, aviation fuel is exempt from tax on international flights under the 1944 Chicago Convention (that also established the ICAO). Implementing a tax on aviation fuel would be a way to include the environmental costs in the price of air transport and would probably reduce demand for air travel, especially from less-wealthy people. However, this regressive nature (i.e. discrimination by wealth) is considered a major drawback of an air travel tax, as are the economic impacts on the tourism industry and is the subject of much debate. A tax on aviation fuel would require a consensus among all governments who are members of ICAO as the unilateral introduction of such taxes at levels which would impact of behaviour could have serious implications on competitiveness.

An alternative approximation for a fuel tax policy would be the extension in the use of airport taxes. Airport taxes represent an established and legal form of taxation. Although they cannot fully reflect the GHG emissions of air travel they can distinguish between long and short haul flights. Unlike fuel taxes where pre-fuelling is possible, airport taxes are unavoidable to anyone needing to actually visit the country by air. However the transfer 


\begin{tabular}{|c|c|}
\hline $\begin{array}{l}\text { Voluntary } \\
\text { carbon offset } \\
\text { programs are } \\
\text { offered by } \\
\text { many airlines }\end{array}$ & $\begin{array}{l}\text { market would come under competition and there is a potential for policy leakage if set too } \\
\text { high. Such a policy development would therefore benefit from pan-European action to } \\
\text { avoid, for example, aircraft from the USA flying via Frankfurt rather than London if the UK } \\
\text { increased its airport taxes. } \\
\text { In terms of currently available options for behavioural change, air travellers can offset their } \\
\text { flight emissions through voluntary offsetting programmes, reduce the weight of their } \\
\text { baggage or opt to reduce or eliminate their use of air travel. Currently, over } 30 \text { airlines run } \\
\text { voluntary carbon offset programs with different methodologies for calculating emissions } \\
\text { and different criteria for offset projects. Carbon offsetting programmes provide passengers } \\
\text { the opportunity to purchase carbon offsets that are designed to offset the environmental } \\
\text { impact of their airplane trip. }\end{array}$ \\
\hline $\begin{array}{l}\text { Well-designed } \\
\text { information } \\
\text { campaigns to } \\
\text { raise } \\
\text { awareness } \\
\text { and influence } \\
\text { attitudes/ } \\
\text { practices }\end{array}$ & 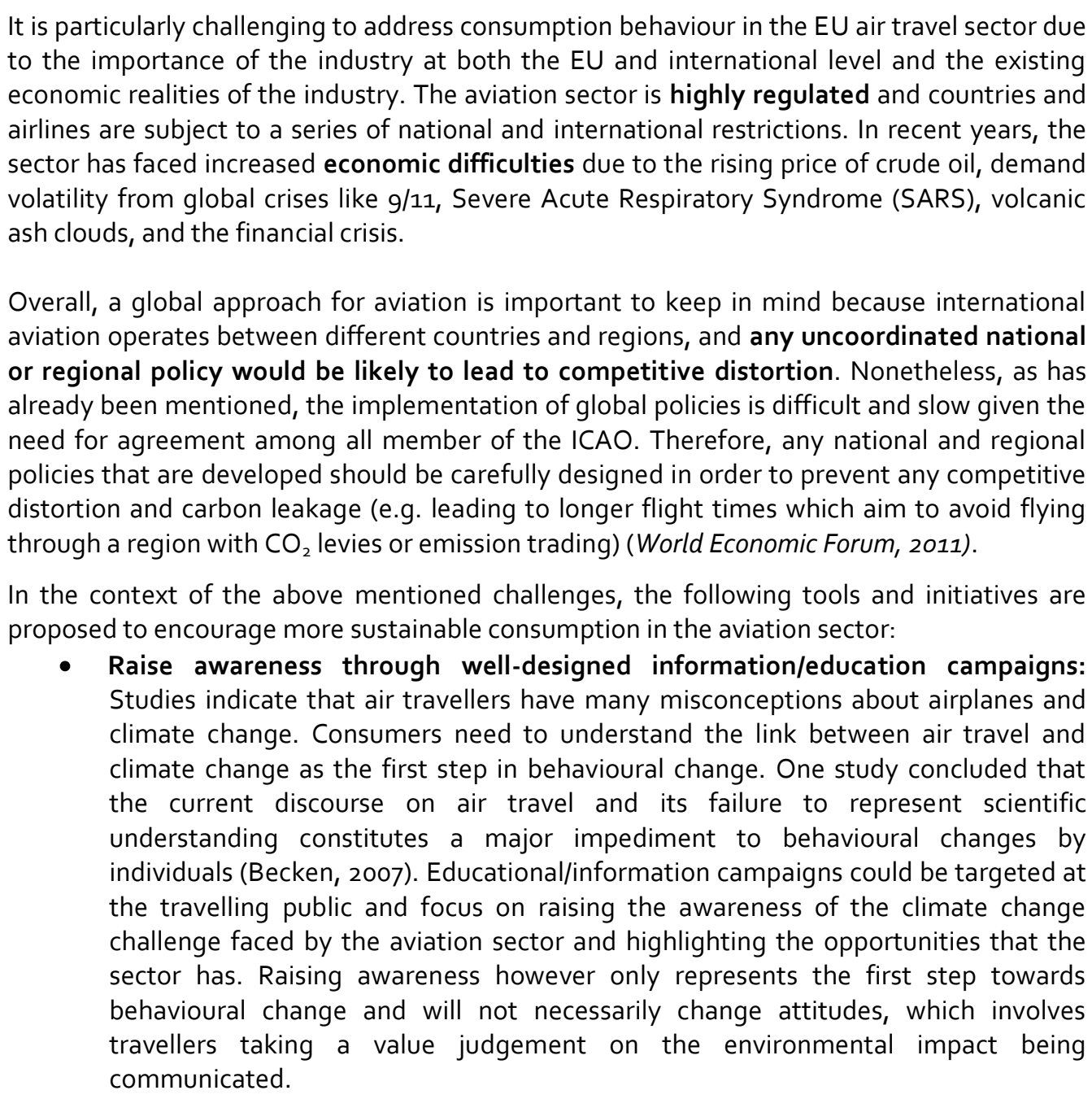 \\
\hline & $\begin{array}{l}\text { - Influence attitudes, values, practices and norms through well-designed } \\
\text { information/education campaigns: Whilst some people will automatically act on } \\
\text { the factual information provided, many require the information to be framed within } \\
\text { a particular context in order to influence their attitudes to the environmental impact } \\
\text { of air travel. For example, impacts can be put into scale relative to other sources of } \\
\text { GHGs. Other approaches include highlighting the apparently unsustainable growth } \\
\text { pattern within the sector. Campaigns might propose concrete practices (such as } \\
\text { only flying once a year), or social norms (such as using the train where available). } \\
\text { Such messages could be advocated by celebrities as people are heavily influenced } \\
\text { by those that they trust. Such messages will often, although not necessarily, be }\end{array}$ \\
\hline
\end{tabular}




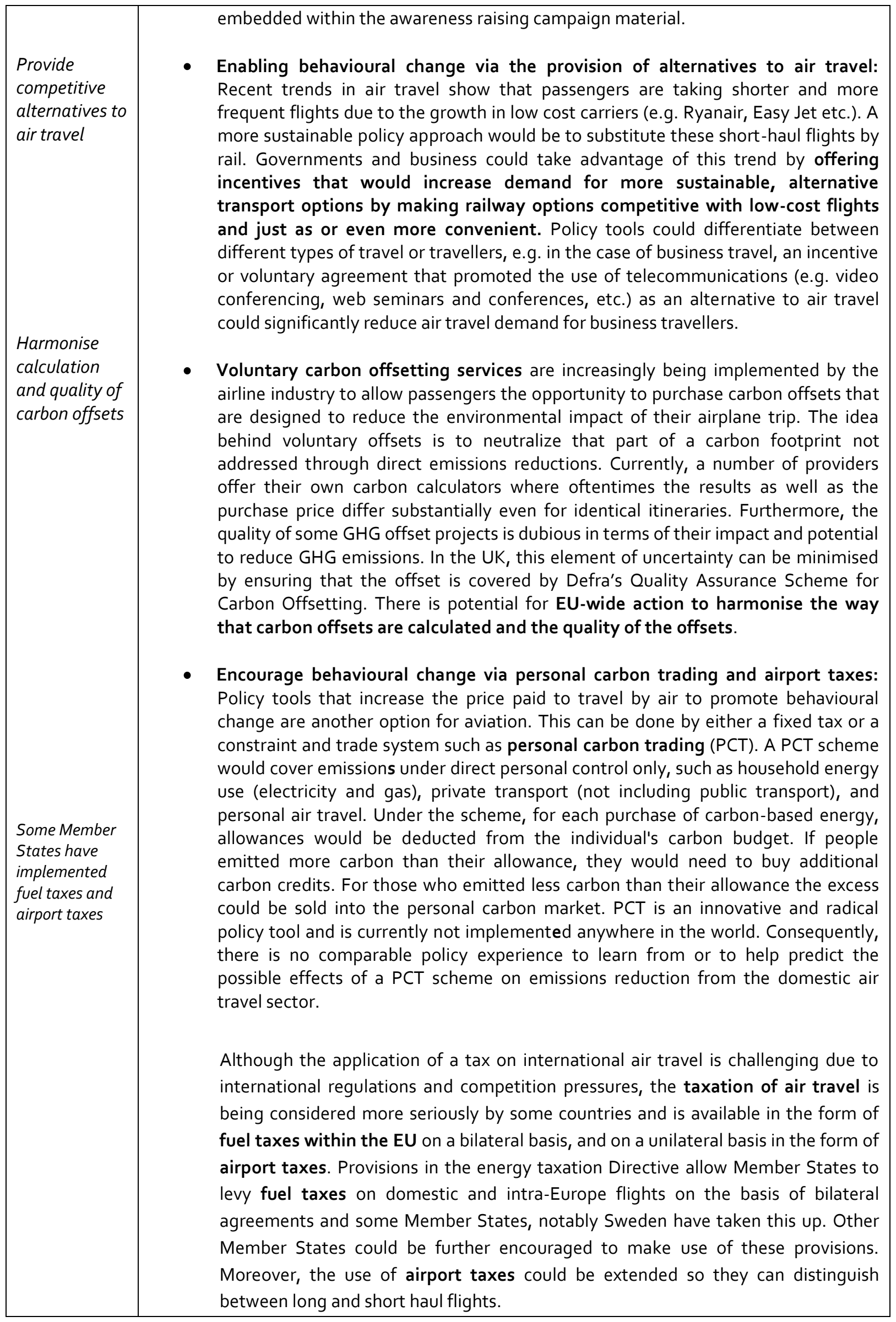




\begin{tabular}{|c|c|}
\hline Refe & \\
\hline & 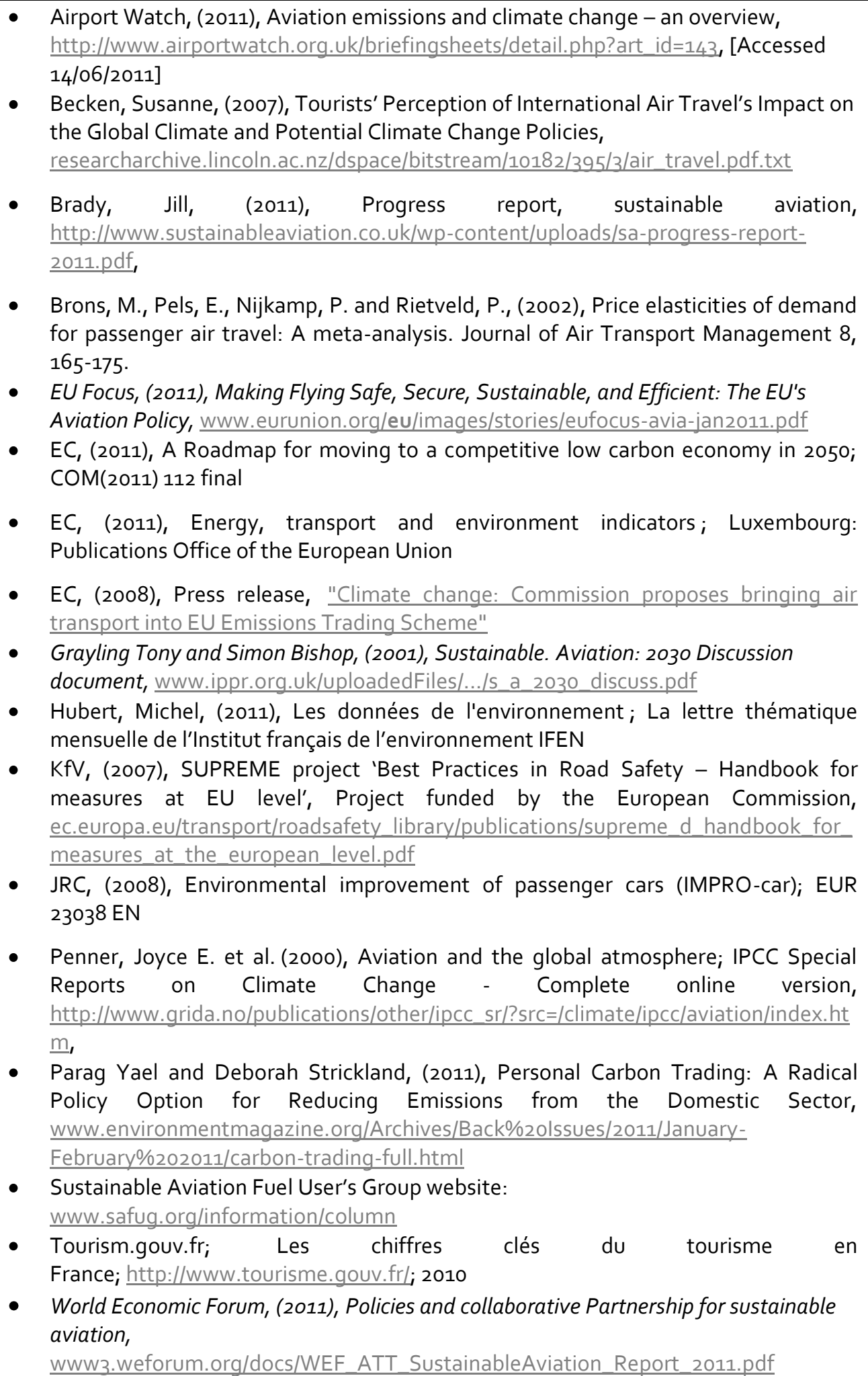 \\
\hline
\end{tabular}




\title{
Housing - infrastructure
}

\author{
Sectoral analysis \\ General $\quad$ The construction market accounts for $10 \%$ of GDP and $7 \%$ of the workforce in the EU (EC, \\ trends in the 2011). Housing has a significant impact on the environment, particularly through energy \\ sector consumption, materials, land use (and soil sealing), biodiversity and water \\ consumption $^{163}$. In addition, in terms of wider sustainability issues, its design and quality has \\ an important effect on people's well-being and factors such as urban planning may play a \\ role in the sustainability of communities.
}

One third of

Around one fifth of environmental pressures are caused during the construction of total material use in Europe is for housing buildings (JRC/IPTS, 2008). Energy use in buildings, including commercial and public buildings, represents approximately $40 \%$ of total final energy consumption and $36 \%$ of $\mathrm{CO}_{2}$ emissions in Europe (EC, 2010). In the $E U$, more than $50 \%$ of all materials extracted from the earth are transformed into construction materials (EC, 2011) and around one third of total material use in Europe is for housing, with consequent negative impacts on land and biodiversity from mining and waste disposal (EEA, 2010a). Although construction and demolition waste in the EU is increasingly recycled (EEA, 2010c), the resulting savings only substitute a fraction of construction resource use. Housing construction, especially diffuse

Construction residential sprawl, and related infrastructure are responsible for a high share of land-take in

leads to high

land-take and Europe, which has increased to $0.61 \%$ (percentage of initial year) in the period 2000 to 2006 compared to $0.57 \%$ in the previous decade, but land-take for housing has slowed slightly. land sealing Land sealing (i.e. reducing the potential for water penetration) is also a significant impact of housing and infrastructure; sealed land loses its soil functions, is detrimental to biodiversity and can increase the risk of flooding (EEA, 2010b, EEA, 2010d, EEA, 2010e and EEA, 2010f). However, re-utilisation of developed urban land has increased considerably, and this can avoid further impact of urban development on land use and soil sealing (EEA, 2010b). The IMPRO buildings study claims that if the measures examined are carried out on the buildings considered, the emissions of GHGs from these buildings may be cut by around 30 to $50 \%$ over the next 40 years (JRC/IPTS, 2008).

Trend towards

smaller

households

and growing

demand of

living space

per person

expected to

continue to

Dwelling type has important consequences for energy use, material use and soil sealing. For example, single-family houses typically use 1.5 to 2 times more energy per $\mathrm{m}^{2}$ than multifamily buildings, and have a higher demand for land per unit of floor area and material use than multi-family and high-rise buildings (JRC/IPTS, 2008) (EEA, 2010a). Single-family houses make up $57 \%$ of homes in the 19 EEA member countries for which data are available $\left(E E A, 2010 a^{164}\right)$. Rising energy consumption for space heating is mainly due to an increase in housing space per person (EEA, 2010a). The past trend in the EU towards fewer people per household is likely to continue until 2020 (Jiang and O'Neill, 2009) leading to a growth in demand for living space per person. In addition to the projected slight growth in population, these factors are expected to increase the total area of dwelling space (EEA, 2010a). Moreover, low-density housing reduces the economic viability and technical efficiency of district heating and public transport systems. This matches the four trends that are often mentioned in literature for the next decades: baby boomers ${ }^{165}$ will enter their peak home-

\footnotetext{
${ }^{163}$ Energy and water consumption through energy- and water-using products, embedded water, and utilities pricing and metering are covered under separate analyses within the report; however, the installation of energy saving features and water collecting devices, such as water butts and cisterns, are included in this assessment.

${ }^{164}$ Calculated based on Odyssee data, 2009

${ }^{165}$ Refers to the generation born during the demographic 'baby boom' after World War Il from 1946 to the early 1960 .
} 


\section{Housing - infrastructure}

\begin{tabular}{|c|c|}
\hline & $\begin{array}{l}\text { selling years, late baby boomers }{ }^{166} \text { will enter their peak home-buying years, there will be } \\
\text { new demand for smaller homes and there will be new demand for more energy-efficient } \\
\text { homes. However, the economic downturn adds uncertainty about the future trends of the } \\
\text { housing market, including the ability and willingness of buyers to pay more for sustainable } \\
\text { housing and the volume of housing being built, which can be used as positive examples for } \\
\text { the future. }\end{array}$ \\
\hline $\begin{array}{l}\text { Suffer from } \\
\text { weak } \\
\text { incentives and } \\
\text { lack of } \\
\text { information }\end{array}$ & $\begin{array}{l}\text { There are several issues that may act as barriers to more sustainable housing infrastructure: } \\
\text { - High capital cost of construction and purchase, } \\
\text { - } \\
\text { - } \\
\text { housing), } \\
\text { non-essential features for housing (such as sustainability technologies), and } \\
\text { The slow rate of turnover in the housing stock. } \\
\text { Identity, norms, affordability and complexity may pose challenges to developing sustainable } \\
\text { housing infrastructure. Home ownership, design and location can be a very personal choice, } \\
\text { and the trend toward single-person households and increased space per dwelling may } \\
\text { demonstrate the development of a social norm that could be at odds with a sustainable } \\
\text { housing infrastructure. In addition, due to affordability issues many homes are tenanted, } \\
\text { leading to split incentives in relation to the benefits of sustainability-relevant technologies, } \\
\text { for example energy saving features such as loft insulation }{ }^{167} \text {. Furthermore, the complexity } \\
\text { and technical nature of many sustainability solutions may make communication of the } \\
\text { solutions challenging. In the UK for example research on energy efficiency policies in housing } \\
\text { has shown that with regards to investing in energy saving technologies, } 20 \% \text { of people with } \\
\text { no basic insulation are completely unengaged; householders are uncertain about the } \\
\text { benefits and; householders substantially overestimate costs (UK DECC, 2011). This highlights } \\
\text { the lack of focus of existing policies to make energy efficiency more identifiable for those } \\
\text { who are motivated by displaying their environmental credentials as opposed to only saving } \\
\text { money. }\end{array}$ \\
\hline
\end{tabular}

\footnotetext{
${ }^{166}$ Refers to the generation born at the end of the post-World War II demographic 'baby boom' in the early $1960 s$.

${ }^{167}$ A landlord who rents out his property may want to reduce capital costs of the property. As energy saving features can be expensive, and the landlord owner would not benefit directly from the reduced energy bills, they may decide not to install features such as loft insulation. The tenant however would benefit from reduced energy bills but is unlikely to make capital investments into a property they are renting for a fixed duration where they will benefit for a short time but will not gain further benefits after leaving the property. Hence the incentives of the landlord and the tenant are split and energy saving features may not be installed.
} 


\section{Housing - infrastructure}

The public sector plays an important role in housing infrastructure, both through construction of social housing and management of urban planning. There is significant pressure to provide (affordable) housing and the construction sector may not wish to make the research and development investments or the capital investments required to provide sustainable housing. There is also a potential for the debate over sustainable housing to focus on the downsides of potential changes (for example, smaller houses, more inhabitants per dwellings, denser cities, complex house designs).

\section{Sectoral analysis of tools}

\section{Selection of available tools}

\begin{tabular}{|c|c|c|c|c|c|}
\hline Tool name and location & 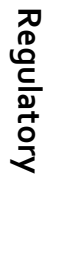 & $\stackrel{\underline{n}}{\underline{\underline{Q}}}$ & 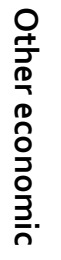 & $\begin{array}{l}\overline{3} \\
\overline{0} \\
\frac{0}{3} \\
3 \\
0 \\
0 \\
\text { o. }\end{array}$ & 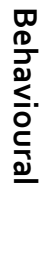 \\
\hline Lead Markets Initiative for sustainable construction (EU) & $x$ & & & $x$ & \\
\hline Energy Performance of Buildings Directive (EU) & $\mathrm{X}$ & & & 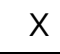 & \\
\hline Eco-Design of Energy-Related Products Directive (EU) & $\mathrm{X}$ & & & $\mathrm{X}$ & \\
\hline $\begin{array}{l}\text { Code for Sustainable Homes (minimum standards for energy and } \\
\text { water use) (UK) }\end{array}$ & $\mathrm{X}$ & & & & \\
\hline $\begin{array}{l}\text { Target for all new housing to be zero carbon by } 2016 \text { backed by an } \\
\text { exemption from stamp duty land tax (UK) }\end{array}$ & $x$ & $\mathrm{X}$ & & & \\
\hline Natural Resources Canada's ecoENERGY Retrofit program (INT) & & & $x$ & & \\
\hline Building certification (BREEAM and LEED) (INT) & & & & $\mathrm{x}$ & \\
\hline Transition Towns (INT) & & & & & $x$ \\
\hline Middelgrunden Wind Cooperative (DK) & & & & & $x$ \\
\hline $\begin{array}{l}\text { Eco-housing and communities (BedZed, Freiburg solar settlement, } \\
\text { Sieben Linden Ecovillage) (DE, UK) }\end{array}$ & & & & & $x$ \\
\hline $\begin{array}{l}\text { Certification of sustainable building materials (Forest Stewardship } \\
\text { Council) (INT) }\end{array}$ & & & & $x$ & \\
\hline $\begin{array}{l}\text { Ban on unsustainable building materials (FLEGT Voluntary } \\
\text { Partnership Agreements) (EU) }\end{array}$ & $\mathrm{X}$ & & & & \\
\hline
\end{tabular}

Overview of available tools

EU focus has been on

promoting
There are many technologies, tools and policies addressing sustainable housing across the EU and many initiatives have been developed by both policy-makers and grassroots organisations. Hence there is significant potential to reduce the impact of the sector and address sustainability concerns through increased uptake and harmonisation of these existing initiatives and policies. This might be further improved by ensuring good urban design to enable and facilitate sustainable behaviours and improve people's wellbeing.

The EU's Lead Markets Initiative includes a sustainable construction strand which seeks to address the issue of achieving a sustainable construction market through four work areas: 


\section{Housing - infrastructure}

\begin{tabular}{|l|l|l|l|l}
\hline $\begin{array}{l}\text { sustainability } \\
\text { on supply side } \\
\text { rather than } \\
\text { changing } \\
\text { consumer } \\
\text { demands }\end{array}$ & $\begin{array}{l}\text { second generation Euro-codes, screening of national building regulations, a network } \\
\text { Contracting Authorities, and upgrading the skills of construction workers. It aims to provide a } \\
\text { common reference model on sustainability in the market by improving the efficiency of the } \\
\text { use of the regulatory framework, standardisation, and public procurement practices to foster } \\
\text { innovation for sustainability. }\end{array}$ \\
$\begin{array}{l}\text { The Energy Performance of Buildings Directive (EPBD) (2010/31/EU) requires Member } \\
\text { States to apply minimum requirements on the energy performance of new and existing } \\
\text { buildings when undergoing major renovations. All new buildings are to fulfil a near zero- } \\
\text { energy standard by the end of 2020 and public buildings by the end of 2018. The Eco-Design } \\
\text { of Energy-Related Products Directive (2009/125/EC) was extended in 2009 to products that } \\
\text { can influence energy use such as windows. It has to date been used mostly to set energy- } \\
\text { efficiency performance criteria and there is an opportunity to steer product design in a more } \\
\text { sustainable direction. }\end{array}$
\end{tabular}

Economic tools such as retrofit subsidies/grants which aim to stimulate and enable the purchase of sustainability technologies in housing through the provision of funds are another popular tool, e.g. Natural Resources Canada's ecoENERGY Retrofit program (see Task 3 report). Such tools can help to overcome the affordability barrier to sustainable housing.

Certification schemes such as BREEAM and LEED are international standards that rate the sustainability of housing and other buildings. This certification helps to ensure a minimum standard and provides a form of labelling. Such schemes and the EPBD provide consumers with relevant information on which sustainable housing choices might be made.

Community schemes such as Transition Towns (see assessment below on citizen community action) and cooperatives such as the Middelgrunden Wind Turbine Cooperative (see Task 3 report) have also been developed to change behaviour patterns and allow local communities to invest in sustainable local infrastructure.

The main tools in use are as follows:

Significant

potential for

innovative

behavioural

tools that

target the

demand side

in housing

infrastructure

sector

- Regulatory tools that set minimum standards, ban the use of unsustainable materials - these aim to improve sustainability of the supply;

- Regulatory tools that require provision of information on performance - these aim to provide a benchmark against which to compare performance to minimum requirements and stimulate demand through provision of information;

- Funding schemes to incentivise installation of sustainability features - these enable and encourage purchase of specific infrastructure technologies such as loft insulation; and

- Behavioural tools - these are often developed as an element of "eco-towns", local cooperatives, or community-led initiatives, and address housing and local infrastructure as part of a wider dialogue on compelling sustainable lifestyles.

Some initiatives already cover a combination of tools (for example the EU's Lead Markets Initiative for sustainable construction and the UK's combination of a zero carbon emission target and fiscal incentive), and in the literature it is apparent that a combination of tools is required in order to achieve sustainable housing. In terms of grants and subsidies for retrofit of existing housing, there is evidence that more information campaigns are required to educate the public about the potential of sustainability features, such as installing energysaving technologies, including their lifecycle cost savings where relevant. However, policymakers appear to focus mainly on promoting sustainability actions on the supply side, where there are currently fewer innovative behavioural tools in use that seek to change the expectations and demands of consumers, those examples that do exist appear to be one-offs or originate from local community action. This highlights the potential for an emerging gap between policy push in this area and citizen pull. 


\section{Housing - infrastructure}
Elements of an effective sectoral toolbox
The technical complexity of housing and sustainability issues (energy consumption, land- use, biodiversity, water consumption, etc.) and the many actors involved in its provision (designers, planners, construction, buyers, etc.) need to be considered and addressed when developing tools and policies in this sector.

Due to infrastructure lock-in, retrofitting and renovations are very important

Measures to incentivise installation of sustainability features

- Information campaigns are required to educate the construction industry and to inform both public authorities and the general public about the benefits of sustainable housing and potential savings to be achieved.

- $\quad$ On the supply side, the harmonisation of building regulations and enforcement of minimum standards is required. The EPBD seeks to address one of the main drivers of environmental impacts - energy consumption. However, this should be developed further to include the many sustainability aspects covered by schemes such as the international standards BREEAM and LEED.

- On the demand side, there is a need not only to provide targeted information but also to strongly stimulate demand through incentives to buyers in order to change the social norms toward a preference for sustainable housing and hence to shift the market toward the provision of such housing. Due to the fact that much of the existing housing infrastructure will be in use in 2050 retrofitting and other housing renovations are also critical.In terms of the design and appearance of sustainable housing, a successful strategy will be differentiated according to different buyers. While some are happy to have the energy efficient status of their house hidden and are rather motivated by financial savings, others may want the sustainability status to be highly visible so that it forms part of their environmental identity. An equivalent can be seen with hybrid cars where some manufacturers offer hybrid technology as an option within a model and others have designed a car which is only sold with the technology and therefore acts as a status symbol. In order to address the affordability challenge, the further development of subsidies, green loans and fiscal measures is required to incentivise installation of sustainability features, allow innovation and stimulate demand.

- To avoid split incentives, mechanisms need to be in place to ensure that investors (both from the supply side and demand side) recoup the benefits of their investments.

Regarding larger investments, public-private initiatives could also be an effective means of enabling sustainable developments in partnership with local communities, which may have the added benefit of educating the local community and raising awareness on wider sustainability issues and behaviours. In addition, the development of reliable differentiator mechanisms, such as certification and labelling, is required to allow educated actors (informed via information tools) to distinguish performance levels and to provide a framework on which fiscal measures can be established.

\section{References}

- Cecodhas, (2009), Housing Europe: The Social and Green Way, http://cms.horus.be/files/99907/MediaArchive/News section/Members Newsletters Housing\%20Europe\%20MANIFESTO.pdf

- CEB, (2010), Sustainable Housing and Urban Development: the CEB's Contribution, www.coebank.org/Upload/infocentre/brochure/en/housing.pdf

- EC, (2010), COM 2002/91/EC: Directive on the Energy Performance of Buildings, www.managenergy.net/products/R210.htm

- EC, (2011), Industrial innovation: Sustainable construction, http://ec.europa.eu/enterprise/policies/innovation/policy/lead-marketinitiative/sustainable-construction/index_en.htm\#h2-2nd-generation-eurocodes 


\section{Housing - infrastructure}

- EEA, (2010a), The European Environment, State and Outlook: Consumption and the Environment, http://www.eea.europa.eu/soer/europe/consumption-andenvironment

- EEA, (2010b), The European environment - state and outlook 2010: land use, European Environment Agency

- EEA, (2010c), The European environment - state and outlook 2010: material resources and waste, European Environment Agency.

- EEA, (2010d), The European environment - state and outlook 2010: urban environment, European Environment Agency.

- EEA, (2010e), The European environment - state and outlook 2010: soil. European Environment Agency

- EEA, (2010f), The European environment - state and outlook 2010: biodiversity. European Environment Agency

- Jiang, L. and B.C. O'Neill, (2009), Household projections for rural and urban areas of major regions of the world, IIASA Interim Report IR-09-026, Laxenburg, Austria: IIASA.

- JRC/IPTS, (2008), Environmental Improvement Potentials of Residential Buildings (IMPRO-Building), http://ftp.jrc.es/EURdoc/JRC46667.pdf

- UK Department for Communities and Local Government, (2011), Planning, building and the environment Sustainability, http://www.communities.gov.uk/planningandbuilding/sustainability/

- UK Department of Energy and Climate Change, (2011), The challenge of making existing homes energy efficient, http://www.westsuffolkac.co.uk/docs/BwC140411GarethJenkins.pdf

- UK Sustainable Development Commission, (2006), Stock Take: Delivering improvements in existing housing, http://www.sdcommission.org.uk/publications.php?id=400

\section{Housing - energy using appliances ${ }^{168}$}

\section{Sectoral analysis}

General trends in the sector
Energy consumption in buildings - for space heating, water heating and use of electric appliances - is a key cause of environmental impacts. Household energy consumption accounts for about $30 \%$ of all electricity consumption ${ }^{169}$ in OECD countries and demand for appliances is growing at a rapid rate (Emmert et al 2010). According to the OECD, the use of electrical and electronic equipment (EEE) causes $20 \%$ of the end-use sector's $\mathrm{CO}_{2}$ emissions (OECD, 2011). Within EU-27, EEE accounted for a $61 \%$ share of the end use energy

\footnotetext{
${ }^{168}$ This analysis focuses on the use of end-of-life electrical and electronic equipment (EEE), such as socalled "brown goods" (e.g. computers and consumer electronics, TVs, displays, printers), heating, ventilation and air-condition equipment (HVAC) (e.g. electric water heaters, space heating appliances) and so-called "white goods" (e.g. refrigerators, washing machines, and dishwashers). The energy-related products Directive (ErP) 2009/125/EC refers to these domestic appliances as energy-using products (EuPs) and energy-related products (ErPs). This analysis focuses on the use and end-of-life phase of these products. Energy use for transportation as well as indirect energy consumption (e.g. energy used in manufacturing of EEE) is not covered.
}

${ }^{169}$ The figure for electricity consumption is assumed to include energy use for water and space heating 


\section{Housing - energy using appliances ${ }^{168}$}

consumption of ErPs in 2007. HVAC alone represents more than half the final energy consumption amongst ErPs (Tukker et al., 2011). The EEA SOER 2010 revealed that $\mathrm{CO}_{2}$ emissions from the residential (...) sector have fallen significantly since 1990 whereas greenhouse gas emission increases could be observed due to the consumption of halocarbons (HFCs) used in the production of cooling devices such as air conditioning systems and refrigerators (EEA 2010).

The 2006 EIPRO study identified household (electrical) appliances as the product group of "midrange" environmental importance. Environmental impacts caused by domestic space heating and domestic EEE appliances mainly concern GHGs (24\%), acidification (21\%), resource use (35\%) and primary energy use (32\%) (EIPRO, 2006). Household appliances also cause environmental impacts at the end-of-life. The increasing stock of electrical appliances is accompanied by the tendency towards shorter application periods of each product as cycles of innovation are getting shorter. In the short-term this trend leads to a steady rise in electronic waste. It is estimated that the generation of waste EEE will increase by roughly $11 \%$ between 2008 and 2014 across the EU-27, Norway and Switzerland, mainly due to rapid technological advancement accompanied by reduced prices (EEA 2010).

Efficiency gains from large appliances and space heating have been more than offset by the rapid diffusion of new small appliances such as personal computers, mobile phones and

Demand for

small

appliances

growing

rapidly,

offsetting

efficiency

gains

Social,

technical and

political

challenges

faced

Need to

address

amount and

type of

appliances

consumed and

change use

patterns other home electronics and the increased use of air conditioning. "Between 1990 and 2006, energy consumption for space heating increased by only $5 \%$, compared to $52 \%$ for appliances energy consumption" (OECD, 2011). As a result of households increasing their stock of electrical appliances, overall domestic energy consumption has increased and the electricity consumption of households for consumer electronics and information and communication technologies is expected to increase substantially in the coming years (EEA 2010). According to recent OECD findings, households today on average own 10 electrical appliances. Factors that influence the number of domestic appliances owned by a household are mainly income growth, followed by increasing household size, ageing society and an increased size of the residence. These factors lead to an increasing average number of domestic appliances whereas environmental concerns and pro-environmental attitudes are found to reduce the total number of appliances that a household possesses (OECD, 2011).

The main social challenge policy-makers need to tackle is to change the quantity of private household appliances consumed (i.e. reduce the number of household appliances purchased), the quality of appliances in place (i.e. shift towards the purchase of more energy efficient EuPs and ErPs) and change use patterns (i.e. towards minimized private energy consumption during the use phase). These challenges derive from the key determinants of household consumption patterns as revealed by the 2011 OECD study namely economic growth, a growing world population, an ageing population as well as changing lifestyles, factors. Habit also plays a key role in much of the unnecessary energy consumed by appliances when people fail to turn appliances off when not in use. Underlying many challenges is the low power consumption required for most appliances relative to the value derived from them. Appliances provide important and valued information and convenience in people's lives which exceeds the financial cost of the energy consumed during their use.

Technical challenges mainly relate to improving the eco-design of household appliances. Improved recyclability or even complete reusability ("cradle-to-cradle" principle) aims at maximizing resource efficiency. Minimized energy performance and automatic low power mode in household appliances aim at energy efficiency and reducing GHG emissions. The latter could be tackled by future regulatory instruments. One interesting option is the use of new technological innovations to direct user behaviour towards energy saving patterns, e.g. sensors in dishwashers or washing machines identifying the degree of staining and adjusting not only the amount of water and energy but may also not start a washing programme if the machine is only half loaded. 


\section{Housing - energy using appliances ${ }^{168}$}

Political challenges relate to how to restrict or ban the sale of inefficient products, encourage technological innovation and therefore support future R\&D activities better taking into account ecological criteria, and incentivise purchase of energy-efficient devices, improve information and awareness.

\section{Sectoral analysis of tools}

\section{Selection of available tools}

\begin{tabular}{|c|c|c|c|c|c|}
\hline Tool name and location & 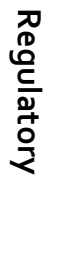 & $\stackrel{\underline{n}}{\underline{\underline{n}}}$ & 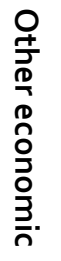 & 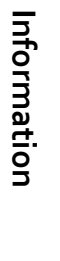 & 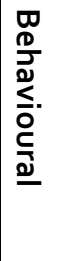 \\
\hline EU Energy Label (EU)/Energy labelling Directive (2010/30/EU); & $\mathrm{X}$ & & & $x$ & \\
\hline Energy-related products Directive (ErP) 2009/125/EC (EU) & $\mathrm{X}$ & & & $\mathrm{X}$ & \\
\hline Eco-design of Energy Using Products Directive (EuP) (EU) & $x$ & & & & \\
\hline Waste Electrical and Electronic Equipment Directive (WEEE) (EU) & $x$ & & & & \\
\hline $\begin{array}{l}\text { Restriction of the use of Hazardous Substances in electrical and } \\
\text { electronic equipment (RoHS) (EU) }\end{array}$ & $x$ & & & & \\
\hline $\begin{array}{l}\text { Public information campaign - "Initiative EnergieEffizienz" of DENA } \\
\text { (DE) }\end{array}$ & & & & & $x$ \\
\hline Public information campaign - EcoTopTen (DE) & & & & $x$ & \\
\hline Public information campaign - "Energy Bus" (2003-2005) (PL) & & & & $x$ & \\
\hline $\begin{array}{l}\text { Tax credits for energy efficient appliances and equipment (e.g. lower } \\
\text { VAT for energy-efficient eco-labelled white goods) (UK, FR) }\end{array}$ & & $\mathrm{X}$ & & & \\
\hline Eco-taxation: Residential electricity charges (e.g. DK, FI, DE, NL, SE) & & $\mathrm{X}$ & & & \\
\hline $\begin{array}{l}\text { ISO TYPE-I Ecolabelling Schemes (e.g. EU-Ecolabel, Blue Angel, } \\
\text { Nordic Swan) }\end{array}$ & & & & $x$ & \\
\hline Voluntary product labelling (e.g. TCO, Energy star) (EU) & & & & $x$ & \\
\hline Smart metering (various MS) & & & $\mathrm{X}$ & & $x$ \\
\hline Government funded NGO - "The Energy Saving Trust" (UK) & & & & $\mathrm{X}$ & \\
\hline
\end{tabular}

Overview of A number of policies and instruments exist at EU and MS level which seek to contribute to available tools the EU objective of reducing energy consumption by $20 \%$ by 2020 . In a number of countries, governments have also announced improvements in the energy efficiency of household appliances as a policy goal.

Direct market regulation is achieved by various EU regulatory tools which mainly target producers. These tools concern all stages along the product lifecycle: eco-design, production, consumption and end-of-life, and therefore address resource efficiency, harmful substances, disposal requirements etc. As a mandatory instrument, the EU energy efficiency label also has a major impact on the provision of green product alternatives. 


\section{Housing - energy using appliances ${ }^{168}$}

\begin{tabular}{|c|c|}
\hline $\begin{array}{l}\text { Application of } \\
\text { voluntary } \\
\text { information } \\
\text { tools not } \\
\text { widespread } \\
\text { and have had } \\
\text { limited effect }\end{array}$ & 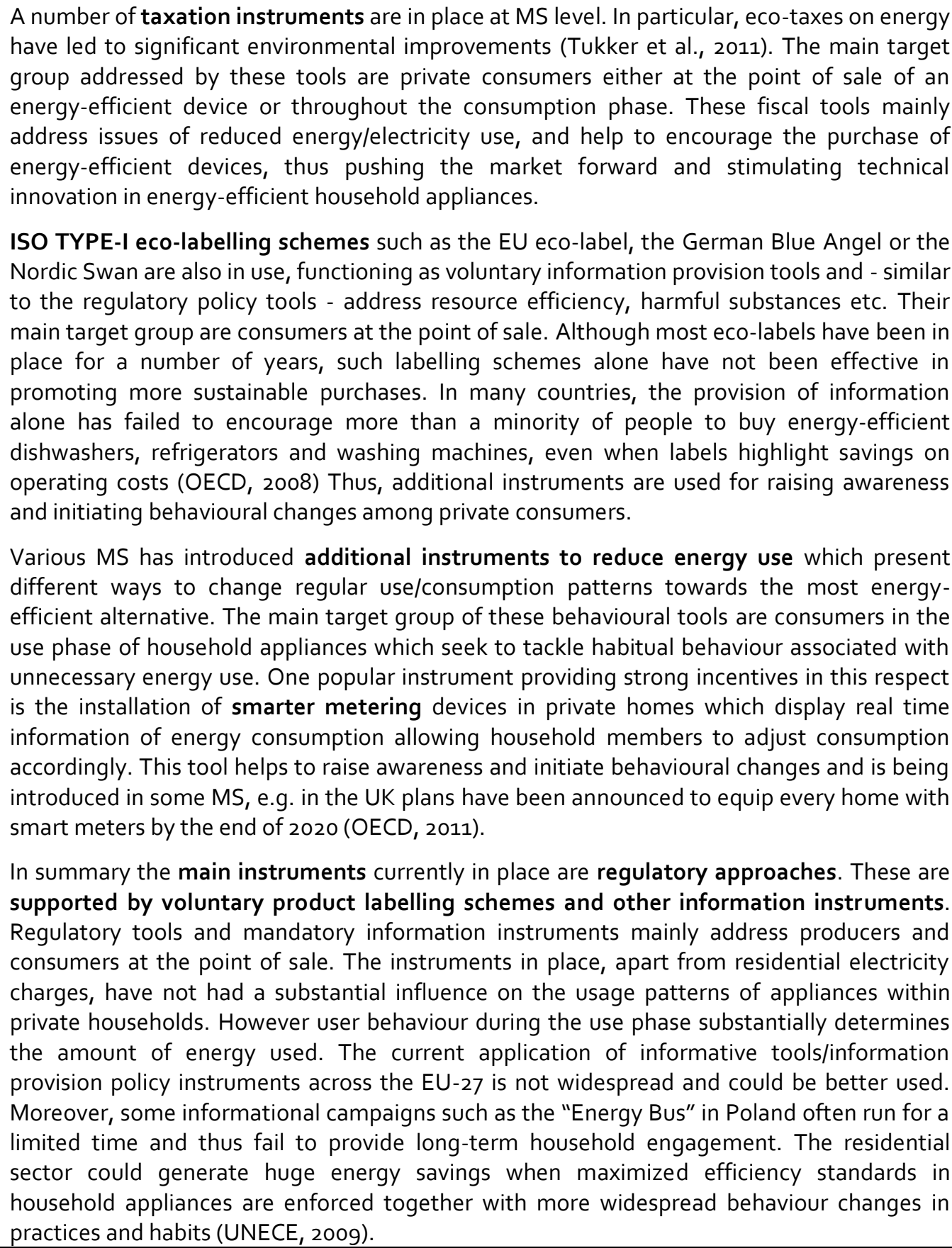 \\
\hline $\begin{array}{l}\text { Elements of } \\
\text { an effective } \\
\text { sectoral } \\
\text { toolbox }\end{array}$ & $\begin{array}{l}\text { A collection of different instruments is needed to minimise residential energy use. In order to } \\
\text { gain efficient and long-term policy results various variables need to be considered. DEFRA's } \\
\text { 4E's model considers the importance of targeting tools and measures for different groups. } \\
\text { This approach ensures the acceptability of environment-related taxes and charges } \\
\text { ("Encourage") and behavioural approaches ("Engage"). An effective toolbox should include } \\
\text { all instruments mentioned in DEFRA's } 4 E^{\prime} \text { 's model encouraging, enabling, engaging and } \\
\text { exemplifying all target groups. In addition, instruments should address all lifecycle stages of } \\
\text { EEE (the demand and the supply side at the same time) and will need to consider all relevant } \\
\text { target groups in order to address effectively the above-named challenges. }\end{array}$ \\
\hline
\end{tabular}




\section{Housing - energy using appliances ${ }^{168}$}

Well-designed information and labelling tools together with financial incentives

Ensure availability of substitutes/ new technologies to support behaviour change

\begin{tabular}{|l|l|l|l|l|}
\hline 4E's & Production phase & Point of sale & Use phase & Disposal \\
\hline Encourage & $\begin{array}{l}\text { EU Energy Label, } \\
\text { ErP Directive, } \\
\text { Eco Design Directive } \\
\text { RoHS }\end{array}$ & $\begin{array}{l}\text { EU Energy Label, } \\
\text { Tax credits }\end{array}$ & $\begin{array}{l}\text { Energy taxation, } \\
\text { Smart metering }\end{array}$ & WEEE Directive \\
\hline Enable & $\begin{array}{l}\text { Ecolabelling } \\
\text { schemes }\end{array}$ & $\begin{array}{l}\text { Ecolabelling schemes, } \\
\text { EcoTopTen, } \\
\text { Energy Saving Trust }\end{array}$ & $\begin{array}{l}\text { Smart metering, } \\
\text { "Energy Bus" }\end{array}$ & -.- \\
\hline Engage & Energy Saving Trust & Energy Saving Trust & $\begin{array}{l}\text { "Initiative } \\
\text { EnergieEffizienz" }\end{array}$ & -.- \\
\hline Exemplify &.-- &.-- &.-- \\
\hline
\end{tabular}

From this overview, it is evident that various policy tools to "Encourage" producers and consumers are already in place. These tools complement each other and address all lifecycle stages of EEE. Various policy tools to "Enable" producers and consumers are also applied. These tools focus on production, point of sale and the use phase only, thus missing the disposal of product phase. Only few policy tools to "Engage" the target groups are currently applied. These tools focus on the point of sale and use phase. Policy tools to "Exemplify", such as strategies to "lead by example" (e.g. sustainable public procurement), could not be identified. Current instruments mainly address the producers ("production phase") and purchase at the point of sale. Policies need to better take into account the use and disposal phase along the $4 \mathrm{E}$ 's model.

The inter-relation between incentive-based instruments with informational instruments to spur behavioural change should be taken into account when designing policy in this area. Well-designed information and labelling tools together with financial incentives should be introduced. In some MS for example, the mandatory EU energy efficiency label has been reinforced with an energy tax. This inter-relation and in particular the tax designed with a clear-cut environmental objective can lead to significant environmental improvements ${ }^{170}$.

The availability of appropriate substitutes or new technologies to support change in behaviour should also be ensured as the strongest environmental effects have been observed where substitutes were available, or where a new technology has supported this change (Tukker et al., 2011). Installing smart meters encourages people to reduce energy consumption; however major savings are only achieved when more efficient appliances are available on the market. Therefore, policy tools need to be designed to increase the range of substitution possibilities. Technological innovations Energy efficiency standards of appliances can be progressively tightened and those products that fail to meet these standards penalised. The top-runner approach can be used to promote a market push towards the most efficient product.

When selecting policy tools to effectively encourage behavioural change it is also necessary to keep in mind the significant time-lag required for households to adjust their consumption / behaviour patterns (OECD, 2011). The application of well-designed information-based measures may lead to notably reduced energy consumption in the short-term, whereas economic incentives such as taxes and charges have a more significant impact in the longterm.

\footnotetext{
${ }^{170}$ As households facing higher costs tend to purchase energy-efficient appliances, change heating and cooling systems etc. (OECD 2008).
} 


\begin{tabular}{|c|c|}
\hline \multicolumn{2}{|c|}{ Housing - energy using appliances ${ }^{168}$} \\
\hline & 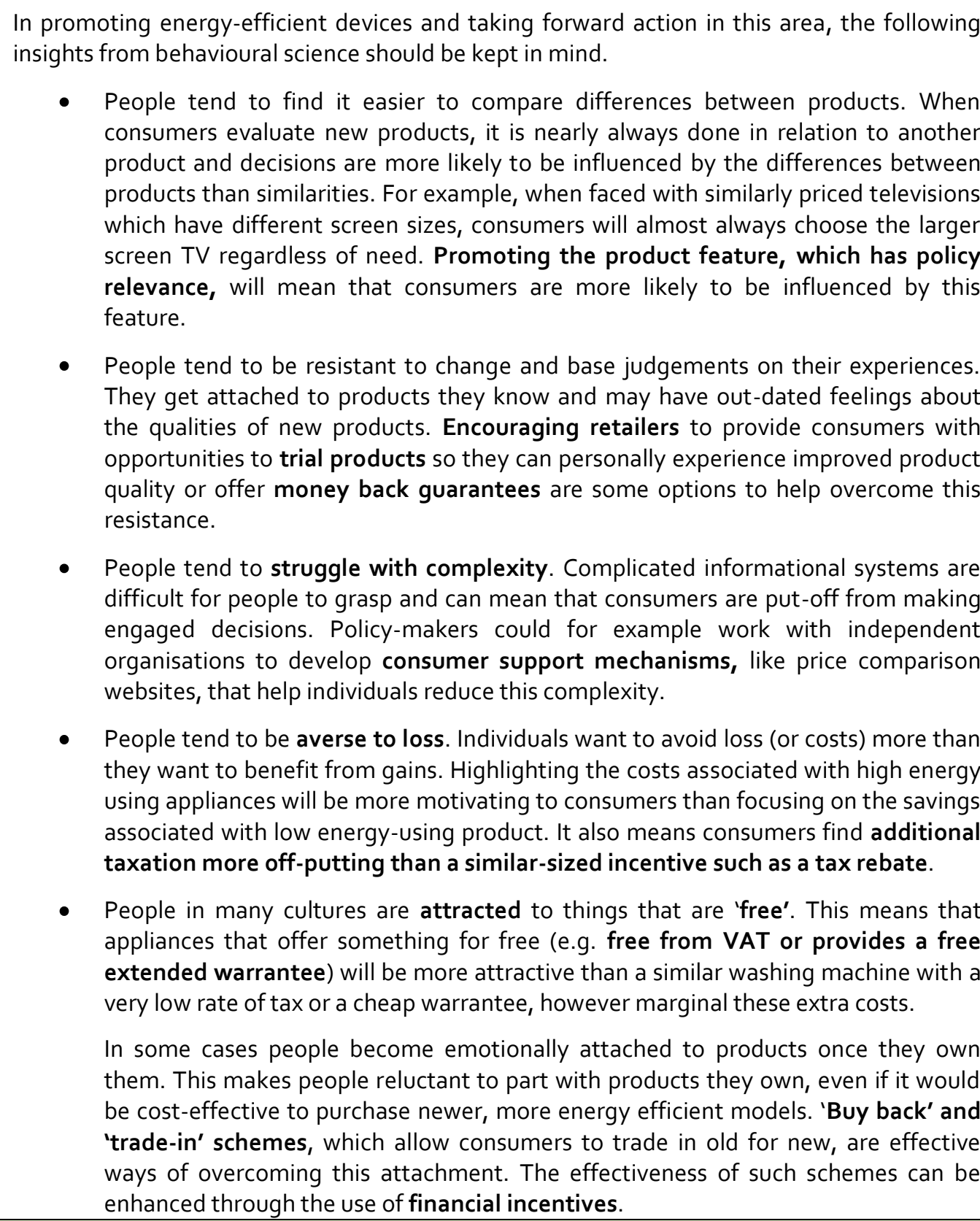 \\
\hline \multicolumn{2}{|l|}{ References } \\
\hline & 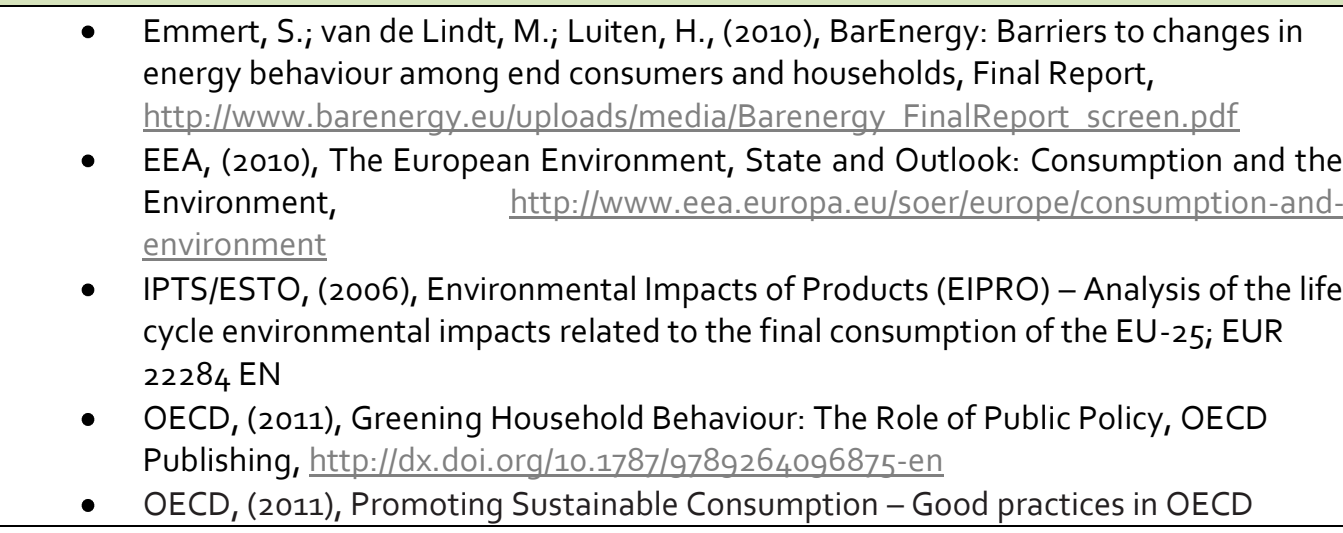 \\
\hline
\end{tabular}




\section{Housing - energy using appliance ${ }^{168}$}

\begin{tabular}{|c|c|}
\hline & $\begin{array}{l}\text { countries, OECD Publishing, http://www.oecd.org/dataoecd/1/59/40317373.pdf } \\
\text { PSI, (2009), Designing policy to influence consumers - Consumer behaviour relating } \\
\text { to the purchasing of environmentally preferable goods, Briefing note 3: consumer } \\
\text { behaviour and electronics } \\
\text { - } \text { Rubik, F.; Scheer, D., (2006), Integrated Product Policy. A Policy Paper, } \\
\text { http://www.ioew.de/uploads/tx_ukioewdb/ipp_paper.pdf } \\
\text { - Tukker, A.; Diaz Lopez, F.; Mudgal, S., (2011), Analysis of the future application of } \\
\text { product policy instruments in the EU, First Interim Report (WP1 - WP2); Delft } \\
\text { - Tukker et al, (2008),Sustainable Consumption Policies Effectiveness Evaluation } \\
\text { (SCOPE }{ }^{2} \text { ), Final Report, http://www.endseurope.com/docs/g0528e.pdf } \\
\text { - UNECE, (2011), Green Homes - towards energy-efficient housing in the United } \\
\text { Nations, Economic Commission for Europe region; Geneva, } \\
\text { http://www.unece.org/publications/oes/greenhomes.e.pdf }\end{array}$ \\
\hline
\end{tabular}

\section{Housing - water using appliances}

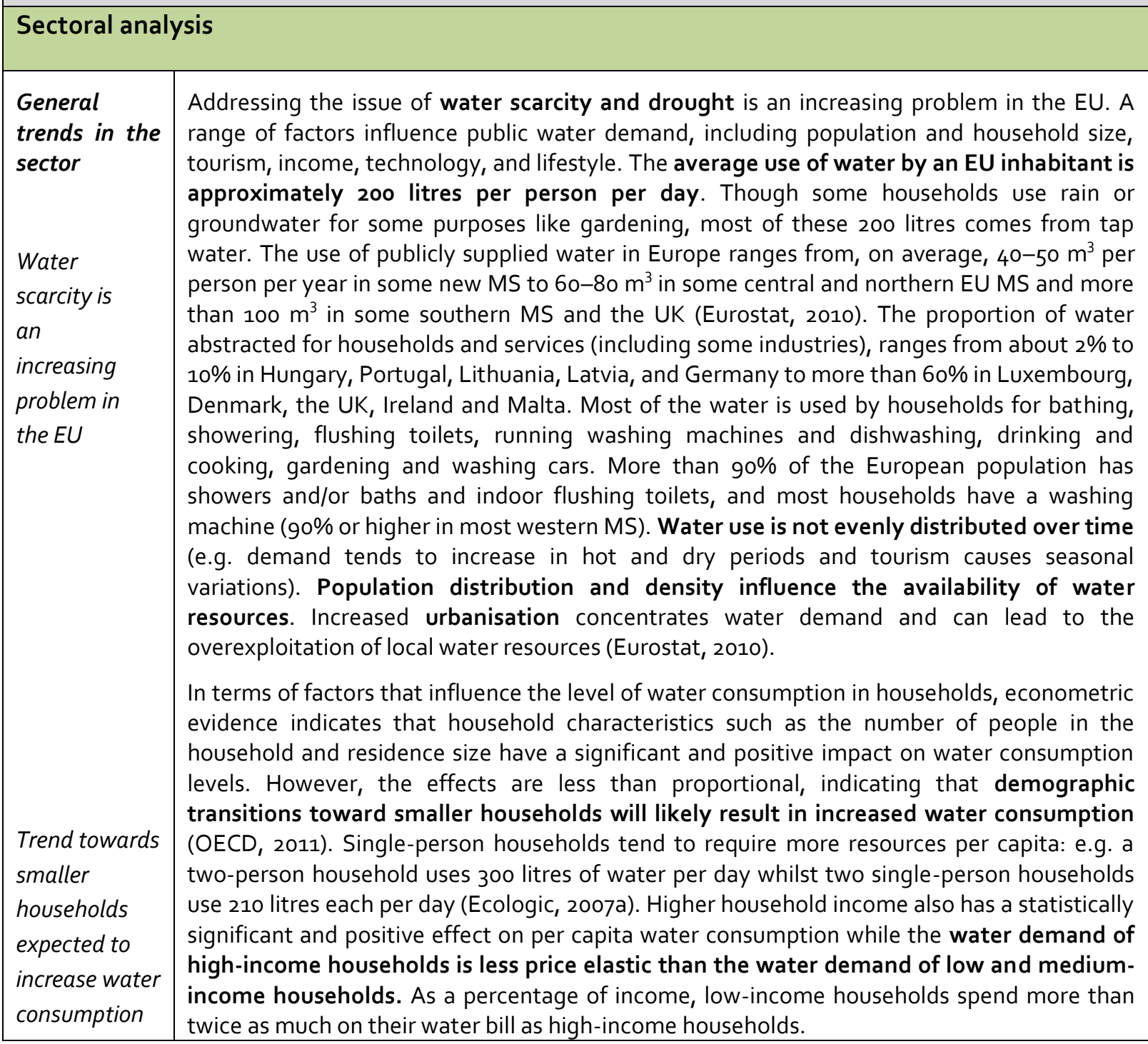




\begin{tabular}{|c|c|}
\hline \multicolumn{2}{|c|}{ Housing - water using appliances } \\
\hline & $\begin{array}{l}\text { Public water demand in Eastern Europe has declined by } 40 \% \text { since the early } 1990 \text { as a result } \\
\text { of higher water prices and the economic downturn. A similar but less marked reduction in } \\
\text { demand is apparent in Western Europe over recent years, driven by changes in awareness } \\
\text { and behaviour and increases in water prices. In Southern Europe domestic use has increased } \\
\text { by } 12 \% \text { (EEA, 2010b). A study entitled 'European Outlook on Water Use' which formulated } \\
\text { scenarios for water use to } 2030 \text { found that the trend of total European abstractions is } \\
\text { downward. It projected that total water withdrawals in the Europe-30 countries would } \\
\text { decrease by approximately } 11 \% \text { between } 2000 \text { and } 2030 \text {, with } 18 \text { countries having a } \\
\text { decreasing trend. It suggested that no single sector will dominate water use in Europe in the } \\
\text { future, and thus water conservation efforts in Europe should not be focussed on any } \\
\text { individual sector. The report argued that future domestic water use in new EU MS } \\
\text { remained a major unknown and that interventions to encourage water conservation could } \\
\text { perhaps avoid projected increases in domestic water use in these countries. The report also } \\
\text { suggested that technological improvements in water use sectors should continue to } \\
\text { significantly improve the efficiency of water use (Flörke and Alcamo, 2004). }\end{array}$ \\
\hline $\begin{array}{l}\text { Social, } \\
\text { technical and } \\
\text { political } \\
\text { challenges } \\
\text { faced }\end{array}$ & $\begin{array}{l}\text { Levels of household water use vary between EU countries due to the following factors: } \\
\text { - Technical performance of different supply systems resulting in different leakage } \\
\text { rates (from } 3 \% \text { to more than } 60 \% \text { ); } \\
\text { - Different levels of water consumption per person per day; } \\
\text { - Social and economic factors including age, environmental education, income and } \\
\text { living standards; } \\
\text { - Variation in application and efficiency of different technologies used in } \\
\text { households (Ecologic, 2007a). }\end{array}$ \\
\hline Potential & $\begin{array}{l}\text { Such issues will need to be addressed according to the situation in different countries and } \\
\text { there is an opportunity for sharing best practices and learning from what has been done in } \\
\text { other countries or regions. }\end{array}$ \\
\hline $\begin{array}{l}\text { of water- } \\
\text { saving } \\
\text { devices/ } \\
\text { appliances }\end{array}$ & $\begin{array}{l}\text { The reductions of leakage in water supply networks, water saving devices and more } \\
\text { efficient household appliances have the potential for up to } 50 \% \text { water savings. Market and } \\
\text { installation costs for household water-saving devices and appliances vary between types } \\
\text { of device or brand name. Toilets can vary from } € 100-800 ; \text { washing machines are usually } \\
€ 500+; \text { showerheads can be found for as little as } € 20 \text {. These water saving technologies are } \\
\text { easy to introduce and implement and have short payback periods for some water-saving } \\
\text { appliances - e.g. as little as } 1 \text { year for some washing machines but up to } 11 \text { years for some } \\
\text { toilets. Such factors further enhancing their uptake possibilities. Applying these measures } \\
\text { would allow for a reduction in water consumption from } 150 \text { litres/person/day to } 80 \\
\text { litres/person/day. A similar reduction could be applied to public water supply leading to an } \\
\text { estimated potential saving of up to } 33 \% \text { of today's abstraction (Ecologic, 2007a). }\end{array}$ \\
\hline & $\begin{array}{l}\text { Addressing issues of water demand, for example through approaches such as economic } \\
\text { cost-recovery and water pricing will be important in encouraging a more sustainable use of } \\
\text { water and is increasingly recognised. However these approaches face significant political } \\
\text { barriers for instance in relation to subsidiarity concerns at the EU level and overcoming } \\
\text { certain vested interests at the national level. }\end{array}$ \\
\hline $\begin{array}{l}\text { Quantitative } \\
\text { water } \\
\text { management } \\
\text { is a politically } \\
\text { sensitive issue }\end{array}$ & $\begin{array}{l}\text { Given that low-income households spend more than twice as much of their income on their } \\
\text { water bill as high-income households, in the absence of support, low-income households will } \\
\text { suffer the most from increases in the volumetric price of water. Full-cost water pricing, } \\
\text { coupled with assistance to low-income households in the form of a low or zero fixed fee, or } \\
\text { via transfer payments, can help ensure water is used efficiently and allocated equitably } \\
\text { across residential consumers. According to an OECD study charging for water on a } \\
\text { volumetric basis reduces water consumption by } 25 \% \text {, and a } 1 \% \text { increase in the average }\end{array}$ \\
\hline
\end{tabular}




\section{Housing - water using appliances}

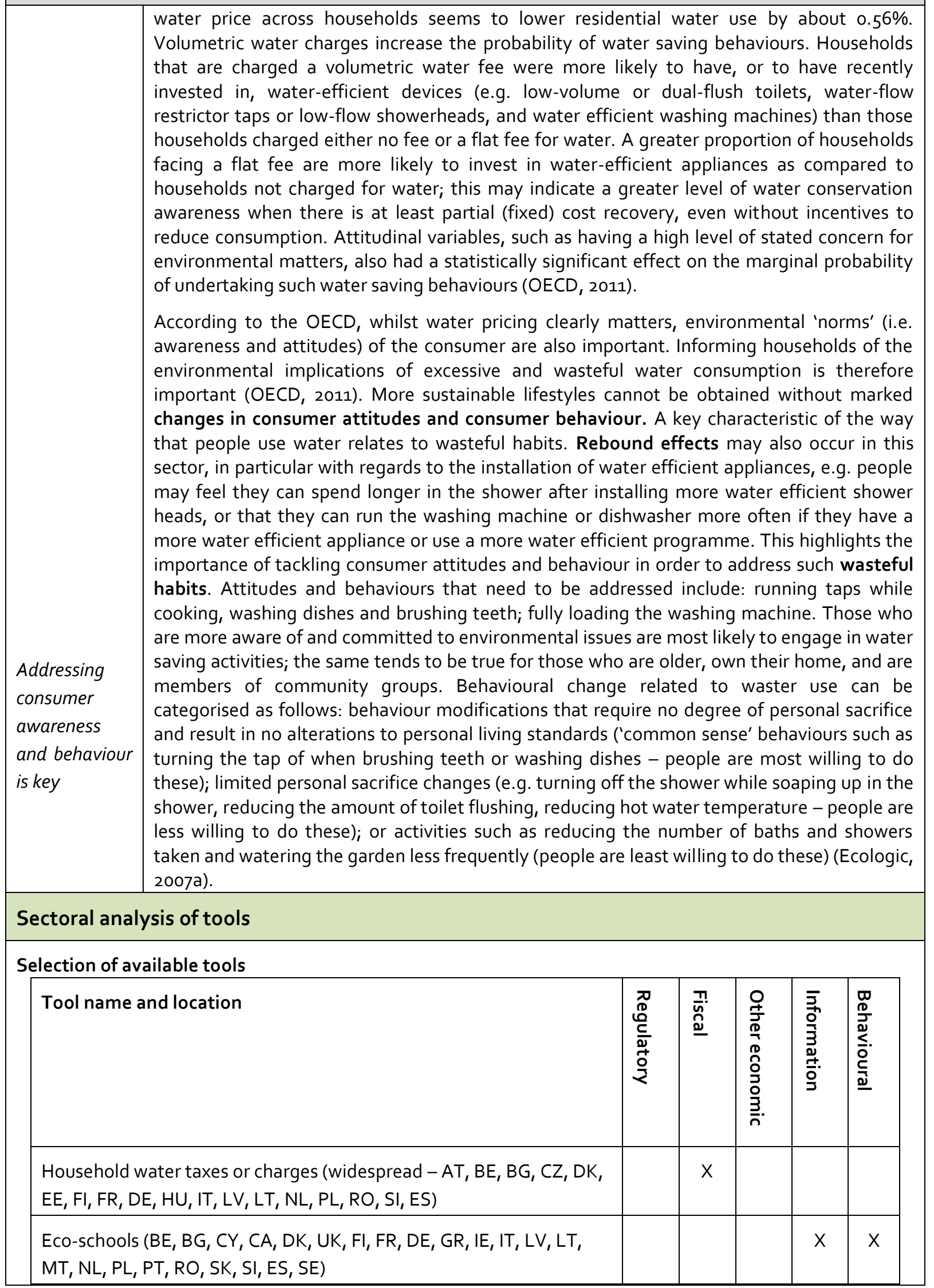




\section{Housing - water using appliances}

\begin{tabular}{|l|l|l|l|}
\hline $\begin{array}{l}\text { Waterwise Marque (UK) - awarded to products that reduce water } \\
\text { wastage or raise awareness on water efficiency }\end{array}$ & & & $\mathrm{X}$ \\
\hline Hippo the Water Saver (UK) & & & $\mathrm{X}$ \\
\hline $\begin{array}{l}\text { Schemes to support the purchase of rainwater harvesting and waste } \\
\text { water reuse equipment (FR, CY, NL) }\end{array}$ & $\mathrm{X}$ & $\mathrm{X}$ & \\
\hline $\begin{array}{l}\text { Development of schemes to enable businesses to claim allowances } \\
\text { for investments in water-efficient technologies and equipment (UK) }\end{array}$ & $\mathrm{X}$ & $\mathrm{X}$ & \\
\hline $\begin{array}{l}\text { River Basin Management Plans including water efficiency standards } \\
\text { in buildings or water using devices (BG, CY, IE, SK) }\end{array}$ & $\mathrm{X}$ & & \\
\hline $\begin{array}{l}\text { Extension of metering of domestic water consumption (most } \\
\text { Member States) }\end{array}$ & & $\mathrm{X}$ \\
\hline $\begin{array}{l}\text { Free water/energy efficiency kits - including devices to fit to } \\
\text { showerhead and toilet cistern - distributed by Sainsbury's } \\
\text { supermarket to its customers (UK) }\end{array}$ & & $\mathrm{X}$ \\
\hline $\begin{array}{l}\text { EU ecolabel - standards for dishwashers and washing machines } \\
\text { include water consumption }\end{array}$ & & $\mathrm{X}$ \\
\hline
\end{tabular}

Overview of available tools

EU focus on improving quality of water. The need to address demand is however increasingly recognised

Various measures are in place at national level
A broad range of tools exist and are currently in use to promote more sustainable levels of water consumption by households, including regulatory, fiscal, other economic, information and behavioural tools. At the EU regulatory level, the Water Framework Directive (WFD) requires Member States to ensure that the price charged to water consumers - such as for the abstraction and distribution of fresh water and the collection and treatment of waste water - reflects the true costs (with potential for some derogations e.g. in less-favoured areas or to provide basic services at an affordable price). This principle has a long tradition in some countries, but less so in others (OECD, 2011). In 2007, the European Commission identified an initial set of policy options to be taken at European, regional, and national levels to address water scarcity within the EU (Eurostat, 2010).

At the national level there is a huge variety in the types of metered tariff for public water supply including flat-rate tariff, uniform volumetric tariff, two-part or binomial tariff (sum of a flat rate tariff and a uniform volumetric tariff), and lock tariffs which also usually incorporate a flat-rate charge, plus declining block tariffs and rising block tariffs. Two-part, rising block and declining block tariffs are widespread and there has been a general shift to block tariffs. Seasonal tariffs (summer/winter) are uncommon, but are increasingly used as a response to water scarcity situations and droughts. Peak tariffs (hourly or daily) have only been tested in pilot/trial schemes (Ecologic, 2007a). Many countries meter household water usage (and apply related water consumption charges).

Many countries also tax water use. Taxes may be based on consumption, the size of the house or number of occupants. Progressively graduated water prices based on taxes have been effective in helping to reduce water consumption in Denmark and Hungary and have the effect of minimising the regressive impact of water charging. Household water consumption in Denmark was greatly reduced by a $150 \%$ increase in the price of water through a combination of taxes. Denmark, Hungary and the Netherlands have also successfully combined public information campaigns with increases in household water prices to decrease water wastage. (OECD, 2008)

Mandatory restrictions, e.g. hosepipe bans, are commonly applied as a temporary measures in response to severe and unexpected water shortages since it is felt that suddenly imposing 


\section{Housing - water using appliances}

\begin{tabular}{|c|c|}
\hline & $\begin{array}{l}\text { higher prices would not generate a sufficient behavioural response. It is sometimes argued } \\
\text { that such a policy places less of a burden on poorer households than a pricing policy (OECD, } \\
\text { 2011). } \\
\text { Some MS have included water efficiency standards for buildings or water using devices in } \\
\text { their River Basin Management Plans. A small number of MS also have schemes to support } \\
\text { the purchase of rainwater harvesting, waste water reuse, or water-efficient equipment } \\
\text { for households and businesses. } \\
\text { Awareness-raising and behaviour change tools appear to be widely used in many countries. } \\
\text { Information campaigns are considered to be an important part of initiatives such as } \\
\text { promoting water-saving devices, raising prices to pay for leakage and encouraging more } \\
\text { rational water use (Ecologic, 20o7a). In addition, behaviour change measures such as those } \\
\text { promoting investment in residential water-saving equipment are gaining ground in some } \\
\text { countries. The most important factors influencing investment in water-saving devices } \\
\text { include home ownership and water charging on a volumetric basis. Eco-labelling (in general) } \\
\text { also complements marginal pricing of water at the point of use (OECD, 2011) and is currently } \\
\text { used at EU and the national level. The more specific labelling of products (e.g. washing } \\
\text { machines or toilets) according to their water efficiency helps to inform consumers about the } \\
\text { water consumption level of products and enables them to make informed decisions. } \\
\text { Labelling can also create pressure on the producers of products to incorporate available } \\
\text { water saving techniques into product design (although this is most effective when labelling } \\
\text { for certain products is mandatory) (Ecologic, 20o7a). It is important to note that labels do not } \\
\text { relate purely to rational and cognitive thought processes. Other important elements of labels } \\
\text { are the levels of recognition (i.e. does consumer emotively recall more than the label tells } \\
\text { them) and leading on from this, levels of trust in the verification process and the intention of } \\
\text { people proposing it. }\end{array}$ \\
\hline $\begin{array}{l}\text { Elements of } \\
\text { an effective } \\
\text { sectoral } \\
\text { toolbox }\end{array}$ & $\begin{array}{l}\text { The appropriate mix of measures may vary between MS or indeed between regions or } \\
\text { localities due to the wide range of factors including climate, population density, income etc., } \\
\text { that influence household water consumption. Measures should therefore take these factors } \\
\text { into account and flexibility should be afforded to policy-makers, rather than trying to design } \\
\text { a 'one-size-fits-all' toolkit. } \\
\text { According to the EEA, given that Europe cannot endlessly increase its water supply, demand } \\
\text { must be reduced through policies to encourage demand management. Demand } \\
\text { management measures could include the use of economic instruments; water loss controls; } \\
\text { water-reuse and recycling; increased efficiency of domestic, agricultural and industrial water } \\
\text { use; and water-saving campaigns supported by public education programmes (EEA, 201oa). } \\
\text { Such demand management measures could be promoted through guidelines and sharing } \\
\text { best practices. } \\
\text { Implementation of the Water Framework Directive's provisions on water tariffs and } \\
\text { compulsory metering could be improved. Charging households for the amount of water } \\
\text { they use is effective in promoting water conservation. This action alone would, on average, } \\
\text { lower household water consumption by about } 20 \% \text {. In addition, volumetric charging for } \\
\text { water appears to increase the likelihood that households will undertake several water saving } \\
\text { behaviours and investments. Metering for water consumption may both increase } \\
\text { awareness of consumption and allow service providers to price water on a per unit basis. To } \\
\text { minimise the regressive impact of water charging, full-cost water pricing could be coupled } \\
\text { with assistance to low-income households/progressively graduate water prices based on } \\
\text { taxes. } \\
\text { Awareness in and of itself seems to have an impact on investing in water-efficient appliances }\end{array}$ \\
\hline
\end{tabular}




\section{Housing - water using appliances}

measures with $\quad$ and undertaking water-saving behaviours. This suggests that water charges can work in awareness- $\quad$ tandem with water saving campaigns to reinforce desired water conservation. In this raising and behaviour change tools regard, it will likely prove effective to introduce or increase charging in one go as a part of a wider water conservation campaign. This has the effect of raising awareness of the issue with the public more than if it was done in increments. It also provides a mechanism which a wider sector of the population can relate to by highlighting both the environmental imperative to the environmentally concerned and private cost to all. Due to the apparent price inelasticity of household water demand, restrictions on water use - e.g. hosepipe bans - are also useful as temporary responses to severe and unexpected water shortages (OECD, 2011).

Awareness-raising and behaviour change tools are clearly beneficial to complement more prescriptive tools such as taxation and charging. Raising the environmental 'norms' (i.e. awareness and attitudes) of the consumer (i.e. providing information on the environmental implications of excessive and wasteful water consumption, together with the promotion of behaviours and water-saving devices (e.g. special taps or tap attachments, dual flush toilets, water-efficient washing machines and dishwashers) that can help to reduce water consumption) should help to promote more sustainable household water consumption and counter any potential rebound effects. This can be done through broad public information campaigns or more targeted measures such as eco-labelling schemes. Eco-labels also have a positive and significant effect on the probability of investing in water-efficient appliances.

\section{References}

- $\quad E C$, (2011), Third Follow up Report to the Communication on water scarcity and droughts in the European Union $\operatorname{COM}(2007) 414$ final, $\operatorname{COM}(2011) 133$, 2011, http://eurlex.europa.eu/LexUriServ/LexUriServ.do?uri=COM:2011:0133:FIN:EN:PDF

- EC, (2007), Second Follow-up Report to the Communication on water scarcity and

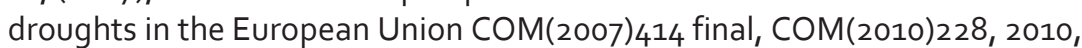
http://ec.europa.eu/environment/water/quantity/pdf/com 20100228 report.pdf

- Eco-schools website, (2011), http://www.eco-schools.org/page.php?id=56, accessed $02 / 06 / 11$

- Ecologic, (2007a), EU Water saving potential (Part 1-Report), 2007, http://ec.europa.eu/environment/water/quantity/pdf/water_saving_1.pdf

- Ecologic, (2007b), EU Water saving potential (Part 2 - Case Studies), 2007, http://ec.europa.eu/environment/water/quantity/pdf/water_saving_2.pdf

- EEA, (2010a), State and outlook for the environment thematic assessment - Water resources: quantity and flows

- EEA, (2010b), Use of freshwater resources (CSI 018), 2010, http://www.eea.europa.eu/data-and-maps/indicators/use-of-freshwater-resources/useof-freshwater-resources-assessment-2

- $E E A / O E C D$, Database on instruments used in environmental policy: Policy instruments used to address Natural resource management, accessed 03/06/11, http://www2.oecd.org/ecoinst/queries/index.htm

- Eurostat, (2010), Environmental statistics and accounts in Europe, 2010 edition

- OECD, (2008), Promoting Sustainable Consumption: Good Practices in OECD Countries, 2008, http://www.oecd.org/dataoecd/1/59/40317373.pdf

- OECD, (2011), Greening Household Behaviour: The Role of Public Policy, http://www.oecdilibrary.org/docserver/download/fulltext/9710141e.pdf? expires=1307092165\&id=id\&accn ame=0ido16742\&checksum $=9 \mathrm{~A}_{2} \mathrm{~B}_{49}$ FBCFEFo7D 97D2E9BFB0156CB8C

- Flörke, M., and Alcamo, J., (2004), Centre for Environmental Systems Research, University of Kassel, European Outlook on Water Use, 2004 


\section{Food and drink}

\section{Sectoral analysis}

General

trends in the

sector

Significant

environmental

impacts,

especially

from

consumption

of meat and

dairy products

Changes in

composition of

diets and way

food is

produced and

sold expected

to continue
In recent decades, while there have been only minor changes to the total amount of food consumed in the EU, there have been marked changes in the composition of diets and the way food is produced and sold. Some general trends in European food consumption as identified in the 2010 EEA SOER are:

- The replacement of beef and lamb by pork and in particular poultry (although beef consumption is rising in newer Member States) due to inter alia price differences, a general trend towards healthier food, and the ease with which poultry can be combined with pre-prepared foods;

- Increasing consumption of fruit in the EU-15 in 1990-2005, which may be due to the greater availability and reduced prices of (imported) fruit;

- Increasing purchases of pre-prepared and frozen meals and convenience foods due to smaller household sizes and reduced time spent on food preparation;

- Increasing expenditure and frequency of eating take-away food and in restaurants;

- A significant increase in quantities of imported food - meat imports into the EU-15 increased by $120 \%$ between 1990 and 2007 , cereal imports increased by $83 \%$, frozen vegetables by $174 \%$, and bananas by $92 \%$ over the same period; and

- A marked rise in consumption of bottled water in many European countries (EEA, 2010).

Food and drink consumption are estimated to cause $15 \%$ of GHG emissions, $37 \%$ of acidifying emissions, $14 \%$ of tropospheric ozone precursors and $19 \%$ of material resource use activated by national consumption (EEA 2010). Some $\mathbf{1 5 - 3 0 \%}$ of key pressures caused by consumption can be allocated to the food and drink sector, which contributes approximately 2 tonnes $\mathrm{CO}_{2}$-equivalents of GHG per capita per year (ETC-SCP 2009) (ETCRWM 2008). These findings are similar to those of the EIPRO project (Environmental Impacts of Products) which found that food and drink consumption is responsible for $20-30 \%$ of the various environmental impacts of total consumption, and in the case of eutrophication for more than $50 \%$. The impacts analysed in this study were: abiotic resource depletion, acidification, eco-toxicity, global warming, eutrophication, human toxicity, ozone layer depletion, and photochemical oxidation (JRC/IPTS, 2006) (EEA, 2010).

The consumption of meat and dairy products is responsible for the bulk of key impacts caused by eating and drinking (EEA, 2010). A JRC/IPTS study on the environmental improvement potentials of meat and dairy products (IMPRO) found that meat and dairy products contribute $24 \%$ of the overall environmental impacts caused by total consumption in the EU-27, but account for only $6 \%$ of total expenditure (JRC/IPTS, 2008) (EEA, 2010). The same study shows that in the EU-27, meat and dairy products contribute about $30-40 \%$ of aquatic and terrestrial eutrophication, $14 \%$ of GHG emissions, and $35 \%$ of nature occupation caused by total European consumption. Another key issue is that of food waste. Based on data from Eurostat and national data, it has been estimated that annual food waste generation in the EU-27 is around 89 million tonnes or $179 \mathrm{~kg}$ per person, of which $42 \%$ was from households, 39\% from manufacturing and the rest from other sources including retailers and the food service sector, but excluding agricultural waste (Bio Intelligence Service et al, 2010) (EEA, 2010). A further major issue related to food consumption is the overexploitation of fish stocks (EEA, 2010). The direct negative environmental effects of food and drink consumption (e.g. from travelling to shops, storing, cooking and generating waste) tend to be smaller than the indirect effects of food and drink consumption but these are on the increase (EEA, 2005).

Assuming a recovery of the economy, increasing incomes and relatively stable food prices, the major trend over the next ten years could be shifting consumption patterns rather than 


\section{Food and drink}

a marked increase in per person consumption volumes (OECD/FAO, 2009) (EEA, 2010). For example, rising incomes is likely to result in consumers spending extra money on quality, diversity and convenience, rather than quantity. Increased demand for quality may result in purchases of more environment-damaging food, e.g. off-season vegetables and fruits transported by plane, while on the other hand the quality aspect may also lead to food choices that reflect more environmentally conscious behaviour, e.g. increased consumption of organic / local produced / GMO-free food (EEA, 2005).

The European Commission projects that by 2020, beef/veal and sheep/goat meat production would drop by $7 \%$ and $11 \%$ respectively while pig and poultry meat production would expand by $7 \%$ each. This shift is due to a combination of factors, including health scares such as Bovine Spongiform Encephalopathy (BSE) and foot and mouth disease, price differences, and nutritional advice that white meat is healthier than red meat. On a per capita basis, overall EU meat consumption is expected to reach $85.4 \mathrm{~kg}$ in 2020, 2\% higher than 2009 . According to the Commission's projections, poultry meat consumption would increase the most (above 6\%) while pig meat growth would remain below $5 \%$ on aggregate between 2009 and 2020. Demand for cheese and fresh dairy products is also expected to grow, with the production of fresh dairy products projected to increase by about $8 \%$ from 2009 to 2020 and cheese output expected to grow by about $10 \%$ over the same period (EC, 2010). The continued globalisation of the food supply could mean that new food-safety risks emerge, previously controlled risks could be re-introduced, and contaminated food could be spread across greater geographical distances, leading to possible greater focus on food safety in the future. Current trends regarding variety, pre-prepared processed food and convenience are also expected to continue, driven partly by the trend to individualism, smaller households and more double-income households; while globalisation and more trade will lead to the increasing availability of more 'exotic' and out-of-season foods.

The projected decline in the consumption of beef is likely to have some positive effects on a number of key environmental impacts from cattle farming by reducing nitrate pollution and methane emissions if intensive beef farming is reduced (EEA, 2010). A rapid growth in poultry consumption will have major implications for animal waste disposal and for animal welfare if the growth takes place in the intensive sector. A small but continuing growth in calories consumed could also raise questions about the health of the European population (Danish EPA, 2004) (EEA, 2010). A 2009 JRC study investigating the environmental implications of a switch to healthier diets in Europe found that a shift in diet to one which reduced the consumption of red meat would reduce the overall environmental impacts related to food consumption by around $8 \%$, however the negative impacts on fish stocks of enhanced consumption of fish is not taken into account (JRC/IPTS, 2009).

Social,

technical and

political

challenges

faced

Structure of

food supply

chain is a
Changes in both consumption and production are important to ensure more sustainable food consumption patterns. On the production side, diverging interests and political sensitivities surrounding the reform of the CAP and CFP will be among the key challenges that will need to be overcome. Other political challenges relate to the prevailing paradigm of free consumer choice, free markets and free trade which make public authorities reluctant to act in the area of consumer choice and have meant that interventions tend to be restricted to soft measures like education and awareness raising rather than price mechanisms or bans. Subsidiarity concerns are an important challenge to EU level intervention in this area (JRC/IPTS, 2009).

Other challenges relate to the interests and the current structure of the food supply chain in which market power in concentrated in a limited number of retailers and producers of intermediate or finished food products. These actors have the potential to play an important role in supporting sustainable changes in the production chain. However they 


\section{Food and drink}

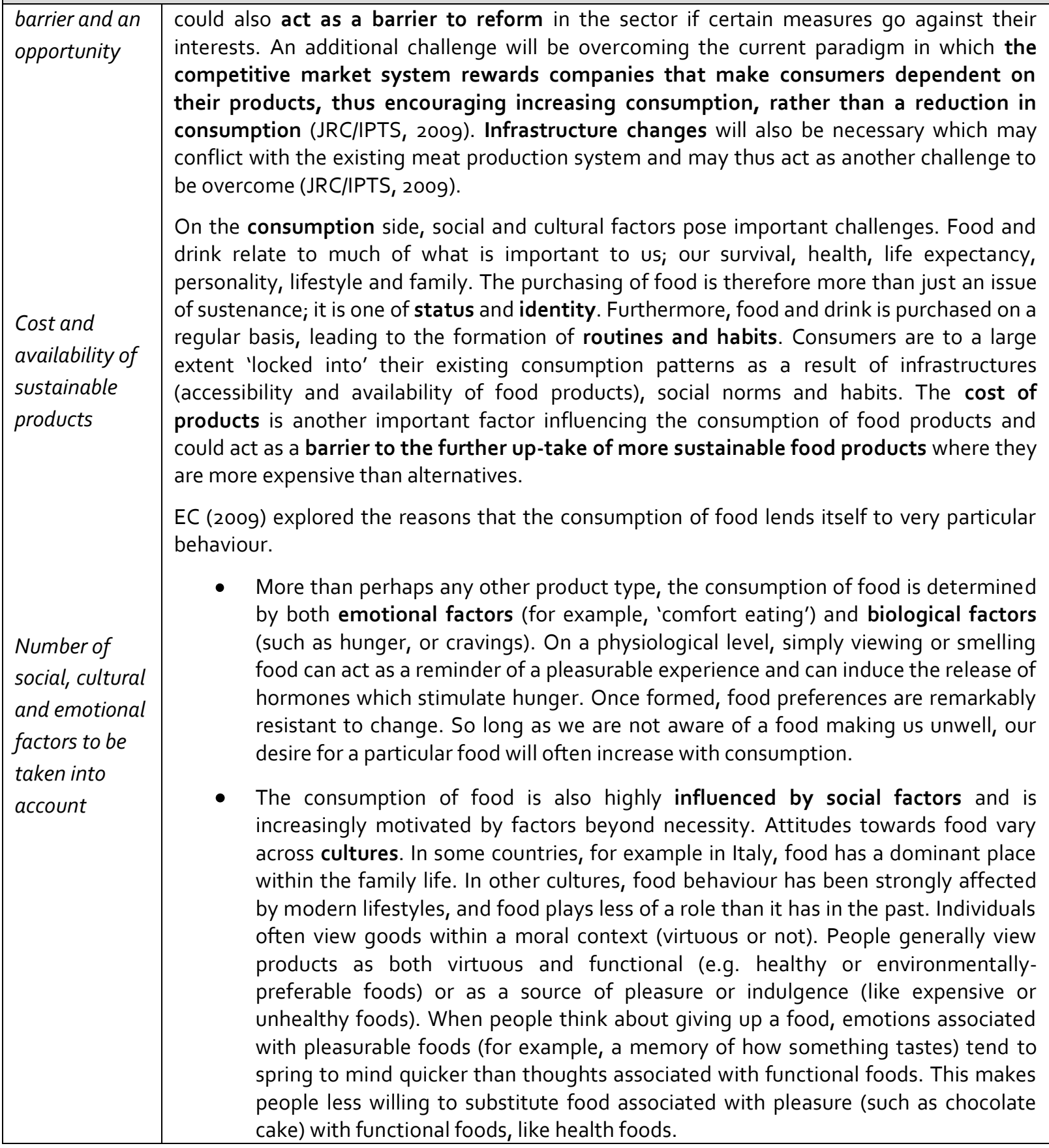




\begin{tabular}{|c|c|c|c|c|c|}
\hline \multicolumn{6}{|l|}{ Selection of available tools } \\
\hline Tool name and location & 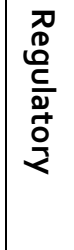 & $\begin{array}{c}\underline{\underline{u}} \\
\underline{\underline{\underline{u}}}\end{array}$ & 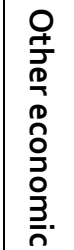 & 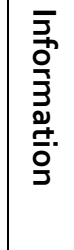 & 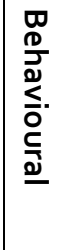 \\
\hline $\begin{array}{l}\text { Voluntary certification schemes e.g. Marine Stewardship } \\
\text { Council, organic food labelling (various countries) }\end{array}$ & & & & $x$ & \\
\hline $\begin{array}{l}\text { Legislative measures to support / promote more sustainable } \\
\text { food production and processing methods, e.g. under the CAP, } \\
\text { CFP and IPPC/IED Directive }\end{array}$ & $x$ & & & & \\
\hline Love food hate waste (Herefordshire and Worcestershire, UK) & & & & & $x$ \\
\hline Slow food movement (various countries) & & & & & $x$ \\
\hline $\begin{array}{l}\text { Initiatives to support localisation of food chain, e.g. Open } \\
\text { garden foundation (HU), food clubs (various countries) }\end{array}$ & & & & & $x$ \\
\hline Campaign to encourage meat-free days (UK, $\mathrm{BE}, \mathrm{DE})$ & & & & & $x$ \\
\hline $\begin{array}{l}\text { Voluntary initiatives by retailers such as choice editing, } \\
\text { information campaigns, imposing standards on downstream } \\
\text { suppliers etc. (various countries) }\end{array}$ & & & & $x$ & $x$ \\
\hline $\begin{array}{l}\text { Voluntary initiatives between retailers and CSOs, e.g. MSC } \\
\text { sustainable supermarket league table, Project Ocean with } \\
\text { Selfridges (UK) }\end{array}$ & & & & $x$ & \\
\hline $\begin{array}{l}\text { Campaigns by NGOs, individuals or citizen groups to promote } \\
\text { more sustainable food consumption, e.g. Fishfight (UK, ES), } \\
\text { fish2fork (UK) }\end{array}$ & & & & $x$ & \\
\hline
\end{tabular}

Overview of A number of different tools that address environmental effects at different points of the available chain of food production and consumption can be identified. Regulatory measures largely tools $\quad$ relate to the production / process side of the chain, in particular legislative requirements for agriculture, fisheries and the IPPC Directive (now IED) relating to food production and processing. Various EU/national/local organic and other labelling schemes (e.g. on product origins and the environmental and energy intensity embodied within) help consumers make informed decisions about what to buy and aim to encourage more sustainable patterns of food consumption. Eco-design requirements, e.g. in relation to packaging waste, encourage innovation and help promote eco-efficiency in production and processing. Several consumer information, education, and training initiatives supported by public authorities are also underway.

A number of

Retailers across the EU are involved in a number of voluntary initiatives such as the Retail Forum for sustainability that was launched in 2009 to take forward some of the objectives of initiatives the SCP/SIP Action Plan. Some retailers have adopted voluntary codes of conduct and a number of retailer-led quality assurance schemes and supply chain initiatives have been 


\begin{tabular}{|c|c|}
\hline $\begin{array}{l}\text { among } \\
\text { retailers and } \\
\text { at the local/ } \\
\text { community } \\
\text { level are } \\
\text { underway }\end{array}$ & 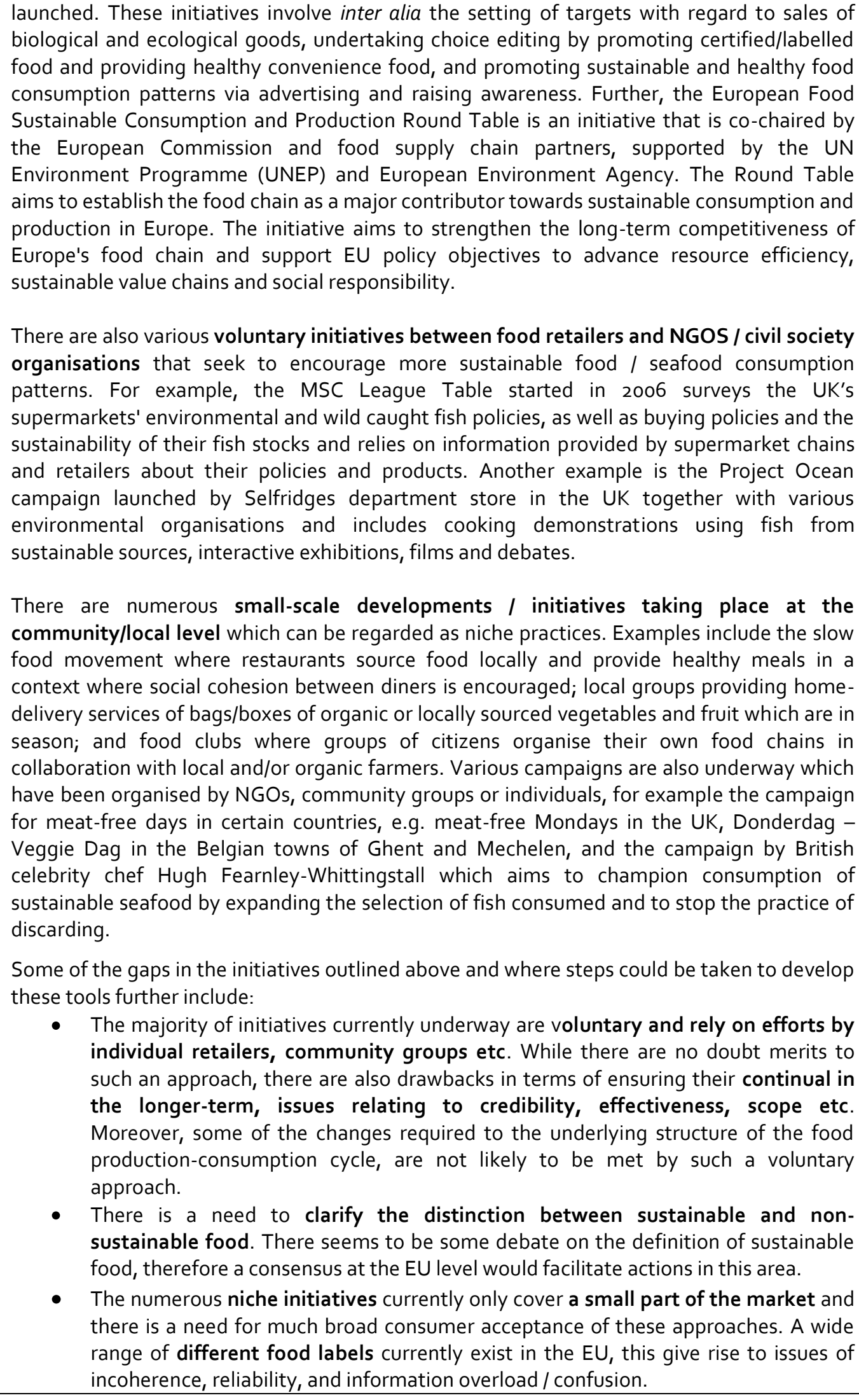 \\
\hline $\begin{array}{l}\text { Elements of } \\
\text { an effective } \\
\text { sectoral } \\
\text { toolbox }\end{array}$ & $\begin{array}{l}\text { An effective toolbox in the food sector would include measures that target the whole chain } \\
\text { of production and consumption. To a large part these measures will be complementary, for } \\
\text { example increased demand for sustainable products by consumers will help to drive more } \\
\text { innovative production methods by producers and retailers which will lead to greater }\end{array}$ \\
\hline
\end{tabular}




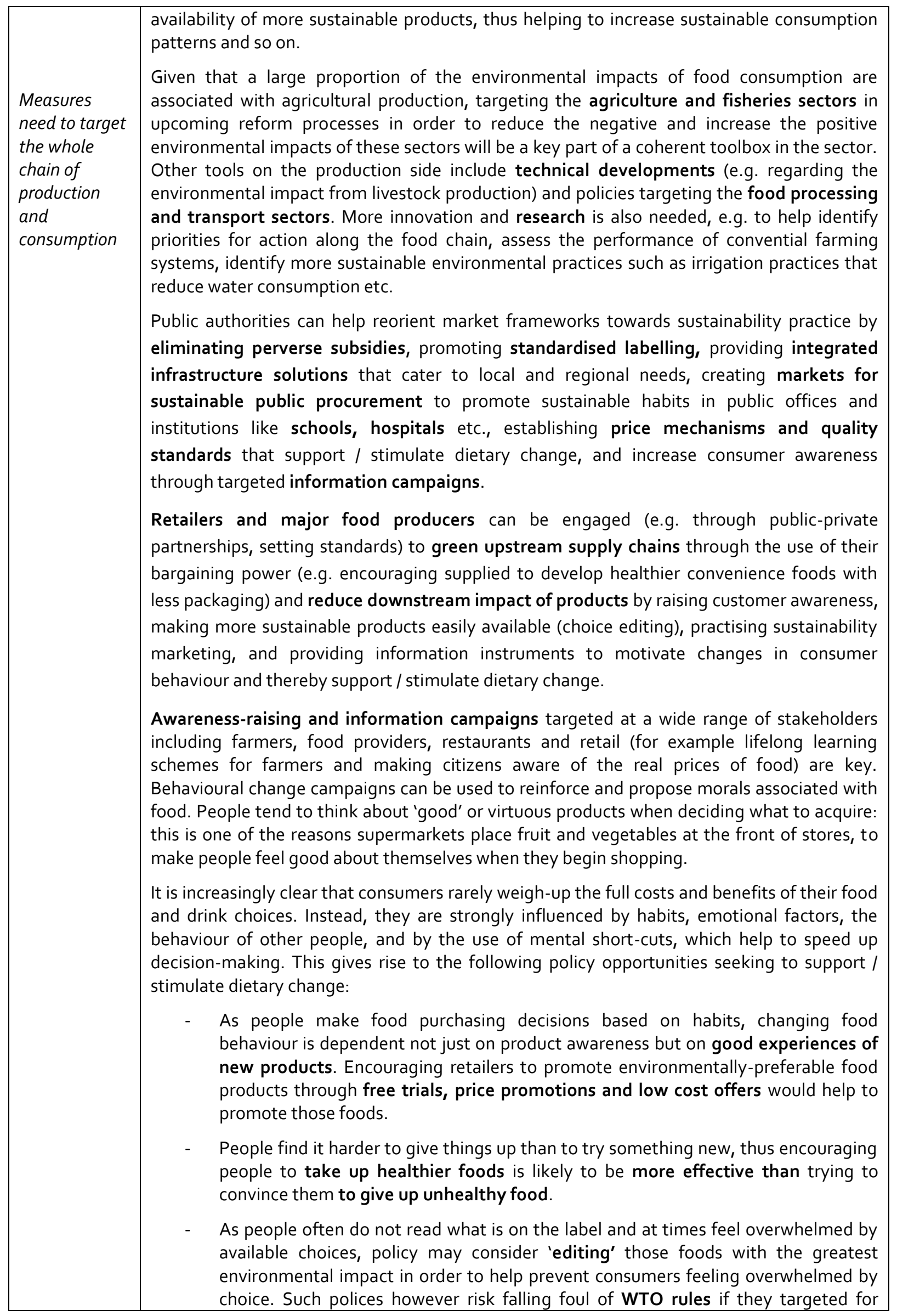




\begin{tabular}{|c|c|}
\hline & $\begin{array}{l}\text { example air freighted produce, and thus would need to be carefully designed. } \\
\text { - As people find it easier to compare products which are easily comparable, ensuring } \\
\text { standardised product information and packaging for food products can make this } \\
\text { process easier. } \\
\text { There is however an emerging social trend in more sophisticated consumers who do not } \\
\text { follow such short-cuts when purchasing food. Marketing professionals have identified an } \\
\text { emerging group of so called 'trysumers' who have been "freed from the shackles of } \\
\text { convention and scarcity, immune to most advertising, and enjoying full access to } \\
\text { information, reviews, and navigation, experienced consumers are trying out new appliances, } \\
\text { new services, new flavours, new authors, new destinations, new artists, new relationships, } \\
\text { new anything with post-mass-market gusto" (Cotton, 20o7). Associated closely with slow } \\
\text { food and to a lesser extent fair trade, food plays an important part of this trend as trysumers } \\
\text { independently seek unique and new experiences which provide stories to share with their } \\
\text { friends. This provides an opportunity for a sub-section of the food production chain in Europe } \\
\text { to de-intensify but remain competitive as they are able to provide a unique story directly to } \\
\text { their customers. Support for local/community-led niche practices and initiatives will be } \\
\text { important to encourage the further take-up of such practices. Clarifying the distinction } \\
\text { between sustainable and non-sustainable food, e.g. in terms of the overall benefits of } \\
\text { organic agriculture, local production etc., will be important to help ensure these initiatives } \\
\text { support the most appropriate consumption patterns. }\end{array}$ \\
\hline \multicolumn{2}{|l|}{ References } \\
\hline & 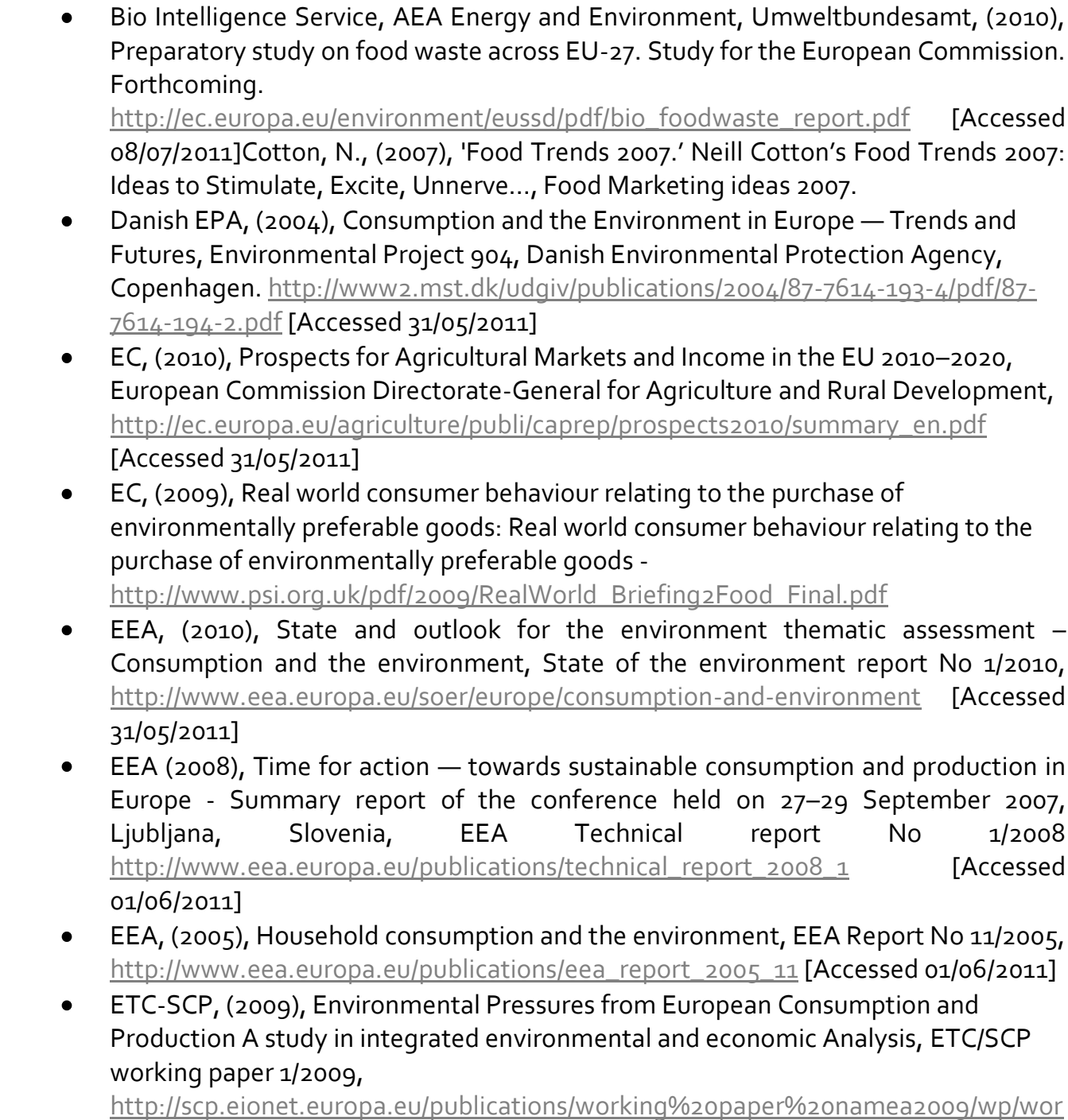 \\
\hline
\end{tabular}




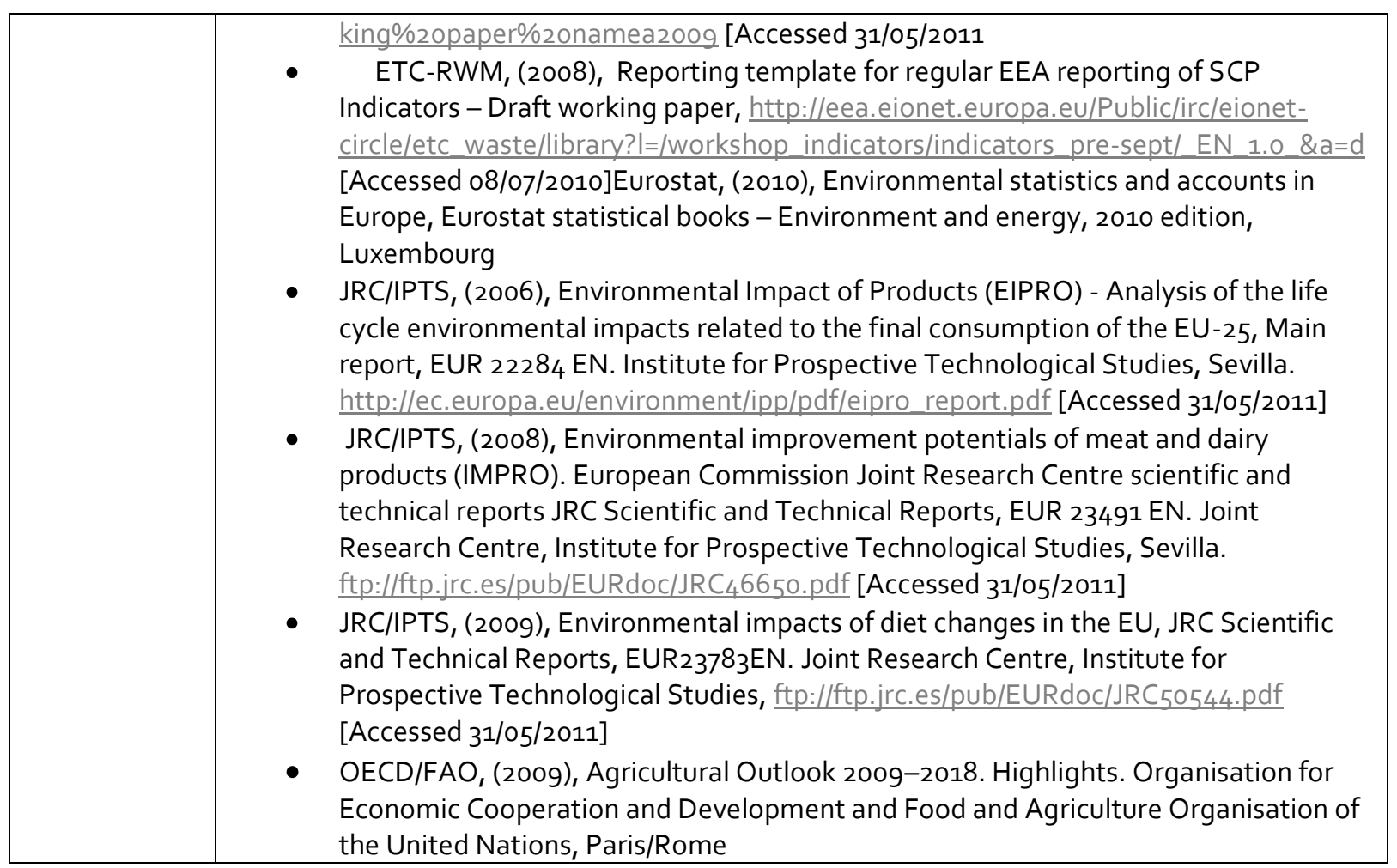

\section{Clothing and textiles ${ }^{172}$}

\begin{tabular}{|c|c|}
\hline \multicolumn{2}{|c|}{ Sectoral analysis } \\
\hline $\begin{array}{l}\text { Rising } \\
\text { consumption } \\
\text { levels } \\
\text { aggravating } \\
\text { environmental } \\
\text { impact }\end{array}$ & $\begin{array}{l}\text { Clothing and textiles have a significant environmental impact during their lifecycle, which is } \\
\text { aggravated by rising consumption levels (Defra, 2011). The European Commission's } 2006 \\
\text { EIPRO study found that clothing is the fourth highest impact area (following food and drink, } \\
\text { transport and housing), with an estimated share of } 2-10 \% \text { in total environmental impact, } \\
\text { depending partly on whether or not washing, drying and ironing of clothes is included. The } \\
\text { use of energy and toxic chemicals during the whole lifecycle is considered the factor with } \\
\text { the greatest environmental impact of the sector. Extensive water use is another important } \\
\text { environmental concern as well as the fast increase in waste volumes due to the shortening } \\
\text { lifecycle of clothes - cheap/fast fashion already has a market share of } 20 \% \text { in the UK and } \\
\text { continues to grow (Allwood et al., 2006). } \\
\text { According to the yet unpublished IMPRO Textiles report, consumption in the EU-27 adds up } \\
\text { to } 9.5 \text { million tons of textile products each year, } 71 \% \text { of which are clothing textiles and } 29 \% \\
\text { household textiles. The report finds that the production, processing } 172 \text { and use phases } \\
\text { contribute most to environmental impacts. The main impacts of the production and } \\
\text { processing phase stem from unsustainable (cotton) farming methods, the use of chemicals } \\
\text { and high use of electricity. Washing, tumble drying and ironing during the use phase are } \\
\text { responsible for a high share of impacts due to high water and energy usage. The impact of }\end{array}$ \\
\hline
\end{tabular}

\footnotetext{
${ }^{171}$ The product category of textiles and clothing encompasses clothes, household fabric (such as domestic carpets) and footwear. This case assessment focuses on clothes (fashion).

172 "Production and processing - this phase includes the production or extraction of raw materials (e.g. cultivation of fibre producing crops), leading to the processing of the fibre, followed by the confection of yarn and fabric, and finally the finishing, cutting and sewing steps." [4]
} 


\section{Clothing and textiles ${ }^{121}$}

\begin{tabular}{|c|c|}
\hline & $\begin{array}{l}\text { the end-of-life phase depends significantly on whether or not textiles are reused or recycled, } \\
\text { incinerated (resulting in reduced waste volumes and energy recovery) or sent to landfill. Of } \\
\text { the } 14 \text { million tonnes of textile waste generated in Europe, only } 5 \text { million tonnes are } \\
\text { recovered, with } 75 \% \text { of this being reused or recycled (Oakdene Hollins, 2011). Another issue } \\
\text { of textile production relates to the social and labour conditions of workers in the textile } \\
\text { industry in emerging economies and developing countries which have been heavily criticized } \\
\text { over the past decade (see case study on fair trade clothes in Task } 3 \text { report). } \\
\text { Clothes are becoming cheaper, have a shorter lifespan ("fast fashion") and are purchased in } \\
\text { ever growing quantities (Allwood et al., 2006). With the volume of clothing consumption } \\
\text { rising, the end-of-life phase becomes more important. Product innovations (so-called } \\
\text { 'smart' functions) could help reduce the impact of the use phase and/or extend the lifespan } \\
\text { of the garment. Although there is still a low level of awareness for sustainability issues } \\
\text { related to clothing, consumers are increasingly concerned about the social and } \\
\text { environmental impact during the production and processing phase. Consumer pressure as } \\
\text { well as legislation will increase the demand for environmentally sound products and } \\
\text { improved working conditions. The eco-fashion segment of the market is already growing. } \\
\text { Increasing numbers of small fashion labels with a rather comprehensive sustainability } \\
\text { approach exist and many sell their clothes via the internet. High street market leaders such } \\
\text { as H\&M, Tesco, Marks \& Spencer, C\&A and others are also making a move towards } \\
\text { sustainable fashion (e.g. using organic cotton) (Oneko, S., 2011). However, at least in some } \\
\text { countries like the UK, consumers feel that there is inadequate supply of ethical fashion on } \\
\text { the market and the trustworthiness of sustainability claims of companies is questioned } \\
\text { (Fisher et al., 20o8). Labelling and certification could help to establish trust in sustainable } \\
\text { products. }\end{array}$ \\
\hline $\begin{array}{l}\text { Social, } \\
\text { technical and } \\
\text { political } \\
\text { challenges } \\
\text { faced }\end{array}$ & 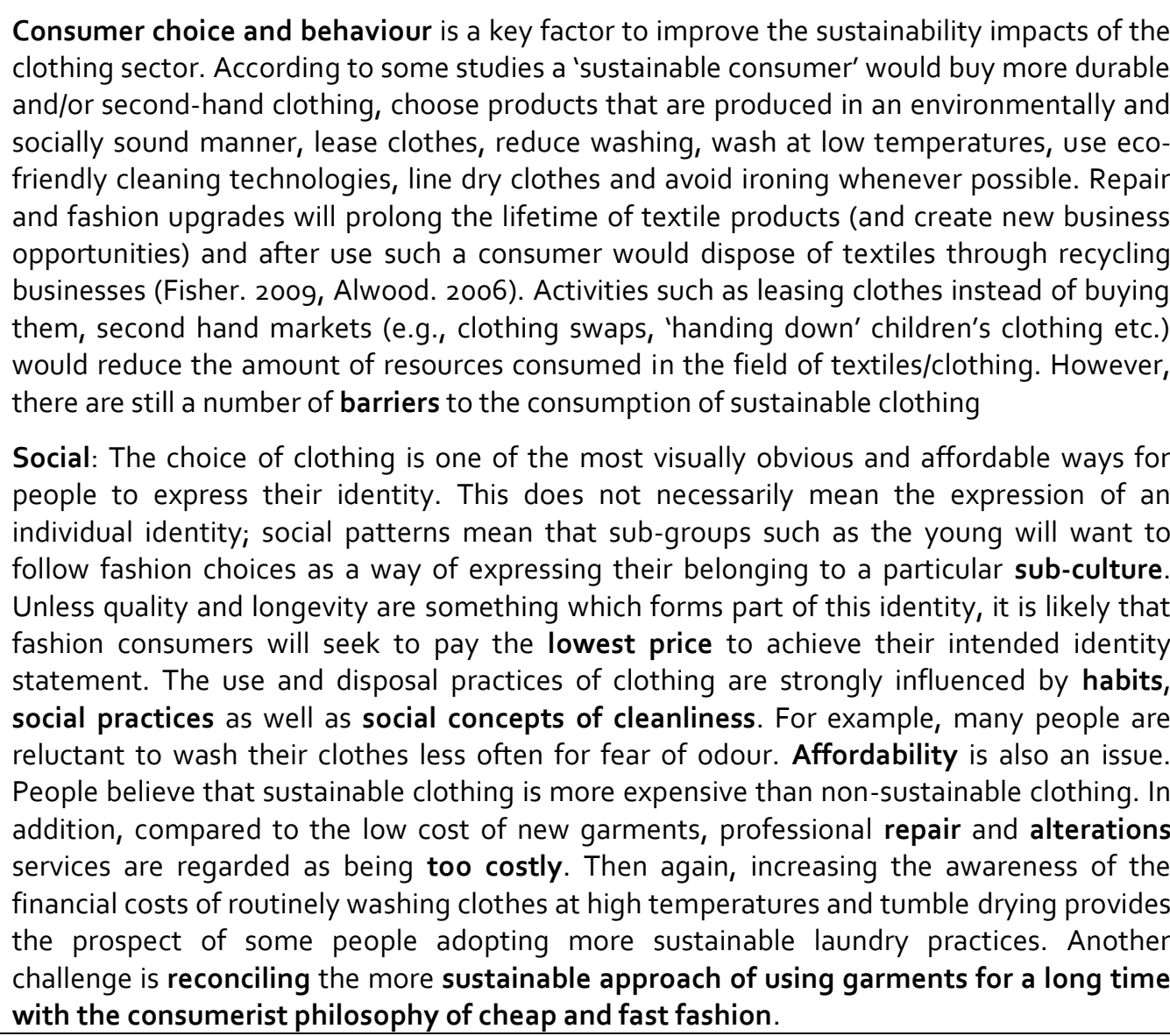 \\
\hline
\end{tabular}




\section{Clothing and textiles ${ }^{121}$}

Technical: Sustainable use such as washing at reduced temperatures and line drying clothes is often hindered by a lack of space and appropriate weather conditions. There is further scope for improvements in appliance efficiency as part of product policy. The rebound effect could also be an issue when improving appliance efficiency, for example if households buy or use a more efficient tumble dryer instead of line drying clothes. Therefore, consumer choice and behavioural change is very important in this area.

Political: An important political constraint is the reluctance of policy-makers to create policies that intervene in people's lifestyle choices and the low social acceptance for such interventions. WTO rules do not allow the establishment of barriers to trade on the grounds of social standards and greatly limit the scope for restrictions for environmental reasons.

\section{Sectoral analysis of tools}

Selection of available tools

\begin{tabular}{|c|c|c|c|c|}
\hline Tool name and location & 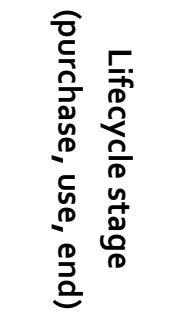 & 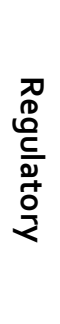 & 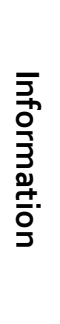 & 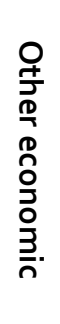 \\
\hline Sustainable Clothing Roadmap (UK) & Several & & $x$ & \\
\hline European eco label for clothing/footwear/detergents & Purchase & & $\mathrm{x}$ & \\
\hline Blue Angel for clothing/shoes (DE) & Purchase & & X & \\
\hline Door step textile collections for reuse/recycling & End-of-life & & & $x$ \\
\hline $\begin{array}{l}\text { Other product labels (Oeko-Tex 10oplus Standard, Global } \\
\text { Organic Textile Standard [GOTS], ...) }\end{array}$ & Purchase & & $\mathrm{x}$ & \\
\hline $\begin{array}{l}\text { Information campaigns: "wash right" (pan EU), "wash at } \\
30^{\circ} \mathrm{C} \text { " (UK) }\end{array}$ & Use & & 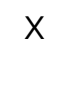 & \\
\hline $\begin{array}{l}\text { "FairWertung" label } \\
\text { (fair recycling and reuse of used clothing and textiles) (DE) }\end{array}$ & End-of-life & & $\mathrm{x}$ & \\
\hline Oxfam Clothes Exchange by Marks \& Spencer (UK, IE) & End-of-life & & & $x$ \\
\hline $\begin{array}{l}\text { TRAID (collect, sort, reconstruct or redesign items to sell } \\
\text { them in charity shops) (UK) }\end{array}$ & End-of-life & & & $\mathrm{x}$ \\
\hline
\end{tabular}

Overview of In order to promote more sustainable consumption in the clothing sector, both the supply available and demand side would need to be addressed. With the EU eco-design Directive, REACH tools $\quad$ legislation and the EMAS voluntary instrument, EU legislation has so far primarily targeted the production phase by trying to influence the type of products used in the production process and the production process itself. However, most textile products are imported ${ }^{173}$ ${ }^{173} 90 \%$ of the UK clothing is imported (Defra 2011) and imports account for more than $80 \%$ of the German textile
market (Schmidt 2003) 


\section{Clothing and textiles ${ }^{12}$}

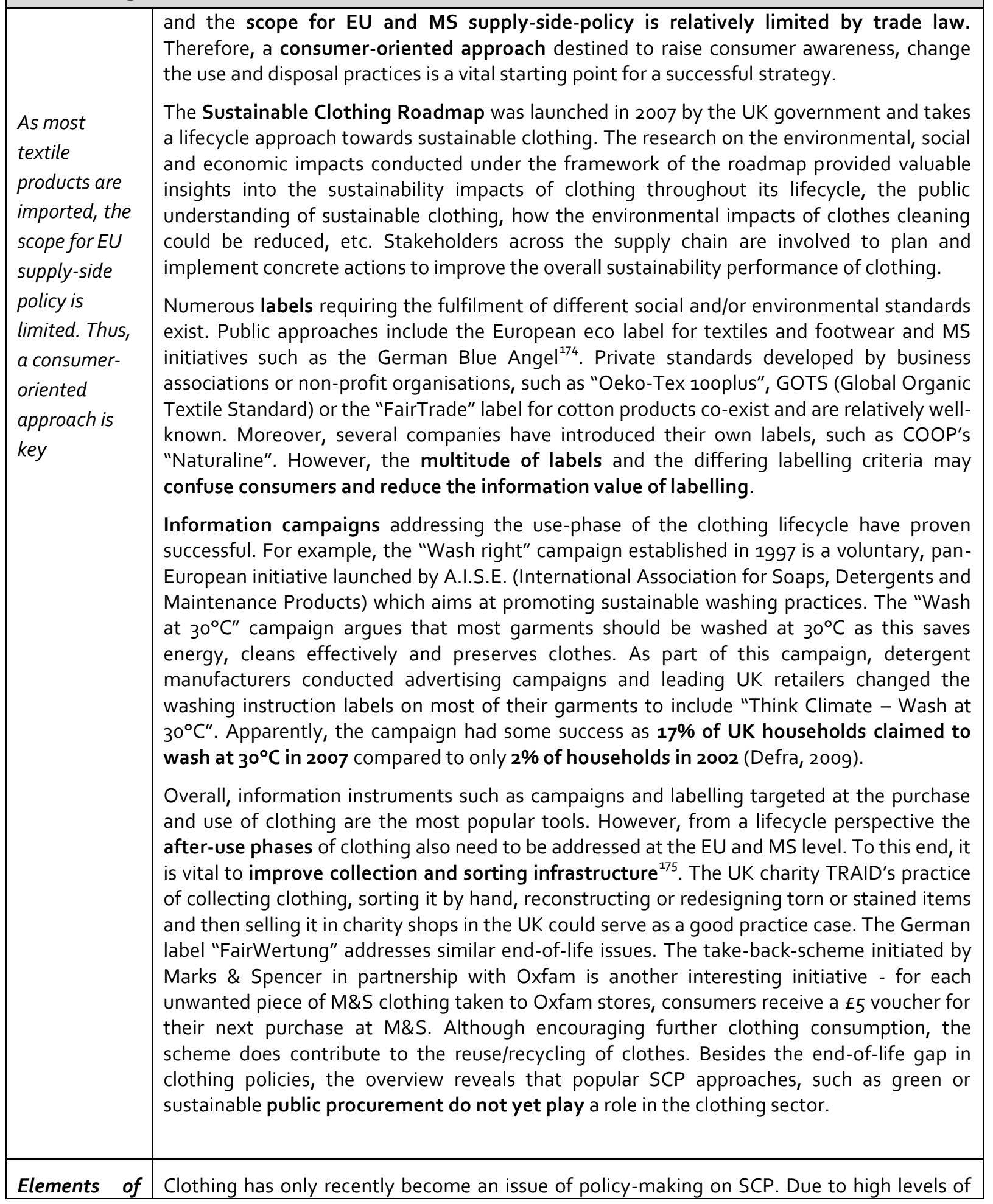

\footnotetext{
${ }^{174}$ The Blue Angel for textiles (released in February 2011) sets high sustainability standards covering both social and environmental issues. However, to date, the label has not been awarded to any textile product.

${ }^{175}$ It should be noted here, that whilst domestic second-hand markets add to sustainability, the export of used textiles to developing countries can create massive problems for the local textile industries.
} 


\section{Clothing and textiles ${ }^{12}$}

an effective clothing imports to the EU, direct supply-side policies have a limited impact. Hence, sectoral $\quad$ upstream sustainability issues will be addressed more effectively by influencing the toolbox $\quad$ purchasing decisions of private (and public) consumers. Ecological and social supply-chain issues as well as more sustainable clothing practices in the use phase (washing, drying, and maintenance) are not yet fully integrated in public awareness. Thus, consumer education, e.g. through standardised labelling and certification schemes and targeted information

Increase awareness of sustainability issues along whole lifecycle of clothing/ campaigns, should be a major focus of future public policies. The same holds true - though with smaller environmental pressures - for end-of-life policies (take-back schemes, reuse, recycling), in particular given trends such as fast fashion and the spread of textile discounters.

Partnering with retail industry in the development and implementation of sustainable clothing policies is important as retailers are gatekeepers with a strong influence on the upstream supply-chains and a major channel through which to reach the consumer, e.g. at textiles the point-of-sale. Thus, engaging the retail industry (e.g. through public-private partnerships, setting standards) in greening upstream supply-chains and influencing consumer behaviour e.g. through information provision and choice editing will be important tools.

Given that $50 \%$ of the world textile exports and $75 \%$ of world clothing exports come from developing countries, the EU and its MS could use development cooperation to promote and incentivise environmental and social improvements in the textile and clothing industries of these countries.

WTO rules would not prevent the introduction of additional taxes on clothing so long as they did not discriminate in any way against imported goods. A potential far reaching approach might be taken from what is being proposed in the UK for the control of the sale of cheap alcohol. Minimum prices for certain categories of garments could be introduced to prevent 'disposable' consumption patterns and steered through quality standards. Introducing additional taxes / minimum prices would however be politically difficult to implement and might currently be considered to be disproportionate to the problem faced. Furthermore, minimum prices could represent a significant market distortion and might be considered discriminatory against exporting countries (such as China) with a comparative advantage in low labour costs.

\section{References}

- Allwood J. M., Laursen S. E. and Bocken C. M., (2006), Well dressed? - The present and future sustainability of clothing and textiles in the United Kingdom. University of Cambridge Institute for Manufacturing.

- Defra, (2011), Sustainable Clothing Roadmap: Progress report 2011, Department for Environment, Food and Rural Affairs, London.

- Defra, (2009), Reducing the environmental impact of clothes cleaning

- EC, (2006), Environmental Impacts of Products (EIPRO) - Analysis of the life cycle environmental impacts related to the final consumption of the EU-25; EUR 22284 EN.

- JRC IPTS, IMPRO Textiles, European Commission, publication pending.

- Fisher T., Cooper T., Woodward S., Hiller A. and Goworek H., (2008), Public Understanding of Sustainable Clothing: A report to the Department for Environment, Food and Rural Affairs. Defra, London. Oakdene Hollins, (2011), http://www.oakdenehollins.co.uk/textiles-clothing.php

- Oneko, S., (2011), Greening the high street: marketing trick or real deal?, in: http://www.theecologist.org/green green living/clothing/881447/greening the high str eet_marketing_trick_or_real_deal.html

- Schmidt, E., (2003), Nachhaltigkeit und Globalisierung am Beispiel Textilien. Verbraucherzentrale Bundesverband e.V., Berlin

\section{Other sources}




\section{Clothing and textiles ${ }^{12}$}

- http://www.blaver-engel.de/de/produkte_marken/produktsuche/produkttyp.php?id=573

- http://ec.europa.eu/environment/ecolabel/ecolabelled_products/product_categories_en. $\underline{\mathrm{htm}}$

- http://www.reuk.co.uk/Wash-Most-Clothes-at-3o-Degrees.htm

- http://www.traid.org.uk/how.html

- Kloos, Dominic (2009) Sozial-Ökologische Mode auf dem Prüfstand. Südwind e.V.

\section{Tourism}

\section{Sectoral analysis}

\section{General} trends in the sector

Tourism and the environment closely interlinked. Environmenta I degradation is detrimental to the tourism industry.
According to the latest EEA State of the Environment Report (2010), Europe is a key tourist destination with six EU Member States in the world's top ten travel destinations. In addition, European tourists are one of the largest groups travelling to third countries, providing an extremely important source of revenue in many countries. The EU's tourism industry is of high economic importance, generating more than $5 \%$ of EU GDP and employing around $5.2 \%$ of the total labour force. Specific trends in the tourism sector include more frequent, but shorter leisure trips and the spread of low-cost air travel, which has been an important driver of the growth in the number of trips and the trend towards more frequent and shorter stays (EEA, 2010). The number of people with time and money for tourist trips has generally increased in Europe, especially among the elderly, singles, and couples without children (EEA, 2010).

Tourism has multiple environmental impacts both inside and outside Europe, which include the travel to destinations, building of facilities such as hotels, second homes or tourism infrastructure and activities at the destinations (i.e. ski resorts, golfing and swimming are responsible for heavy water use and land degradation) (EEA, 2010). Other tourism related environment pressures also contribute to the loss of habitats for wildlife through activities such as over-visiting vulnerable habitats, disturbance of wildlife, sale of endangered species to tourists, and trampling of dune environments. According to the 2010 EEA SOER, transport connected to tourism accounts for about $8 \%$ of GHG emissions in the EU-15. In the EU-15, most trips are made by car, followed by air. Car travel accounts for about $41 \%$ of GHG emissions from tourism, and trips made by plane account for about $55 \%$ despite only being used for $20 \%$ of trips (EEA, 2010). Trends in tourism are however changing: it is expected that experimental tourism - which includes eco-tourism, nature, heritage, cultural, and soft adventure tourism, as well as sub-sectors such as rural and community tourism - is among the sectors that will grow most quickly over the next two decades (EEA, 2010). These tourism sub-sectors have significant potential in terms of sustainable consumption and low environmental impact sectors.

Climate change is expected to affect major tourism areas in Europe in the future. For example, water demand for tourism is likely to increase with climate change, with warmer and longer summers driving up demand and worsening water stress, and shorter snow seasons in areas such as the Alps (EEA, 2010). A recent scenario developed by an international team of experts from the World Tourism Organization (UNWTO), the United Nations Environment Programme (UNEP) and the World Meteorological Organization (WMO) estimate that by 2035 , based on a 'business as usual' projection:

- Global tourism will grow by $179 \%$ in terms of the number of trips made, while guest nights will grow by $156 \%$.

- Passenger kilometres travelled will rise by $222 \%$, while $\mathrm{CO}_{2}$ emissions will increase at somewhat lower levels (152\%) due to efficiency improvements. 


\section{Tourism}

- The share of aviation-related emissions will grow from $40 \%$ in 2005 to $52 \%$ by 2035 . Tourism's contribution to global warming including all greenhouse gasses will be even larger, with an expected increase in radioactive forcing of up to $188 \%$, most of which will be caused by aviation.

Tourism also has a role to play in people's identity and status. Building on this, the marketing profession has identified an emerging group within the younger generation, the so called 'trysumers' who have been defined as being "freed from the shackles of convention and scarcity, immune to most advertising, and enjoying full access to information, reviews, and navigation, experienced consumers are trying out new appliances, new services, new flavours, new authors, new destinations, new artists, new relationships, new anything with post-mass-market gusto." (Cotton, 2007). Tourism (or leisure travel) plays an important part of this trend as trysumers independently seek unique and new experiences, which provide stories to tell their friends on their return. Furthermore, recreational activities such as tourism offer opportunities for people to rebalance their lives through less conspicuous consumption by allowing them to spend more time on leisure activities.

Social, technical and political challenges faced

Tourists do not always make the link between their activities and impacts on the local community and environment

Integrating sustainability in some
Social challenges: The values, attitudes and behaviour of tourists are determined by their social environment, cultural identity and way of life which may in certain cases be in conflict with the local customs of the places they are visiting. Tourism is also heterogeneous in nature, made up of many different types of travellers, seeking a wide range of tourism products and with varying needs, desires and motivations. Demand is influenced by many factors, such as the latest fashions and trends. Tourist destinations often depend on the availability of time and money, on images, perceptions and attitudes.

Tourism plays a dual and ambivalent role in terms of contributing to cultural exchange and sustainable development. On the one hand, tourism can be a highly sheltered, short-term consumer experience where tourists do not really experience local culture and remain isolated from negative impacts at the local level. On the other hand, tourism may increase recognition of the importance of respecting cultural diversity. It offers opportunities to educate consumers regarding responsible tourism and sustainable development. Recreational activities such as tourism offer opportunities for people to rebalance their lives through less conspicuous consumption. Unfortunately, tourists often lack information and awareness about their impact in a different culture and environment, about the impacts of tourism on socio-economic and socio-cultural development, and about the environmental costs of tourism. While tourists may be open to learning, they are often unaware of inappropriate behaviour and have little guidance on how to improve. Others may refuse to adapt to local lifestyles, even if informed, insisting on their freedom to behave as they want.

Technical challenges: A recent study (Graci, 2007) looked into some of the technical challenges related to sustainable tourism development. Some of the most important barriers that were identified include inadequate resources such as high costs, lack of information, data, skills, knowledge, expertise, and time. Despite the numerous ideas for initiatives (i.e., payments to fisherman to stop illegal fishing), without adequate resources many of these plans fail. Current infrastructure of the tourist destinations, as well as physical attributes such as the location and age of facilities are common barriers faced in a destination. For example, barrels of fresh water are shipped in on a daily basis to a popular tourist island destination in Indonesia. Structures such as a sewage treatment plants (sewage is currently either disposed of in homemade septic tanks or open pits on the side of the road in the village) cannot be built on the island as salt water will degrade the infrastructure.

Political challenges: Tourism is the world's largest industry, with a profound impact on the environment. The tourism industry employs an estimated $10 \%$ of the global workforce and capital formation. Due to the significance of this industry and given that environmental degradation has already had an impact on many tourist destinations; the need to implement 


\section{Tourism}

countries is

difficult due to

their economic

dependence

on tourism

activities

Demographic

trends

highlight

some of the

opportunities

and

challenges

facing the

sector

more sustainable practices has come to the forefront of global issues. However, whilst maintaining the jobs and income from tourism is an important political imperative in some European countries, in some less developed countries the hard currency income from tourism represents a central part of their economy (and society) and represents many of the pitfalls of an economy reliant on the export of commodities. Such countries effectively seek to export their climate, environment (in the form of beaches etc.) and unskilled cheap labour. Where a number of competing economies are reliant on income from tourism, competition will tend to drive out any profit from such markets with a corresponding 'race-to-the bottom' in terms of sustainability practices.

There is also a lack of reliable and appropriate (e.g. age and gender, disaggregated) research data on the determinants of tourist demand, motivation and behaviour. Few countries, whether those where tourists come from or those which are tourist destinations, collect such data that would be helpful for sustainable development criteria. Most studies of tourist behaviour focus on mainstream markets or market segments rather than assessing or modelling sustainable alternatives.

Another significant challenge relates to the demographic trends observed in Europe and the resulting changes in tourist behaviour or expectations. In particular, the number of persons aged over 65 is expected to reach $20 \%$ of the European population in 2020 . This population group, consisting of individuals with both purchasing power and leisure time, represent a significant political force in a country as the group most likely to vote in elections. There may therefore be some political reluctance to intervene in this age group's ability to have frequent holidays as part of their retirement.

\section{Sectoral analysis of tools}

\section{Selection of available tools}

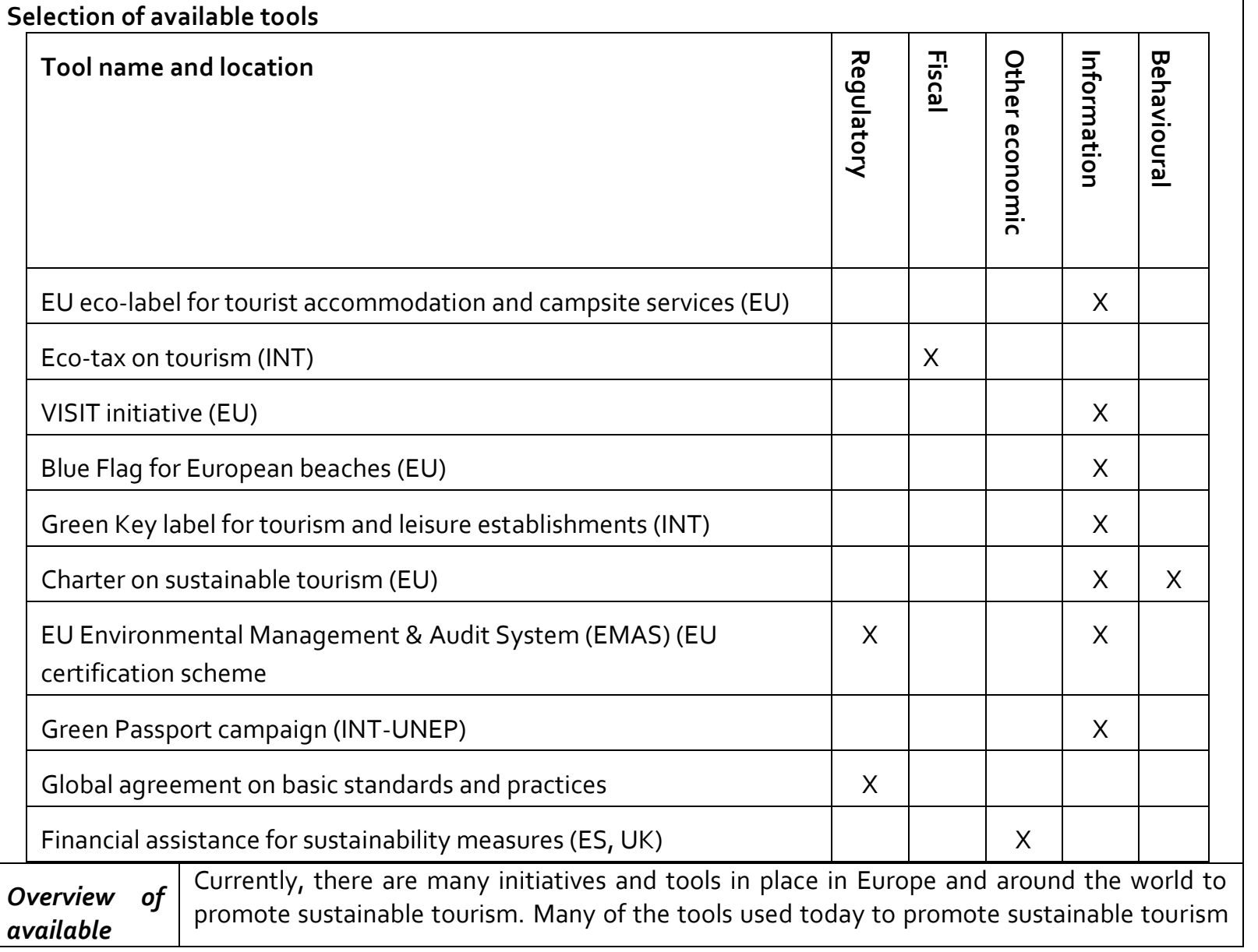




\section{Tourism}

tools

include information tools such as labels and certification schemes. To a lesser extent, awareness raising campaigns are also used (e.g. Green Passport information campaign). In some cases, eco-taxes and other economic tools have been used to influence behaviour through financial impacts and by sending signals via the market.

Other EU initiatives include the Blue Flag for European beaches, the European eco-label for tourist accommodation and campsite services, the European Destinations of Excellence

Information

tools are

widely;

however there

remains a lack

of awareness

among

tourists of the

impact of their

activities. (EDEN) project and the use of the European Environment Management and Auditing Scheme (EMAS) certification for hotels and other accommodation. There are also many national and regional environmental certificates and labels for tourism businesses such as stakeholder collaboration in the tourist industry (TRAVELIFE), benchmarking for sustainable tourism (TOURBENCH), and cooperation of environmental labels in the area of tourism (VISIT - see case study on VISIT initiative in Task 3 report for more information). Sustainability principles have also been included in many national and regional tourism strategies. Hungary for example is developing a dedicated eco-tourism strategy and is currently undertaking a number of activities to encourage sustainable tourism at national and local levels including tourist carrying capacity assessments, managing access to vulnerable areas to protect wildlife, and programmes aimed at greening tourist accommodation.

A number of other initiatives are in the pipeline. For instance, the 2010 European Commission Communication on tourism proposes a number of actions to promote the development of sustainable, responsible and high quality tourism including:

- Sustainability indicators for destinations,

- A charter for sustainable and responsible tourism and a prize for tourist businesses following the charter, and

- A strategy for sustainable coastal and marine tourism

The Marrakech Process Task Force on Sustainable Tourism has also developed a number of policy recommendations which inter alia recommend that:

- Governments integrate sustainable tourism planning into national and regional development plans and that financing from national and international organisations dealing with investments in public infrastructure related to tourism or investments in private tourism businesses should estimate their social and environmental impacts and adopt economic measures to compensate for and offset unavoidable impacts;

- Corporations adopt corporate social and environmental responsibility (CSER) principles in their tourism investments;

- Guidelines for the behaviour of tourists at destinations should be promoted using networks, media and other communication channels;

- Governments and businesses set baseline and measurable targets, review progress and report progress towards the achievement of sustainable tourism objectives

The use of EMAS certification is still quite limited in the tourism sector with only 230 hotels and other accommodation in the EU currently certified (EEA, 2010). Furthermore, assessments of whether these activities are successful in reducing the environmental impacts of tourism are currently lacking (EEA, 2010). According to the literature, some of the most important barriers to the development of sustainable tourism include the lack of awareness and information of tourists and the tourism industry of the harmful

Economic and regulatory tools are limited to what can be environmental impacts of tourism and tourism-related activities. This lack of information would be a critical area that would need to be addressed.

More could also be done to tackle the most important source of environmental pressures from tourism, namely air travel and car based tourism. In this line, the aviation sector will be included in the EU Emissions Trading Scheme (ETS) system from 2012 and the International 


\section{Tourism}

\begin{tabular}{|l|l|l}
\hline $\begin{array}{l}\text { achieved } \\
\text { within the } \\
\text { domestic EU }\end{array}$ & $\begin{array}{l}\text { Air Transport Association (IATA) has announced that the air-line industry is committed to } \\
\text { achieving carbon-neutral growth from } 2020 \text { globally (see assessment on air travel for further } \\
\text { information) (EEA, 2010). }\end{array}$ \\
$\begin{array}{l}\text { Despite these initiatives, it should be noted that the economic and regulatory policy tools } \\
\text { available to EU Member States are limited to what can be achieved within the domestic EU } \\
\text { tourism sector and what can be achieved at the point of departure through for example } \\
\text { aviation taxes (see assessment of the air travel sector). EU citizens may in some ways be } \\
\text { considered as importers of tourism; but unlike product imports tourism is consumed directly } \\
\text { in the exporting country and is therefore beyond any direct control of the tourists' home } \\
\text { government. The package of policy tools available is therefore presently limited to } \\
\text { mainstreaming voluntary and informational initiatives such as certification schemes, eco- } \\
\text { friendly hotel labels etc. One way to overcome this would be to seek international } \\
\text { agreement on basic standards within the sector. However, this would be fraught with } \\
\text { difficulties as it would require agreement by all major tourist receiving countries and would } \\
\text { tend towards the lowest common denominator which is unlikely to be very ambitious as } \\
\text { many of these countries rely on the currency which tourism brings. }\end{array}$
\end{tabular}

Elements of an effective sectoral toolbox

Cultural heritage and nature based tourism have potential to attract interest of tourists.

Introduce additional information tools that engage
Tourism policy is transversal and overlaps with several other important consumption sectors such as air travel, housing, food, and transport. Tourism also touches upon or is impacted (both directly and indirectly) by several other EU policies such as competition, internal market, taxation, consumer protection, the environment, employment and training, culture or regional and rural development policy. Thus it is important to keep in mind these possible overlaps with other EU policies when developing a policy package for sustainable tourism in the interest of policy coherence (e.g. a tax on car use could have an indirect impact in tourism if it persuades consumers/tourists to take a train rather than their personal car). Moreover, the 'carrying capacity' of tourism areas in terms of visitors and their impacts in designing initiatives in the area need to be kept in mind when designing policy initiatives in this area.

One of the major gaps in current policies to promote sustainable tourism is that the demand/consumption side of tourism is not widely addressed in existing tourism policy. Consumers (tourists) play a major role in shaping sustainable tourism as tourists' demand for more 'sustainable' tourism services and facilities can influence the performance of the private sector. The UNEP tourism programme recommends that the best and most effective ways to reach out to consumers is through effective promotions, information and price signals, and also ensuring that the industry is aware of new motivations such as cultural heritage and nature based tourism, rather than assuming that most tourists are uninterested in issues of environmental quality and impact. Most of the literature reviewed also reiterates the importance of consumer engagement in the development of sustainable tourism. Therefore two main tool categories have been identified as critical towards promoting sustainable tourism from a consumption side perspective:

- Information tools: In addition to the numerous tourism labels and certification schemes that already exist, other information tools are necessary to more effectively engage consumers and industry. This includes information and education programmes in cooperation with local stakeholders that provide information to tourists on appropriate behaviour (sensitivity, respect for/adaptation to local culture), the potential harmful environmental impacts of tourism, and the benefits of participating in activities such as eco-tourism ${ }^{176}$. This can be done by

\footnotetext{
${ }^{176}$ The International Ecotourism Society defines ecotourism as "responsible travel to natural areas that conserves the environment and improves the well-being of local people" (International Ecotourism Society 2011). Its purpose is to
} 


\section{Tourism}

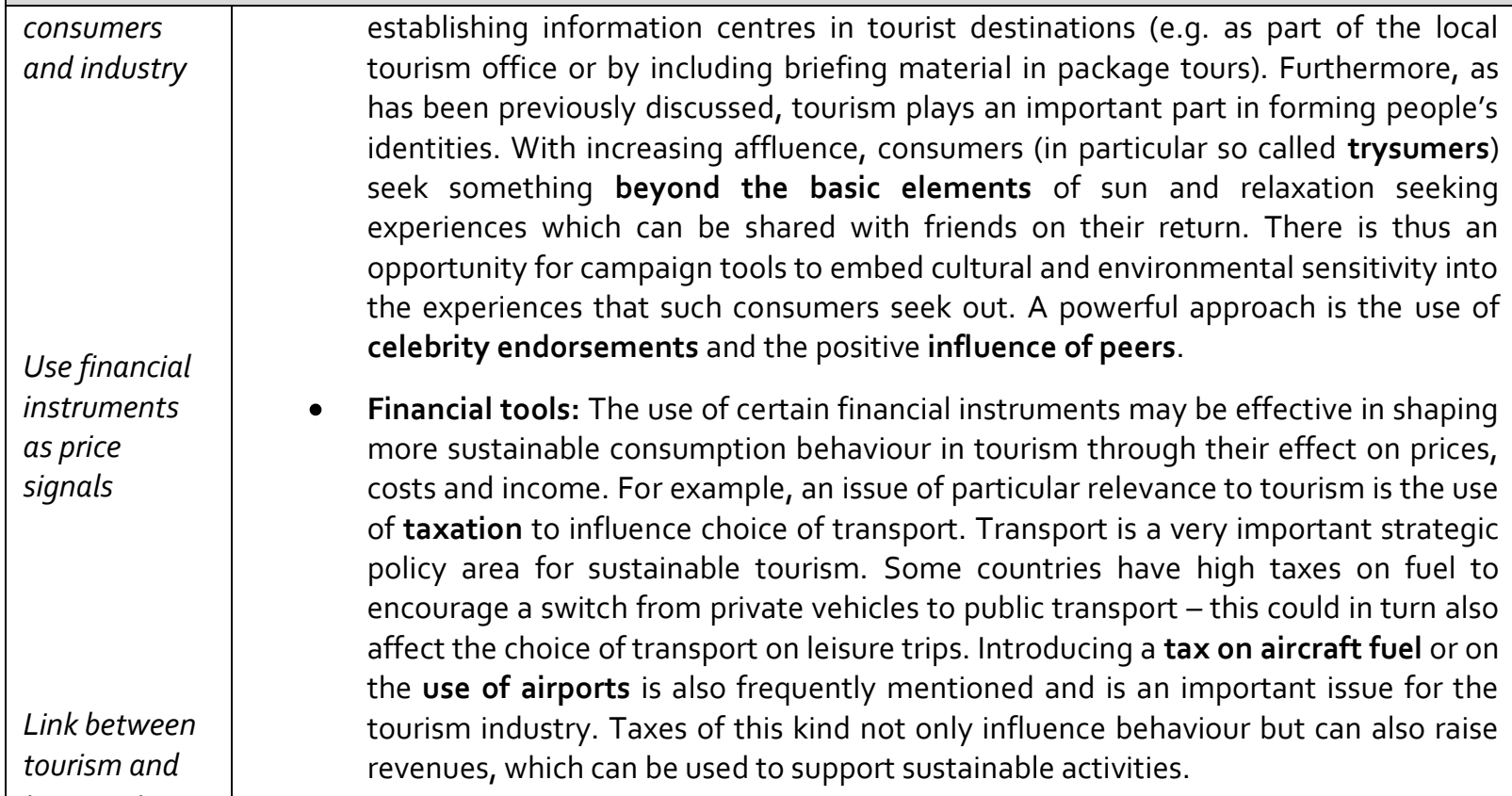

transport

policy

- Regulatory tools: The available regulatory tools centre on the standards and codes of conduct of tourist activities. These standards and codes could be implemented unilaterally to permit all operators within a particular country to compete fairly without breaching the standards. While this could also realistically be achieved at an EU-wide level, it seems less feasible at the international level as all countries effectively have a veto within the process. A major challenge would be how to define tourism in a way, which could not be circumvented by operators. A tax on particular modes of transport not only impacts tourism but also directly addresses the mobility sector. An example of an approach to effectively integrate general tourism and transport policy could be to strive towards improving accessibility to manage tourist traffic in ways that minimizes congestion and the adverse impacts on local communities and environments.

Local level participation with communities and business are important.
With the above tools in mind, participation with local communities and provision of infrastructure are also key policy approaches to consider in ensuring that the policy tools are successfully implemented. A key aspect of more sustainable tourism is to work in effective partnerships in local destinations. It is at this local level where tourism needs to be effectively integrated into local sustainable development. Public acceptance and participation in local initiatives is essential in ensuring long-term success of the initiative and should be carefully executed and based on the principle of assisting local communities. However, as seen through the Middelgrunden wind farm case study, the public participation and acceptance process can take time (see Task 3 report) and this is also likely to be the case for the tourism sector.

Governments can also play an important role in improving the conditions for sustainable consumer behaviour by providing and promoting sustainable tourism facilities and infrastructure such as transport infrastructure and public transport services. Examples of physical infrastructure measures include for example careful assessments of the

educate the traveller; provide funds for ecological conservation; directly benefit the economic development and political empowerment of local communities; and foster respect for different cultures and for human rights. Ecotourism is often associated with volunteering and participating in low environmental impact activities. See www.wwoof.org for more information on an eco-tourism activity that promotes volunteering on organic farms and helps people share more sustainable ways of living. 


\section{Tourism}

\begin{tabular}{|c|c|}
\hline & $\begin{array}{l}\text { environmental, social and economic impact of any new transport infrastructure proposals } \\
\text { especially new roads, developing park and ride schemes in popular tourist areas, or } \\
\text { developing dedicated walking and cycling trails for use by tourists that take into account } \\
\text { 'carrying capacity' of tourism areas in terms of visitors and their impacts. }\end{array}$ \\
\hline \multicolumn{2}{|l|}{ References } \\
\hline & 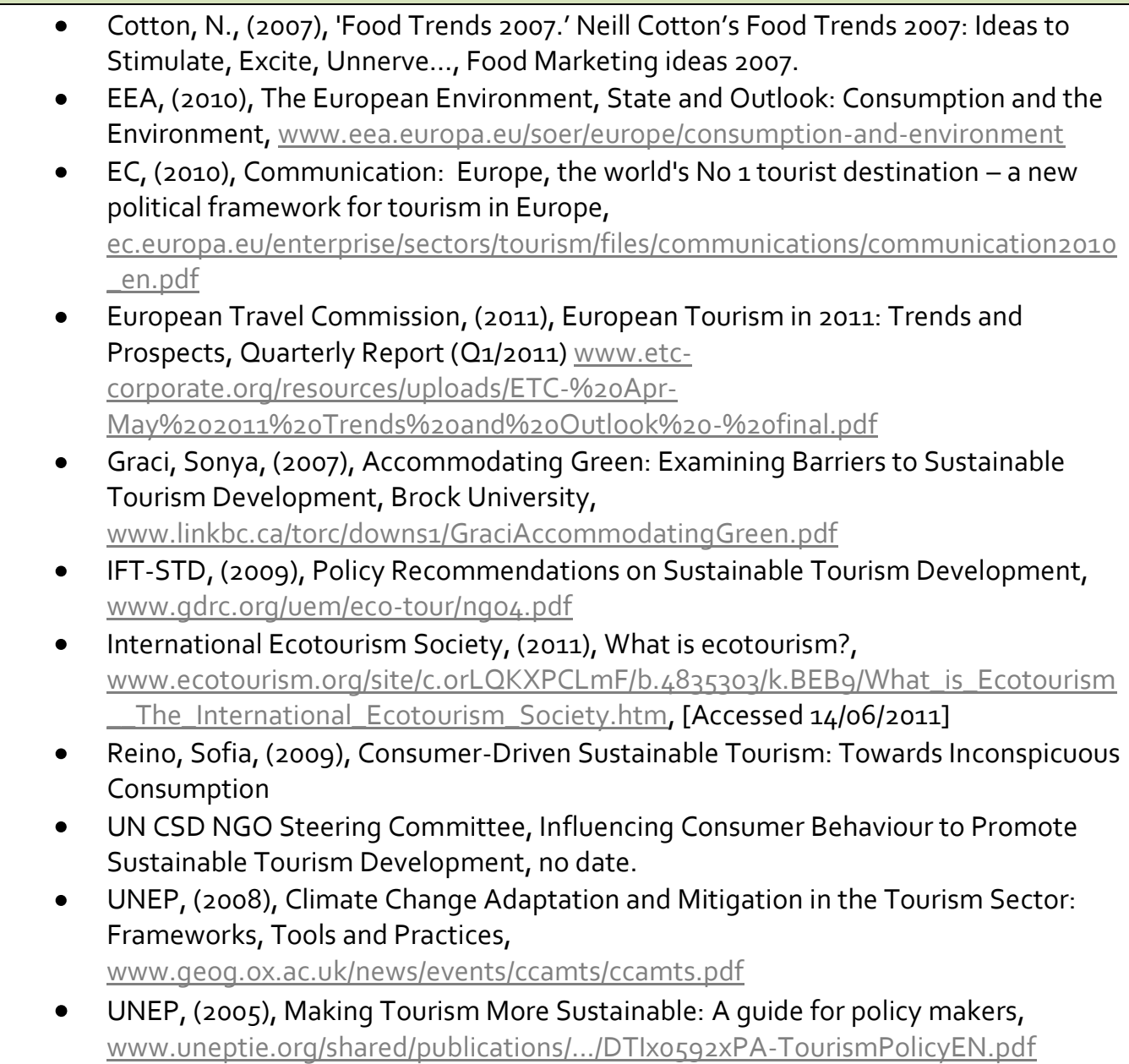 \\
\hline
\end{tabular}

\section{Citizen community action}

\section{Sectoral analysis}

\begin{tabular}{|c|c|}
\hline $\begin{array}{l}\text { General } \\
\text { trends in the } \\
\text { sector }\end{array}$ & $\begin{array}{l}\text { EU policy on sustainable consumption does not yet clearly define sustainable consumption. } \\
\text { A } 1994 \text { Oslo Symposium on sustainable consumption proposed the following: "the use of } \\
\text { services and related products which respond to basic needs and bring a better quality of life } \\
\text { while minimising the use of natural resources and toxic materials as well as emissions of } \\
\text { waste and pollutants over the lifecycle of the service or product so as not to jeopardise the } \\
\text { needs of future generations". Hence, there is a distinction between sustainable consumption } \\
\text { and 'green consumerism' in that sustainable consumption refers to satisfying basic needs } \\
\text { (rather than 'wants' and luxuries) and considers the ability of future generations to meet } \\
\text { their needs. }\end{array}$ \\
\hline & tainable consumption can be achieved through better produ \\
\hline
\end{tabular}




\section{Citizen community action}

\begin{tabular}{|c|c|}
\hline $\begin{array}{l}\text { Citizen-led } \\
\text { initiatives } \\
\text { such as } \\
\text { EcoTeams and } \\
\text { Transition } \\
\text { Towns also } \\
\text { exist }\end{array}$ & 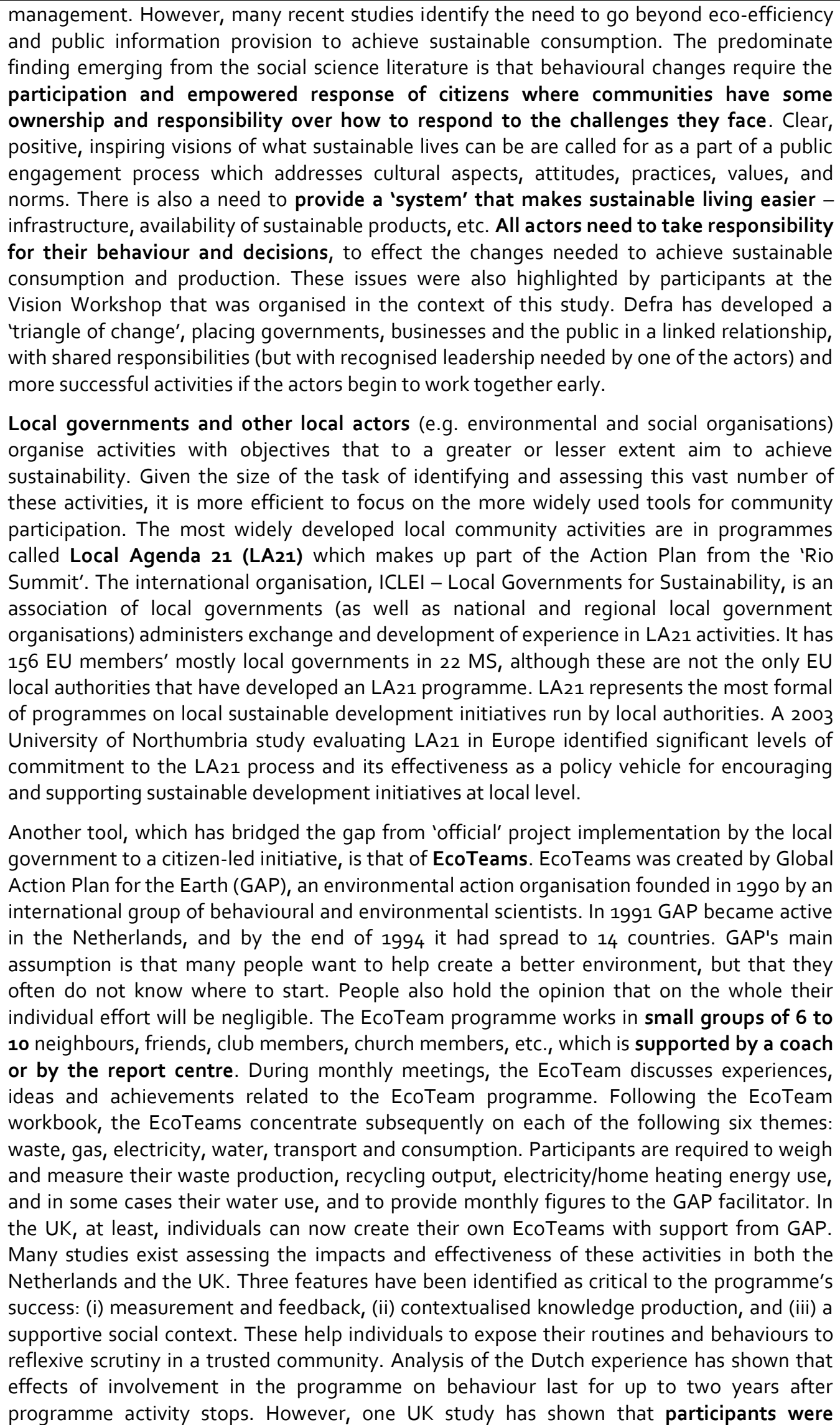 \\
\hline
\end{tabular}




\section{Citizen community action}

\begin{tabular}{|c|c|}
\hline & $\begin{array}{l}\text { already fairly 'green' before joining an EcoTeam. } \\
\text { A more recent development that is fully citizen-led is that called Transition Towns (TTs). The } \\
\text { first TT was Totnes in the UK which started in } 2005 \text {. This local community based initiative } \\
\text { aims to build a local community response to two key issues - peak oil and climate change. } \\
\text { The initiative emerged from the creator's background in permaculture design and builds on } \\
\text { the concepts of 'intentional relocalisation' and resilience as a means of changing local society } \\
\text { and economy elements to face these two challenges. There are now } 370 \text { 'official' such TTs, } \\
\text { representing villages, municipalities, cities, etc., mostly in Europe, North America and } \\
\text { Australia and New Zealand, but also in South America and Asia. The TT approach is very } \\
\text { inclusive, building on eight principles that address many of the requirements for sustainable } \\
\text { lifestyles that studies suggest need to go beyond information provision. These principles } \\
\text { include positive visioning, inclusion and openness, enabling sharing and networking, building } \\
\text { resilience, and subsidiarity (self-organisation and decision-making at the appropriate level). } \\
\text { The TT approach is not disconnected from formal government structures, indeed it seeks to } \\
\text { work with local authorities and government bodies organised at higher levels. This is due } \\
\text { to a number of reasons including the recognition that local, individual action on its own is not } \\
\text { enough to tackle serious environmental (and other) challenges being faced and that local } \\
\text { authorities have established connections to societal organisations (environmental, health, } \\
\text { social, etc.) and other local bodies that can help to ensure the more successful development } \\
\text { of TT activities. }\end{array}$ \\
\hline $\begin{array}{l}\text { Need to go } \\
\text { beyond } \\
\text { information } \\
\text { tools to } \\
\text { address } \\
\text { societal values } \\
\text { and norms }\end{array}$ & 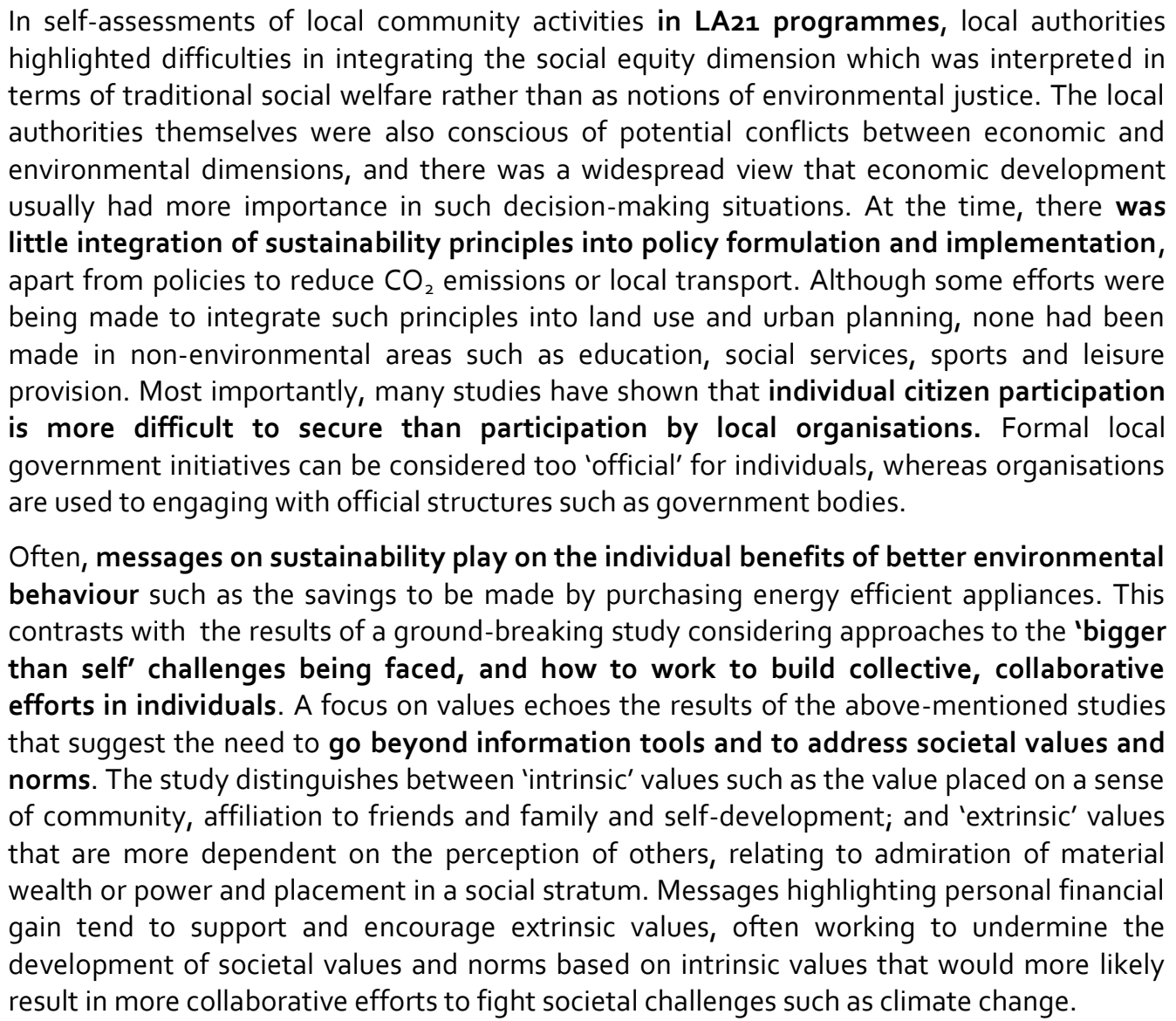 \\
\hline
\end{tabular}




\section{Citizen community action}

Selection of available tools

\begin{tabular}{|c|c|c|c|c|c|}
\hline Initiative and location & 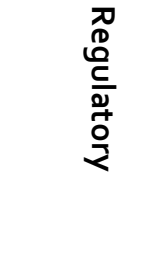 & $\stackrel{T}{\underline{\Lambda}}$ & 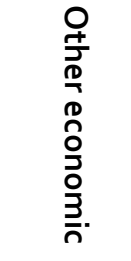 & 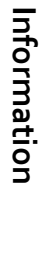 & 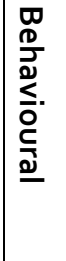 \\
\hline Local Agenda 21 (various local authorities across the EU) & & & & $\mathrm{X}$ & $\mathrm{x}$ \\
\hline EcoTeams (various locations in NL, UK) & & & & $\mathrm{x}$ & $\mathrm{x}$ \\
\hline Transition Towns & & & & & $\mathrm{X}$ \\
\hline Futuro Price label (AT) & & & & $\mathrm{x}$ & \\
\hline Plastic bag levy/ban (IE, IT) & $\begin{array}{c}\mathrm{X} \\
(\operatorname{Ban}-\mathrm{IT})\end{array}$ & & $\begin{array}{l}\text { X (Levy } \\
\text { - IE) }\end{array}$ & & \\
\hline $\begin{array}{l}\text { Environmental taxation - water, waste, energy, vehicles, } \\
\text { products, etc. (various countries) }\end{array}$ & & $x$ & & & \\
\hline $\begin{array}{l}\text { Education, awareness-raising and public information - } \\
\text { various activities (various countries) }\end{array}$ & & & & $x$ & \\
\hline Environmental labelling & & & & $x$ & \\
\hline Consumer information & & & & $x$ & \\
\hline National indicators & & & & $\mathrm{X}$ & \\
\hline
\end{tabular}

Overview of Since the development of the SCP public policy agenda in the early 2000s, a number of MS available $\quad$ have developed their own SCP policies or have integrated SCP objectives into other existing tools $\quad$ policies such as on sustainable development. A number of 'push' and 'pull' mechanisms (e.g. eco-design, eco-labelling, green public procurement etc.) have been introduced encouraging the development of more sustainable products, their purchase, use and disposal, with varying levels of coherence between mechanisms. New measures such as the recently launched Smart Cities \& Communities Initiative will help in the dissemination of knowledge among local authorities on innovative low carbon technologies.

Information Much national and local level activity on sustainable consumption has tended to focus on provision alone is not enough to effect behavioural information provision as a means of raising awareness as a first step to achieving behavioural change. Many local, regional and national authorities run public campaigns on consumption-related issues addressing climate change, energy, waste, water and products. However, studies have shown that information provision alone or as a major element of public body activities is not always enough to effect behavioural change. The level of change funding available to public authorities for such campaigns is also considerably less than that spent on corporate advertising which often communicate contradictory messages e.g. encouraging unsustainable purchasing decisions etc.

Another tool used by public authorities is verification schemes combined with labelling, where such initiatives exist at EU level (e.g. Ecolabel, Energy Label, organic logo), at national level (e.g. national and regional ecolabels), independent labels (e.g. Forestry Stewardship Council, Marine Stewardship Council, Fair Trade, etc.) or industry labels (e.g. for textiles, paints, etc.). There has been a recognised proliferation of labels, many of which the public is either not aware of or are unclear of its message. Therefore there is a role for government to 


\section{Citizen community action}

provide coordination and public endorsement for such labels as a means of identifying better performing products. But these labels alone will unlikely be sufficient to encourage or achieve sustainable consumption as they rarely challenge the level of consumption.

Some local and regional authorities have built partnerships with societal organisations (environmental groups, consumer organisations, health groups, etc.) to communicate messages more actively to the public so as to increase individual buy-in on stimulate behavioural change. These activities depend on public authority funding and can be too short-lived to effect long-term change. They can also communicate messages that are not consistent with existing systems or infrastructure (e.g. waste prevention/reduction campaigns that encourage recycling in places where not all residents have access to public recycling services or where key materials such as plastic are not recycled).

The above mentioned tools face a challenge when initiated by top-level government in that successful community-led initiatives require that the local community feels empowered to take the lead, whereas top-down interventions can often leave communities feeling that the government is still responsible for the successes of their initiatives. Community empowerment is a bottom-up process which needs to come from communities, While there are some things that governments can do to facilitate community empowerment, it is important that governments understand how their actions might be acting as barriers. Citizen-led activities such as the Transition Town movement are fed and developed by the ideas of local residents and aim to achieve local resilience through local support for activities such as community supported agriculture, use of local materials in construction, local currencies, local energy generation and other means of engaging with local businesses to increase their presence in the local community. At the same time, as noted above, the Transition Town approach is not completely disconnected from formal government structures and indeed seeks to work with local authorities and government bodies to ensure the more successful development of activities.

A review for Defra (PSI, 2010) found the following elements important when engaging citizens in (natural) environmental protection:

- People's values and identities: The review of the 'Big Society' concept demonstrated the importance of understanding the diverse values and motives of different groups within communities.

- Balancing lay and expert knowledge: The review explored the difference between 'communication to explain' and 'communication as mutual learning', the latter allowing for different forms of knowledge to be accommodated within a situation. The review highlighted that experts and the general public often hold different values and that there is a need to include more subjective assessments based on public preferences.

- Engaging people in the evaluation of outcomes: The emergence of the 'Big Society' highlights the need for more widespread but 'light touch' evaluations of small-scale initiatives that engage citizens in land-use decision-making. Such evaluations need to combine objective environmental and social outcome measures with measures of the often more subjective outcomes considered by local communities to be socially or environmentally desirable.

- The role of place attachment: Place attachment (or the emotional bond between people and places) was found to have a significant influence on citizens and can be a driving motivation for communities to act.

- The role of influential individuals: The review for the Big Society found reference to 'community champions', 'community pioneers', 'mavens', 'catalytic individuals', all of whom demonstrate the necessary enthusiasm and community knowledge to tap into local pools of social capital and mobilise community 


\section{Citizen community action}

\begin{tabular}{|c|c|}
\hline & $\begin{array}{l}\text { members to engage in community efforts. Such individuals occur in all walks of life, } \\
\text { with no particular social, economic or geographical characteristics. The one } \\
\text { characteristic that they were found to have in common was not necessarily pro- } \\
\text { environmental values but an overwhelming commitment to altruism. }\end{array}$ \\
\hline $\begin{array}{l}\text { Elements of } \\
\text { an effective } \\
\text { sectoral } \\
\text { toolbox }\end{array}$ & 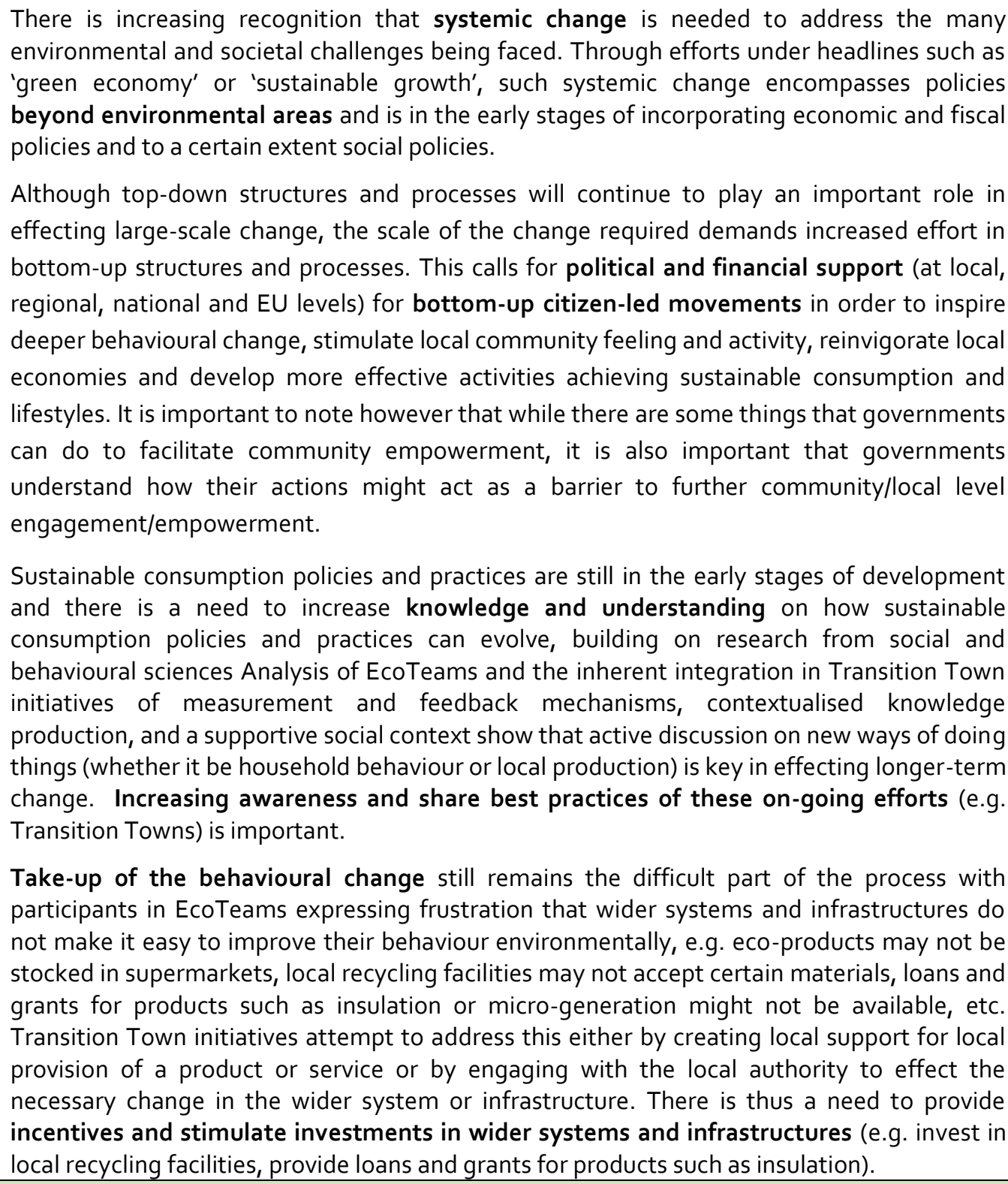 \\
\hline \multicolumn{2}{|l|}{ References } \\
\hline & $\begin{array}{l}\text { - EC, (2004), Sustainable Consumption and Production in the European Union } \\
\text { - } E C(2011), \text { Smart Cities \& Communities Initiative, } \\
\text { http://ec. europa.eu/energy/technology/initiatives/smart cities en.htm } \\
\text { - Evans, B. and Theobald, K., (2003), LASALA: Evaluating Local Agenda } 21 \text { in Europe; } \\
\text { Journal of Environmental Planning and Management, 46(5), 781-794, September } \\
2003 \\
\text { - Harland, P. and Staats, H., (no year provided), Effectiveness of the EcoTeam } \\
\text { Program in the Netherlands: A Long Term View; Leiden University, } \\
\text { - Hargreaves, T., Haxeltine, A., Longhurst, N., and Seyfang, G., (2011), Sustainability } \\
\text { transitions from the bottom-up: Civil society, the multi-level perspective and }\end{array}$ \\
\hline
\end{tabular}




\section{Citizen community action}

\begin{tabular}{|l|l|}
\hline practice theory, CSERGE Working Paper 2011-01, University of East Anglia, UK \\
Hargreaves, T., Nye, M. and Burgess, J., (2008), Social experiments in sustainable \\
consumption: an evidence-based approach with potential for engaging low-income \\
communities; Local Environment: The International Journal of Justice and \\
Sustainability; Volume 13, Issue 8, 2008, Pages 743 - 758 (abstract only) \\
- Hopkins, R., (2010), Localisation and Resilience at the Local Level: The Case of \\
Transition Town Totnes; thesis submitted to University of Plymouth \\
- Nye, M. and Hargreaves, T., (2010), Exploring the Social Dynamics of \\
Proenvironmental Behaviour Change: A Comparative Study of Intervention \\
Processes at Home and Work; Journal of Industrial Ecology, Volume 14, Number 1, \\
2010, Pages 137-149 \\
Nye, M. and Burgess, J., (2008), Promoting Durable Change in Household Waste \\
and Energy Use Behaviour, \\
http://www. vea.ac.uk/env/cserge/pub/ext/evaluating ecoteams.pdf \\
Policy Studies Institute (PSI), (2010), Social Research Evidence Review to Inform \\
Natural Environment Policy, Policy Studies Institute (PSI) in partnership with Centre \\
for Rural Economy (CRE) Land Use Consultants (LUC), Defra project code NEo109. \\
Transition Network website: http://www.transitionnetwork.org/ \\
United Nations Environment Programme, (2011), Visions for Change: \\
Recommendations for Effective Policies on Sustainable Lifestyles \\
UK Sustainable Development Commission, (2011), Making Sustainable Lives Easier \\
WWF-UK, (2010), Common Cause: The Case for Working with our Cultural Values, \\
September 2010
\end{tabular}


This page is left intentionally blank 


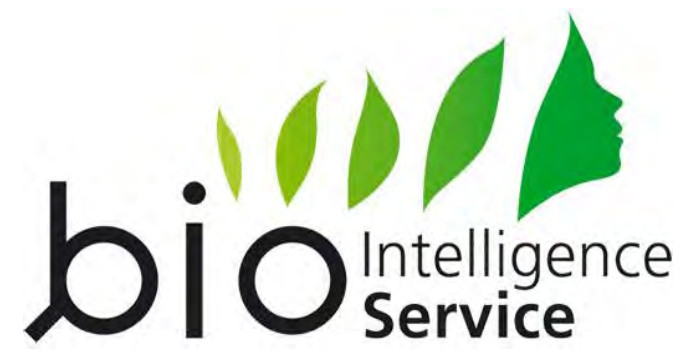

August 2012

20-22 Villa Deshayes

75014 Paris

+ 33 (0) 153901180

biois.com 
ISBN 978-92-79-25952-4

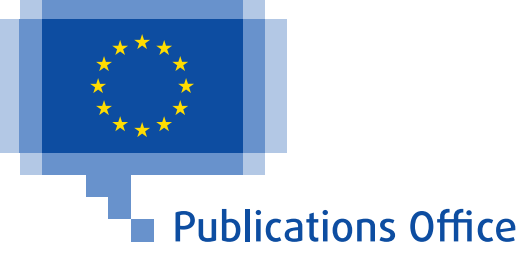

